Florida International University FIU Digital Commons

\title{
Origin of the Grande Ronde Formation flows, Columbia River Flood Basalt Group
}

Sedelia Rodriguez Durand

Florida International University

DOI: $10.25148 /$ etd.FI15101254

Follow this and additional works at: https://digitalcommons.fiu.edu/etd

Part of the Geology Commons

\section{Recommended Citation}

Durand, Sedelia Rodriguez, "Origin of the Grande Ronde Formation flows, Columbia River Flood Basalt Group" (2006). FIU Electronic Theses and Dissertations. 3105.

https://digitalcommons.fiu.edu/etd/3105 
Miami, Florida

A dissertation submitted in partial fulfillment of the

requirements for the degree of

DOCTOR OF PHILOSOPHY

in

GEOSCIENCES

by

Sedelia Rodriguez Durand

2006 
To: Interim Dean Mark Szchuman

College of Arts and Sciences

This dissertation, written by Sedelia Rodriguez Durand, entitled Origin of the Grande Ronde Formation Flows, Columbia River Flood Basalt Group, having been approved in respect to style and intellectual content, is referred to you for judgment.

We have read this dissertation and recommend that it be approved.

Grenville Draper

Stephen Haggerty

Rosemary Hickey-Vargas

Andrew Macfarlane

Stephen P. Reidel

Gautam Sen, Major Professor

Date of Defense: March 8, 2006

The dissertation of Sedelia Rodriguez Durand is approved.

Interim Dean Mark Szchuman

College of Arts and Sciences

Interim Dean Stephan L. Mintz

University Graduate School

Florida International University, 2006 


\section{DEDICATION}

I would like to dedicate this dissertation to my son Xavier, who gave me the strength to move forward no matter what obstacles stood in my way and who made me realize that anything was possible. 


\section{ACKNOWLEDGMENTS}

This dissertation could not have been written without the invaluable assistance of numerous individuals. Firstly, I am deeply grateful to my major professor, Gautam Sen, for all his guidance and patience. I wish to thank my committee members Drs. Rosemary Hickey-Vargas, Grenville Draper, Andrew Macfarlane and Steve Haggerty, without whom numerous facets of this research project would not have come to fruition. I would especially like to thank Steve Reidel for providing samples, helping me in the field and for numerous discussions about the CRBG and politics. I would also like to thank Peter Hooper and Heather Petcovic for providing me with the necessary samples that allowed me to complete this project.

I would like to express my deepest gratitude to my best friend Gita Shokouhi for always being there for me. I wish to thank Jonell Durand for all his support and encouragment throughout these years. I also would like to thank Douglas Varela, for without him constantly urging me to achieve more, I wouldn't be here today. I wish to thank my family and my good friend Jessica Kennedy for their love and support.

I wish to warmly thank the following individuals for providing the resources that contributed to the completion of this project: Debby Arnold, Bonnie Boddicker, Barbara Maloney, Rosa Necolardes, Diane Pirie, and Tom Beasley. I also wish to acknowledge my appreciation to all the graduate students who made life more bearable during all these years. Special thanks go to Melroy Borges and Kevin Chau for all their help with my computer problems, research questions and life in general. Finally, I would like to thank FIU's Dissertation Year Fellowship for providing the funding necessary to complete my degree. 


\section{ABSTRACT OF THE DISSERTATION \\ ORIGIN OF THE GRANDE RONDE FORMATION FLOWS, COLUMBIA RIVER \\ FLOOD BASALT GROUP}

by

Sedelia Rodriguez Durand

Florida International University, 2006

Miami, Florida

Professor Gautam Sen, Major Professor

Lavas belonging to the Grande Ronde Formation (GRB) constitute about $63 \%$ of the Columbia River Basalt Group (CRBG), a flood basalt province in the NW United States. A puzzling feature is the lack of phenocrysts $(<5 \%)$ in these chemically evolved lavas. Based mainly on this observation it has been hypothesized that GRB lavas were nearly primary melts generated by large-scale melting of eclogite. Another recent hypothesis holds that GRB magmas were extremely hydrous and rose rapidly from the mantle such that the dissolved water kept the magmas close to their liquidi. I present new textural and chemical evidence to show that GRB lavas were neither primary nor hydrous melts but were derived from other melts via efficient fractional crystallization and mixing in shallow intrusive systems. Texture and chemical features further suggest that the melt mixing process may have been exothermic, which forced variable melting of some of the existing phenocrysts.

Finally, reported here are the results of efforts to simulate the higher pressure histories of GRB using COMAGMAT and MELTS softwares. The intent was to evaluate (1) whether such melts could be derived from primary melts formed by partial melting of a peridotite source as an alternative to the eclogite model, or if bulk melting of eclogite is required; and (2) at what pressure such primary melts could have been in equilibrium with the mantle. I carried out both 
forward and inverse modeling. The best fit forward model indicates that most primitive parent melts related to GRB could have been multiply saturated at $\sim 1.5-2.0 \mathrm{GPa}$. I interpret this result to indicate that the parental melts last equilibrated with a peridotitic mantle at $1.5-2.0 \mathrm{GPa}$ and such partial melts rose to $\sim 0.2 \mathrm{GPa}$ where they underwent efficient mixing and fractionation before erupting. These models suggest that the source rock was not eclogitic but a fertile spinel Iherzolite, and that the melts had $\sim 0.5 \%$ water. 


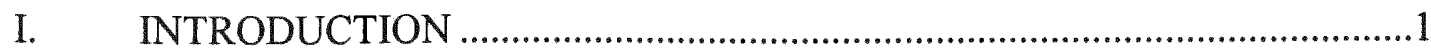

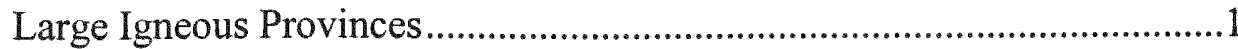

Columbia River Basalt Group..........................................................

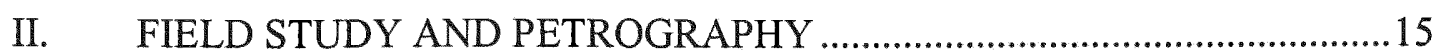

A. FIELD STUDY

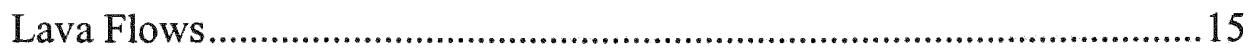

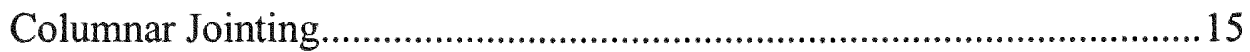

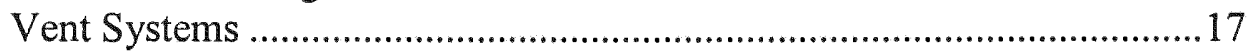

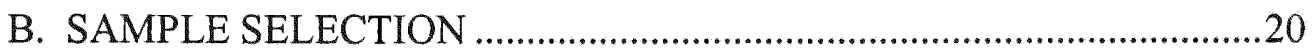

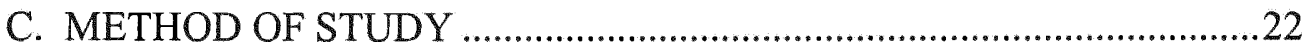

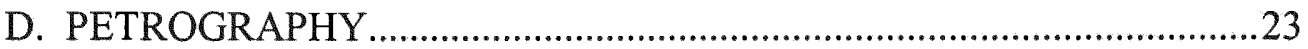

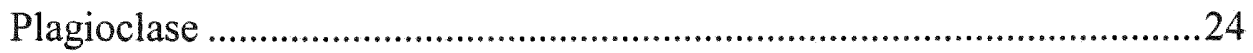

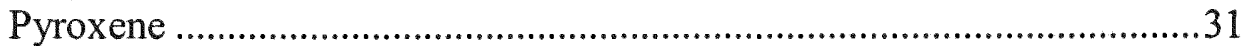

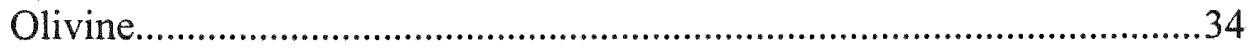

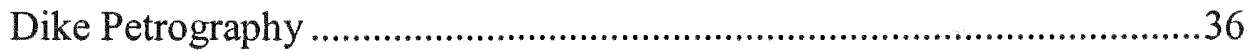

Joseph Creek Dike (GRB) ..........................................................36

Imnaha Dike (BLM) ..................................................................

III. GEOCHEMISTRY AND MINERAL CHEMISTRY …..............................40

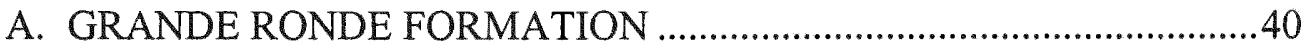

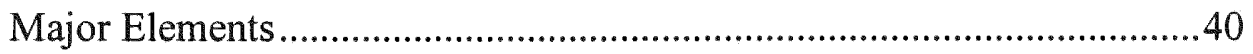

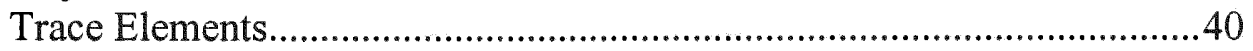

Radiogenic Isotopes ........................................................................42

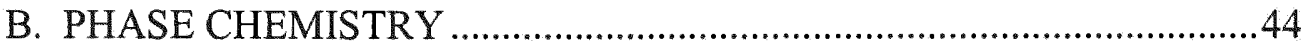

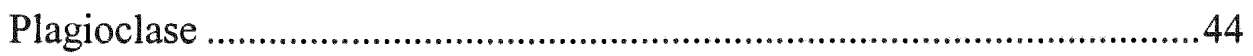

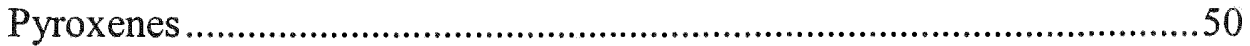

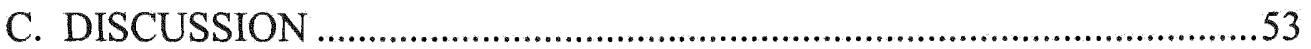

Evidence for Low-Pressure Equilibration.............................................53

Pre-eruption Magma Mixing and Magma Mingling.................................55

Residence Times in GRB Magma Chambers ..........................................5

More on Shallow Fractionation and Mixing.........................................59

Lava Flow Cooling Rates and flow Rates...............................................60

Eruption Conditions: Thermometry and Barometry ..............................65

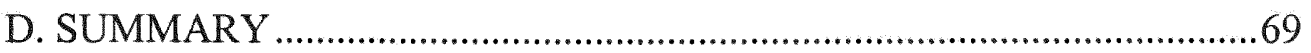




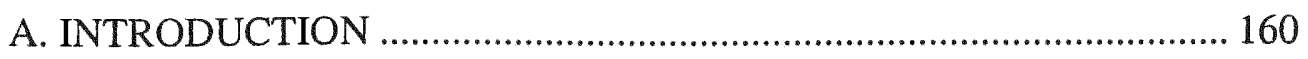

B. GEOCHEMICAL MODELING ............................................................. 163

Forward and Inverse Modeling of Major Elements 163

C. RESULTS AND DISCUSSION ......................................................... 167

Inverse Modeling of "Dry" Primary Magma .......................................... 167

Inverse Hydrous Models ..................................................................... 172

Forward Models: Peridotite Sources.................................................. 175

Role of H2O: Forward "Wet" Models .................................................. 179

P,T Conditions of Magma Formation: Multiple

Saturation of PRIM: A Cautionary Note ............................................... 182

Eclogite Source: Forward Models ..................................................... 184

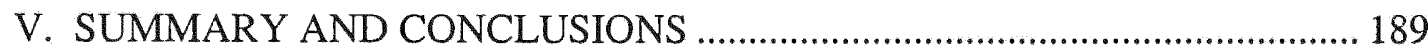

ALTERNATIVE MODELS TO THE PLUME HYPOTHESIS .................. 190

BACK TO THE PLUME MODEL HYPOTHESIS ................................... 191

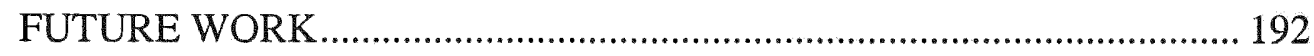

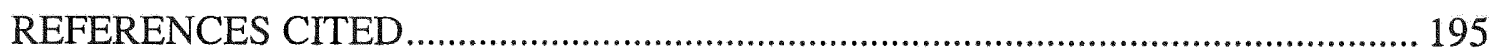

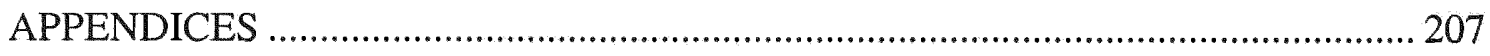

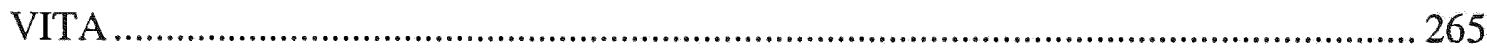




\section{LIST OF TABLES}

TABLE

1. Microprobe Analyses of Plagioclase Phenocrysts .......................................................

2. Microprobe Analyses of Pyroxene Phenocrysts ............................................................96

3. Microprobe Analyses of Groundmass Plagioclase .................................................. 118

4. Microprobe Analyses of Groundmass Pyroxene ......................................................137

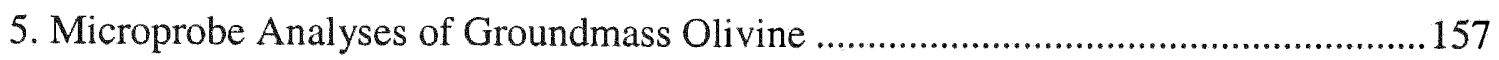

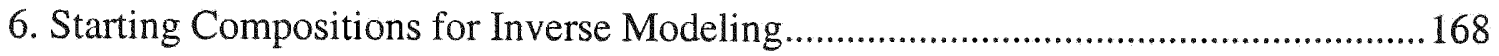

7. Comparison of PRIM phase assemblages for dry best fit model...............................169

8. Comparison of PRIM phase assemblages for hydrous best fit models...................... 173

9. Starting Experimental Compositions for Forward Modeling .................................. 176

10. Phase assemblages for 1 atm and 2 kb Forward dry "runs" ................................. 177

11. Phase assemblages for $2 \mathrm{~kb}$ Forward wet "runs"................................................... 180

12. Starting Compositions for Eclogite (CRB72-31) Forward Modeling...................... 185

13. Comparison of (CRB72-31) for 2 and $3 \mathrm{GPa}$ Forward Models............................. 185

14. Starting Compositions for Garnet Pyroxenite 77SL-582 Forward Modeling.......... 187 
FIGURE

PAGE

1. Map of Columbia River Basalt Group .................................................................. 4

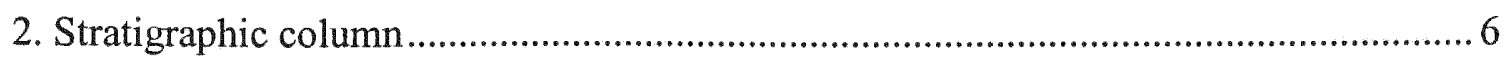

3. Geist and Richards Model........................................................10

4. Takahashi Plume head model...................................................11

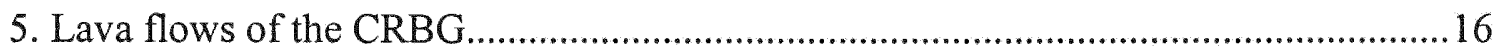

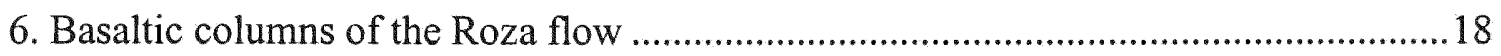

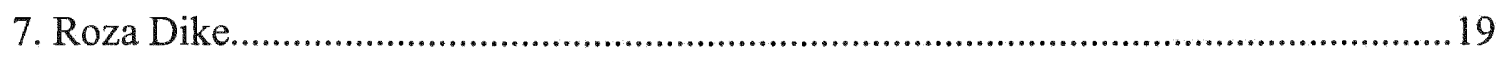

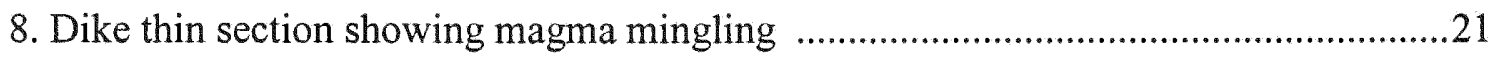

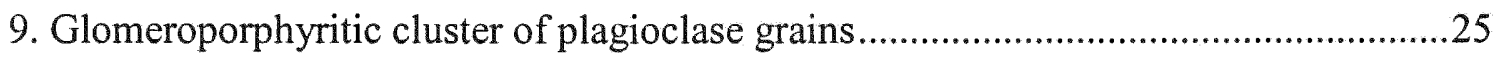

10. Glomeroporphyritic cluster of plagioclase, augite and opx .....................................26

11. Large zoned and partially resorbed plagioclase phenocryst ......................................28

12. Plagioclase phenocrysts showing extensive resorption of the cores..........................29

13. X-ray map of a GRB reversely zoned plagioclase phenocryst .....................................30

14. Plagioclase phenocrysts with oscillatory zoning ....................................................... 30

15. Augite-rimmed pigeonite juxtaposed against augite phenocryst .................................32

16. Back-scatter image of orthopyroxene grain rimmed by augite..................................32

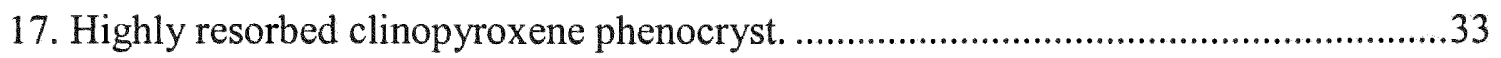

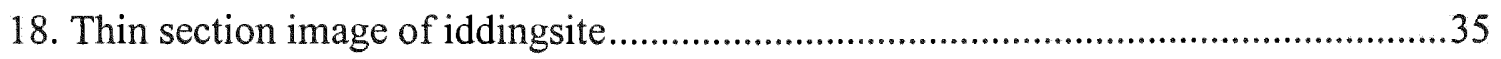

19. Thin section image showing magma mingling in a dike ..........................................39

20. Thin section image of olivine crystal in an Imnaha dike ..........................................39

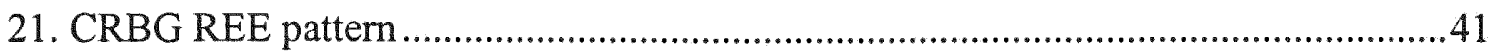


22. Plot of ${ }^{143} \mathrm{Nd} /{ }^{144} \mathrm{Nd}$ versus ${ }^{87} \mathrm{Sr} /{ }^{86} \mathrm{Sr}$

23. Plot of Anorthite vs. relative stratigraphic height (lower sections) ...........................45

24. Plot of Anorthite vs. relative stratigraphic height (upper sections) ............................46

25. Plagioclase and Pyroxene Equilibrium Plots ..............................................................48

26. Thin section image of resorbed plagioclase phenocryst ..........................................49

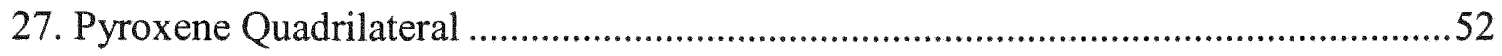

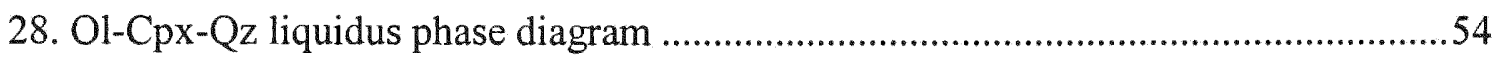

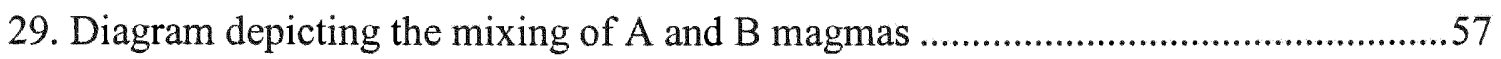

30. Graph depicting cooling rates for GRB groundmass pyroxene ..............................64

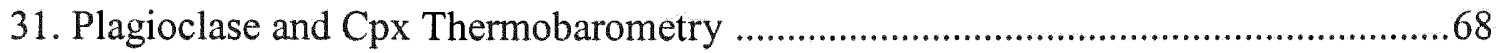

32. GRB compared with other LIPs and presently active plume lavas .........................162

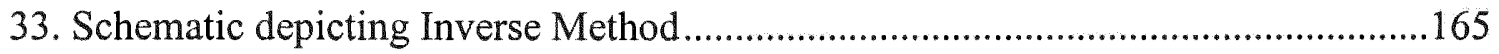

34. Graphs showing "best fit" Inverse models obtained with COMAGMAT .................171

35. $\mathrm{CaO} / \mathrm{Al}_{2} \mathrm{O}_{3}$ vs. $\mathrm{MgO}$ Graph of modeled dry PRIM composition.............................172

36. Graphs depicting wet "best fit" Inverse models obtained with COMAGMAT ........175

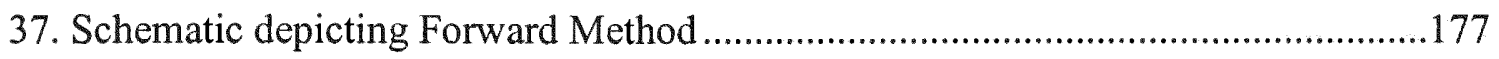

38. Graphs depicting dry "best fit" Forward models obtained with COMAGMAT ......179

39. Graphs depicting wet "best fit" Forward models obtained with COMAGMAT ......181

40. Phase diagram for PRIM depicting multiphase saturation ....................................183

41. Graphs depicting eclogite (CRB72-31) models obtained with COMAGMAT ........186

42. Graphs depicting eclogite (CRB72-31) models obtained with COMAGMAT ........188

43. Diagram depicting model for the generation of the CRBG ....................................192 


\section{CHAPTER 1}

\section{INTRODUCTION}

\section{Large Igneous Provinces}

Continental flood basalts (CFB) or large igneous provinces (LIP) are formed by the eruption of large volumes of lava onto the continental and oceanic crust. Lava volumes can range from $200,000 \mathrm{~km}^{3}$ (Columbia River Basalt Group) up to 1.5 million cubic kilometers (Siberian Traps); (Hooper et al., 2002; Reichow et al., 2002; Renne, 2002; Camp et al., 2003; Camp and Ross, 2004). The maximum flux of these eruptions is generated in relatively short time scales, usually less than a million years. These eruptions have occurred throughout Earth's history in different locations around the world. The eruptions can release large amounts of greenhouse gases such as carbon dioxide, sulfur dioxide and hydrogen sulfide. When these gases are released into the upper troposphere and lower stratosphere they can create global warming effects and affect Earth's climate for many years (Thordarson and Self, 1996; Self et al., 1997). Consequently, these types of eruptions have been linked to mass extinction events throughout Earth's history. For example, the largest recorded extinction event, when approximately $90 \%$ of the species on Earth became extinct (Permian Extinction), occurred around the same time as the Siberian Traps (largest LIP eruption), approximately 250 million years ago (Renne, 2002).

Most CFB's are assumed to have been formed by hot spot or mantle plume activity. It has been proposed that a mantle plume is necessary to account for the unique characteristics of LIPs (Brandon and Goles, 1988; Richards et al., 1989; Campbell and Griffiths, 1990; Hooper, 1990). Studying flood basalt eruptions, therefore, may yield 
important information on melt generation processes in LIPs and other products of plume related activity such as ocean island basalts (OIB) like those of the Hawaiian Islands.

In addition, the study of LIPs can lead to information on magma generation and transport and the role of global tectonics. For example, at approximately $30 \mathrm{Ma}$ the North American plate collided with the East Pacific Rise changing the tectonic setting of the Pacific Northwest. This change caused the strike slip motion that created the San Andreas Fault system (Atwater, 1970), and an extensional regime further east which created the Basin and Range province (Christiansen and Lipman, 1972). Dickinson (1997) proposed that torsional deformation of the North American continental block that occurred in response to shear movement imposed by the Pacific plate, created a mantle perturbation. This mantle perturbation in turn could have caused a type of decompressional melting in the CRBG plateau that perhaps aided in the formation of the voluminous Columbia River Basalt Group (CRBG) flows (Dickinson, 1997).

\section{Columbia River Basalt Group}

The CRBG of the Pacific Northwest is the smallest, youngest and most wellpreserved continental flood basalt province (Waters, 1961; Watkins and Baksi, 1974; McKee et al., 1977; 1981; Swanson et al., 1979; Hooper, 1982, 1984, 2000, Hooper et al., 2002; Reidel, 1983, Reidel et al., 1989, Reidel and Tolan, 1992; Swanson, et al., 1989). The CRBG has been extensively studied for insights into the processes that create rapid voluminous basalt eruptions on continents as well as on the ocean floor (Waters, 1961; Watkins and Baksi, 1974; McKee et al., 1977; 1981; Baksi, 1989). Although small when compared to other flood basalts, the CRBG contains over $234,000 \mathrm{~km}^{3}$ of lava (Camp and Ross, 2004). Some individual lava flows extend from western Idaho all the way to the 
Pacific Ocean approximately $600 \mathrm{~km}$ away (Shaw and Swanson, 1970; Reidel et al., 1989), making them the longest known lava flows on Earth. Major and trace-element compositions do not change over the entire lengths of some of these flows (Shaw and Swanson, 1970). Typical flow volumes are 10 to $20 \mathrm{~km}^{3}$ (Basaltic Volcanism on Terrestrial Planets, BVTP, 1981). Lava flow thickness range from a few meters up to 45 $\mathrm{m}$, with an average thickness of $30 \mathrm{~m}$ (BVTP, 1981). The basalts cover an area of approximately $200,000 \mathrm{~km}^{2}$ occupying parts of Washington, Oregon and Idaho (Waters, 1961); (Figure 1).

The lavas of the CRBG erupted between 17 and 6 million years ago (Watkins and Baksi, 1974; McKee et al., 1977, 1981; Swanson et al., 1979), through fissures that became the Chief Joseph dike swarm near the mutual borders of Idaho, Washington, and Oregon. Recently, Hooper et al. (2002) and Camp (1995), Camp et al. (2003) and Camp and Ross (2004) have proposed the inclusion of lava formations south of the CRBG plateau, mainly the Steens Mountain Basalt, and younger eruptions of high alumina basalts, termed the Oregon Plateau Basalts (OPB in Figure 1). Furthermore, Coe et al. (2005) propose that the Lovejoy Basalts of northeastern and central California could possibly be related to the same magma generation event. The addition of these formations would increase both the areal extent and volume of the CRBG. It is doubtful however, that this increase would change the current status of the CRBG, considering that other flood basalt provinces such as the Siberian Traps and Ontong Java Plateau are orders of magnitude larger than the CRBG (Reichow et al., 2002) and have erupted over a million $\mathrm{km}^{3}$ of basalt (Reichow et al., 2002; and others). 


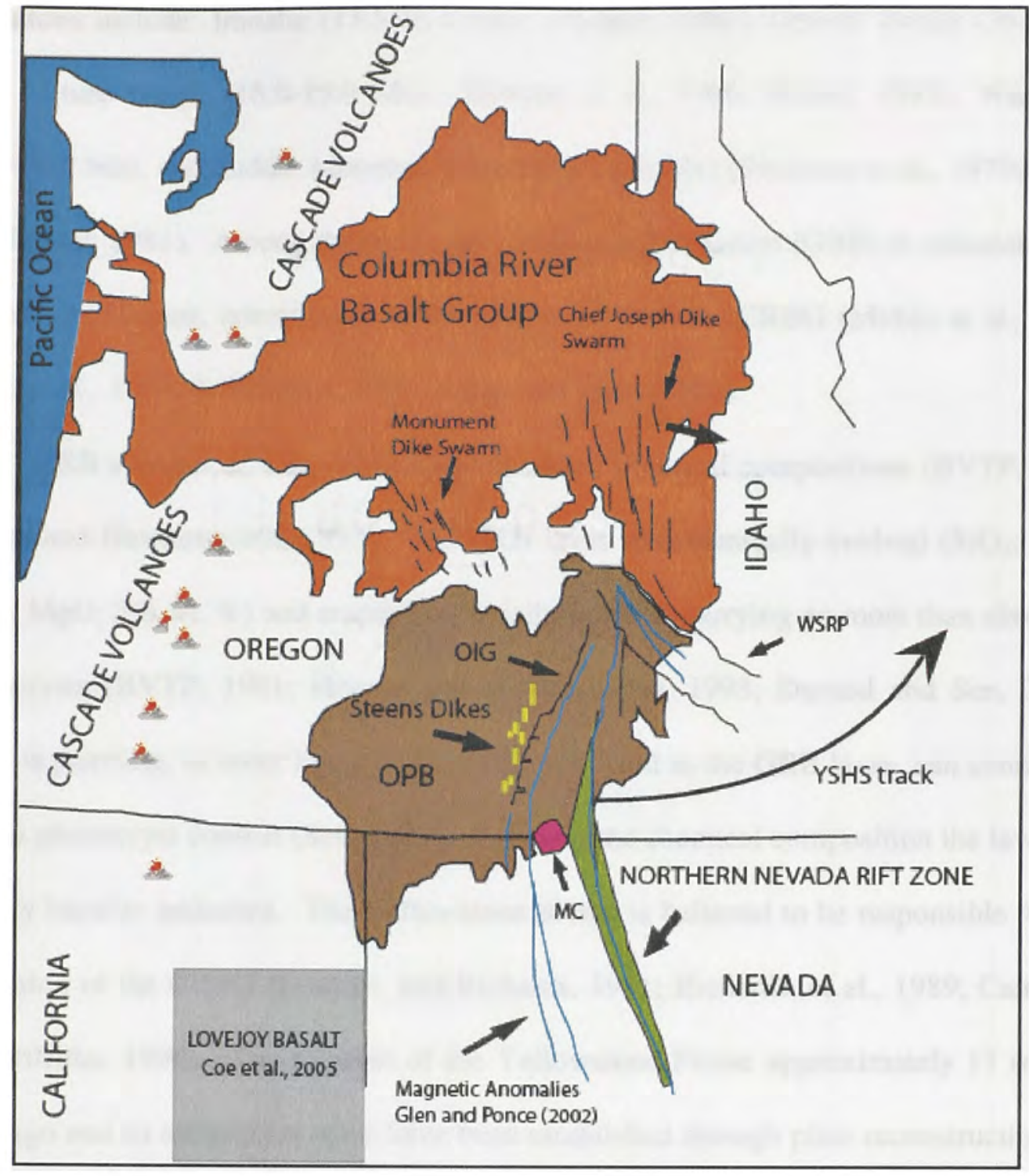

Figure 1-Map of Columbia River Basalt Group adapted from Camp and Ross, 2004; Coe et al., 2005. Map shows proposed additions to the flood basalt province, namely the Oregon Plateau Basalt and the Lovejoy Basalt. OIG-Oregon Idaho Graben; OPB-Oregon Plateau Basalt; MC-McDermitt Caldera; YSHSYellowstone Hotspot; WSRP-Western Snake River Plain. 
The CRBG has been formally divided into five formations based on age and first order geochemical differences (Waters, 1961; Swanson et al., 1979) (Figure 2). These formations include: Imnaha (17.5-16.5 Ma); (Hooper, 1984), Grande Ronde (16.5-15.6 Ma); Picture Gorge (16.0-15.0 Ma), (Mangan et al., 1986; Reidel, 1983), Wanapum (15.6-14.5 Ma), and Saddle Mountain Basalt (14.5-6.0 Ma) (Swanson et al., 1979; Camp and Hooper, 1981). Among them, the Grande Ronde Formation (GRB) is volumetrically the most significant, constituting about $63 \%$ to $87 \%$ of the CRBG (Mckee et al., 1977; Reidel et al., 1989; Tolan et al., 1989; Camp and Ross, 2004).

GRB consists of $4 \mathrm{~km}$ of flows with varied chemical compositions (BVTP, 1981; Hooper and Hawkesworth, 1993). The GRB lavas are chemically evolved $\left(\mathrm{SiO}_{2}: 52-57\right.$ wt. \%, MgO: 3-6 wt. \%) and erupted essentially as melts carrying no more than about 5\% phenocrysts (BVTP, 1981; Hooper and Hawkesworth, 1993; Durand and Sen, 2004), which is puzzling, as other lavas as chemically evolved as the GRB lavas, can contain up to $15 \%$ phenocryst content (Sen, 1983). Based on the chemical composition the lavas are actually basaltic andesites. The Yellowstone plume is believed to be responsible for the generation of the CRBG (Duncan, and Richards, 1991; Richards, et al., 1989; Campbell and Griffiths, 1990). The location of the Yellowstone Plume approximately 17 million years ago and its subsequent track have been established through plate reconstructions by Engebretson et al. (1984) and Pierce and Morgan (1992); they place the plume near the CRBG eruptive center in southeastern Oregon during the time of the eruptions of the Grande Ronde Formation. 


\begin{tabular}{|c|c|c|c|c|c|}
\hline Group & Formation & Member & Samples & Age & $\begin{array}{l}\text { Magnetic } \\
\text { Polarity }\end{array}$ \\
\hline & $\begin{array}{l}\text { Saddle } \\
\text { Mountain }\end{array}$ & $\begin{array}{l}\text { See Reidel and } \\
\text { others (1989) }\end{array}$ & & 6.0 & \\
\hline & Wanapum & $\begin{array}{l}\text { See Reidel and } \\
\text { others (1989) }\end{array}$ & & 14.5 & \\
\hline & \multirow{10}{*}{ 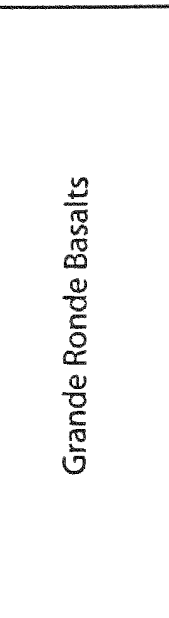 } & SentinelBluffs Unit & $\begin{array}{l}\text { GR-SBM2269, } \\
\text { GR-SBM2570, } \\
\text { GR-SBM2978 }\end{array}$ & \multirow[t]{15}{*}{15.6} & \multirow{6}{*}{ N2 } \\
\hline & & Slack Canyon Unit & & & \\
\hline & & $\begin{array}{l}\text { Field Spring Unit } \\
\text { Winter Water Unit }\end{array}$ & & & \\
\hline & & Umtanum Unit & GR-U3406 & & \\
\hline & & Ortley Unit & $\begin{array}{l}\text { GR-O4014, } \\
\text { GR-O4352 }\end{array}$ & & \\
\hline & & $\begin{array}{l}\text { Armstrong Canyon } \\
\text { Unit }\end{array}$ & & & \\
\hline & & Meyer Ridge Unit & & & \multirow{3}{*}{ R2 } \\
\hline & & $\begin{array}{l}\text { Wapshilla Ridge } \\
\text { Unit } \\
\text { Grouse Creek Unit }\end{array}$ & & & \\
\hline & & Mt. Horrible Unit & & & \\
\hline & & China Creek Unit & $\mathrm{CHI}-40$ & & \multirow[b]{2}{*}{ N1 } \\
\hline & \multirow{3}{*}{ 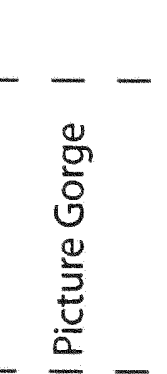 } & Downey Gulch Unit & $\begin{array}{l}\mathrm{CHI}-38,39,41 \\
44,45\end{array}$ & & \\
\hline & & Center Creek Unit & $\begin{array}{l}\text { GR-17, 18, } \\
\text { CHI-30-32, } \\
\text { CHI-34, 36 }\end{array}$ & & \\
\hline & & Rogersburg Unit & $\begin{array}{l}\text { GR-13, } 16 \\
\text { CHI-29 }\end{array}$ & & \\
\hline & $\stackrel{2}{D}$ & Teepee Butte Unit & $\begin{array}{l}\text { GR-3, 8-10, } \\
\text { CHI-28 }\end{array}$ & & R1 \\
\hline & 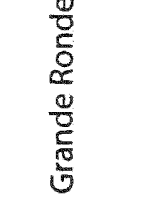 & $\begin{array}{l}\text { Buckhorn Springs } \\
\text { Unit }\end{array}$ & $\begin{array}{l}\text { GR-1, 2, } \\
\text { CHI-17-22, } 24\end{array}$ & & \\
\hline & Imnaha & $\begin{array}{l}\text { See Hooper and } \\
\text { others (1984) }\end{array}$ & & 17.5 & \\
\hline
\end{tabular}

Figure 2- Stratigraphic column of the Columbia River Basalts Group. Samples from the Grande Ronde Basalt Formation analyzed during this study are shown adjacent to the specific GRB units they were collected from. 
The plume or hot spot track can be traced from the site of the initial eruptions which produced a rhyolitic field approximately 16.5 Ma through the silicic Eastern Snake River Plain (ESRP) and ending in Wyoming at the Yellowstone caldera, where the plume is thought to be at the present time.

Several questions remain unanswered regarding the genesis of the CRBG. For example, if the Yellowstone Plume was indeed responsible for the CRBG eruptions, then why was it located $500 \mathrm{~km}$ south of the eruptive vents that fed the CRBG at $16.5 \mathrm{Ma}$ ? There is also no evidence of a plume prior to this event (Geist and Richards, 1993). Furthermore, the lavas are different from other plume or hot spot related lavas in the lack of hot temperature magmas such as picrites. Picrites can be generated by the elevated temperatures associated with mantle plumes (Hooper, 1990 and others). In addition, the lavas erupted directly above the plume location are silicic, rather than the usual tholeiitic lavas associated with mantle plumes (Hooper, 1990 and others). Some investigators have attributed the silicic compositions to crustal anextesis of the continental and accreted oceanic crust in the area (Carlson et al., 1981; Carlson, 1984; Carlson \& Hart, 1988).

There are several other inconsistencies with a typical plume model. For example, it is coincidental that the purported plume track along ESRP eruptions also follows an ancient tectonic boundary (www.mantleplumes.org/CRB.html). In addition, volcanism directly above the projected plume path 16.5 million years ago appears to extend to the north (CRBG), east (ESRP), and west (Newberry Trend). This "mirror" volcanism is difficult to explain with a simple eastern-tracking plume migration hypothesis. Volcanism appears to move northward to create the mostly tholeiitic CRBG, while at the same time producing a rhyolite field directly above, the silicic Brothers Fault volcanics 
(Newberry trend) to the northwest, and the ESRP to the east (Camp et al., 2003; and others).

Because the eruptive vents for the CRBG are located approximately $500 \mathrm{~km}$ north of the projected plume location at the time of major eruptions $(\sim 16.5 \mathrm{Ma})$, it has been proposed that the lava traveled long distances in a similar manner to what has been seen on other planets (e.g., Mars), where giant radiating dike swarms have been seen around plume-like structures (Ernst et al., 1995). Camp and Ross (2004) suggest that the CRBG dikes are similar in scale and pattern to radiating swarms indicating a radial geometry. Ernst and Buchan (2003) reconstructed the orientation of the Chief Joseph dike swarm, the Monument dike swarm, and the Northern Nevada Rift Zone and found that these triangulate to a focal point east of Steens Mountain. Camp and Ross (2004) suggest that this point may have been the central location of a mantle plume at $17 \mathrm{Ma}$. This point also marks the site of the earliest eruptions of Steens Mountain (Hooper et al., 2002), which has been described as a shield volcano (Mankenin et al., 1987). A circular magnetic anomaly near the crest of the mountain delineates the volcano's central vent (Camp and Ross, 2004). The lavas are tholeiitic (becoming mildly alkalic up section) and are thinner and more complex, typical of shield volcano development (Clague and Moore, 1991). Camp and Ross (2004) postulate that giant radiating dike swarms fed the CRBG as well as the Steens Mountain basalts. In spite of difficulties with plume models, both plume and non-plume models continue to be invoked for the origin of CRBG lavas. An alternative non-plume proposal is that the CRBG magmas formed due to back arc spreading behind the Cascade arc and at the northern end of the Basin and Range province (Hart and Carlson, 1987; Carlson and Hart, 1988; Swanson et al., 1989; Smith, 
1992). White and Mackenzie (1989) proposed that the lithospheric thinning was caused by plume-related extension. Whether the extension was the cause or a consequence of the eruptions remains a topic of some debate (Hooper, et al., 2002; White and Mackenzie, 1989; Richards et al., 1989; Hooper, 1990).

The absence of the proposed mantle plume directly beneath the CRBG plateau prior the eruption of the CRBG is intriguing. Geist and Richards (1993) propose that the mantle plume was blocked by the subducting Farallon plate and thus the surface did not exhibit any prior mantle plume activity. At approximately $17.5 \mathrm{Ma}$, They suggest that the plume head penetrated the subducting plate and broke through the slab. This event caused the plume head to be deflected north, placing the plume head beneath the eruptive center for the CRBG (Figure 3). Once the plume head was sheared off as the North American plate moved over the plume, the plume tail recovered to a near vertical conduit and continued on its original northeast path forming the Snake River plain and Yellowstone plateau. The Geist and Richards model explains both the absence of plume activity prior to the CRBG and why the eruptive vents for the CRBG were located so far north (approximately $500 \mathrm{~km}$ ) of the projected plume path. Pierce and Morgan (1992) proposed a similar model in which a mantle plume intercepted the base of the lithosphere approximately 16.5 Ma. The plume head spread outward to generate the CRBG and other volcanic outpourings near the Oregon-Idaho-Nevada border (Pierce and Morgan, 1992).

A petrologic model has been proposed by Takahashi et al. (1998); that calls for a subducted component (eclogite) entrained in a mantle plume (Figure 4). 


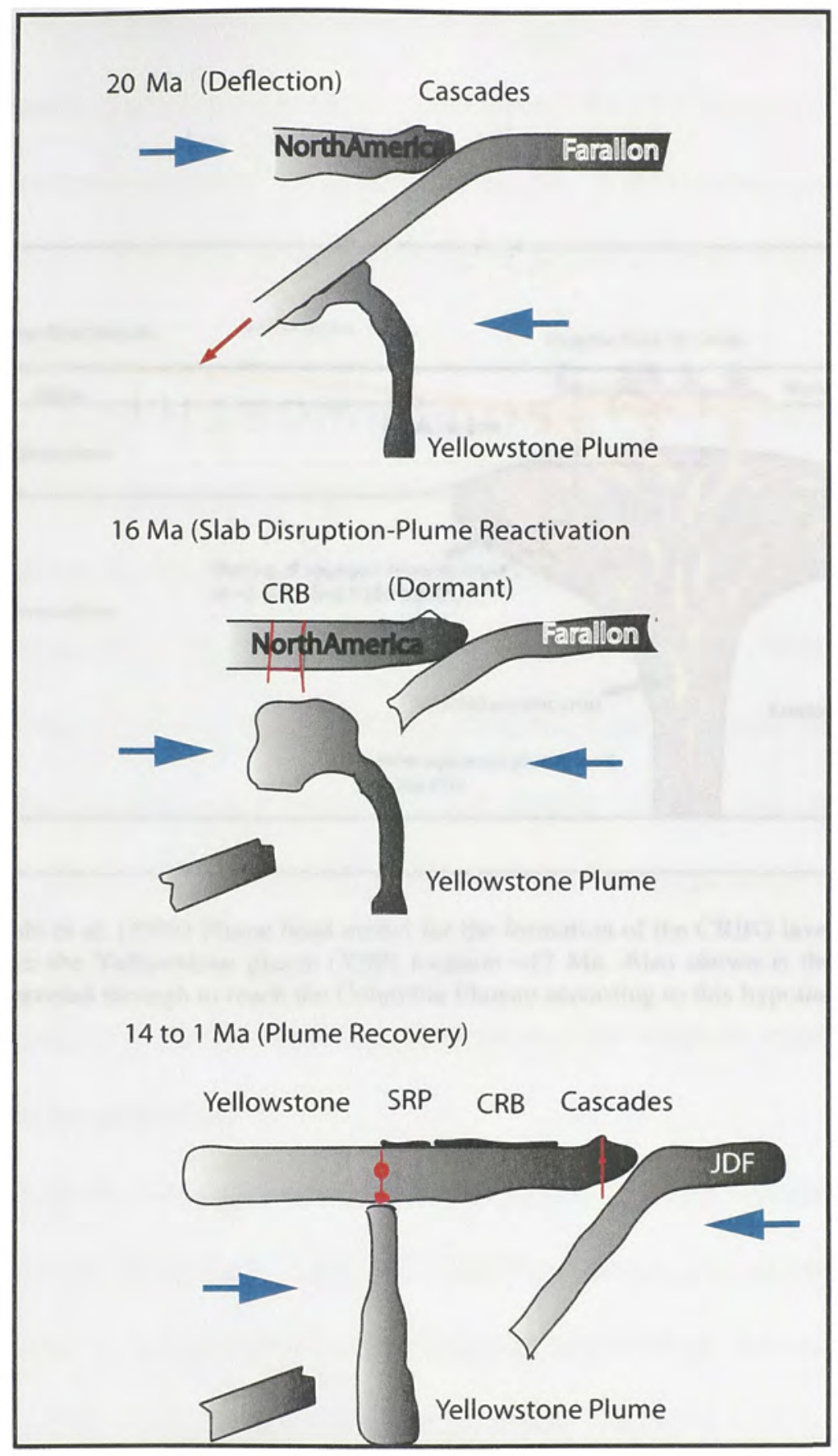

Figure 3-Geist and Richards model depicting the Yellowstone plume being deflected by the Farallon plate. This caused the plume head to move under the Columbia plateau approximately 17.5 Ma. The plume tail recovered and continue to its present location beneath the Yellowstone caldera in Wyoming. CRBColumbia River Basalts; SRP-Snake River Plain; JDF-Juan de Fuca Plate. 


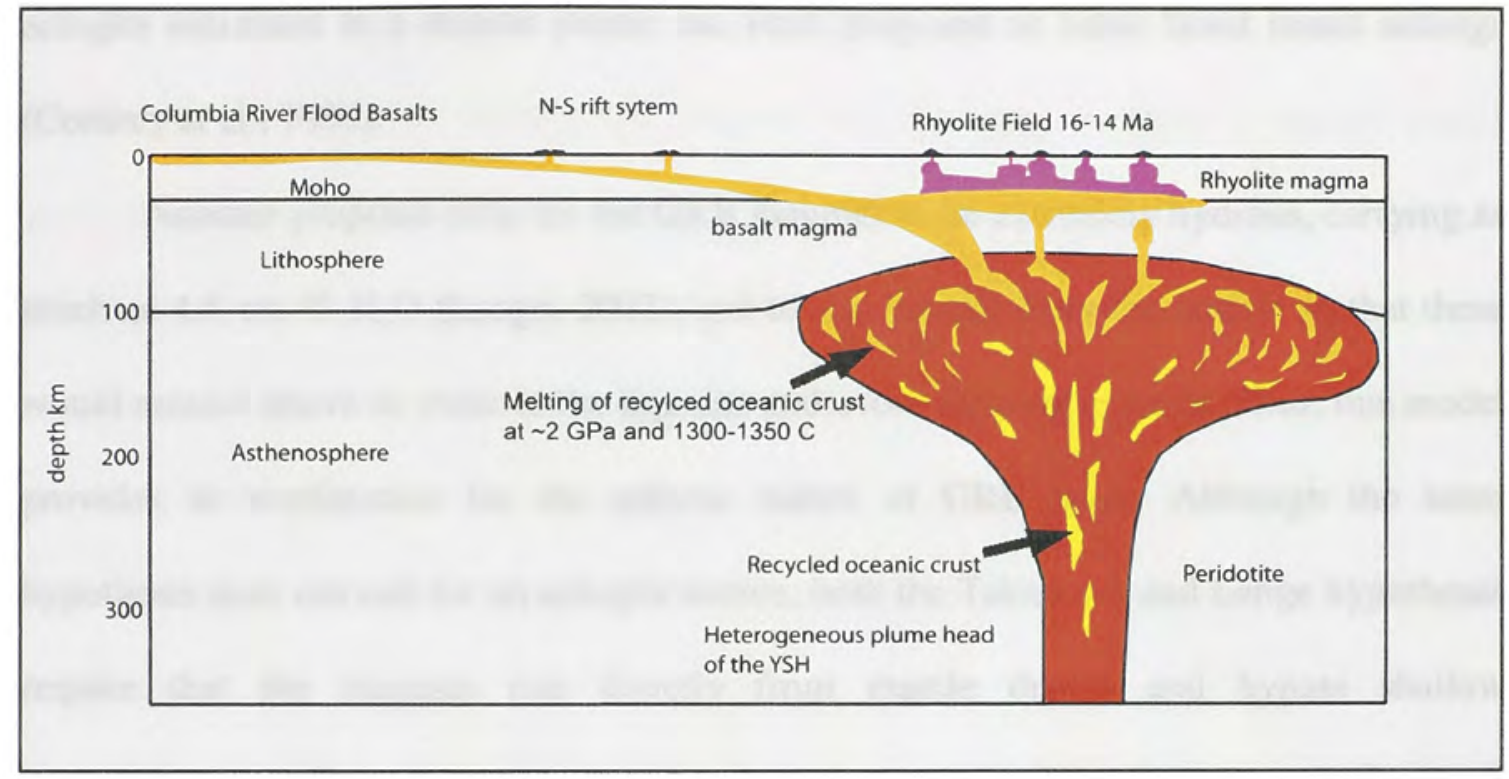

Figure 4- Takahashi et al. (1998) Plume head model for the formation of the CRBG lavas and the rhyolitic field directly above the Yellowstone plume (YSP) location $\sim 17 \mathrm{Ma}$. Also shown is the North South rift system the lavas traveled through to reach the Columbia Plateau according to this hypothesis. 
The authors proposed that many of the GRB magmas were produced by $30-50 \%$ melting of the eclogite. The Takahashi et al. (1998) model suggests that the GRB are primary or near-primary melts that originated near the crust-mantle boundary and bypassed any shallow-level fractionation prior to eruption (Figure 4). A subducted component such as eclogite entrained in a mantle plume has been proposed in other flood basalt settings (Cordrey et al., 1997).

Another proposal calls for the GRB magmas to be extremely hydrous, carrying as much as 4.4 wt. $\% \mathrm{H}_{2} \mathrm{O}$ (Lange, 2002), and to rise rapidly from the mantle so that these would remain above or close to the liquidus and avoid forming crystals. Thus, this model provides an explanation for the aphyric nature of GRB lavas. Although the latter hypothesis does not call for an eclogite source, both the Takahashi and Lange hypotheses require that the magmas rise directly from mantle depths and bypass shallow crystallization. This scenario is required because shallow-level crystallizationdifferentiation processes would result in degassing of the magmas and would also sufficiently modify the original melt signature so that the original mantle-equilibration history could not be unraveled.

Analysis of the GRB phenocrysts (Durand and Sen, 2004; Caprarelli and Reidel, 2004, 2005); provide evidence for shallow level fractionation. For example, GRB lavas plot near the 1-atm pseudo cotectic on the cpx-ol-qz and pl-ol-qz diagrams (Durand and Sen, 2004, see figure 28 in Chapter 3). The presence of a shallow level magma chamber, where such fractionation could occur, has been disputed by Hooper et al. (1982) and others. They point to the lack of large collapse structures, such as calderas, on the surface. Others (Reidel et al., 1984) suggest that the Pasco Basin subsided both before, 
during and after the main lava eruptions, perhaps as a result of the collapse of a large magma chamber at shallow depths. If crystal fractionation of a partial melt of an upper mantle peridotite (thought to be the source rock of most plumes) was the source for the CRBG lavas, then the source magma must have fractionated in a crustal magma chamber(s) before erupting; and extremely efficient crystal separation had to occur in order for these magmas to erupt with virtually no phenocrysts. Such a process would leave behind gabbro cumulates at shallow depths beneath the feeder dikes. Seismic velocity and density measurements beneath the Columbia River plateau suggest that a high density layer is not present (Catching and Mooney, 1988; Saltus, 1993) however, geophysical data in the area is difficult to obtain and therefore the findings thus far are not conclusive and more analyses are needed to verify this assumption (Reidel, S.P., pers. comm.).

As is apparent from the numerous petrogenic models presented above, there is no consensus on what caused the eruption of large volumes of lava in the Columbia Plateau, or whether the resultant basaltic andesites are low-pressure fractionates or primary melts. This study focuses primarily on the Grande Ronde Basalts given that they constitute over $63 \%$ of the entire volume of the CRBG (Camp and Ross, 2004 and others).

The remainder of this dissertation will be subdivided into four parts. Chapter two will include field and petrographic studies. Chapter 3 will discuss the mineral chemistry of the Grande Ronde lavas, emphasizing the phenocrysts, since these constitute one of the most puzzling aspects of this formation. Although phenocrysts comprise less than $5 \%$ phenocryst in these rocks, a substantial study of major and minor element variations was conducted. Groundmass analyses of major and minor elements were also performed. 
Both a petrographic study using a transmitted light microscope and an electron microprobe study were conducted. Chapter 4 focuses on computer simulations of the potential Grande Ronde parental magmas in order to explain the origin of the lavas, i.e., pressure, temperature, $\mathrm{H}_{2} \mathrm{O}$ content and phase appearance. The computer simulation programs COMAGMAT (Ariskin, 1993) and MELTS (Sack and Ghiorso, 1994) were used in the simulations. Chapter 5 presents the summary and conclusions followed by a discussion of two tectonic models for the generation of the CRBG, and finally a proposal for future work. 


\section{CHAPTER 2.}

\section{FIELD STUDY AND PETROGRAPHY}

Lava flows

The CRBG lavas were generated as large fissure eruptions that poured from large dike swarms concentrated in the eastern edge of the plateau near the Idaho-Washington border. Flows up to $>600 \mathrm{~km}$ in length have been reported (Ho and Cashman, 1997; Tolan et al., 1989). The Pomona flow traveled from the site of eruption in western Idaho to the Pacific Ocean $600 \mathrm{~km}$ away, making it one of the longest known lava flows on Earth (Tolan et al., 1989). If not impeded by the ocean, this flow could have possibly been longer (Keszthelyi and Self, 1998). Additionally, the Gingko flow of the Wanapum Formation, traveled approximately $500 \mathrm{~km}$ covering more than $37,000 \mathrm{~km}^{2}$ (Ho and Cashman, 1997). Interestingly these flows have been reported to be extremely homogenous in bulk composition and texture. The GRB in particular seems to be remarkably homogenous considering its large volume $\left(149,000 \mathrm{~km}^{3}\right)($ Swanson et al., 1979). During peak activity of the CRBG, the average interval between major eruptions was approximately 13,500 years and the average volume per major flow was about 1350 $\mathrm{km}^{3}$ (Tolan et al., 1989).

\section{Columnar Jointing}

In general, columnar basalts have internal jointing classified as colonnades and entablatures (Figure 5). The term colonnade refers to small columns of fine-grained basalt that are generally restricted to the top and bottom of the lava flow. 


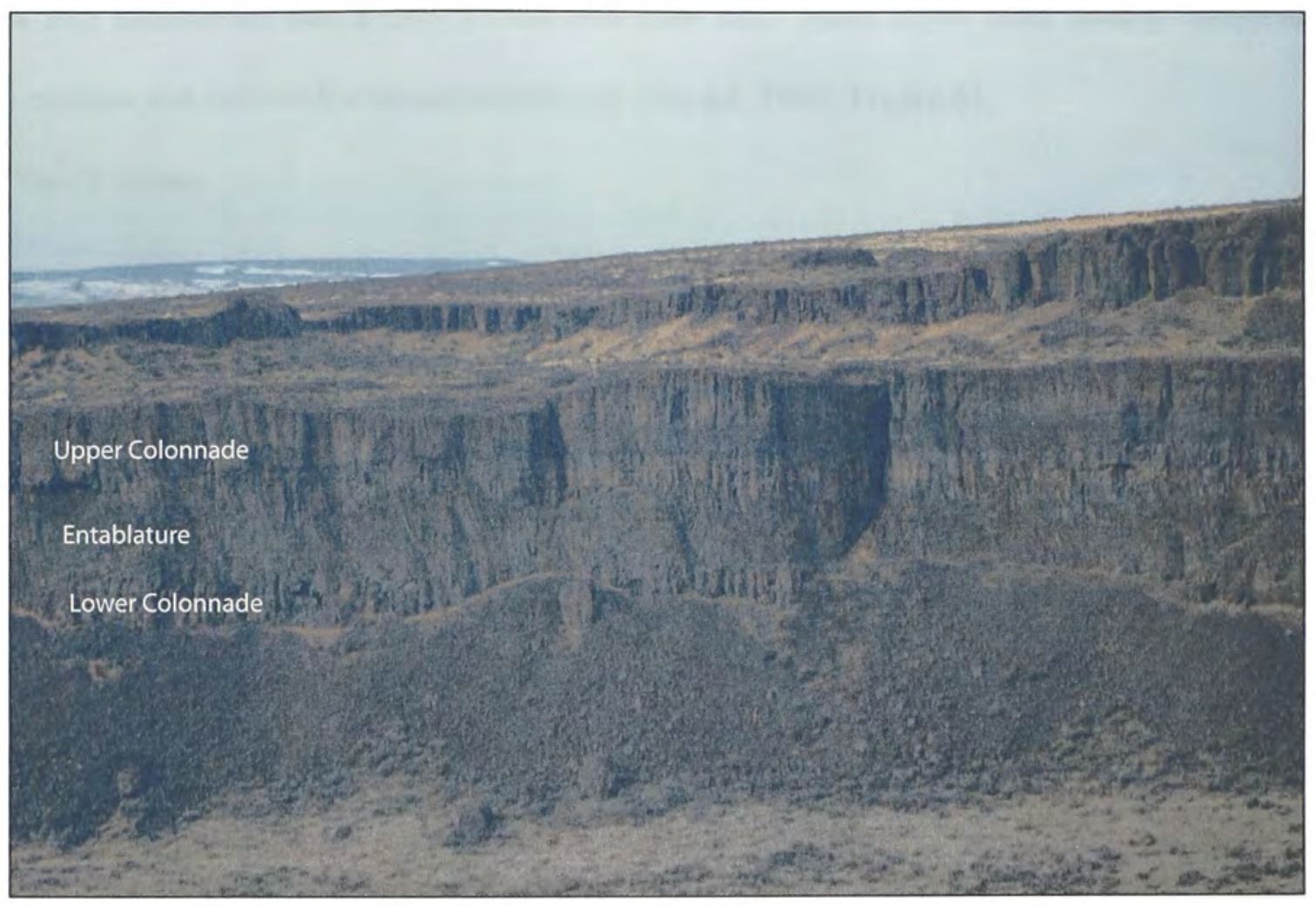

Figure 5- Lava flows of the Columbia River Basalt Group in Washington State. The CRBG flows form extensive plateaus composed of numerous layers of lava. Picture displays the columnar basalt features seen throughout the CRBG plateau, with upper and lower colonnade and entablature structures (see text below for discussion). 
Colonnades show quench textures which indicate they cooled more rapidly than the coarser and therefore slower cooling entablature structure that lies in between the upper and lower colonnades (Long and Wood, 1987). According to Reidel (1983), a typical basalt flow in the CRBG plateau is composed of three parts, a well-developed colonnade, a thin entablature and a thin scoriaceous flow top. Most flows have stubby, irregular columns and lack well-defined entablature (Reidel, 1983; Figure 6).

Vent Systems

Dikes and vents that fed the CRBG are concentrated in the southeast corner of the plateau (Swanson et al., 1979). These dikes are generally a few meters wide but can be wider than 20 meters in some locations (Swanson, 1970; Figure 7). NNW-oriented fissures 10 to over $100 \mathrm{~km}$ in length and up to several meters wide fed the extensive lava flows of the CRBG (Swanson et al., 1979). Average lava flows are 30 to $50 \mathrm{~m}$ thick but can be as much as $100 \mathrm{~m}$ thick (Reidel, 1983, 2005). Most of the dikes are restricted to the thinner, and more mafic, accreted terrains of the Blue Mountain province in northeastern Oregon (Hooper, 2003). Evidence for multiple magmatic intrusions within a single dike can be seen in thin sections analyzed in this study. Mingling of at least two different magmas is evident from the textures illustrated in figure 8. One of the magmas is fine grained and glassy while the other is more coarse grained. This observation suggests that magma conduits were long-lived and were replenished more than once.

The two major feeder dike swarms are the Chief Joseph dike swarm, and the Monument dike swarm (Waters, 1961; Swanson et al., 1979; see figure 1 in INTRODUCTION). 


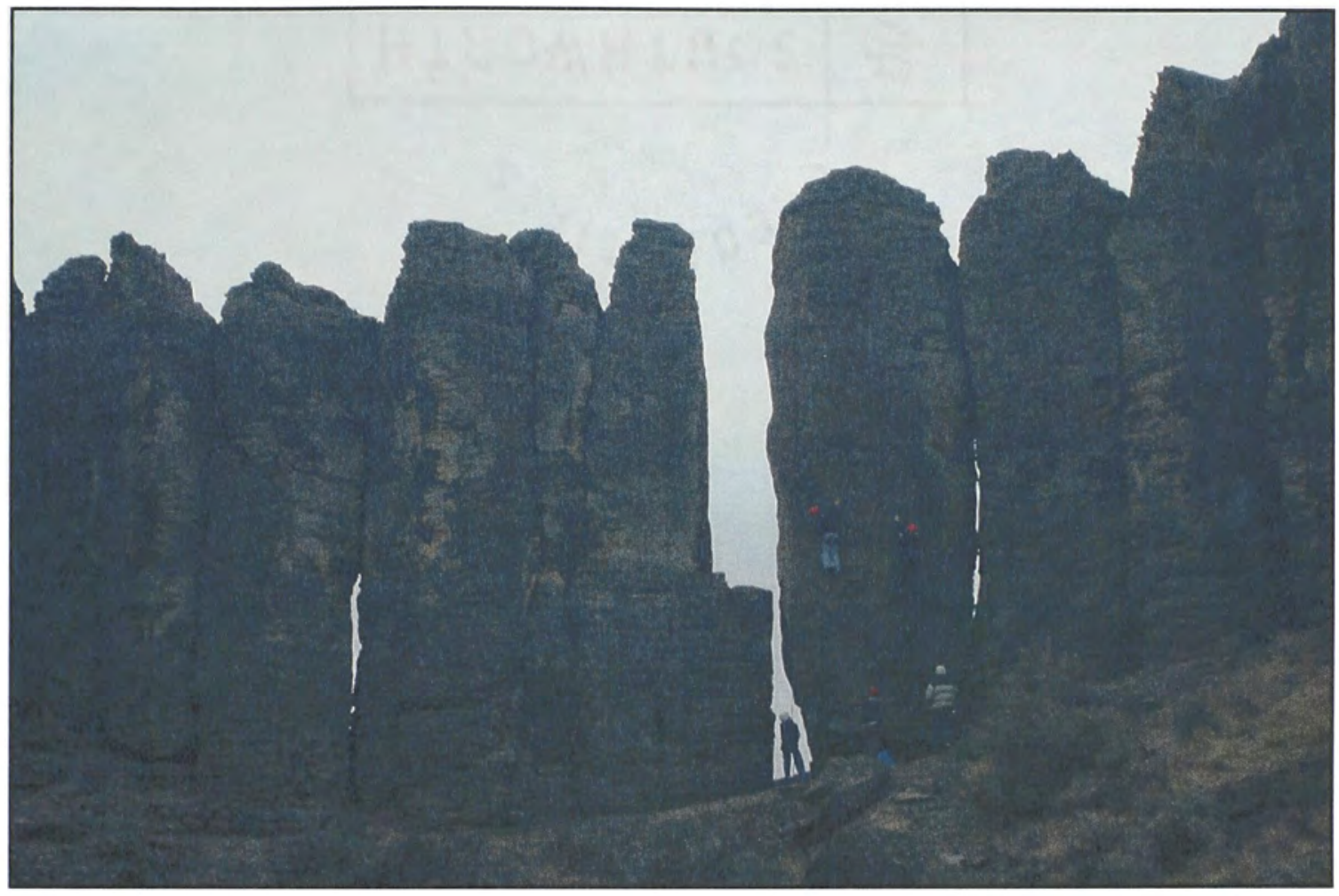

Figure 6- Basaltic columns of the Roza flow (Wanapum Basalt Formation) of the Columbia River Basalt Group, located in Washington State. 


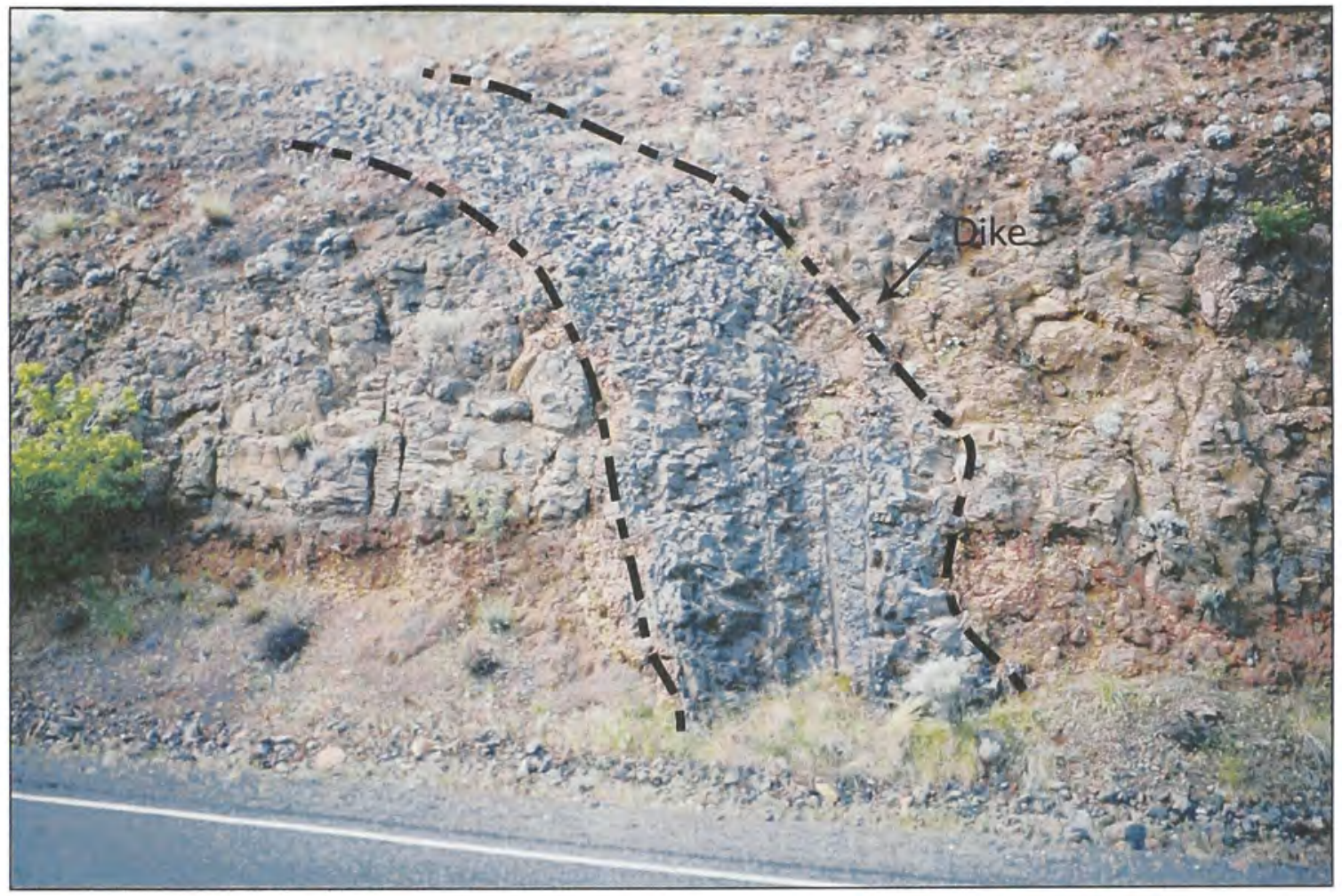

Figure 7- Exposed Roza dike that fed the Roza flow of the CRBG Wanapum Formation located in Washington State. 
The majority of the CRBG lavas were erupted from the Chief Joseph dike swarm, including the Imnaha, GRB, Wanapum, and Saddle Mountain basalt formations. The Monument dike swarm produced the Picture Gorge Basalt, which has similar chemical compositions to the Imnaha Formation but, are more primitive and are similar to some of the Basin and Range lavas (Hooper, 1984; Hooper and Hawkesworth, 1993).

Here, I report the textural features and mineral chemistry of the phenocrysts in Grande Ronde Formation lavas from two well-known field sections-the Grande Ronde Formation section (type section), the China Creek section (cf. Reidel, 1983), the Sentinel Bluffs Member, and informal members; Umtanum and Ortley (See Figure 2 in INTRODUCTION). GR and China Creek samples were previously analyzed for major, trace, and isotope chemistry by others (Hooper, 1982; Reidel et al., 1989; Swanson et al., 1979; Hooper and Hawkesworth, 1993; Mangan et al., 1986; Hooper et al., 2002, and references therein).

\section{SAMPLE SELECTION}

Samples examined in the present study encompass the lower to middle sections of the Grande Ronde Formation, from the Buckhorn Springs unit to the China Creek unit, representing two magnetostratigraphic units, R1 and N1 (See Figure 2 in INTRODUCTION). Samples were also analyzed from the middle to upper sections of the GRB formation (Umtanum and Ortley) and from the youngest member of the GRB, the Sentinel Bluffs Member. These represent the N2 magnetostratigraphic unit (See Figure 2 in INTRODUCTION). The bulk of the samples analyzed here were collected by S.P. Reidel and P.R. Hooper and were previously analyzed for elemental and isotopic compositions by Reidel (1983) and Hooper and Hawkesworth (1993). 


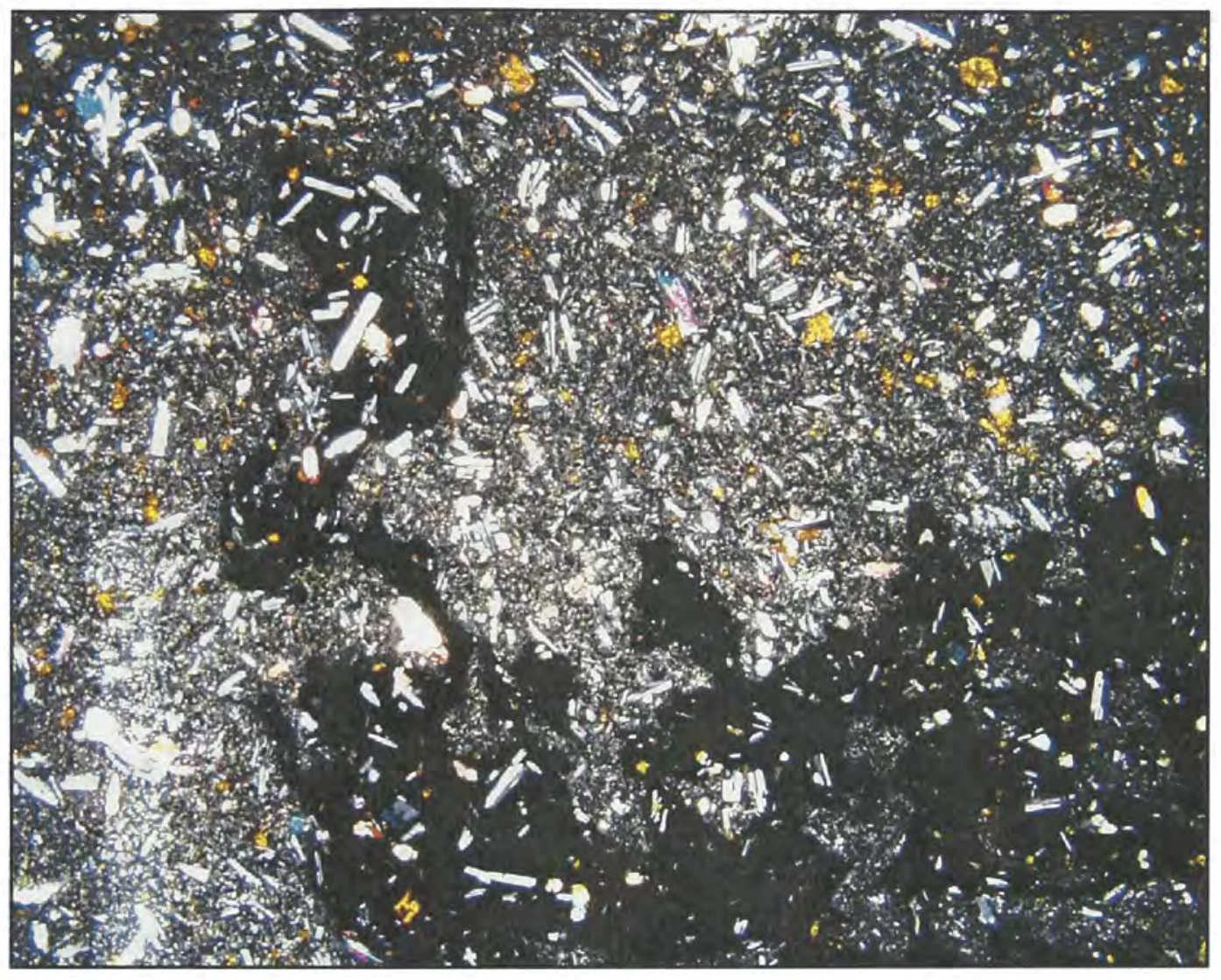

Figure 8-Cross-polarized image of a dike thin section showing products of at least two different magmas, indicating that the same dike was used by at least two or more batches of magma that mingled in the dike. (Width of field of view represents $5.2 \mathrm{~mm}$ ). 
Additionally, I collected samples across the width of a GRB dike, from chilled margin, through the interior, to chilled margin of each dike. Imnaha dike samples were collected by H. Petcovic.

\section{METHOD OF STUDY}

Thirty-one rock thin sections were initially inspected using an optical microscope and were then analyzed at the Florida Center for Analytical Electron Microscopy (FCAEM), Florida International University (FIU), on a fully automated electron microprobe (JEOL Superprobe, JSM-8900R) equipped with five wavelength dispersive spectrometers (WDS) and an energy dispersive spectrometer (EDS). All analyses reported here were analyzed with WDS. The operating conditions included an accelerating voltage of $15 \mathrm{kV}$ and $20 \mathrm{nA}$ current at the Faraday cup. The probe diameter was 1-2 $\mu \mathrm{m}$ and all analyses were performed in a fixed spot mode. Standards used for $\mathrm{Mg}$, and $\mathrm{Fe}$ were olivine (ol), ol and plagioclase $\left(\mathrm{An}_{65}\right)$ for $\mathrm{Si}$, plagioclase $\left(\mathrm{An}_{65}\right)$ and pyrope-garnet for $\mathrm{Al}$, plagioclase $\left(\mathrm{An}_{65}\right)$ and diopside- 2 for $\mathrm{Ca}, \mathrm{Cr}_{2} \mathrm{O}_{3}$ for $\mathrm{Cr}$, rutile for $\mathrm{Ti}$, albite- 2 for $\mathrm{Na}$, orthoclase and sanidine for $\mathrm{K}$, and rhodonite (2) for Mn. The on-peak time was 10 seconds for both standard and unknown and five seconds for the high and low background on each element mentioned above. The electron beam was extremely stable and counting statistics were excellent, so that standard analysis was reproducible to within $+/-2 \%$ of the absolute values for all major elements. The $\varphi \rho Z$ (CITZAF) correction program (Goldstein et al., 1992) was utilized to correct for the effects of matrix, density, and atomic number. Several spot analyses were performed on the samples in order to minimize analytical uncertainties of sodium loss on all the phenocryst 
phases. Methods similar to Keshav and Sen (2001) were adopted for analyzing for sodium.

In addition, backscatter electron images were collected on the various textural features found in GRB lavas. These include: zoning patterns and resorption features of major minerals, generally plagioclase and clinopyroxene.

\section{PETROGRAPHY}

Basaltic andesites from the GRB flows are generally aphyric to sparsely phyric $(<5 \%)$. The modal percent of phenocrysts in individual flows stays relatively constant with stratigraphic height. The phenocrysts mainly consist of plagioclase and augite $(60 \%$ Plagioclase, $40 \%$ pyroxene). Textures vary from slightly porphyritic to intergranular and intersertal.

Plagioclase (average size $1.5 \mathrm{~mm}$ ) and augite $(0.3-1.0 \mathrm{~mm}$ ) are the most common phenocryst phases, with plagioclase being dominant. Some small relatively Fe-rich, olivine $\left(\mathrm{Fo}_{30-50}\right)$ crystals do occur in the groundmass of some samples, but whether they are a part of the groundmass or are microphenocrysts is not clear. Larger phenocrysts of olivine (altered to iddingsite) are present $(<1 \%)$ in some flows. Pigeonite and orthopyroxene phenocrysts are generally rare (see also Reidel, 1983). Iron-titanium oxide phenocrysts were not found in any of the flows studied.

The groundmass is generally microcrystalline to glassy composed of plagioclase, augite, olivine (rare), pigeonite, Fe-Ti oxides and black and light brown glass. Iron oxides are generally restricted to the groundmass and these are Ti-magnetites and ilmenites with euhedral to subhedral morphologies. 
Pockets of rhyolitic glass are found in the groundmass of several of the thin sections analyzed (CHI-45). Rhyolitic glass is also found as inclusions in several plagioclase grains (CHI-45). The glass found in these thin sections is similar to those found by Lambert et al (1989) in all CRBG formations. They find two phases, described as a chlorophaeite-rich glass and a granite-glass. Several quartz (xenocrysts?) were found in some of the sections (GRB-2, GRB-17, and CHI-45). Secondary interstitial shallow level carbonate phases are sparsely located throughout the flows sections sampled.

Plagioclase

Plagioclase is the most abundant phase and has the largest sized phenocrysts in the GRB basaltic flows. Generally the phenocryst size averages approximately $1.5 \mathrm{~mm}$ in length and $0.002 \mathrm{~mm}$ in width. The rare larger phenocrysts can be up to $5.0 \mathrm{~mm}$ in length and $0.012 \mathrm{~mm}$ in width. The smaller phenocrysts or microphenocrysts are as small as $0.002 \mathrm{~mm}$. Crystals are labeled microphenocrysts if the grain is significantly larger than groundmass grains, but smaller than typical phenocryst grains $(>0.3 \mathrm{~mm})$. Although the plagioclase phenocrysts are the most abundant, these are still small in modal abundance $(<5 \%)$ compared to the total Grande Ronde flow volumes and as such the flows are considered aphyric to sparsely phyric. Phyric flows are found intermittingly in some of the GRB flows (i.e., GRB-10, GRB-16), however the overall majority of the formation is aphyric. Plagioclase phenocrysts and microphenocrysts are found as single crystals and as crystal aggregates or as glomeroporphyritic clusters. These clusters in some cases contain only plagioclase grains (Figure 9). However, plagioclase clusters are found with clusters of pyroxene grains (Figure 10). Most plagioclase phenocrysts are tabular with euhedral to subhedral morphologies. 


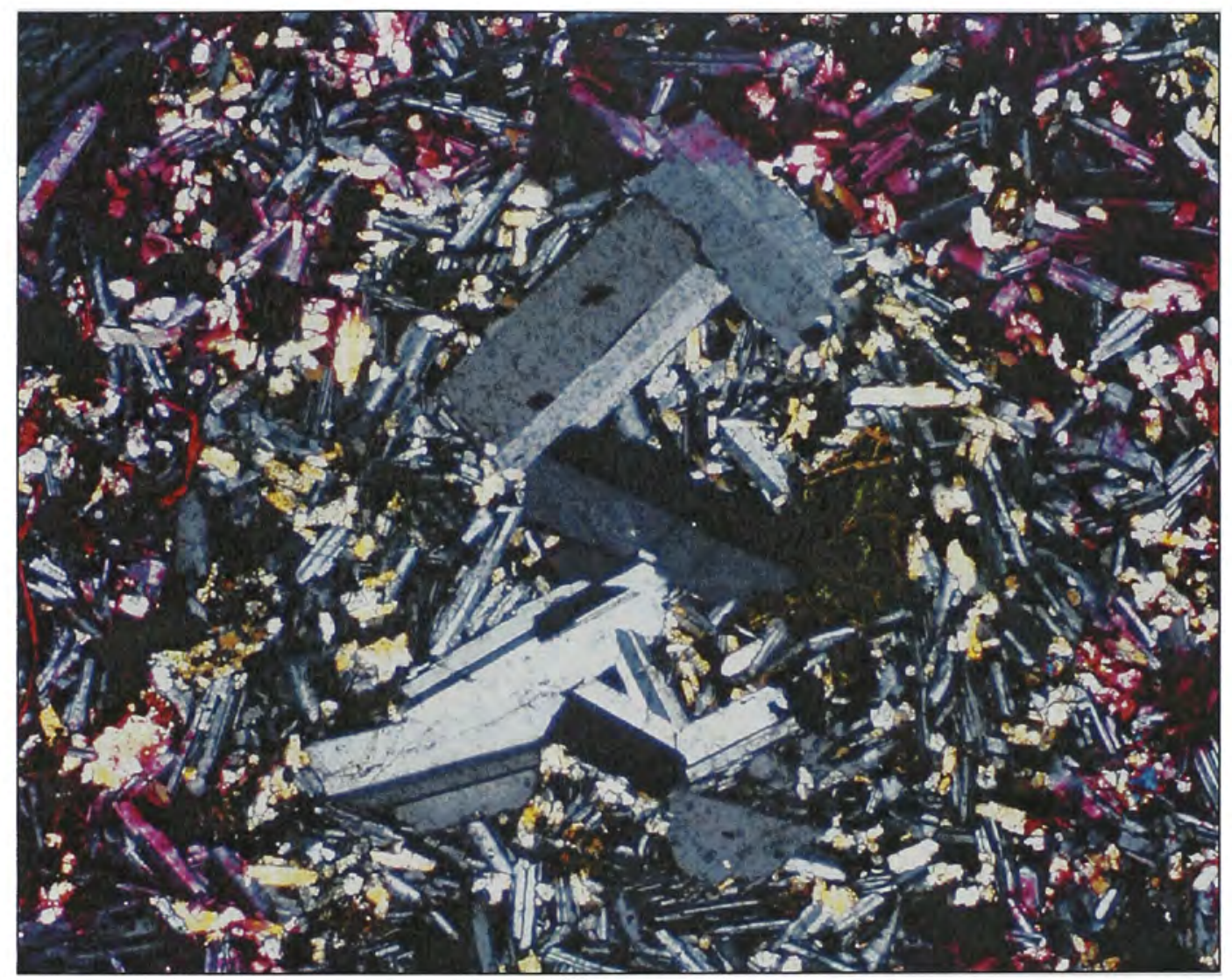

Figure 9- Glomeroporphyritic cluster of plagioclase grains in a GRB flow (Sample GR-16). (Crossed polars: Width of field of view represents $2.5 \mathrm{~mm}$ ). 


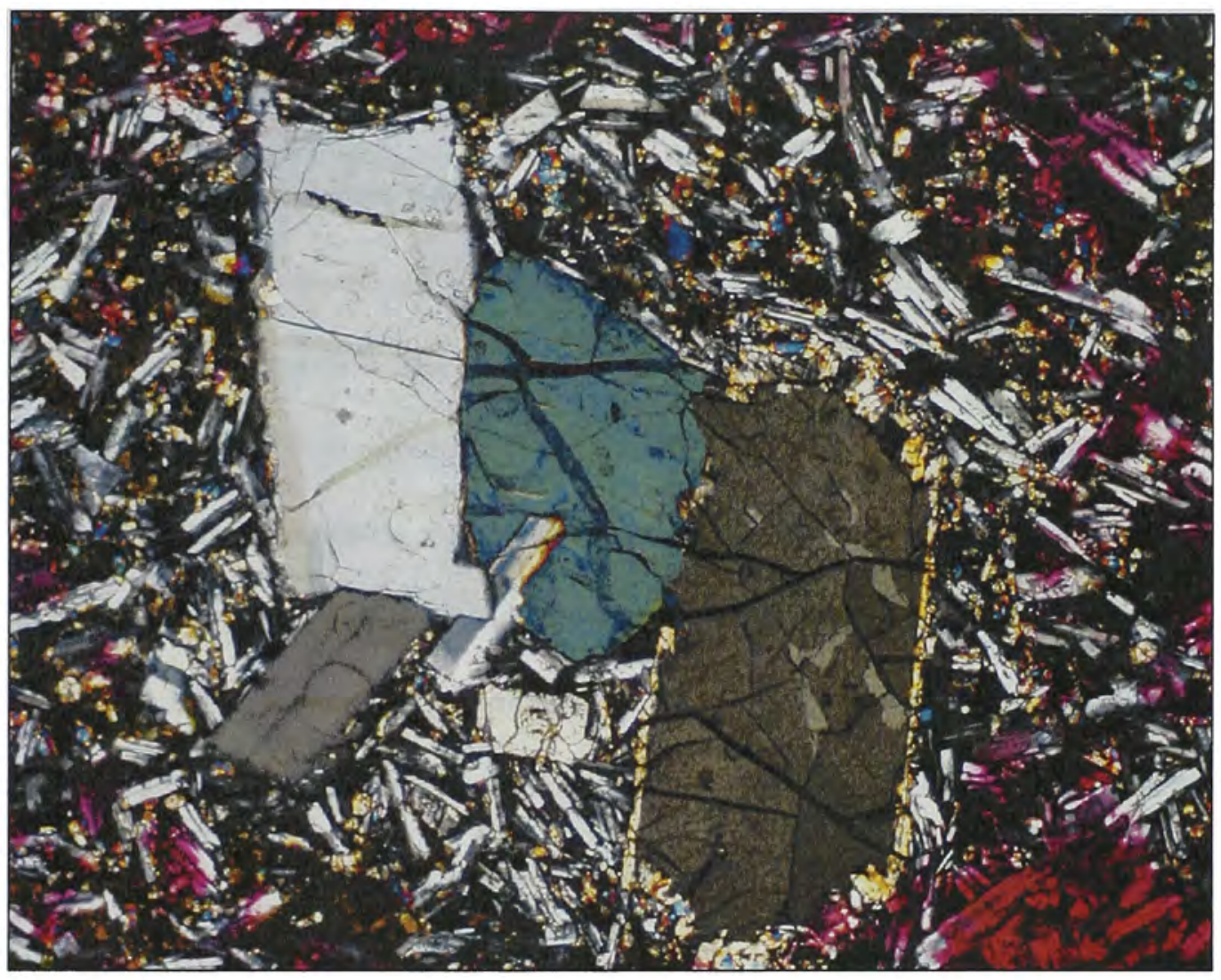

Figure 10- Glomeroporphyritic cluster of plagioclase, augite (blue) and opx (brown) grains in a GRB flow (Sample O-4352). (Crossed polars: Width of field of view represents $2.5 \mathrm{~mm}$ ). 
In general however, the largest phenocrysts are euhedral. Some of these phenocrysts show resorption along rims. Melt (glass and mineral) inclusions are often trapped in a ring-like manner around the resorbed areas (Figure 11). These ring-like inclusions are mostly found in the lower units. Mesh resorption, or spongy resorption in the core of some phenocrysts, is also observed (Figure 11). The existing anhedral crystals show extensive evidence of resorption (sieve texture). Of interest are several phenocrysts which are extremely resorbed (Figures 12 and 26). Some of these resorbed phenocrysts have An contents of up to 96 (Figure 26). Overall the plagioclase phenocrysts are better preserved than the pyroxene phenocrysts.

Zoning is present in plagioclase phenocrysts throughout the GRB formation. The zoning patterns persist throughout the formation from the lower flows to the upper flows in the samples analyzed. The lower members however appear to have more zoned phenocrysts than the middle to upper members. Many plagioclase phenocrysts exhibit reverse zoning (Figure 13). In some cases both normal and reverse zoned plagioclase can be found in individual samples. Oscillatory zoning is also found within the same samples that exhibit normal and reverse zoning patterns (Figure 14). Some crystals have patchy zoning trends where patches of varied compositions occur throughout the grain. Plagioclase morphology in the groundmass ranges from euhedral to subhedral. Zoning in groundmass plagioclase is not as evident as it is in the phenocryst population however zoning is seen in some of the plagioclase crystals analyzed. The type of zoning is generally oscillatory. Zoning is even less evident in the younger GRB flows. Resorption features are also not seen as often in the groundmass. 


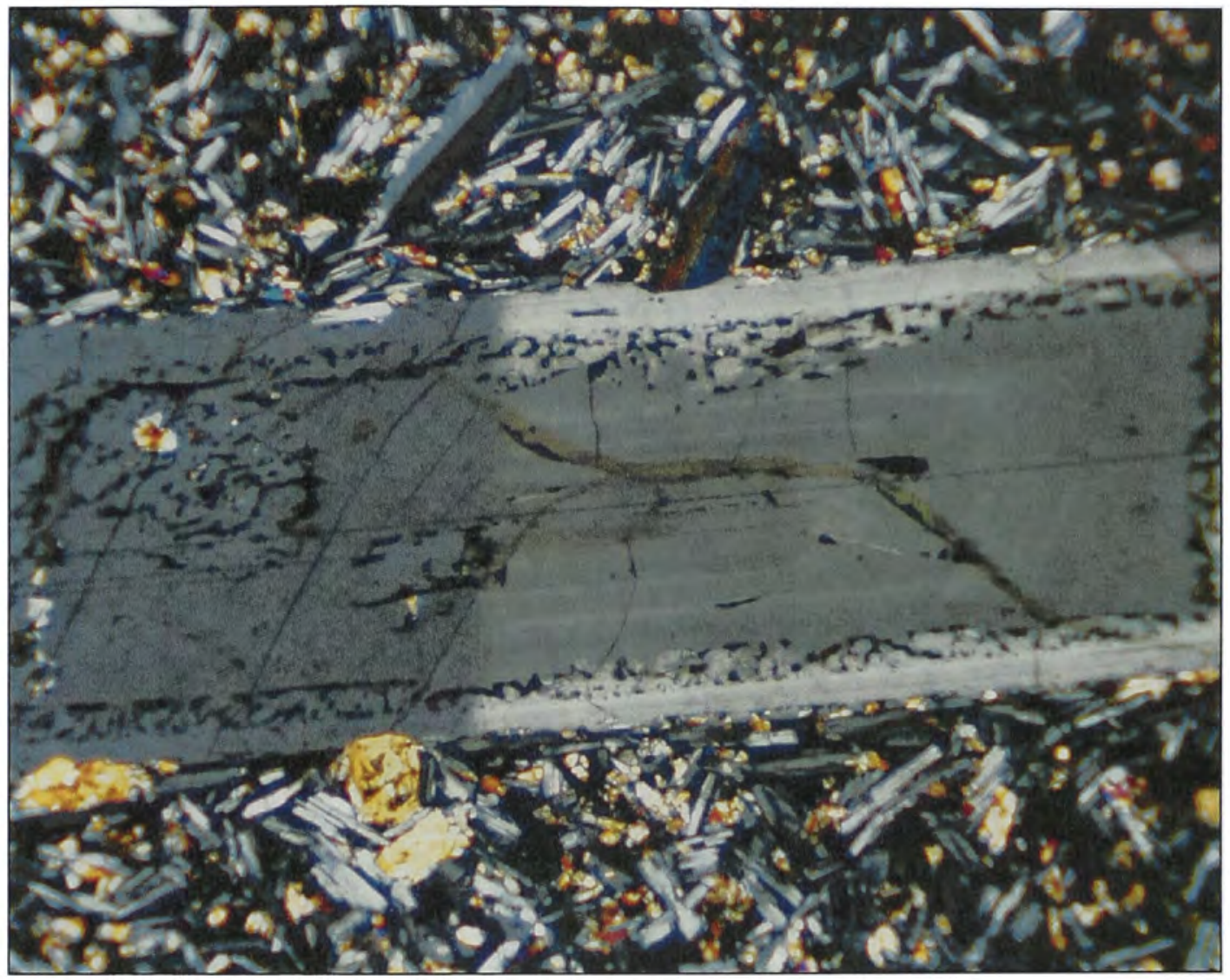

Figure 11- Large zoned and partially resorbed plagioclase phenocryst with melt (glass) inclusions. Outer rim is more anorthitic $\left(\mathrm{An}_{60}\right)$ than core $\left(\mathrm{An}_{47}\right)$ (Sample GR-3). (Crossed polars: Width of field of view represents $3 \mathrm{~mm}$ ). 


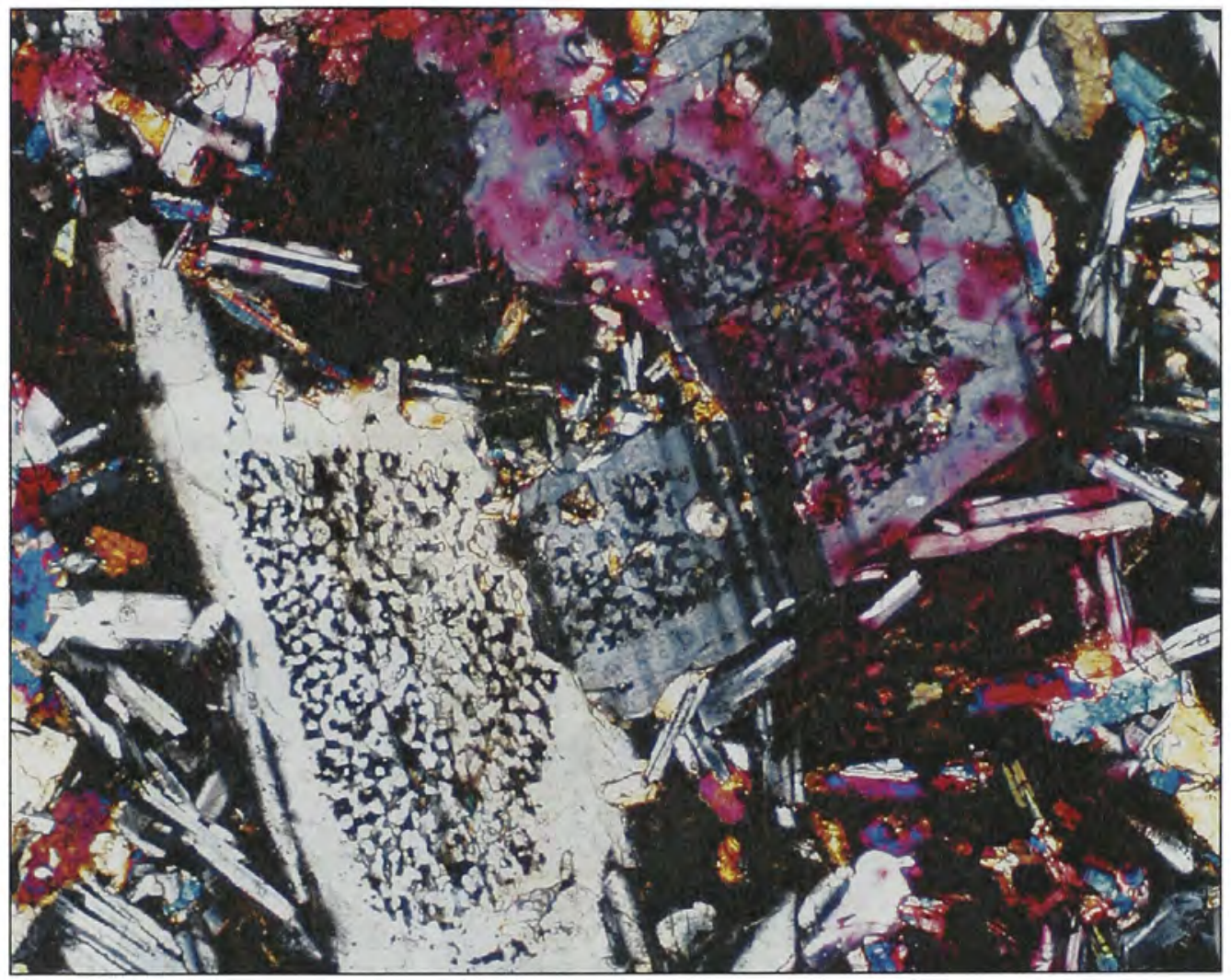

Figure 12- Several plagioclase phenocrysts showing extensive resorption of the core surrounded by euhedral rims (GR-2269). This is a typical sieve texture. (Crossed polars: Width of field of view represents $2.5 \mathrm{~mm})$. 


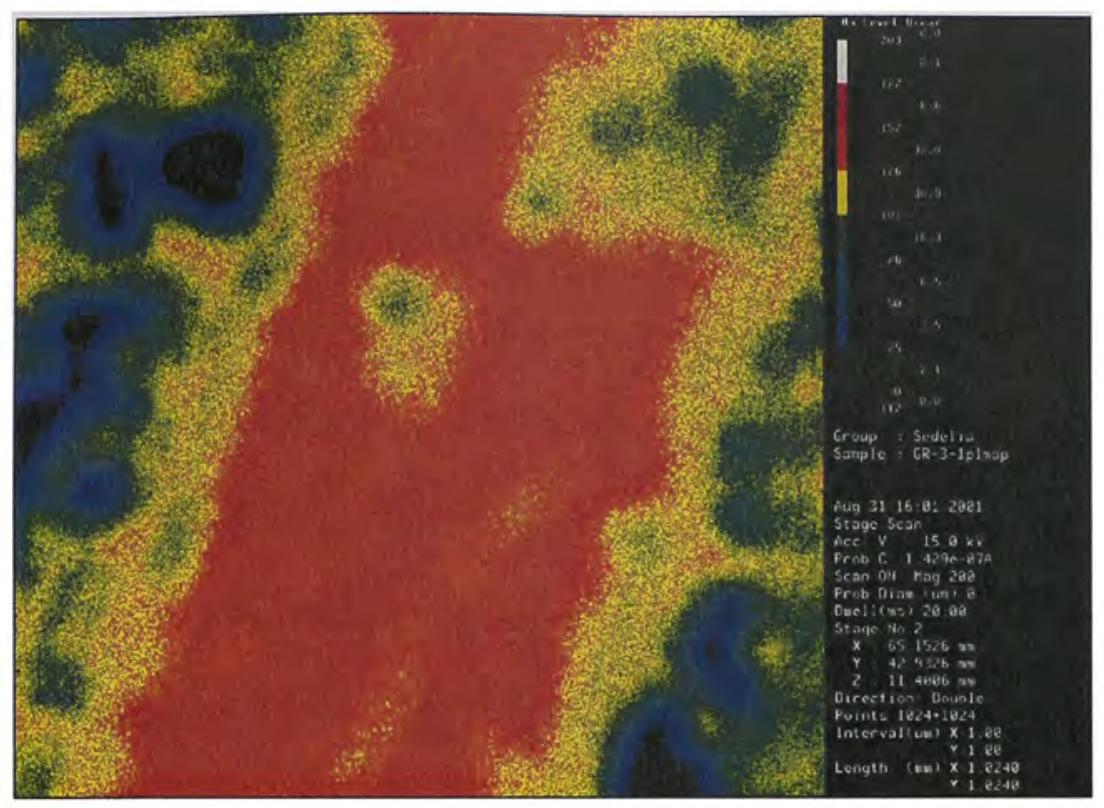

Figure 13- X-ray map depicting oxide concentrations, Red area indicates higher $\mathrm{Na}$, the yellow area indicates lower $\mathrm{Na}$, higher $\mathrm{Ca}$. This is an example of a GRB reversely zoned plagioclase phenocryst (Sample GR-3).

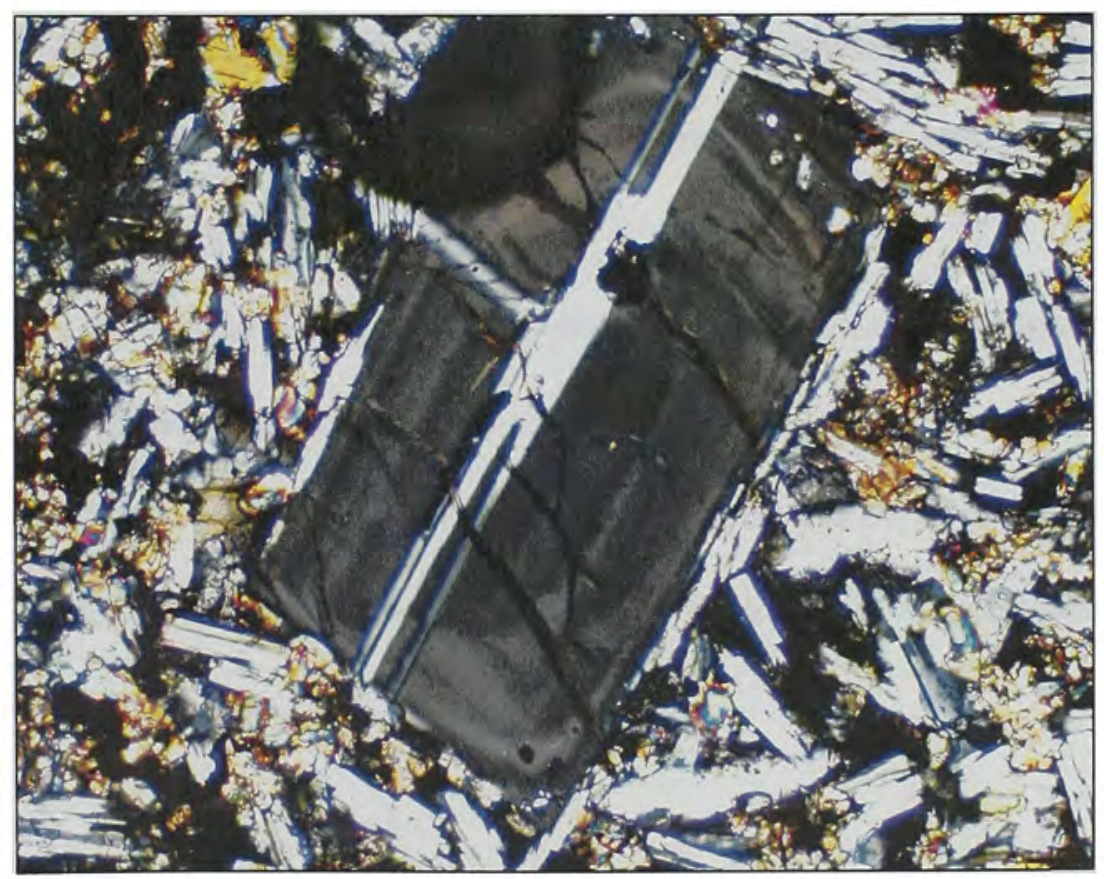

Figure 14- Plagioclase phenocrysts with oscillatory zoning (Sample CHI-20). (Crossed polars: Width of field of view represents $1.1 \mathrm{~mm}$ ). 
Pyroxene

Euhedral crystals of augite occur as isolated phenocrysts or in clusters, sometimes showing a thin but distinct outer zone. Where present, pigeonite phenocrysts show disequilibrium characteristics: for example, Figure 15 shows a pigeonite phenocryst with a rounded (resorbed) outline and surrounded by a thin rim of augite. A euhedral augite phenocryst is juxtaposed to it. Furthermore, low-Al orthopyroxene phenocrysts or microphenocrysts are also rimmed by augite (Figure 16, and Reidel, 1978). Euhedral pyroxene phenocrysts are found in all sections, but more commonly pyroxene grains are subhedral to anhedral in these lavas. An extremely resorbed pyroxene (CHI-20) has an augitic composition throughout most of the crystal however some parts of the crystal have lower-Ca compositions and glassy spots (Figure 17). This could indicate that this augite was in the process of being resorbed by a new magma and that pigeonite was beginning to form, then the magma was erupted interrupting this process and quenching some partial melt areas into glass.

Low-Ca pyroxenes are represented primarily by pigeonite, which is ubiquitous throughout the GRB. It occurs both in the groundmass and as microphenocrysts. Pigeonite crystals are commonly anhedral; rarely are any euhedral grains found. Some pigeonite phenocrysts are rimmed by augite and some others are highly resorbed but lack the augite rims (Figure 17). 


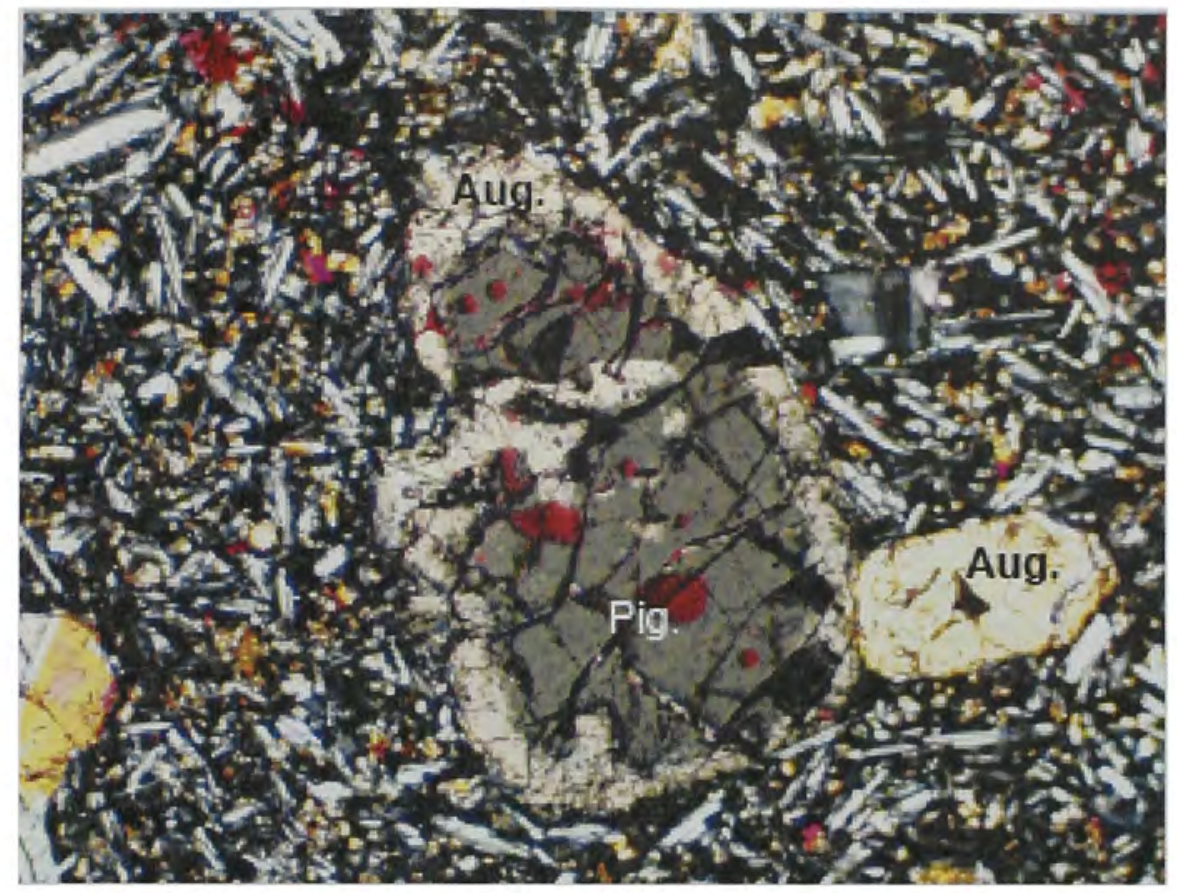

Figure 15- Augite-rimmed resorbed pigeonite (darker grain in the center of image) juxtaposed against a euhedral augite phenocryst (Sample CHI-24). (Crossed polars: Width of field of view represents $1.1 \mathrm{~mm}$ ).

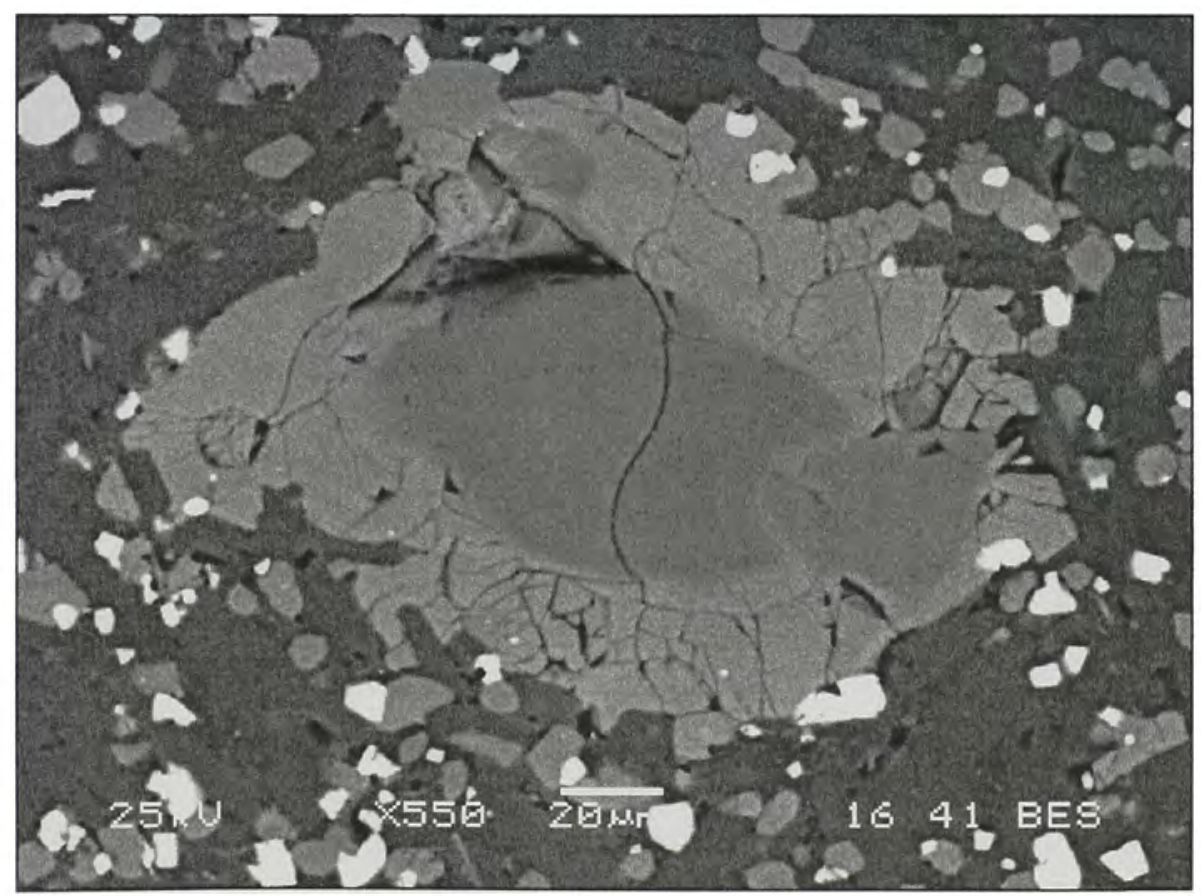

Figure 16-Back-scatter image of an orthopyroxene grain rimmed by augite, Dog 39, (sample provided by S.P. Reidel). Darker grains are plagioclase crystals and bright grains are Fe-Ti oxides. 


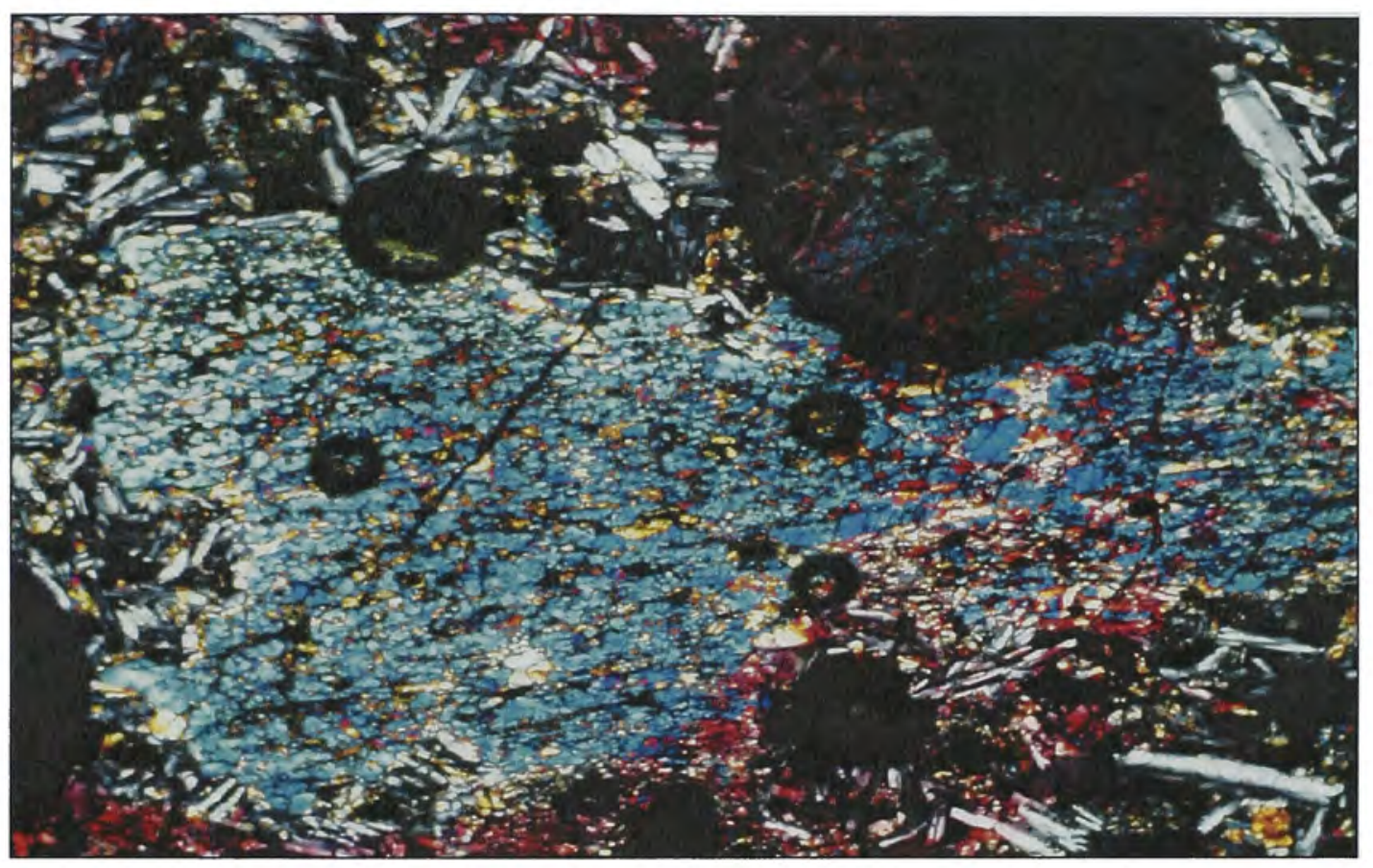

Figure 17- Crossed polar photomicrograph of a highly resorbed clinopyroxene phenocryst (CHI-20). (Width of field of view represents $2.5 \mathrm{~mm}$ ). 
Orthopyroxene is rare as a phenocryst phase as well as in the groundmass. Grande Ronde sample GRB-O4352 is the only sample that contains an opx phenocryst $(0.45 \mathrm{~mm})$ in the samples studied (Figure 10). This opx phenocryst appears to have been in the initial process of resorption, and has a thin glassy rim. A smaller resorbed subophitic augite phenocryst and a larger subhedral plagioclase phenocryst are adjacent to this grain. Reidel (1983) has also found opx in his samples. For example, an opx rimmed by pigeonite is found in sample number Dog 39 of Reidel (Figure 16). Sub-ophitic and ophitic textures are seen in the phenocryst clusters throughout the sections. Many pyroxenes, both pigeonite and augite, are not only resorbed along the rims but also within the cores. Many of the phenocrysts and microphenocrysts are found as glomeroporphyritic clusters with plagioclase phenocrysts.

In summary, some spectacular reaction textures are shown by the pyroxenes- opx rimmed by pigeonite, pigeonite rimmed by augite, and augite rimmed by pigeonite. In the middle and upper flows analyzed, patchy zoning is found within individual groundmass and microphenocrysts grains.

\section{Olivine}

Unaltered olivine phenocrysts are not present in any of the flows studied. The olivines are altered to iddingsite and can only be recognized by the euhedral olivine shape (Figure 18). These altered olivine crystals can be as large as $3 \mathrm{~mm}$. Modal abundance of altered olivine (iddingsite) averages $1.03 \%$ with no more than $3.0 \%$ in any flow (Camp, 1976). Reidel (1978) found one partially altered olivine phenocryst in only one China Creek flow (CHI-27). This olivine has a $\mathrm{Fo}_{67}$ core and $\mathrm{Fo}_{47}$ rim (Reidel, 1978). 


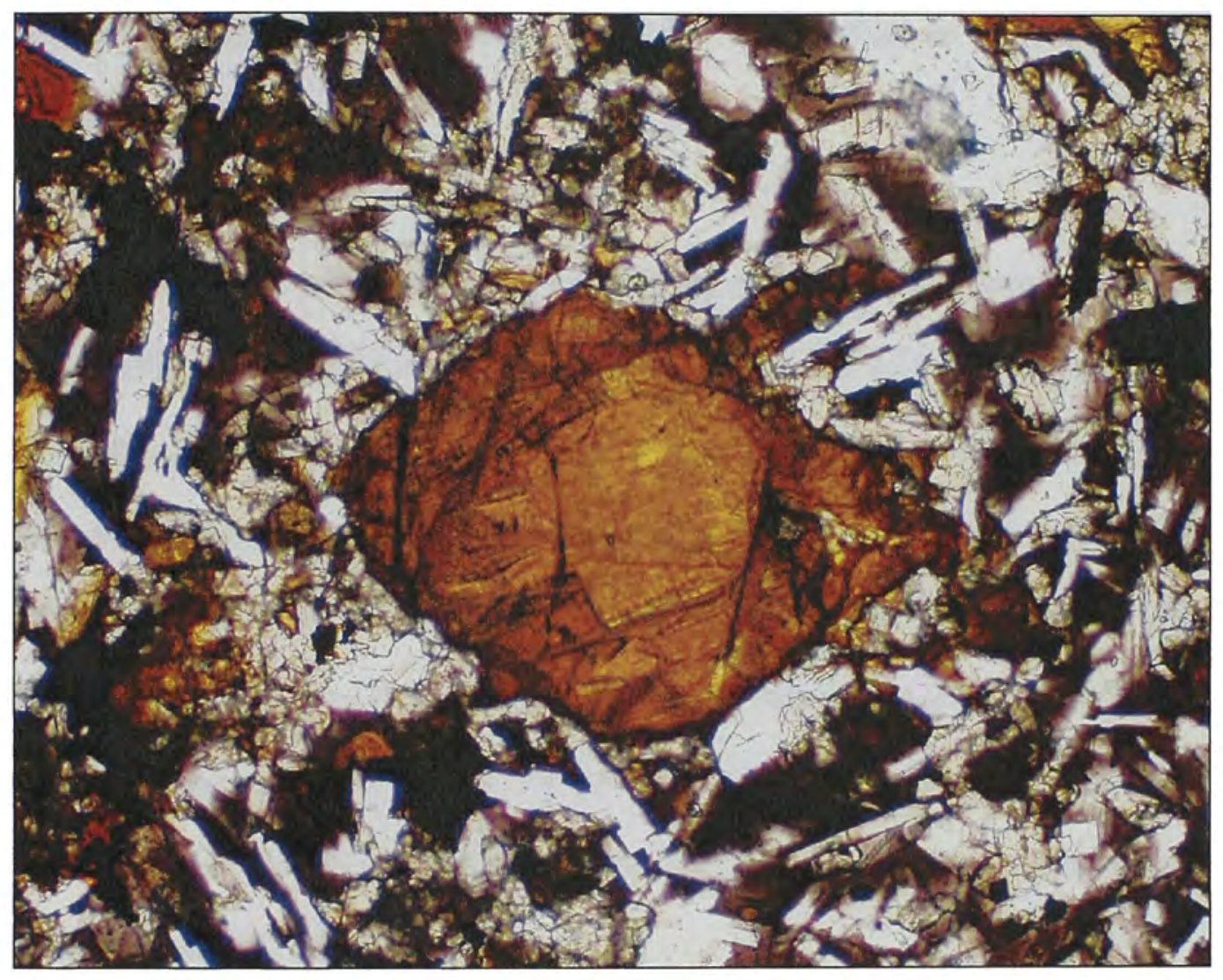

Figure 18-Crossed polar photomicrograph of Iddingsite, believed to be the alteration product of altered olivine phenocryst. Notice the distinct euhedral olivine shape of the crystal (Sample CHI-32). (Plane polarized light: Width of field of view represents $1.15 \mathrm{~mm}$ ). 
Olivine crystals are present as groundmass crystals of some samples, but whether these are really part of the groundmass or are extensively resorbed phenocrysts is not clear. Most groundmass crystals are anhedral to subhedral and are homogenous with no evidence of zoning. $\mathrm{Mg}$ numbers $\left[100 * \mathrm{Mg} /\left(\mathrm{Mg}+\mathrm{Fe}^{2+}\right)\right]$ in groundmass crystals range from $\mathrm{Fo}_{21}$ to $\mathrm{Fo}_{60}$. In addition, olivine $\left(\mathrm{Fo}_{60}\right)$ is observed as an inclusion in several groundmass pyroxene grains.

\section{DIKE PETROGRAPHY}

Samples were collected across the width of two dikes, one that fed the Imnaha Formation (Big Lookout Mountain dike) and another that fed the GRB Formation (Joseph Creek dike). The GRB dike shows features that suggest that at least two different magmas mingled and flowed through the same dike (Figure 19). There appear to be two or three magmas of different degree of darkness due to variation in glass content. Magma mingling can only be seen in the interior of the GRB dike and not along the rims of the dike, which suggests that the interior of the dike was open to distinct magma intrusion episodes. The Imnaha dike does not display these features and is significantly coarser grained than the GRB dike.

\section{Joseph Creek dike (GRB Formation)}

Samples collected across the width of the Joseph Creek dike captured only one of the chill margins (sample \# W-1). The chilled margin is fine-grained to glassy with black and yellow-brown glass. The chill margin has both plagioclase $(<5 \%)$ and clinopyroxene $(<1 \%)$ microphenocrysts $(<0.3 \mathrm{~mm})$, but no phenocrysts $(>0.3 \mathrm{~mm})$. Several clusters of plagioclase and clinopyroxene microphenocrysts occur. 
Morphologies range from euhedral to subhedral for plagioclase, and subhedral to anhedral for clinopyroxene grains. Anhedral unaltered olivine crystals $(<1 \%)$ are seen only in the groundmass. Slight zoning is seen in a few plagioclase microphenocrysts.

Samples W-2 and W-3, which were collected farther in from the chilled margin, are both glass-rich. Petrographically, there appears to be two distinct magmas mingled in these samples: one of these has a darker glassy texture; the other has a lighter more coarse-grained texture (Figure 19). Both W-2 and W-3 have 5-10\% modal plagioclase (up to $0.4 \mathrm{~mm}$ ) and $1-5 \%$ modal clinopyroxene (up to $0.3 \mathrm{~mm}$ ) phenocrysts and microphenocrysts. Plagioclase and cpx crystals are more resorbed in W-2 and W-3. Plagioclase and cpx phenocrysts and microphenocrysts range from euhedral to anhedral in these two samples.

Samples W-4, W-6 and W-7 are all glass-rich to fine-grained; sample W-7 has the highest glass content. The glass is black, and yellow-orange where altered. Textures and modal percent of phenocrysts and microphenocrysts in these samples are similar to W-2 and W-3. Sample W-5 is medium to coarse-grained comes from the center of the dike. The texture ranges from intergranular to intersertal. There are less than $1 \%$ plagioclase phenocrysts and 5-10\% euhedral to subhedral microphenocrysts. Pyroxene is only present as microphenocrysts $(<1 \%)$ and in the groundmass. The largest plagioclase phenocrysts are $0.5 \mathrm{~mm}$ in width. Largest $\mathrm{cpx}$ phenocrysts are $0.4 \mathrm{~mm}$ in width. Timagnetite and ilmenite are only present as groundmass crystals.

\section{Big Lookout Mountain Dike (Imnaha Formation)}

Unlike the majority of GRB dike and flow samples, the Imnaha Formation is coarse grained, with large plagioclase, olivine and clinopyroxene grains occurring in 
most of the samples studied. Typically these phenocrysts have unzoned cores, but some larger plagioclase grains display oscillatory zoning. The matrix is typically intergranular, with some subophitic textures. Ti-magnetite and ilmenite are only present in the groundmass. Brown to yellow glass is seen in the mesostasis. Needles of apatite, alkali feldspar and microgranophyric textures are also found in minor amounts in the groundmass.

The Imnaha Formation has unaltered olivine grains, unlike the GRB Formation (Figure 20). These crystals are euhedral to subhedral. In some cases skeletal olivine is also found in the groundmass. These skeletal olivines generally have higher $\mathrm{Mg}$ number $\left[\mathrm{Mg} /\left(\mathrm{Mg}+\mathrm{Fe}^{*}\right)\right]$ of $\sim 71$. Generally the olivine $(1-2 \mathrm{~mm})$ and plagioclase grains are larger than the pyroxene grains $(\sim 1 \mathrm{~mm})$. Many of these olivine grains include melt and mineral (Fe-oxide) inclusions.

Subhedral to euhedral plagioclase grains in the Imnaha Formation dikes are often of considerable size ( $>3 \mathrm{~cm}$ in length). They are also modally more abundant than both olivine and pyroxene crystals. The plagioclase grains mark a clear distinction from the younger GRB formation. Zoning is not a common feature of these crystals although some oscillatory zoning is present in some of the smaller plagioclase grains. Reverse zoning is not detected in any of the grains analyzed. In some cases, plagioclase grains completely enclose olivine grains. Plagioclase grains also contain melt inclusions. The pyroxenes in all flows are augites. These augites are usually smaller with subhedral to anhedral grains. Some of the augite crystals contain small melt inclusions. 


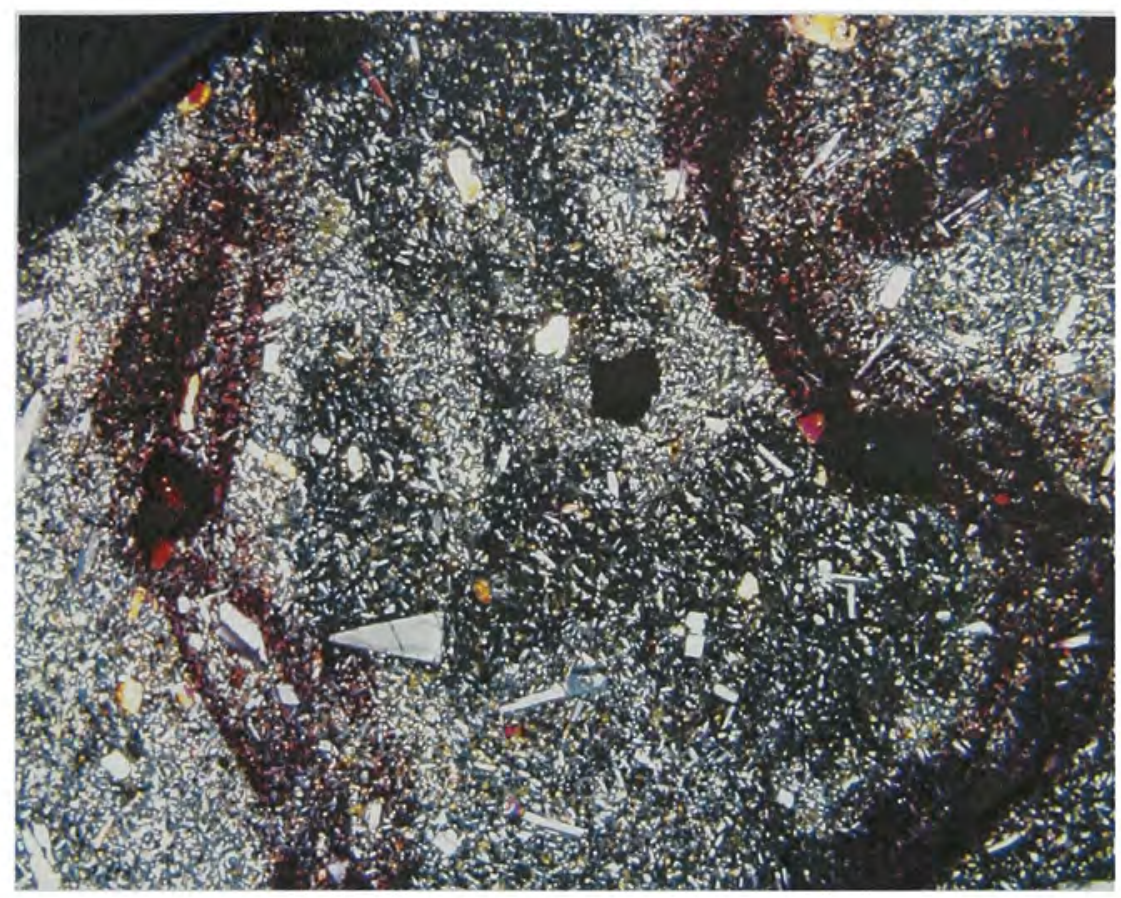

Figure 19-Crossed polars image of the GRB dike showing two magmas, lighter coarser grained and darker more glassy (W-2). (Width of field of view represents $5.2 \mathrm{~mm}$ ).

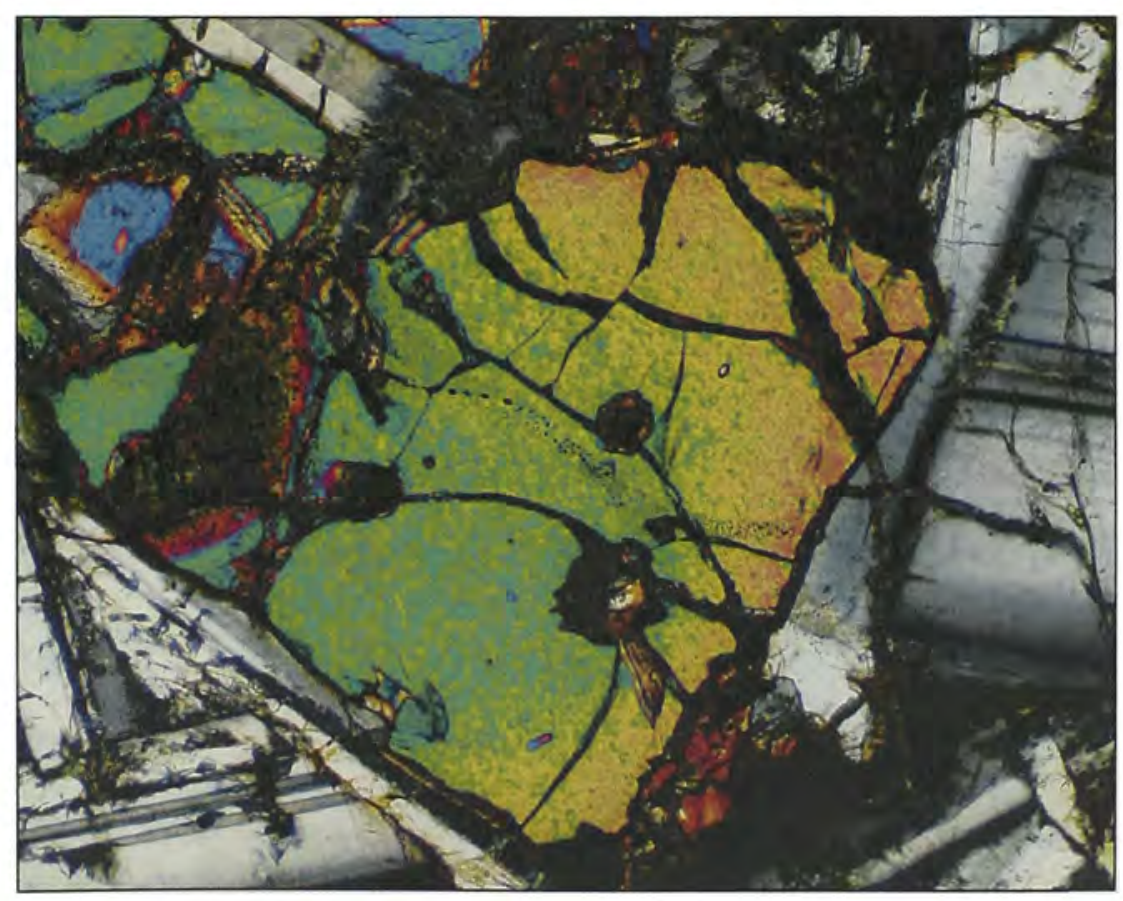

Figure 20- Photomicrograph of an olivine crystal in the Imnaha dike (BLM). Olivine has several small melt inclusions and is surrounded by plagioclase (gray) and pyroxene (blue). Crossed polarized light: Width of field of view represents $1.15 \mathrm{~mm}$ ). 


\section{CHAPTER 3}

\section{GEOCHEMISTRY AND MINERAL CHEMISTRY}

\section{GRANDE RONDE FORMATION}

\section{Major Elements}

Some general aspects of geochemistry that have been discussed by previous researchers are presented first as background material. Then, I present my mineral chemical data. Imnaha basalts are relatively rich in $\mathrm{MgO}(4.5-7.1 \mathrm{wt} \%)$ with intermediate $\mathrm{SiO}_{2}$ values and low $\mathrm{K}_{2} \mathrm{O}$ content relative to $\mathrm{MgO}$ (Hooper, 1984; Hooper and Hawkesworth, 1993). The Grande Ronde Formation on the other hand comprises basaltic andesites based on the higher $\mathrm{SiO}_{2}$ concentrations in these rocks (Hooper and Hawkesworth, 1993). The GRB basaltic andesites generally have low MgO contents (3.05.5 wt \%) with the highest $\mathrm{SiO}_{2}(52-58$ wt \%) relative to $\mathrm{MgO}$ in the CRBG. The Wanapum Basalt has high $\mathrm{TiO}_{2}$ and $\mathrm{FeO}$ contents and low $\mathrm{SiO}_{2}$ when compared with GRB. Saddle Mountain Formation shows the greatest chemical dispersion among CRBG lavas with the lowest $\mathrm{MgO}(2.7 \mathrm{wt} \%)$ and highest $\mathrm{MgO}(8.2 \mathrm{wt} \%)$ values. The SMB lavas also have some of the highest total $\mathrm{FeO}(17.5 \mathrm{wt} \%)$ (Hooper and Hawkesworth, 1993). Whole rock $\mathrm{Mg}$ numbers $\left[\left(100 * \mathrm{Mg} /\left(\mathrm{Mg}+\mathrm{Fe}^{2+}\right)\right]\right.$ of $\mathrm{GRB}$ lavas range from 30 to 64, and $\mathrm{SiO}_{2}$ values range from 52-58. $\mathrm{TiO}_{2}$ values range from 0.7 to $3.6 \mathrm{wt}$. \% (Erlank et al., 1988).

\section{Trace Elements}

All CRBG lavas are enriched in light-REE and are similar to ocean island basalts (Hooper and Hawkesworth, 1993; figure 21). Many flows have relatively high large ion lithophile elements (LILE)/high field strength elements (HFSE) ratios $(\mathrm{Ba} / \mathrm{Nb}=10-80)$. 


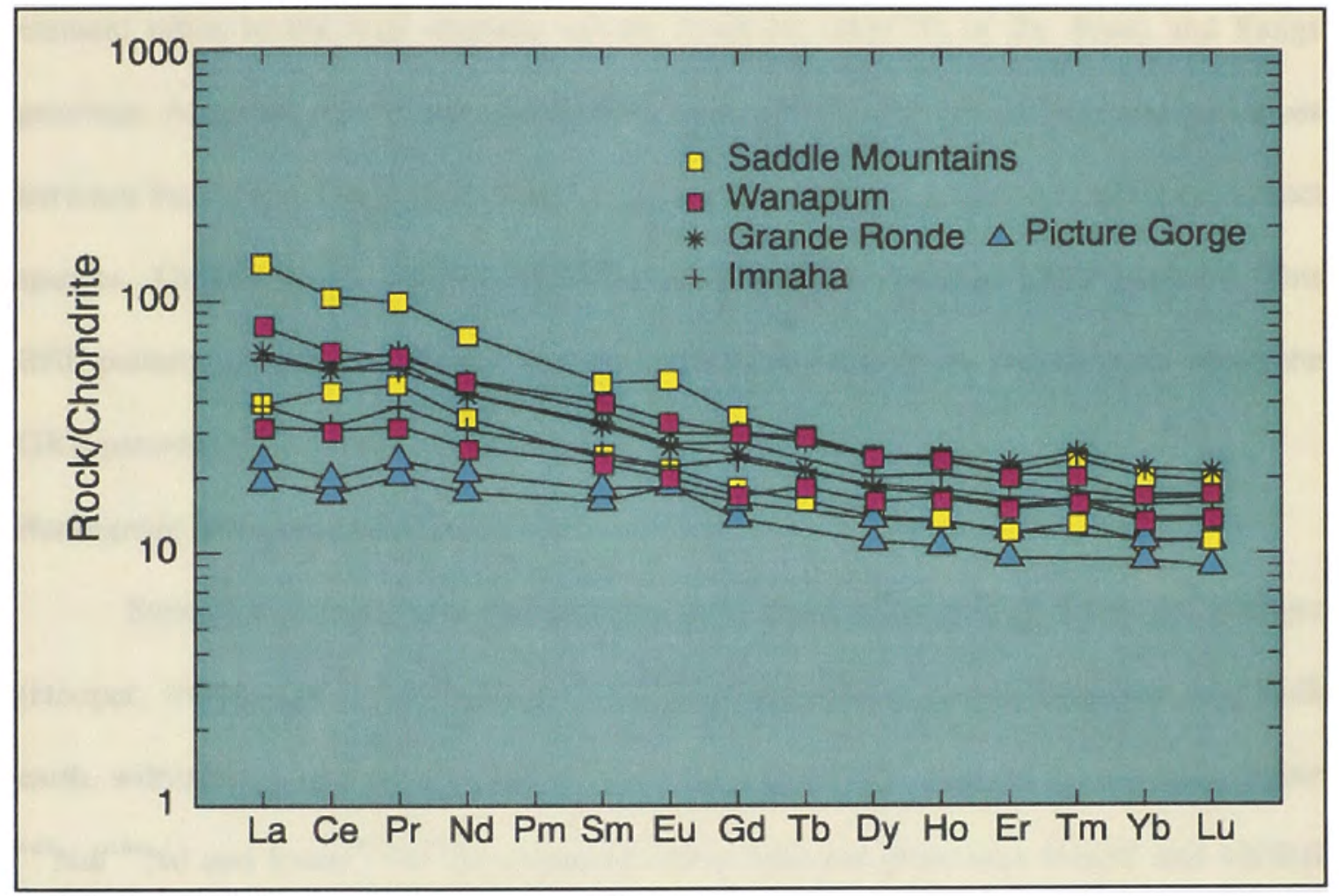

Figure 21-Chondrite-normalized rare earth element patterns of some typical CRBG samples. Winter (2001). An Introduction to Igneous and Metamorphic Petrology. Prentice Hall. Data from Hooper and Hawkesworth (1993) J. Petrol., 34, 1203-1246. 
High LILE/HFSE ratios are commonly attributed to the preferential mobilization of LILE in hydrous fluids derived from the subducted slab (Pearce, 1983; Hawkesworth et al., 1991). The Picture Gorge Basalt, which is coeval with the Grande Ronde Basalt, erupted from a different set of fissures, namely the Monument dike swarm, and has similar trace element ratios to the high alumina olivine tholeiites (HAOT) of the Basin and Range province. According to Hooper and Hawkesworth (1993), the lack of intermediate values between the Picture Gorge and CRBG suggests that these were derived from two distinct sources. Grande Ronde lavas exhibit a flat MREE-HREE enriched LREE patterns. This REE pattern suggests that garnet was not a residual phase in the mantle with which the GRB parental magmas last equilibrated

\section{Radiogenic Isotope Compositions}

Strontium isotope ratios become generally more radiogenic as flows get younger (Hooper, 1984). On ${ }^{143} \mathrm{Nd} /{ }^{144} \mathrm{Nd}$ vs. ${ }^{87} \mathrm{Sr} /{ }^{86} \mathrm{Sr}$ plots, Grande Ronde lavas plot near bulk earth, within the ocean island basalt (OIB) field (Figure 22). Imnaha basalts have higher ${ }^{143} \mathrm{Nd} /{ }^{144} \mathrm{Nd}$ and lower ${ }^{87} \mathrm{Sr} /{ }^{86} \mathrm{Sr}$ values $(0.703-0.704)$ and plots near HAOT and MORB fields, but still within the OIB field (McDougall, 1976; Hooper and Hawkesworth, 1993). Wanapum basalts also plot near bulk earth, but with lower ${ }^{143} \mathrm{Nd} /{ }^{144} \mathrm{Nd}$ values than Grande Ronde basalts. Average Grande Ronde and Wanapum ${ }^{87} \mathrm{Sr} /{ }^{86} \mathrm{Sr}$ values are approximately 0.705 (McDougall, 1976). Saddle Mountain basalts, the youngest formation, are very different from the rest of the group: these lavas are highly enriched and ${ }^{87} \mathrm{Sr} /{ }^{86} \mathrm{Sr}$ ratios have a large range from approximately 0.708 to 0.715 (De Paolo and Wasserburg, 1979; Nelson, 1980; BVTP, 1981; Carlson, et al., 1981; Hooper and Hawkesworth, 1993) (See figure 22). 


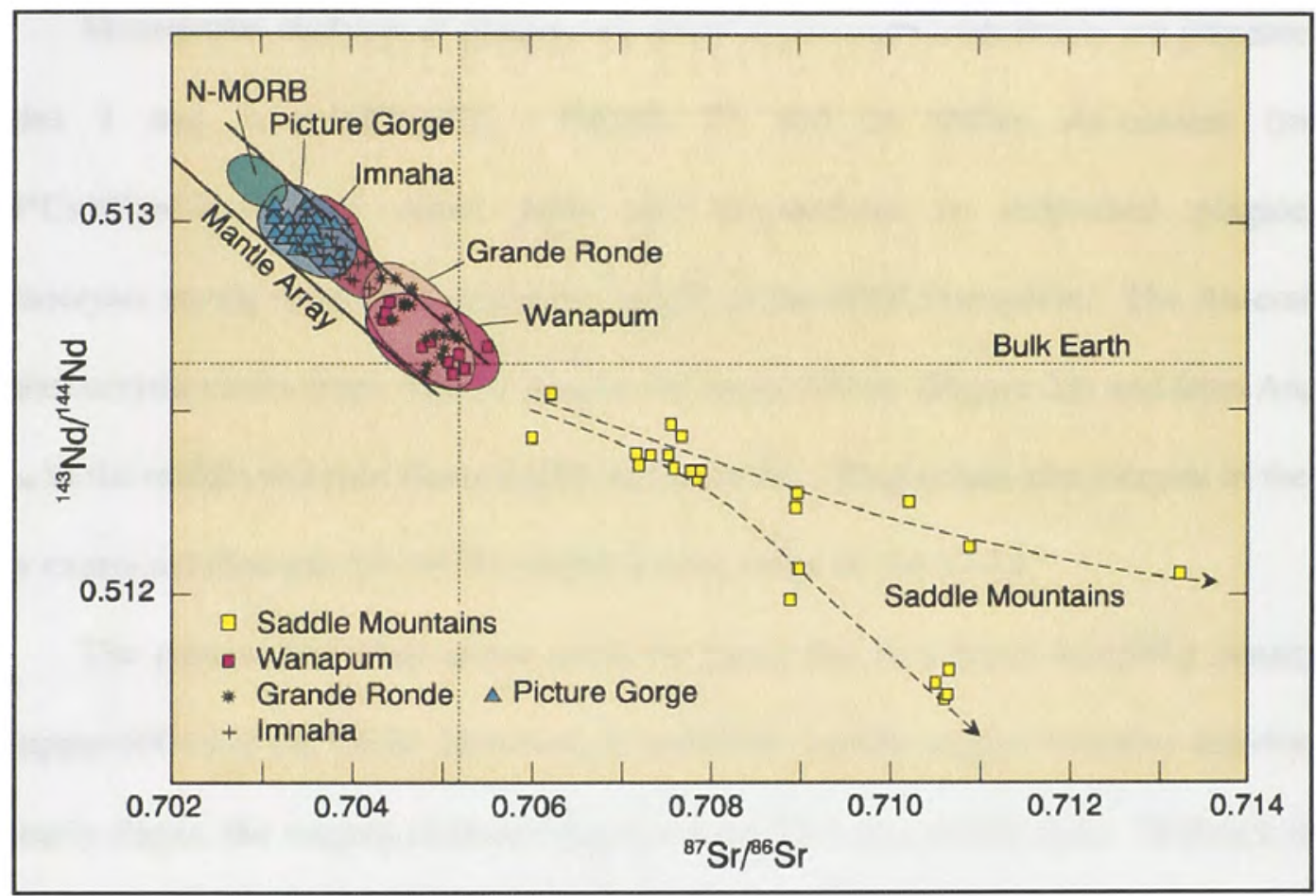

Figure 22- $87 \mathrm{Sr} / 86 \mathrm{Sr}$ vs. $143 \mathrm{Nd} / 144 \mathrm{Nd}$ for the CRBG. Winter (2001). An Introduction to Igneous and Metamorphic Petrology. Prentice Hall. 
Helium and neon isotope analysis of Imnaha basalt fluid inclusions have yielded ${ }^{3} \mathrm{He} /{ }^{4} \mathrm{He}$ ratios of 11.4 times atmosphere, and ${ }^{20} \mathrm{Ne} /{ }^{22} \mathrm{Ne}$, and ${ }^{21} \mathrm{Ne} /{ }^{22} \mathrm{Ne}$ characteristic of a plume component (Dodson et al., 1997).

\section{PHASE CHEMISTRY}

\section{Plagioclase}

Microprobe analyses of plagioclase phenocrysts and Groundmass are presented in Tables 1 and 3, respectively. Figures 23 and 24 shows An-content (molar $100 * \mathrm{Ca} /(\mathrm{Ca}+\mathrm{Na}+\mathrm{K}))$ of cores, rims and groundmass in individual plagioclase phenocrysts versus relative stratigraphic height of the GRB Formation. The An-content of phenocrysts varies from $\mathrm{An}_{59}$ to $\mathrm{An}_{96}$ in the lower $250 \mathrm{~m}$ (Figure 23) and from $\mathrm{An}_{65}$ to $\mathrm{An}_{79}$ in the middle to upper flows ( $>250 \mathrm{~m}$; figure 24). Plagioclase phenocrysts in the top flow examined (Sample SB-2978) exhibit a wide range of An 37-74.

The pattern described above could be partly due to a lesser sampling density in the upper $600 \mathrm{~m}$ of the GRB. However, it could also signify magma chamber activity. In the early stages, the magma chamber may not have been in a steady state. Different input melts carrying phenocrysts incompletely mixed in the chamber and then erupted as lavas with highly variable phenocrysts. With time, as the chamber reached a steady state, phenocrysts formed in well mixed magmas. The top flow shows a larger An range, which includes the lowest An compositions in the phenocrysts. A straightforward interpretation is that this lava was formed as the last liquid that was squeezed out of GRB magma chamber, carrying with it crystals that not only formed from the most differentiated melts, but also from more primitive crystals that probably formed from earlier magma batches. 


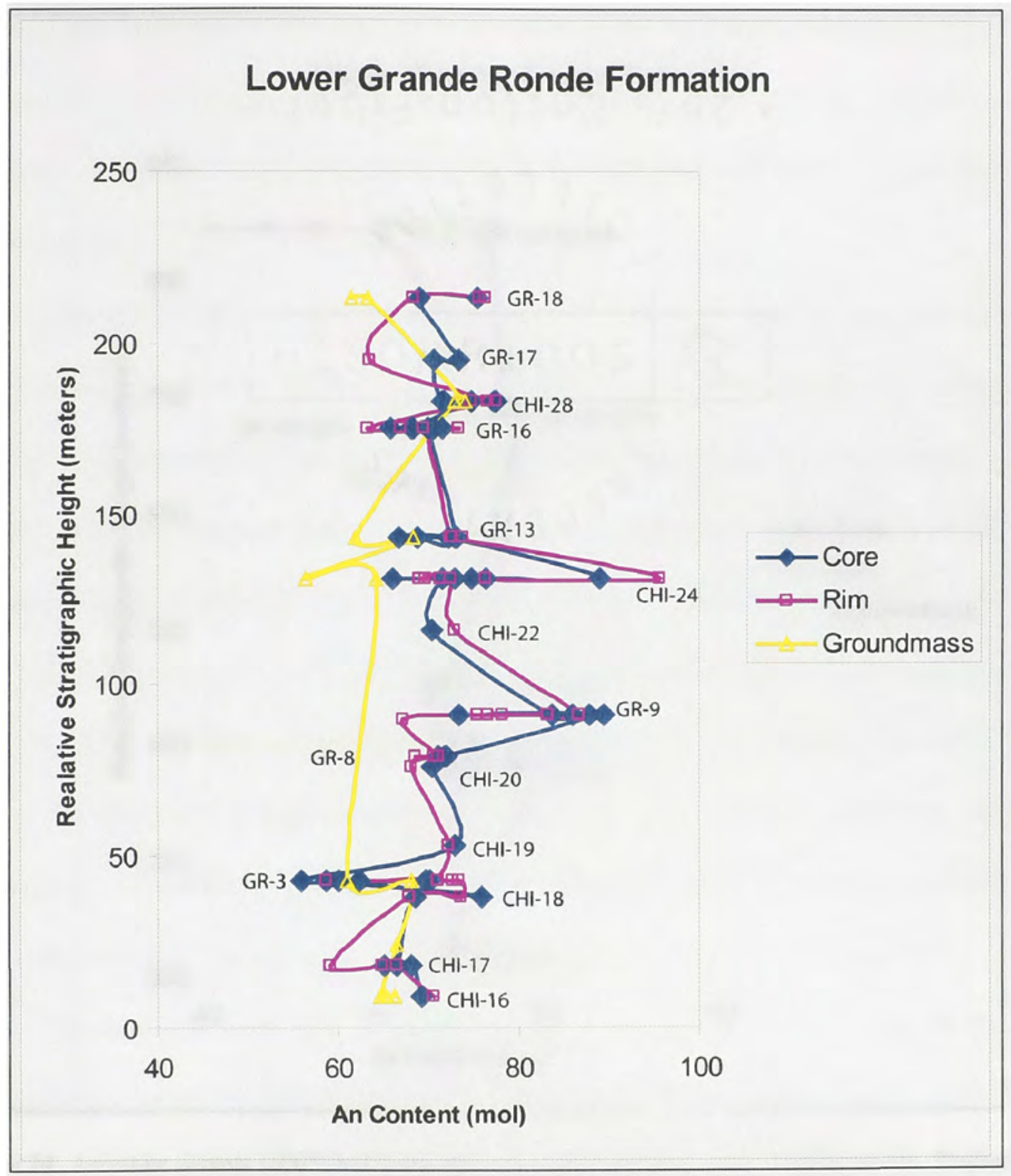

Figure 23- Anorthite content $(100 * \mathrm{Ca} /(\mathrm{Ca}+\mathrm{Na}+\mathrm{K}))$ of older sections of the Grande Ronde. Plagioclase phenocrysts are plotted against relative stratigraphic height depicting core, rim, and groundmass compositions for the samples analyzed by electron microscopy in this study. 


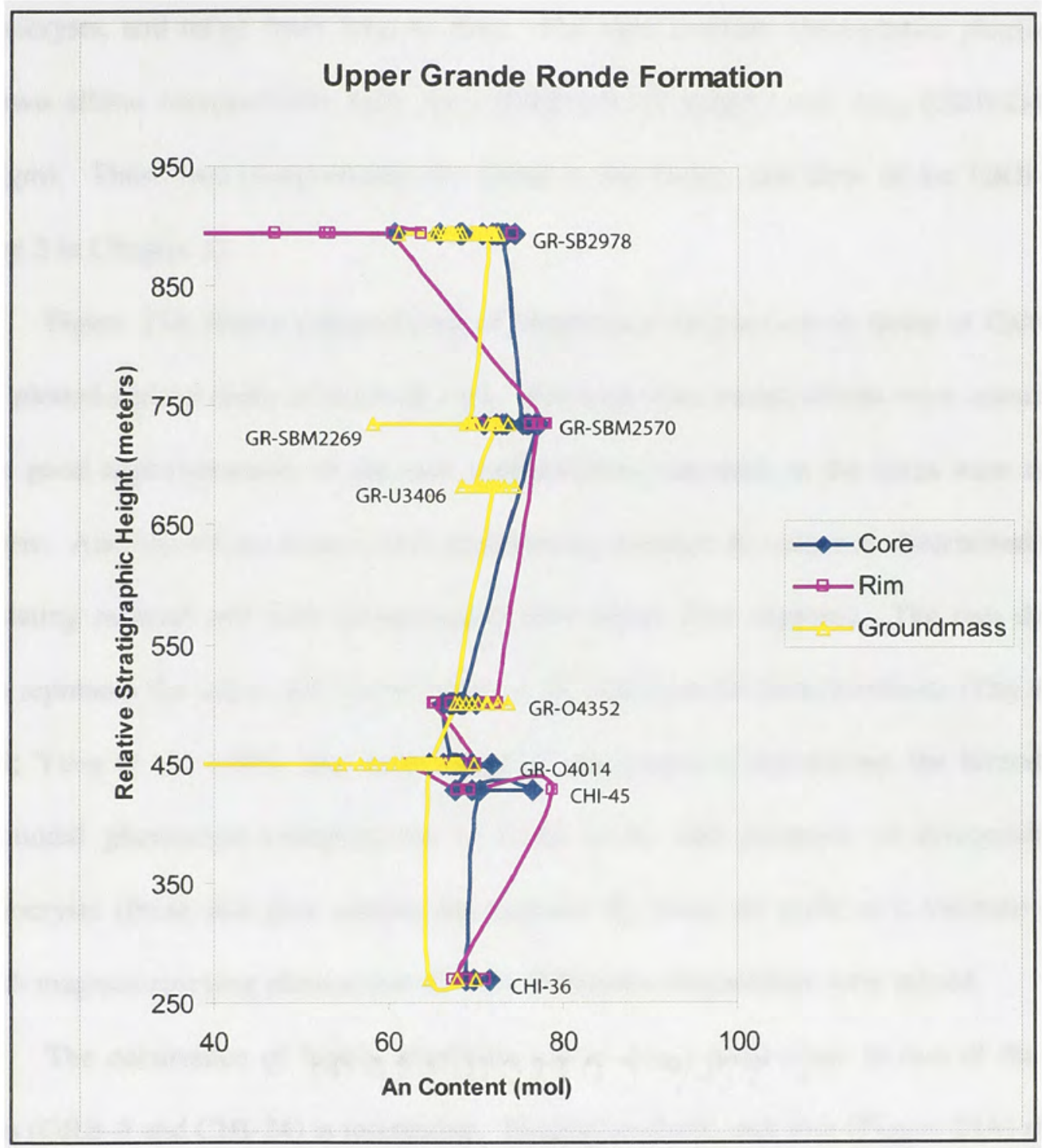

Figure 24- Anorthite content $(100 * \mathrm{Ca} /(\mathrm{Ca}+\mathrm{Na}+\mathrm{K}))$ of younger sections of the Grande Ronde. Plagioclase phenocrysts are plotted against relative stratigraphic height depicting core, rim, and groundmass compositions for the samples analyzed by electron microscopy in this study. 
Groundmass plagioclase compositions are also plotted in figure 23 , which shows that the groundmass crystals generally have lower An contents than the phenocrysts. Groundmass plagioclases do not have the large compositional range shown by the phenocrysts, and range from $\mathrm{An}_{56}$ to $\mathrm{An}_{74}$. The most extreme Groundmass plagioclase are two albitic compositions with $\mathrm{An}_{17}$ (GRB-O4352-1plgm) and $\mathrm{An}_{24}$ (GRB-O435212plgm). These two compositions are found in the Ortley unit flow of the GRB (See figure 2 in Chapter 1).

Figure $25 \mathrm{~A}$ shows compositions of plagioclase phenocrysts in terms of $\mathrm{Ca} /(\mathrm{Ca}+$ $\mathrm{Na}$ ), plotted against those of the bulk rock. The bulk-rock compositions were considered to be good approximations of the melt compositions inasmuch as the lavas were nearly aphyric. Also shown are dashed lines representing constant $K_{\mathrm{d}}$ values as determined from coexisting mineral and melt compositions (See figure 25A caption). The two dashed lines represent the upper and lower limits of all experimental determinations (Thy et al., 1999; Yang et al., 1996). The large range of phenocryst compositions, the bimodal to polymodal phenocryst compositions in some lavas, and presence of disequilibrium phenocrysts (those that plot outside the constant $K_{\mathrm{d}}$ lines) all point to a mechanism in which magmas carrying phenocrysts of very different compositions were mixed.

The occurrence of highly anorthitic (up to $\mathrm{An}_{96}$ ) plagioclase in two of the lava flows (GRB-9 and CHI-24) is interesting. Plagioclase/bulk rock plot (Figure 25A) shows that phenocrysts were clearly out of equilibrium with their host lava. This is also supported by the highly resorbed texture (Figure 26). 
A.

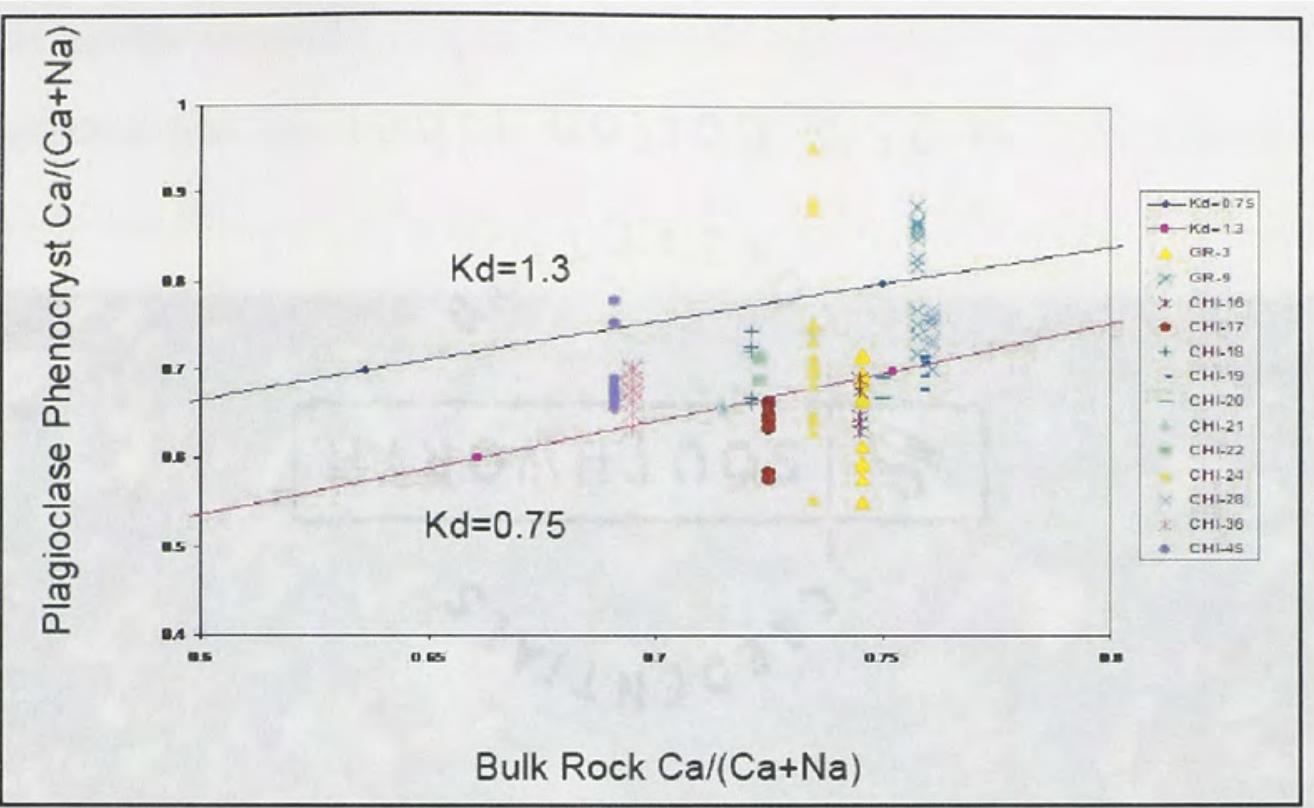

B.

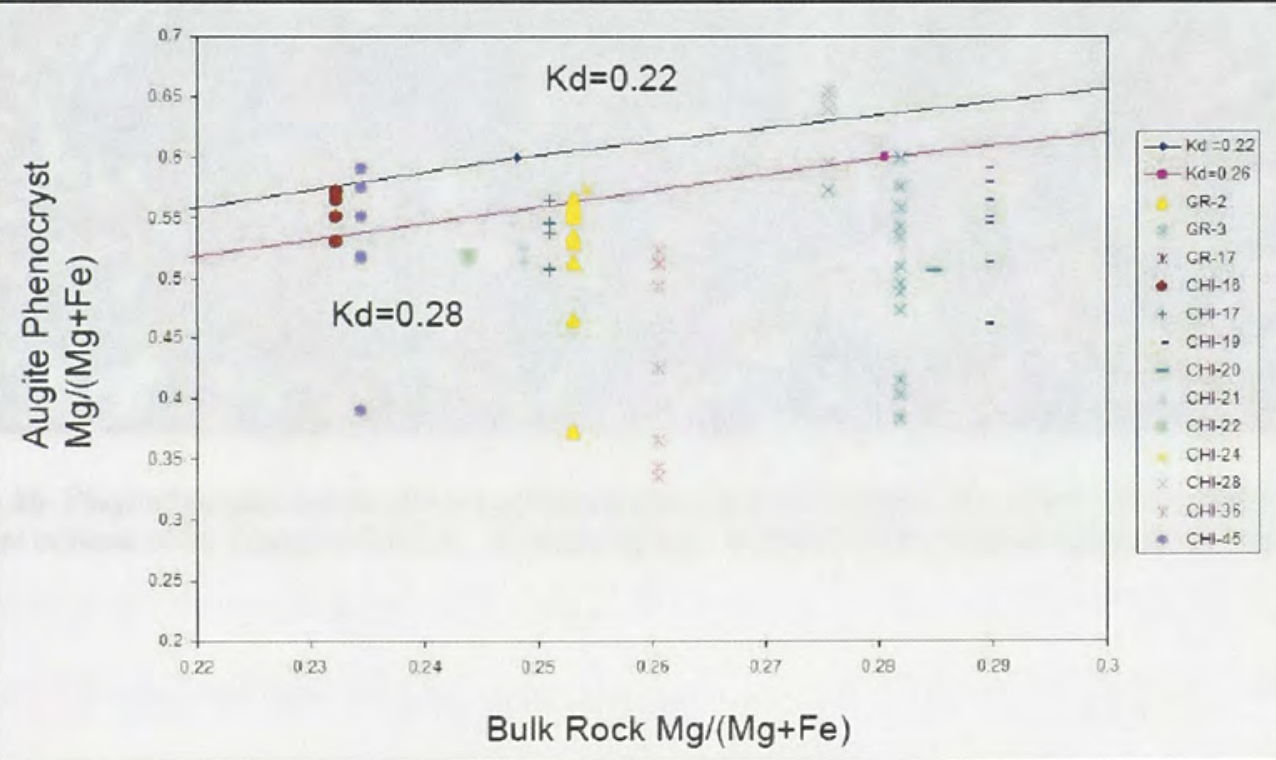

Figure 25- A and B: Anorthite (An) content $[=\operatorname{molar} \mathrm{Ca} /(\mathrm{Ca}+\mathrm{Na})]$ of plagioclase plotted against that of whole rock $\left(=\right.$ melt). Dashed lines-two constant values of $K_{\mathrm{d}}\left(=\left[X_{\mathrm{Ca}}{ }^{\mathrm{pl}}\right]\left[X_{\mathrm{Na}}{ }^{\text {melt }}\right]\right) /\left(\left[X_{\mathrm{Ca}}{ }^{\text {melt }}\right]\left[X_{\mathrm{Na}}{ }^{\mathrm{pl}}\right]\right)$ representing extremes of experimentally constrained values (Thy et al., 1999). 


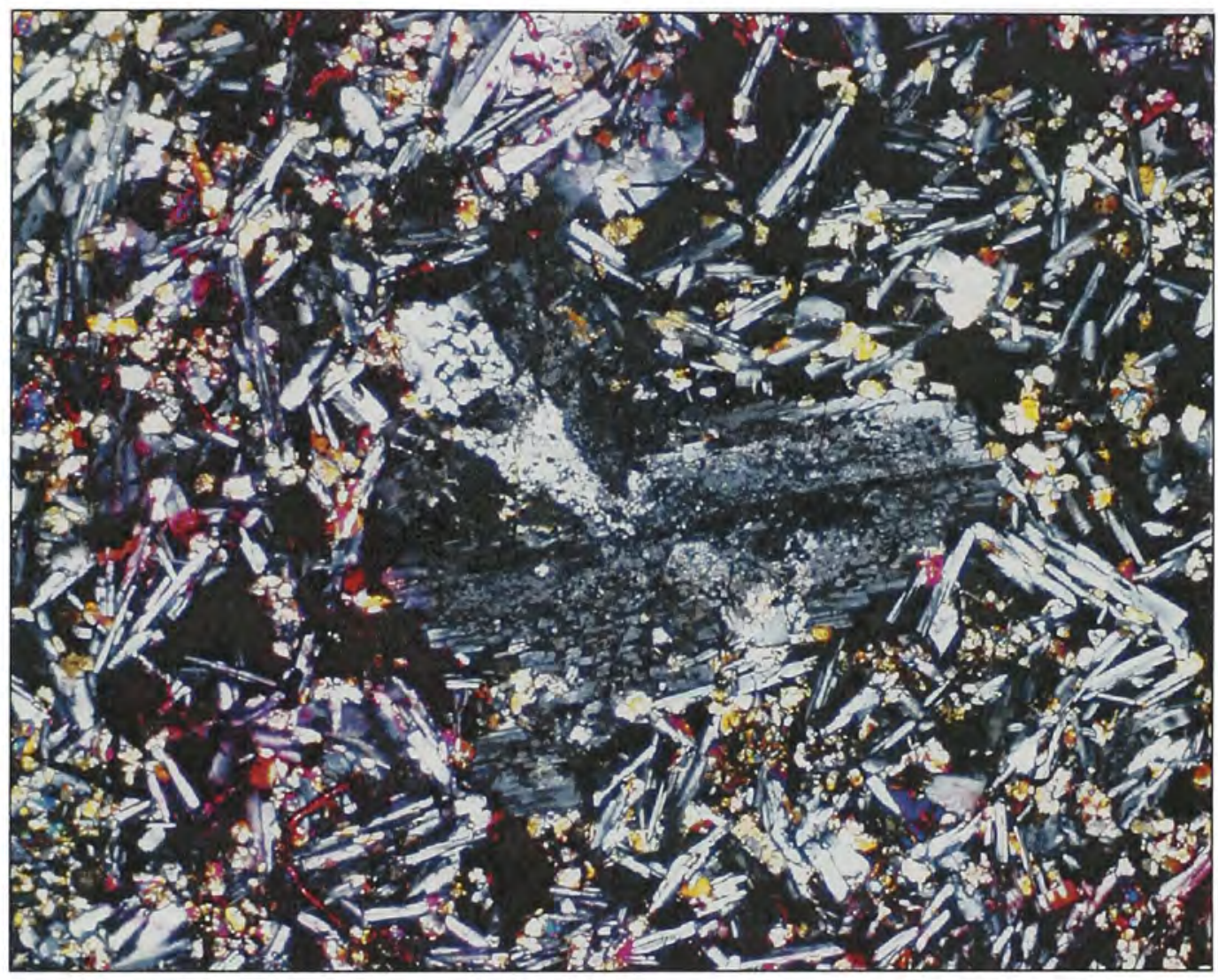

Figure 26- Plagioclase phenocryst showing extreme resorption throughout the crystal. This crystal has an anorthite content of 96 (Sample CHI-24). (Crossed polars: Width of field of view represents $2.5 \mathrm{~mm}$ ). 
Phase-equilibrium experiments on hydrous mafic to intermediate-composition basaltic systems and the common occurrence of highly anorthitic plagioclase in high-Al basalts and andesites from convergent plate boundaries indicate that such high-An plagioclase commonly crystallizes from $\mathrm{H}_{2} \mathrm{O}$-rich basaltic magma (see discussion and references in Sen, 2001).

This finding lends some support to Lange's (2002) contention that GRB magmas were extremely hydrous. The rarity of the highly anorthitic plagioclase phenocrysts may indicate that only a few formed from hydrous parent melts prior to any degassing, whereas most plagioclase phenocrysts formed at shallow crustal depths after their parent magmas had mostly degassed. Alternatively, only a few input melts may have been hydrous, while the bulk, were relatively anhydrous.

Pyroxene

$\mathrm{Mg}$ numbers $\left[100 * \mathrm{Mg} /\left(\mathrm{Mg}+\mathrm{Fe}^{2+}\right)\right]$ for pyroxene phenocrysts range from 36 to 79 , with the mean at 65 . The lower sections (GR and China Creek type sections) have Mg \#'s ranging from 48 to 79 , middle sections (Umtanum, Ortley) have Mg\#'s ranging from 36 to 71 , and upper sections (Sentinel Bluffs) range from 48 to $76 . \mathrm{Mg}$ numbers for Groundmass pyroxene range from 34 to 76 , with an average value of 62 . Groundmass pyroxene in the lower sections (GR and China Creek type sections) have Mg \#'s ranging from 41-73 while middle sections (Umtanum, Ortley) have Mg\#'s ranging from 34 to 73 and upper sections (Sentinel Bluffs) range from 45 to 76 . There does not appear to be a consistent trend in the Mg\#'s in either the Groundmass or in the phenocrysts.

Figure 25B shows compositions of augite phenocrysts in terms of $\mathrm{Mg} /\left(\mathrm{Mg}+\mathrm{Fe}^{*}\right)$ plotted against those of the bulk rock. Also shown are constant $\mathrm{K}_{\mathrm{d}}$ (dashed) lines defined 
by experimentally determined coexisting mineral and melt compositions (See figure 25 caption). The two dashed lines represent the upper and lower limits of all experimental determinations (Thy et al., 1999; Yang et al., 1996). This figure, like figure 25A, shows a large range of phenocryst compositions, many of which are clearly out of equilibrium.

This provides further evidence for a mechanism in which magmas carrying phenocrysts of very different compositions were well mixed. Resorption features and the presence of normally and reversely zoned phenocrysts in individual samples point to preeruption magma mixing as an important mechanism that controlled the erupted lava compositions (cf. Kuo and Kirkpatrick, 1982; Sen, 1983; Durand and Sen, 2004).

Figure 27 shows augite and pigeonite phenocryst compositions in a pyroxene quadrilateral, which also includes some experimentally determined isotherms for pyroxenes that crystallize from tholeiitic basalt magmas at 1 atm pressure (Lindsley, 1983). This diagram indicates that the pyroxene phenocrysts formed between $1200^{\circ}$ and $1000{ }^{\circ} \mathrm{C}$. Schiffman and Lofgren (1982) performed 1-atm melting experiments on pillow basalts from the GRB. They were able to duplicate the pillow basalt textures in most cases indicating that indeed the basalts evolved in a low pressure environment. Pillow outer rim textures were duplicated in runs cooled from $1125^{\circ} \mathrm{C}$ at very fast cooling rates $\left(>2100{ }^{\circ} \mathrm{C} / \mathrm{hr}\right.$ ), inner rim textures were duplicated in runs cooled at rates between $450^{\circ}$ and $84^{\circ} \mathrm{C} / \mathrm{hr}$ and the pillow interiors were duplicated in experiments at cooling rates between $42^{\circ}$ and $10^{\circ} / \mathrm{hr}$ (Schiffman and Lofgren, 1982). Cooling rates less than $10^{\circ} \mathrm{C} / \mathrm{hr}$ were not found in any of the runs for the pillow basalts. The colonnade basalt that overlies the pillow basalts, however, exhibits a texture analogous to those produced in an experiment cooled at $1^{\circ} \mathrm{C} / \mathrm{hr}$ (Schiffman and Lofgren, 1982). 


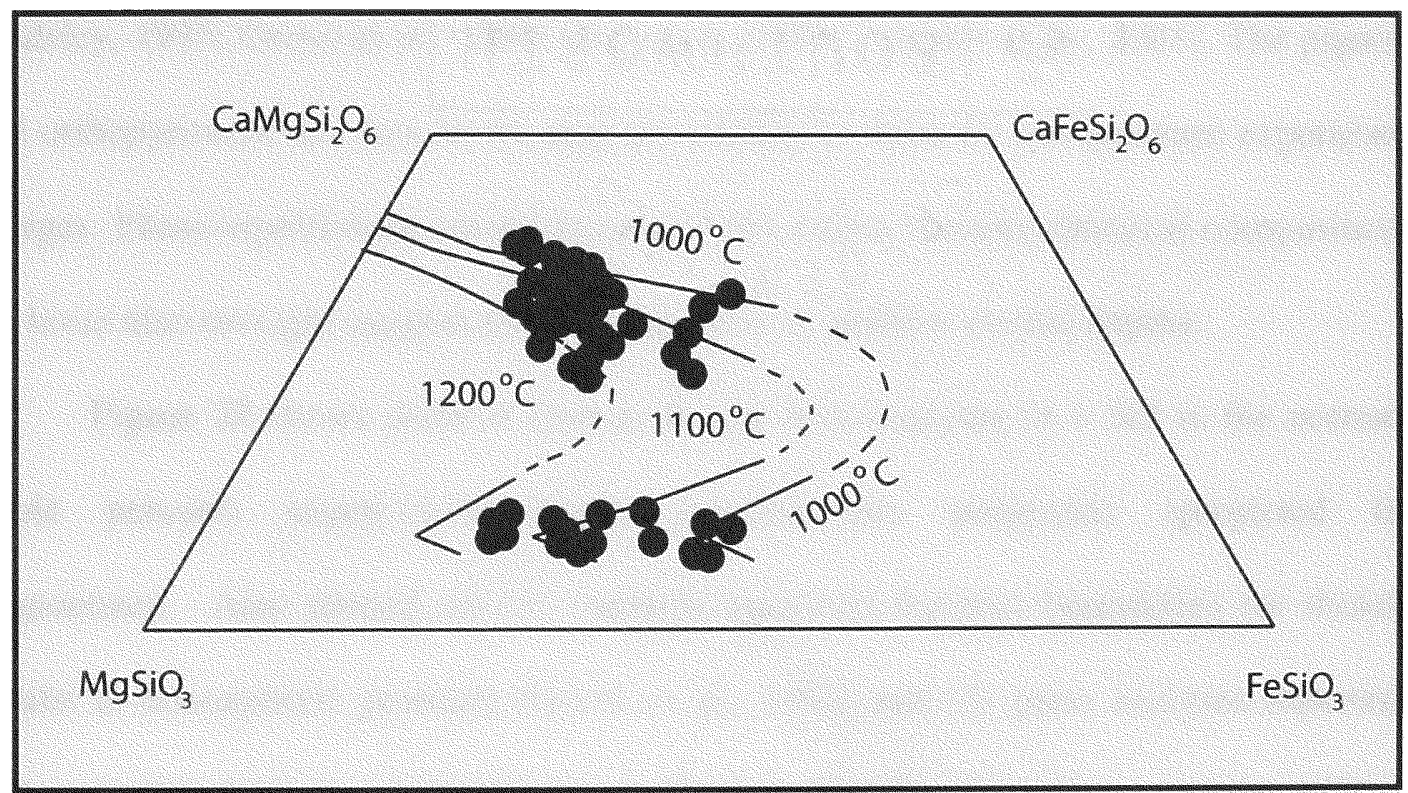

Figure 27- Pyroxene quadrilateral showing 1 atm isotherms (Lindsley, 1983) and compositions of augite and pigeonite phenocrysts in Grande Ronde lavas. The temperature of crystallization was between $1200-$ $1000^{\circ} \mathrm{C}$. 


\section{DISCUSSION}

\section{Evidence for Low-Pressure Equilibration}

Plagioclase, pigeonite, augite, olivine (altered), and a few orthopyroxene phenocrysts are typical crystallization assemblages in experimental crystallization studies of tholeiitic basalts at 1 atm pressure (cf. Basaltic Volcanism Study Project, 1981; Lindsley, 1983; Grove et al., 1989; Thy et al., 1999; Latypov et al., 2001). The pigeonite and orthopyroxene are low in $\mathrm{Al}$, and are similar to those in low-pressure experimental charges. Phase-equilibrium considerations of the major element chemical composition of the lavas also strongly suggest their equilibration at shallow crustal depths.

Figure 28 shows plots of Grande Ronde lava analyses $(n=50)$ in the normative (mole percent) augite-olivine-quartz pseudoternary projection (projected from plagioclase). Also plotted are (1) multiply saturated liquidus boundaries for tholeiitic basalts at atmospheric pressure (Grove et al., 1982) and (2) glass analyses reported in high-pressure melting experiments on Grande Ronde Formation starting materials (Takahashi et al., 1998). Grande Ronde lavas form a tight cluster close to the atmospheric-pressure liquidus boundary, suggesting that the erupted lavas last equilibrated at or near atmospheric conditions. The linear cluster of Grande Ronde lavas can be explained by magma mixing (mixing line from A to B is shown in Figure 28) between a less differentiated liquid, such as B (with olivine, augite, and plagioclase phenocrysts), and a more evolved melt saturated with pigeonite ( \pm orthopyroxene, plagioclase and augite). Note that such magma mixing would force pigeonite crystals to become unstable and, therefore, react with the mixed melt, which is consistent with the 


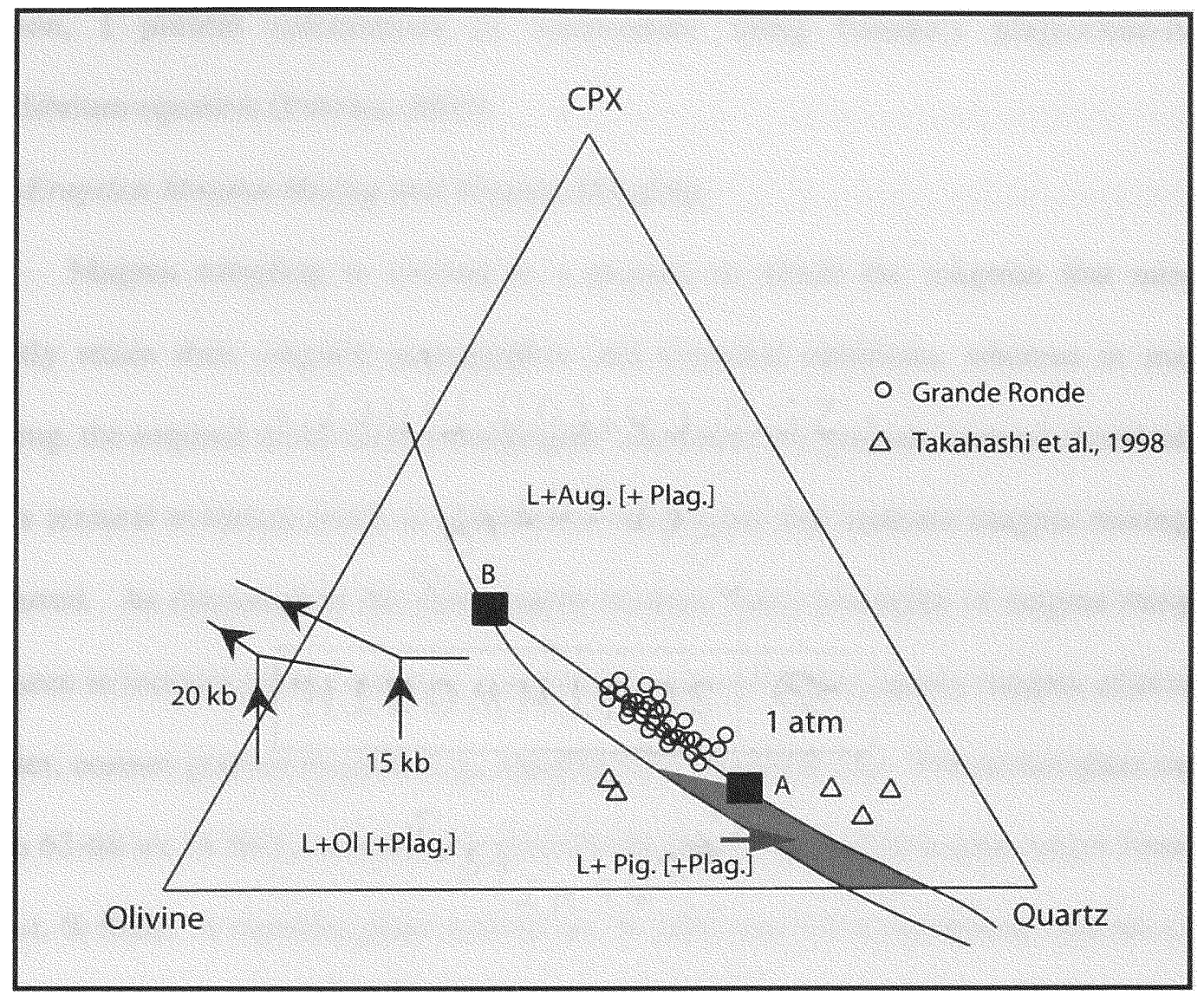

Figure 28- Liquidus (L) phase diagram (mol\%, projected from plagioclase) for tholeiitic basalts at atmospheric pressure (Grove et al., 1982). Circles-Grande Ronde lavas. Triangles-experimentally produced partial melts from eclogite at high-pressure (Takahashi et al., 1998). Thick line-a hypothetical mixing line between two end-member melts, B and A. I contend that the linear cluster of Grande Ronde Formation lavas is due to low-pressure mixing between a less evolved melt (such as B) and a highly evolved, pigeonite-saturated melt (A). 
petrography of these rocks (resorbed pigeonite: discussed earlier). Augite would be stable in the mixed melt and would therefore nucleate on the resorbed pigeonite phenocrysts (and orthopyroxene, if present), forming a rim around them. In a later section, I present calculations of temperature using Putirka's plagioclase-liquid equilibrium equation (Putirka, 2005).

\section{Pre-Eruption Magma Mixing and Magma Mingling}

Magma mingling is viewed as a process in which the magmas that mingled mostly retain their original petrographic and chemical identities, whereas in magma mixing, the original melts loose petrographic identities, but provide mineral chemical and other textural evidence (such as phenocryst resorption) that indicate magma mixing has occurred. As discussed in the petrography section, many examples of magma mingling are seen in individual thin sections, comprising veins of darker, glassy magma adjacent to lighter, coarser grained magma (e.g., samples CHI-38, GRB-16). The darker glass ranges from 63-68 wt. $\% \mathrm{SiO}_{2}$, whereas the glass in the lighter, crystal rich area ranges from 5863 wt. $\% \mathrm{SiO}_{2}$. A rhyolitic glass with 82 wt. $\% \mathrm{SiO}_{2}$ was found juxtaposed against a dark glass with 63 wt. $\% \mathrm{SiO}_{2}$. Anorthite content of plagioclase in the lighter areas is 68-70, while in the darker areas, it is 65-66. In, GRB dike and GRB flows, the lighter colored area is coarser grained than the darker, glassier and fine grained area it interacts with (see Figures 8 and 19). The plagioclase compositions associated with lighter glass is An6870, whereas it is An65-66 in the dark glass.

Reverse zoned and resorbed plagioclase phenocrysts, resorbed pigeonite phenocrysts, and euhedral augite rims on resorbed pigeonite and low-Al opx cores in some lavas all point to an extensive melt mixing process that forced such disequilibrium 
textures. The augite rims on the resorbed pigeonite would point to a reaction relationship such as L+Pig $\rightarrow$ Aug; however, such a reaction does not occur in experimental phase equilibrium studies of tholeiitic basalts (BVTP, 1981). On the other hand, such a texture is easily explained by magma mixing between a less differentiated magma (melt $\mathrm{B}$ in Figures 28 and 29) carrying pigeonite phenocrysts and another magma (melt A) carrying augite (+olivine and plagioclase) phenocrysts. Such mixing would lead to a new magma whose composition would fall inside the augite liquidus field, forcing the pigeonite crystals to be out of equilibrium with the new magma. In such a scenario, pigeonite crystals would start to dissolve while augite would nucleate. In sample $\mathrm{CHI}-24$ from GRB (Figure 15), the growth of the augite rim on the dissolving pigeonite reached a point where the pigeonite crystal became isolated from the melt (rimmed by augite) and could no longer dissolve. In contrast, the spongy pyroxene in sample CHI-20 (Figure 17) kept dissolving because the mixed melt may have been superheated so that it did not reach augite saturation. Reverse zoning and resorption of plagioclase (see figures 11-13 and 26) also point to a rise in temperature during the mixing process. This could have dissolved some of the phenocrysts making the lavas aphyric to near-aphyric. 


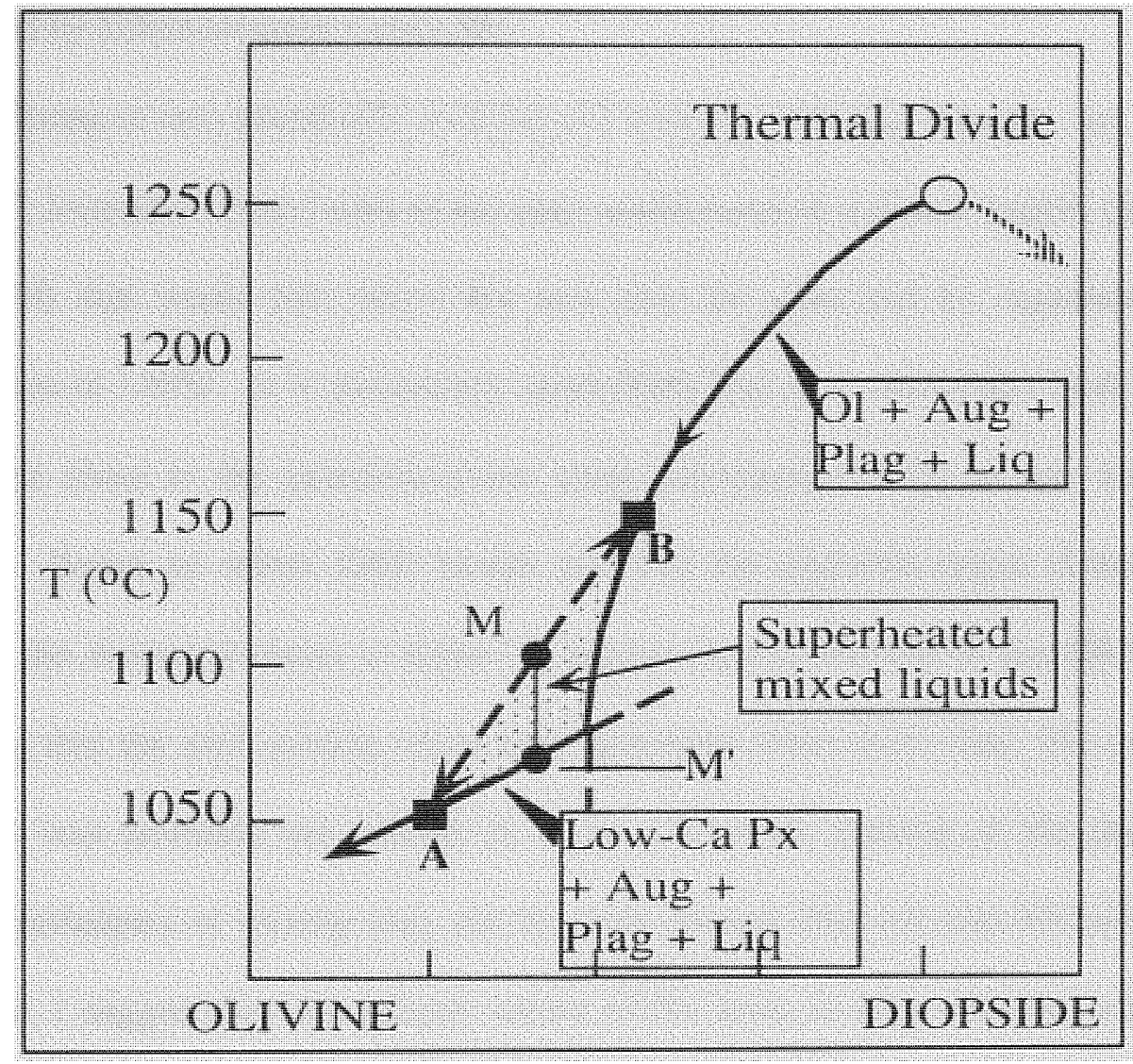

Figure 29- This diagram is projected from plagioclase onto the join formed by olivine-diopside boundary (from Walker et al., 1979). Gray curves represent liquidus surfaces. When melts A and B are mixed to produce a new melt, $M$, it is going to lie above its corresponding liquidus temperature (i.e., it will be superheated), which is at $\mathrm{M}$. This diagram implies that mixed melts are going to be slightly superheated. Ol-olivine; aug-augite; plag-plagioclase; liq-liquid; px-pyroxene. 
Walker et al. (1979) experimentally examined how melt mixing within similar compositional range can generate extra heat. Of particular relevance is the low temperature 'cusp' that occurs on the liquidus where the curves $C a$-poor $p x+p l+a u g+l i q$ and ol+aug+plag+liq meet in the system pl-ol-aug-silica (Figs. 28 and 29). Such a cusp is required by Schreinemaker's principle.

Mixing of two chemically evolved and multiply saturated magmas, say A and B in Fig. 29, located on either sides of the cusp would result in a mixed magma (magma M in Fig. 29) that would plot above the area near the cusp and be superheated by a temperature of $\sim 50^{\circ} \mathrm{C}$. It is particularly noteworthy that $\mathrm{M}$ is chemically quite evolved, as it plots close to the pseudoinvariant point aug+pig+pl+ol+liq at one atmosphere pressure. Based on where GRB basalts plot and the pigeonite-augite disequilibrium textures, the mixing scenario in figure 29 appears highly relevant to the GRB basalts, indicating that the melt mixing could have generated some extra heat. The amount of superheat was probably not enough to cause wholescale melting of the phenocrysts because enthalpies of mixing may not be large enough [Russell and Nicholls, 1990]. Therefore, I suggest the near-aphyric nature of the lavas to very efficient near-surface fractional crystallization process that removed the bulk of the crystals from the magma by a mechanism such as solidus front crystallization in shallow magma chambers (Marsh, 1989, 1996; discussed in Durand and Sen, 2004).

\section{Phenocryst Residence Times in GRB Magma Chambers}

I used a simple approach to calculate the residence time of a GRB phenocryst in a magma chamber. Crystal growth time- $[(\mathrm{t})=\mathrm{L}$ (length of the phenocryst)/G (growth rate)]. The largest phenocryst found in my samples is $1.2 \mathrm{~mm}$ (length). Using growth 
rate of $10^{-10} \mathrm{~cm} / \mathrm{s}$ (Marsh, 1996), I obtain 3.8 years for residence time. This result is very similar to that of Ramos et al. (2005) who used diffusion relations of ${ }^{87} \mathrm{Sr} /{ }^{86} \mathrm{Sr}$ across plagioclase zone boundaries to determine phenocryst residence times. This result indicates that GRB phenocrysts had extremely short residence times. This implies that the GRB magma chamber was partially flushed out every 4 to 5 years.

\section{More on Shallow Fractionation and Mixing}

The volatile contents of magmas are controlled by the laws of phase equilibria, which do not permit a high percentage of dissolved water in basaltic melts within the shallow crust (Lange, 2002). If all parent magmas of the Grande Ronde Formation contained high amounts of $\mathrm{H}_{2} \mathrm{O}$ and were therefore essentially crystal free at depth (as proposed by Lange, 2002), these would have lost dissolved volatiles by degassing during extensive shallow-level magma mixing and fractionation. Shallow degassing would in turn result in rapid crystallization along the walls of the shallow conduits (perhaps a network of dikes and sills: Marsh, 1989, 1996). The efficient removal of phenocrysts could have been accomplished by punctuated differentiation (Marsh, 1989, 1996). In punctuated differentiation, magma which formed at higher pressures is emplaced in a shallow chamber already phenocrysts. Inward-propagating solidification fronts within the shallow chamber captures many phenocrysts along the margins, and a largely molten zone forms in the center of the chamber. Successive batches of melt equilibrated at higher pressure, and then emplaced in this chamber would mix with the resident melt, while breaking off phenocrysts from the partly solidified zones. The magma replenishment would create volume instability within the chamber and would force some of the nearly 
crystal-free mixed melts to be erupted via dike-like conduits (Marsh, 1989, 1996). It is suggested that this flushing out of melt happened on a frequency of 4-5 year time scales.

\section{Lava Flow Cooling Rates and Speed}

Cooling rates of CRBG lavas have been the subject of much discussion. In order to explain the presence of long lava flows in the CRBG, Shaw and Swanson (1970) have proposed that flows were erupted at high eruption rates $\left(>1 \mathrm{~km}^{3} /\right.$ day $\left./ \mathrm{km}\right)$. Model calculations performed by Shaw and Swanson (1970) indicate that flows traveled 5-15 $\mathrm{km}$ per hour, or faster, and advanced as sheet floods. Furthermore, calculations of viscosity based on the chemical composition showed that the viscosity of the flows was not unusually low and that the viscosity of the CRBG lava flows (500 poise) was only slightly greater than that of modern Kilauea lava. According to Shaw and Swanson (1970), the high rate of eruption combined with the huge volume of available magma enabled the flows to travel so far. Also, Shaw and Swanson (1970) suggest that the textural and compositionally homogeneous nature of the lavas can be explained by turbulent flow conditions which would mix and homogenize the flows constantly as these traveled. Evidence for rapid rates of eruption include the presence of sideromelane in water quenched rims of pillows in areas that are far away from the vents that these were erupted from (Swanson et al., 1979). In addition, glass in these flows contains less than $5 \%$ crystals, and many crystals have branching, skeletal shapes typical of rapid quenching events (Lofgren, 1982). Ho and Cashman (1997) also find that in the $500 \mathrm{~km}$ long Ginkgo flow (Wanapum Formation) temperatures do not change significantly over the extent of the flow. The temperature change is only about $15-20^{\circ} \mathrm{C}$ over the entire length.

Shaw and Swanson propose that for a $1000 \mathrm{~km}^{3}$ flow, emplacement took place in days to 
weeks. They contend that the CRBG eruption rates are very similar to historical Kilauea which has average eruption rates of $10^{-3}$ to $10^{-4} \mathrm{~km}^{3} /$ day $/ \mathrm{km}$ (Shaw and Swanson, 1970; Swanson et al., 1975).

On the other hand, Self et al. (1997) suggest that emplacement took place over months to years. They propose that for the lava to flow long distances, tube-like emplacement and emplacement by lava inflation is necessary. Lava tubes form when the surface of a lava flow cools and solidifies, while the still-molten interior flows through and drains away, forming a tunnel. This mechanism insulates lava from the surface, as a result the hotter lava can travel longer distances without significant cooling. Similarly, in lava inflation, the solid upper crust is uplifted above a still molten lava interior. As more lava is injected into the interior of the flow, the rigid outer crust inflates. Multiple lava injections cause the lava flow to increase in thickness. Initial thicknesses can range from $20-30 \mathrm{~cm}$ and can increase up to $5 \mathrm{~m}$ or more (Hon et al., 1994). Tube-like emplacement (lava tubes) and lava inflation mechanisms are typically observed in the pahoehoe lava flows of Hawaii. Lava tubes have not been observed in CRBG flows; however, Reidel (2005), reports that the Cohassett Flow (Sentinel Bluffs Member) of the GRB shows evidence of inflated lava flows.

The average magma supply rate for the $\mathrm{CRBG}$ was 0.1 cubic kilometer per year (Swanson, 1972), which is identical to those calculated for present day Mauna Loa and Kilauea volcanoes (Jackson et al., 1972). Jackson et al. (1972) assert that this is the approximate modern rate of magma production in a melting spot that is approximately 7 x $10^{4} \mathrm{~km}^{2}$ in area. Utilizing similar parameters, Jackson et al. (1972) calculated that the melting regime beneath the CRBG plateau would be approximately $2 \times 10^{5} \mathrm{~km}^{2}$. 
Some workers however believe that the maximum rate of supply, in late Grande Ronde time, was 2-3 times that at Kilauea based on revisions of the geomagnetic time scale (Baksi, 1989).

A large number of lava flows appear to have traveled up to $500 \mathrm{~km}$ without ample crystallization or a significant decrease in temperature (Shaw and Swanson, 1970; Ho and Cashman, 1997). Ho and Cashman (1997) found that flows quenched to glass when they entered water even after traveling for hundreds of kilometers and that the crystal content of the glass was not much higher than that found in the chilled margins of the feeder dikes ( $11 \%$ at the vent to $\sim 16 \%$ at the end of the flow). These findings provide evidence for very little cooling of the long lava flow of the CRBG. Several scenarios have been proposed to explain this finding; for example, the lava flows could have been superheated and therefore the flows did not cool enough to form a significant number of crystals (Ho and Cashman, 1997; Durand and Sen, 2004), or the lava flows were insulated by a crust thick enough to prevent the internal lava from cooling (inflated flows) and allowing it to flow a long distance, as has been observed in Hawaiian lava flows (Shaw and Swanson, 1970).

Measured crystallinities and phase compositions of natural and experimental samples from one of the long CRBG flows (the Gingko flow) tightly constrain the minimum temperature of this particular flow to $1085^{\circ} \mathrm{C} \pm 5^{\circ} \mathrm{C}$ (Ho and Cashman, 1997). Ho and Cashman concluded that the maximum temperature change throughout the 500 $\mathrm{km}$ length of the flow was only $20^{\circ} \mathrm{C}$, which implies cooling rates between 0.02 to 0.04 ${ }^{\circ} \mathrm{C} / \mathrm{km}$. These cooling rates are much smaller than for Hawaiian aa flows $\left(1.0-4.4^{\circ} \mathrm{C} / \mathrm{km}\right)$ and for active Kilauea lava tubes $\left(0.6-1.0^{\circ} \mathrm{C} / \mathrm{km}\right)$ (Helz, et al., 1992; Cashman et al., 
1994). Low cooling rates mean rapid emplacement or that transport was extremely thermally efficient (Ho and Cashman, 1997).

I obtained cooling rates for Grande Ronde lavas using a very different method based on $\mathrm{Al}_{2} \mathrm{O}_{3}$ and $\mathrm{TiO}_{2}$ contents of groundmass pyroxenes. This method makes use of an earlier experimental determination of Grove and Bence, (1977) that the partitioning of $\mathrm{TiO}_{2}$ and $\mathrm{Al}_{2} \mathrm{O}_{3}$ in pyroxenes is strongly cooling rate dependent (Figure 30). Both augite and low-calcium pyroxenes show the same rate dependency.

Grande Ronde groundmass pyroxene $\mathrm{Al}$ and $\mathrm{Ti}$, normalized to 6 oxygen, contents were plotted on a graph with the 1:1, 1:2, 1:4 trends of Grove and Bence (1977). The majority of GRB lavas plot inside the $4^{\circ} \mathrm{C}$ per hour cooling rate trend, although it appears that the magma (s) had a range of cooling rates from less than $1{ }^{\circ} \mathrm{C}$ per hour to greater than $10^{\circ} \mathrm{C}$ per hour (Figure 30$)$. A flow rate for an average GRB long lava flow $(100 \mathrm{~km})$ was obtained by taking the cooling rate obtained from the Ti-Al plot $\left(4^{\circ} \mathrm{C} / \mathrm{hr}\right.$ ) (Figure 31) and the change in temperature of the melt $(\Delta T)$. This change in temperature indicates the difference between the eruption temperature (liquidus) and the temperature of crystallization (solidus) for the GRB melts. Temperatures were obtained from MELTS thermodynamics software calculations (Sack and Ghiorso, 1994)

Time $=\Delta \mathrm{T} /$ Cooling Rate $\left(4^{\circ} \mathrm{C} / \mathrm{hr}\right)$

- $\Delta \mathrm{T}=$ (difference between the temperature of eruption (liquidus) minus temperature at which the melt solidifies)

- $1159^{\circ} \mathrm{C}-799^{\circ} \mathrm{C}$ (Obtained from MELTS)

- Time $=90$ hours

- Flow velocity=distance/time;

Therefore, flow velocity for a $100 \mathrm{~km}$ long lava flow would be $100 \mathrm{~km} / 90 \mathrm{hr}$ or 1.1 $\mathrm{km} / \mathrm{hr}$, and of a $600 \mathrm{~km}$ lava flow it would be $6.7 \mathrm{~km} / \mathrm{hr}$. 


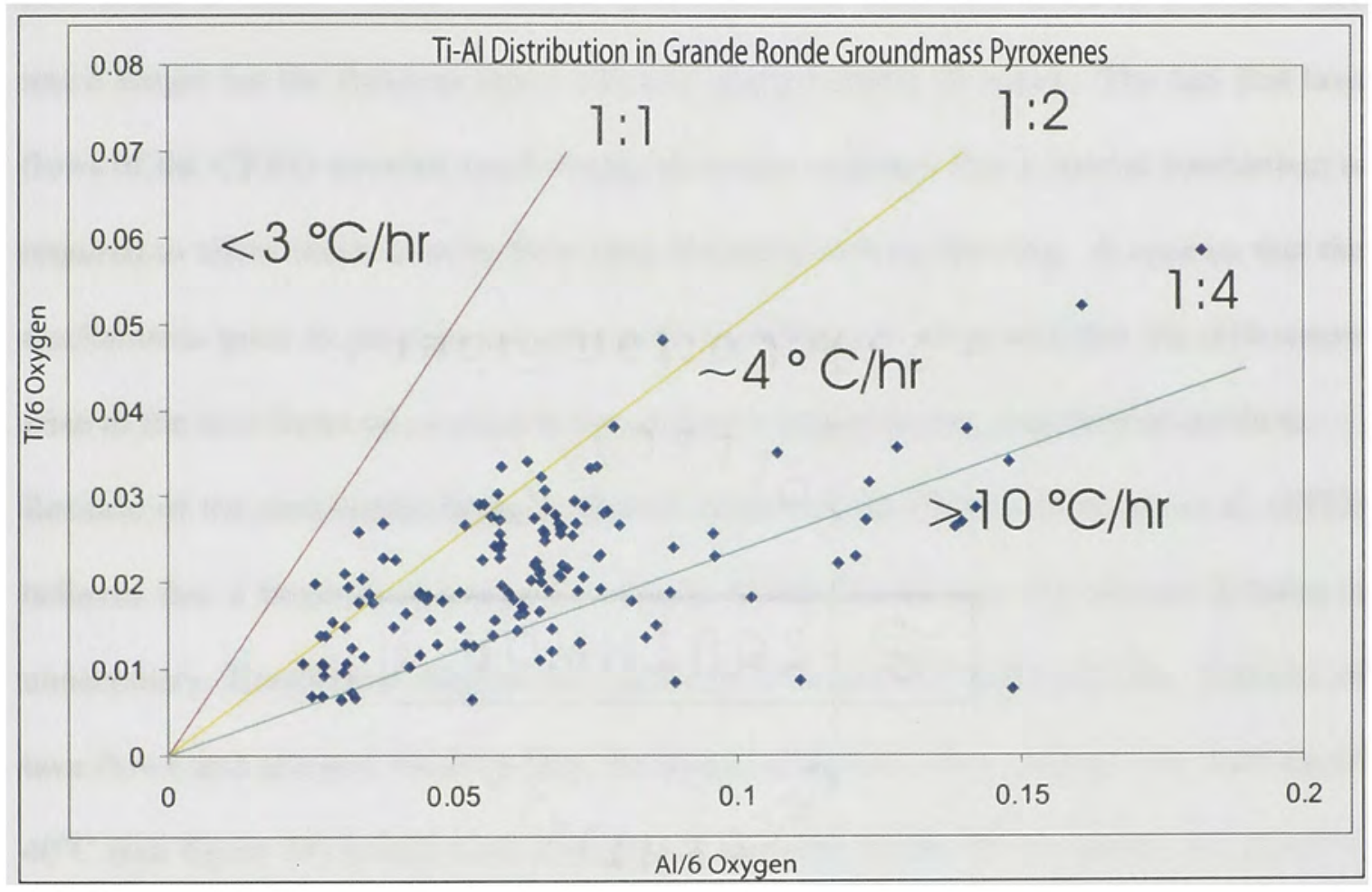

Figure 30- Graph showing Ti vs. Al Groundmass data indicating Grande Ronde lava cooling rates for Groundmass pyroxene. 
For the sake of comparison, an aa flow from Hawaii's Mauna Loa volcano had a measured velocity of approximately $1.98 \mathrm{~km} /$ hour (Decker et al., 1987). Considering that aa is more viscous and has a lower temperature than pahoehoe flows, this rate is at the lower end of the spectrum of lava flow rates. At this rate, it would take this Hawaii flow 50.5 hours to travel $100 \mathrm{~km}$. At the calculated flow rates for the GRB, it would take much longer for the flows to travel $100 \mathrm{~km}$, approximately 91 hours. The fact that lava flows of the CRBG traveled much longer distances indicates that a special mechanism is required to allow these lavas to flow long distances without freezing. It appears that the mechanisms prior to eruption are similar to the Hawaiian lavas and that the differences arise as the lava flows on or close to the surface in upper crustal chambers or conduits.

Because of the similarities between Hawaii lavas and the CRBG, Swanson et al. (1975) believes that a larger heat source for Grande Ronde Basalt than for modern Kilauea is unnecessary. Exothermal magma mixing could have lowered the kinematic viscosity of lava flows and allowed these to flow for longer distances. For example, an increase of $40^{\circ} \mathrm{C}$ (see figure 29 ) would have lowered the viscosity of the mixed magma by about 50 poise, which is a significant number. The center of a $30 \mathrm{~m}$ thick near-liquidus lava flow with a Newtonian viscosity of 300 poise would travel at $15 \mathrm{~km} /$ hour over a slope of 1 degree based on the following equations (http://www.geo.ua.edu/volcanology/lecture notes.html).

$$
\eta \dot{\eta}=\operatorname{g} \rho \sin \mathrm{Ad} 2 / 3 \mathrm{~V}
$$

[where $\eta$ is the viscosity, $g$ is acceleration of gravity, $\rho$ is density of magma $\left(2.8 \mathrm{~g} / \mathrm{cm}^{3}\right)$, A is slope angle, $\mathrm{V}$ is velocity, and $\mathrm{d}$ is depth of flow.] 
The same lava flow superheated by $40^{\circ}$ will travel at $25 \mathrm{~km} /$ hour. These numbers represent appropriate average velocities for GRB lava flows [Shaw and Swanson, 1970]. Eruption Conditions: Thermometry and Barometry

I calculated eruption conditions using the plagioclase phenocryst data obtained during this study and whole rock data from Hooper and Hawkesworth (1993). Pressure and temperature conditions were calculated for plagioclase crystals that were in equilibrium with appropriate liquid compositions (whole rock data was assumed to be the same as the liquid in this case since most of the GRB is aphyric).

Plagioclase-liquid thermo barometers of Putirka (2005) were used to estimate the pressure and temperature of crystallization and the water contents of the GRB lavas. Although the Sugawara (2001) and Ghiorso (1994) thermometers provide more accurate temperature estimates than earlier calibrations, these do not provide a means for calculating pressure from plagioclase-liquid equilibrium (Putirka, 2005). To remedy this shortcoming Putirka developed a plagioclase-liquid thermometer and barometer. Putirka's (2005) thermometers (below) yield an error that is $30-40 \%$ lower than Sugawara (2001) and Ghiorso (1994) models:

Putirka's Plagioclase-liquid thermometer based on his Model [A] as:

$$
\begin{aligned}
& 104 / \mathrm{T}(\mathrm{K})=68.8-0.86 \ln \left(\mathrm{An}^{\mathrm{P}} /\left(\mathrm{Ca}^{\mathrm{liq}}\left(\mathrm{Al}^{l i q}\right) 2\left(\mathrm{Si}^{l i q}\right)^{2}\right)+179\left(\mathrm{Al}^{l i q}\right)-113(\mathrm{Al} /(\mathrm{Al}+\mathrm{Si}))^{l i q} q_{-}\right. \\
& 7.92\left(\mathrm{AbAn}^{\mathrm{P}}\right)-6.13 \times 10-2(\mathrm{P}(\mathrm{kb}))-91.6\left(\mathrm{CaAl}^{l i q}\right)-155\left(\mathrm{Si}^{l i q}\right)+110.3\left(\mathrm{Si}^{l i q}\right)^{2}-149\left(\mathrm{Al}^{l i q}\right)^{2}
\end{aligned}
$$

(Where $P$ and liq denote plagioclase and liquid phases, respectively and $\mathrm{Ca}^{\text {liq }}, \mathrm{Al}^{\text {liq }}$, and $S i^{\text {liq }}$ represent the abundances of these elements in the liquid). 
Temperatures calculated using Putirka's Model [A] range from $1089^{\circ} \mathrm{C}$ to $1127^{\circ} \mathrm{C}$, which are slightly lower than those calculated by Caprarelli and Reidel (2005) using Putirka's clinopyroxene-liquid geothermometer $\left(1120-1222^{\circ} \mathrm{C}\right)$. Caprarelli and Reidel (2005) interpret these results as consistent with crustal-level magma chamber evolution. Note that their calculations were not limited to the GRB Formation, however, but included the entire CRBG stratigraphy. Interestingly, one of the younger members of the CRBG, the Pomona Member (12 Ma), had the highest temperature calculated. Higher potential temperatures are expected to translate into larger volumes of erupted magmas (Caprarelli and Reidel, 2005); however in this case, the Pomona Member is part of the Late Saddle Mountain Formation comprising $1 \%$ by volume of the CRBG (Hooper, 1988). Caprarelli and Reidel (2005) suggest that the temperature differences reflect magma chamber heterogeneities.

I also calculated pressure using Putirka's (2005) Model [C]:

$$
\begin{gathered}
\mathrm{P}(\mathrm{kb})=-42.2+4.94 \times 10-2(\mathrm{~T}(\mathrm{~K}))+1.16 \times 10-2 \mathrm{~T}(\mathrm{~K}) \ln \left(\mathrm{Ab}^{\mathrm{Pl}} \mathrm{Al}^{\mathrm{liq}} \mathrm{Ca}^{\mathrm{liq}} /\left(\mathrm{An}^{\mathrm{Pl}} \mathrm{Na}^{\mathrm{liq}} \mathrm{Si}^{\mathrm{liq}}\right)\right)- \\
382.3\left(\mathrm{Si}^{\mathrm{liq}}\right)^{2}+514.2\left(\mathrm{Si}^{\mathrm{liq}}\right)^{3}-19.6 \ln \left(\mathrm{Ab}^{\mathrm{Pl}}\right)-139.8\left(\mathrm{Ca}^{\mathrm{liq}}\right)+287.2\left(\mathrm{Na}^{\mathrm{liq}}\right)+163.9\left(\mathrm{~K}^{\mathrm{liq}}\right)
\end{gathered}
$$

(Where Pl and liq denote plagioclase and liquid phases, respectively and $\mathrm{Ca}{ }^{l i q}, A l^{l i q}$, and $S i{ }^{\text {liq }}$ represent the abundances of these elements in the liquid).

Although my calculated temperatures for the GRB obtained from the plagioclaseliquid geothermometer of Putirka are lower than those calculated from the clinopyroxeneliquid thermometer, my pressure results are very close to that of Caprarelli and Reidel (2005). Clinopyroxene-liquid barometry gave pressures ranging from 0 to $0.66 \mathrm{GPa}$, while I obtain pressures of $0.35 \mathrm{GPa}$ to $0.61 \mathrm{GPa}$ from the plagioclase-liquid barometer. 
The results of the two sets of pressure estimates by using very different barometry are very similar (Figure 31).

$\mathrm{H}_{2} \mathrm{O}$ contents of the magmas were derived by using Putirka's Model $[\mathrm{H}]$ and the temperatures calculated above.

$$
\begin{gathered}
\mathrm{H}_{2} \mathrm{O}(\text { wt. \% })=24.757-2.26 \times 10^{-3} \mathrm{~T}(\mathrm{~K}) \ln \left(\mathrm{An}^{\mathrm{Pl}} /\left(\mathrm{Ca}^{\text {liq }}\left(\mathrm{Al}^{\mathrm{liq}}\right)^{2} \mathrm{Si}^{\mathrm{liq}}\right)^{2}\right)- \\
3.847\left(\mathrm{Ab}^{\mathrm{Pl}}\right)+1.927\left(\mathrm{An}^{\mathrm{Pl}} /\left(\mathrm{Ca}^{\text {liq }} /\left(\mathrm{Ca}^{\mathrm{liq}}+\mathrm{Na}^{\mathrm{liq}}\right)\right)\right.
\end{gathered}
$$

(Where Pl and liq denote plagioclase and liquid phases, respectively and $\mathrm{Ca}^{\text {liq }}, \mathrm{Al}^{\text {liq }}$, and $S i^{l i q}$ represent the abundances of these elements in the liquid).

The results of the $\mathrm{H}_{2} \mathrm{O}$ calculations show that water contents are very low reaching the limits of the model, and some results are negative. I obtain dissolved $\mathrm{H}_{2} \mathrm{O}$ contents ranging from 0 to 0.29 wt. $\% \mathrm{H}_{2} \mathrm{O}$, which indicate either that the GRB magmas were very dry to begin with, or that, even if the original magmas were wet, they degassed significantly during ascent.

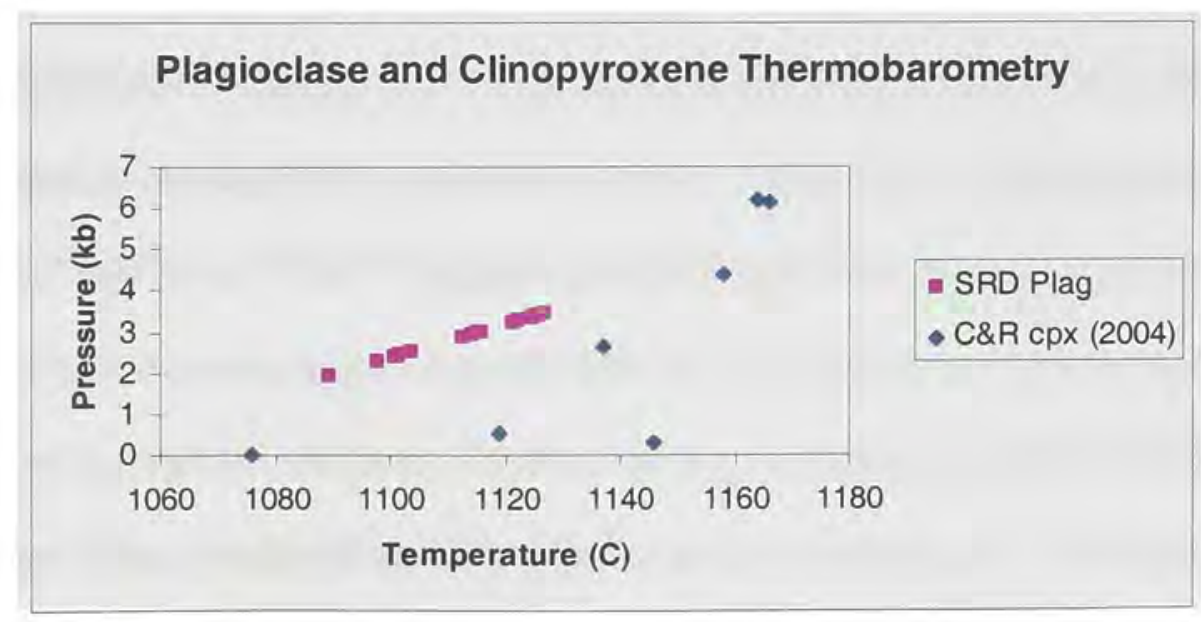

Figure 31- A comparison between plagioclase thermobarometric calculations conducted in this study and data from pyroxene calculations of Caprarelli and Reidel (2004). Plagioclase seems to fall in between the pyroxene values, both show low pressure and temperature values. 


\section{SUMMARY}

The results of petrographic and mineral chemistry analyses of the Grande Ronde basalts provide considerable insight into the generation of the formation. The following is a summary of the findings and observations outlined earlier. The largest and most abundant phenocryst phase in the GRB is plagioclase followed by augite and pigeonite. Olivine phenocrysts are rarely observed because most olivine phenocrysts have been completely altered to iddingsite. Unaltered olivine grains are generally only found in the groundmass. The Imnaha formation being fairly phyric with phenocryst of plagioclase, augite, and olivine, differs dramatically from the GRB. Many phenocrysts in the GRB show extensive resorption and evidence of magma mixing. For example, reverse and normal zoning patterns are seen throughout the flows, some of this zoning within single thin sections. Several of these crystals are also resorbed. In addition, magma mingling is seen in the flows and dikes of the GRB.

The GRB is generally chemically evolved with low $\mathrm{Mg}$ numbers $\left[\left(100 * \mathrm{Mg} /\left(\mathrm{Mg}+\mathrm{Fe}^{2+}\right)\right.\right.$ ranging from 30 to 64$]$ and high $\mathrm{SiO}_{2}(52-58 \mathrm{wt} \%)$. These lavas are enriched in incompatible elements and show a relatively flat HREE pattern. When plotted on ${ }^{87} \mathrm{Sr} /{ }^{86} \mathrm{Sr}$ vs. ${ }^{143} \mathrm{Nd} /{ }^{144} \mathrm{Nd}$ graph, the GRB (and Wanapum) plot near bulk earth.

Several features suggest that the GRB last fractionated at shallow depths before erupting on the surface. Evidence for this shallow processing includes the GRB's phase assemblage (Plag.+Augite+Pigeonite) which typical of magma that fractionated in the middle to upper crust. GRB lavas also plot near the 1-atm cotectic on an augite-olivinequartz pseudoternary projection, indicating once more that the lavas last equilibrated in shallow conduits. Because of the extensive resorption and zoning seen in the 
phenocrysts, it is suggested that superheated mixing of the magma is responsible for the lack of some of the phenocrysts in the GRB.

Other findings in the GRB include the presence of a few high-An plagioclase phenocrysts. These are interpreted to be due to the presence of a $\mathrm{H}_{2} \mathrm{O}$-rich source in the mantle. Many of these plagioclase phenocrysts (and pyroxenes) are out of equilibrium with the groundmass. Residence time in magma chamber(s) calculations indicate that if indeed these magmas last resided in shallow level conduits, they were processed rather rapidly as residence time calculation indicate very short durations ( $<5$ years). Lava flow rates obtained from calculated GRB cooling rates indicate that GRB lava flow rates are not significantly different than modern Hawaiian flow lava flow rates. This finding indicates that a special mechanism is required to generate the larger volumes observed at the CRBG plateau.

As a final point, calculations to determine the temperature, pressure and $\mathrm{H}_{2} \mathrm{O}$ content of the GRB were performed. The temperature results range from $1089{ }^{\circ} \mathrm{C}$ to $1127{ }^{\circ} \mathrm{C}$ while pressures from $0.35 \mathrm{GPa}$ to $0.61 \mathrm{GPa}$ were obtained. The erupted lavas had a maximum of $0.3 \mathrm{wt} . \% \mathrm{H}_{2} \mathrm{O}$, indicating that magmas were largely degassed at shallow depths or were dry to begin with. 


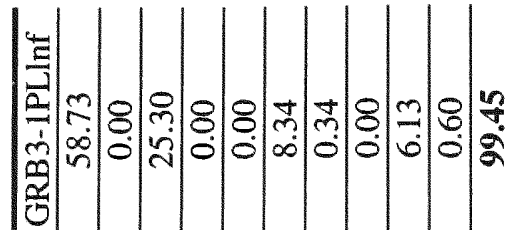

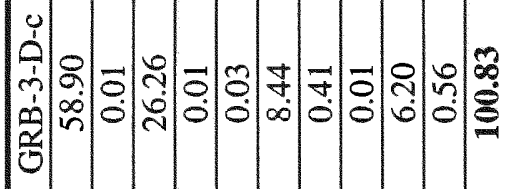

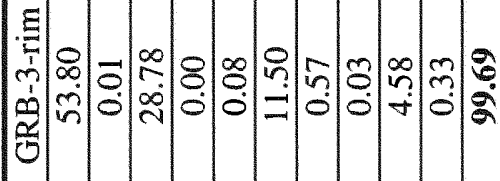

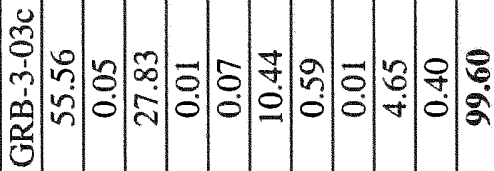

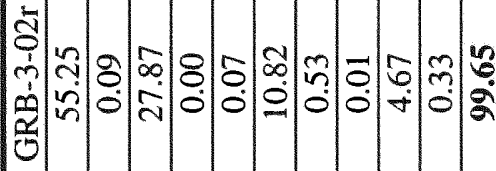

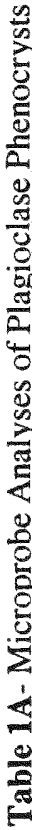

0

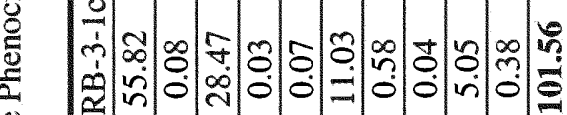

○

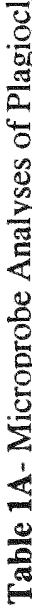

.

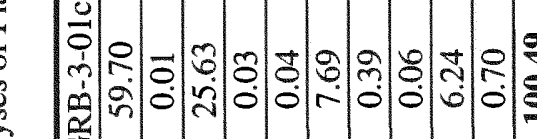

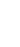

迹

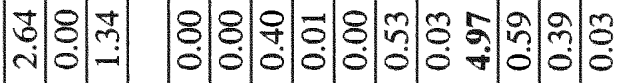

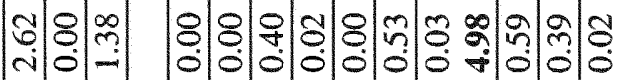

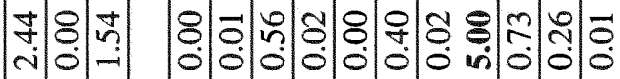

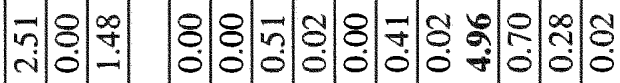

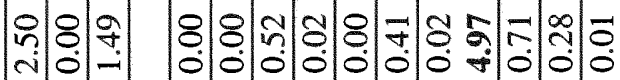

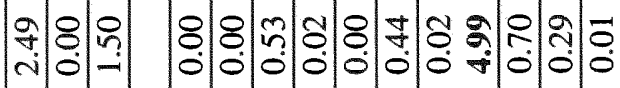

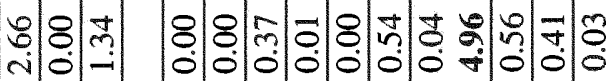




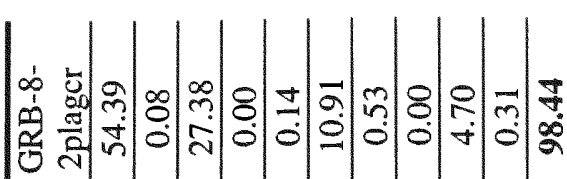

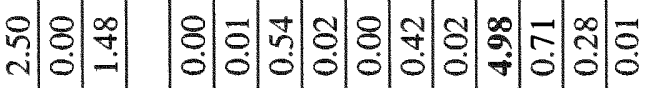

至

新응

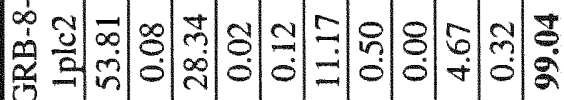

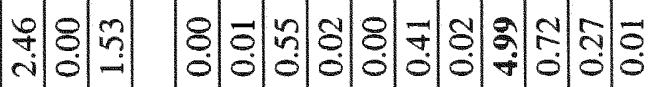

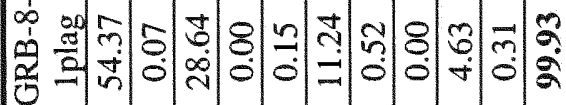

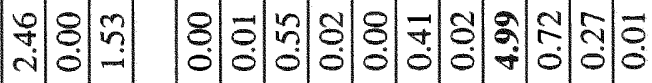

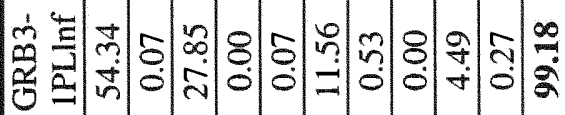

幽: 영

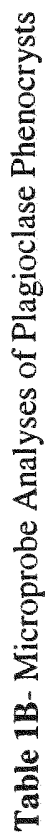

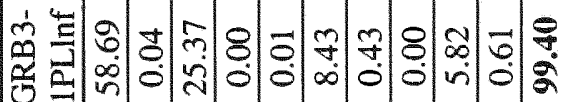

苟

대융

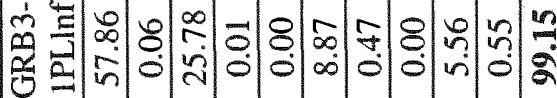

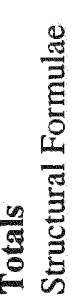

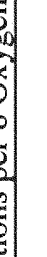

U் 


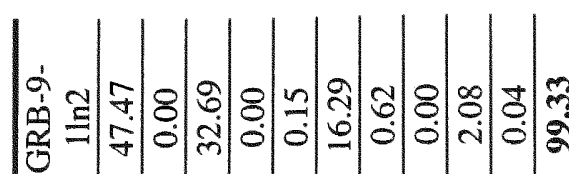

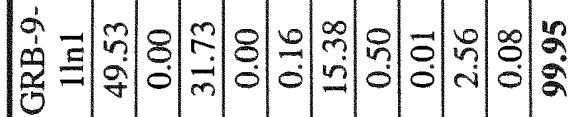

象

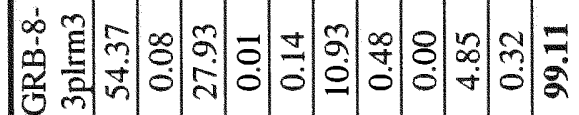

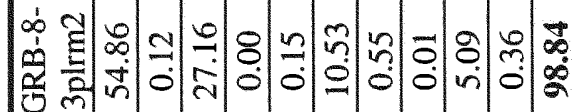

告
중

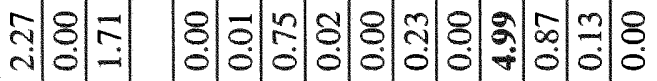

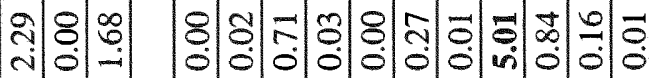

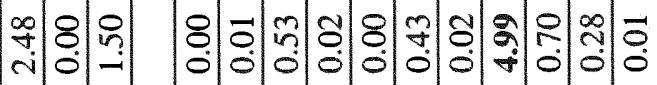

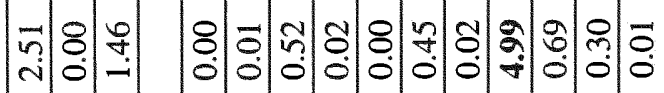

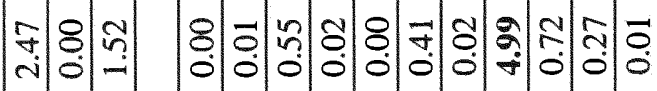

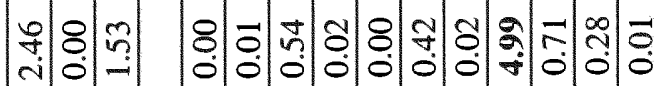

:

粂 m 


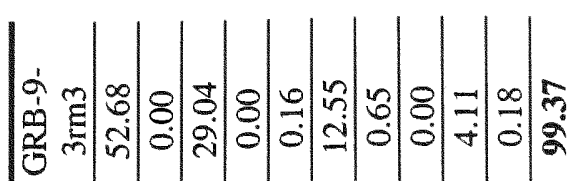

象

商

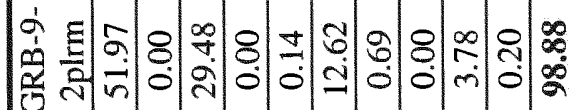

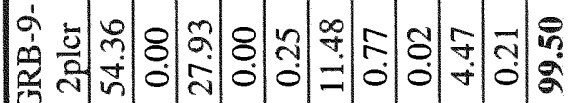

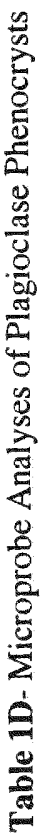

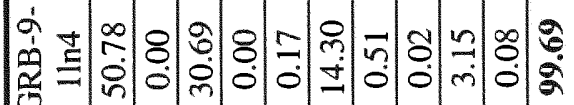

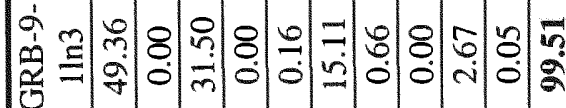

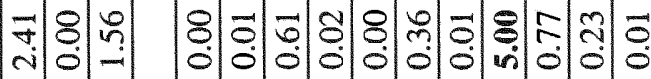

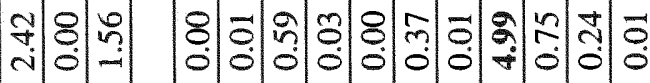

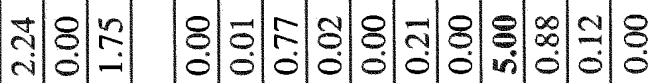

궁영 웅

권영

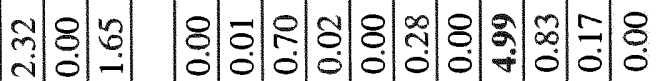

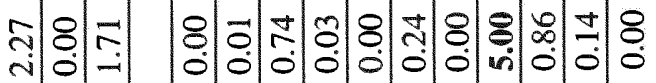

产

.

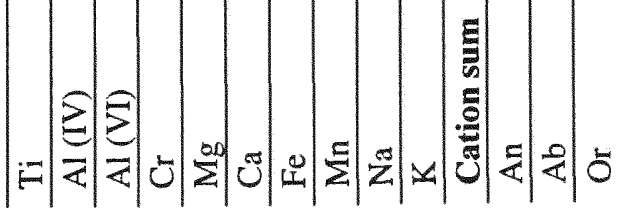




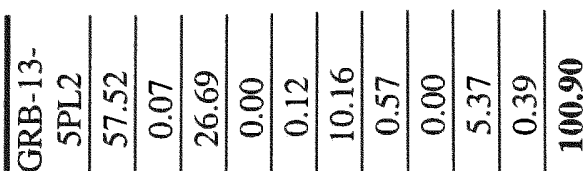

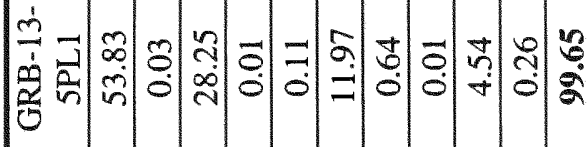

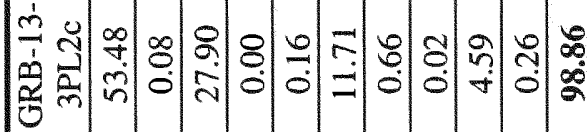

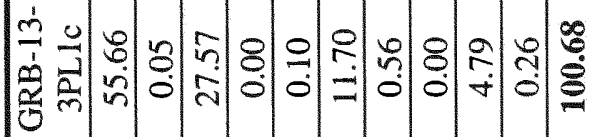

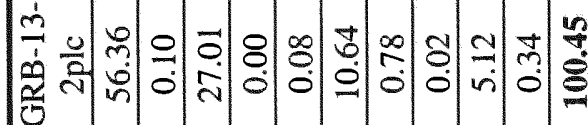

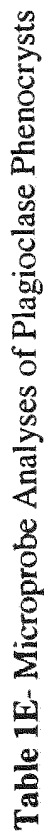

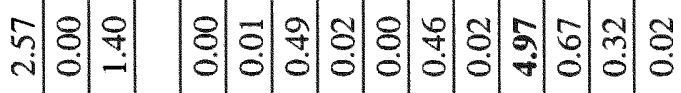

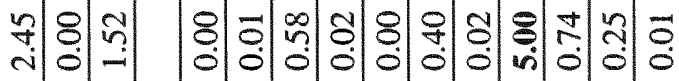

군

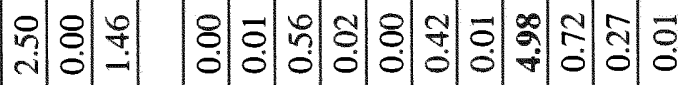

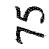

눈영

구영

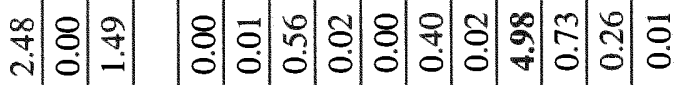

造

造

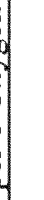

हो

:

5

这 


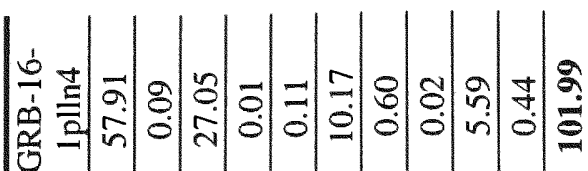

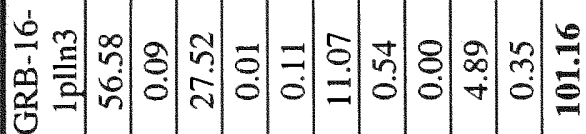

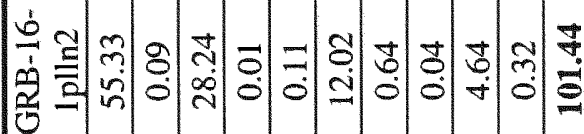

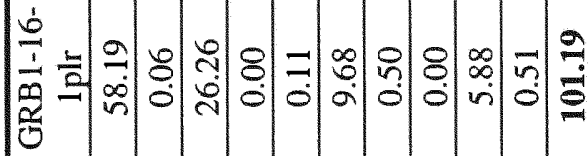

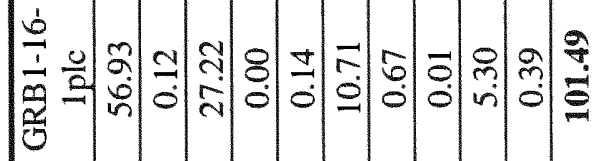

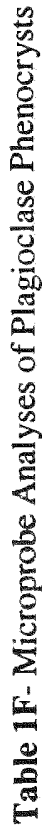

向

茛

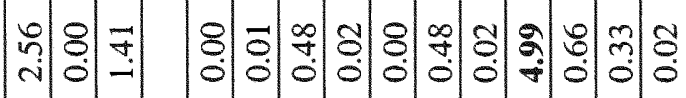

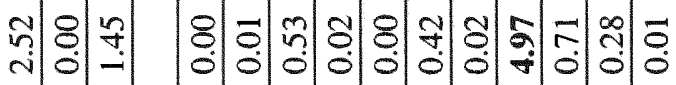

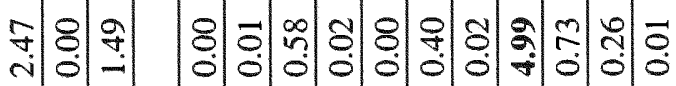

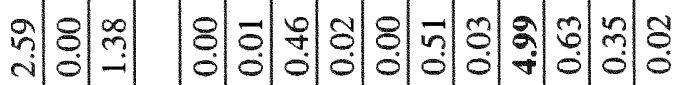

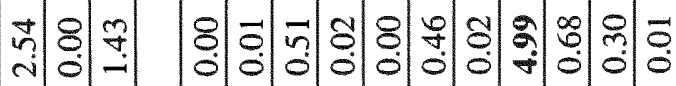

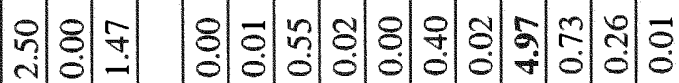

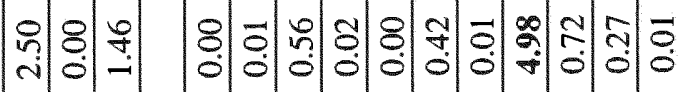

표요

急

돈 $\quad \infty$

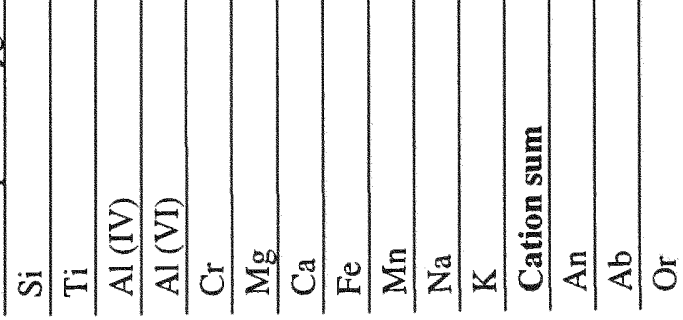




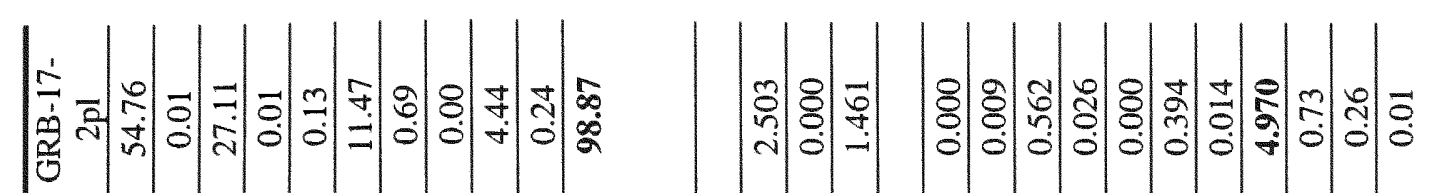

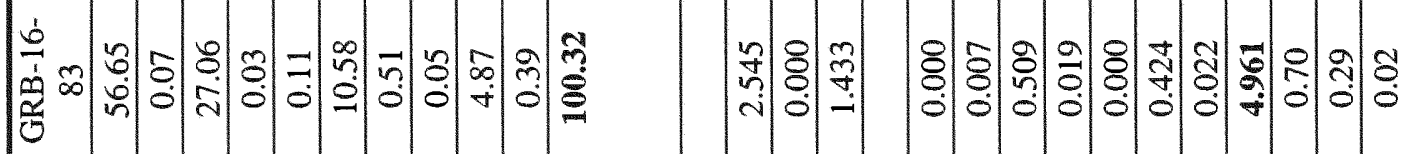

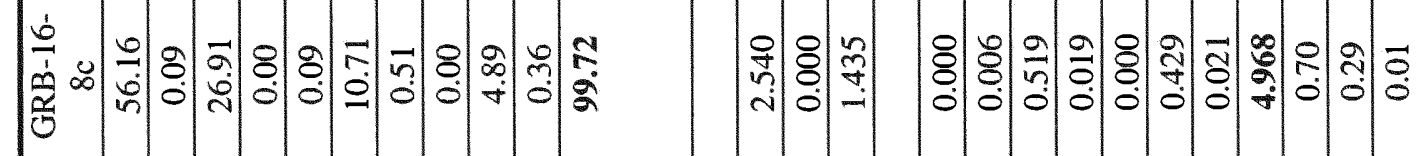

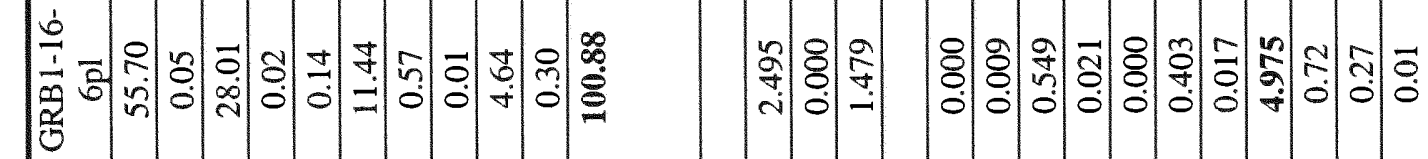

\&

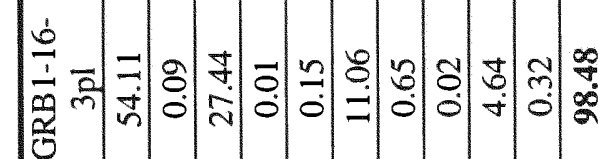

䣋응

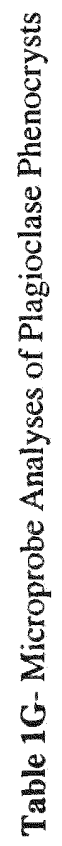

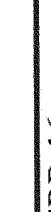

我

象

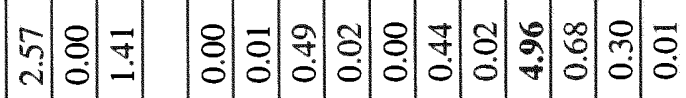

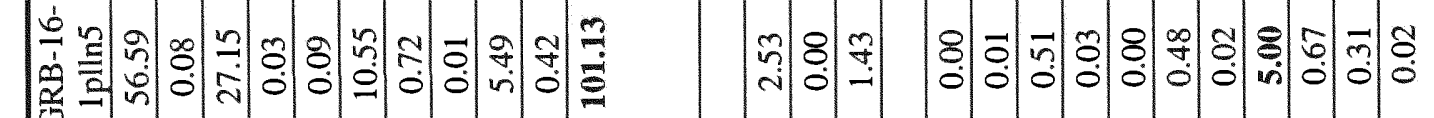

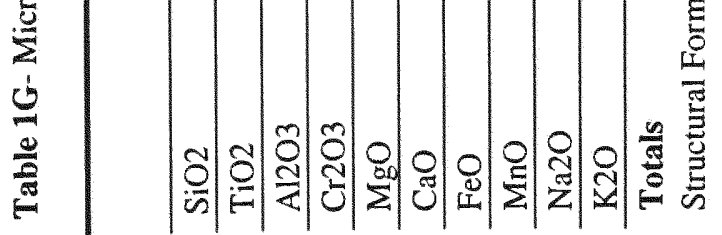

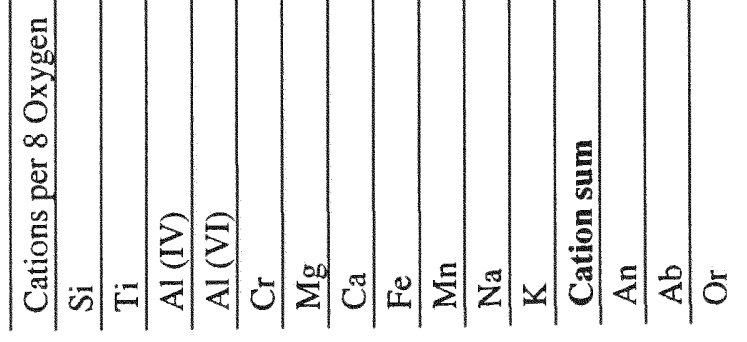




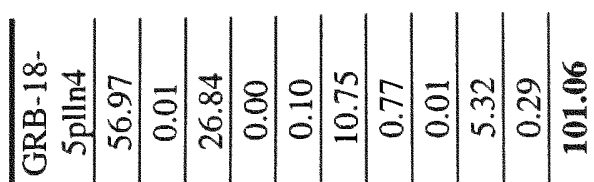

负迸考

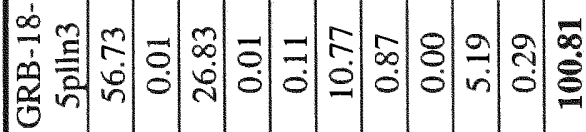

구영 공

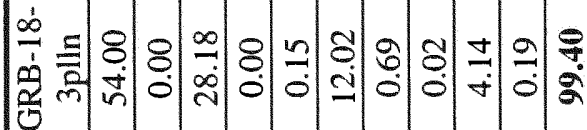

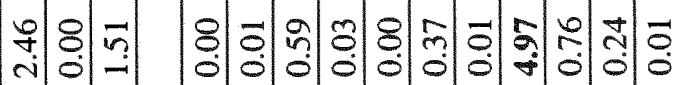

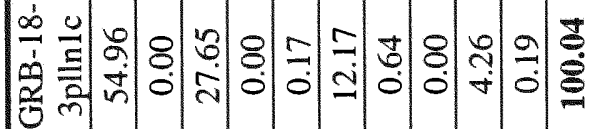

궁영

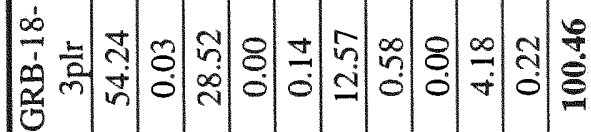

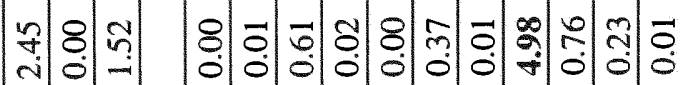

竞

商는

赵串串

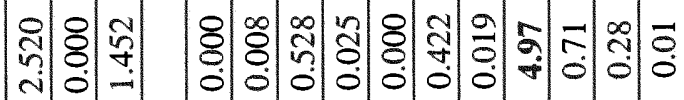

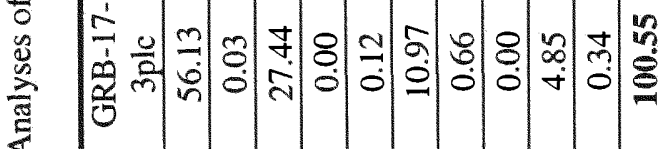

政

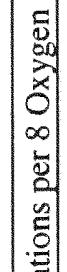

: 


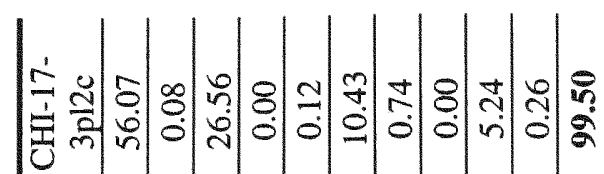

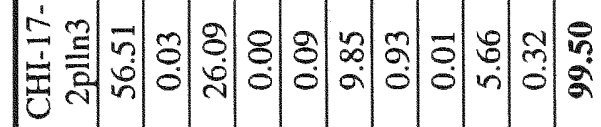

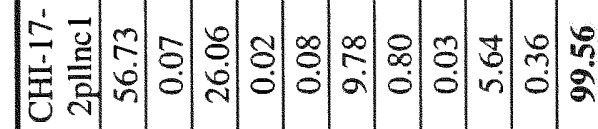

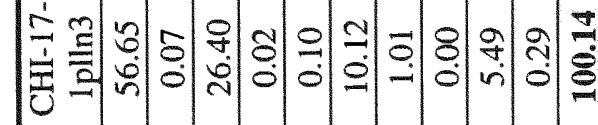

言空

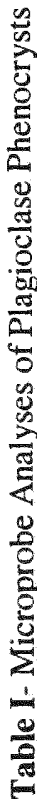

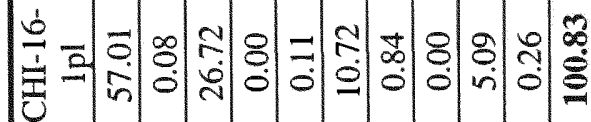

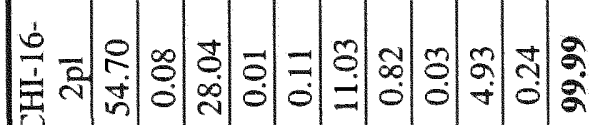

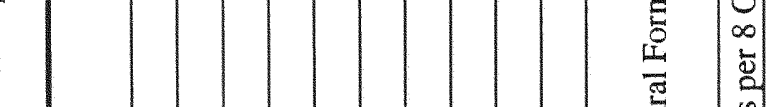

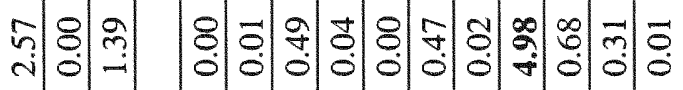

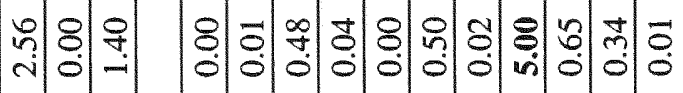

ஸे 영 के

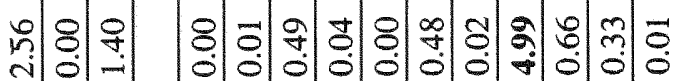

눙

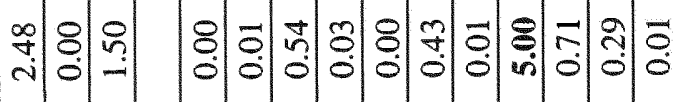

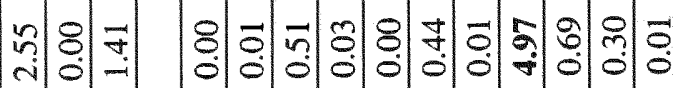

등

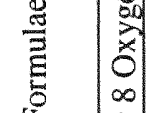

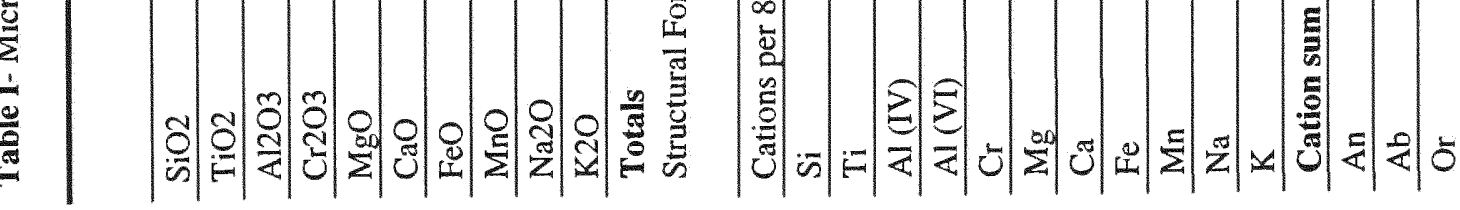




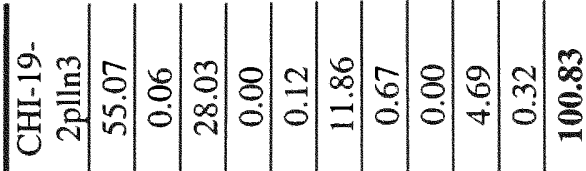

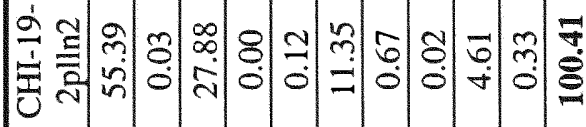

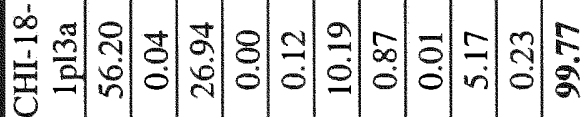

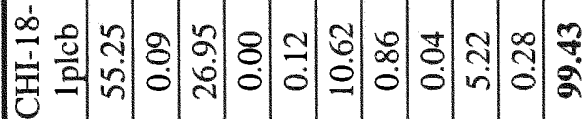

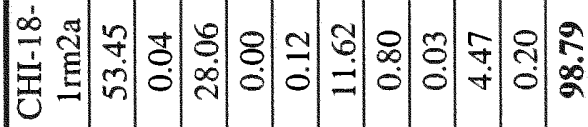

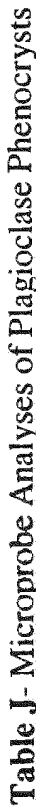

خำ

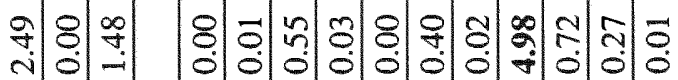

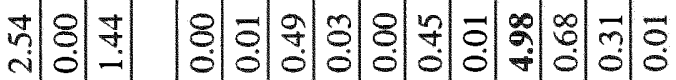

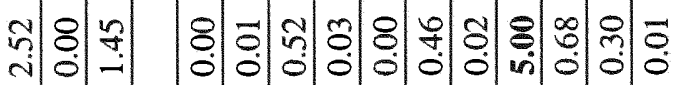

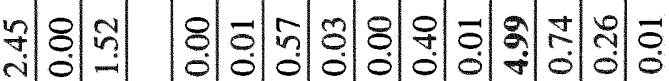

군

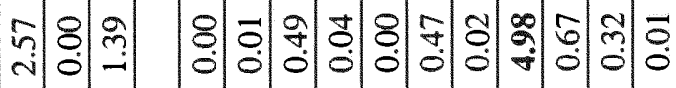
ᄃ

产

$\infty$

$\infty$
$\vdots$
$\vdots$

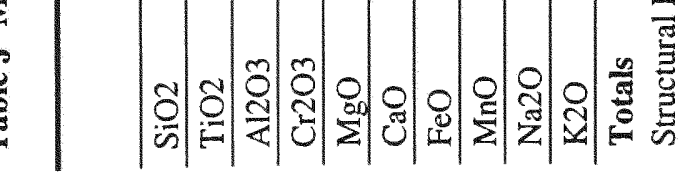




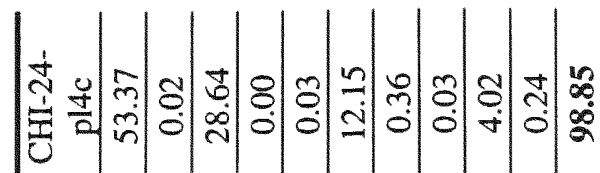

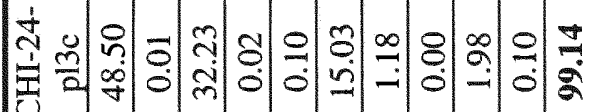

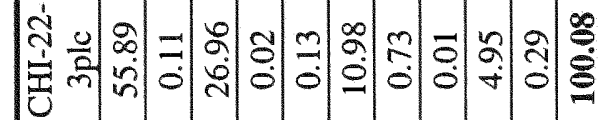

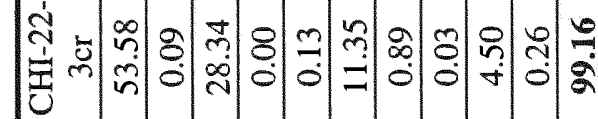

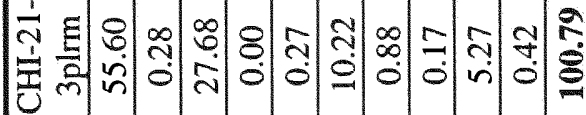

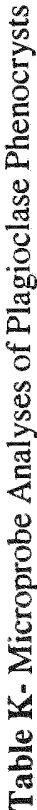

寺络织

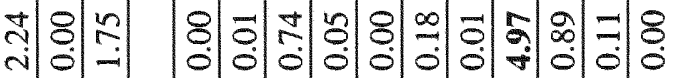

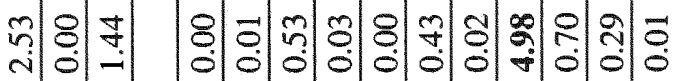

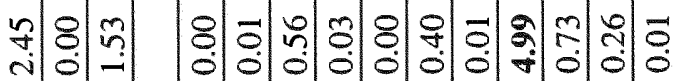

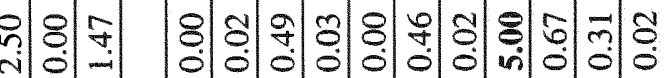

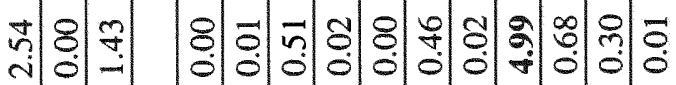

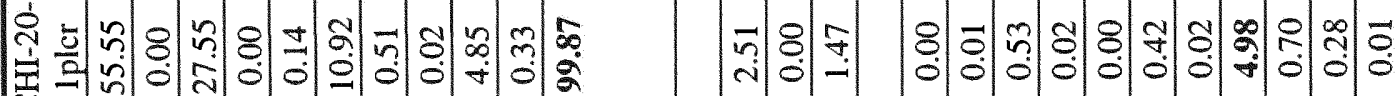




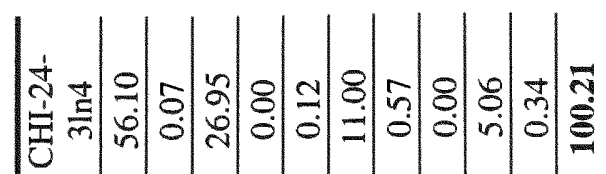

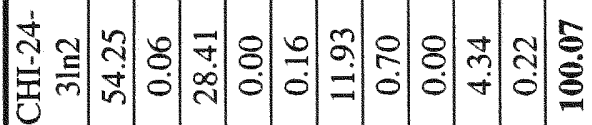

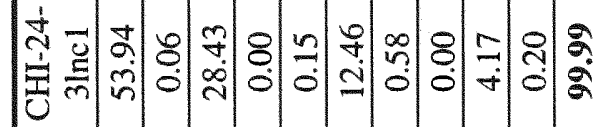

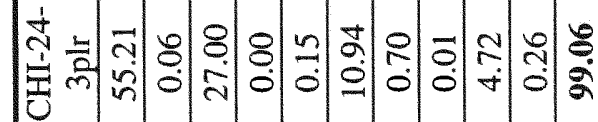

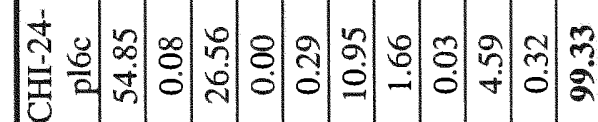

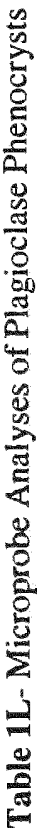

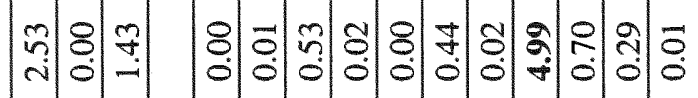

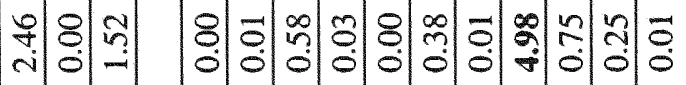

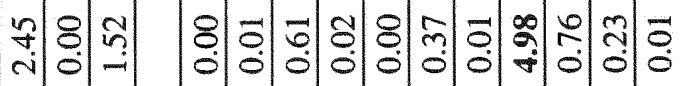

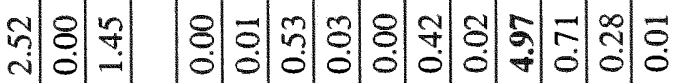

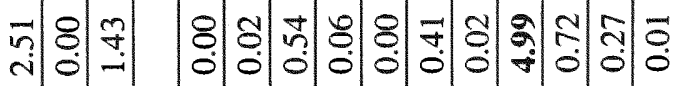

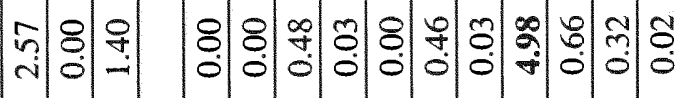

궁영

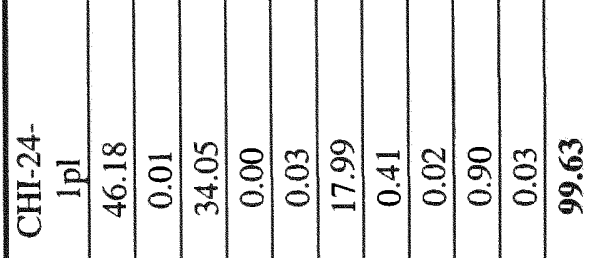

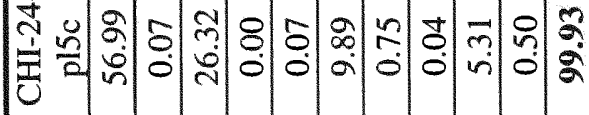

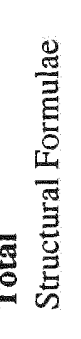

\section{E}

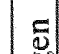

商

(1)

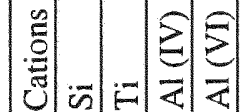

氙

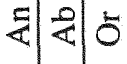




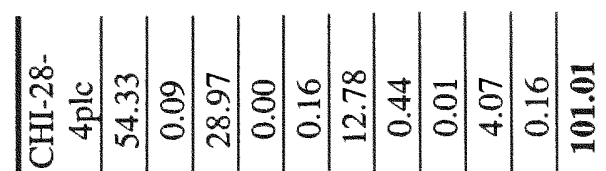

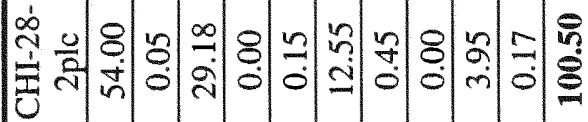

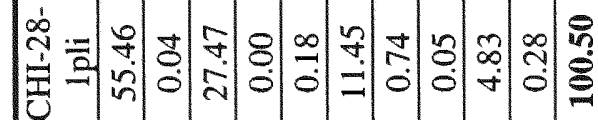

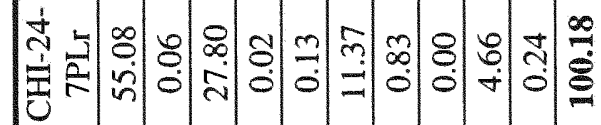

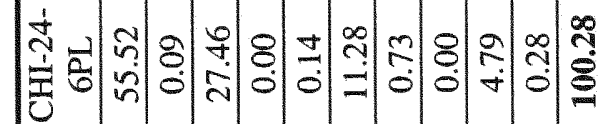

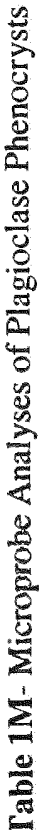

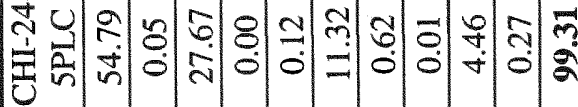

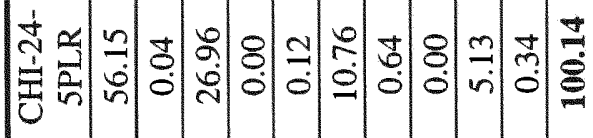

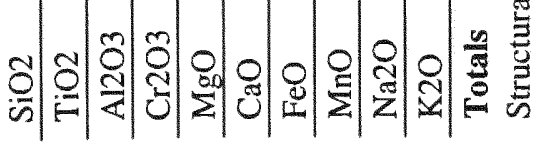

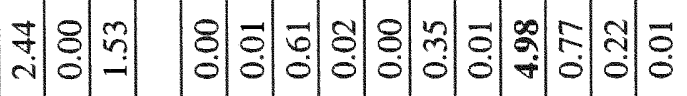

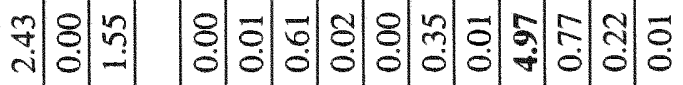

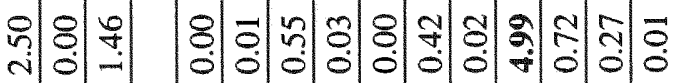

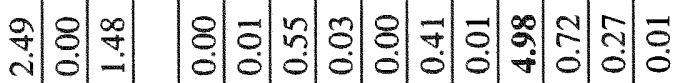

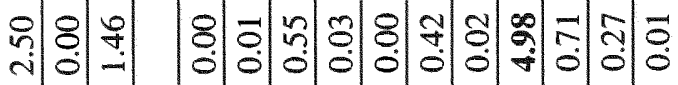

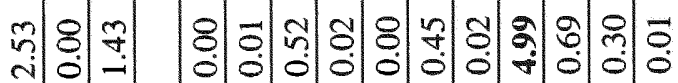

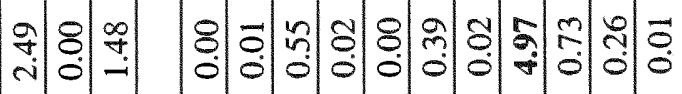

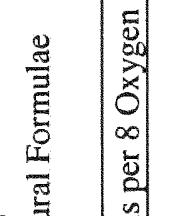

产

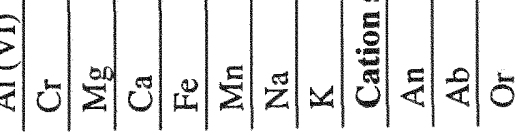




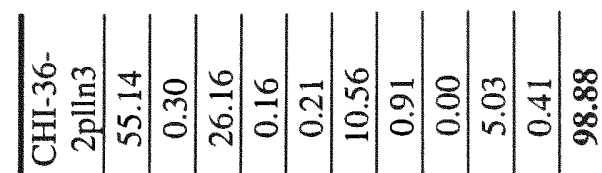

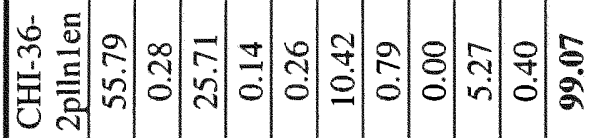

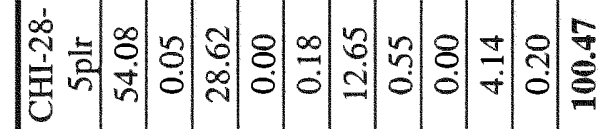

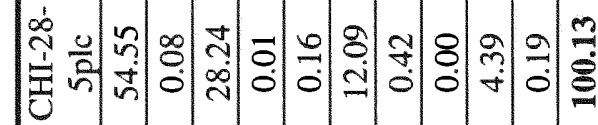

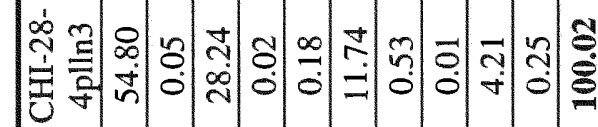

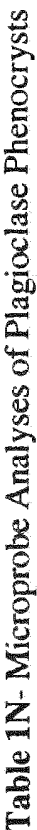

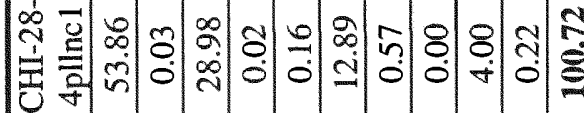

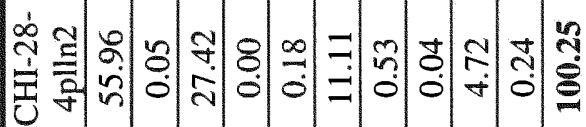

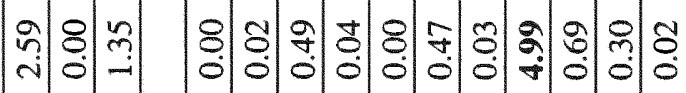

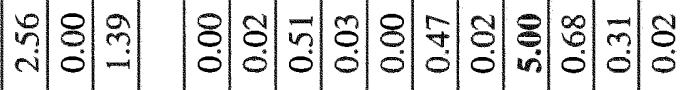

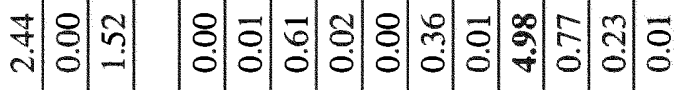

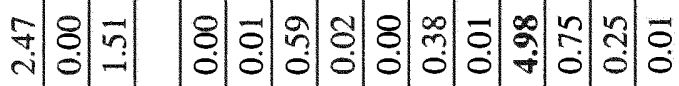

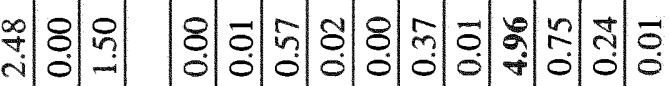

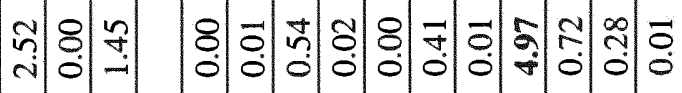

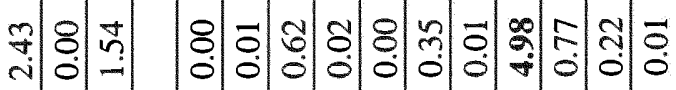

5

鄫 


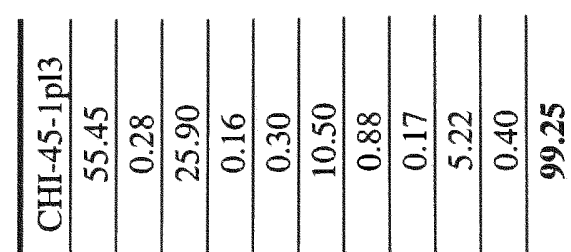

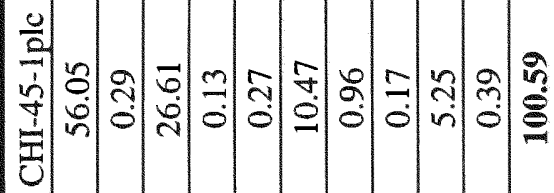

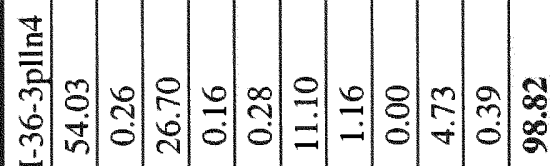

형

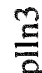

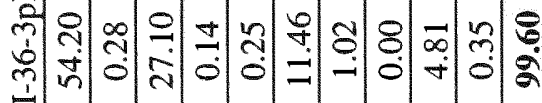

형

$\frac{5}{2}$

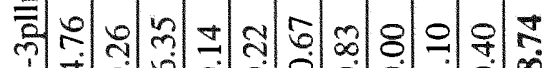

की में के

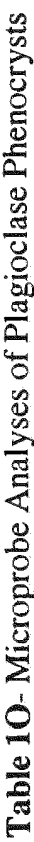

횡

능

站点

它

$\frac{0}{2}$

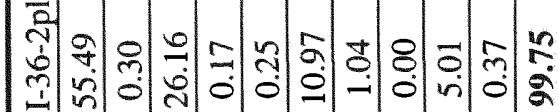

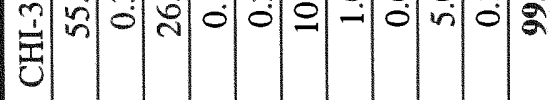

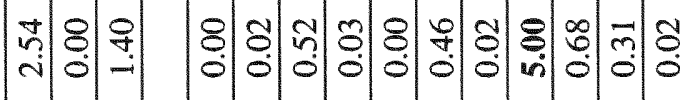

กิ่

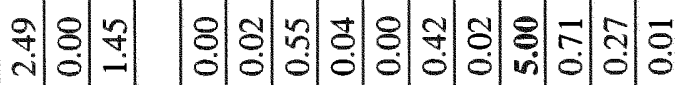

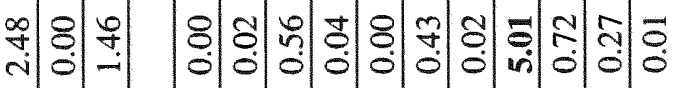

तิં

กิن

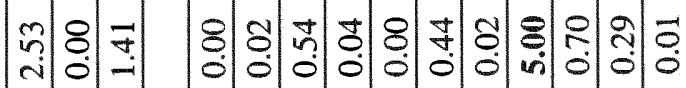

5

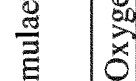

窝

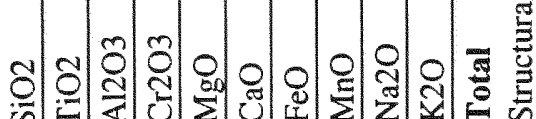

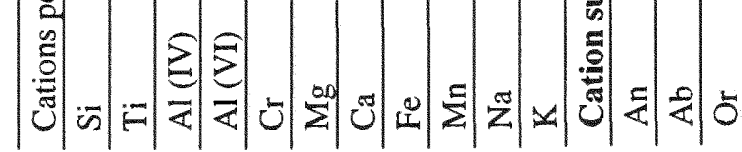




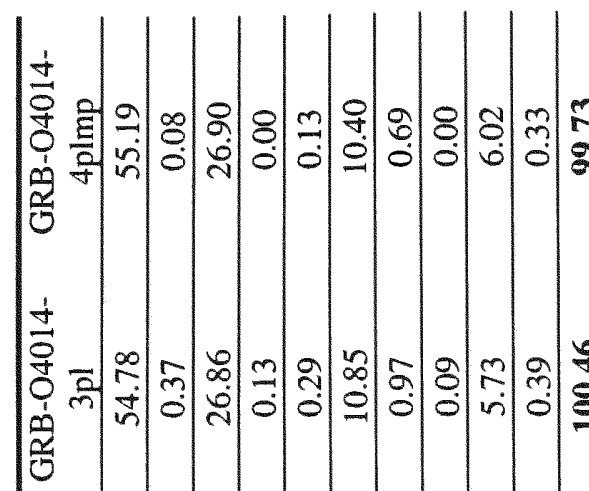

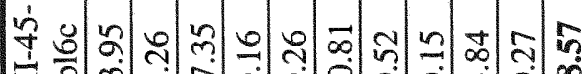

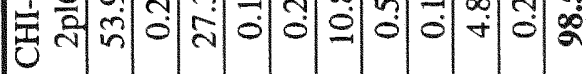

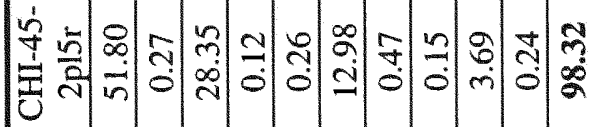

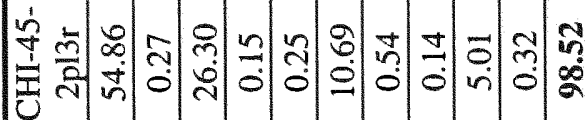

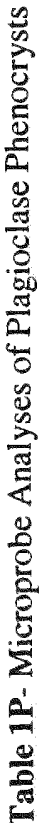

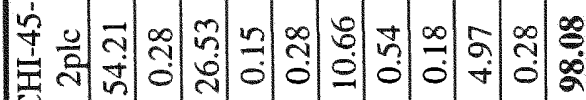

공영려

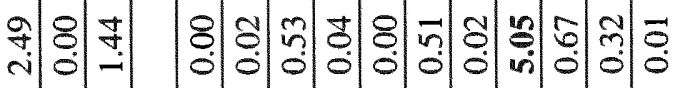

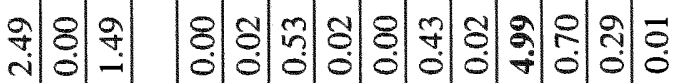

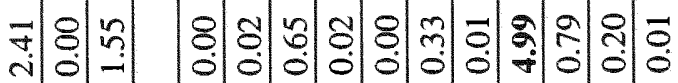

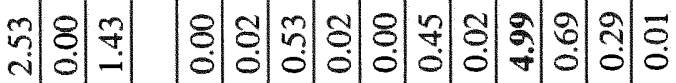

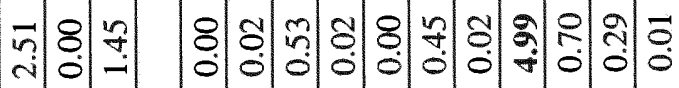

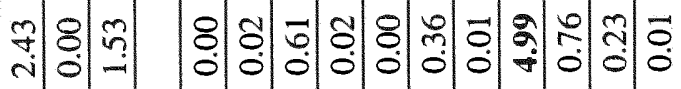

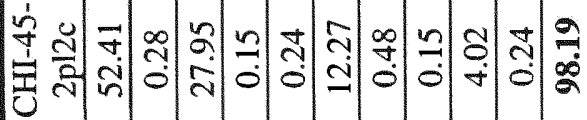

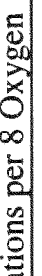

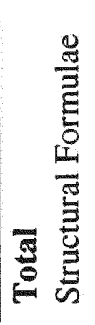


|

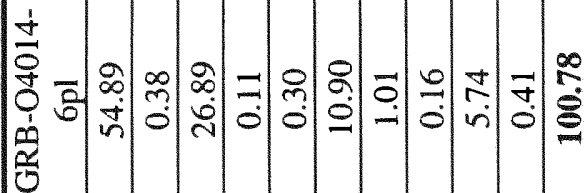

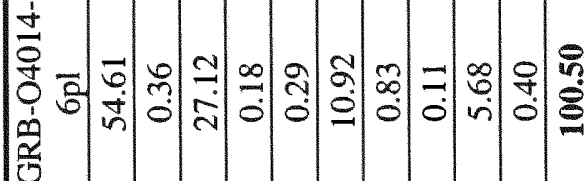

党

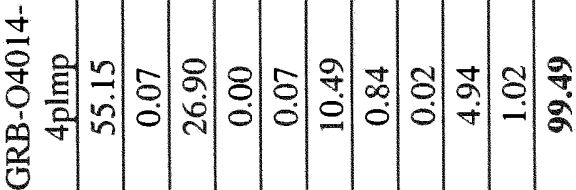

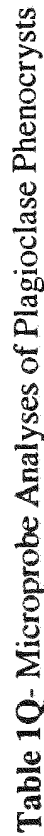

군

궁영 考

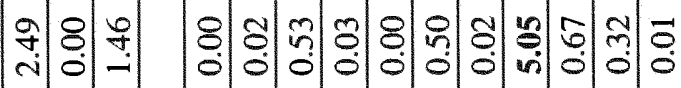

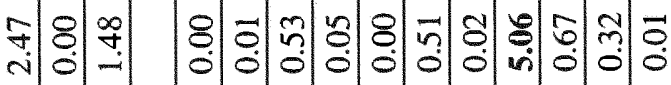

กิ่

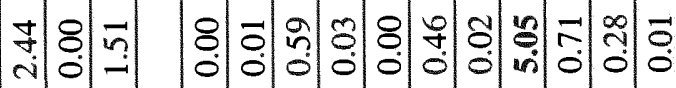

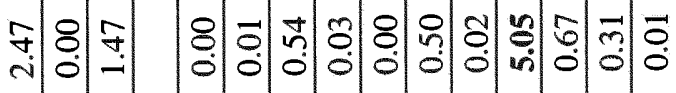

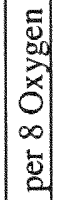

竎

占 ह

:

:

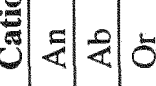




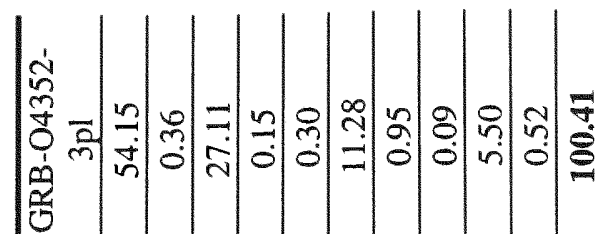

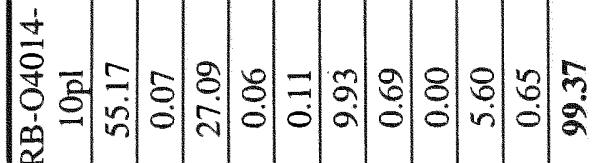
迢

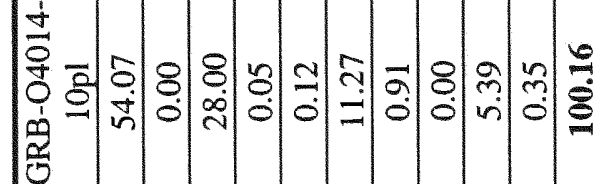

t

旁

旁

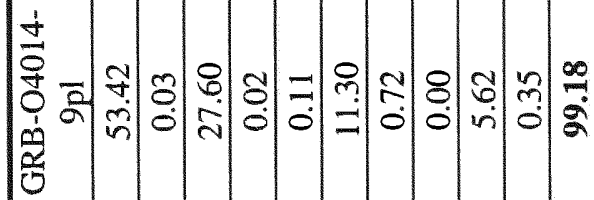

产 造

ก่

\%

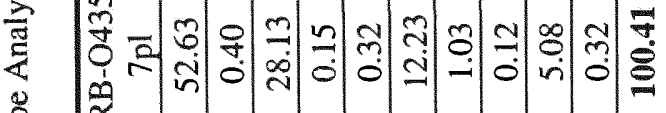

을

要

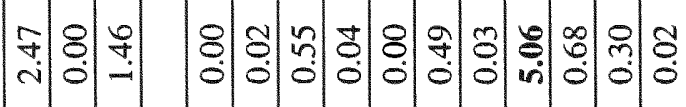

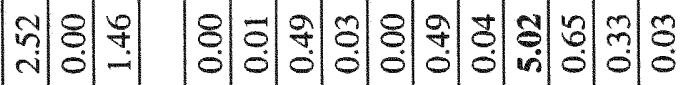

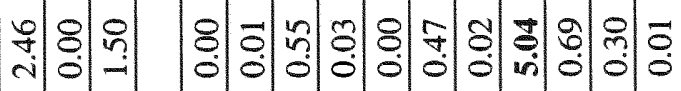

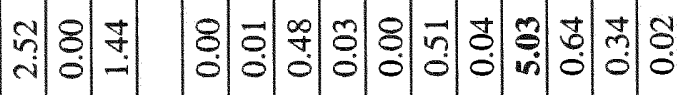

年 8

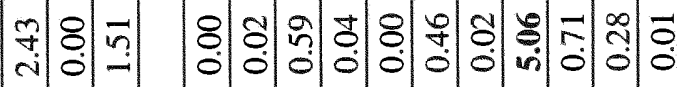

苟 :

:

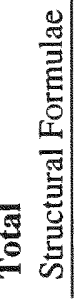




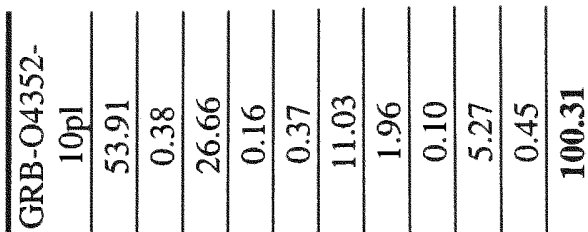

虫

产 (1)

in

岒

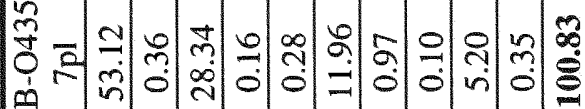
(2)

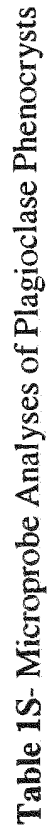

กิ่

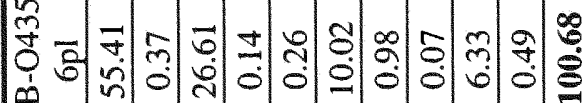
(2)

กิ่

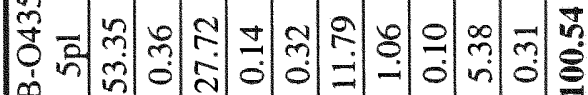
通

ஸ்

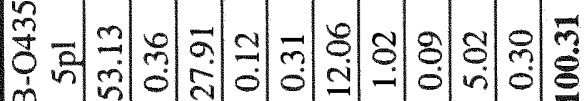
范

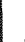

i่

定 á O

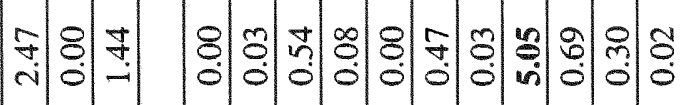

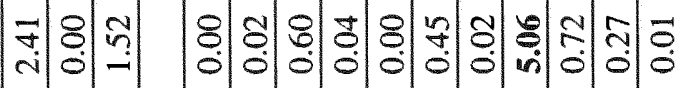

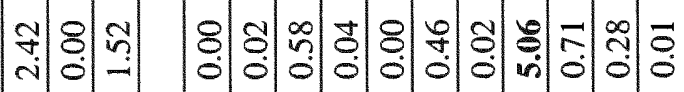

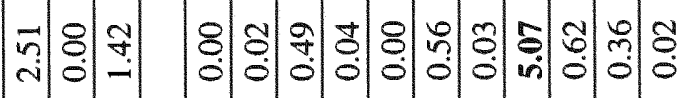

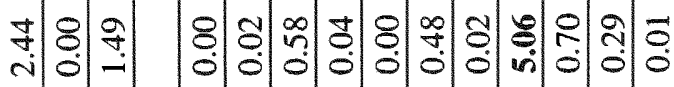

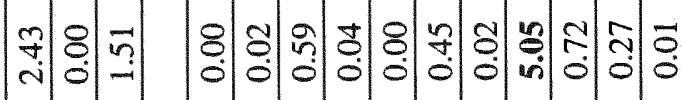

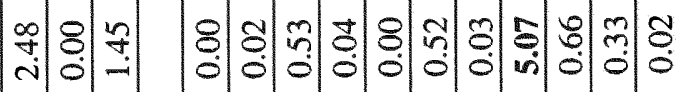

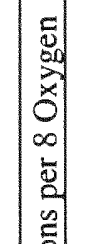

हो

(5)

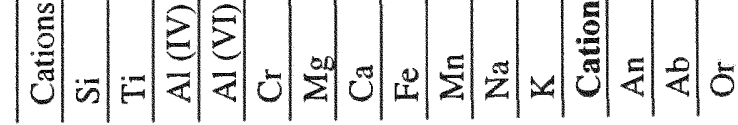


|

$\infty$

告

告

$\infty$

商

通

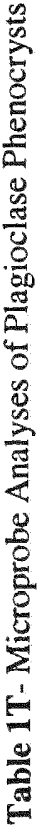

音

光

기일

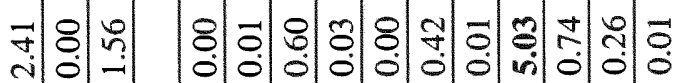

군

군

守 등

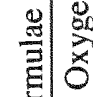

影员

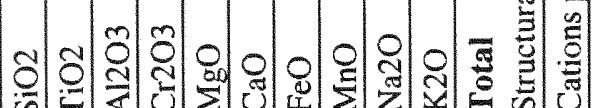

¿2

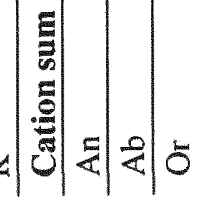




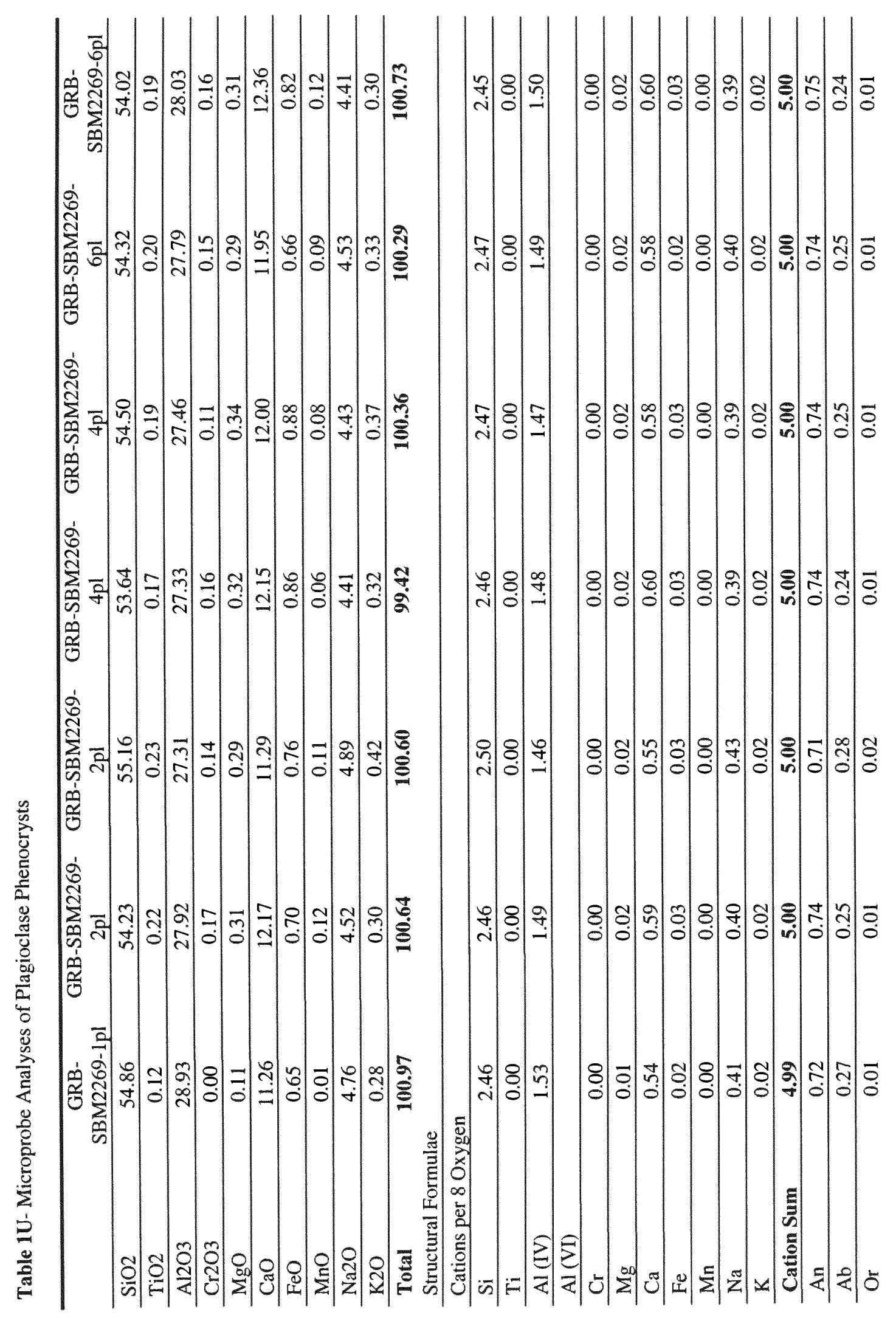




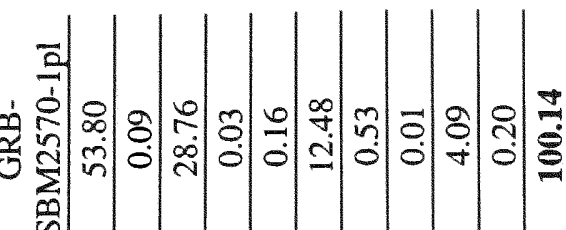

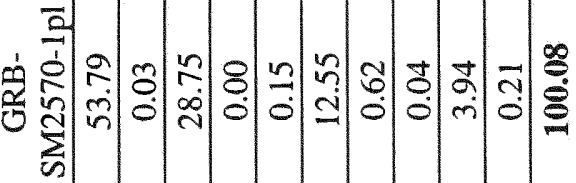

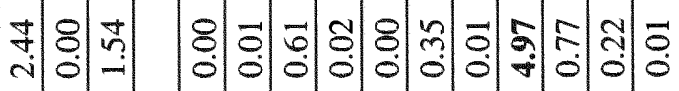

ठें

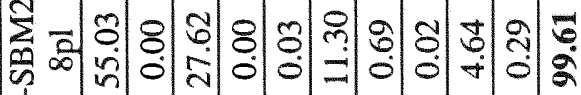

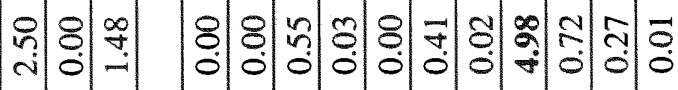

造

oิ่

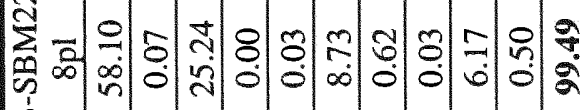

실

造

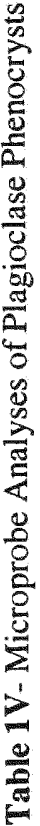

产

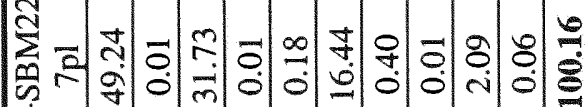

话

궁영 경 웅

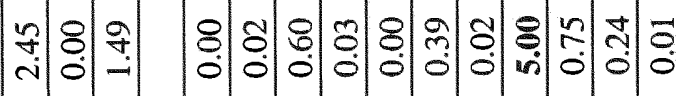

今́

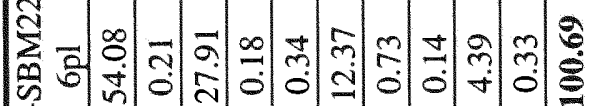

路

g่

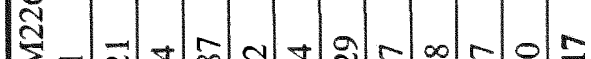

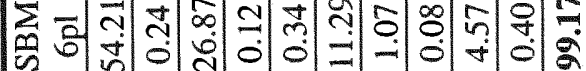

(1)

:

究

댕

高

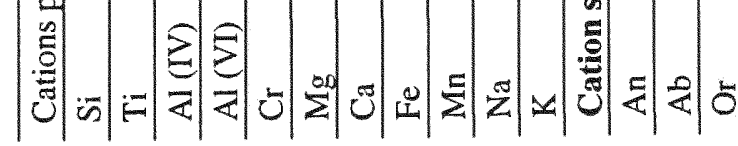




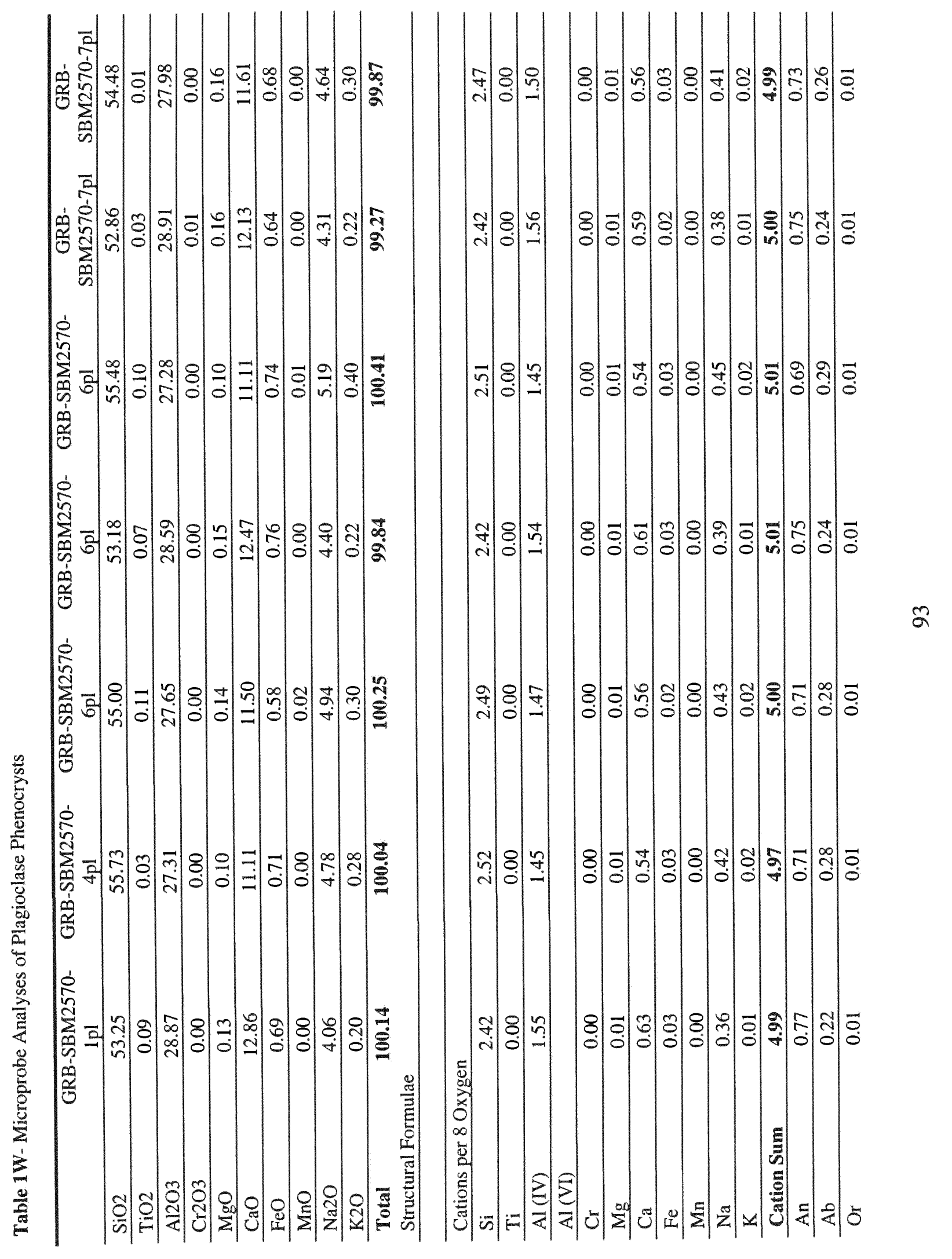




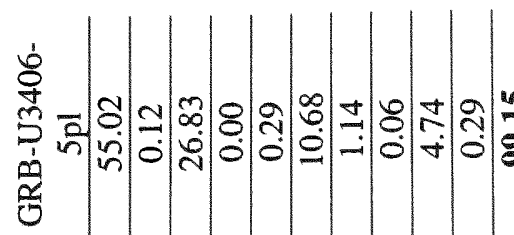

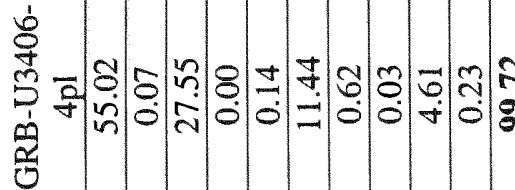

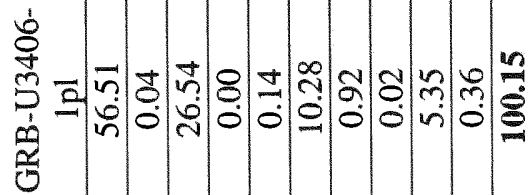

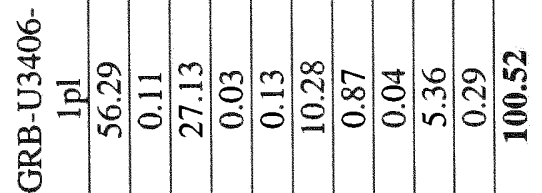

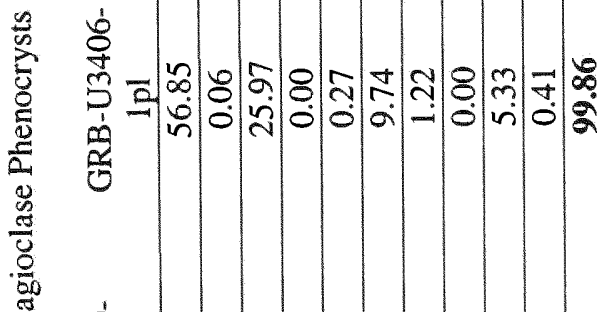

$\frac{\sqrt[3]{3}}{8}$

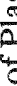

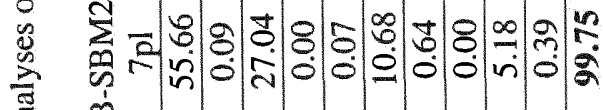

๘ँ

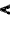

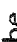


3

สำ융ำ

弯

ชิ

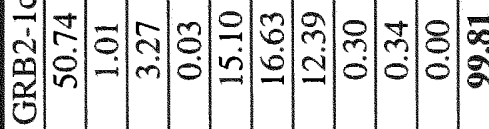

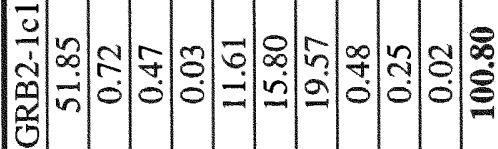

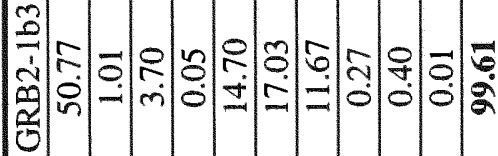

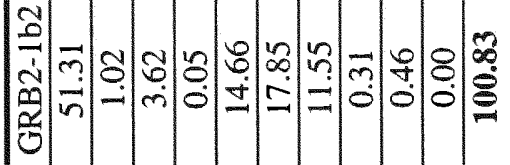

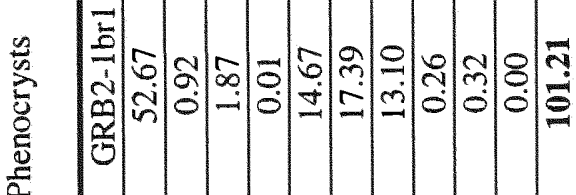

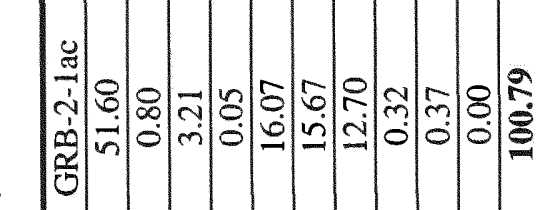

설

열

울

얼

일

ڤ

-

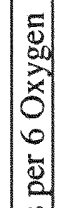

纹 


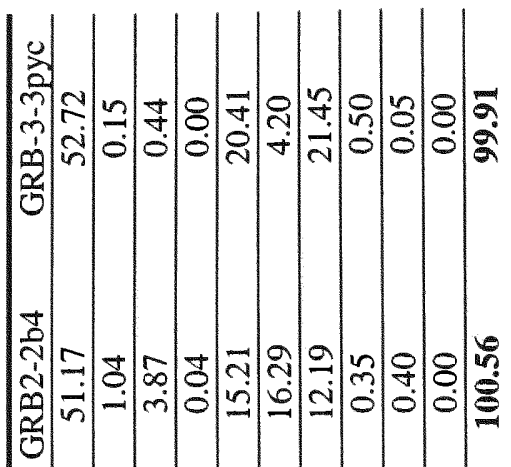

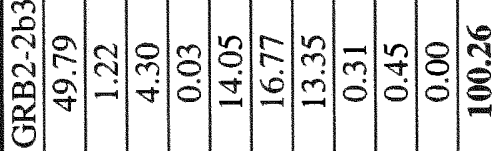

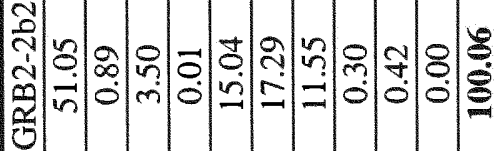

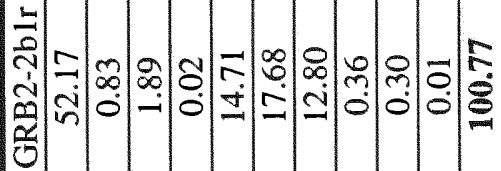

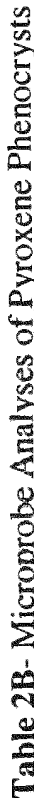

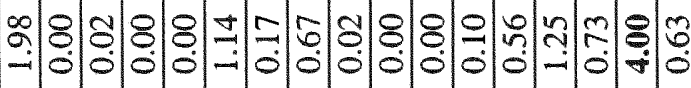

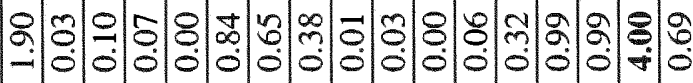

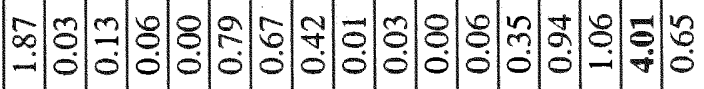

영영

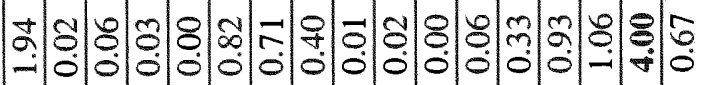

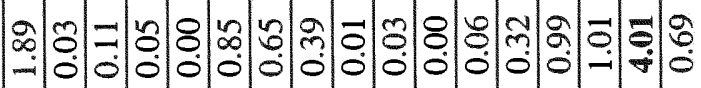

영:

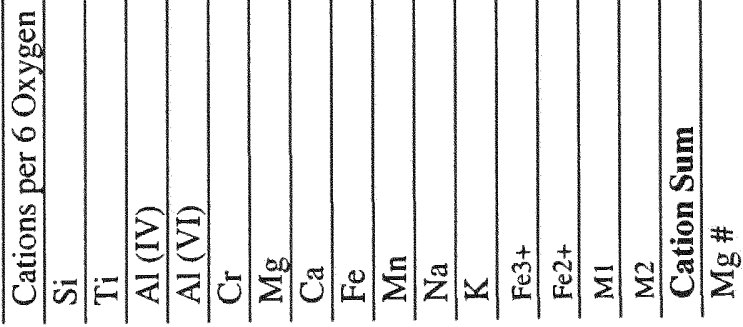




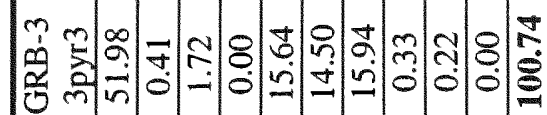

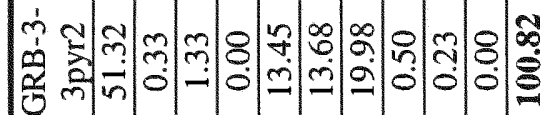

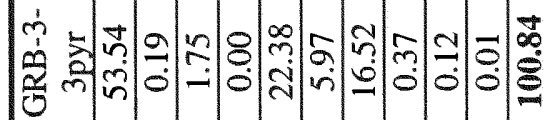

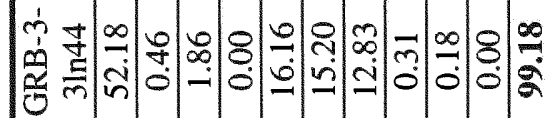

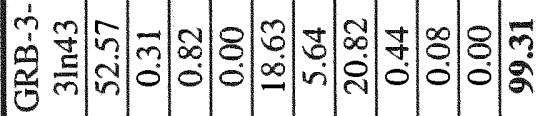

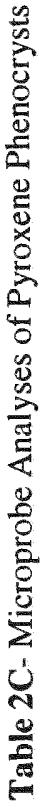

䓵

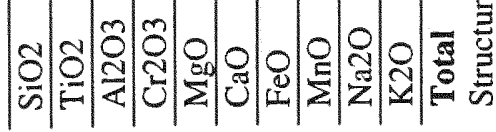

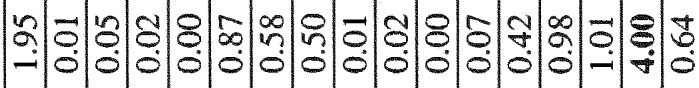

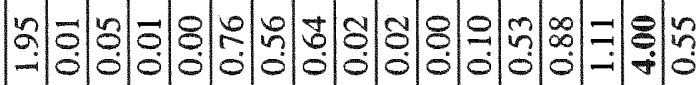

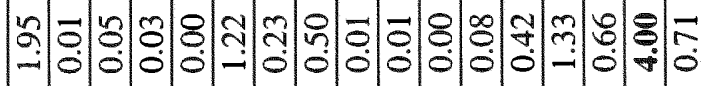

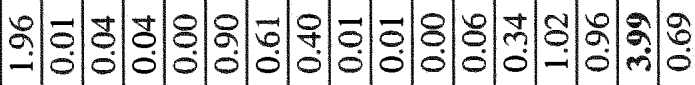

ล

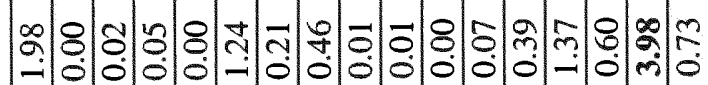

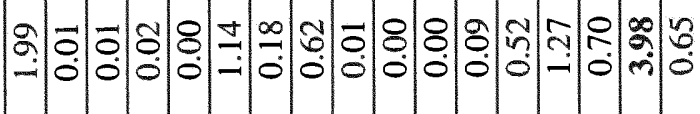

:

亲

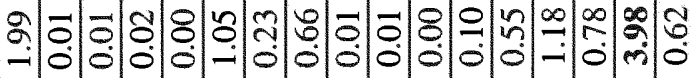

要

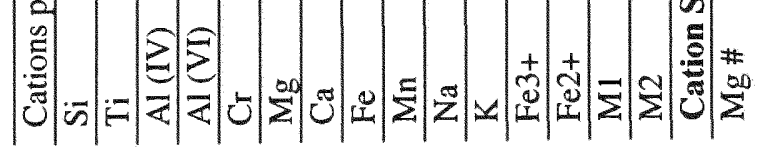




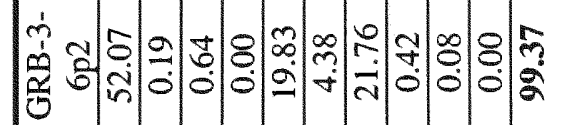

商

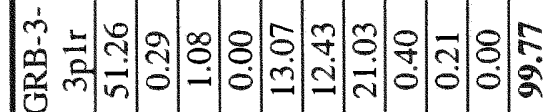

客 ले

然

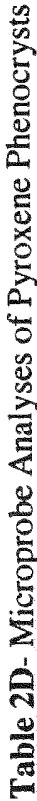

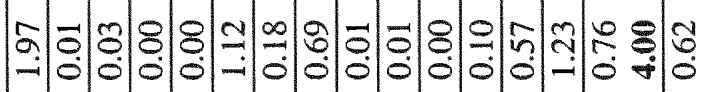

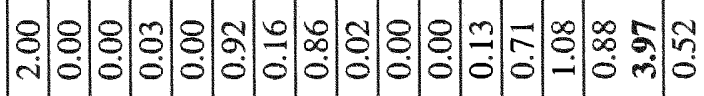

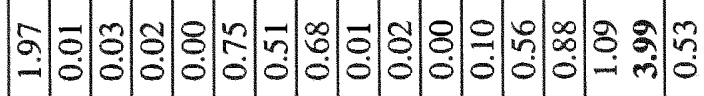

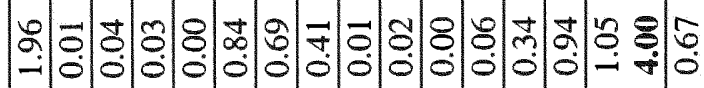

\section{일}

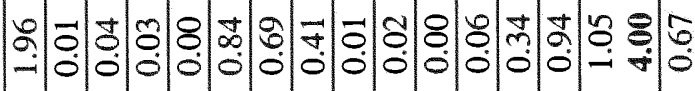

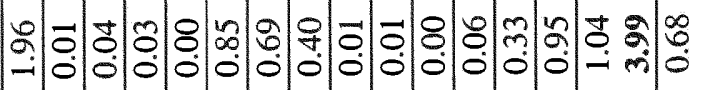


竞

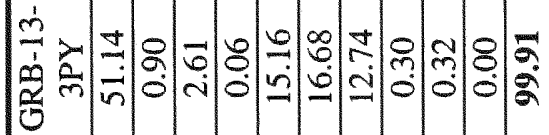

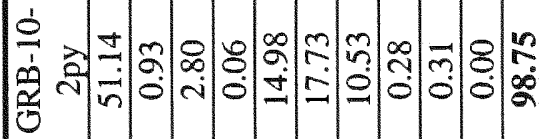

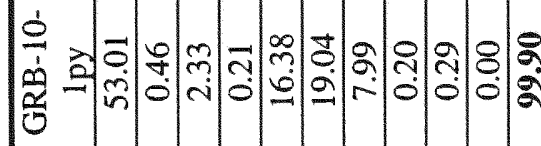

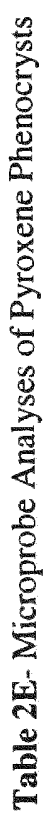

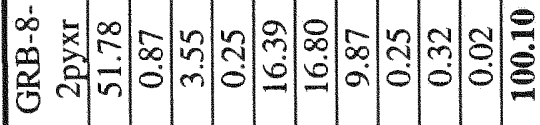

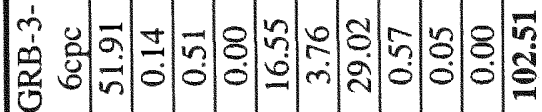

总

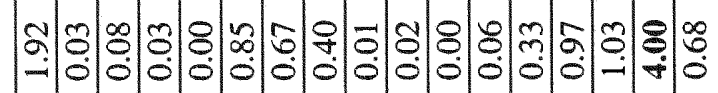

กำ:

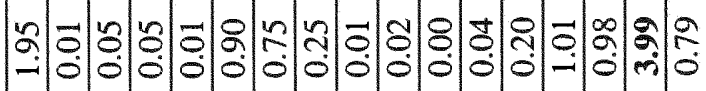

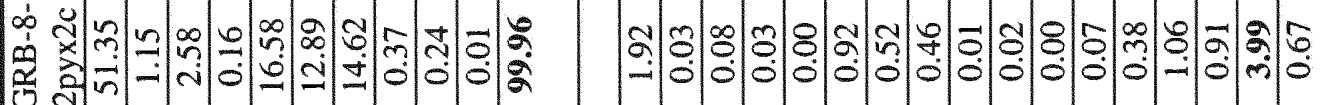

司遂遂:

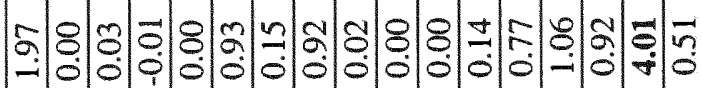

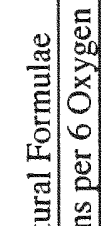




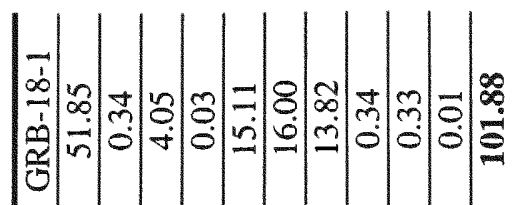

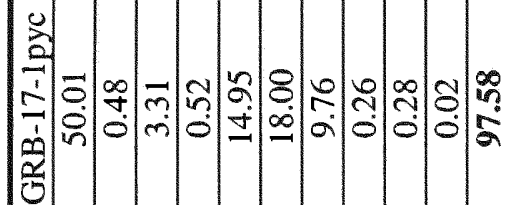

产

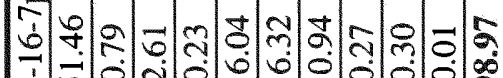
窟

․․

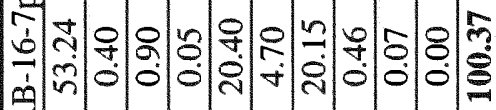

원

ํㅡㅁ

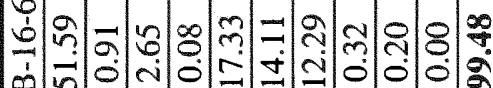
웡

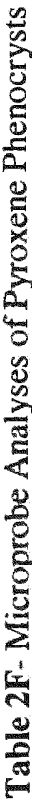

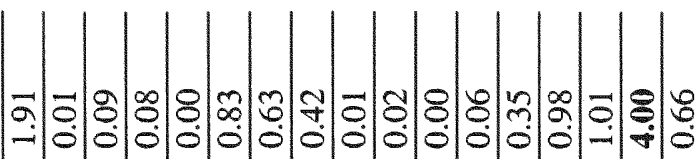

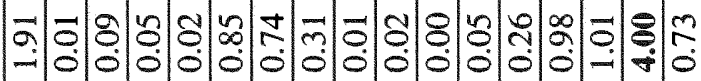

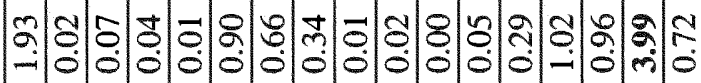

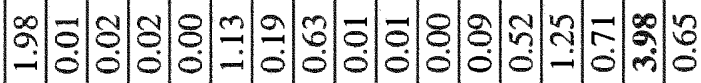

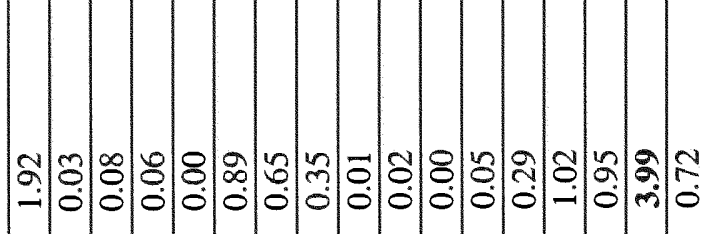

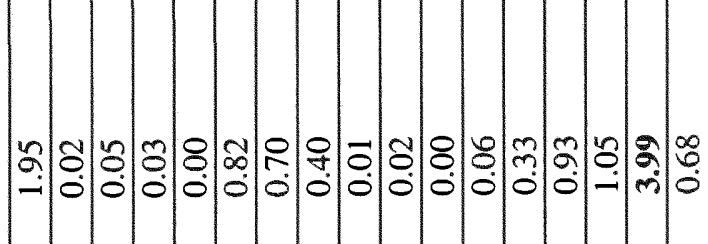

등

番

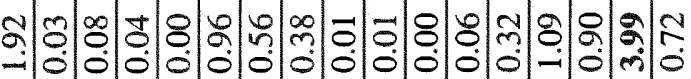

닌

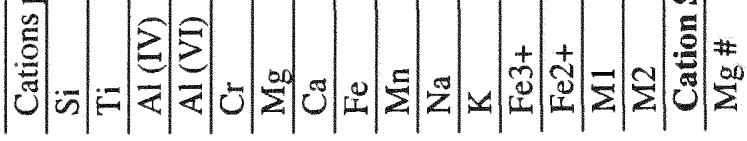




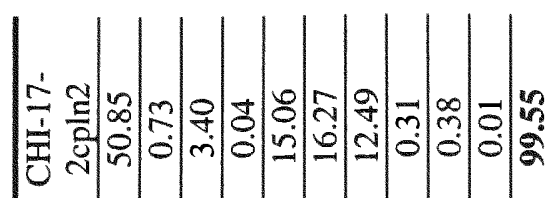

空

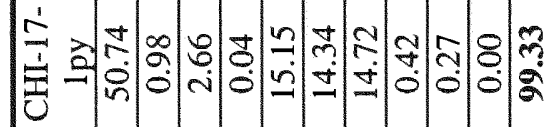

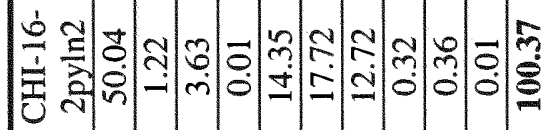

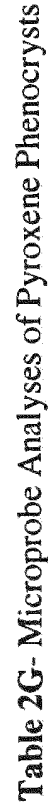

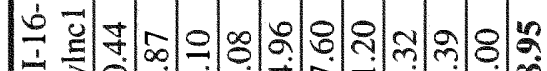

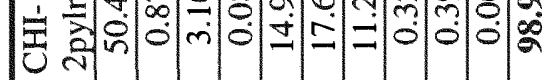

\section{可 궁:}

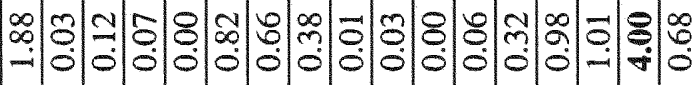

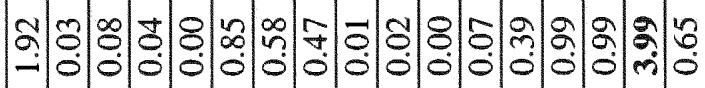

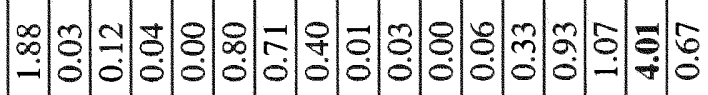

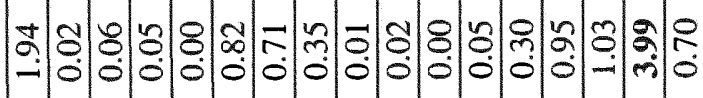

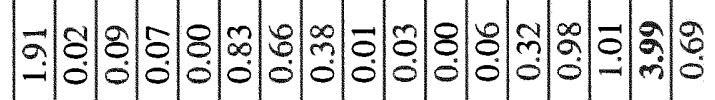
:

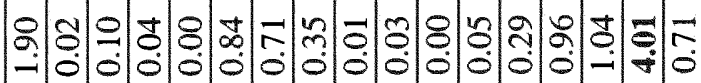

产

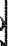


ำ 考

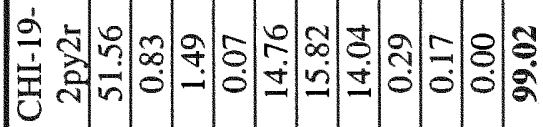

窇 究

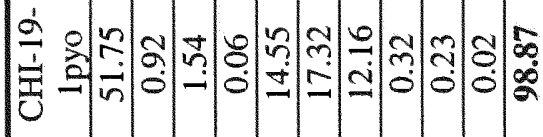

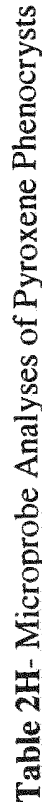

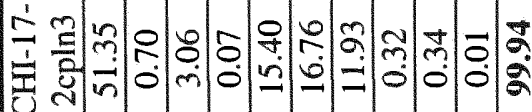

空

हैं

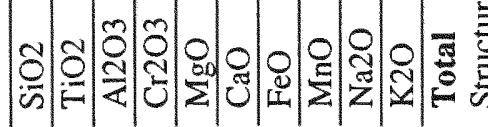

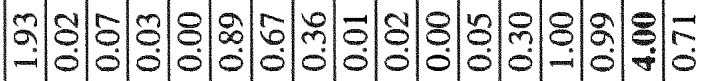

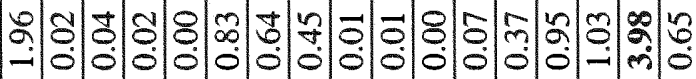

-

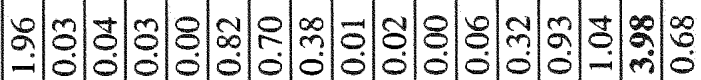

-

일

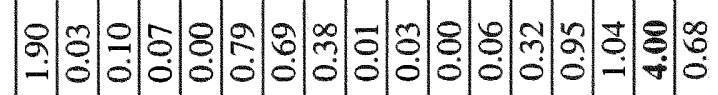

5

글

잉

ส

已

탠.

을

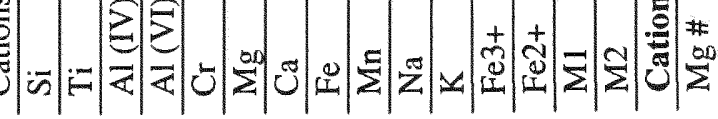




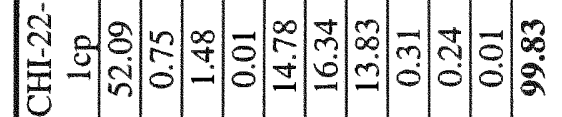

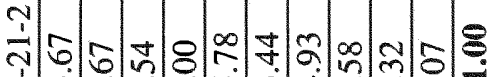

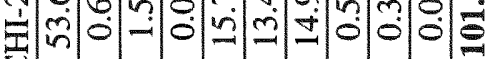

突

穵

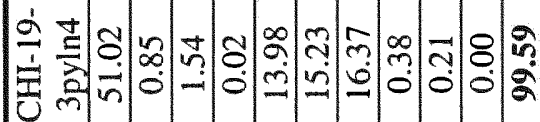

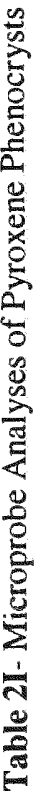

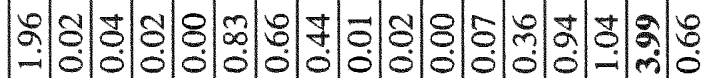

舟

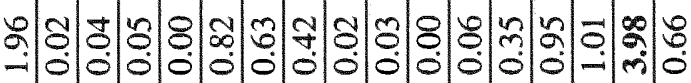

일

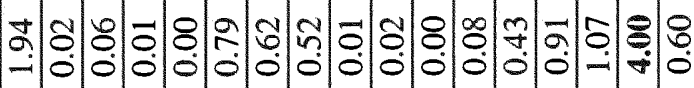

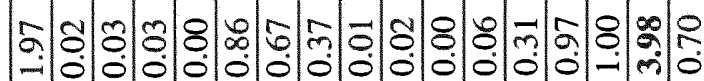

\section{产}

\section{$\%$

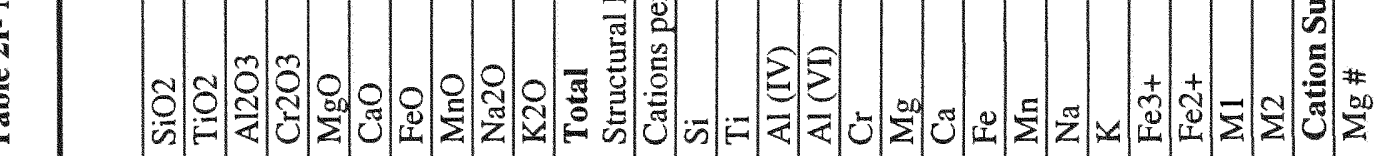




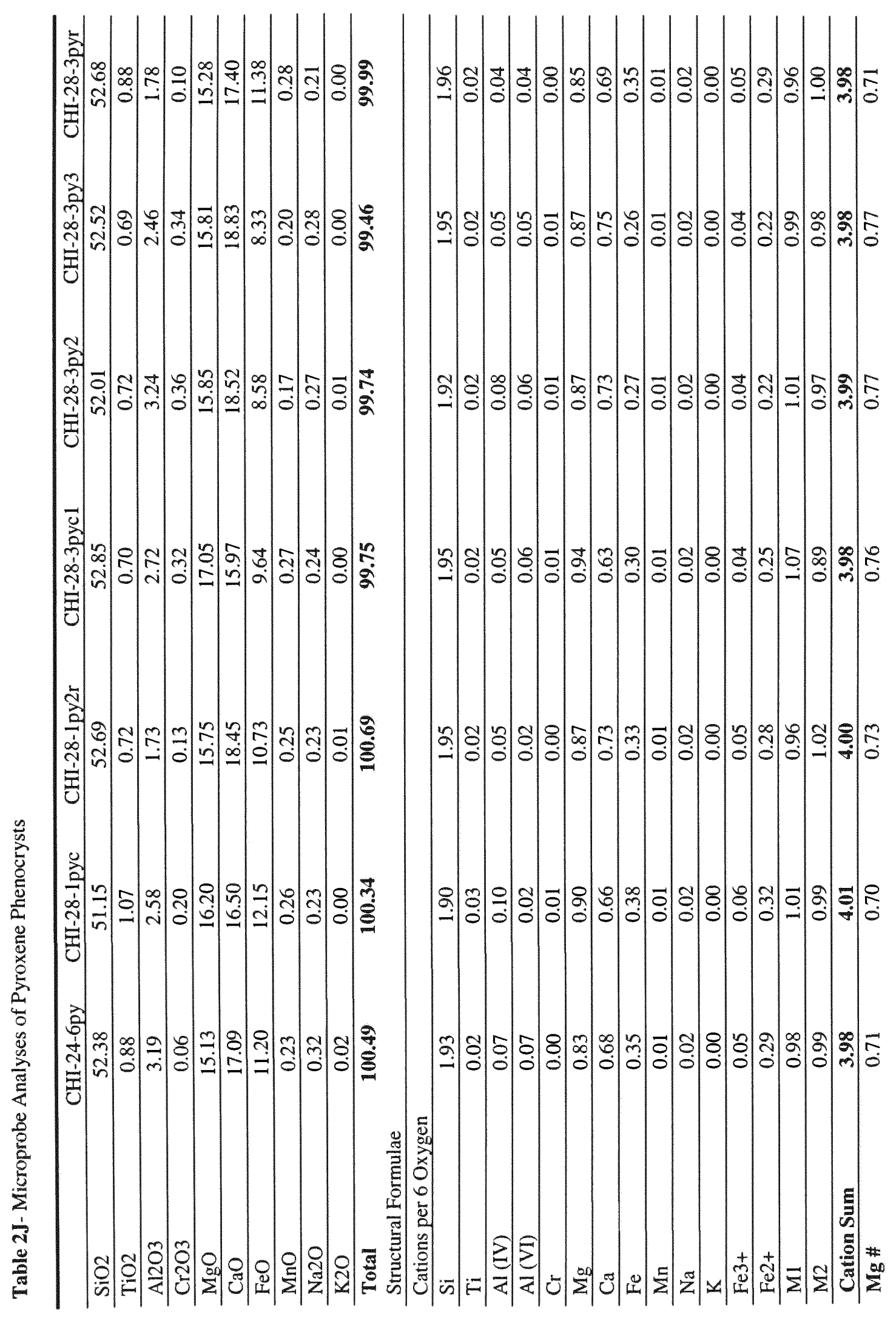




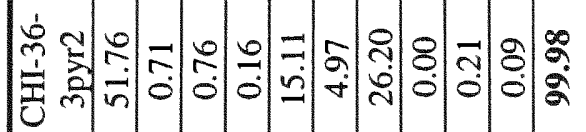

售

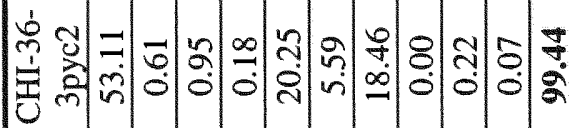

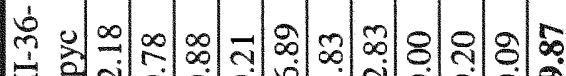

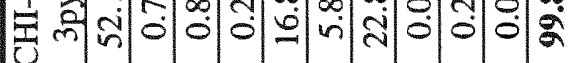

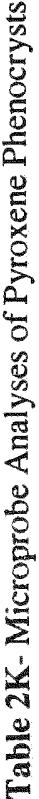

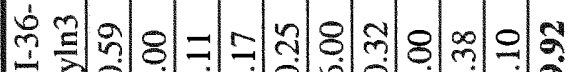

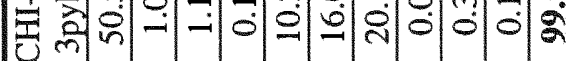

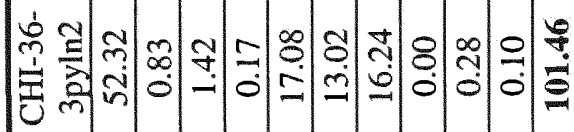

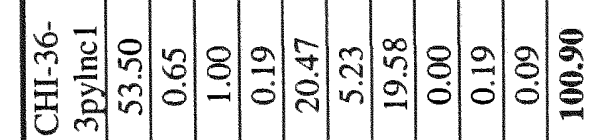

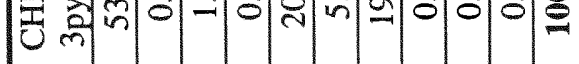

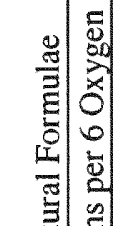

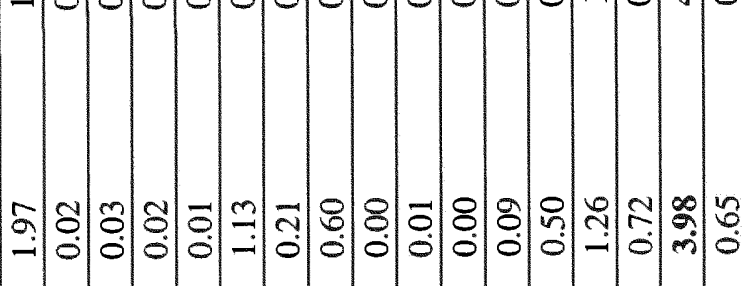

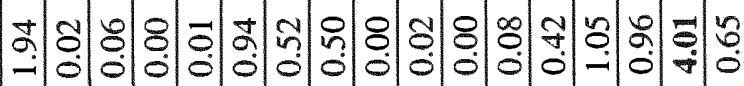

영영

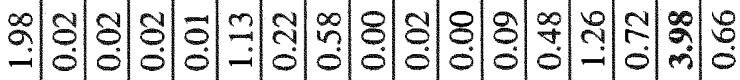

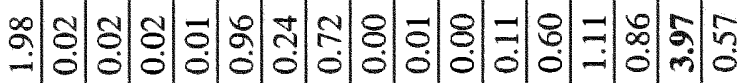

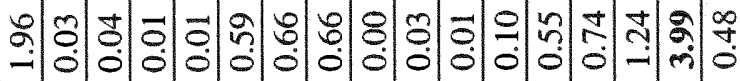

-

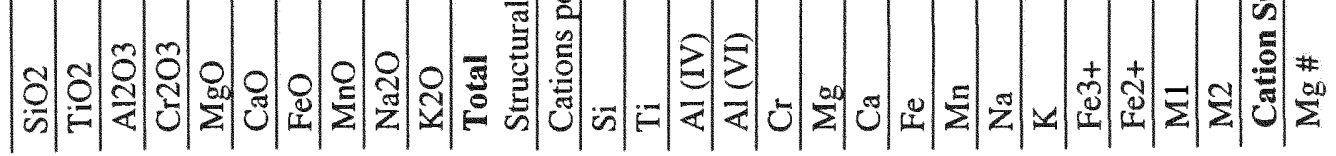




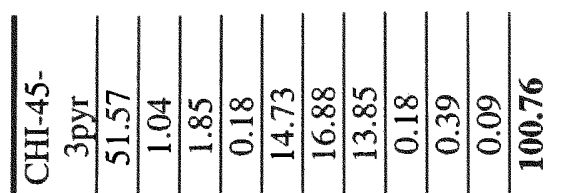

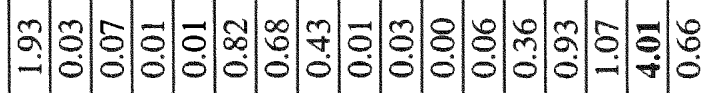

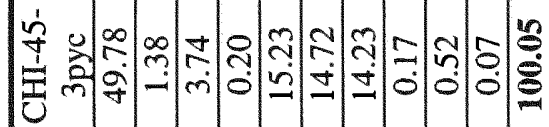

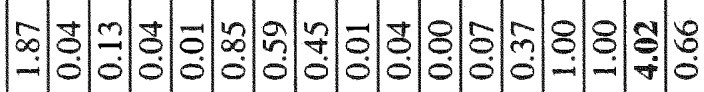

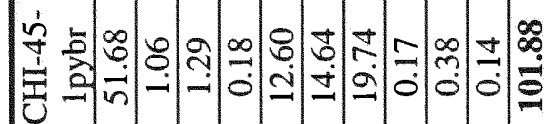

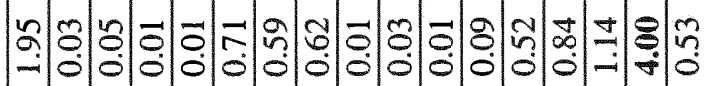

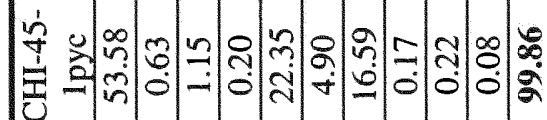

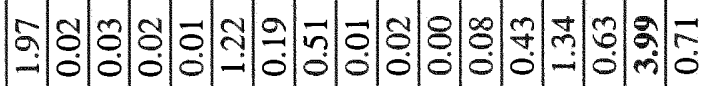

突

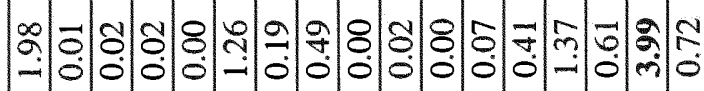

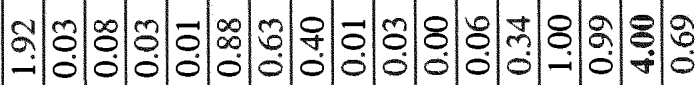

そ)

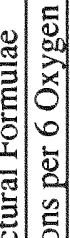

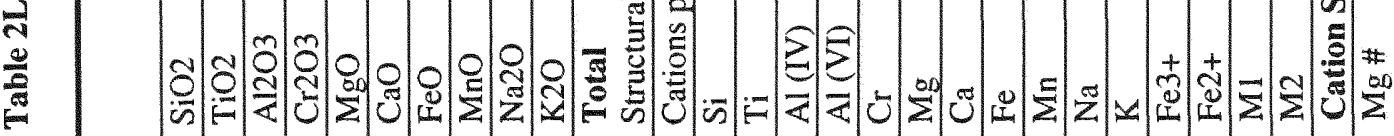

हี้ 


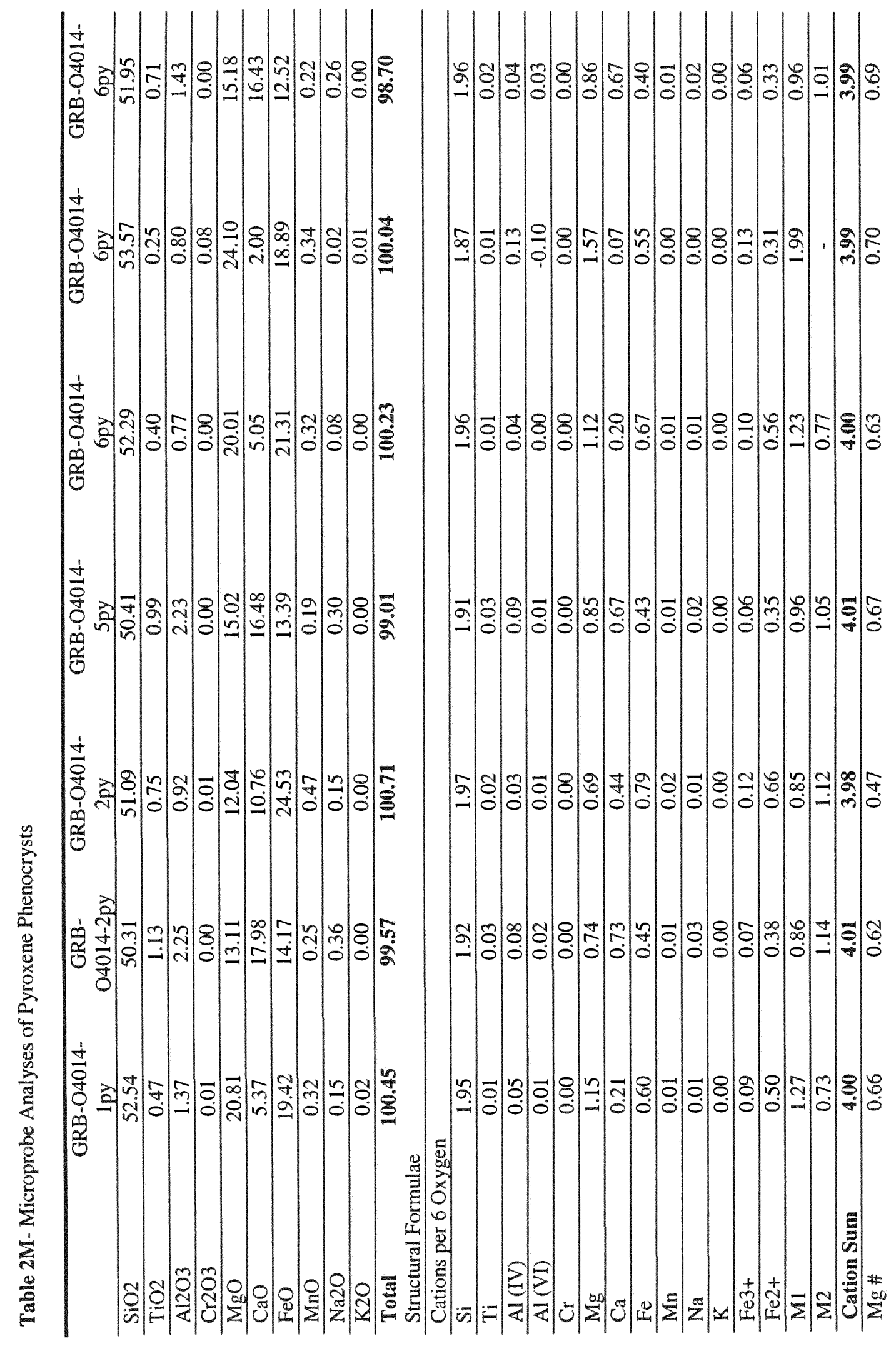




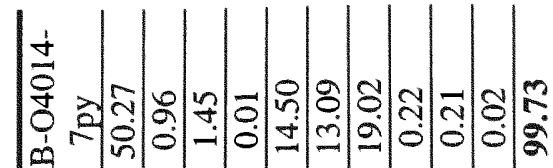

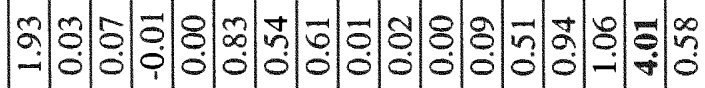

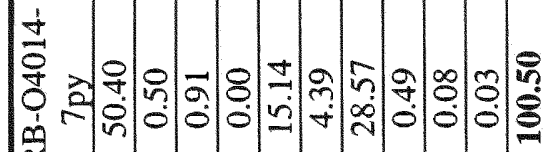

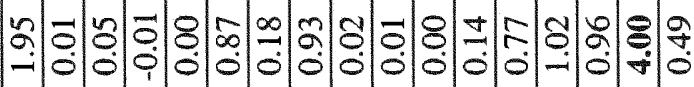

$\frac{1}{5}$

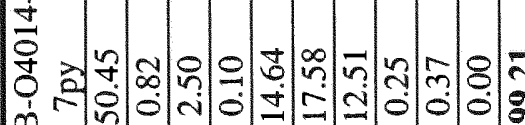

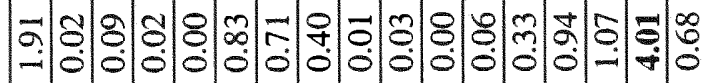

然

8

엉

$\frac{1}{4}$

ㄱำ

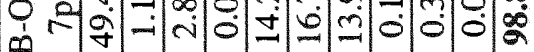

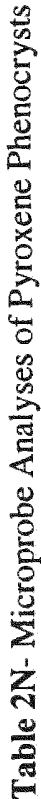

$\frac{2}{0}$

울

$+1$

吉 궁

帒

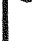

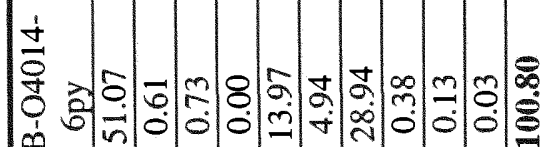

ต่

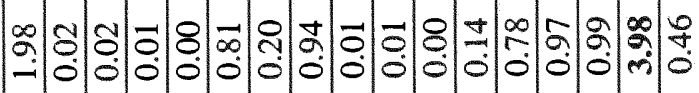

ஊ 0

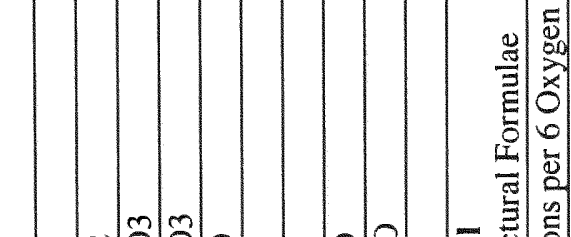

5

돈

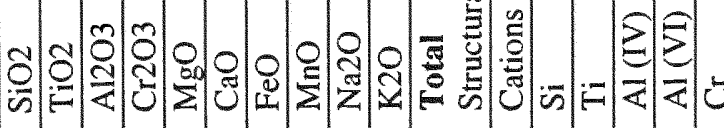

쪽 


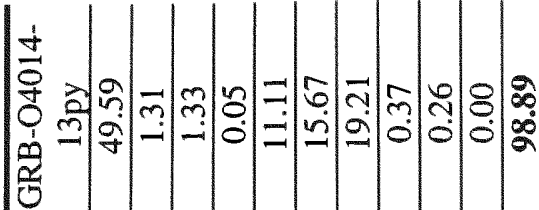

草

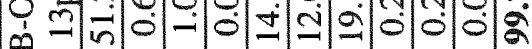
중

年 向 通

id

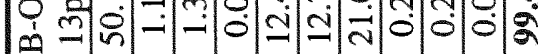
용

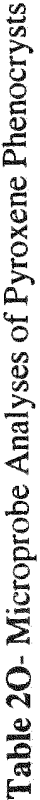

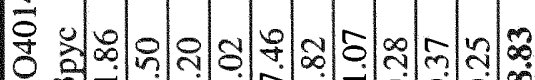
म่ 过

$\frac{0}{9}$

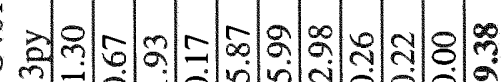
긍 응

辛

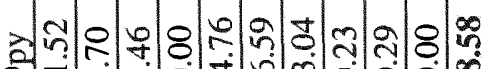

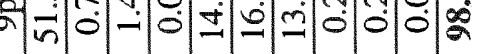

索苛

닐

去管

舟

을 훙 0

2.

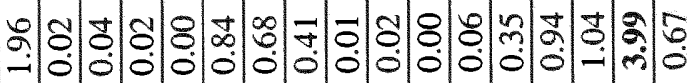

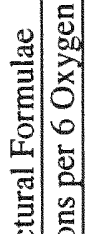

:

- 0 :

:

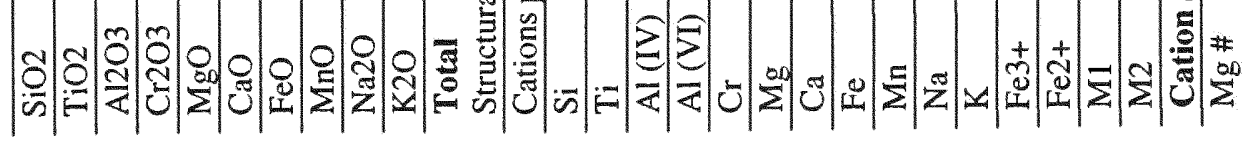


กิ

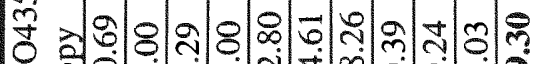

象

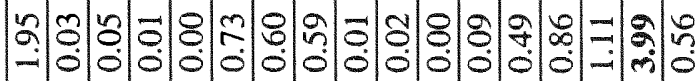

ก่

雚

电

ఏి

莳

ส่

品

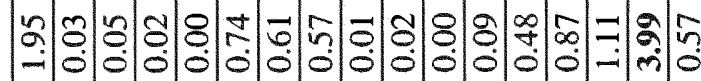

in

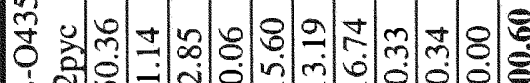
๓ तो म

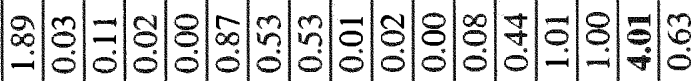

0

กี

m म तो

唄

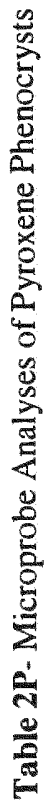
䒛

กิ่

年 궁

तो

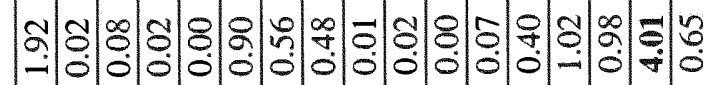
$\frac{2}{0}$

¿

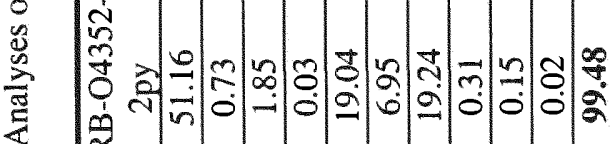

:

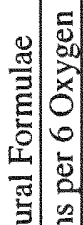

2.

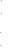




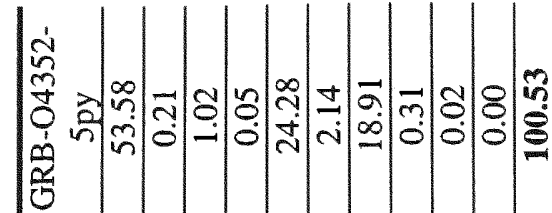

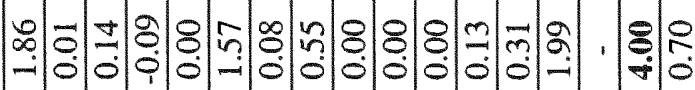

ธ่

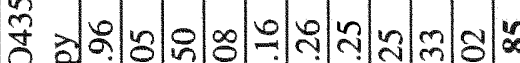

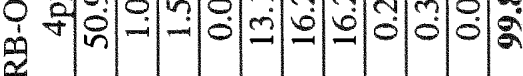

至

ஸ்

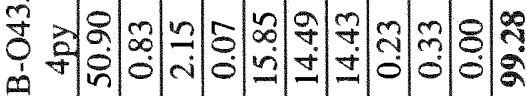
음

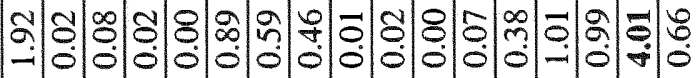

㝏

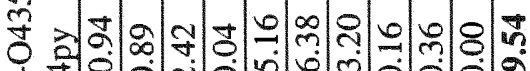
急

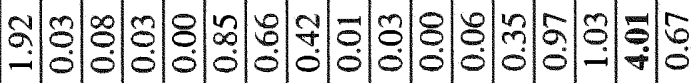

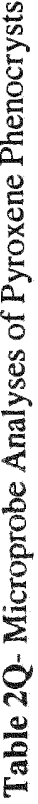

iี่ 敦娄 品

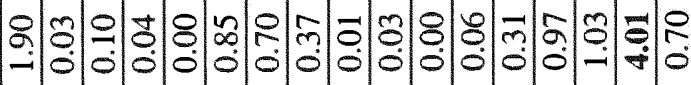

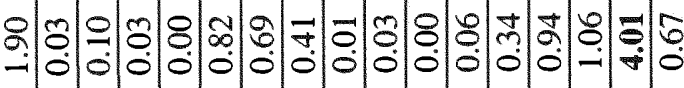

㓂

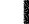

崖

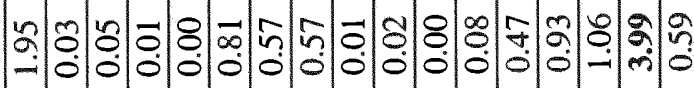
通
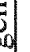
角

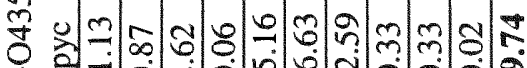

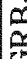

웅

ก่

守

告

ส่

กั่

ติ

뭉

i่

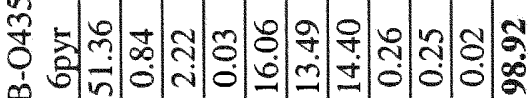

足

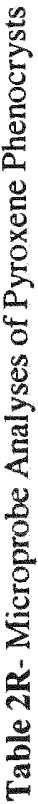

in

닉

我

$\frac{0}{0}$

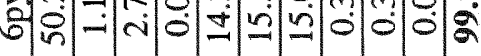

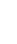

ヘ่

孚

में

$\frac{1}{5}$

ஸ่

告 $\frac{a}{5}$

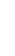

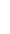

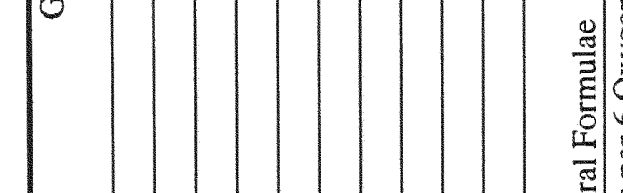




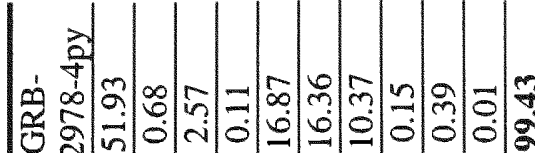
解

$\stackrel{\infty}{\circ}$

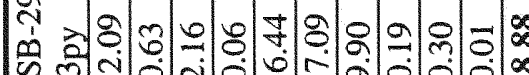
管

枋

ฉิ่

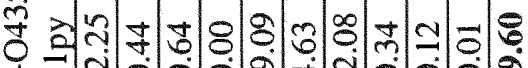

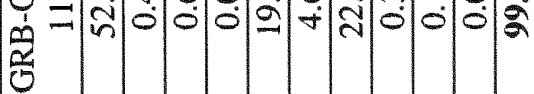

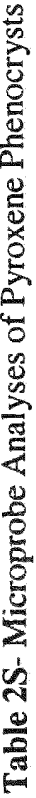

ஸें

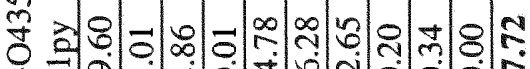

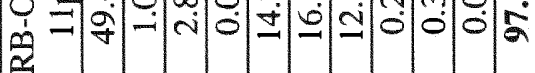
然

官

守 술 然

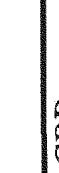

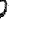

है

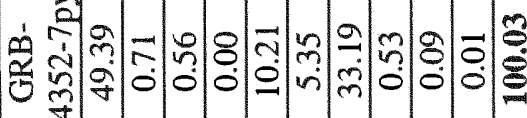
ठे

c่

网

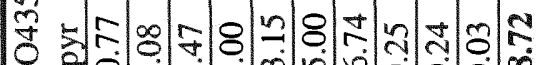

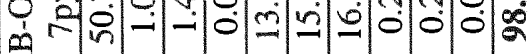
通 0 


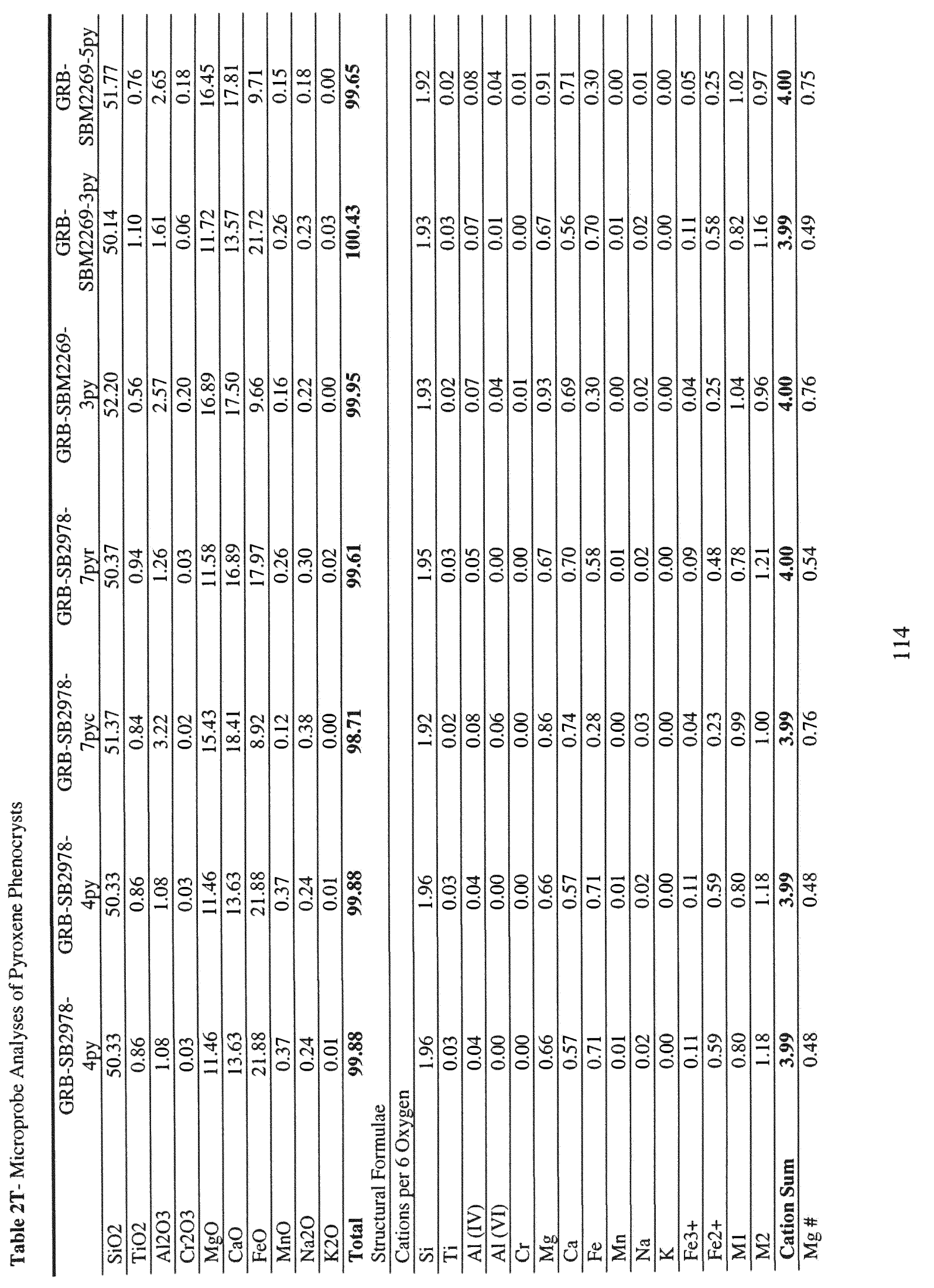




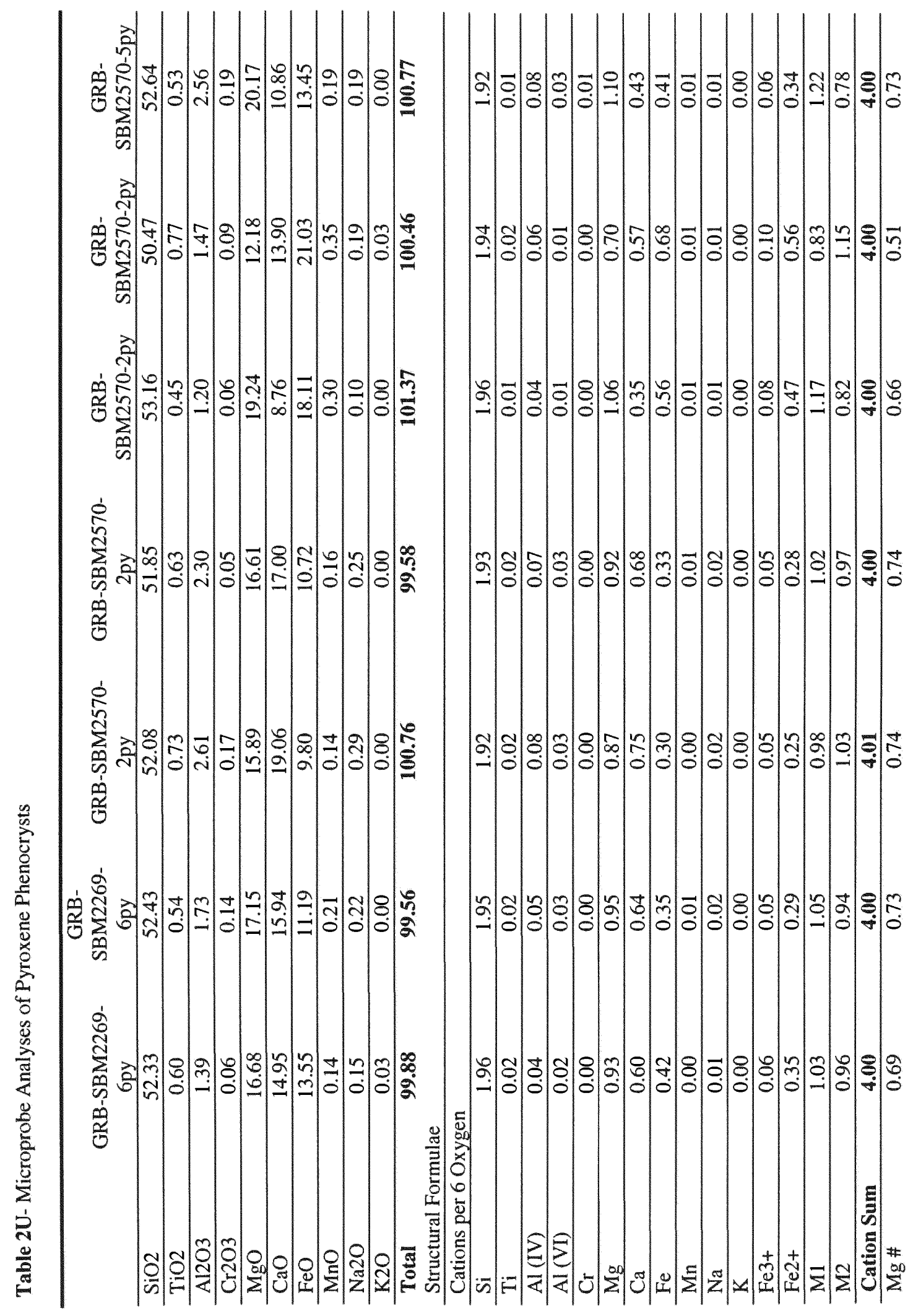




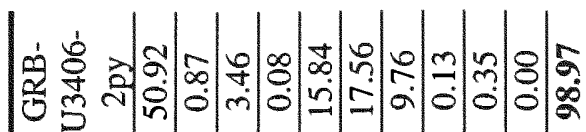

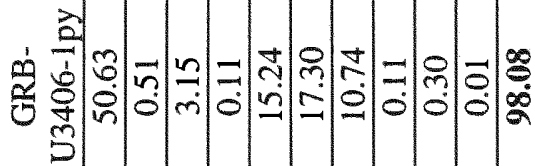

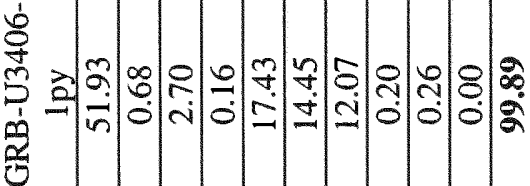

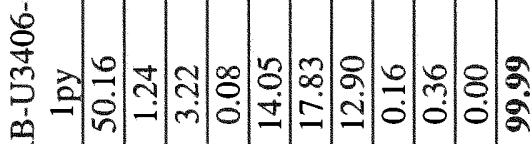

0

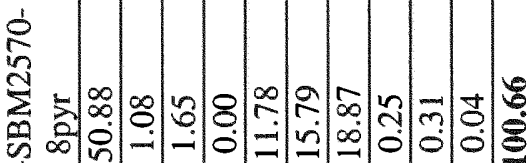

鱼

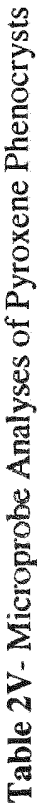

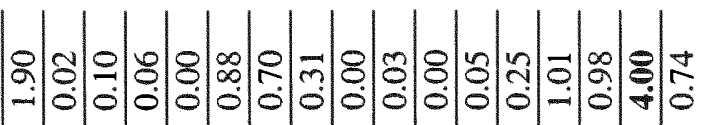

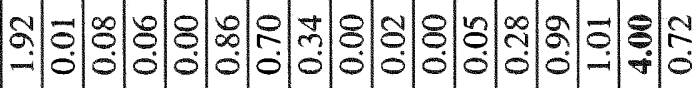

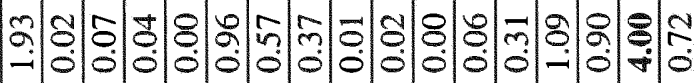

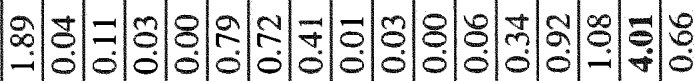

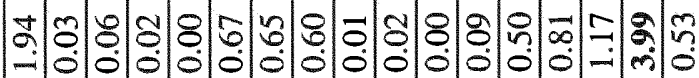

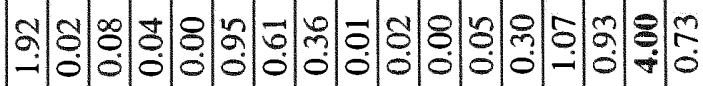

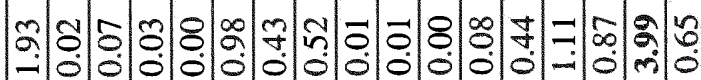

:

$\overline{\mathrm{g}}$

.

.

년

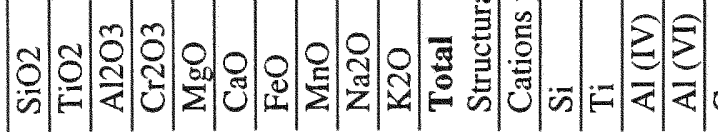

ह 5 . 


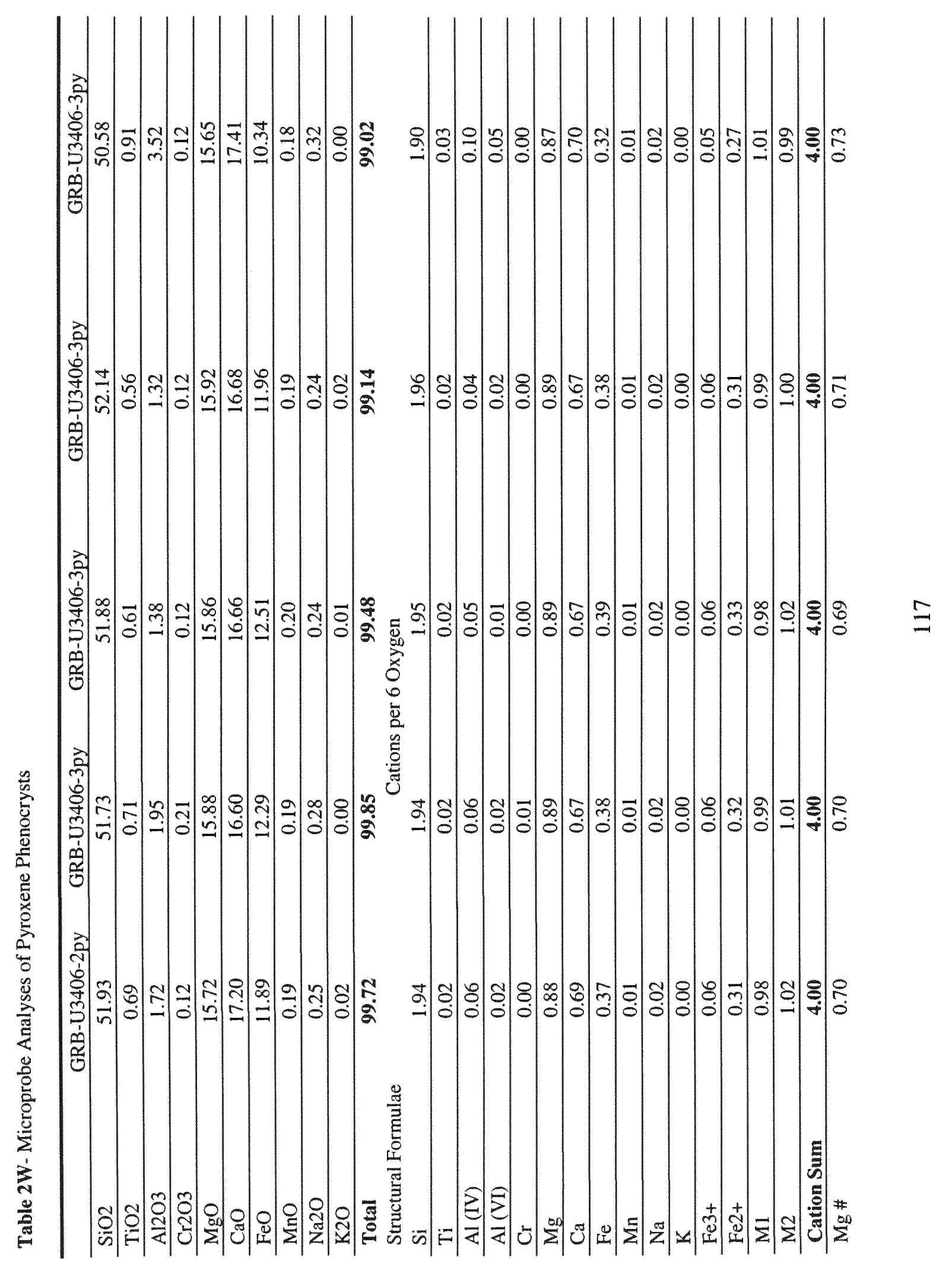




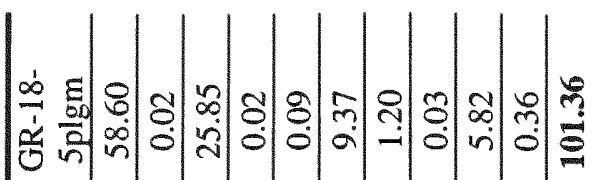
㖰

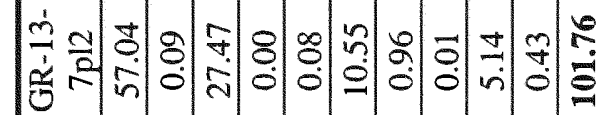

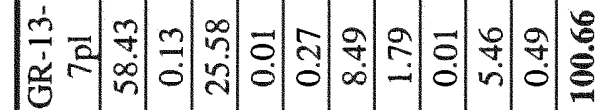

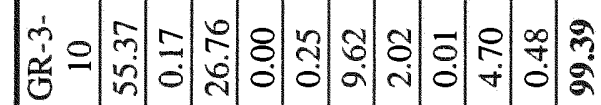

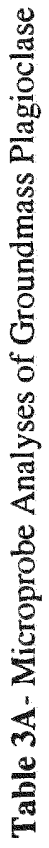

웅

궁

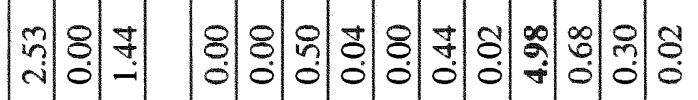

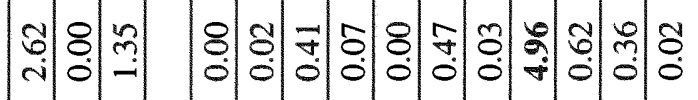

$\stackrel{\infty}{\rightrightarrows}$

กำ

ती

ஸे

5

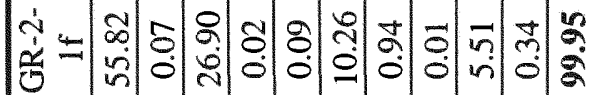

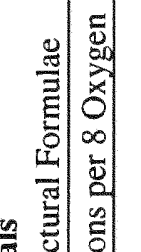

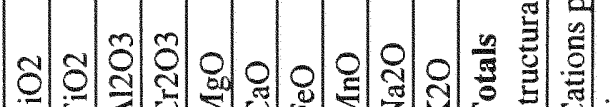

包包

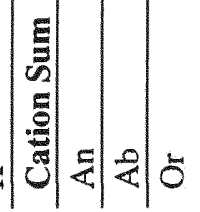




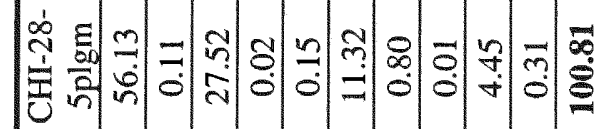

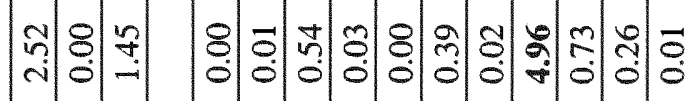

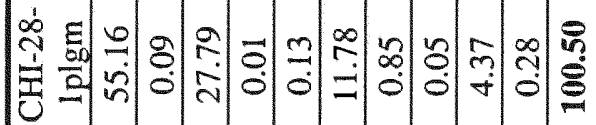

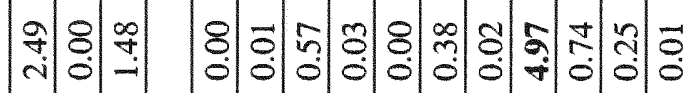

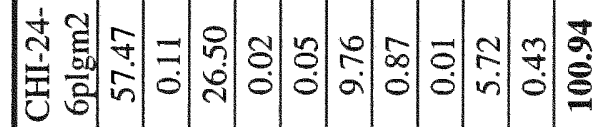

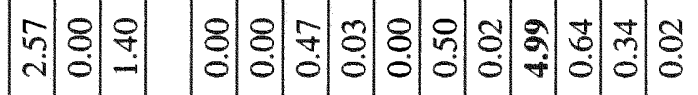

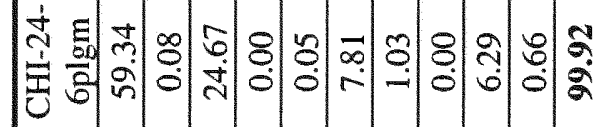

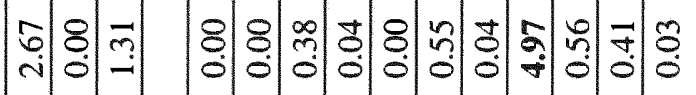

군

定

กิ่

궁

言 붕

ஸी

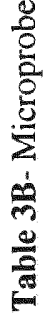

完

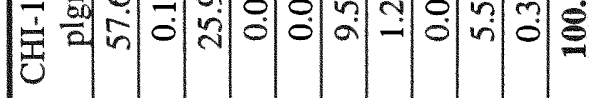


等 중

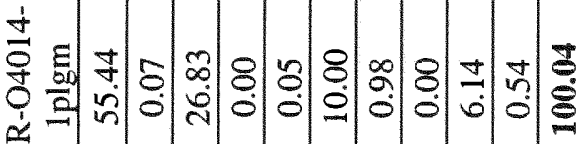
웡

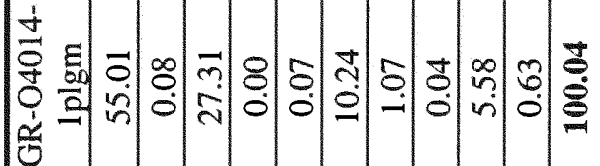

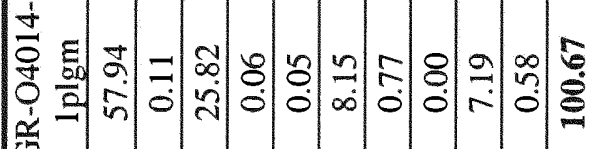

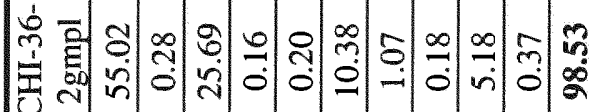

峁

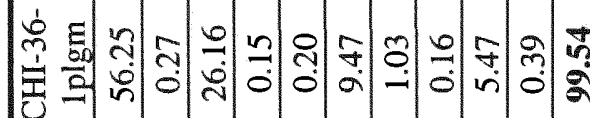

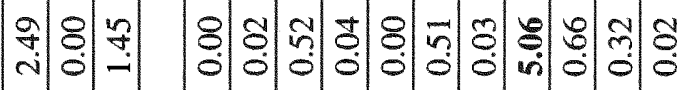

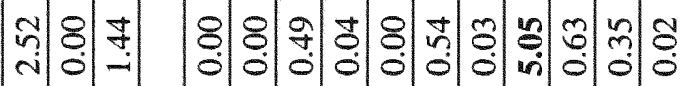

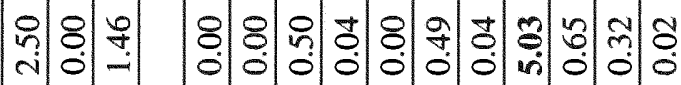

궁 영 웅

ปิ

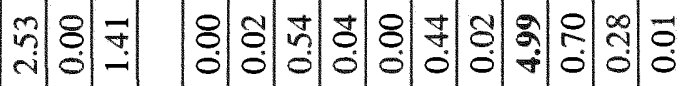

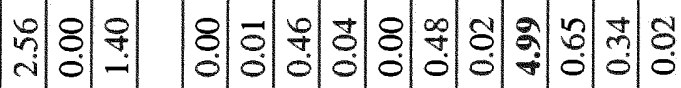

을

5

茪

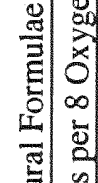

迹

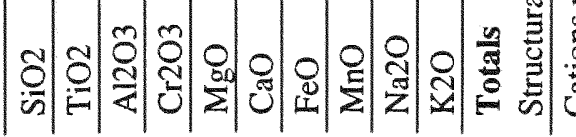

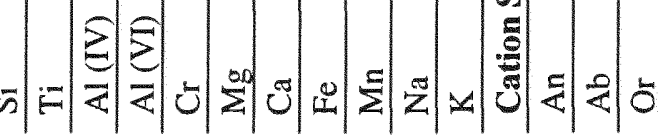




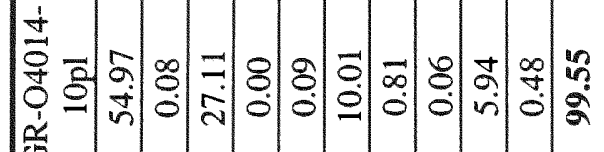

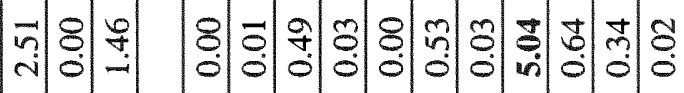

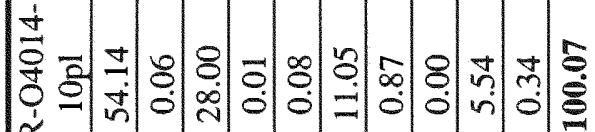
通

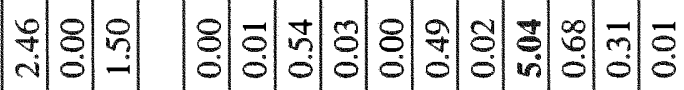

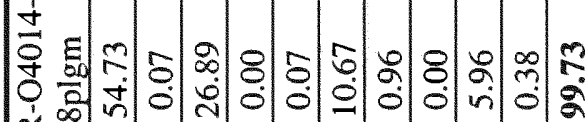
용

管商

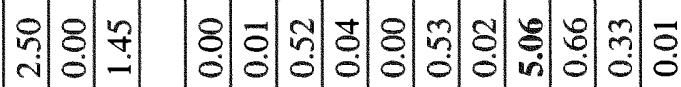

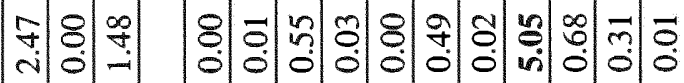

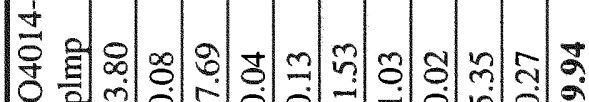

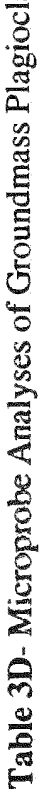

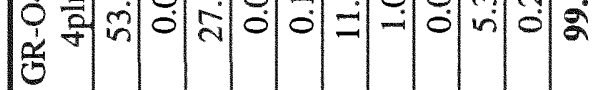

年 웅 矛 웅

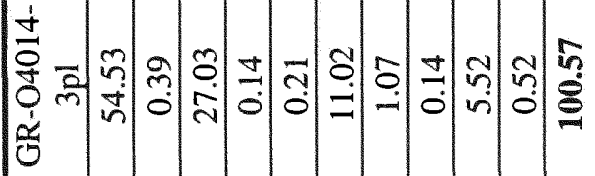

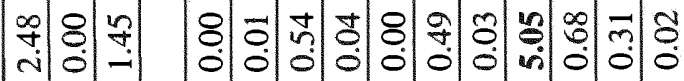

产 严

0 맹

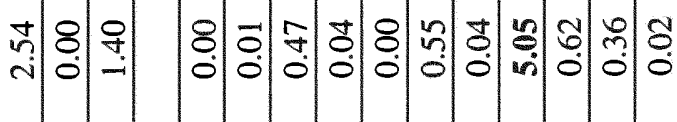




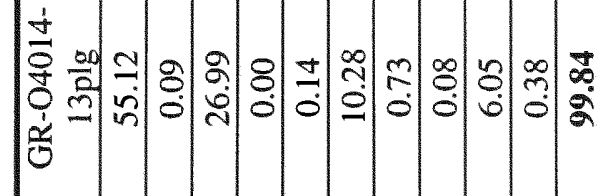

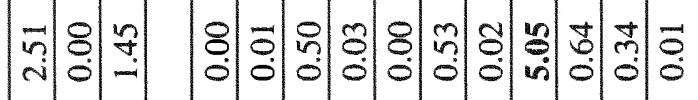

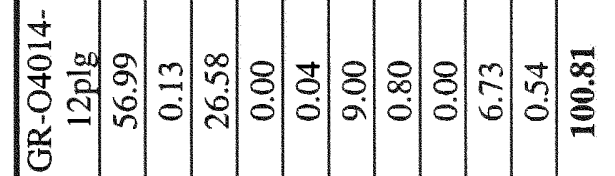

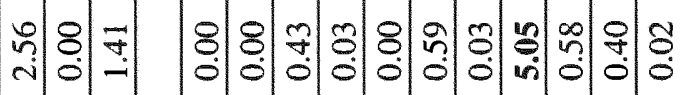

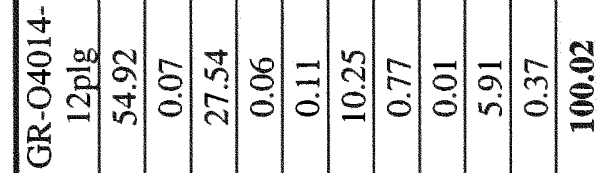

원영 要

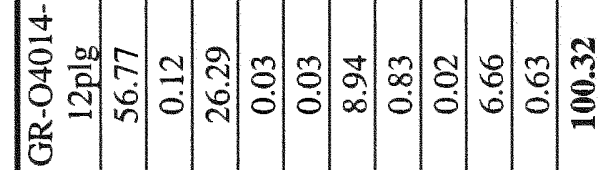

융영 워

I

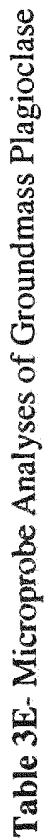

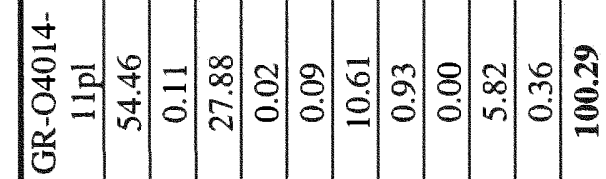

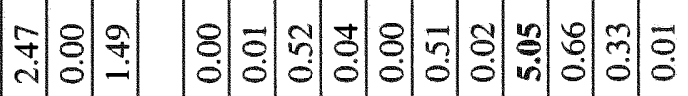

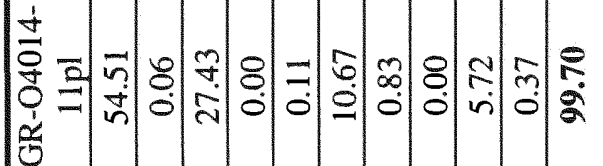

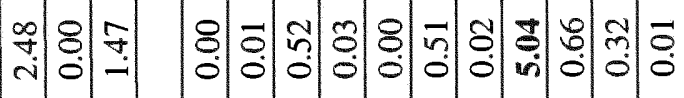

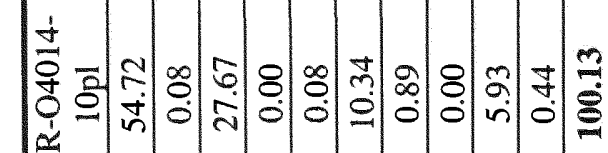
通

象 


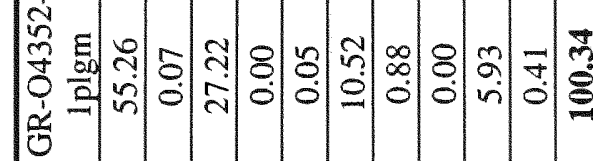

ํํㅇ

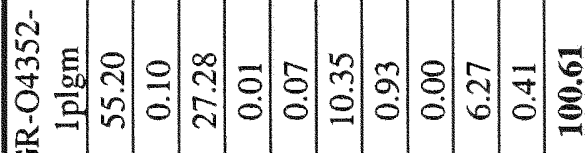

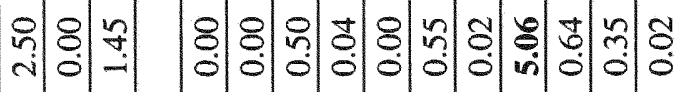

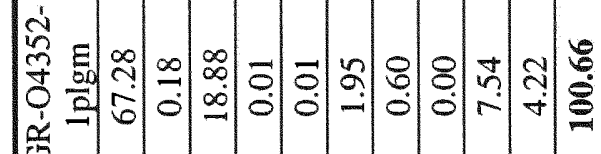

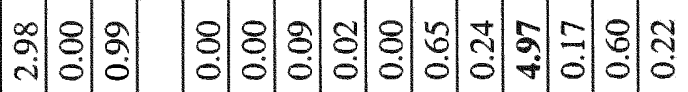

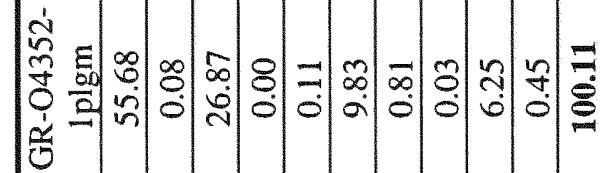

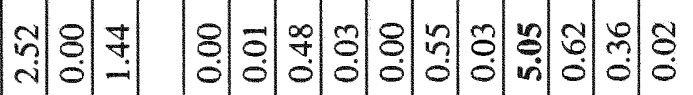

$\Xi$

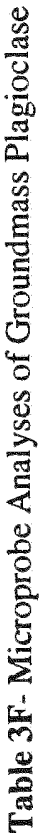

窟

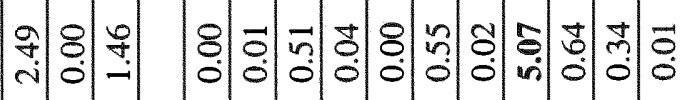

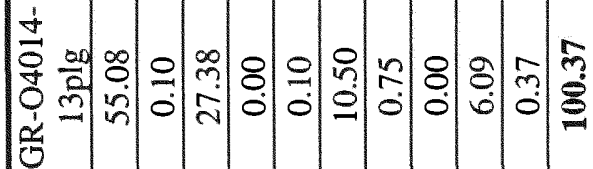

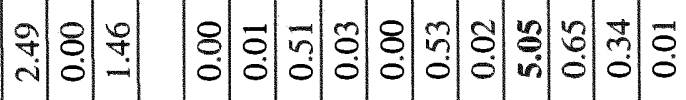

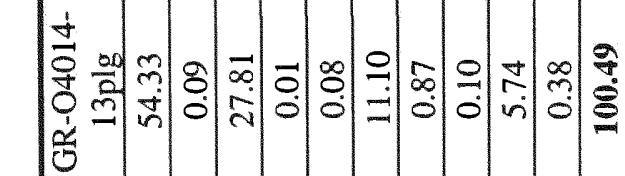

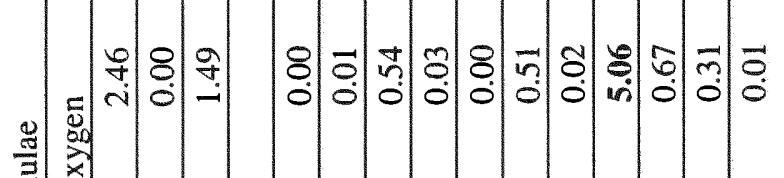

प

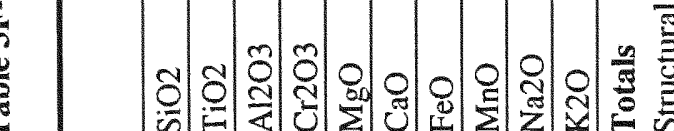

펼

월

E 


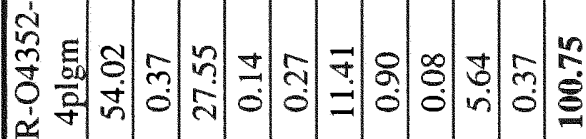
엉

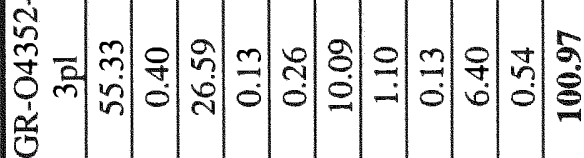

í

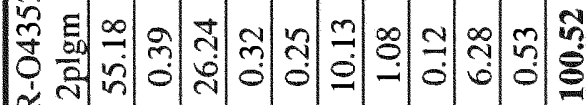
迢

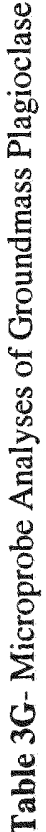

ஸ่

登 品

(่)

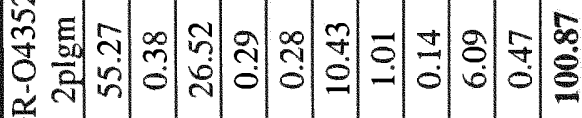
의

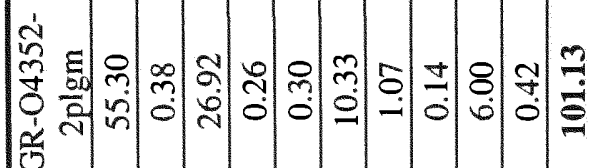
g.

خิ

जุ

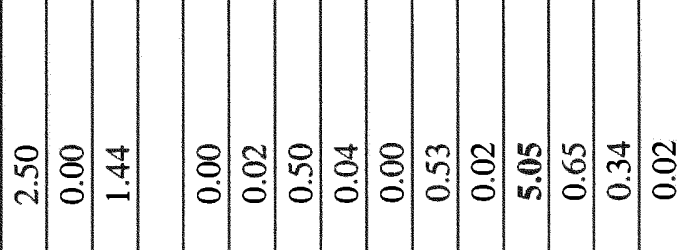

年

ஸิ

సี่

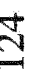

은

年융 导

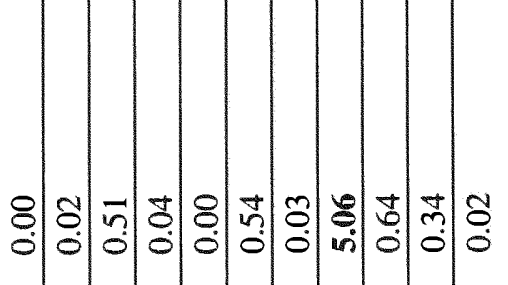

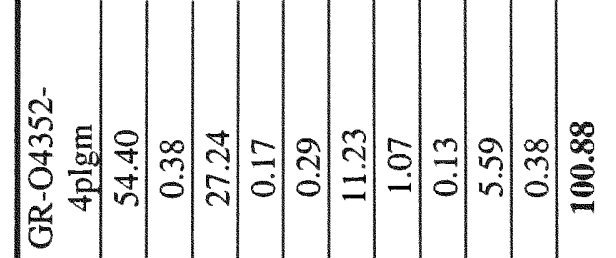




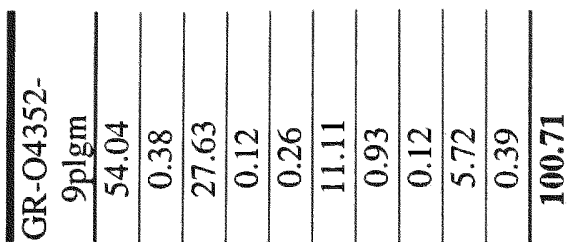

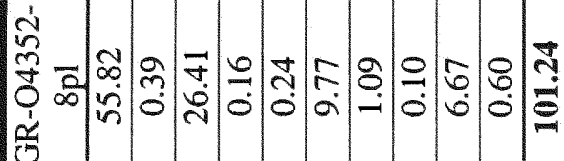

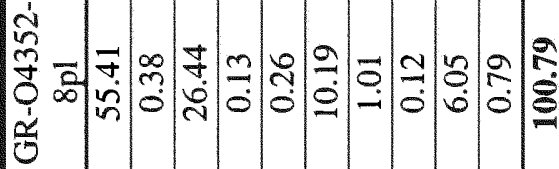

ธ่

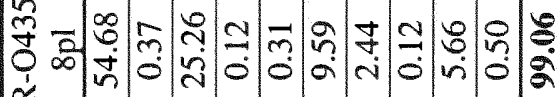
엉

要
若 逭

¿่

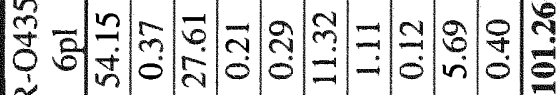
웡

1'

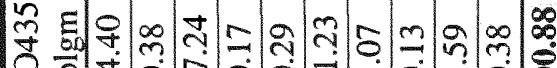

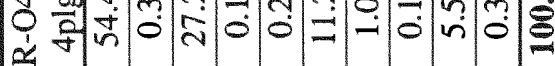
品

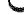

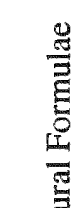

은

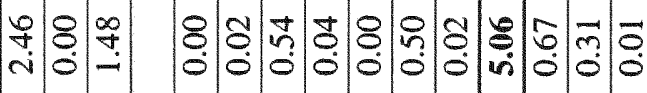

స̂:

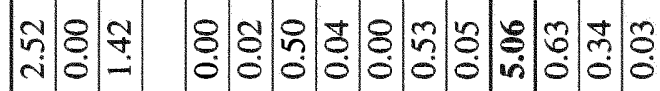

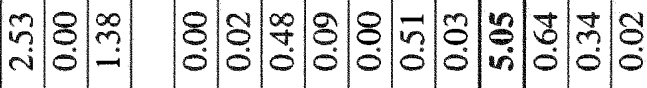

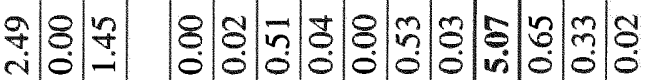

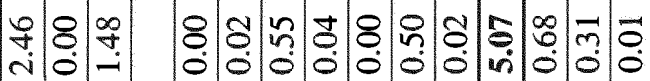

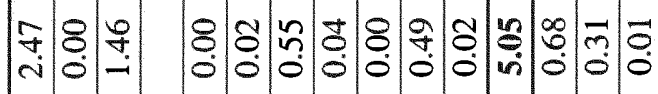
5 
|

ทุ่

ก่

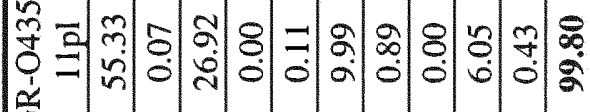

匀

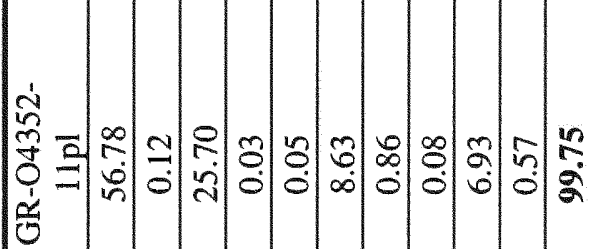

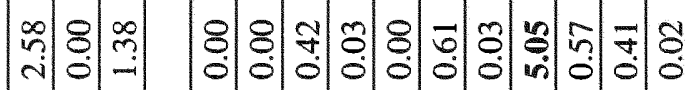

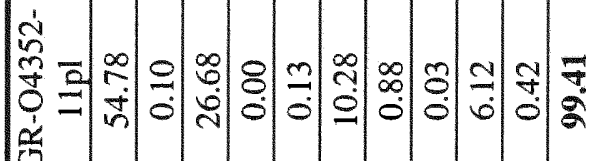

ที่

$\stackrel{0}{-1}$

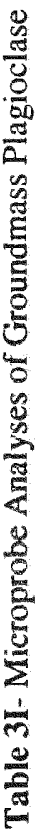

峞

芛

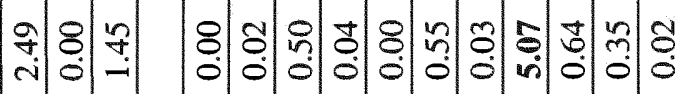

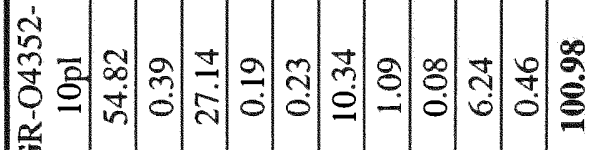

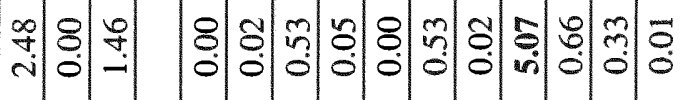

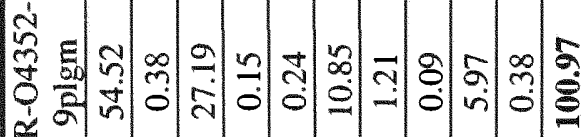
중

a $=$

늬의

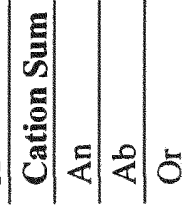


|

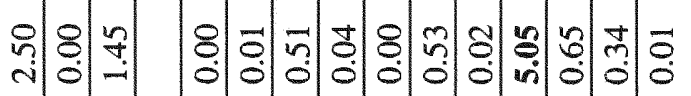

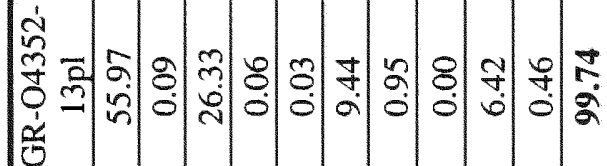

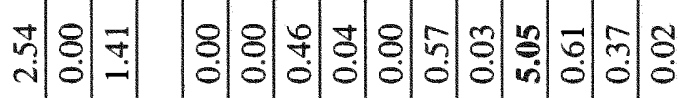

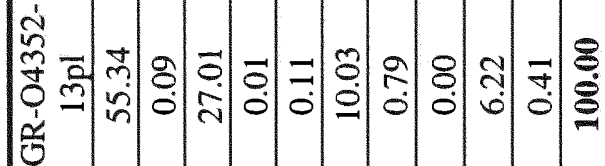

जุ|

¿่

㠃

$\Xi$

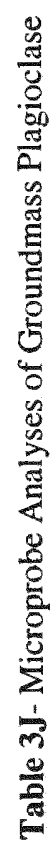

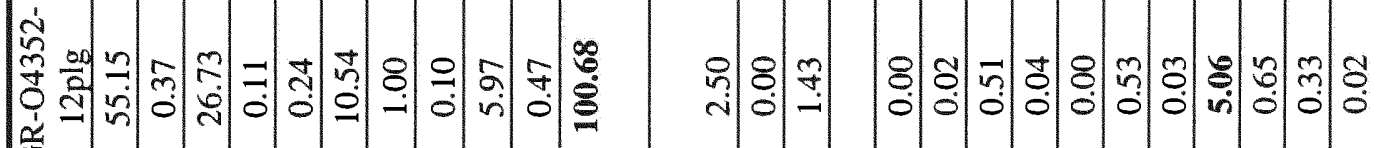
용

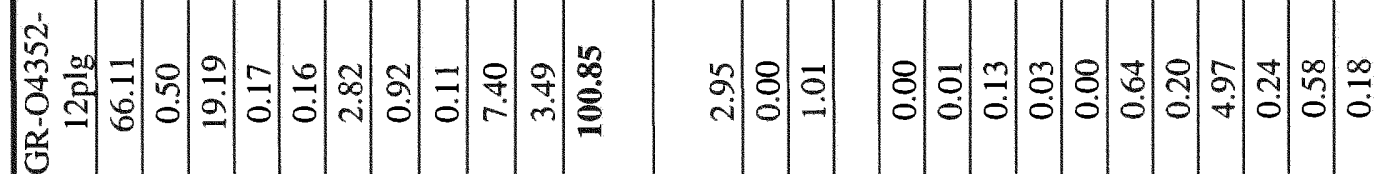
응

i

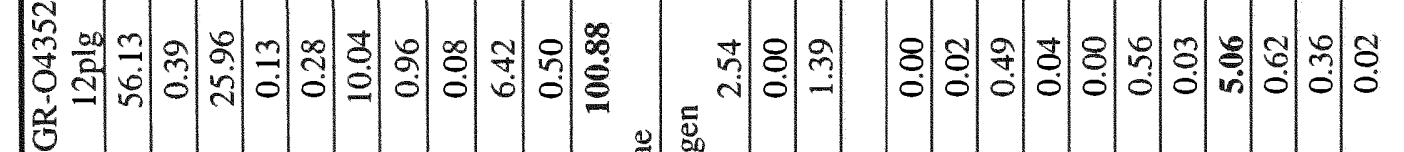
政 离<smiles>[CH]1[CH]C1</smiles> 


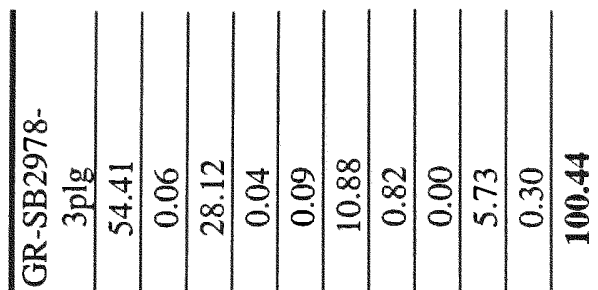

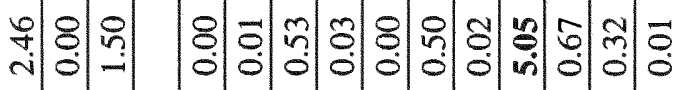

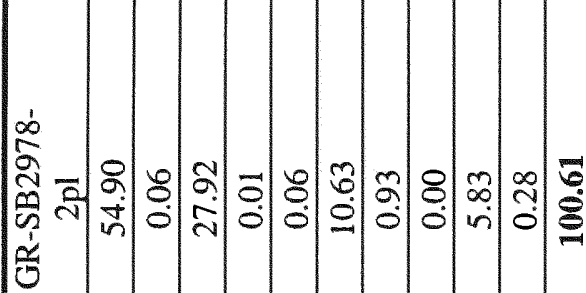

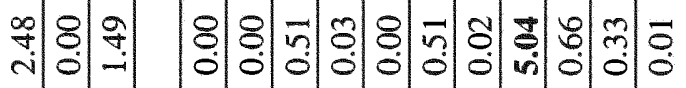

全 造

군

$\infty$

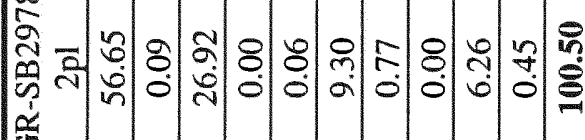

น

啇

군 范

군웅

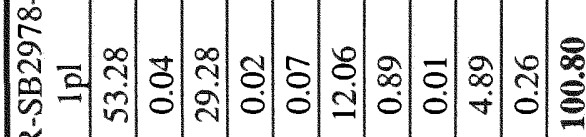
웅

$\infty$

全 造

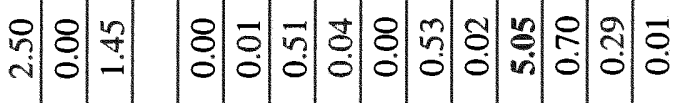


䍃 告 章 영

궁융

究 号

भి

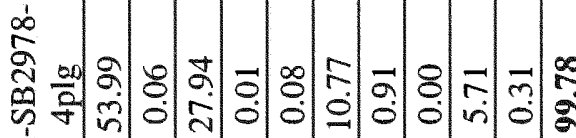
융

구일

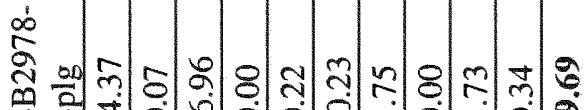

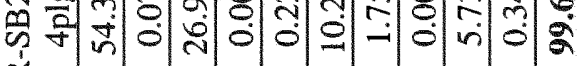
号

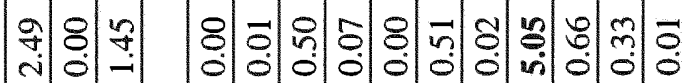

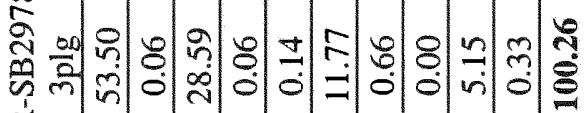

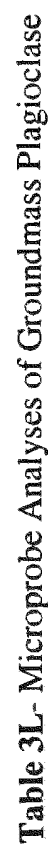

年

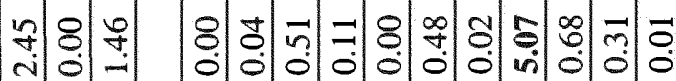

సे 열 응

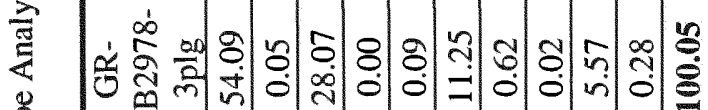

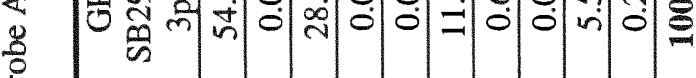
대요

뉜

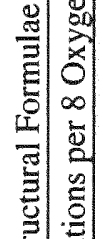

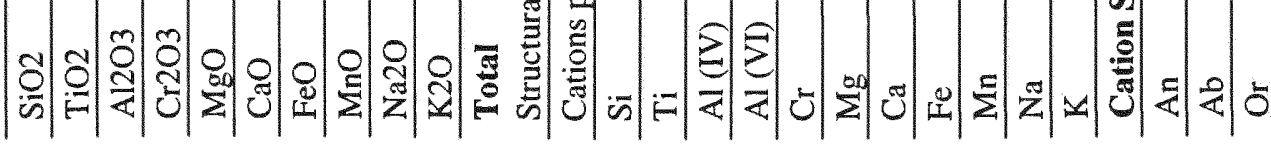




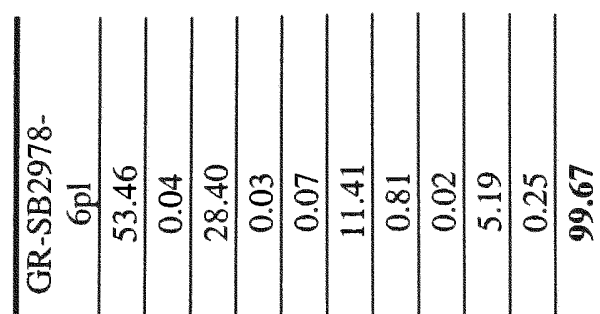

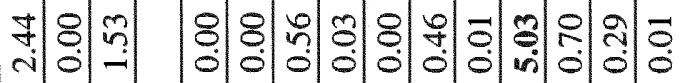

$\stackrel{\infty}{\circ}$

帘 웅

궁웅 숙 웅

$\infty$

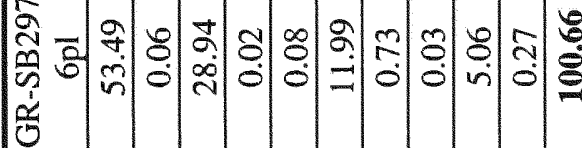

국웅

$\infty$

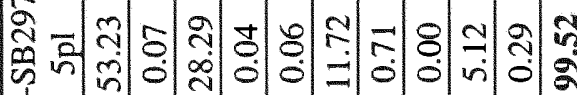
웅

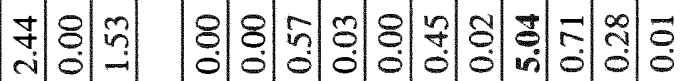

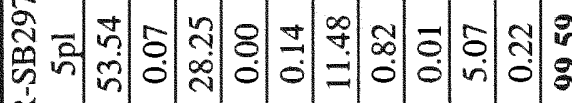

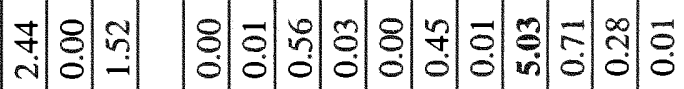
웅

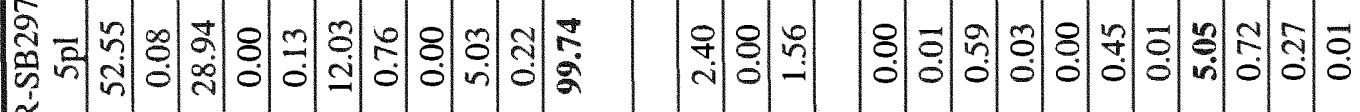

$\infty$ 용

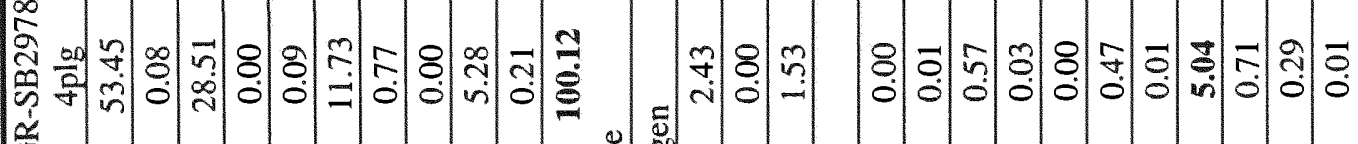
䢔

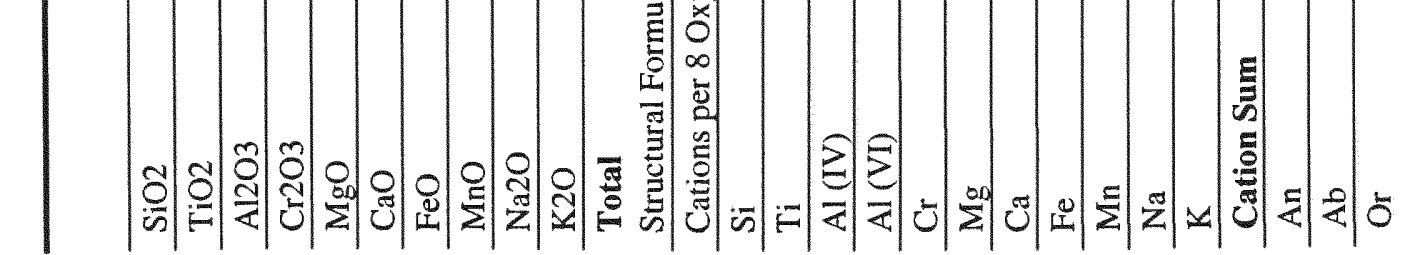


|

逢

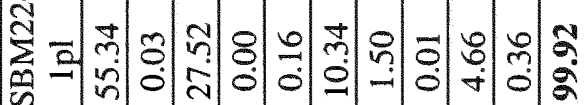
웡

$\infty$

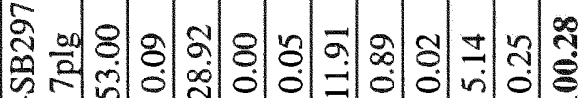
通

$\infty$

商 중

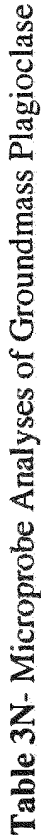

$\infty$

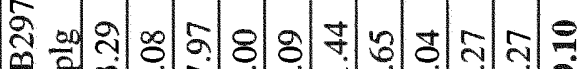

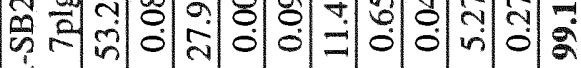
중

$\infty$

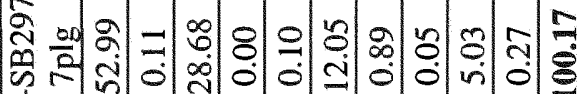
通

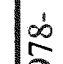

立 흥 范

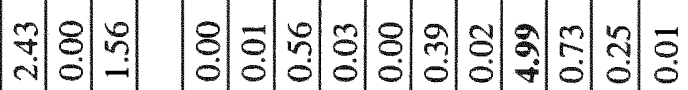

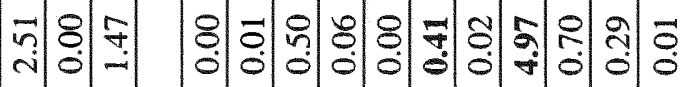

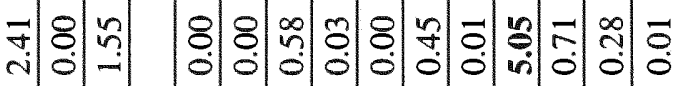

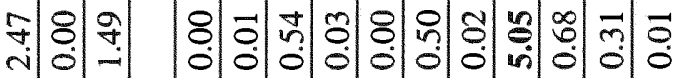

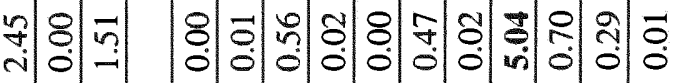

호영무

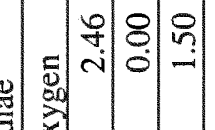

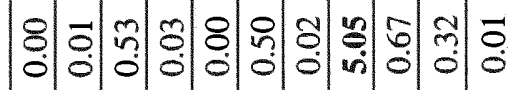


递

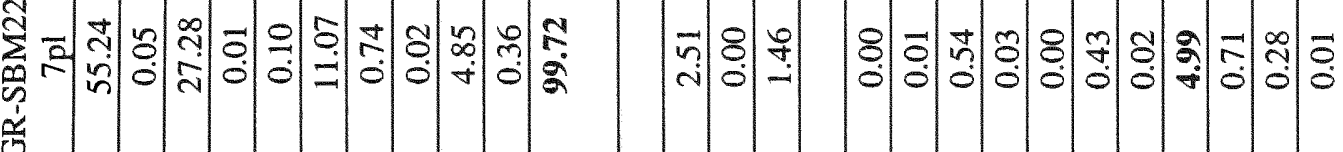

엉

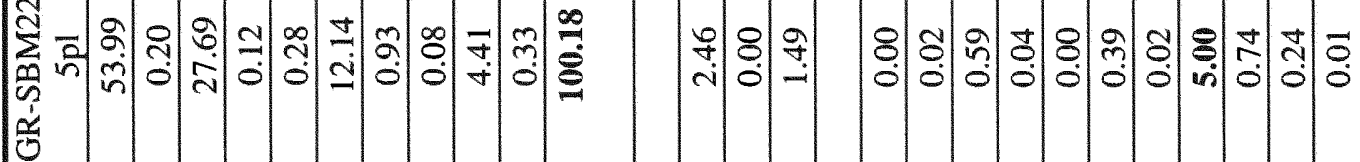

ò

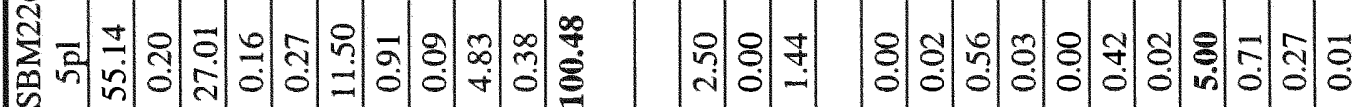

通

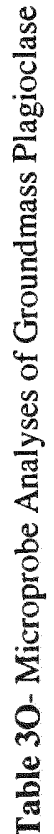

.

傍

䢔

d่

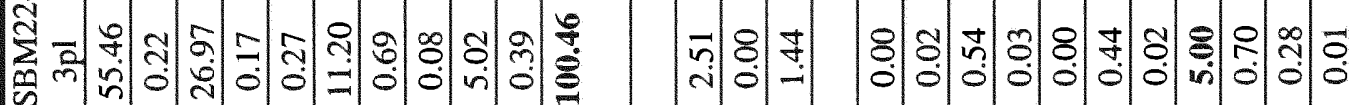
영

ó

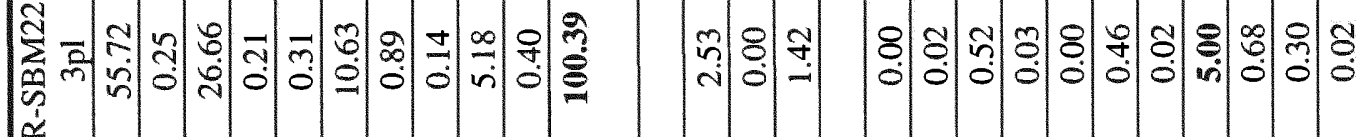
迈

产

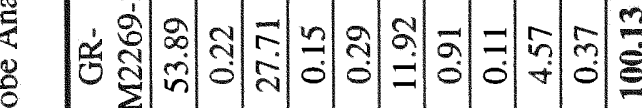

究

奠

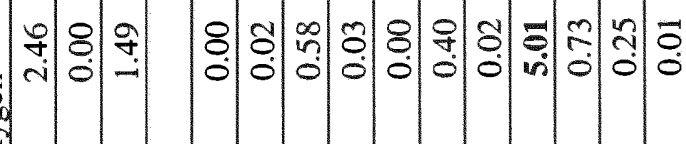
장

政 


\section{完}

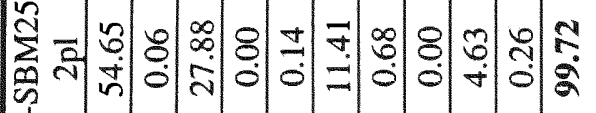

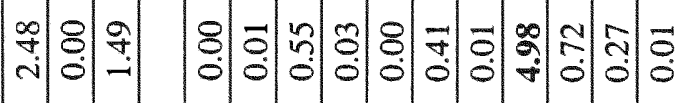

웡

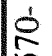

象

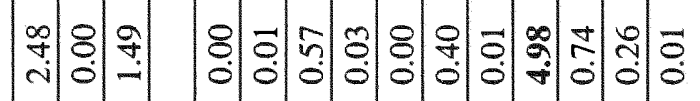

중

일

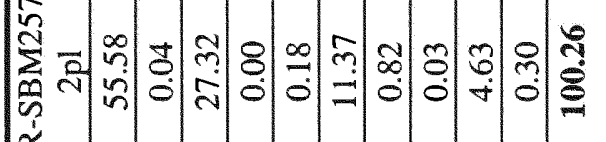

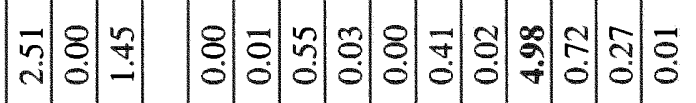

웡

¿े

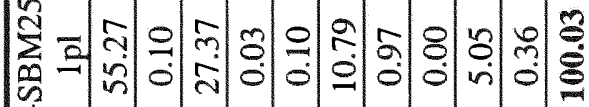

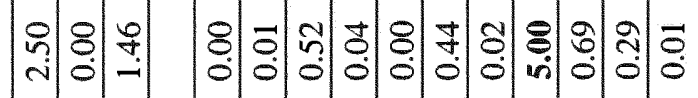

웅

¿

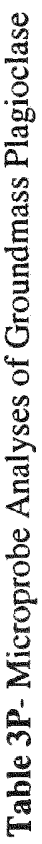

商

䢔

궁 矛 웅

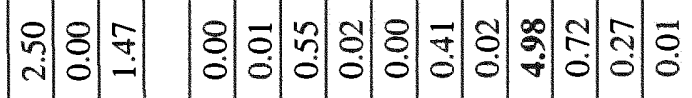

实

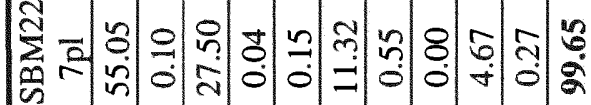

융

군

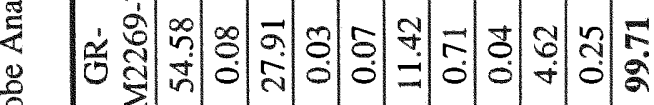

를

군 क्ष 
造

傜

nิ

$\frac{\alpha}{0}$

$\frac{1}{2}$

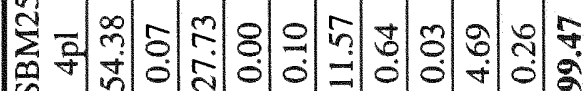

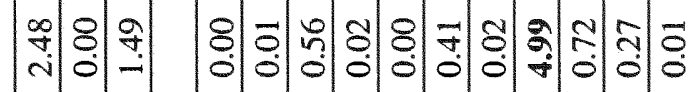

$\frac{\alpha}{0}$

官

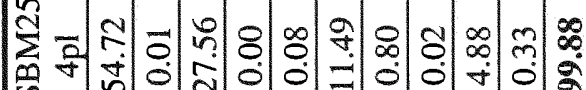

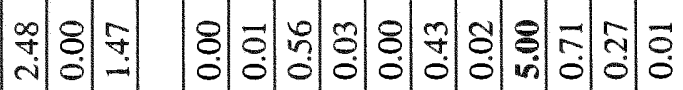

$\frac{2}{0}$

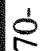

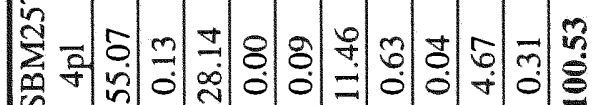

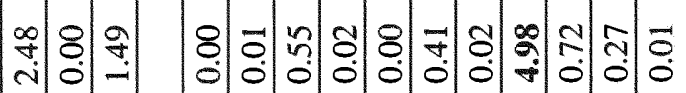

$\frac{\alpha}{0}$

8

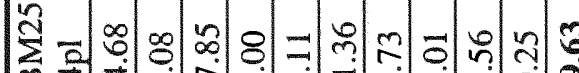

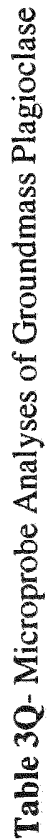

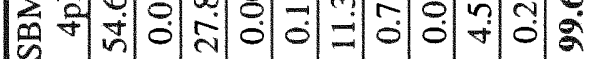

先 $\frac{\alpha}{6}$

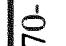

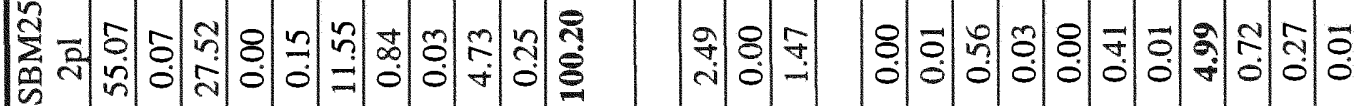

$\frac{1}{0}$

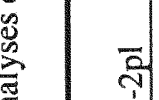

究

旁

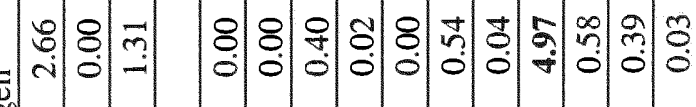

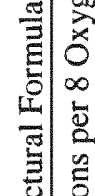


等

守

究

官

贸

范

용

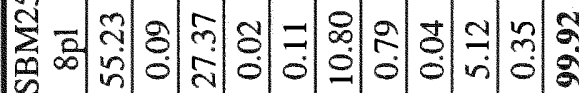

范

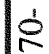

莓

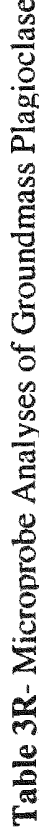

웅

隹

$\frac{1}{0}$

心

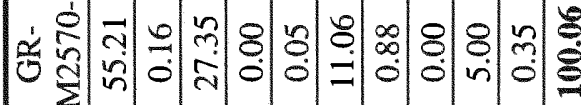

$\bar{n}$
0
0
$\frac{a}{0}$
$\sum_{0}^{0}$

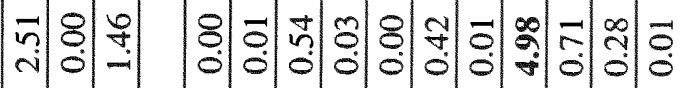

nิ

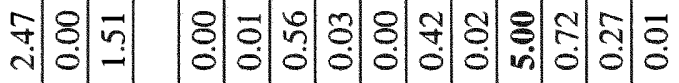

근

긍

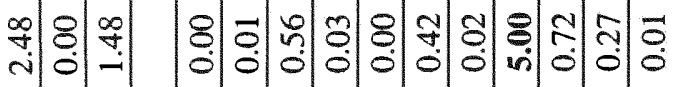




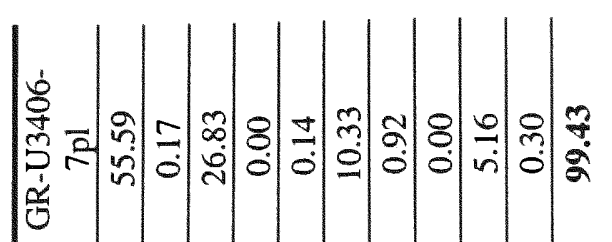

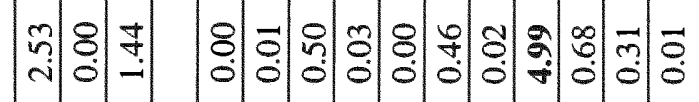

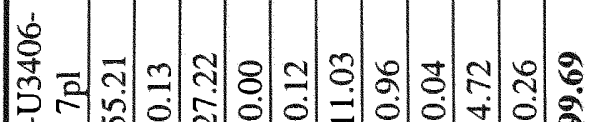

רె:

䢔

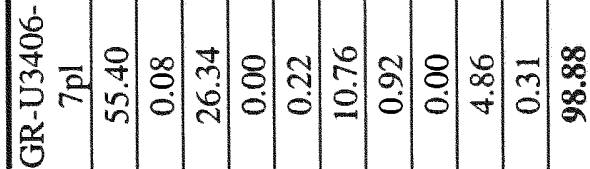

ñ

ஜ́

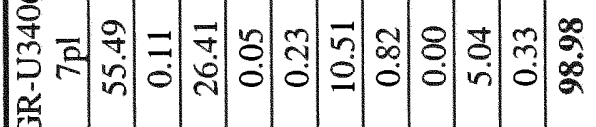

n

造

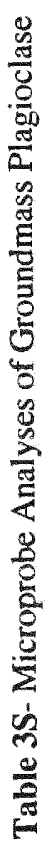

占

官

坒 芯 过

虻

学

它 ०ैํำ

6

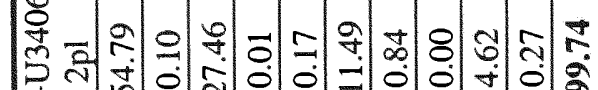

군

造 ती

$\stackrel{8}{3}$

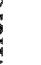

है

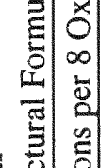

$\infty$ 


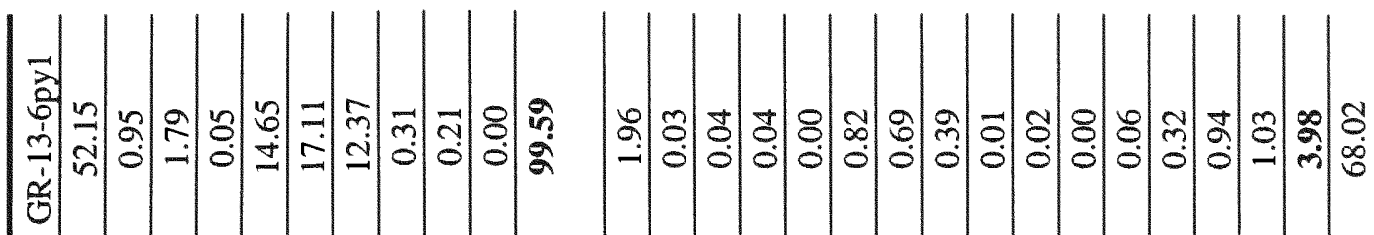

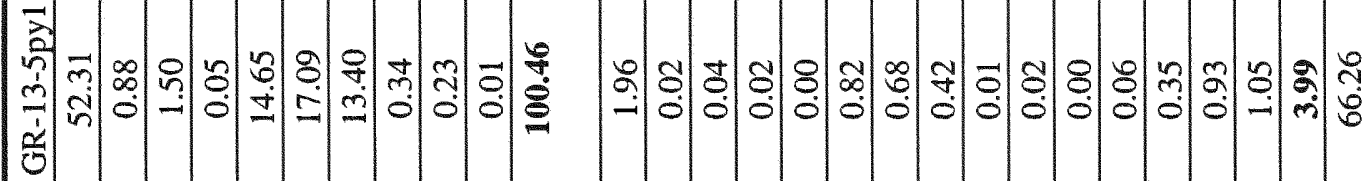

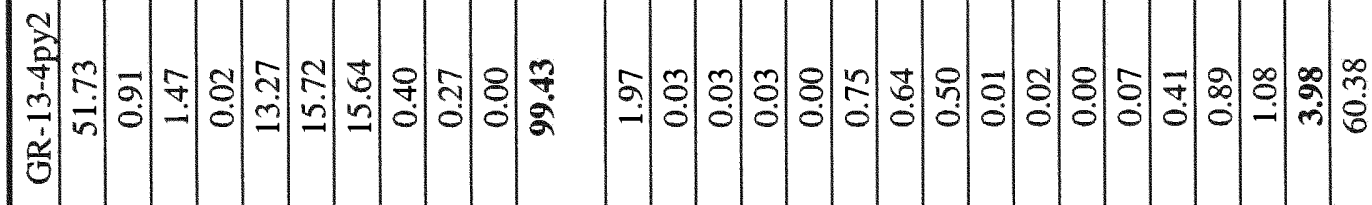

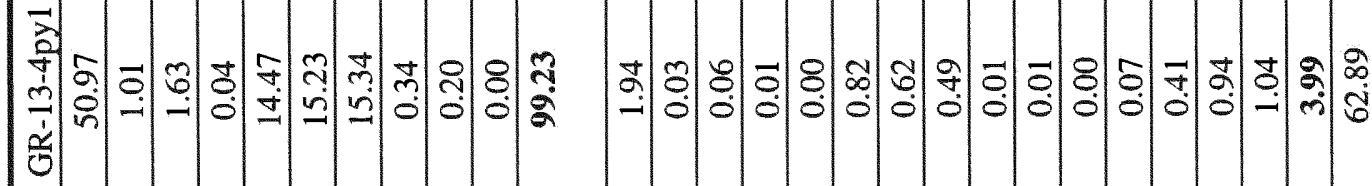

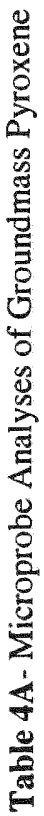

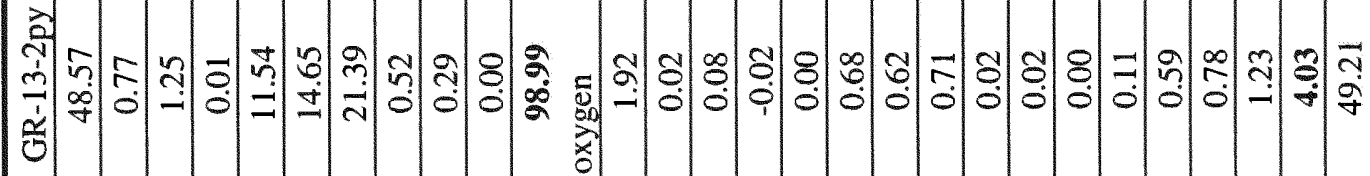

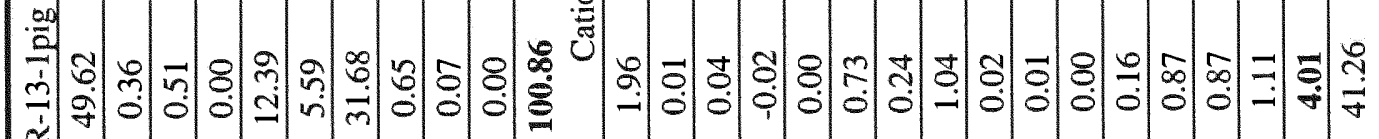
$\frac{2}{0}$

章

굴

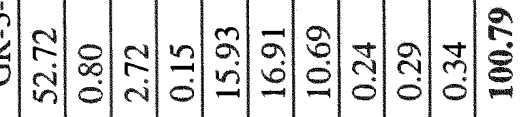

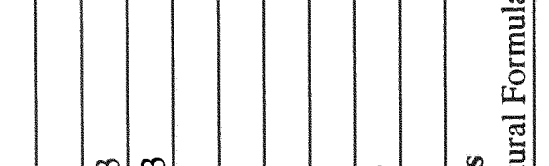

ஸी 


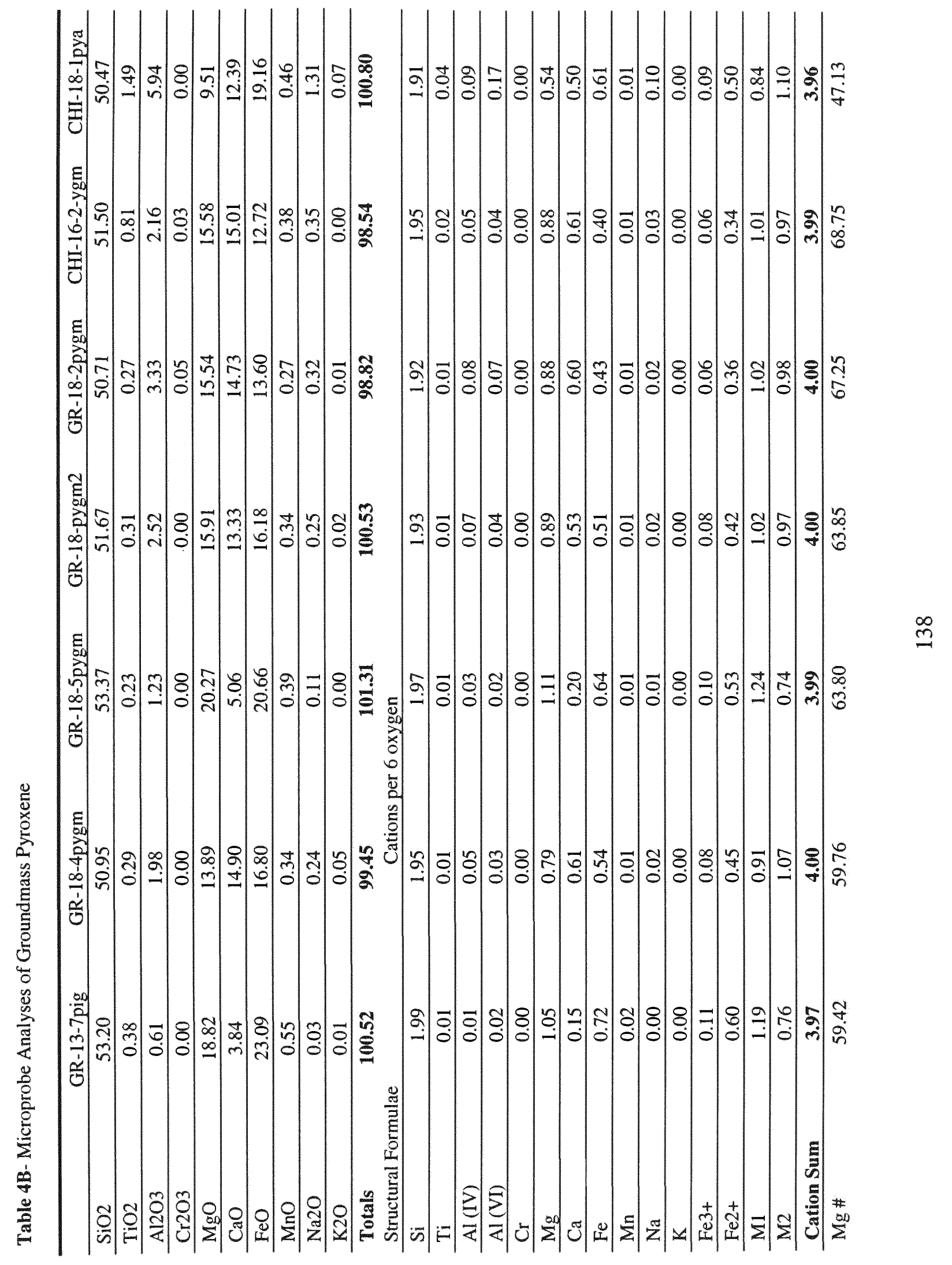




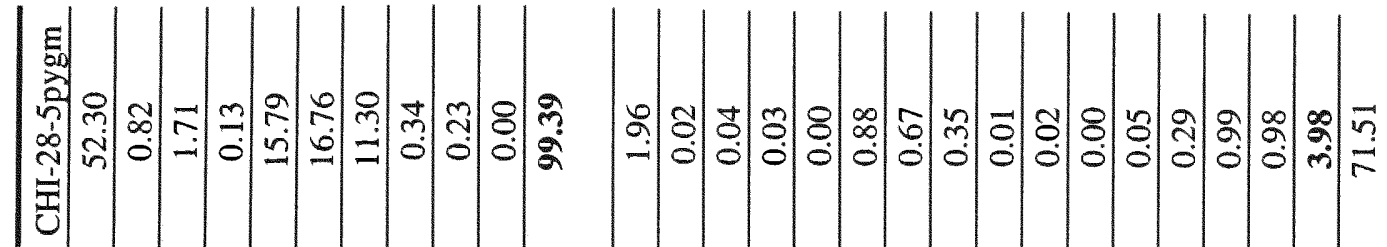

$$
\begin{aligned}
& \sum_{0}
\end{aligned}
$$

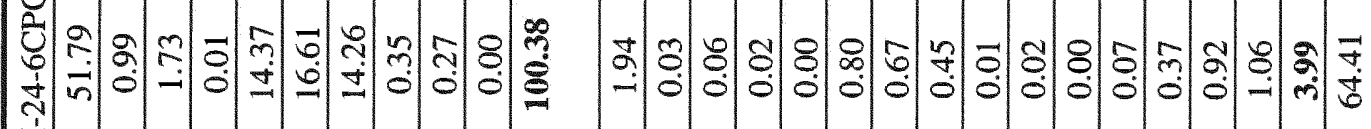

$$
\begin{aligned}
& \text { 空 } \\
& \sum_{0}
\end{aligned}
$$

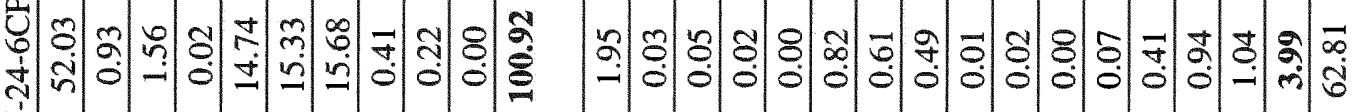

$$
\begin{aligned}
& \text { 窇 }
\end{aligned}
$$

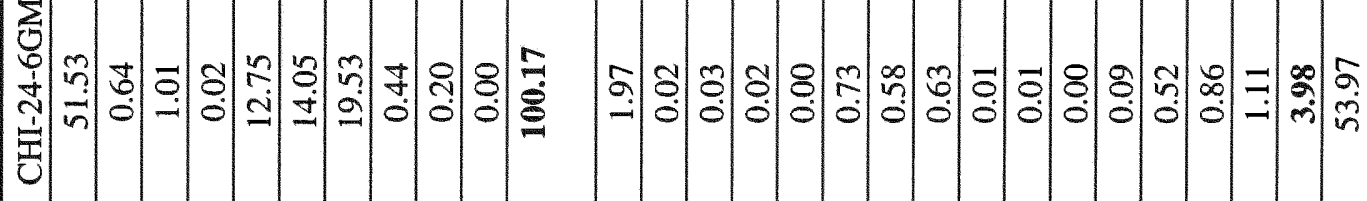

$$
\begin{aligned}
& \text { ․ㅗㅁ }
\end{aligned}
$$

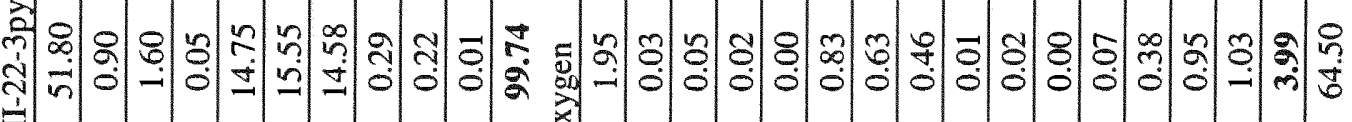

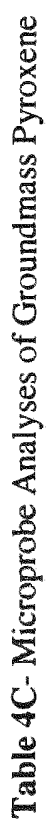

$$
\begin{aligned}
& \text { 횡 } \\
& \text { 항 } \\
& \text { 苟 }
\end{aligned}
$$

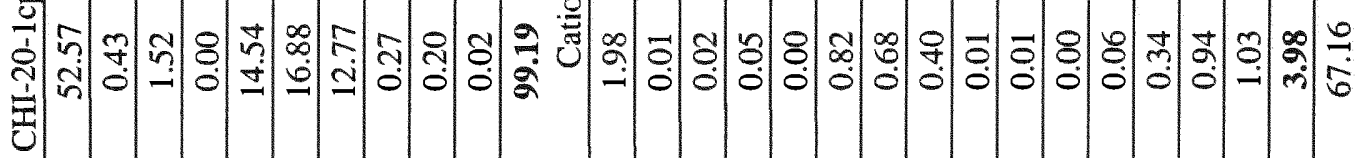

$$
\begin{aligned}
& \text { 를 }
\end{aligned}
$$

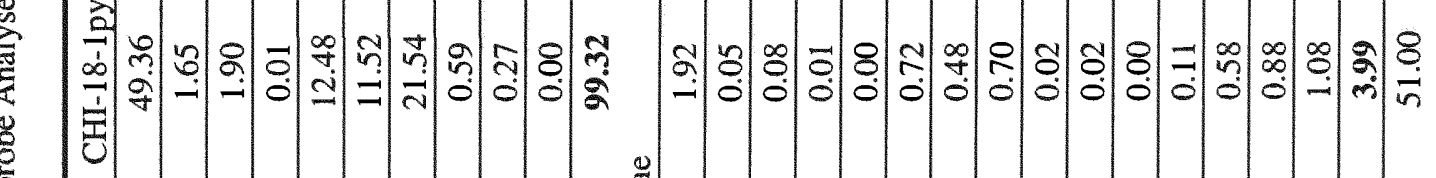

$$
\begin{aligned}
& \text { 善 }
\end{aligned}
$$




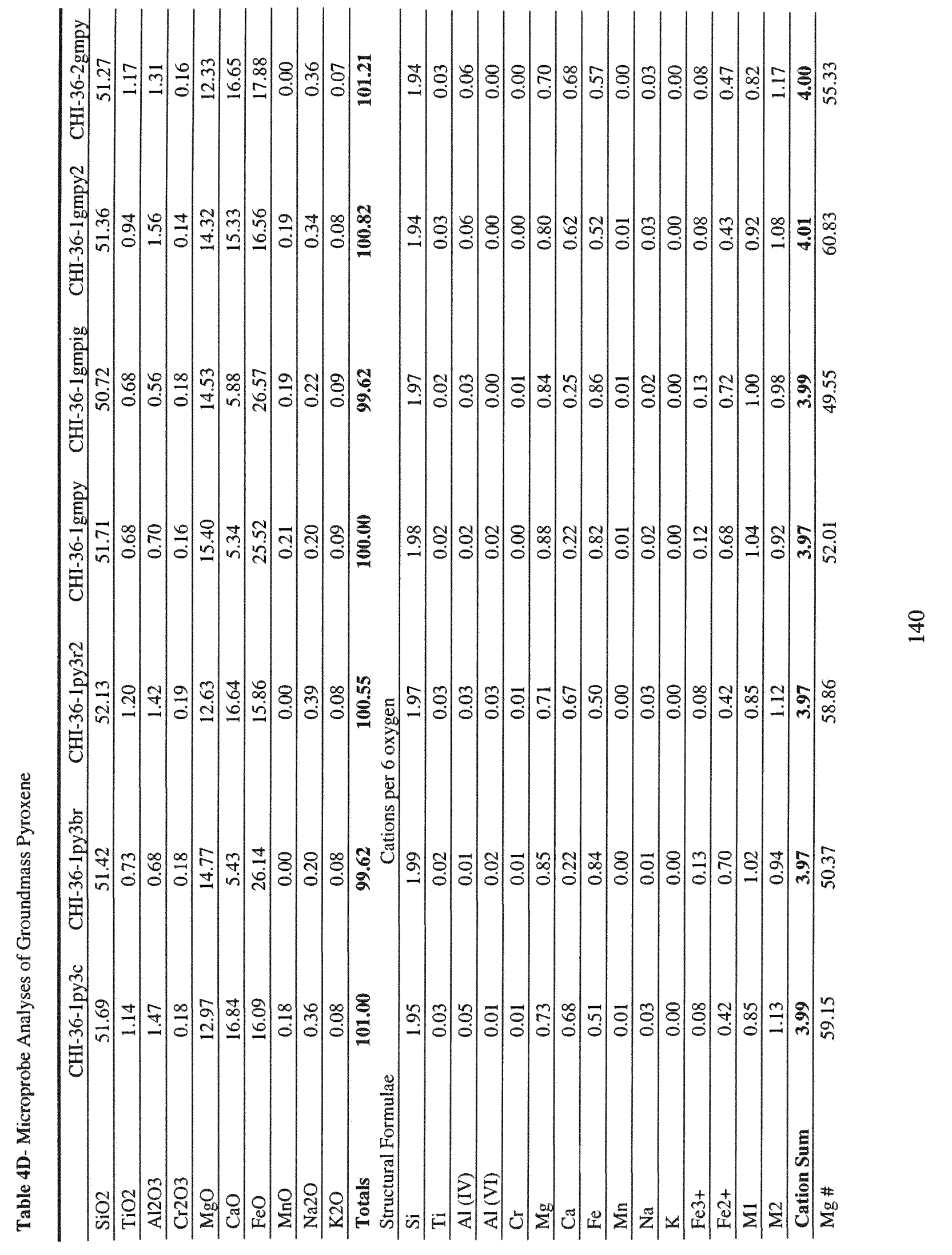




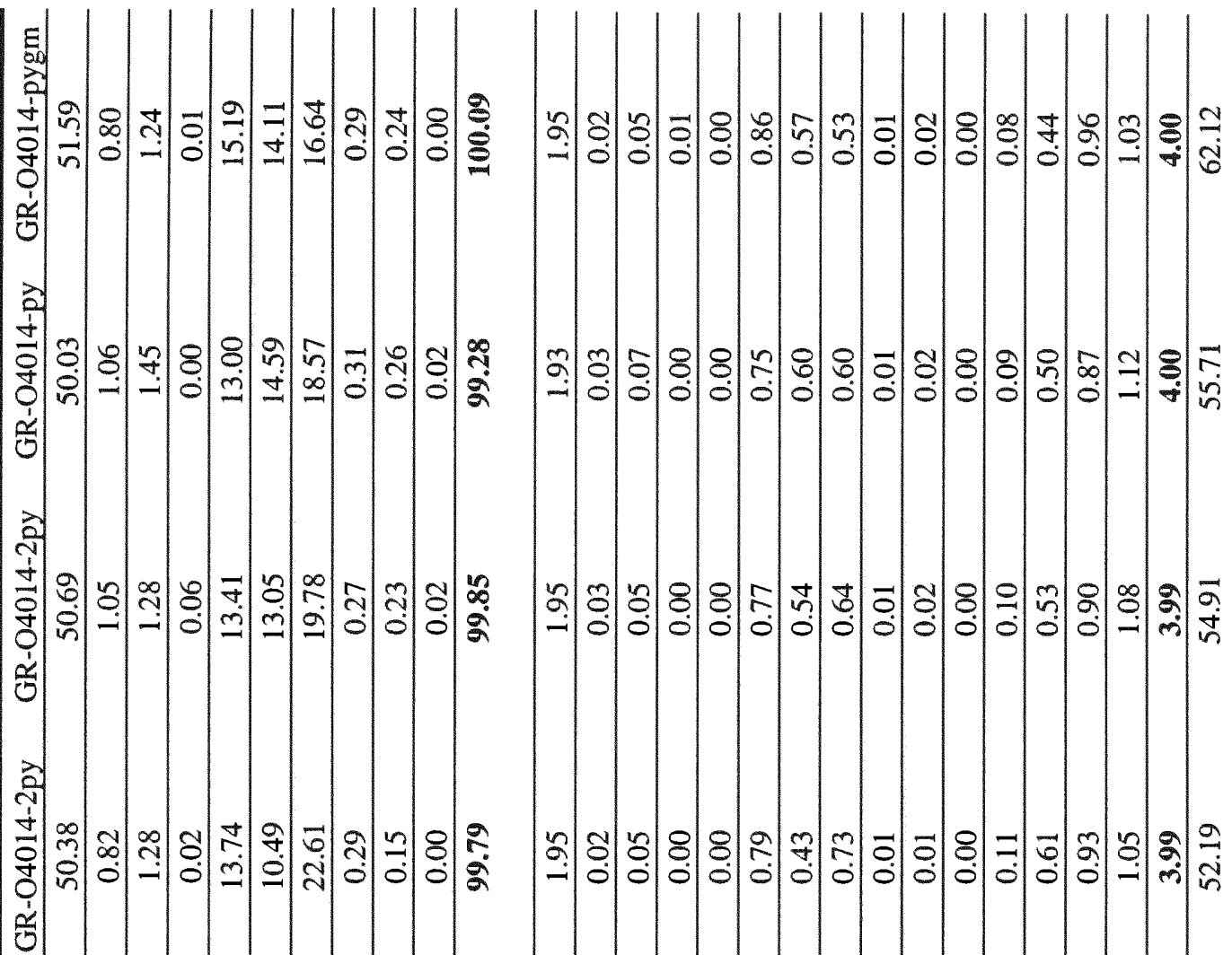

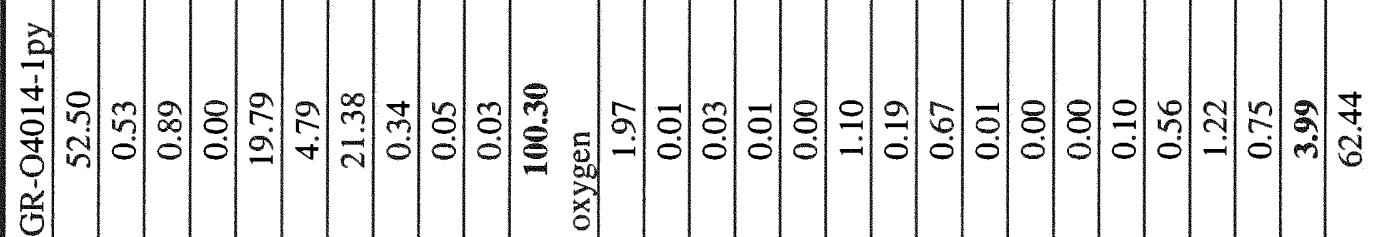



i 3

ఫ.

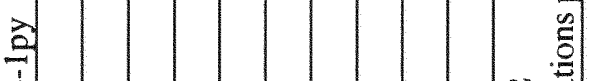

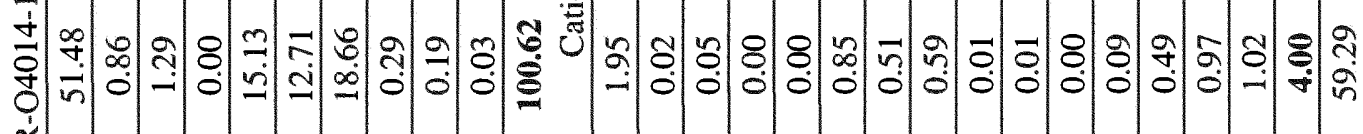

$\frac{\alpha}{0}$

일

西

\&

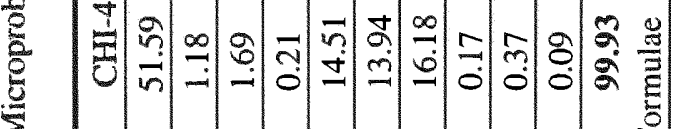

递

을 


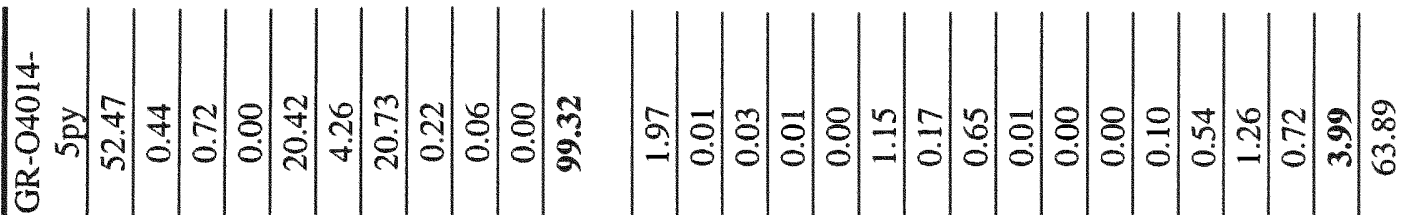

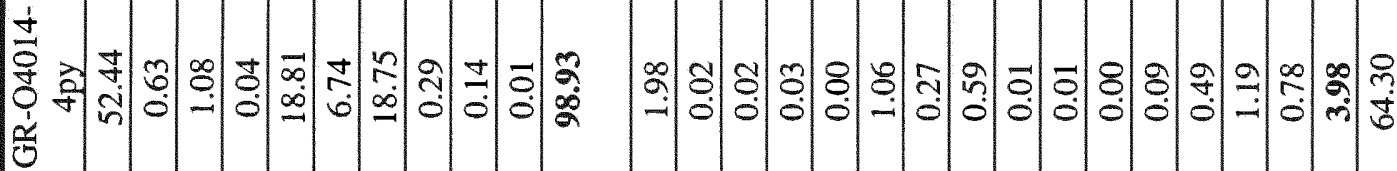

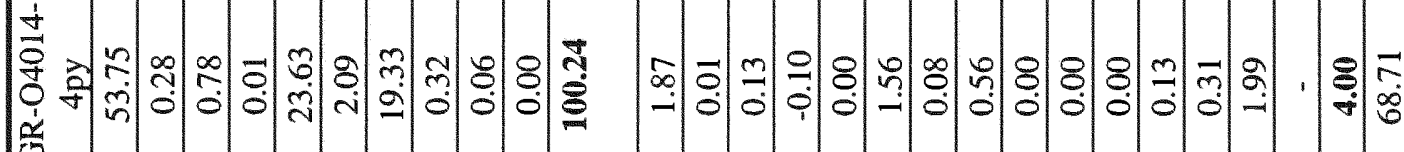

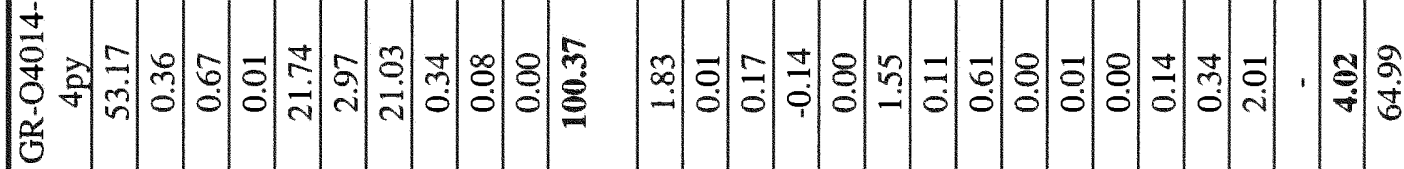

苦各

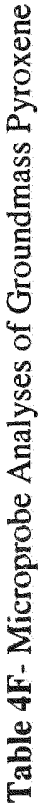
0

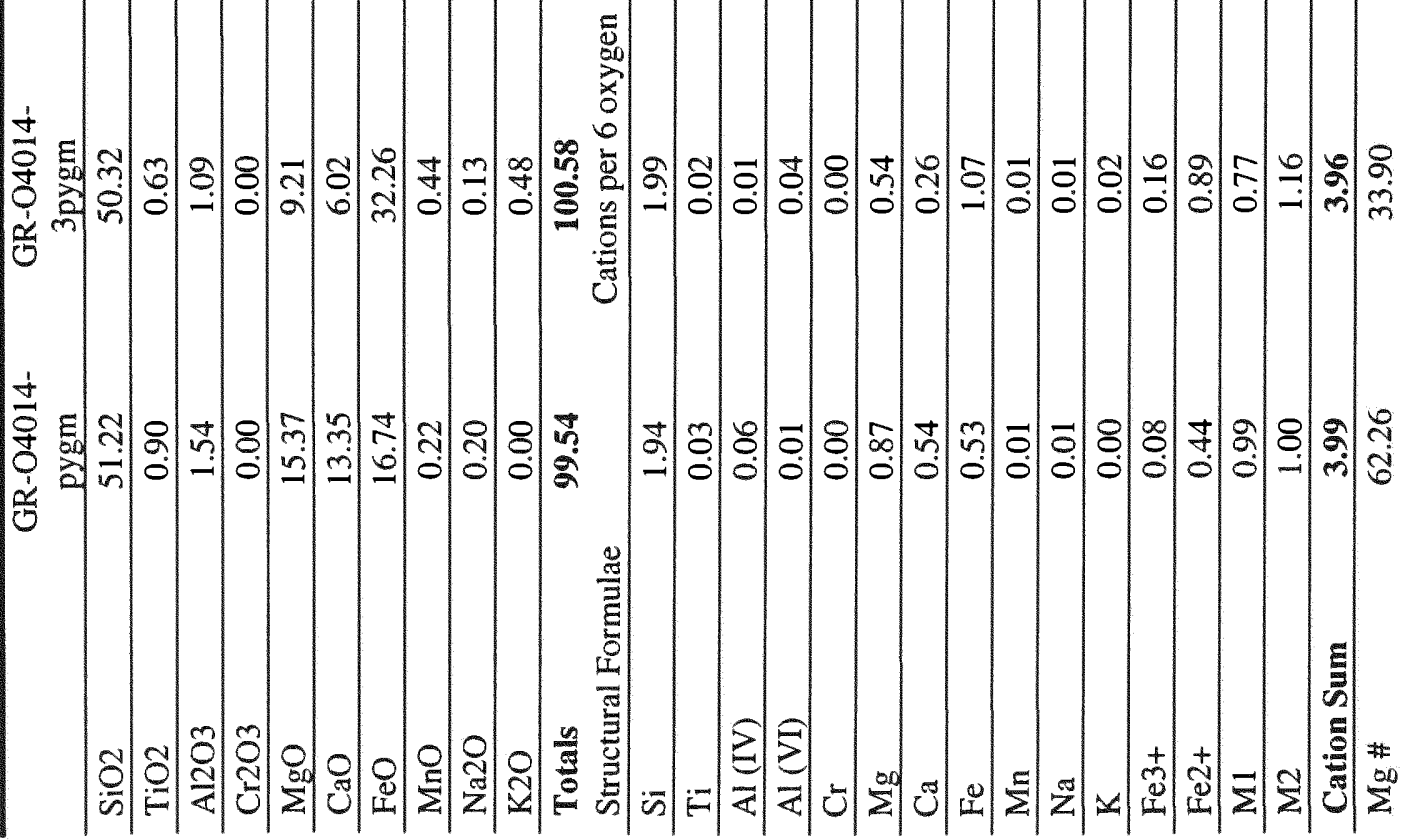




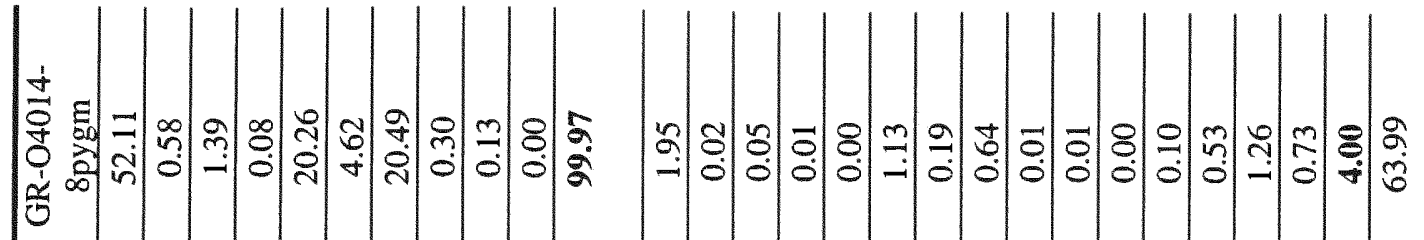

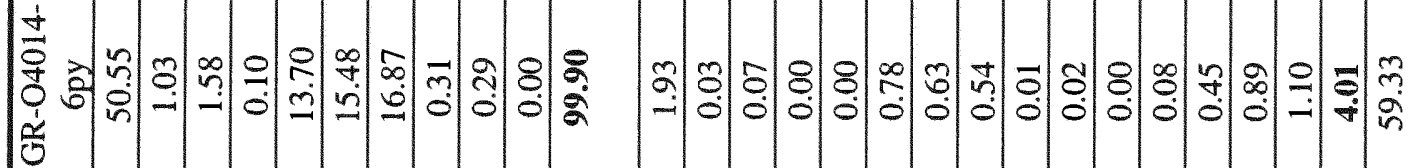

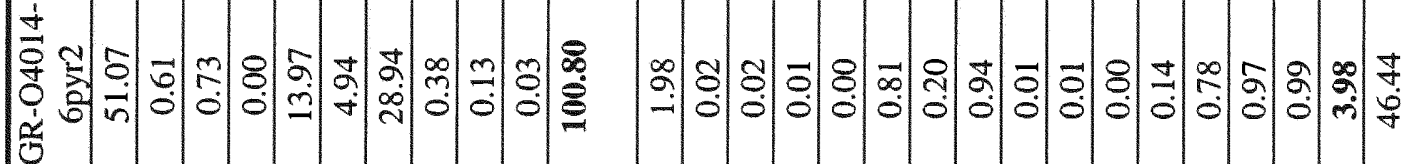

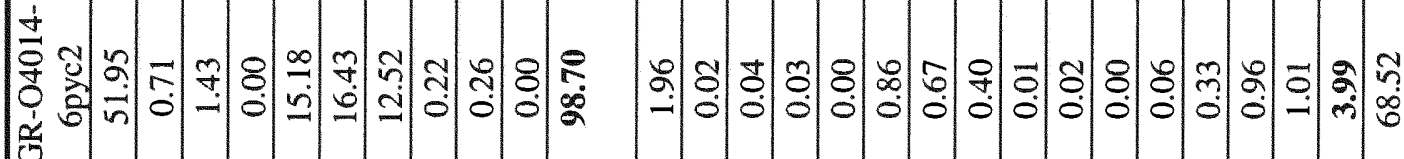

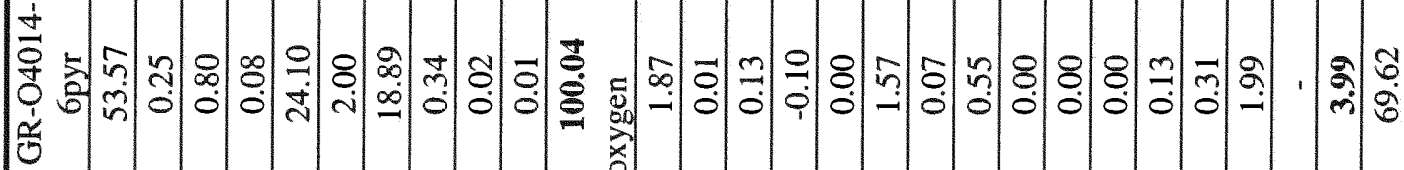

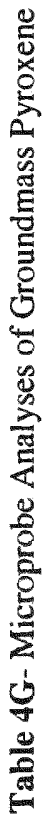

$\sum^{2}$

$\pm \sim 20$.

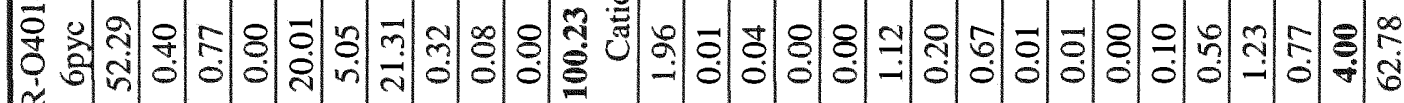
苗

品

亭 迨

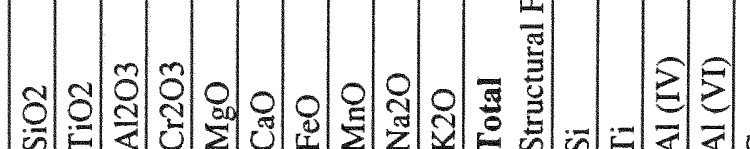

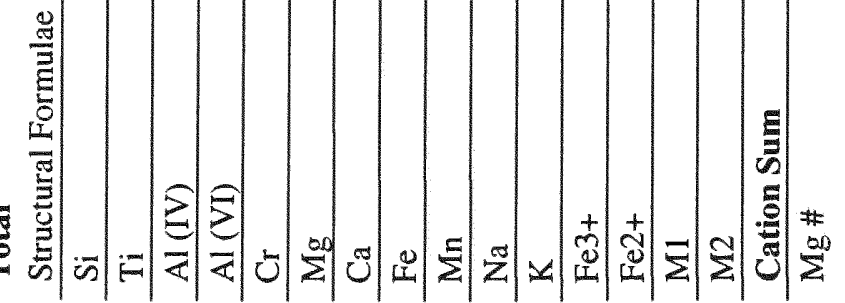




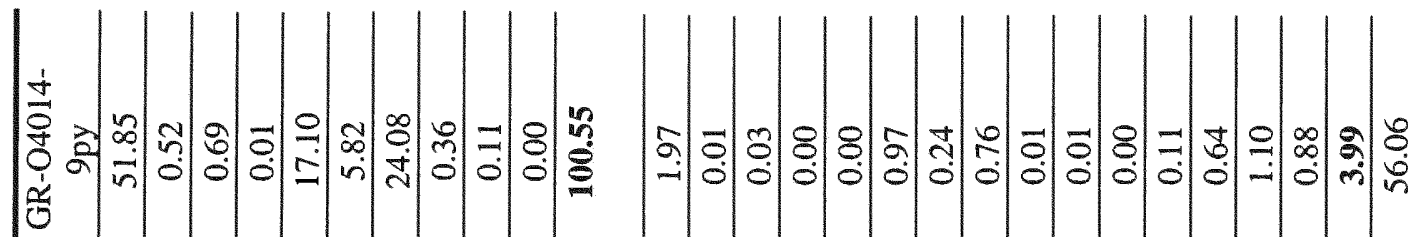

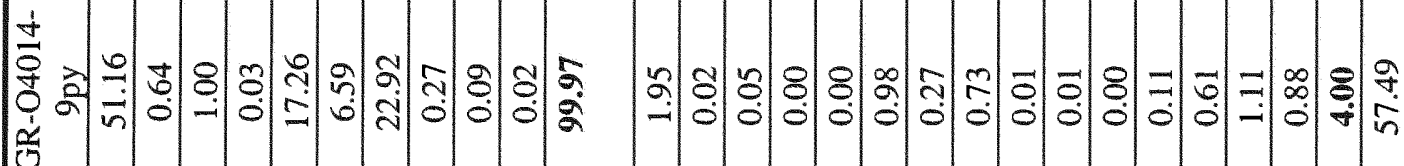

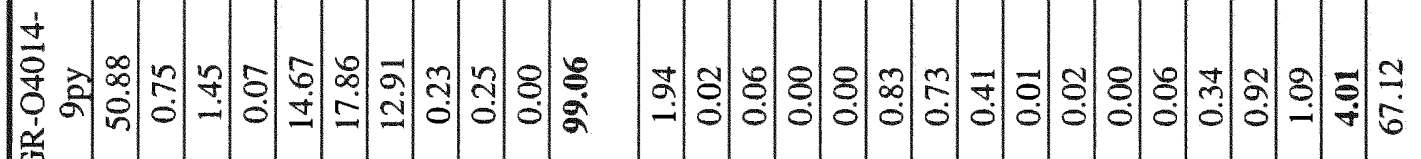
这

吉寺 柋

至

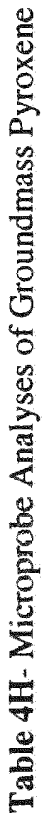
柋

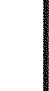

至

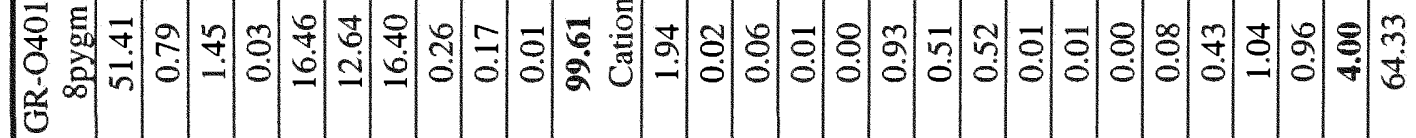

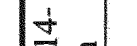

卉姜

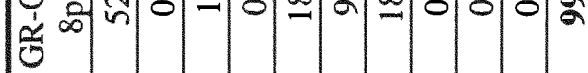
ชิ ह

్ㅗㅀำ

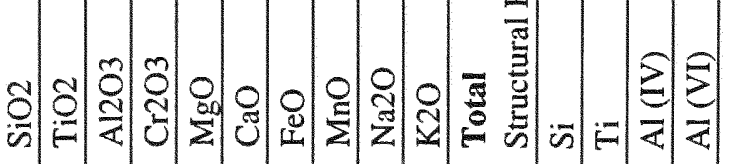

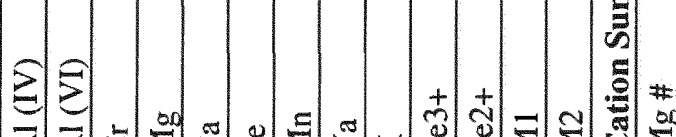




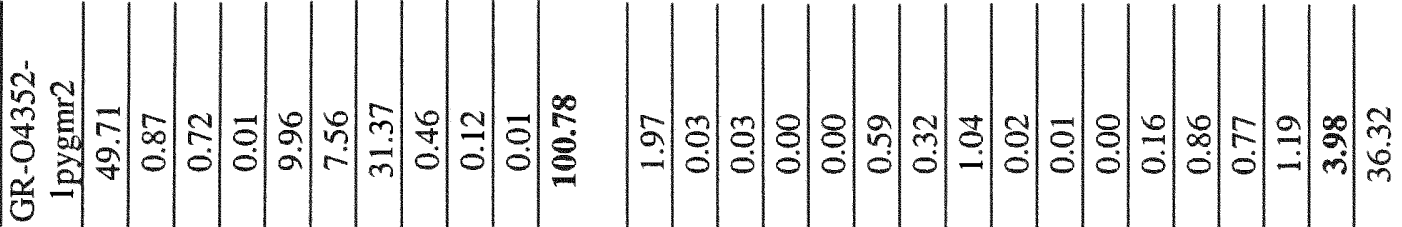

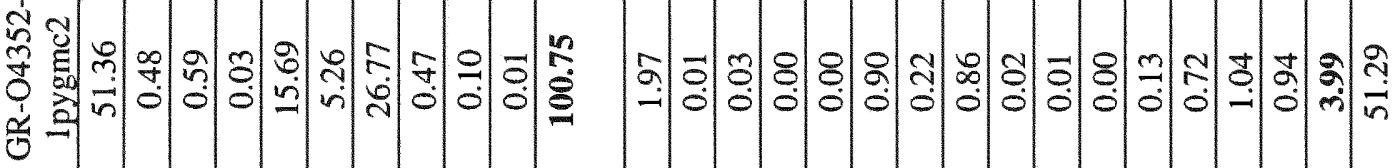

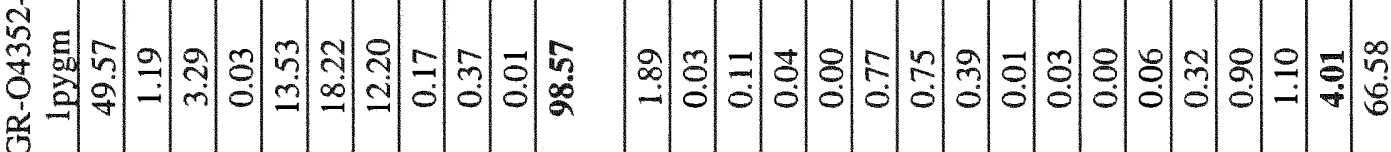
\%

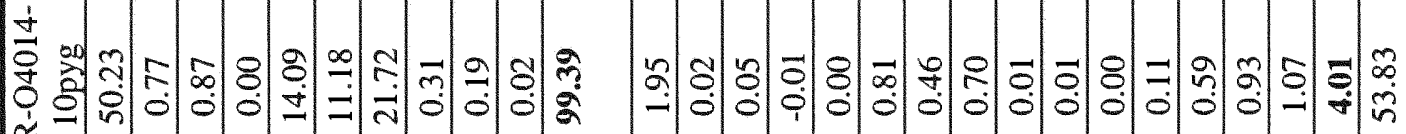
通

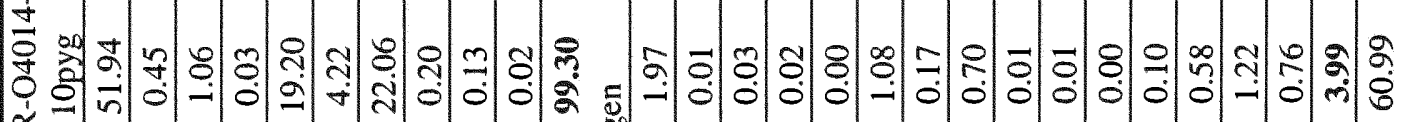

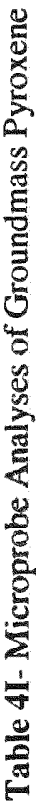
용

$+\frac{1}{4}$

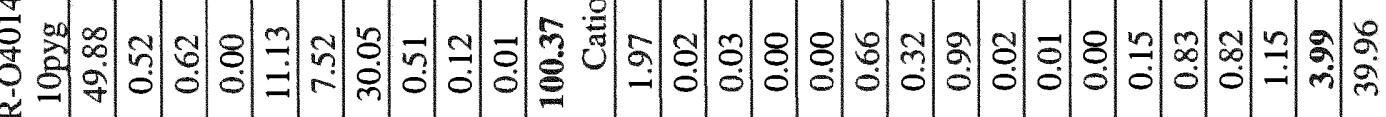
중

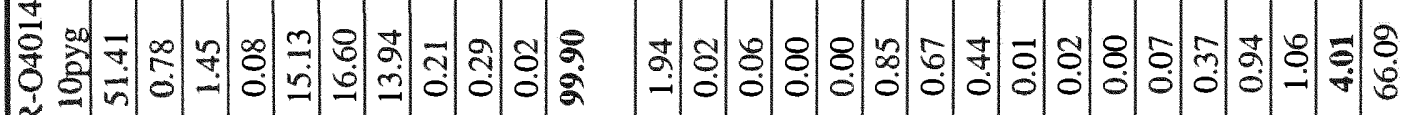
읭

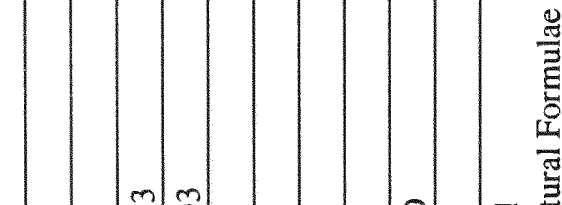

:

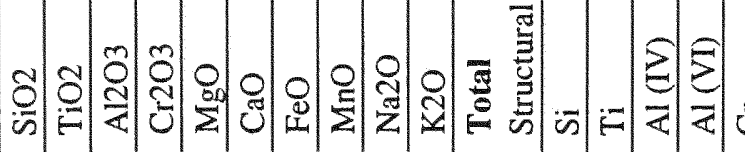




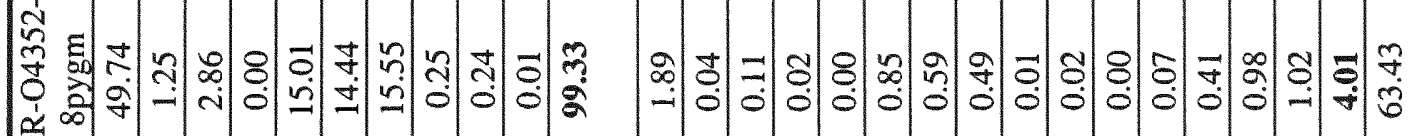
10

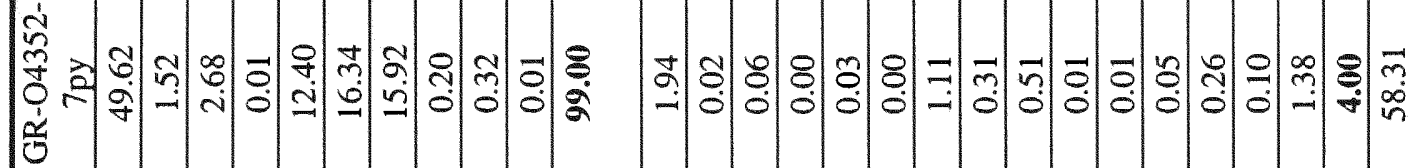

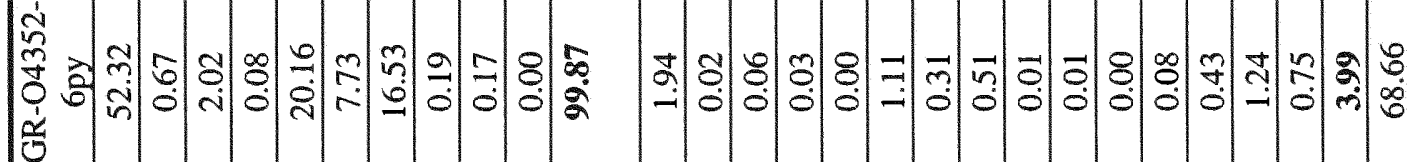

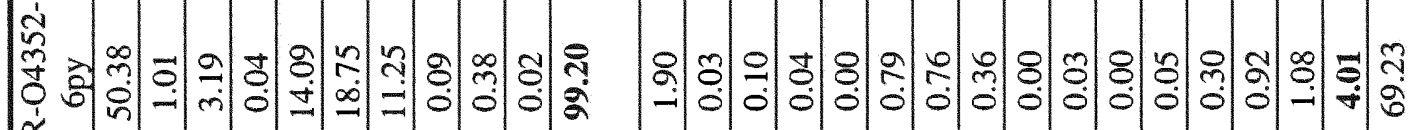
$\frac{1}{0}$

ก่

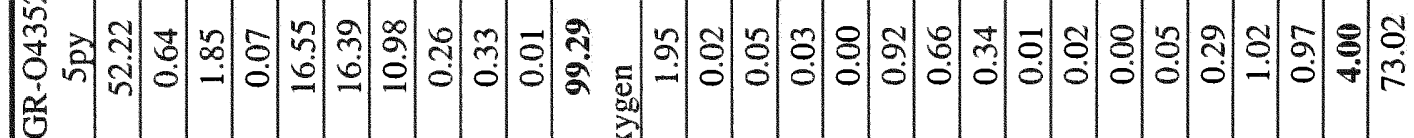

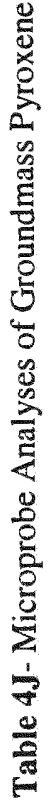
.

弪

品 $\frac{1}{5}$

ป่

学 㭊司至

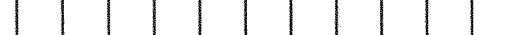

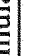

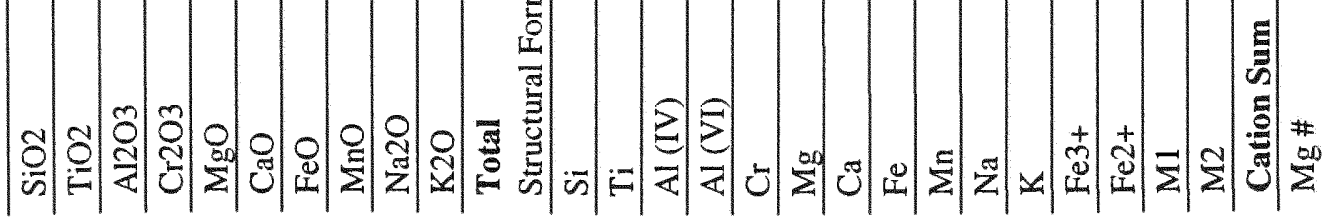




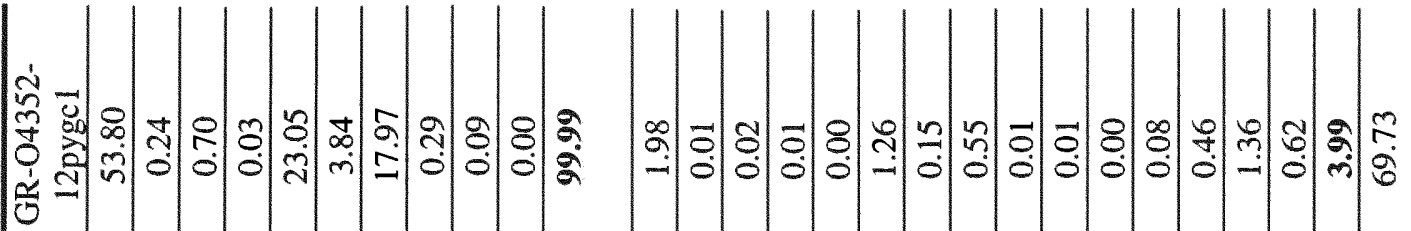

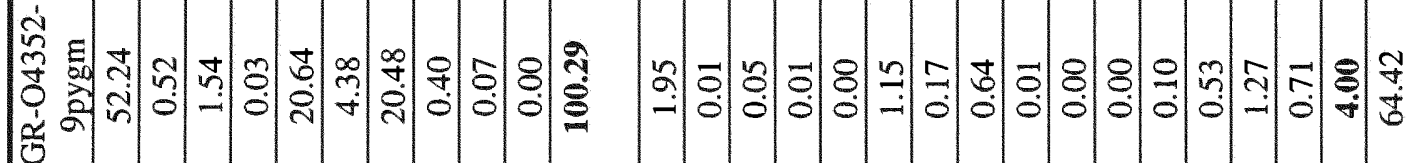

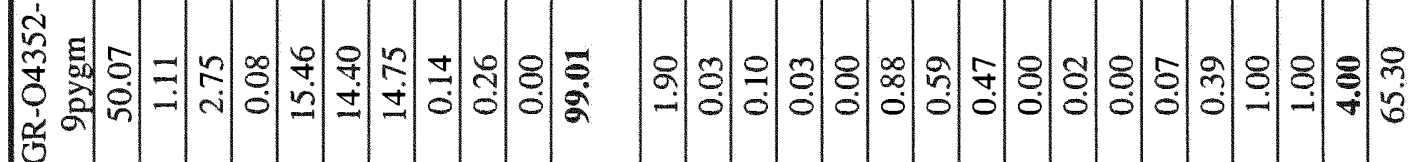

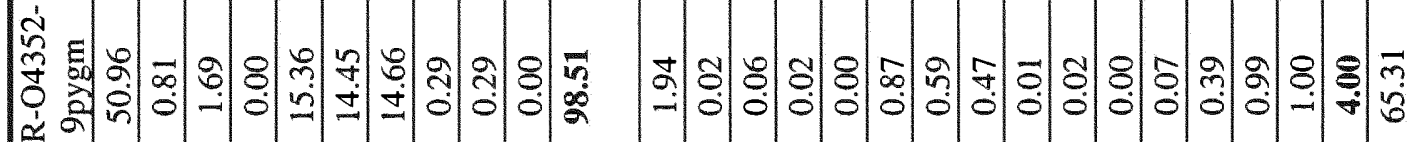
药

ก่

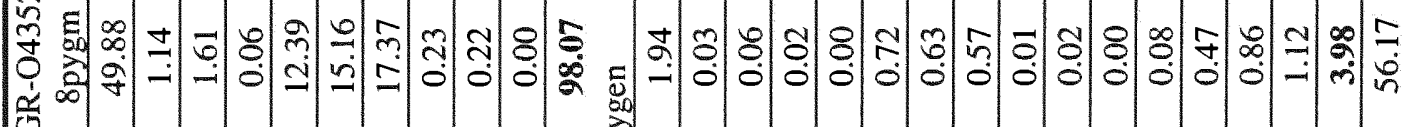
 䒽

告

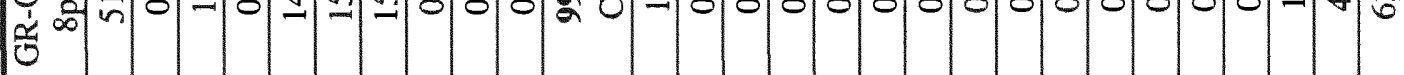

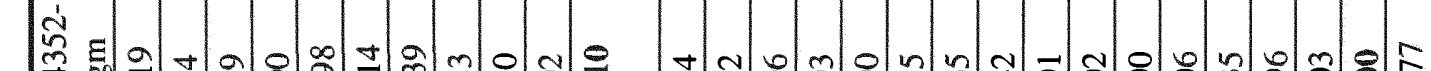
莳 0

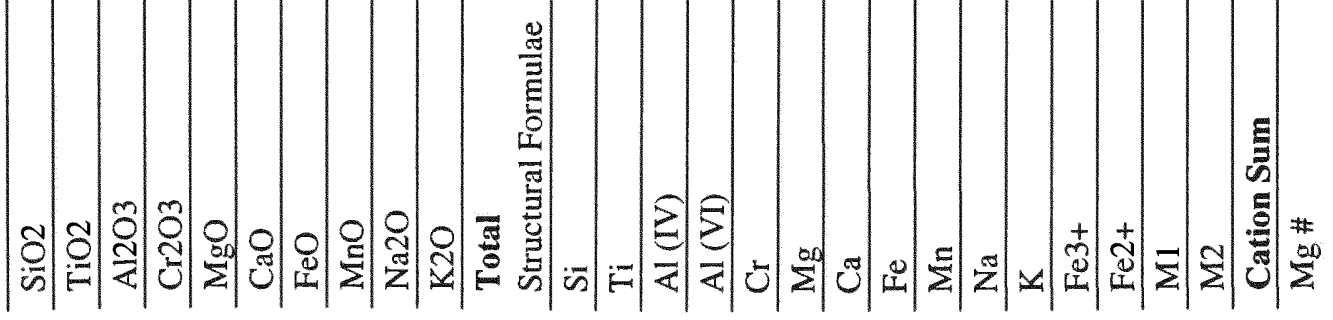




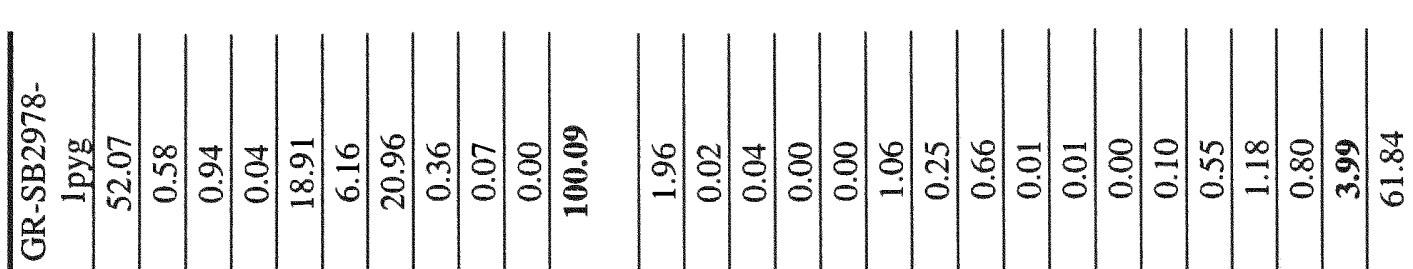

$\infty$

望当 通

$\infty$

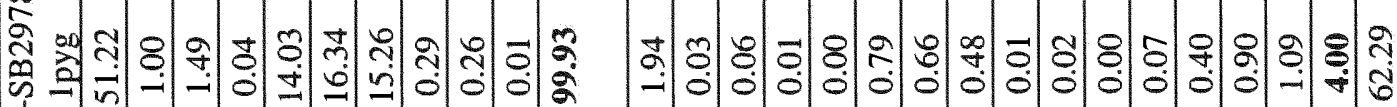
通

$\infty$

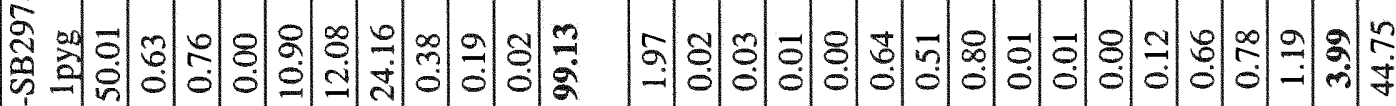
중

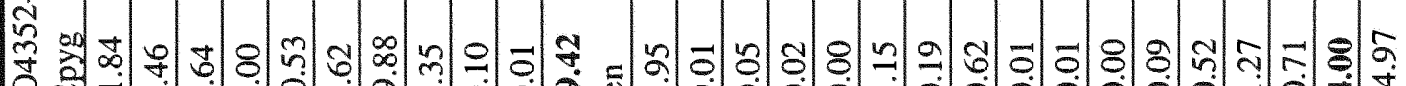
嵌 产

त่

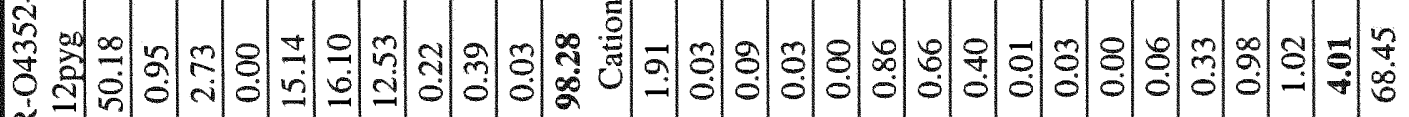
눙

ن่

然 不 


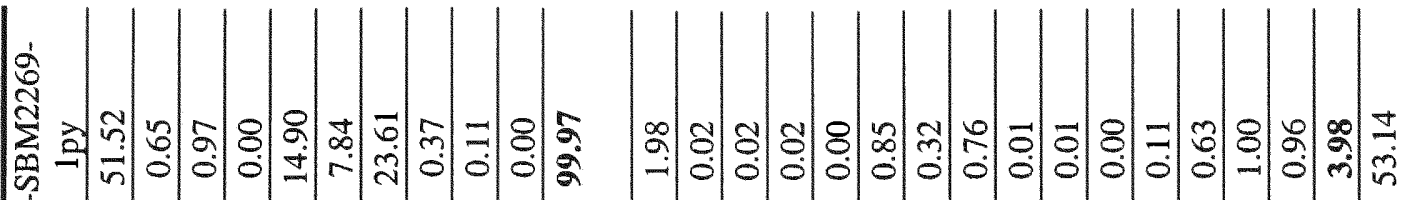
递

$\infty$

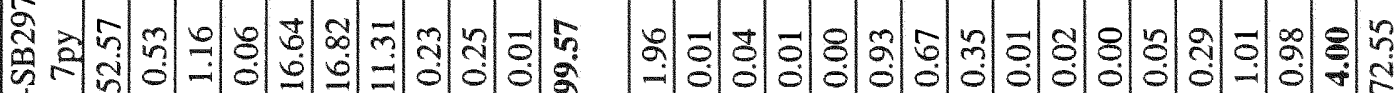
웡

总 견 过

年 递

$\infty$

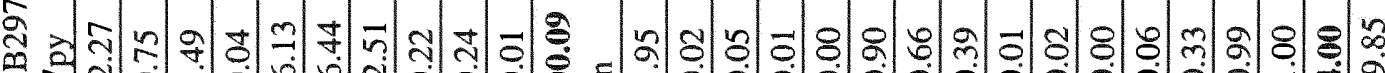
क्षि 상

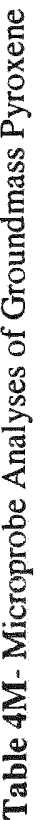
过

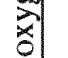

(a)

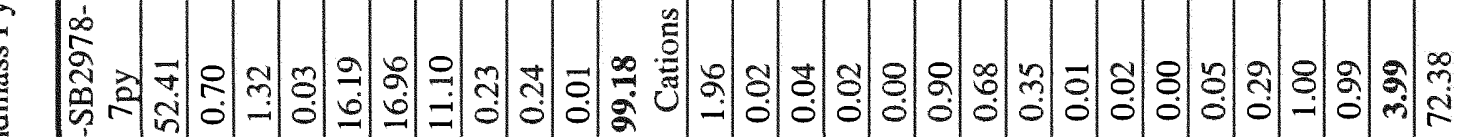
웡

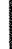

$\infty$

拴 운

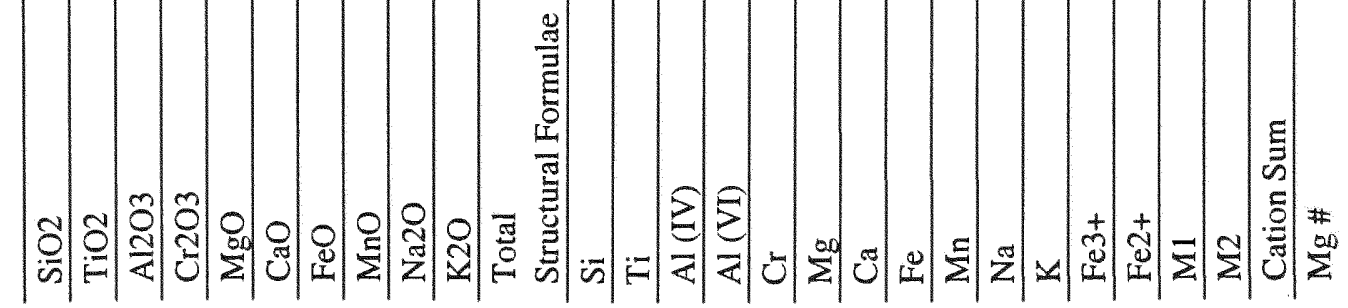




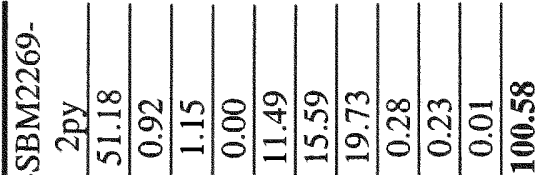
10

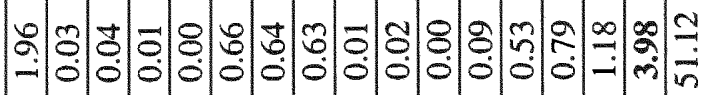

8่

芯 迨

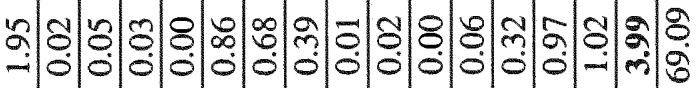

哰

苑 궈 $\frac{\alpha}{0}$

ó

结 नो $\frac{1}{0}$

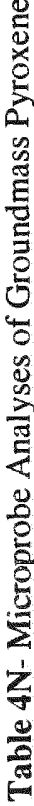

g่

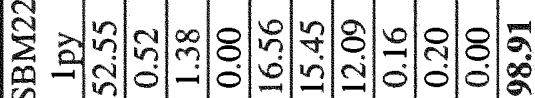
$\frac{\dot{1}}{0}$

ภ́

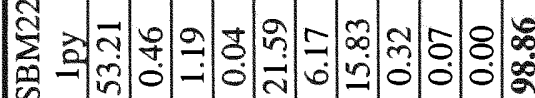
$\frac{1}{0}$

ó

ริ

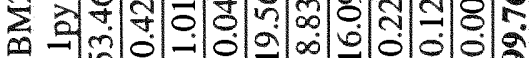
$\frac{\dot{\alpha}}{0}$ 舫

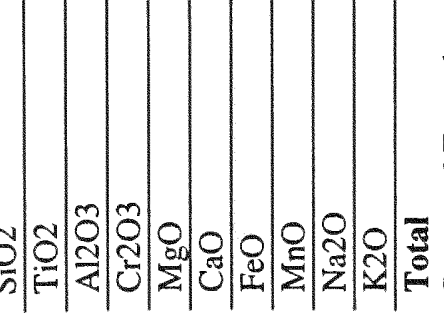

穴

ఏ人

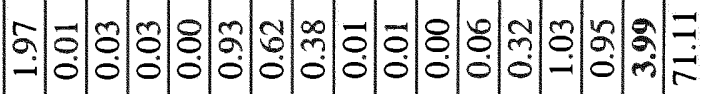

穴

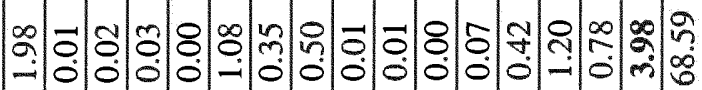
: ชิ $\frac{5}{\square}$

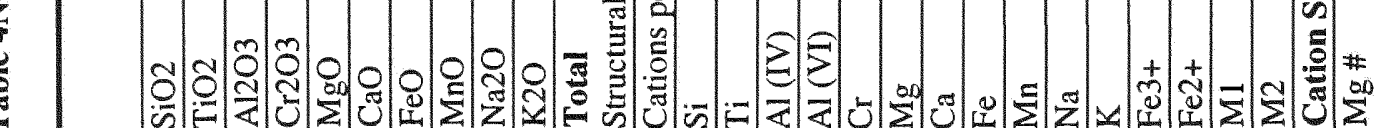

초ำ 
ภิ

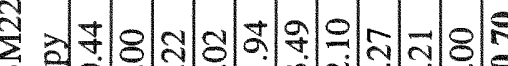
की मी:

通

इ

ถ่ํำ

구일 원

ᄋ́

范 各 运

ช่

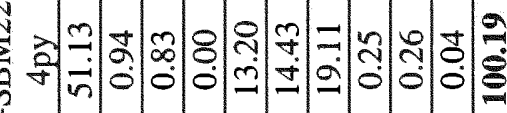
逭

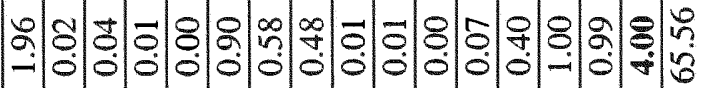

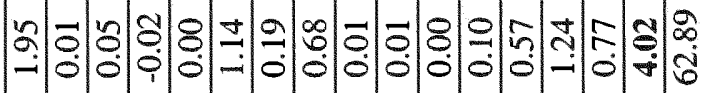

ف่ 药

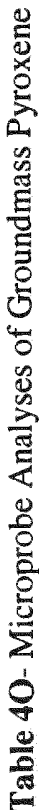
峁

울

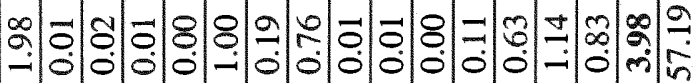

ช่

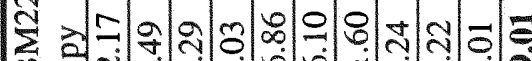
क्षि ती $\frac{2}{0}$

얼

8ิ

สㄴ.

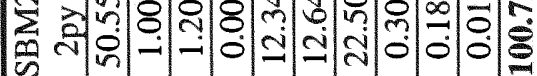
药

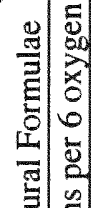

舟 $\Rightarrow$ 


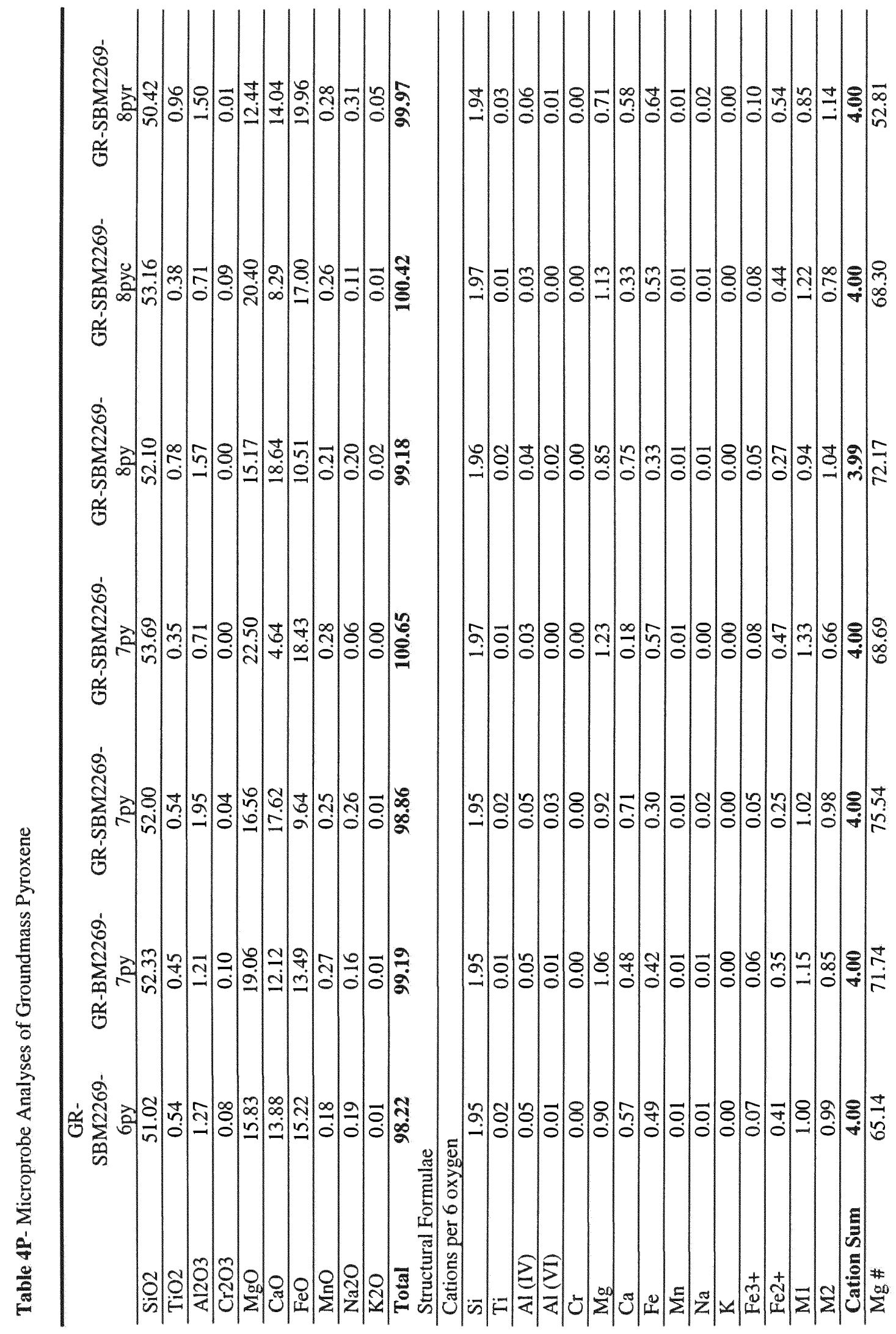




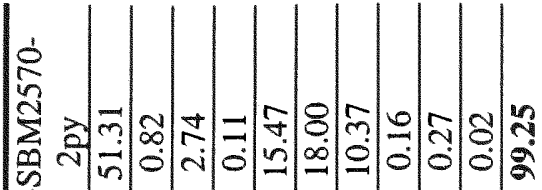

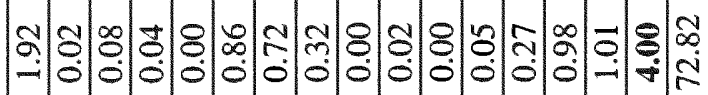

$\frac{\alpha}{0}$

s

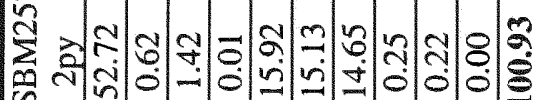

品

$\mathcal{O}$

8

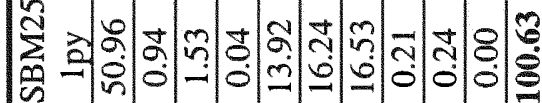

$\frac{2}{0}$

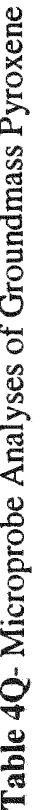

항

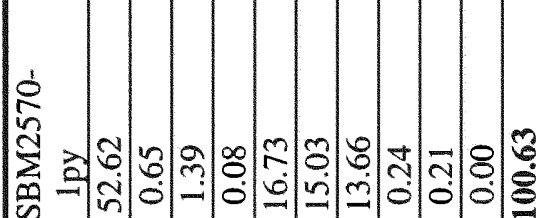
$\frac{\dot{a}}{0}$

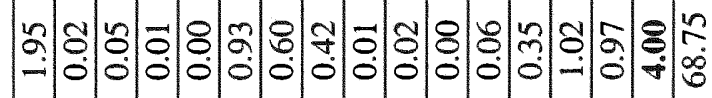

2.

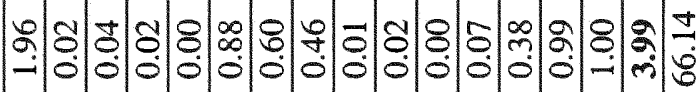

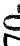
药

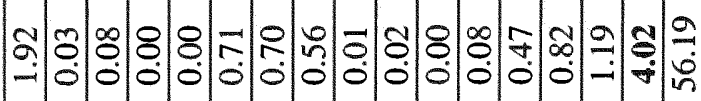

$\frac{\alpha}{0}$

政

政

ง̂n

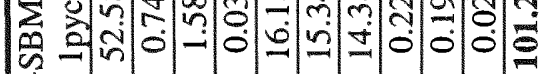

次 告

证

胥

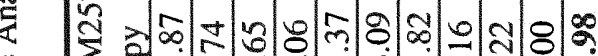

会

ㄴ.

웝

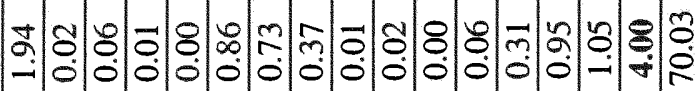

on

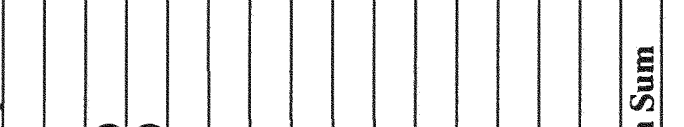

音 


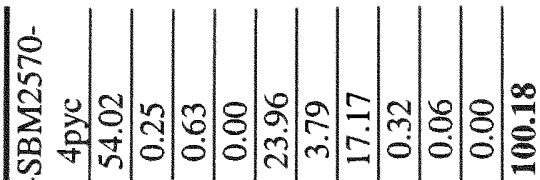

号

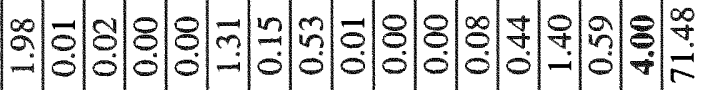

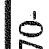

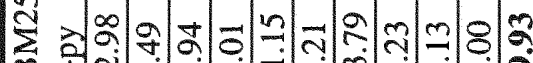
क में 范

舟

$\stackrel{8}{\check{2}}$

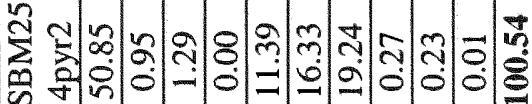
啘

空

ริ่

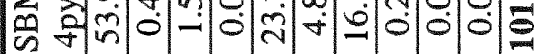
品

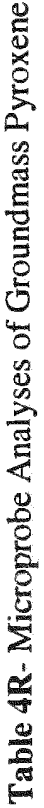
0

8

สิ

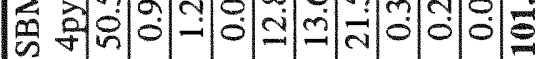

穴

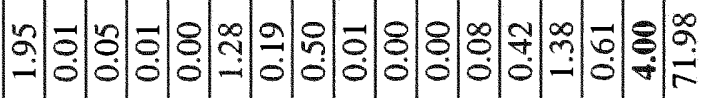

每

용

这

ปี

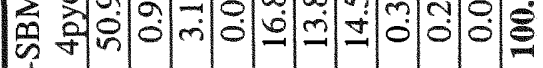

全 告

o

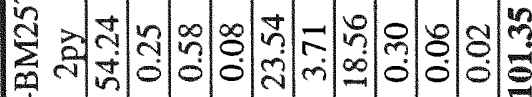
$\frac{\dot{m}}{0}$

5. .

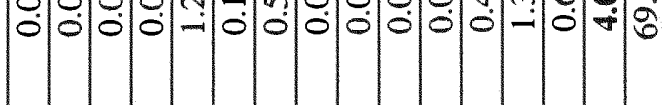

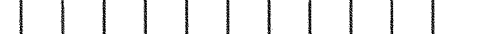


|

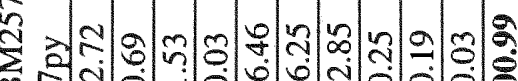
की 品

이리

官

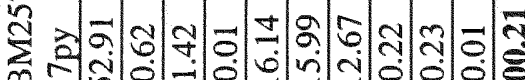
$\stackrel{10}{0}$

ஓ 손 $\rightarrow \infty$ 药 옹

尺े

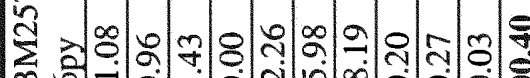
宩 응

\&

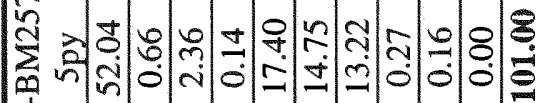

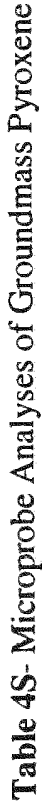
ํํㄴ

官

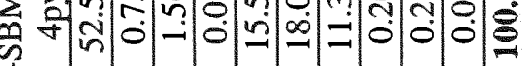
$\frac{1}{0}$

웅

留 范

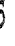

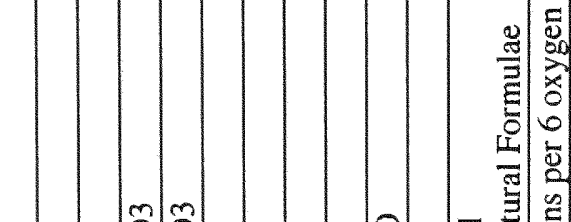

엇

ऽ

そ)

๙

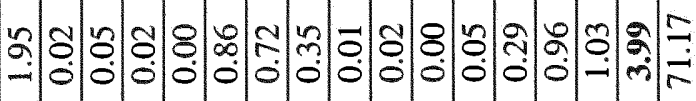

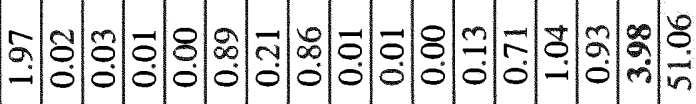

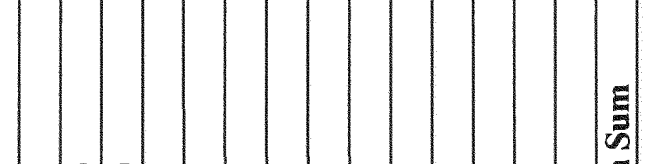

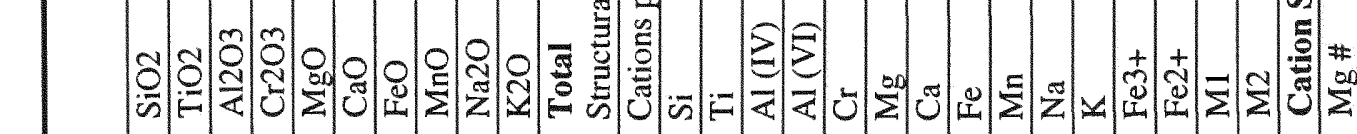




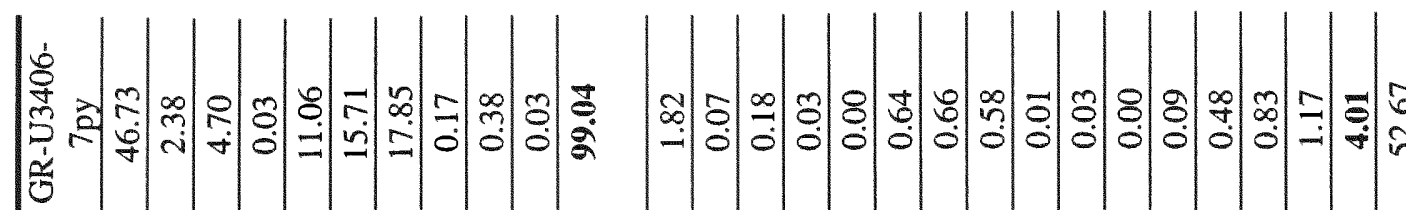

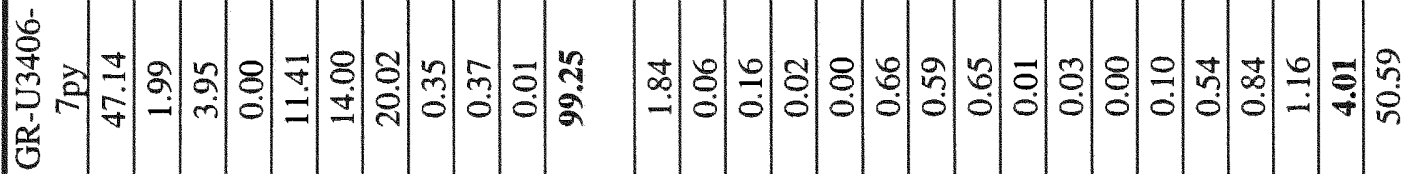

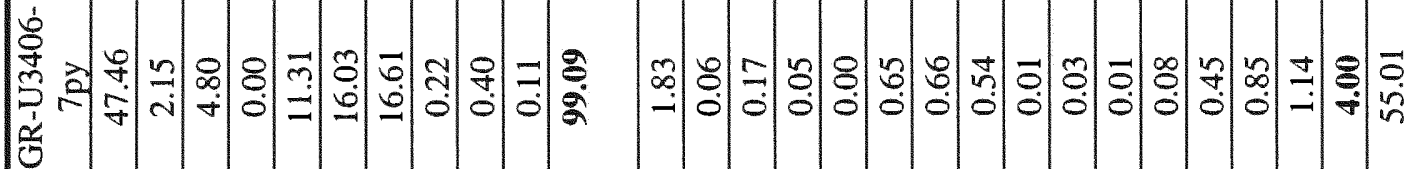

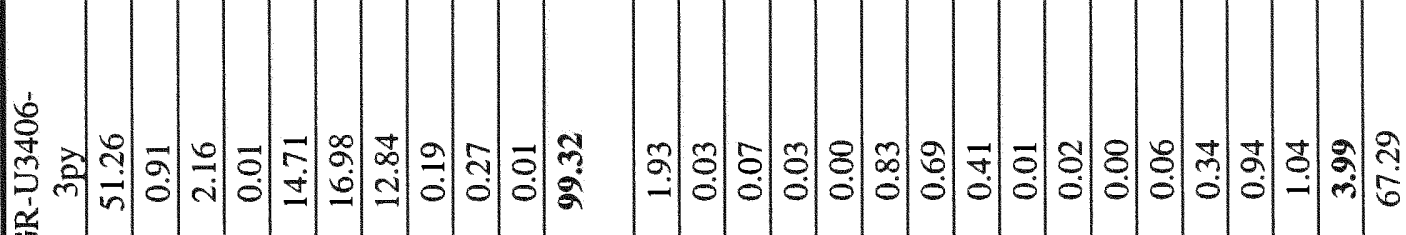
$\frac{\alpha}{5}$

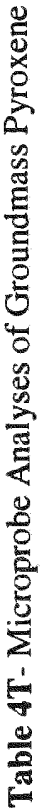

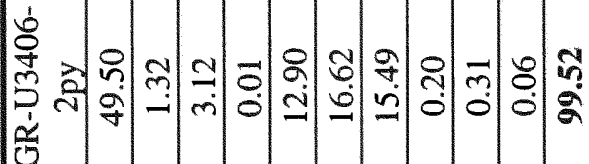

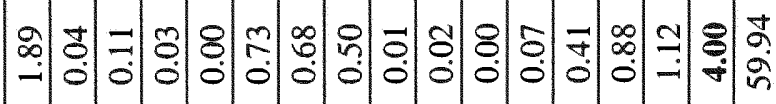

ڤ

官

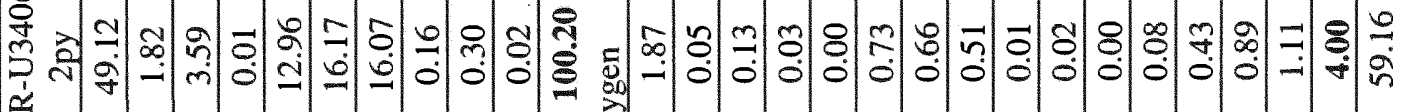
응

告 残 $\frac{\alpha}{0}$

o

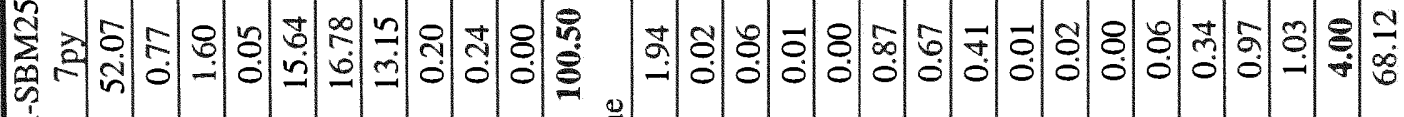
$\frac{1}{5}$ $\frac{\frac{9}{3}}{3}$

인

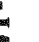

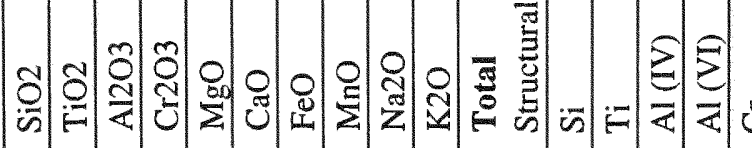




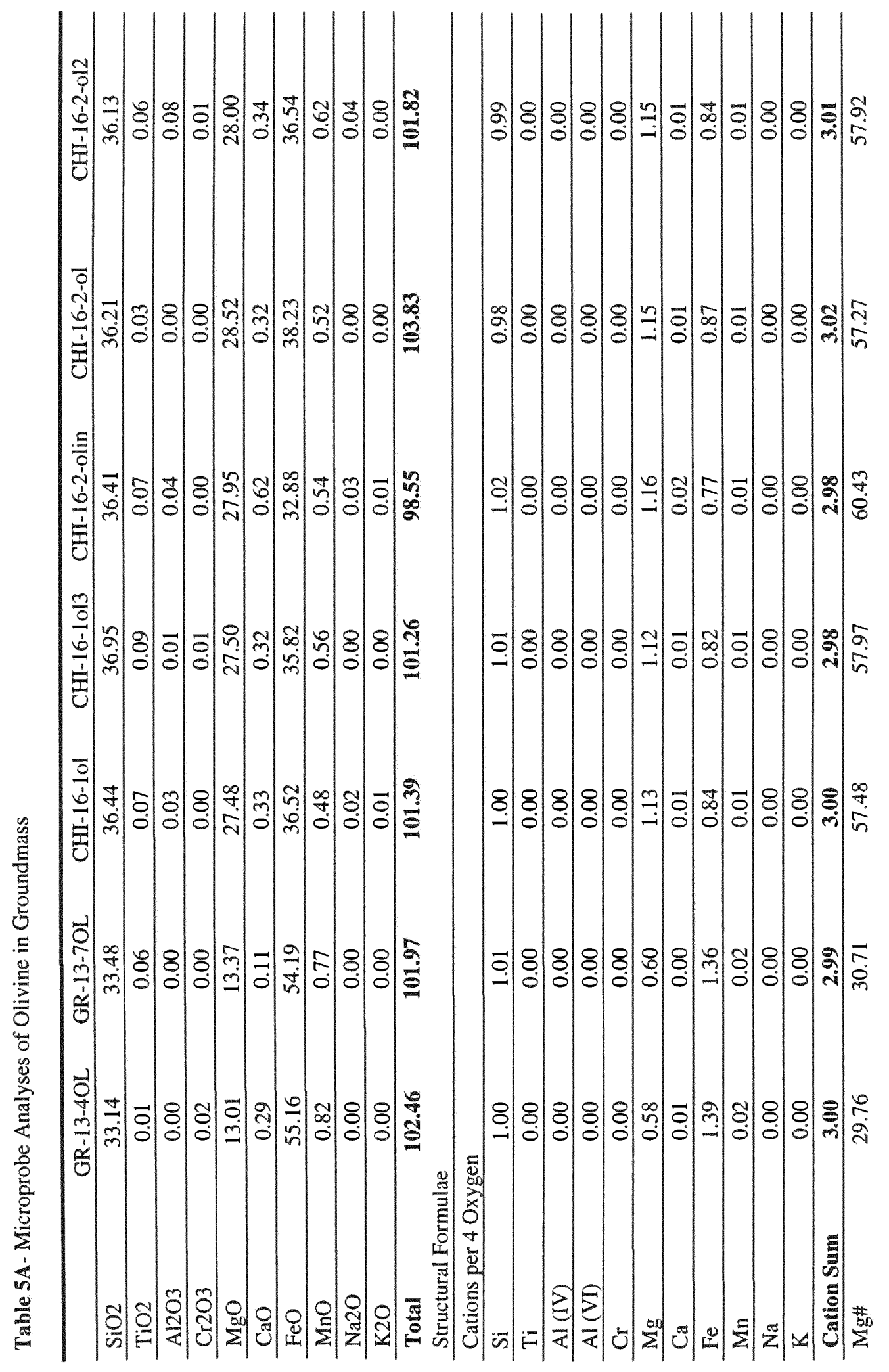




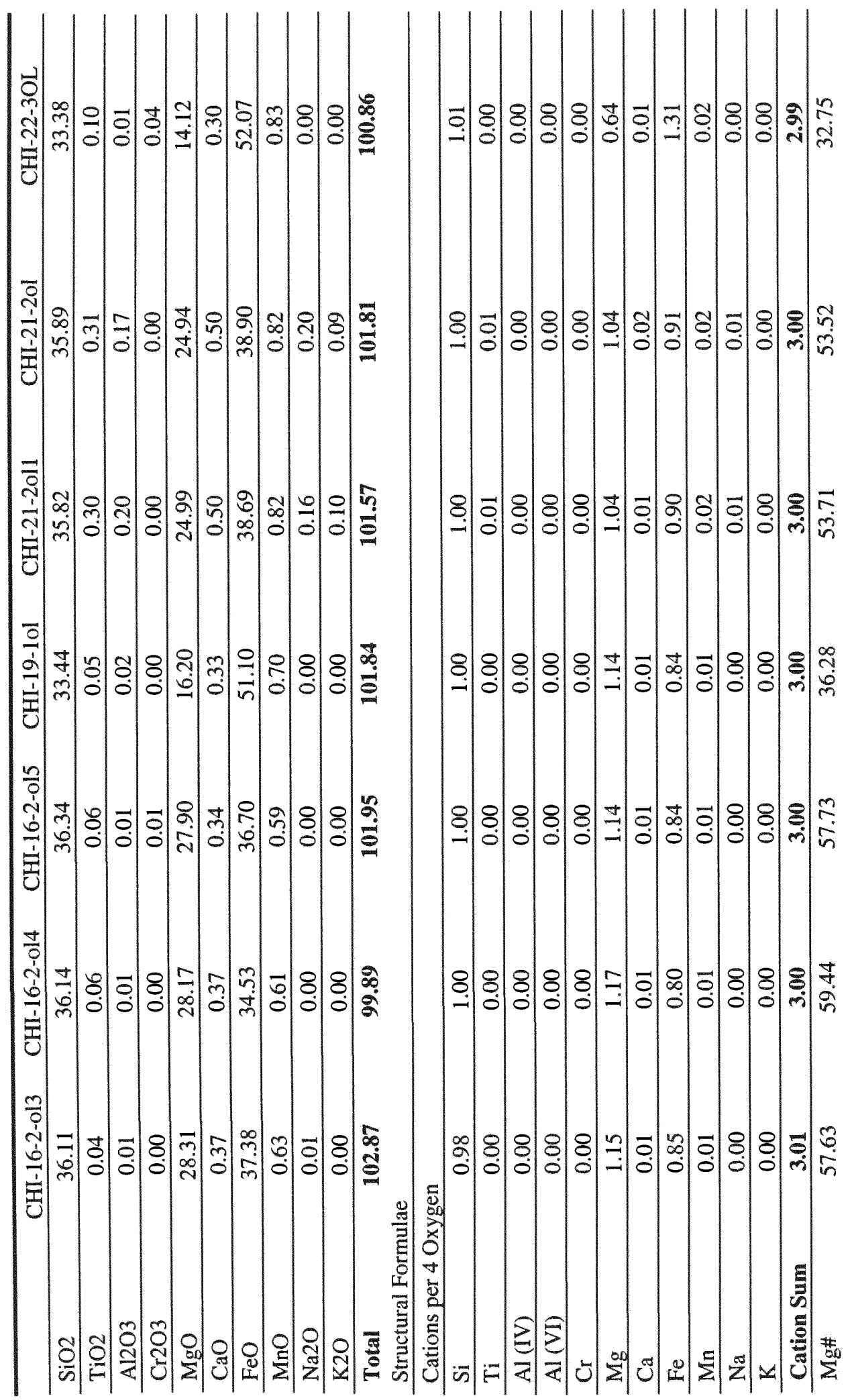




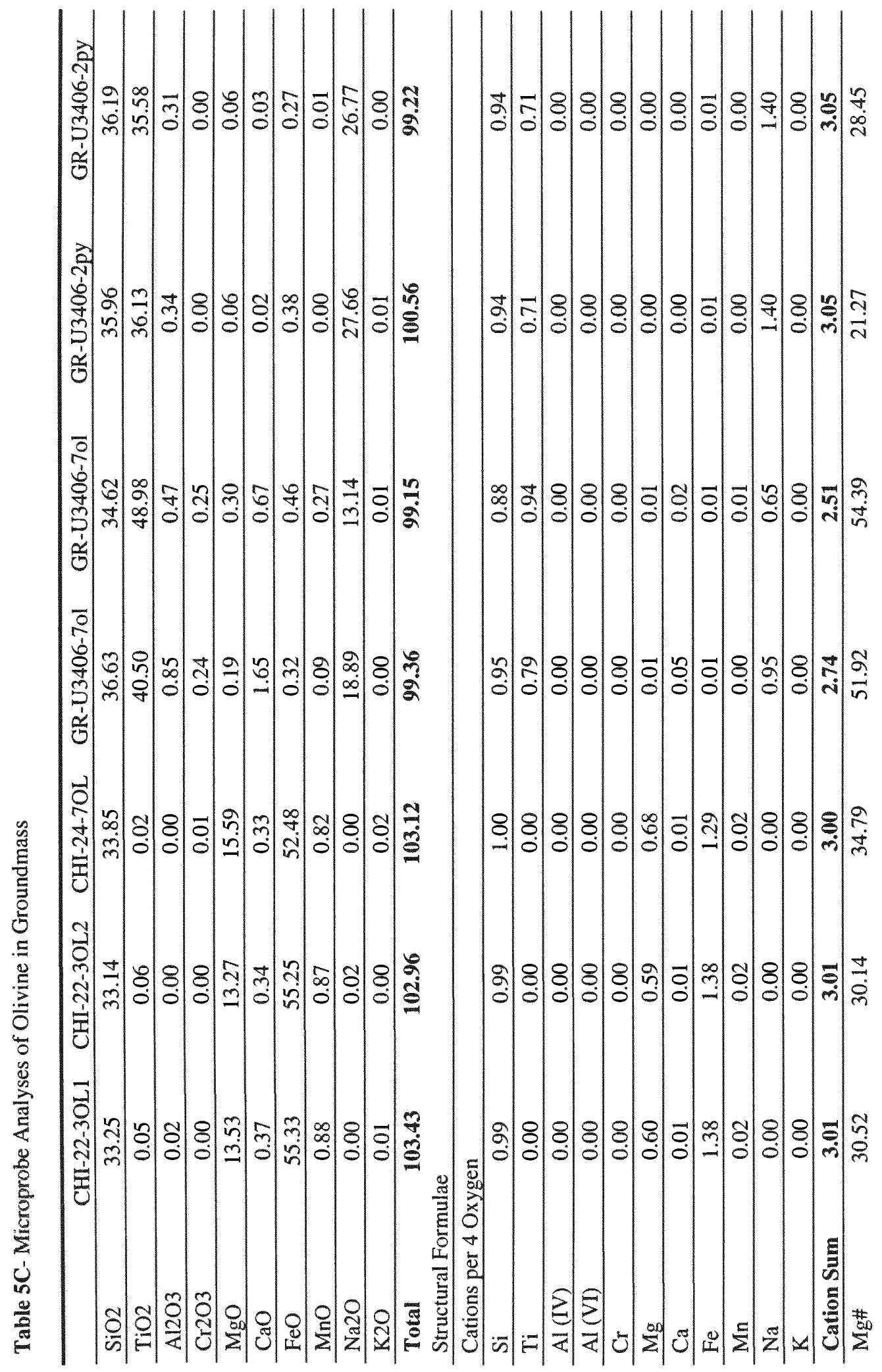




\section{CHAPTER 4.}

\section{MODELING OF MELTING CONDITIONS}

\section{Introduction}

Most geologists consider all large igneous provinces (LIPs) to have a similar mode of origin no matter what the ages, volumes or petrologic characteristics. As pointed out earlier (Chapter 1), the most popular hypothesis has been LIP magma generation by melting of large plume "heads" that rise from the deep mantle, perhaps the D" layer. In such models, the "tail" of a plume persists for millions of years and generates volcanic chains on a moving plate (Richards et al. 1989). However, LIPs differ substantially in age, location, and geochemistry.

The CRBG (particularly, GRB) is different from other LIPs, such as the Deccan Traps (e.g., Hooper, 1997) and from active hot spot basalts e.g. Iceland and Hawaii in terms of all major oxides except $\mathrm{SiO}_{2}$ (Figure 32). From this, one could argue that GRB lavas were derived in some manner that differed from these other provinces. Is this difference attributable to varying source compositions, melting conditions (temperature, pressure, volatile abundance), or ascent paths (i.e., crystallization, crustal contamination, and magma mixing, isobaric vs. polybaric evolution etc.)? These questions can only be answered by modeling of the formation and ascent histories of individual provinces. In this chapter I use geochemical modeling techniques to illustrate the origin of GRB magmas; a comparative analysis with other LIPs will be a future endeavor. 


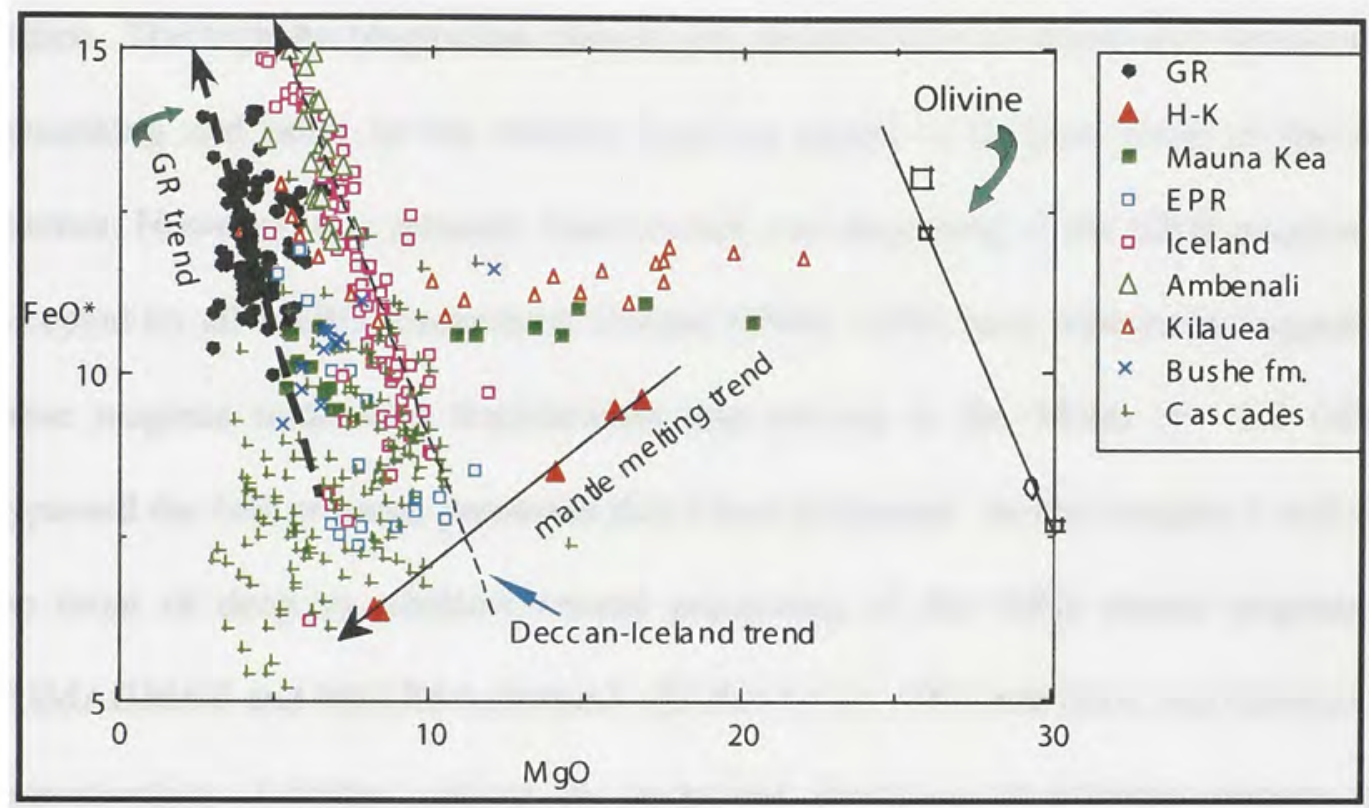

Figure 32- Plot showing how different GRB lavas are from other LIPs and presently active hot spots or plume basalts such as Iceland, Deccan (Ambenali Fm.), and Hawaii in terms of the major oxides, FeO and $\mathrm{MgO}$. Data obtained from the GEOROC database (http://georoc.mpch-mainz.gwdg.de/georoc/). 
In Chapters 2 and 3, based on phenocryst assemblages, textural features, and projected phase compositions on pseudoternary phase diagrams, I concluded that GRB lava was processed in shallow crustal magma chambers. Low-pressure fractionation, magma mixing and mingling, and degassing processes have obliterated the geochemical and physical characteristics that the magma batches inherited from their mantle source region. The high-An plagioclase phenocrysts seem to have survived such intense shallow processing and point to the initially hydrous nature of at least some of the magma batches. However, low pressure fractionation and degassing of the GRB magmas is not accepted by all CRBG researchers, Hooper $(1984,1988)$ have repeatedly suggested that these magmas underwent fractionation and mixing at the Moho ( $\mathrm{P} \sim 1.2 \mathrm{GPa})$ and bypassed the low pressure processes that I have proposed. In this chapter, I will explore the issue of deep vs. shallow crustal processing of the GRB parent magmas using COMAGMAT and MELTS softwares (Ariskin et al., 1993 and Sack and Ghiorso, 1994, respectively). I further extend the numerical modeling to estimate primary magma compositions and their formation conditions (i.e., $\mathrm{P}, \mathrm{T}$, and $\mathrm{XH} 2 \mathrm{O}$ ), and to evaluate the nature of the source rocks (peridotite and/or eclogite).

In this study, I use the terms "primary" magma, "primitive" magma and "parental" magma in the same sense as detailed in Basaltic Volcanism on Terrestrial Planets (BVTP, 1981). A primary magma is one that has equilibrated with the source rock, whether it is a peridotite or an eclogite. It is often thought that tiny fractions of partial melt are generated within the source materials (peridotite, eclogite) over a wide volume (i.e., P-T space), and that these melts accumulate into larger bodies that equilibrate with the upper mantle before ascending toward the crust. I consider the 
accumulated melt volume that equilibrated last with the source mantle volume to be primary magma, although every tiny fraction of melt that contributed to it can also be primary magma. In a suite of genetically related lavas, the one with the highest $\mathrm{Mg} /\left[\mathrm{Mg}+\mathrm{Fe}^{*}\right]$ ratio is considered to be the parental or primitive magma because the idea is that such a magma could differentiate in conduits and generate the other less magnesian lavas. A primitive magma, on the other hand, is any lava with a fairly high $\mathrm{Mg} /\left[\mathrm{Mg}+\mathrm{Fe}^{*}\right]$. Thus, a primary magma is both primitive and parental to a suite of lavas, but the inverse is not necessarily true.

\section{Geochemical Modeling}

\section{Forward and Inverse Modeling of Major Elements}

I carried out both forward and inverse modeling to answer some of the questions outlined above. In inverse modeling, the usual approach is to start with the most magnesian lava (preferably aphyric, because only aphyric or glassy lavas are closest approximations of liquids) in a cogenetic suite of lavas and take it as the parent magma composition. Using partition coefficients or multi-saturation concepts (e.g., BVTP 1981, Herzberg and O'Hara 2002; Asimow and Longhi 2004) one can deduce whether such a composition could have equilibrated with a plausible upper mantle source rock. If a convincing case can be made, such a composition may be considered a primary magma. The $\mathrm{P}, \mathrm{T}$, and $\mathrm{X}_{\mathrm{H} 2 \mathrm{O}}$ conditions at which this primary magma is found to be in equilibrium with the source rock(s) are then considered to be the last mantle equilibration conditions of such a magma (Figure 33). 
INVERSE APPROACH (under wet and dry conditions)

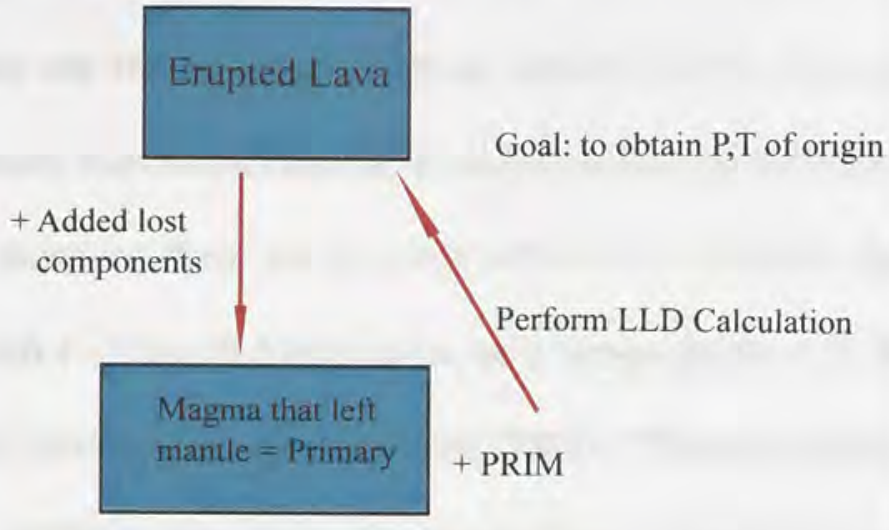

Figure 33- Schematic depicting the Inverse method used to model GRB magma under hydrous and anhydrous conditions at different pressures with a peridotitic starting material.

In reality, however, it is nearly impossible to find a glassy lava with appropriate $\mathrm{MgO}$ required to be in equilibrium with mantle; one rare exception to this is the recent finding by Clague and Moore, (1991) of glass fragments with $15 \% \mathrm{MgO}$ from submarine landslides off Hawaiian shield volcanoes. Such high-MgO glasses could arguably be the best candidates for primary magmas in modern times. More typically, one has to use the most $\mathrm{MgO}$-rich lava and, if possible demonstrate that such lava has not gained its high $\mathrm{MgO}$ by accumulation of olivine phenocrysts, but represents a liquid or near-liquid composition. If this lava has only olivine phenocrysts, then clearly, it has not reached multiphase saturation; and one could argue that such a lava composition can be extrapolated to a mantle-equilibrated primary magma composition by incrementally adding olivine while maintaining appropriate olivine-liquid equilibrium partition coefficient $\left(\mathrm{K}_{\mathrm{d}}=0.3\right.$ for $\mathrm{FeO}, \mathrm{MgO}$ exchange equilibrium between olivine and basaltic melt (Herzberg and O'Hara, 2002). The calculated primary magma must have the right 
composition to be in equilibrium with the upper mantle olivine ( $\left.\mathrm{FO}_{89}{ }^{-92}\right)$. This is the most commonly used approach in inverse modeling (cf. Sen 1994) and it works well for peridotitic source but not for an eclogitic upper mantle simply because eclogites are chemically nothing more than basalts and these compositions can therefore vary greatly.

In the GRB, however, there are no lavas with $15 \mathrm{wt} . \% \mathrm{MgO}$, nor are there any lava magnesian enough $(\sim 8 \mathrm{wt} . \% \mathrm{MgO})$ to be only olivine-phyric. In fact, these lavas are all ol+aug+pig+pl saturated (Durand and Sen, 2004). Thus, one must employ a step beyond the olivine addition calculation for the inverse approach to work. Tholeiitic basalts become olivine-saturated at $~ 8$ wt. \% MgO (Herzberg and O'Hara, 2002), therefore, I extrapolated a linear regression through the GRB data to $8 \mathrm{wt} . \% \mathrm{MgO}$, and selected that to be the parental magma to GRB basalts. Although I concluded earlier that the GRB trend is caused by mixing, the mafic mixing end member (B) lies along the 1 atm cotectic (Figure 28). Thus, for most major elements, the extrapolated $8 \mathrm{wt} . \% \mathrm{MgO}$ parental magma is close to a composition that could form through LLD from a primary magma. To this parental composition, I then added olivine incrementally (in 2 wt $\%$ steps) until a reasonable primary magma composition was obtained (PRIM). This approach is also justified because the evolved mixing end member (A, in figure 28) also lies along the $1 \mathrm{~atm}$ cotectic. To check whether the $8 \mathrm{wt}$. $\% \mathrm{MgO}$ parental melt so calculated can generate a liquid line of descent (LLD) through the GRB data, I ran that primary composition using COMAGMAT to simulate the LLD at $\mathrm{P}<0.6 \mathrm{GPa}$ (required by our mineral data, see chapter 2). In this exercise I assume that the erupted GRB basalts were derived from more primitive magma, and are not primary magmas from eclogitic sources (Chapter 3). 
At this stage I (1) compared my primary magma with experimental melts, and (2) crystallized them at various pressure using pMELTS (Paul Asimow, CalTech, ran these) to look for multiphase saturation points. Multiphase saturation points are "points" defined by intersection of several phase-saturation curves in P-T space (Asimow and Longhi, 2004). For natural magma compositions these are often not points but a fairly tight $P, T$ area where several mineral phases are stable along with the calculated melt phase. The significance of such points is a matter of some debate but in general, these are thought to represent the $\mathrm{P}, \mathrm{T}$ at which the primary magma would have equilibrated with the source rock (e.g., BVTP 1981, but see Asimow and Longhi, 2004).

In the forward modeling approach, I chose starting magma compositions from published data on experimentally generated partial melts of peridotite and eclogite sources at a variety of pressure, temperature, and volatile-bearing (mainly $\mathrm{H}_{2} \mathrm{O}$ ) conditions. Using COMAGMAT and pMELTS, I modeled the compositions of these magmas from their $\mathrm{P}, \mathrm{T}$ of last mantle equilibration to the surface, while crystallizing in magma conduits at a single pressure or multiple pressures. The goal of such exercise was to see if I could derive the tightly grouped GRB liquid compositions from any experimentally produced melt by modeling the crystallization of the parent melt under any set of conditions.

As with all modeling efforts, there exist certain caveats: [1] COMAGMAT and pMELTS (and pHMELTS) have upper pressure limits of 1.5 and $3 \mathrm{GPa}$, respectively (Ariskin et al. 1993; Sack and Ghiorso, 1994). [2] The few melting studies of hydrous peridotite and eclogite mean that the quantitative effect of $\mathrm{H}_{2} \mathrm{O}$ on phase equilibrium is not well constrained. [3] The few high-pressure crystallization studies of basaltic or 
andesitic magmas mean that polybaric crystallization is also not well modeled by these simulations. Temperature, melt fraction, and phase compositions sometimes do not exactly duplicate experimental conditions; however, the overall trends match in most cases [e.g. Asimow and Longhi 2004; Asimow and Longhi 2004; Hirschmann et al., 1998, 1999].

The goal of both inverse and forward modeling was to determine at what $\mathrm{P}, \mathrm{T}$ such magmas could form from an appropriate (eclogite or peridotite) source. Finally, I took the best model primary compositions and then performed a sort of "synthetic reversal experiment"; I took that primary magma composition and ran LLD calculations at various pressures using COMAGMAT in order to simulate the magma's chemical journey from its point of origin to eruption. This exercise revealed surprisingly tight constraints on $\mathrm{P}, \mathrm{T}, \mathrm{X}_{\mathrm{H} 2 \mathrm{O}}$ conditions for the primary GRB magma as described below. RESULTS AND DISCUSSION Inverse Modeling of Dry Primary Magma

A parental magma composition was obtained for the GR basalts by extrapolating a linear regression through the GRB data to $8 \mathrm{wt}$. \% $\mathrm{MgO}$. Olivine was added to this composition until a liquid composition could be found that would be in equilibrium with upper mantle olivine $\left(\mathrm{Fo}_{89}\right)$. The parent and primary magma compositions thus calculated are listed in as PAM and PRIM, respectively in Table 6. Using COMAGMAT, PRIM was then modeled to fractionally crystallize at $2.0 \mathrm{~kb}, 10 \mathrm{~kb}$ and $15 \mathrm{~kb}$. These LLD's are shown in Figure 34 (a-d) and the temperature and phase appearance for 2 and $10 \mathrm{~kb}$ are shown for comparison in Table 7. 
$\mathrm{MgO}$ vs. $\mathrm{FeO}$ and $\mathrm{SiO}_{2}$ plots (Figure 34 a,c) show that all four LLD's could explain the GR data within the margin of error determined from comparisons with experimental data of Grove and Bryan (1983), and Tormey et al. (1987). However, MgO vs. $\mathrm{Al}_{2} \mathrm{O}_{3}$ and $\mathrm{CaO}$ plots (Figure $34 \mathrm{~b}$,d) clearly show that the GRB data cannot be explained by high pressure (i.e., 10 or $15 \mathrm{~kb}$ ) fractionation. At such higher pressures, augite appears before plagioclase and, thus, olivine + augite fractionation leaves the residual liquid with high $\mathrm{Al}_{2} \mathrm{O}_{3}$ and low $\mathrm{CaO}$, which is seen in Table 7. The trend of $\mathrm{MgO}$ vs. $\mathrm{CaO} / \mathrm{Al}_{2} \mathrm{O}_{3}$ ratio in $\mathrm{GRB}$ can only be explained by low pressure (shallow crust) fractionation; higher pressure fractionation results in lower $\mathrm{CaO} / \mathrm{Al}_{2} \mathrm{O}_{3}$ at an early stage of fractionation (Figure 35). This finding is consistent with the phenocryst assemblage and phase equilibria of GRB (Durand and Sen, 2004).

The LLD at $2 \mathrm{~kb}$ displays the best fit with regard to all the major oxides shown here. However, the $2 \mathrm{~kb}$ LLD seems to miss the bulk of the GRB $\mathrm{MgO}-\mathrm{SiO}_{2}$ and $-\mathrm{FeO}$ data (although within uncertainty). Because the presence of high-An phenocrysts signifies that GRB magmas may have been hydrous; therefore, a new set of calculations was performed with variable amounts of dissolved $\mathrm{H}_{2} \mathrm{O}$ in the PRIM.

Table 6- Starting Compositions for Inverse Modeling

\begin{tabular}{|l|c|c|}
\hline & $\begin{array}{c}\text { 8 wt. \% MgO Composition } \\
\text { (PAM) }\end{array}$ & $\begin{array}{c}\text { Olivine addition Composition } \\
\text { (PRIM) }\end{array}$ \\
\hline $\mathrm{SiO} 2$ & 52.0 & 51.16 \\
\hline $\mathrm{TiO} 2$ & 0.82 & 0.76 \\
\hline $\mathrm{Al} 2 \mathrm{O} 3$ & 17.5 & 16.16 \\
\hline $\mathrm{FeO}$ & 7.5 & 7.86 \\
\hline $\mathrm{MgO}$ & 8.0 & 11.07 \\
\hline $\mathrm{CaO}$ & 11.5 & 10.62 \\
\hline $\mathrm{Na} 2 \mathrm{O}$ & 2.57 & 2.37 \\
\hline Total & 100.0 & 100.0 \\
\hline
\end{tabular}


Table 7. Comparison of PRIM Phase Assemblages for best fit 2 and $10 \mathrm{~kb}$ dry runs.

\begin{tabular}{|l|c|c|c|}
\hline Temperature & Phases & Temperature & Phases \\
\hline $\mathbf{T}^{\circ} \mathbf{C}$ & $\mathbf{2 . 0} \mathbf{k b}$ & $\mathbf{T}{ }^{\circ} \mathbf{C}$ & $\mathbf{1 0 ~ k b}$ \\
\hline 1280 & Ol+L & 1311 & Ol+L \\
\hline 1233 & Ol+Plag.+L & 1280 & Ol+Aug. \\
\hline 1189 & Ol+ Plag.+ Aug. +L & 1278 & Aug. \\
\hline 1144 & Plag.+Aug.+Pig. & 1265 & Aug.+Plag. \\
\hline 1101 & Plag.+Aug.+L & 1259 & Plag.+Aug.+Ol \\
\hline 1068 & Plag.+Aug.+Mt+L & 1219 & Plag.+Aug. \\
\hline 1025 & Plag.+Aug.+il+L & & \\
\hline
\end{tabular}



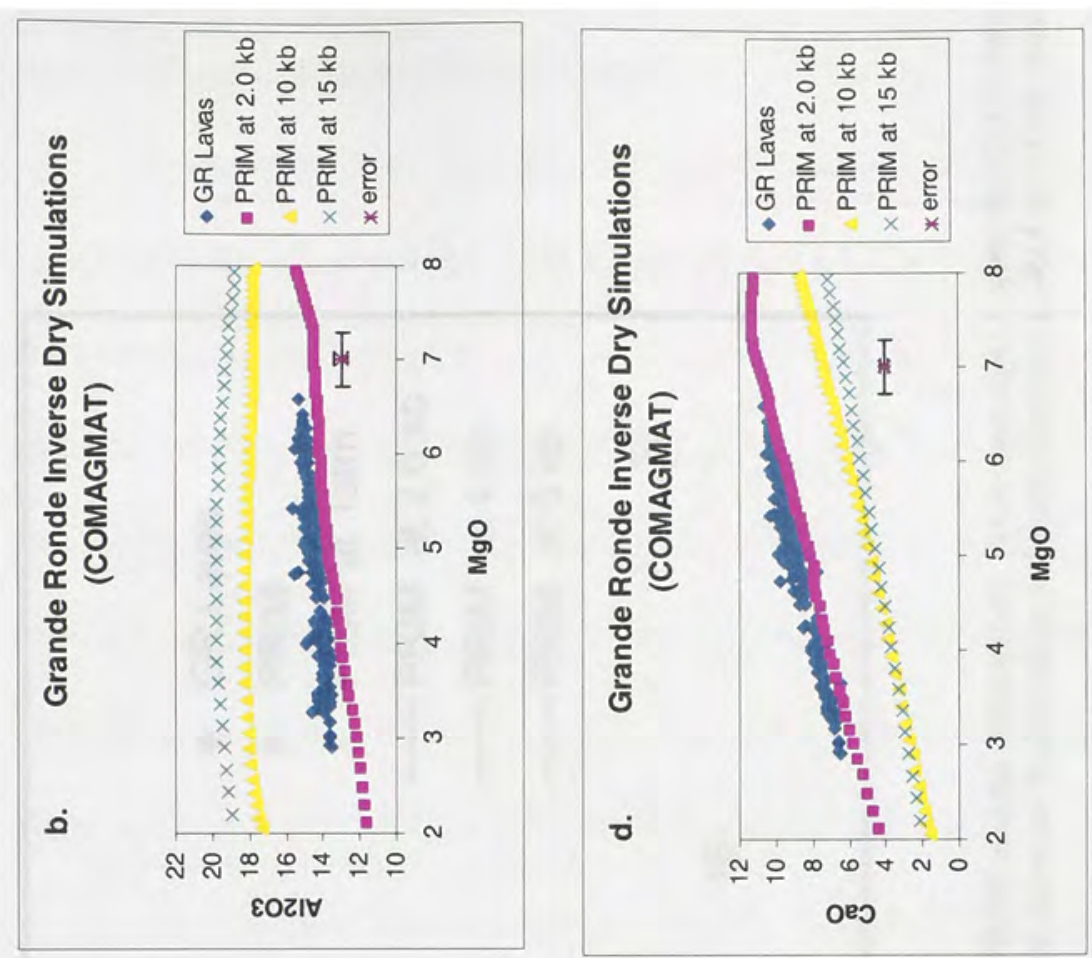

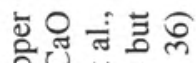
ज. एक

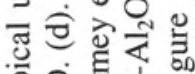

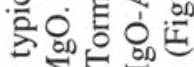
浽 $\Sigma$

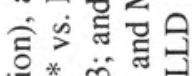
* 똔효 요 ×仓政 흐욜 х 잉

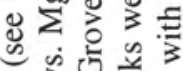
5 O 的党 을 을 으 $\sum$ 응 品

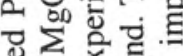

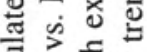

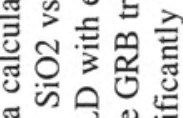
on 0 。马 完定

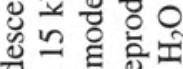
च 등 웅 웅으 등 E 0 . 공

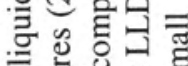
急全全

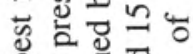
局 ․ㅠㄴ

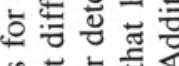

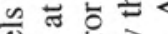
记

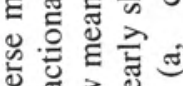
氙芯志

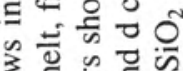
踏的

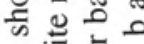
话产造这 흔 ले

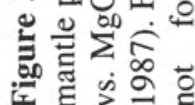




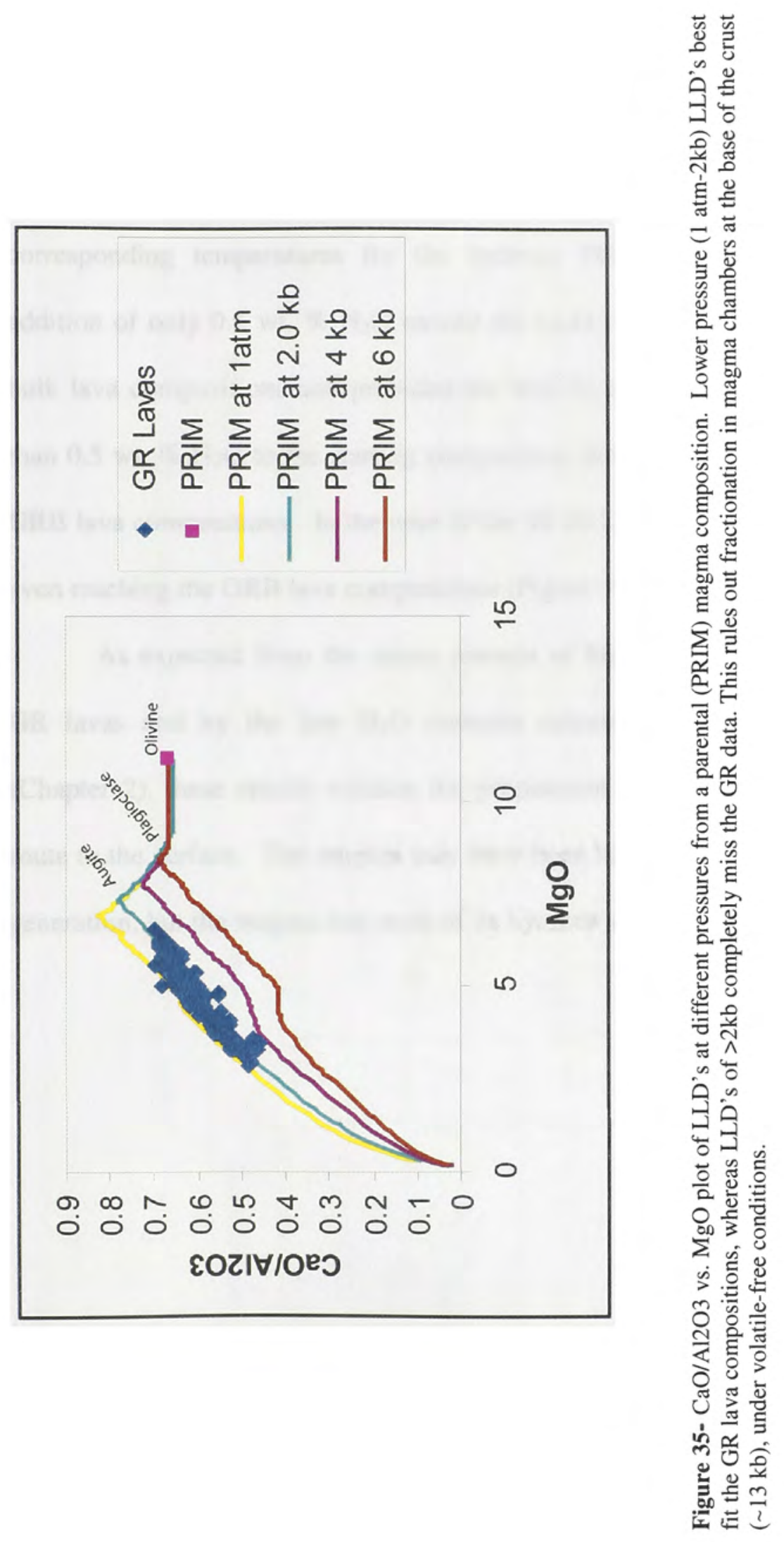


From 0.5 to 5 wt. \% water was added to PRIM and then LLD's were generated at 2, 10, and $15 \mathrm{~kb}$ pressures. Table 8 displays the order of phase appearance and the corresponding temperatures for the hydrous PRIM composition simulations. The addition of only 0.5 wt. $\% \mathrm{H}_{2} \mathrm{O}$ moved the LLD's for $\mathrm{SiO}_{2}$ and $\mathrm{FeO}$ towards the GRB bulk lava compositions and provided the best fit to the GRB lavas. Addition of more than 0.5 wt. $\% \mathrm{H}_{2} \mathrm{O}$ to the starting composition shifted the LLD's too far away from the GRB lava compositions. In the case of the $10 \mathrm{~kb}$ LLD, the hydrous melt runs out before even reaching the GRB lava compositions (Figure 36; a-d).

As expected from the minor amount of high-An plagioclase phenocrysts in the GR lavas and by the low $\mathrm{H}_{2} \mathrm{O}$ contents calculated with Putirka's (2005) equation (Chapter 2), these results validate the proposition that the magma largely degassed en route to the surface. The magma may have been highly hydrous at the source of magma generation, but the magma lost most of its hydrous signature as it rose to the surface. 


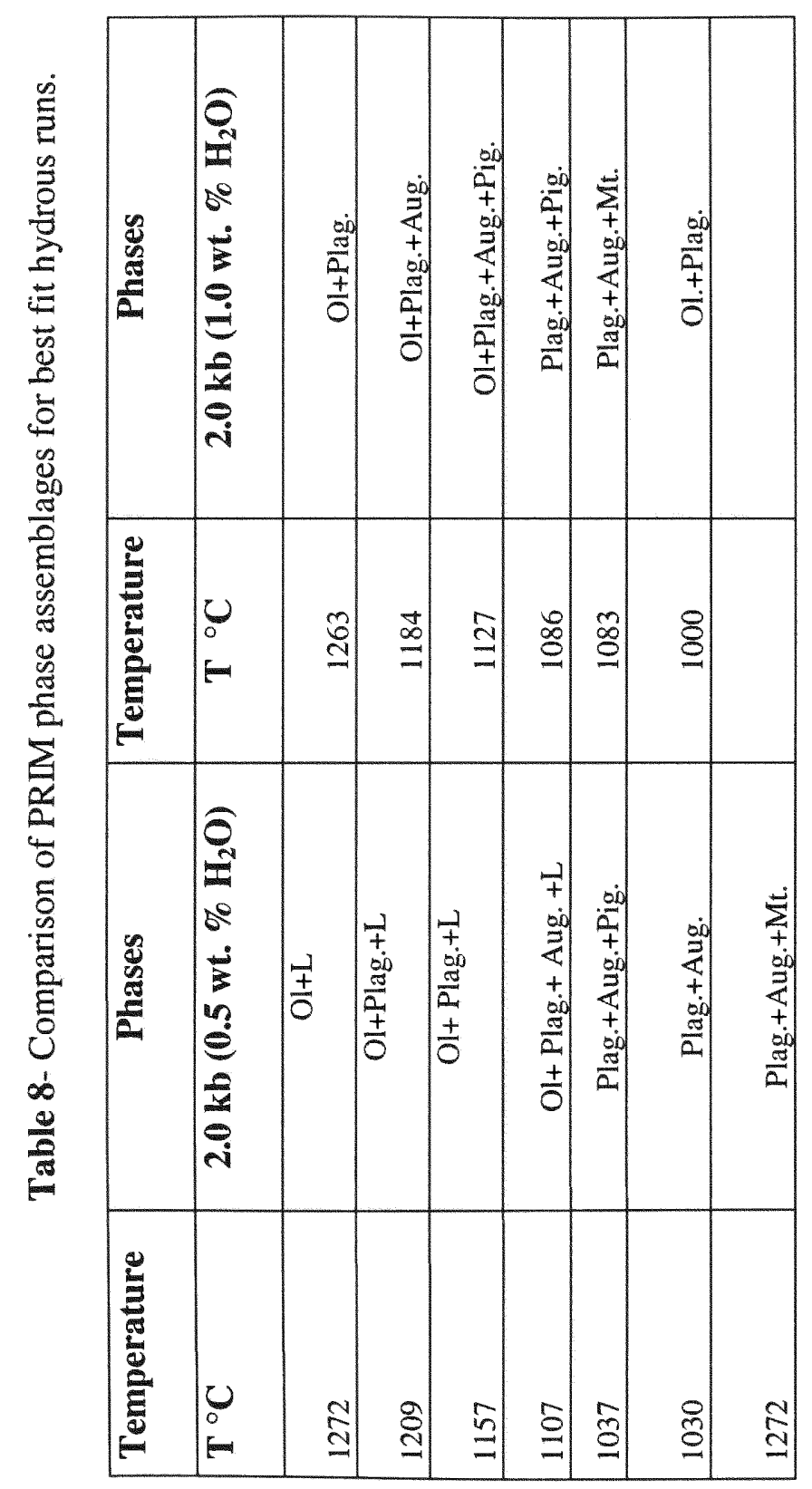



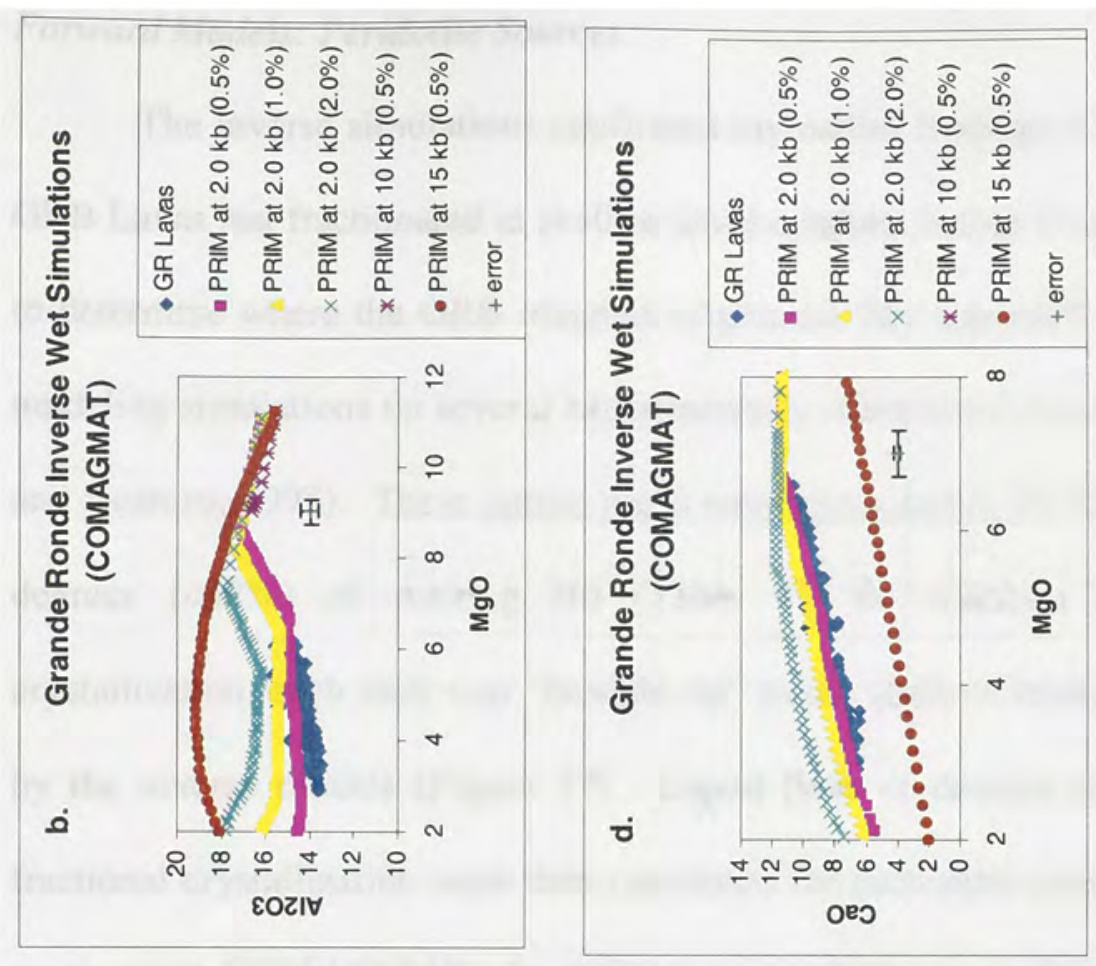

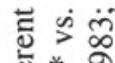

幽

讷

त)

흠믐

冚选通

कิ

웛

ํํㅇ

흔음 일

잉이

기

悉㥹

오ำ ำ

产完

인

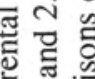

용

이 을

s。

n
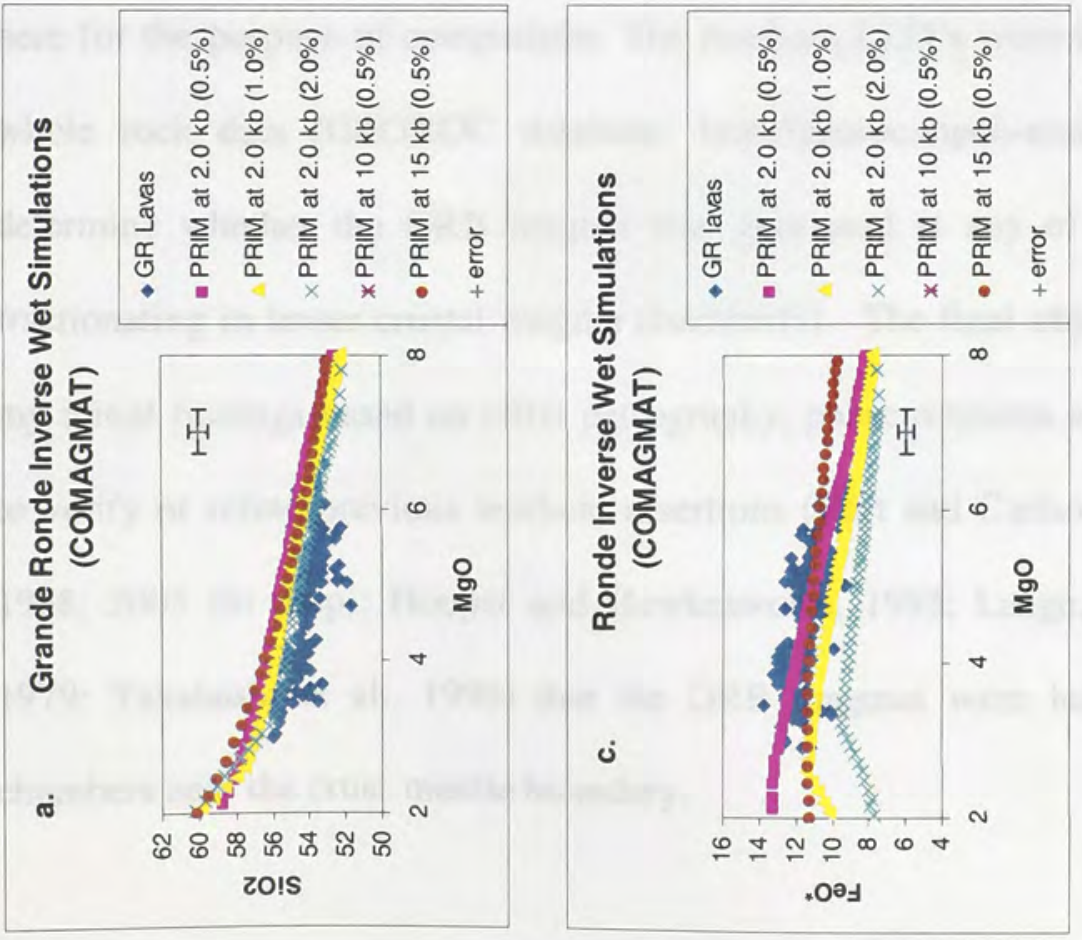
The inverse simulations confirmed my earlier findings (Chapter 2 and 3) that the GRB Lavas last fractionated in shallow-level conduits before erupting. My next goal was to determine where the GRB magmas originated. My approach was to conduct forward modeling simulations on several experimentally-determined mantle compositions (Hirose and Kushiro, 1993). These partial melts were generated at $10-30 \mathrm{~kb}$ by low to moderate degrees $(<17 \%)$ of melting (F) (Table 9). To simulate low-pressure fractional crystallization, each melt was "brought up" to the shallow-levels previously constrained by the inverse models (Figure 37). Liquid lines of descent for both equilibrium and fractional crystallization were then calculated for each melt composition over a pressure range using COMAGMAT. In addition to simulating crystallization under volatile-free conditions, $0.5-2$ wt. \% $\mathrm{H} 2 \mathrm{O}$ was added to each of the starting melts and LLD's were calculated at various pressures. Only the best-fit or most relevant models are discussed here for the purpose of comparison. The resultant LLD's were then compared with GR whole rock data (GEOROC database: http://georoc.mpch-mainz.gwdg.de/georoc/) to determine whether the GRB magma was generated at any of these pressures before fractionating in lower crustal magma chamber(s). The final objective was to (1) verify my initial findings based on GRB petrography, phase relations and $\mathrm{H}_{2} \mathrm{O}$ content and (2) to verify or refute previous workers assertions (Hart and Carlson, 1987; Hooper, 1984, 1988, 2005 (in prep); Hooper and Hawkesworth, 1993; Lange, 2001; Swanson et al., 1979: Takahashi et al., 1998) that the GRB magmas were last processed in magma chambers near the crust-mantle boundary. 
Table 9- Starting experimental compositions (Hirose and Kushiro, 1993)

\begin{tabular}{|c|c|c|c|c|c|c|c|c|c|c|c|c|c|}
\hline \multicolumn{3}{|c}{$\mathrm{P}$ (Kbar) } & $\mathrm{T}$ & $\mathrm{F}$ & $\mathrm{SiO} 2$ & $\mathrm{TiO} 2$ & \multicolumn{1}{c}{$\mathrm{Al} 2 \mathrm{O} 3$} & $\mathrm{FeO} *$ & $\mathrm{MnO}$ & $\mathrm{MgO}$ & $\mathrm{CaO}$ & $\mathrm{Na} 2 \mathrm{O}$ & $\mathrm{K} 2 \mathrm{O}$ \\
\hline KLB-1 & 10.00 & 1250 & 0.07 & 51.32 & 1.09 & 19.09 & 6.38 & 0.23 & 8.14 & 8.85 & 4.60 & 0.27 \\
\hline & 15.00 & 1300 & 0.06 & 50.71 & 1.04 & 19.31 & 6.37 & 0.14 & 8.31 & 7.75 & 5.47 & 0.73 \\
\hline & 20.00 & 1375 & 0.14 & 47.47 & 0.75 & 15.53 & 8.51 & 0.18 & 13.94 & 11.11 & 2.22 & 0.08 \\
\hline & 30.00 & 1500 & 0.17 & 45.67 & 0.99 & 14.33 & 9.59 & 0.17 & 16.73 & 10.64 & 1.80 & 0.07 \\
\hline
\end{tabular}

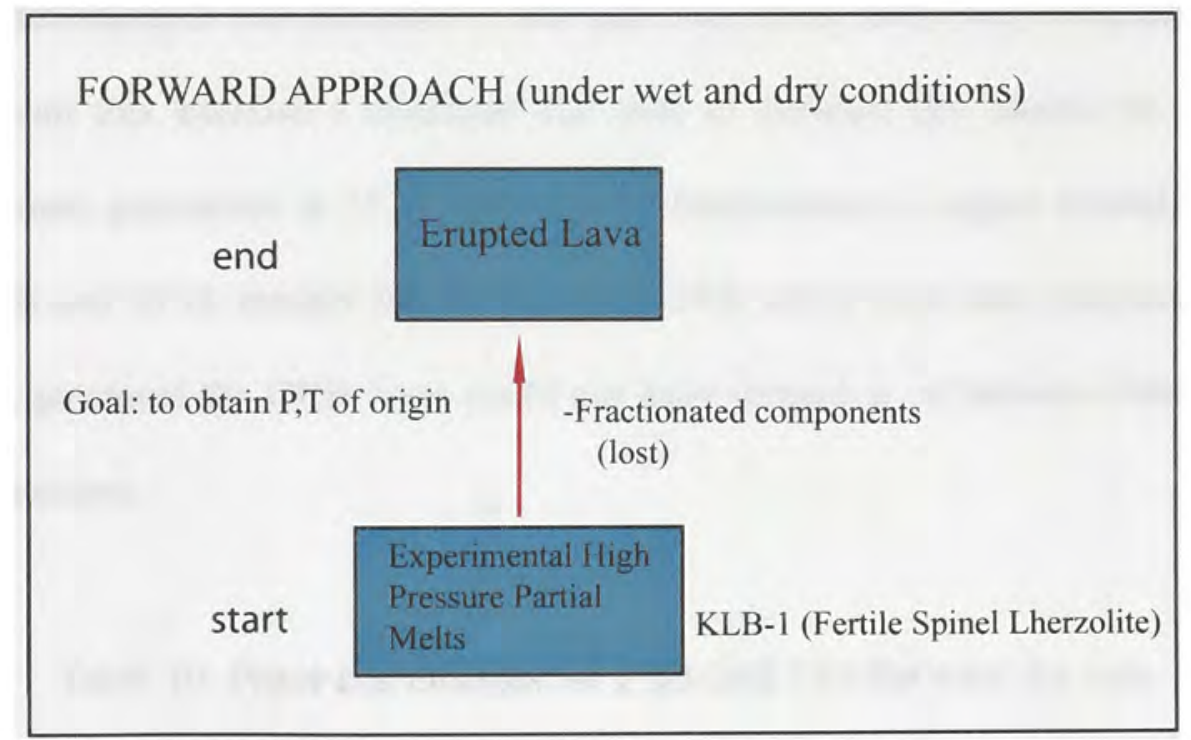

Figure 37-Schematic depicting the Forward method used to model GRB magma under hydrous and anhydrous conditions at different pressures with a peridotitic starting material. 
Figure 38 shows oxide-oxide plots $\left(\mathrm{Al}_{2} \mathrm{O}_{3}-\mathrm{MgO}\right.$, FeO-MgO, $\mathrm{CaO}-\mathrm{MgO}$, and $\left.\mathrm{SiO}_{2}-\mathrm{MgO}\right)$ comparing GRB whole rock data with liquid lines of descent (LLD) for the different experimental partial melts. Liquid lines of descent for fractional crystallization of dry melt were calculated for each melt composition over this pressure range using COMAGMAT. All melts were fractionally crystallized at $1 \mathrm{~atm}$ and $2 \mathrm{~kb}$ and the results are shown in Table10.

Table 10 shows the phase appearance and corresponding temperatures of these best fit dry models. Figure 38 shows that 2 kb LLD's generated from 10, 20, and $30 \mathrm{~kb}$ melts do not at all resemble the GRB data. On the other hand, the melt generated at 15 $\mathrm{kb}$ and fractionated at low pressures ( $1 \mathrm{~atm}$ and $2 \mathrm{~kb}$ ) fit the GRB data remarkably well.

From this exercise I conclude that best fit forward dry model for all oxides involves melt generation at $15 \mathrm{~kb}$ followed by fractionation in upper crustal chambers. The $20 \mathrm{~kb}$ and $30 \mathrm{~kb}$ models fall far from the GRB whole rock data indicating that the melt that generated the GRB lavas could not have formed at or between either of these higher pressures.

Table 10- Phase assemblages for 1 atm and $2 \mathrm{~kb}$ Forward dry runs

\begin{tabular}{|l|c|c|c|}
\hline Temperature & Phases $(15 \mathrm{~kb})$ & Temperature & Phases $(15 \mathrm{~kb})$ \\
\hline $\mathrm{T}{ }^{\circ} \mathrm{C}$ & $1 \mathrm{~atm}$ & $\mathrm{~T}{ }^{\circ} \mathrm{C}$ & $2.0 \mathrm{~kb}$ \\
\hline 1364 & Ol+L & 1361 & Ol+L \\
\hline 1216 & Ol+Plag. & 1223 & Ol+Plag. \\
\hline 1186 & Ol+Plag.+Aug. & 1206 & Ol+Plag.+Aug. \\
\hline 1146 & Ol+Plag.+Aug.+Pig. & 1157 & Plag.+Aug.+Pig. \\
\hline 1144 & Plag.+Aug.+Pig. & 1116 & Plag.+Aug. \\
\hline 1115 & Plag.+Aug. & 1361 & Ol+L \\
\hline 1364 & Ol+L & & \\
\hline
\end{tabular}



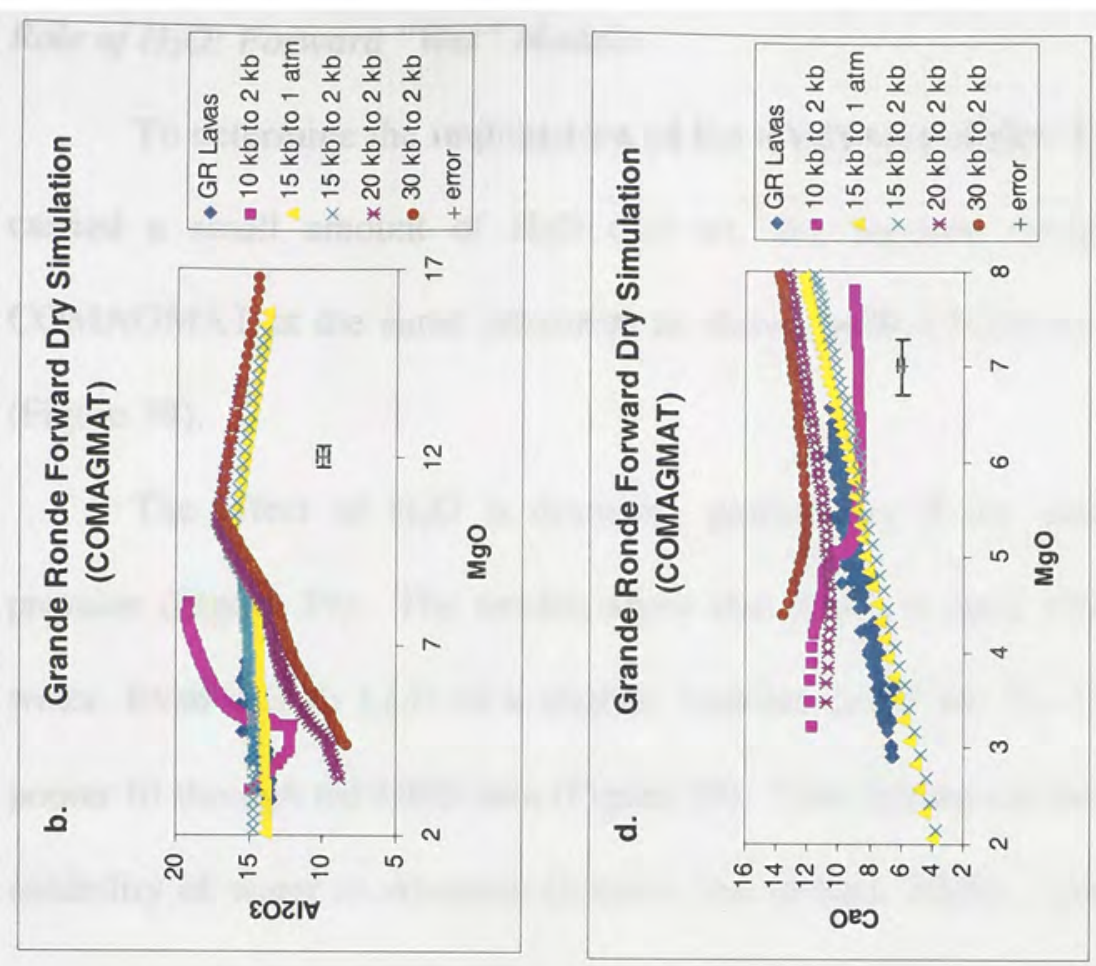

त्रे

문

论

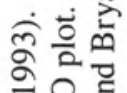

응

กㄹ

岳市

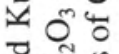

究要

ณ

氖产

ติ

기 층

ธิ์ ำ

क

हิ

호웡

등 웜

है당

몰

츰음

苂
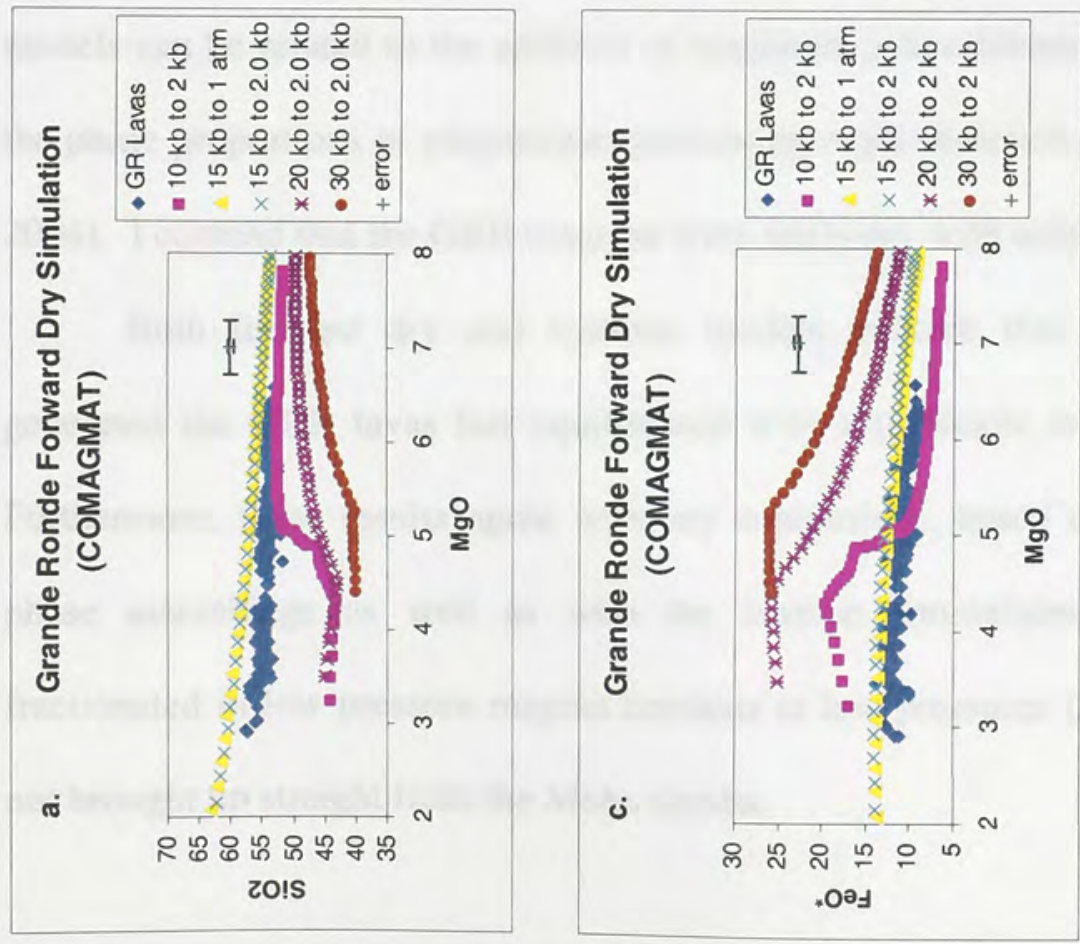

可

ถ

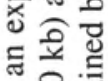

तิ

tᄒ

월

造气

$\because 0$

论

$\Xi$

을 은

으 에 의

进密

岁密

릅

壳

告语完

이으.

ণ ฮ

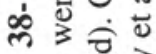

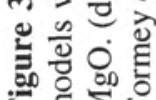


Role of $\mathrm{H}_{2} \mathrm{O}$ : Forward "Wet" Models:

To determine the implications of the inverse simulation finding that GRB magma carried a small amount of $\mathrm{H}_{2} \mathrm{O}(0.5$ wt. \%), forward simulations were run using COMAGMAT at the same pressures as above, with $0.5-2.0$ wt. $\% \mathrm{H}_{2} \mathrm{O}$ added to them (Figure 39).

The effect of $\mathrm{H}_{2} \mathrm{O}$ is dramatic, particularly if the melt crystallizes at higher pressure (Figure 39). The models show that $\mathrm{Al}_{2} \mathrm{O}_{3}$ is most affected by the addition of water. Even a $2 \mathrm{~kb}$ LLD of a slightly hydrous (>0.5 wt. \%) $15 \mathrm{~kb}$ magma generate a poorer fit through the GRB data (Figure 39). This finding can be explained by the higher solubility of water in Alumina (Litasov and Ohtani, 2002). Litasov and Ohtani (2002) experimentally determined that water content in periclase and ferropericlase increases with increasing temperature and $\mathrm{Al}_{2} \mathrm{O}_{3}$ content and that this could be the result of the incorporation of trivalent cations to the structure. Furthermore, the kinks seen in the models can be related to the addition of magnetite \pm hornblende which seems to change the phase proportions of plagioclase, preventing rapid depletion of $\mathrm{Al}_{2} \mathrm{O}_{3}$ (Almeev et al., 2004). I contend that the GRB magmas were fairly dry with only 0.5 wt. $\% \mathrm{H}_{2} \mathrm{O}$.

Both forward dry and hydrous models indicate that the primary melts that generated the GRB lavas last equilibrated with a peridotite source at $15 \mathrm{~kb}$ pressure. Furthermore, these results agree with my conclusions, based on lava petrography and phase assemblage as well as with the inverse simulations, that GRB lavas last fractionated in low-pressure magma conduits at low pressures ( $2 \mathrm{~kb}$ to $1 \mathrm{~atm})$ and were not brought up straight from the Moho depths. 
Table 11- Phase assemblages for $2 \mathrm{~kb}$ Forward wet runs

\begin{tabular}{|c|c|c|c|}
\hline Temperature & Phases & Temperature & Phases \\
\hline $\mathrm{T}^{\circ} \mathrm{C}$ & $2 \mathrm{~kb}\left(0.5\right.$ wt. $\left.\% \mathrm{H}_{2} \mathrm{O}\right)$ & $\mathbf{T}^{\circ} \mathrm{C}$ & $2 \mathrm{~kb}\left(1.0\right.$ wt. $\left.\% \mathrm{H}_{2} \mathrm{O}\right)$ \\
\hline 1353 & $\mathrm{Ol}+\mathrm{L}$ & 1344 & $\mathrm{Ol}+\mathrm{L}$ \\
\hline 1197 & Ol+Plag. & 1171 & Ol+Plag. \\
\hline 1178 & Ol.+Plag.+Aug. & 1151 & Ol.+Plag.+Aug. \\
\hline 1128 & Ol.+Plag + Aug.+Pig. & 1105 & Plag.+Aug.+Pig. \\
\hline 1125 & Plag.+Aug.+Pig. & 993 & Plag.+Aug.+Mt. \\
\hline 1053 & $\begin{array}{l}\text { Plag.+Aug. } \\
\text { Pla }\end{array}$ & 938 & Aug.+Mt. \\
\hline 1005 & Plag.+Aug.+Mt. & & \\
\hline
\end{tabular}



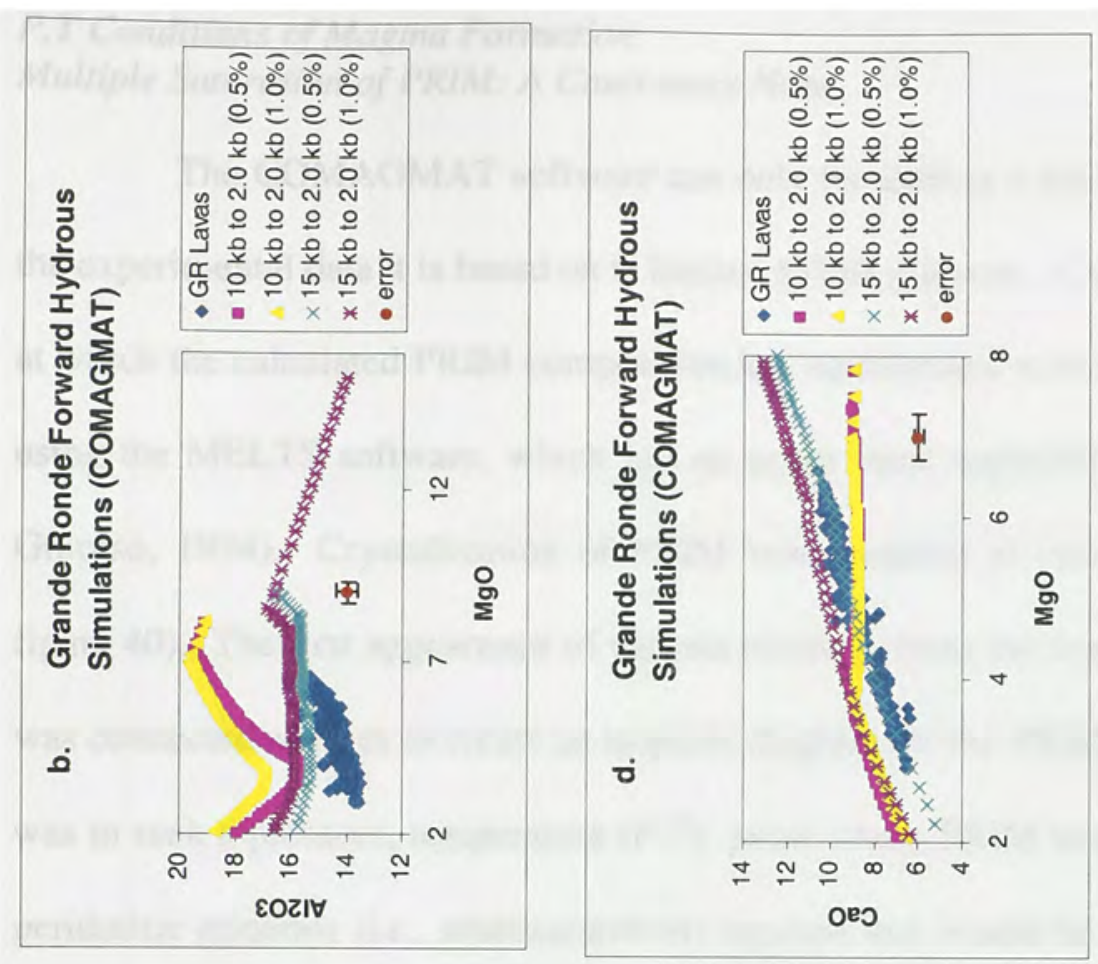

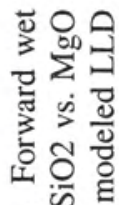

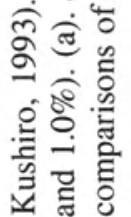

ㅁํㅇำ

ษீ

冚氞

7 웡

象衣

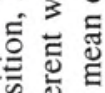

递要

造产

音

츤혼

券

可预
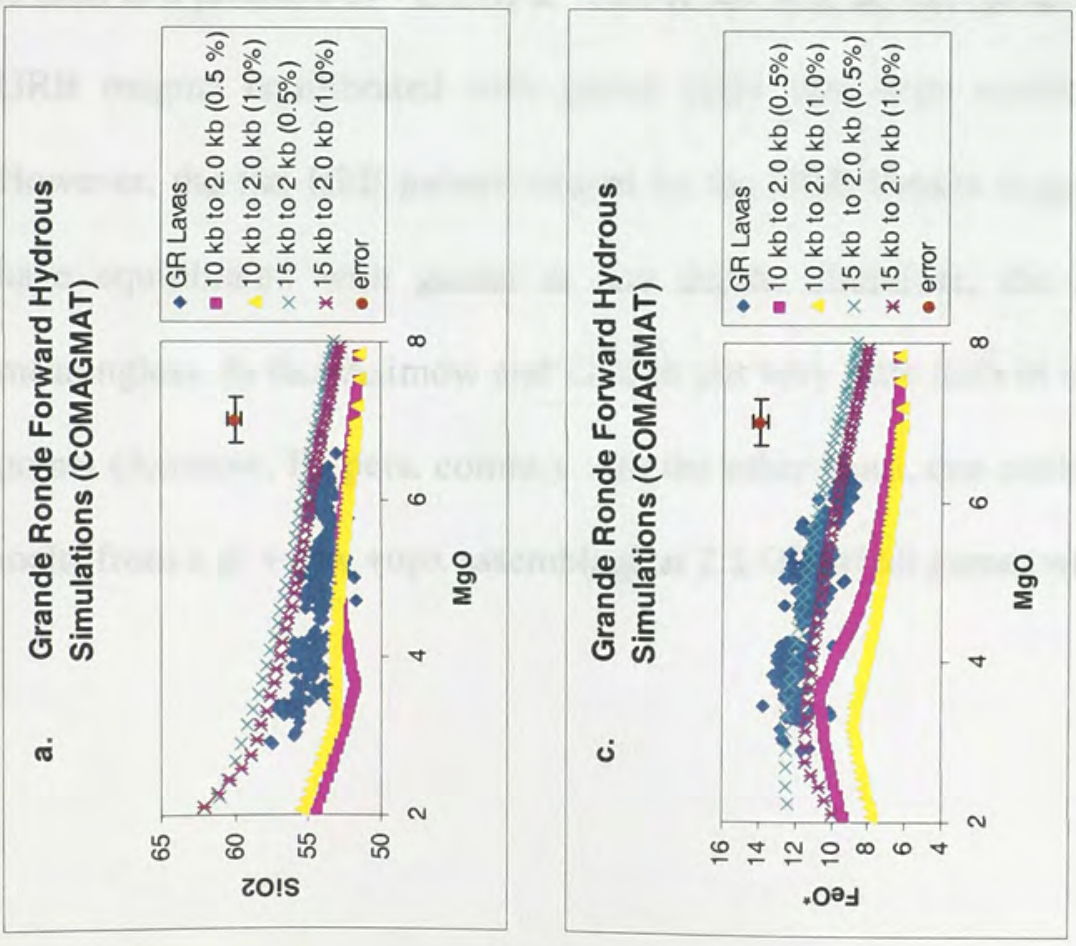

ถับำ

氙先

힝ㅎㅎ

สิ)

흔

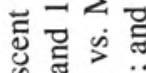

ชैㅇํㅇㅇㅇ

4 讧

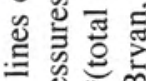

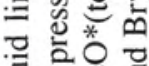

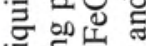

馬它

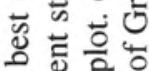

뉸

记它出

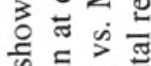

क

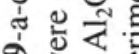

वेड

跎

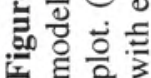


The COMAGMAT software can only be used to a maximum of $15 \mathrm{~kb}$ because the experimental data it is based on is limited to this pressure. Consequently, the pressure at which the calculated PRIM composition last equilibrated with the mantle was modeled using the MELTS software, which has an upper limit applicability of $30 \mathrm{~kb}$ (Sack and Ghiorso, 1994). Crystallization of PRIM was modeled at various pressures (0-30 kb; figure 40). The first appearance of various minerals from the liquid at different pressures was connected as lines to create an isopleth diagram for the PRIM composition. The goal was to seek a pressure, temperature $(\mathrm{P}, \mathrm{T})$ point where PRIM would be saturated with all peridotitic minerals (i.e., multisaturation) because that would be the $\mathrm{P}, \mathrm{T}$ at which PRIM would have last equilibrated in the mantle.

A multiphase saturation (or near saturation) point involving garnet, opx and $\mathrm{cpx}$ is seen at a pressure of $\sim 2.3 \mathrm{GPa}$. This result may be interpreted to indicate that primary GRB magma equilibrated with garnet $(\mathrm{gt})+\mathrm{opx}+\mathrm{cpx}$ residue at $2.3 \mathrm{GPa}(60 \mathrm{~km})$. However, the flat REE pattern shown by the GRB basalts suggests that these could not have equilibrated with garnet at any depth. Therefore, the multisaturation point is meaningless. In fact Asimow and Longhi put very little faith in the use of multisaturation points (Asimow, P., pers. comm.). On the other hand, one could generate GRB primary melts from a gt + cpx +opx assemblage at $2.3 \mathrm{GPa}$ if all garnet were melted (i.e., high F). 


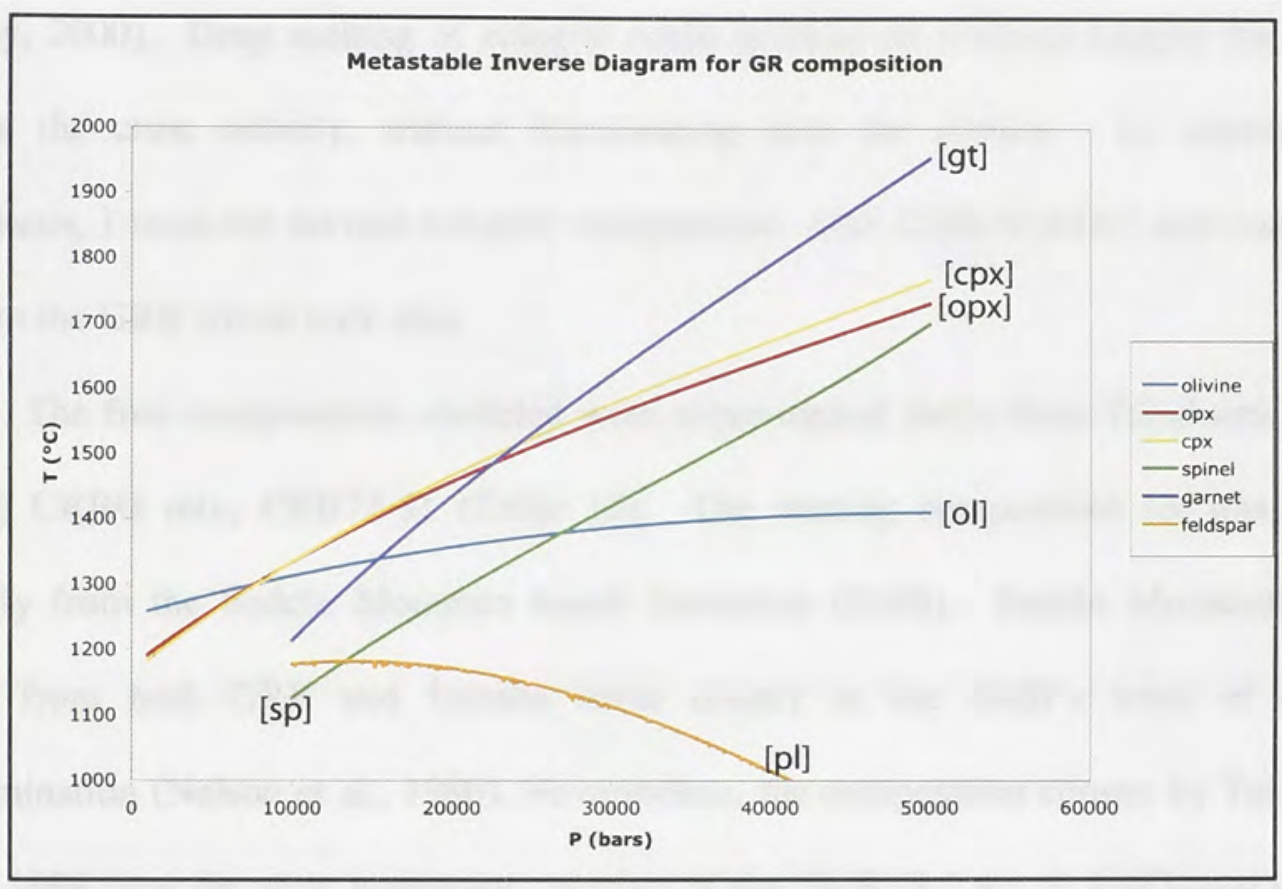

Figure 40- Phase diagram for PRIM depicting the multiphase saturation of garnet, orthoclinopyroxene (opx), clinopyroxene (cpx), point for this GRB composition. The curves show the temperature at which each phase is saturated in the bulk liquid composition. The curves meet at $\sim 2 \mathrm{GPa}$ and $\sim 1450{ }^{\circ} \mathrm{C}$. This plot also shows the stability or saturation curves for olivine, plagioclase feldspar and spinel. 
Eclogite source: forward models

I wanted to test the hypothesis that an eclogitic source is required to account for the unique characteristics (aphyric, evolved nature) exhibited by the GRB lavas. Because eclogite (as a subducted component), is chemically akin to basalt, the melt product has higher $\mathrm{SiO}_{2}$ and $\mathrm{FeO}$ than a peridotite at any pressure (Takahashi, 1998; Wright, 1989; Yaxley, 2000). Deep melting of eclogite could produce an evolved magma that could bypass the crust entirely, without fractionating near the surface. To address this hypothesis, I modeled several eclogitic compositions with COMAGMAT and compared them to the GRB whole rock data.

The first compositions modeled were experimental melts from Takahashi et al's (1998) CRBG mix, CRB72-31 (Table 12). The starting composition for this run is actually from the Saddle Mountain basalt formation (SMB). Saddle Mountain lavas differ from both GRB and Imnaha lavas mainly in the SMB's level of crustal contamination (Nelson et al., 1980). Nevertheless, the composition chosen by Takahashi et al., 1998, was the most magnesian member of the SMB ( $8.2 \mathrm{wt} . \% \mathrm{MgO})$ and closely resembles a typical MORB composition in major elements. Table 13 shows the resultant phases for the two compositions used in Table 12.

Liquid lines of descent at $2 \mathrm{~kb}$ for compositions of partial melts generated at 15 $\mathrm{kb}, 20 \mathrm{~kb}$, and $30 \mathrm{~kb}$ were derived using COMAGMAT. LLD's for all major oxides $\left(\mathrm{SiO}_{2}, \mathrm{FeO}, \mathrm{CaO}\right.$ and $\left.\mathrm{Al}_{2} \mathrm{O}_{3}\right)$ under dry conditions indicate that none of the models fit the GRB data because in all cases the starting melts have lower initial MgO concentrations than the GRB data (Figure 41). The initial increase in $\mathrm{MgO}$ in all of our models is a very interesting feature of all the LLD's, which are not duplicated by the GRB data. 
Table 12- Starting Melt Compositions for Eclogite CRB72-31

\begin{tabular}{|l|c|c|}
\hline \multicolumn{3}{|c|}{ CRB72-31 (F=0.4-0.5) } \\
\hline & $\mathbf{2 . 0 ~ G P a}$ & $\mathbf{3 . 0 ~ G P a}$ \\
\hline $\mathrm{SiO} 2$ & 54.5 & 59.0 \\
\hline $\mathrm{TiO} 2$ & 1.7 & 2.1 \\
\hline $\mathrm{Al} 2 \mathrm{O} 3$ & 17.9 & 16.0 \\
\hline $\mathrm{FeO} *$ & 8.2 & 6.7 \\
\hline $\mathrm{MnO}$ & 0.1 & 0.1 \\
\hline $\mathrm{MgO}$ & 4.6 & 3.3 \\
\hline $\mathrm{CaO}$ & 9.1 & 8.4 \\
\hline $\mathrm{Na2O}$ & 3.0 & 3.2 \\
\hline $\mathrm{K} 2 \mathrm{O}$ & 0.8 & 1.2 \\
\hline Total & 100.0 & 100.0 \\
\hline
\end{tabular}

Table 13- Comparison of Eclogite (CRB72-31) phase assemblages for 2 and $3 \mathrm{GPa}$ Forward runs

\begin{tabular}{|c|c|c|c|}
\hline Temperature & Phases & Temperature & Phases \\
\hline $\mathrm{T}^{\circ} \mathrm{C}$ & $2.0 \mathrm{GPa}$ & $\mathbf{T}^{\circ} \mathrm{C}$ & 3.0 GPa \\
\hline 1225 & Plag.+L & 1176 & Plag.+L \\
\hline 1157 & Plag.+Ol+L & 1139 & Plag.+Aug. $+\mathrm{L}$ \\
\hline 1147 & Plag.+Ol+Aug. $+\mathrm{L}$ & 1088 & Plag.+Aug.+IL+L \\
\hline 1146 & Plag.+Aug.+L (Ol-out) & & \\
\hline 1087 & Plag.+Aug.+IL+L & & \\
\hline 1086 & Plag.+Aug.+IL+Mt, $+\mathrm{L}$ & & \\
\hline
\end{tabular}



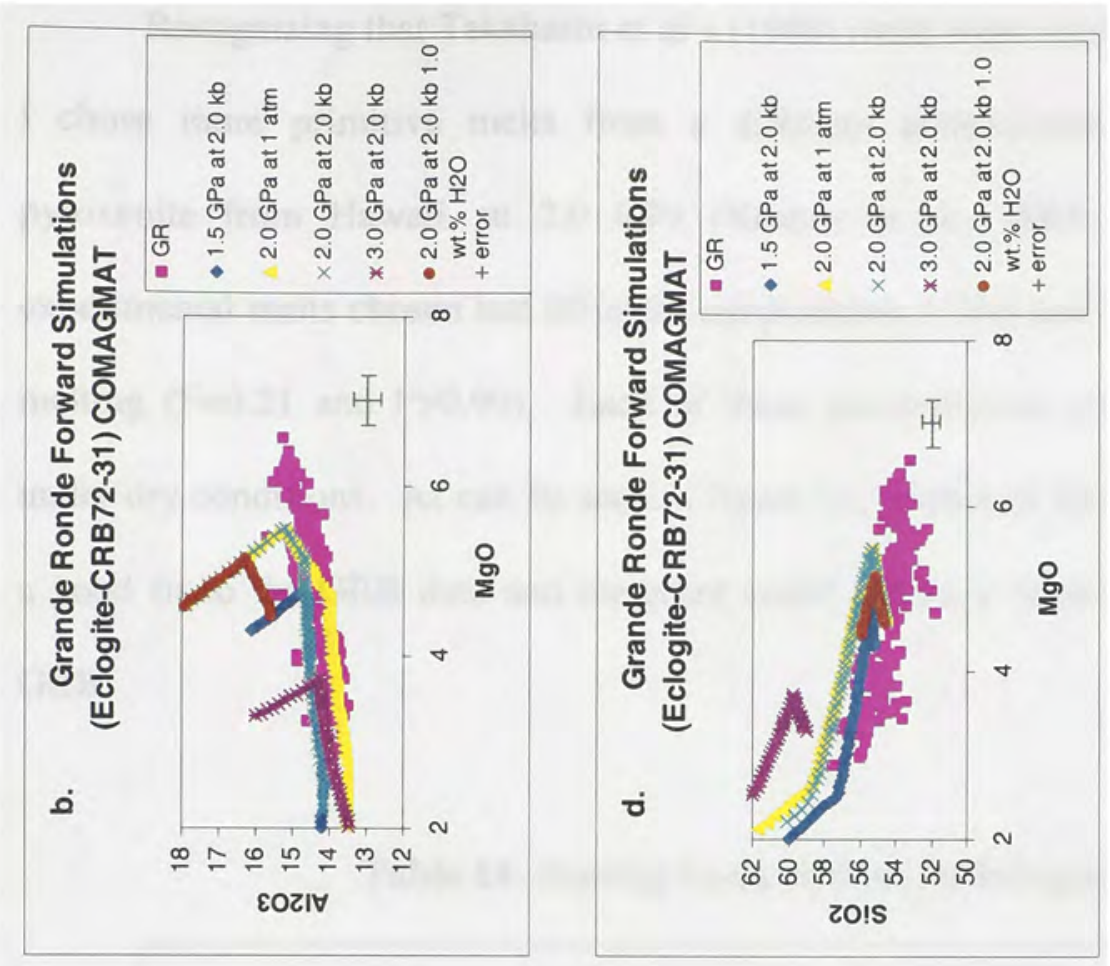

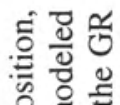

है है

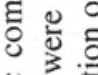

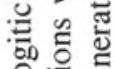

은 음

를

它

웜

氜

넝

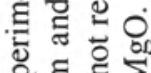

토

๘

ธี च

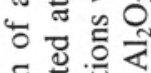

흫

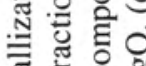

跑芯远

帘娄

픔 을 응

을 可

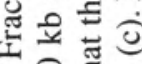

忙恣

워음

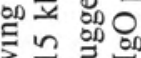
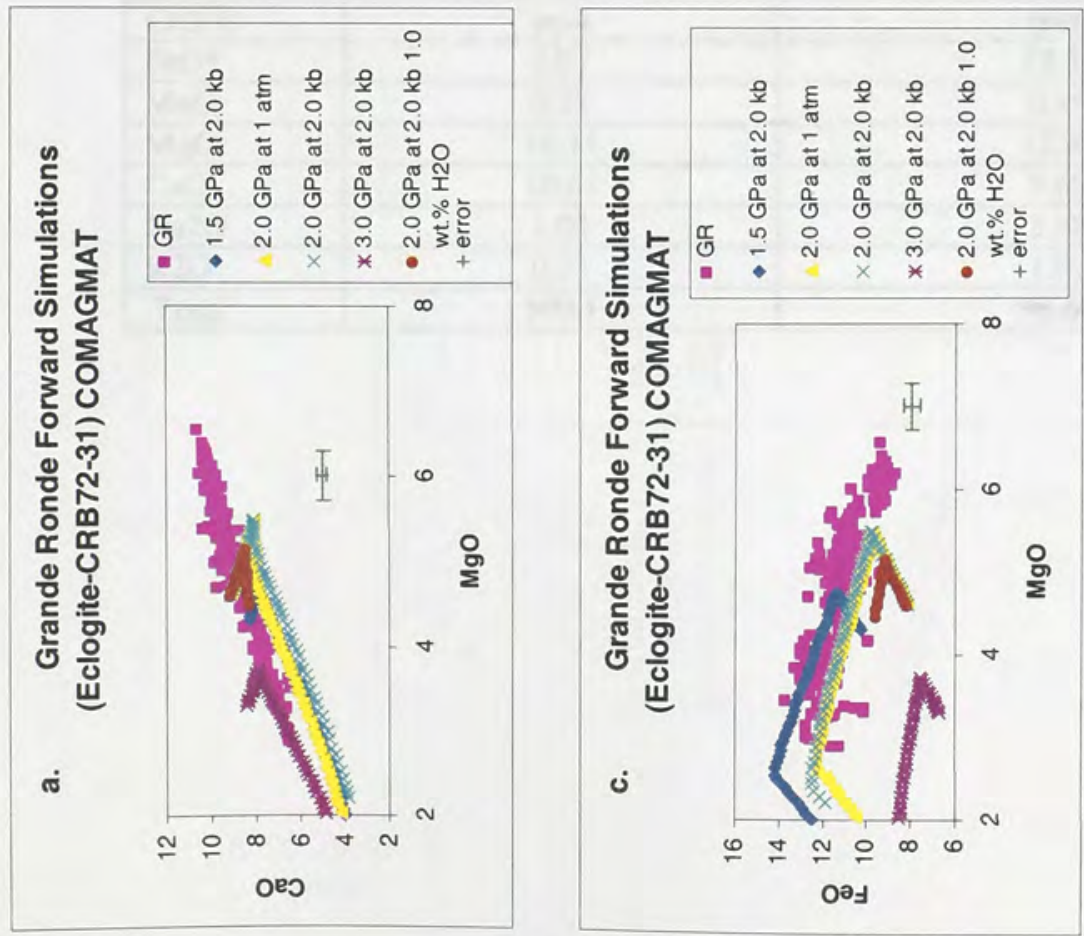

के के

嵩灵

3 บ

远告

की

它矛递官

出范

$\sum_{0}^{ \pm}$

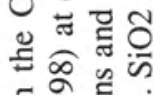

छั ฮิ

๘

$\triangle 0$

형충

䑻 氜

选恶票

ने क्ञ

어을

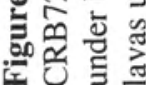


Recognizing that Takahashi et al's (1998) melts were inappropriate starting melts, I chose more primitive melts from a different composition (77SL-582), a garnet pyroxenite from Hawaii, at $2.0 \mathrm{GPa}$ (Keshav et al., 2004; Table 14). The two experimental melts chosen had different temperatures $\left(1340\right.$ and $\left.1440{ }^{\circ} \mathrm{C}\right)$ and degrees of melting $(\mathrm{F}=0.21$ and $\mathrm{F}>0.90)$. Each of these compositions were fractionated at $2 \mathrm{~kb}$ under dry conditions. As can be seen in figure 42 , neither of these compositions provide a good fit to the GRB data and therefore could not have been parental magmas to the GRB.

Table 14- Starting Compositions for Eclogite 77SL-582

\begin{tabular}{|c|c|c|}
\hline \multicolumn{3}{|c|}{$77 \mathrm{SL}-582(\mathrm{P}=2.0 \mathrm{GPa})$} \\
\hline & $\mathrm{T}=1340, \mathrm{~F}=0.21$ & $40, F=>0.9$ \\
\hline $\mathrm{SiO} 2$ & 45.99 & 44.12 \\
\hline TiO2 & 0.69 & 1.51 \\
\hline $\mathrm{Al} 2 \mathrm{O} 3$ & 16.17 & 13.18 \\
\hline $\mathrm{Cr} 2 \mathrm{O} 3$ & 0.14 & 0.08 \\
\hline $\mathrm{FeO}^{*}$ & 8.97 & 13.37 \\
\hline $\mathrm{MnO}$ & 0.21 & 0.19 \\
\hline $\mathrm{MgO}$ & 16.11 & 12.94 \\
\hline $\mathrm{CaO}$ & 10.61 & 9.69 \\
\hline $\mathrm{Na} 2 \mathrm{O}$ & 1.01 & 2.58 \\
\hline $\mathrm{K} 2 \mathrm{O}$ & 0.21 & 1.02 \\
\hline Total & 100.1 & 98.68 \\
\hline
\end{tabular}



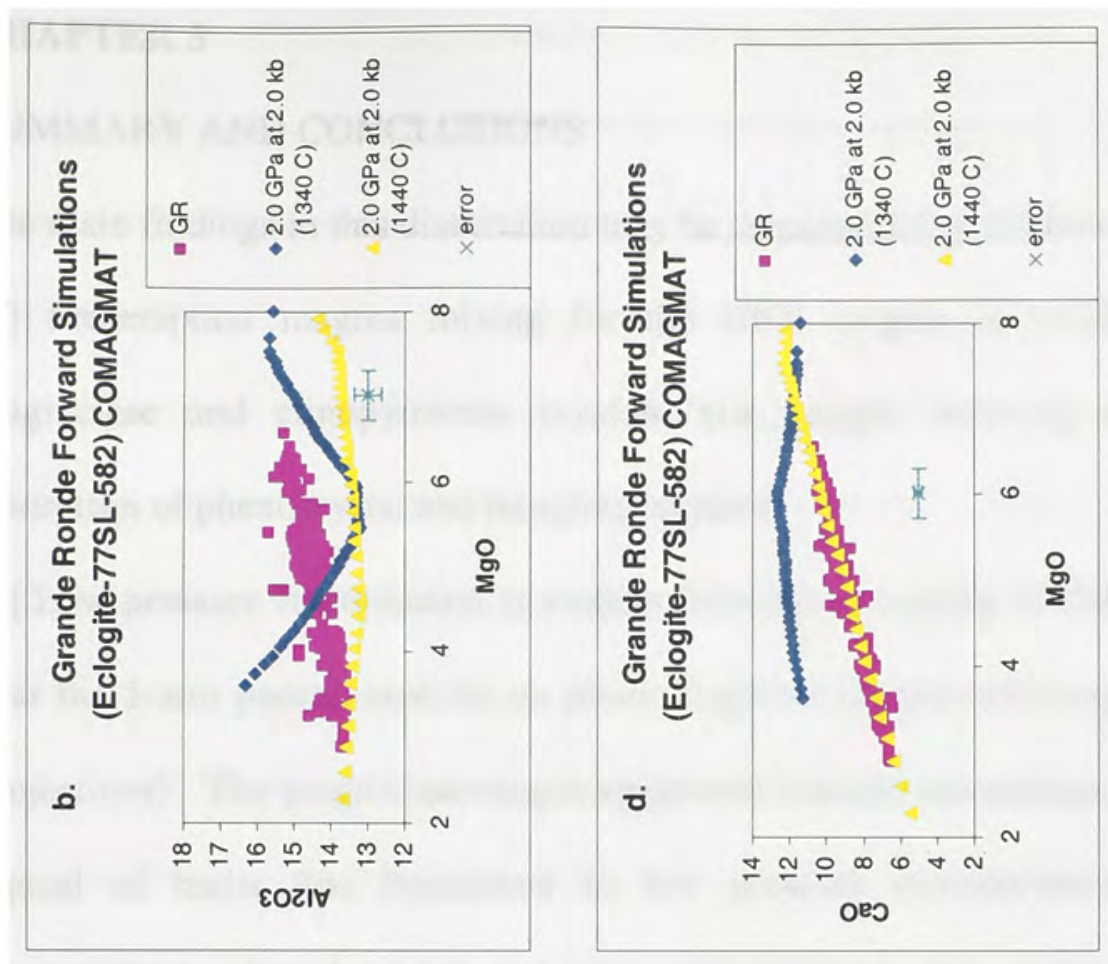

ธิ๊

을 음

ठํ.

总总要

응 웡

ㅎํㅇ

훰 훙

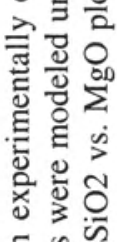

ธิ์

ธี ฐ

올용

跑。

충뉴

ีㅡㄷ

월

江突

密

훈
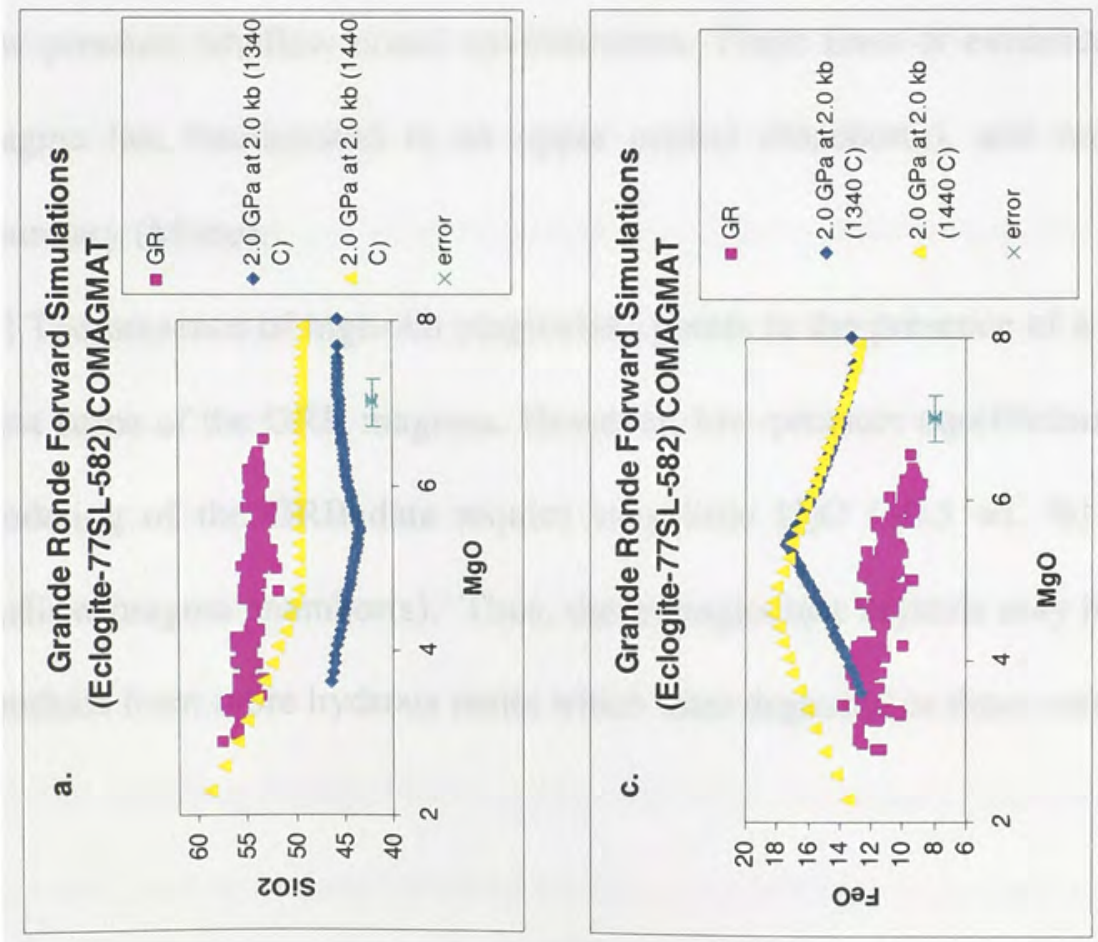

ํํㅇำ

흔웡

逮吉

융

ษ०

$\sum_{i}$ 인

出

过:

ข

ㄷํㅇㅇํㅇ

हี ญ อ

융 क्र

热焉

的㐘

造嵌

业

\% N

产它泀。 


\section{CHAPTER 5}

\section{SUMMARY AND CONCLUSIONS}

The main findings in this dissertation may be summarized as follows:

[1] Pre-eruption magma mixing for the GRB magma is evident from zoning of plagioclase and clinopyroxene crystals, (i.e., augite rimming opx and pigeonite), resorption of phenocrysts, and mingling textures.

[2] Low pressure fractionation is evident from the clustering of GRB lava compositions near the 1-atm pseudo-cotectic on phase diagrams (augite-olivine-quartz pseudo ternary projections). The plagioclase+augite+pigeonite basaltic assemblage of the GRB lavas, is typical of melts that fractionate in low pressure environments. Additionally, cpx compositions plotted on a pyroxene quadrilateral also point to a low-pressure fractionation environment for the GRB magmas. Thermometry and barometry calculations (Putirka, 2005) provide further evidence that these lavas last equilibrated in low-pressure (shallow crust) environments. These lines of evidence show that the GRB magma last fractionated in an upper crustal chamber(s), and not at the crust-mantle boundary (Moho).

[3] The presence of high-An plagioclase points to the presence of a hydrous source for at least some of the GRB magmas. However, low-pressure equilibrium and inverse/forward modeling of the GRB data require very little $\mathrm{H}_{2} \mathrm{O}(\sim 0.5 \mathrm{wt} . \%)$ to be present in the shallow magma chamber(s). Thus, these plagioclase crystals may have formed in deeper conduits from more hydrous melts which later degassed or these can be xenocrysts. 
[4] Most of the CRBG magmas were formed, or last equilibrated, with a fertile spinel lherzolite at approximately $15 \mathrm{~kb}(45 \mathrm{~km})$, these conclusions/observations allow me to develop a reasonable petrotectonic model for the generation of the GRB.

\section{Alternative Models to the Plume Hypothesis}

As stated in the Introduction, there are essentially two types of tectonic models that try to explain the generation of the CRBG magmas - one of these calls for plume melting and the other - backarc spreading. I evaluate these hypotheses in a general way on the basis of my new findings.

It is clear from the present study that the primary magmas were generated at 15 kb, very close to the Moho. For this to occur, the lithosphere had to be greatly thinned underneath the plateau allowing hot asthenosphere, possibly hydrated by the fluids released from the subducting Farallon plate, to rise to shallow depths $(\sim 45-50 \mathrm{~km})$. A recent seismic tomography model noted the occurrence of a thick, high-density horizon beneath the Wallowa Mountains (Columbia plateau), and interpreted it to be residues of the CRBG melting event (Hales et al., 2005). Hales et al. (2005) further inferred that thinning of the lithosphere was caused by the continued back-arc extension created by subduction to the west. This resulted in the dislodging of a large piece of the lower lithosphere. This is entirely consistent with the depth constraints of magma generation mechanism that I discussed above.

Current conditions below the Cascade Arc could have been similar in the midMiocene, when the bulk of the CRBG lavas were erupted. Compositions of parental liquids and temperatures were calculated from the most primitive Cascade arc samples available, this was done by using Fe-Mg equilibrium with a mantle peridotite (Leeman et 
al., 2004). They assumed that magmas ascended from accumulation zones and estimated pressure and temperature of segregation of these magmas. Leeman et al. (2004) determined that the temperature beneath the Cascade Arc today is warmer than in normal arc settings. If conditions were similar 17 to 16 million years ago, it could explain the melting of larger volumes of lava beneath the plateau. The elevated temperatures due to the subduction of a younger slab (Farallon plate), could have raised the temperature above the slab. The combination of detachment of the lower lithosphere, and addition of fluids to the asthenosphere maybe have created an unusual hot and wet situation to exist in the asthenosphere reaching close to the Moho, resulting in sudden production of melts that became the GRB primary magmas. This model is presented schematically in figure 43. The magmas are generated or last equilibrated with largely peridotitic material at a shallow depth $(45 \mathrm{~km})$. Such magmas escaped through the feeder dikes that formed during the back-arc extension event. In this view, the presence of a hot plume is not necessary. However, a plume is not entirely ruled out by this model.

\section{Back to the Plume Model Hypothesis}

Although the back arc spreading model offers some convincing alternatives to the plume model, the large magma volumes present in the CRBG plateau continue to be a troubling aspect and cannot be fully explained by the back arc spreading model. Furthermore, considering that there are other areas with similar tectonic settings, where LIPs are not present, it seems unlikely that this model alone can explain the voluminous GRB lavas. There are aspects of this model however that can be used in conjunction with a plume model to explain the unique characteristics seen in the CRBG. For example, crustal thinning and the formation of fissures due to back arc spreading may have 
facilitated the upward mobility of magma. This tectonic scenario could have allowed large volumes of magma from the plume to follow a "path of least resistance" and briefly fractionate underneath the plateau before erupting. Because seismic tomography detects an area where a large amount of melt was extracted beneath the CRBG plateau, it is clear that magma chamber(s) or conduits are present beneath the plateau. Therefore, as my work shows, the lavas last fractionated in crustal chamber beneath the plateau and large collapse structures are not required (see discussion in INTRODUCTION; Hooper et al., 1982).

The problem with the absence of the plume source beneath the plateau can be explained in a manner similar to what Geist and Richards (1993; figure 3) and/or Camp et al. (2004) have proposed. The first scenario calls for the shearing and deflection of the Yellowstone plume head by the subducting Farallon plate resulting in the plume head moving northward underneath the Columbia Plateau. The alternative model of Camp et al. (2004) calls for the presence of giant radiating dike swarms that traveled approximately $500 \mathrm{~km}$ north to the Columbia plateau. Either way, once the magma reached the area, it had to fractionate for a short period of time in crustal chambers before erupting and forming the CRBG as is indicated by the seismic tomography (Hales, 2005). Future Work

Because my geochemical models indicate that the GRB magma last equilibrated with a spinel lherzolite source at approximately $15 \mathrm{~kb}$, experiments at this pressure are necessary to constrain and verify the geochemical modeling results I obtained. Furthermore, the addition of various amount of $\mathrm{H}_{2} \mathrm{O}$ to these experiments would also serve to constrain what if any amount of $\mathrm{H}_{2} \mathrm{O}$ was present in the magma at this depth. An 
additional method that $\mathrm{I}$ would like to utilize to determine the amount of $\mathrm{H}_{2} \mathrm{O}$ in the CRBG magma would be to analyze melt inclusions in the Imnaha Formation. The Imnaha Formation would be ideal because of the higher abundance of phenocrysts in the lavas. Finally, it is apparent that the controversy of plume vs. non-plume sources for the CRBG has not yet been resolved. Therefore, I will continue to investigate the tectonic setting in the plateau so that I can better constrain the source for the generation of the CRBG continental flood basalt. 


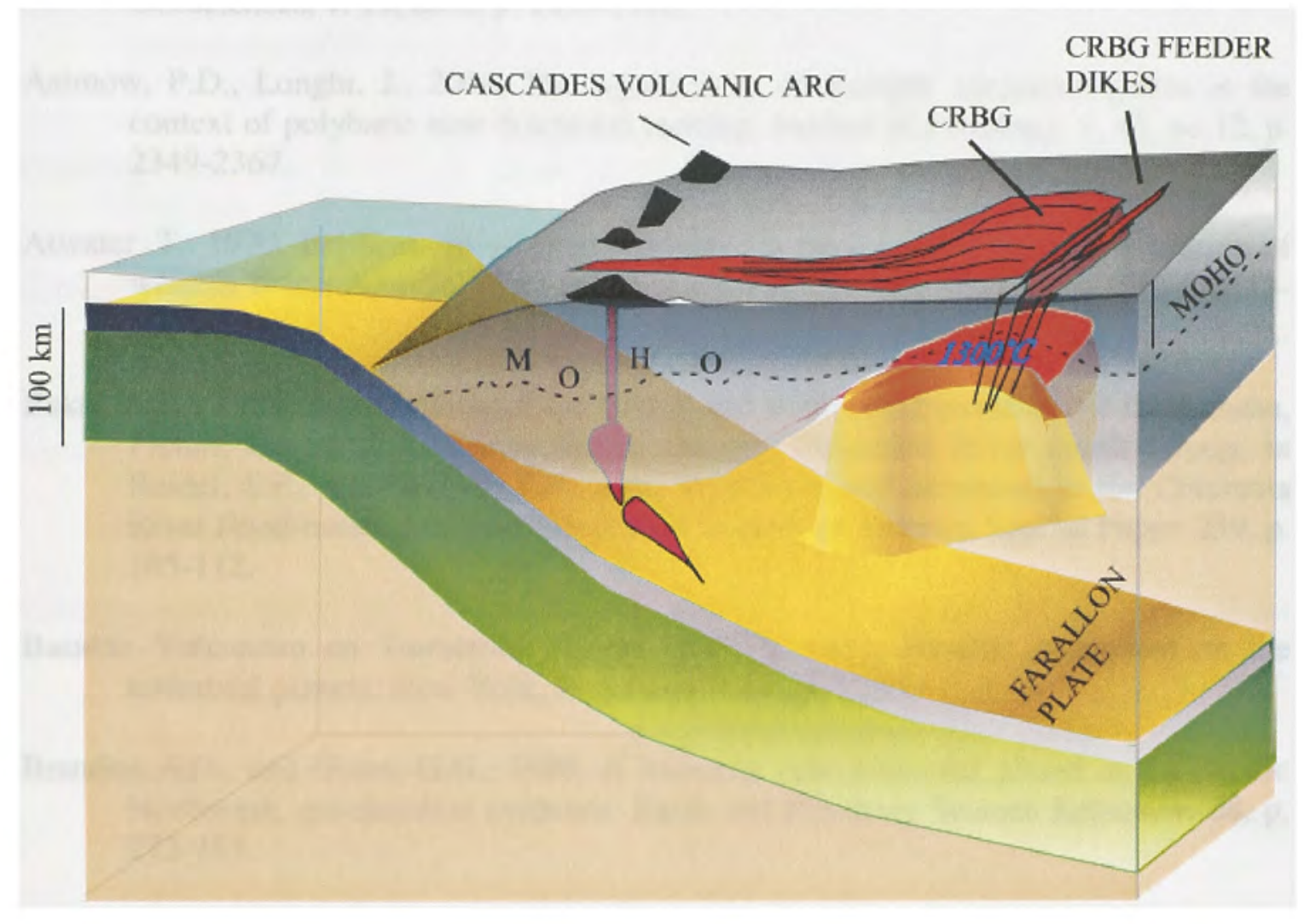

Figure 43-Diagram depicting the conditions that led to magma segregation below the CRBG plateau. As the Farallon Plate was being subducted under the North America Plate, the release of volatile caused melting to occur above the Farallon Plate. In addition, the extensional environment in this area caused thinning of the lithosphere. As a consequence, decompressional melting occurred. It is possible that a combination of two or more processes combined to form the large volumes of lava erupted to produce the flood basalt province. 


\section{REFERENCES CITED}

Almeev, R., Ozerov, A., Ariskin, A.A., Kimura, J., in http://www.ozerov.ru/papers/k080p004_e.pdf.

Ariskin, A.A., Frenkel, M.Y., Barmina, G.S., Nielsen, R.L., 1993, COMAGMAT: a FORTRAN program to model magma differentiation processes: Computers and Geosciences, v. 19, no.8, p. 1155-1170.

Asimow, P.D., Longhi, J., 2004, The significance of multiple saturation points in the context of polybaric near-fractional melting: Journal of Petrology, v. 45, no.12, p. 2349-2367.

Atwater, T., 1970, Implications of plate tectonics for the Cenozoic tectonic evolution of western North America: Geological Society of America Bulletin, v. 81, p. 35133536.

Baksi, A.K., 1989, Reevaluation of the timing and duration of extrusion of the Imnaha, Picture Gorge, and Grande Ronde Basalts, Columbia River basalt Group, in Reidel, S.P., and Hooper, P.R., eds., Volcanism and tectonism in the Columbia River flood-basalt province: Geological Society of America Special Paper 239, p. 105-112.

Basaltic Volcanism on Terrestrial Planets (BVTP), 1981, Basaltic volcanism on the terrestrial planets: New York, Pergamon Press, p. 1286.

Brandon A.D., and Goles, G.G., 1988, A Miocene subcontinental plume in the Pacific Northwest, geochemical evidence: Earth and Planetary Science Letters, v. 88, p. 273-283.

Campbell, S.M. and Griffiths, R.W., 1990, Implications of mantle plumes for the evolution of basalts: Earth and Planetary Science Letters, v. 99, p. 79-93.

Camp, V.C., 1976, Petrochemical stratigraphy and structure of the Columbia River basalt, Lewiston basin area, Idaho-Washington: Washington State University, PhD. Dissertation.

Camp, V.E., Hooper, P.R., 1981, Geologic studies of the Columbia Plateau: Part I. Late Cenozoic evolution of the southeast part of the Columbia River Basalt Province: Geological Society of America Bulletin, v. 92, no.9, p. 659-668.

Camp, V.E., 1995, Mid-Miocene propagation of the Yellowstone mantle plume head beneath the Columbia River basalt source region: Geology, v. 23, no. 5, p. 435438. 
Camp, V.E., Ross, M.E., and Hanson, W.E., 2003, Genesis of flood basalts and Basin and Range volcanic rocks from Steens Mountain to the Malheur River Gorge, Oregon: Geological Society of America Bulletin, v. 115, p. 105-128.

Camp, V.E., Ross, M.E., 2004, Mantle dynamics and genesis of mafic magmatism in the intermontane Pacific Northwest: Journal of Geophysical Research B: Solid Earth, v. 109 , no. 8 p. B08204 1-14.

Caprarelli, G., and Reidel, S.P., 2005, A clinopyroxene-basalt geothermobarometry perspective of Columbia Plateau (NW-USA) Miocene magmatism: Terra Nova, v. 17, p. 265-277.

Caprarelli, G., and Reidel, S. P., 2004, Physical evolution of Grande Ronde Basalt magmas, Columbia River Basalt Group, north-western USA: Mineralogy and Petrology, v. 80, p. 1-25.

Carlson, R.W., Lugmair, G.W., Macdougall, J.D., 1981, Columbia River Volcanism: the question of mantle heterogeneity or crustal contamination: Geochimica, Cosmochimica Acta, v. 45, p. 2483-2499.

Carlson, R.W., 1984, Isotopic Constraints on Columbia River flood basalt fenesis and the nature of the subcontinental mantle: Geochimica, Cosmochimica Acta, v. 48, p. 2357-2372.

Carlson, R.W., Hart, W.K., 1988, Flood basalt volcanism in the northwestern United States: in Macdougall, J.D. eds., Continental Flood Basalts, Dordrecht, Kluwer Academic, p. 35-61.

Cashman, K.V., Mangan, M.T., Newman, S., 1994, Surface degassing and modifications to vesicle size distributions in active basalt flows: Journal of Volcanology and Geothermal Research, v. 61, no.1-2, p. 45-68.

Catchings, R.D.; Mooney, W.D., 1988, Crustal structure of east central Oregon: relation between Newberry Volcano and regional crustal structure: Journal of Geophysical Research, v. 93, no.B9, p. 10 081-10 094.

Christiansen, R.L., Lipman, P.W., 1972, Cenozoic volcanism and plate-tectonic evolution of the western United States. II Late Cenozoic: Philosophical Transactions of the Royal Society of London, v. 271 , v. 271 p. 249-284.

Clague, D.A., Moore, J.G., 1991, Geology and petrology of Mahukona volcano, Hawaii: Bulletin of Volcanology, v. 53, no.3, p. 159-172.

Coe, R.S., Stock, G.M., Lyons, J.J., Beitler, B., Bowen, G.J., 2005, Yellowstone hotspot volcanism in California? A paleomagnetic test of the Lovejoy flood basalt hypothesis: Geology: v. 33, no. 9, p. 697-700. 
Cordrey, M.J., Davies, G.F., Campbell, I.H., 1997, Genesis of flood basalts from eclogite-bearing mantle plumes: Journal of Geophysical Research, v. 102, no. 20, p. 179-197.

Decker, R.W., Wright, T.L., Stauffer, P.H., 1987, Volcanism in Hawaii: U.S. Geological Survey Professional Papers 1350, p. 1667.

De Paolo, D. J., Wasserburg, G. J., 1977, Nd in island arc and continental volcanic rocks: Eos, Transactions, American Geophysical Union, v. 58, no.6, p.533.

Dickinson, W.R., 1997, OVERVIEW: Tectonic implications of Cenozoic volcanism in coastal California: Geological Society of America Bulletin, v. 109, no. 8, p. 936954.

Dodson, A., Kennedy, B.M., DePaolo, D.J., 1997, Helium and neon isotopes in the Imnaha Basalt, Columbia River Basalt Group: Evidence for a Yellowstone plume source: Earth and Planetary Science Letters, v. 150, p. 443-451.

Duncan, R.A., Richards, M.A., 1991, Hotspots, mantle plumes, flood basalts, and true polar wander: Reviews of Geophysics, v. 29, no.1 p. 31-50.

Engebretson, D.C., Cox, A., Thompson, G.A., 1984, Correlation of plate motions with continental tectonics: Laramide to Basin-Range ( North America): Tectonics, v. 3, no.2, p. 115-119.

Erlank, A.J., Allsopp, H.L., Rickard, R.S., Menzies, M.A., Waters, F.G., Hawkesworth C.J., Haggerty, S.E., 1987, Evidence for mantle metasomatism in peridotite nodules from the Kimberley pipes, South Africa: In: Mantle Metasomatism Editor: Menzies M.A.; Hawkesworth C.J., Academic Press Year, p. 221-311.

Ernst, R.E., Wilson, L., Head, J.W., Parfitt, E., Grosfils, E., 1995, Giant radiating dyke swarms on Earth and Venus: Earth-Science Reviews, v. 39, no.1-2, p. 1-58.

Ernst, R.E., Buchanan, K.L., 2003, Recognizing mantle plumes in the geological record: Annual Review of Earth and Planetary Sciences, v. 31 p. 469-523.

Geist, D., and Richards, M., 1993, Origin of the Columbia Plateau and Snake River plain: Deflection of the Yellowstone plume: Geology v. 21, p. 789-792.

Goldstein, J.I., Newbury, D.E., Echlin, P., Joy, D.C., Romig, A.D., Lyman, C.E., Fiori, C., Lifshin, E., 1992, Scanning Electron Microscopy and X-Ray Microanalysis: New York, Plenum Press. 
Ghiorso, M.S., 1994, Algorithms for the estimation of phase stability in heterogeneous thermodynamic systems: Geochimica et Cosmochimica Acta, v. 58, no.24, p. 5489-5501.

Grove, T. L.; Bence, A. E., 1977, Experimental study of pyroxene-liquid interaction in quartz-normative basalt 15597: in Proceedings of the Eighth lunar science conference; petrogenetic studies of mare and highland rocks, eds. Merrill, R. B. Blanchard, D. D., Lofgren, G. E., Mendell, W. W., Gibson, M. S., Robertson, P. C., Gunter, K., Ancelin, M. A., Ridings, R., Eighth lunar science conference, Houston, Tex., United States, Pergamon Press, New York, N.Y., United States (USA).

Grove, T.L., Garlach, D.C., and Sando, I.W., 1982, Origin of calc-alkaline series lavas at Medicine Lake volcano by fractionation, assimilation, and mixing: Contributions to Mineralogy and Petrology, v. 80, p. 160-182.

Grove, T.L., and Bryan, W.B., 1983, Fractionation of pyroxene-phyric MORB at low pressure: an experimental study: Contributions to Mineralogy and Petrology, v. 84, p. 293-309.

Grove, T.L., Juster, T.C., and Perfit, M.R., 1989, Experimental investigations of low-Ca pyroxene stability and olivine-pyroxene-liquid equilibria at 1-atm in natural basaltic and andesitic liquids: Contributions to Mineralogy and Petrology, v. 103, p. 287-305.

Hales, T.C., Abt, D.L., Humphreys, E.D., Roering, J.J., 2005, A lithospheric instability origin for Columbia River flood basalts and Wallowa Mountains uplift in northeast Oregon: Nature, v. 438, no.7069, p. 842-845.

Hart W.K., Carlson, R.W., 1987, Tectonic controls on magma genesis and evolution in the northwestern United States: Journal of Volcanology and Geothermal Research, v. 32, p. 119-135.

Hawkesworth, C.J., Hergt, J.M., McDermott, F., Ellam, R.M.,1991, Destructive margin magmatism and the contributions from the mantle wedge and subducted crust: Australian Journal of Earth Sciences, v. 38, no.5, p. 577-594.

Helz, R.T., Wright, T.L., 1992, Differentiation and magma mixing on Kilauea's east rift zone: a further look at the eruptions of 1955 and 1960 . Part I, the late 1955 lavas: Bulletin of Volcanology, v. 54, no.5, p. 361-384.

Herzberg, C., O'Hara, M.J., 2002, Plume-associated ultramafic magmas of phanerozoic age: Journal of Petrology, v. 43, no.10, p. 1857-1883. 
Hirschmann, M. M., Ghiorso, M. S., Wasylenki, L. E., Asimow, P. D., Stolper, E. M., 1998, Calculation of peridotite partial melting from thermodynamic models of minerals and melts; I, Review of methods and comparison with experiments: Journal of Petrology, v.39, no.6, p.1091-1115.

Hirschmann, M. M., Asimow, P. D., Ghiorso, M. S., Stolper, E. M., 1999, Calculation of peridotite partial melting from thermodynamic models of minerals and metals; III, Controls on isobaric melt production and the effect of water on melt production: Journal of Petrology, v.40, no.5, p.831-851.

Hirose, K., Kushiro, I., 1992, Partial melting of dry peridotites at high pressures: determination of compositions of melts segregated from peridotite using aggregates of diamond: Earth and Planetary Science Letters, v. 114, no.1, p. 477489.

Hon, K., Kauahikaua, J., Denlinger, R., 1994, Emplacement and inflation of pahoehoe sheet flows: Observations and measurements of active lava flows on Kilauea Volcano, Hawaii: Geological Society of America Bulletin, v. 106, no. 3, p. 351370.

Ho, A.M., Cashman, K.V., 1997, Temperature constraints on the Ginkgo Flow of the Columbia River Basalt Group: Geology, v. 25, no.5, pp.403-406.

Hooper, P.R., 1982, The Columbia River Basalts: Science, v. 215, p. 1463-8.

Hooper, P.R., 1984, Physical and chemical constraints on the evolution of the Columbia River basalt: Geology, v. 12, p. 495-499.

Hooper P.R., Thiessen R.L., Kleck W.D., Knowles, C.R., Reidel, S.P., 1984, Imnaha basalt, Columbia River basalt group; Journal of Petrology v. 25, n. 2, p. 473-500.

Hooper, P.R., 1985, A case of simple magma mixing in the Columbia River Basalt Group: The Wilbur Creek, Lapwai, and Asotin Flows, Saddle Mountain Formation: Contributions to Mineralogy and Petrology, v. 91, p. 66-73.

Hooper, P.R., 1988, The Columbia River Basalt: in Macdougall, J.D. eds., Continental Flood Basalts, Dordrecht, Kluwer Academic, p. 1-33.

Hooper, P.R., and Reidel, S.P., 1989, Dikes and Vents Feeding the Columbia River Basalts: in Joseph, N.L., and others, eds., Geologic guidebook for Washington and adjacent areas: Washington Division of Geology and Earth Resources Information Circular 86, p. 255-273.

Hooper, P.R., 1990, The timing of crustal extension and the eruption of continental flood basalts: Nature, v. 345, p. 246-249. 
Hooper, P.R., and Hawkesworth, C.J., 1993, Isotopic and geochemical constraints on the origin and evolution of the Columbia River Basalt: Journal of Petrology, v. 34, p. 1203-1246.

Hooper, P.R., 1997, The Columbia River Flood Basalt Province: Current status, in J. H. Mahoney and M.F. Coffin eds., Large Igneous Provinces: Continental, Oceanic, and Planetary Flood Volcanism: Geophysical Monogram Services, Washington, D.C., v. 100, p. 1-27.

Hooper, P. R., 2000, Chemical Discrimination of Columbia River basalt flows:

Geochemical Geophysical Geosystems, v. 1, Paper number 2000 GC000040.

Hooper, P.R., Binger, G.B., and Lees, K.R., 2002, Ages of the Steens and Columbia River flood basalts and their relationship to extension-related calc-alkalic volcanism in eastern Oregon: Geological Society of America Bulletin, v. 114, p. 43-50.

Hooper, P.R., 2003, The Columbia River Basalts \& Yellowstone Hot Spot: A Mantle Plume? http:/www.mantleplumes.org/CRB.html.

Jackson, E. D., Silver, E. A., Dalrymple, G. B., 1972, Hawaiian-Emperor Chain and its Relation to Cenozoic Circumpacific Tectonics: Geological Society of America Bulletin, v. 83, no. 3, p. 601-617.

Keshav, S., Fei, Y., Gudfinnsson, G.H., Sen, G., 2004, High-pressure melting experiments on garnet clinopyroxenite and the alkalic to tholeitic transition in ocean-island basalts: Earth and Planetary Science Letters, v 223, no.3-4, p. 365379.

Keshav, S., Sen, G., 2001, Majoritic garnets in Hawaiian xenoliths: Preliminary results: Geophysical Research Letters, v. 28, no.18, p. 3509-3512.

Keszthelyi, L. ; Self, S., 1998, Some physical requirements for the emplacement of long basaltic lava flows: Journal of Geophysical Research B: Solid Earth, v.103, no.11, p. $27,447-27,464$.

Kuo, L.C., and Kirkpatrick, R.J., 1982, Preeruption history of phyric basalts from DSDP Legs 45 and 46: Evidence from morphology and zoning patterns in plagioclase: Contributions to Mineralogy and Petrology, v. 79, p. 13-27.

Kushiro, I., 1972, Determination of liquidus relations in synthetic silicate systems with electron probe analysis: the system forsterite-diopside-silica at 1 atmosphere: American Mineralogist, v. 57, p. 1260-1271. 
Latypov, R., Dubrovskii, M.M., Alapieti, T. T., 2001, Graphical analysis of the orthopyroxene-pigeonite-augite-plagioclase equilibrium at liquidus temperatures and low pressures: American Mineralogist, v. 86, p. 547-554.

Lange, R., 2002, Constraints on the preeruptive volatile concentrations in the Columbia River flood basalts: Geology, v. 30, p. 179-182.

Leeman, W.P., Conrey, R.M., Streck, M.J., Lewis, J.F., Evarts, R.C., 2005, Petrologic constraints on the thermal structure of the Cascades arc: Journal of Volcanology and Geothermal Research, v. 140, no.1-3, p. 67-105.

Lindsley, D.H., 1983, Pyroxene thermometry: American Mineralogist, v. 68, p. 477-493.

Litasov, K.D., Ohtani, E., 2003, Effect of Alumina on Water Solubility in Lower Mantle Ferropericlase: Preliminary Results, Geophysical Research Abstracts, European Geophysical Society, v. 5, 05875.

Long P.E., and Wood, B.J., 1987, Structures, textures, and cooling histories of Columbia River basalt flows (USA): Geological Society of America Bulletin, v. 97, no.9 p. 1144-1155.

McDougall, I., 1976, Geochemistry and origin of basalt of the Columbia River Group, Oregon and Washington: Geological Society of America Bulletin, v.87, no.5, p.777-792.Mangan, M.T., Wright, T.L., Swanson, D.A., and Byerly, G.R., 1986, Regional correlation of Grande Ronde Basalt flows, Columbia River Basalt Group, Washington, Oregon, and Idaho: Geological Society of America Bulletin, v. 97 , p. $1300-1318$.

Mankinen, E.A., Larson, E.E., Gromme, C.S., Prevot, M., Coe, R.S., 1987, The Steens Mountain (Oregon) geomagnetic polarity transition: 3. Its regional significance: Journal of Geophysical Research, v. 92, p. 8057-8076.

Marsh, B.D., 1989, Magma chambers: Annual Review of Earth and Planetary Sciences, v. 17, p. $439-474$.

Marsh, B.D., 1996, Solidification fronts and magmatic evolution: Mineralogical Magazine, v. 60, p. 5-40.

McKee, E.H., Swanson, D.A., Wright, T.L., 1977, Duration and volume of Columbia River basalt volcanics, Washington, Oregon, and Idaho: Geological Society of America Abstract, Program 9, p. 463.

McKee, E.H., Hooper, P.R., Kleck, W.D., 1981, Age of Imnaha Basalt-oldest basalt flow of the Colombia River Basalt Group, northwestern U.S.: Isochron/West, v. 31, p. 31-33. 
Meibom, A., and Anderson, D.L., 2003, The statistical upper mantle assemblage: Earth and Planetary Science Letters, v. 217, p. 123-139.

Nelson, D.O., 1980, Strontium isotopic and trace element geochemistry of the Saddle Mountains and Grande Ronde Basalts of the Columbia River Basalt Group: Ph.D. Thesis Oregon State University, Corvallis.

Nelson, D.O., 1989, Geochemistry of the Grande Ronde Basalt of the Columbia River Basalt Group; A reevaluation of source control and assimilation effects: in Reidel, S.P., and Hooper, P.R., eds., Volcanism and Tectonism in the Columbia River flood-basalt province: Geological Society of America Special Paper 239, p. 333342 .

Pearce, T.H., 1984, The analysis of zoning in magmatic crystals with emphasis on olivine: Contributions to Mineralogy and Petrology, v. 86, no.2, p. 149-154.

Philpotts, A.R., and Carroll, M., 1996, Physical properties of partly melted tholeiitic basalt: Geology, v. 24, no. 11, p. 1029-1032.

Pierce, K.L., Morgan, L.A., 1992, The track of the Yellowstone hot spot: Volcanism, faulting, and uplift: in Link, P.K. Kuntz, M.A., Platt, L.B., eds., Regional Geology of Eastern Idaho and Western Wyoming: Geological Society of America Memoir 179, p. 1-53.

Putirka, K.D., 2005, Igneous thermometers and barometers based on plagioclase + liquid equilibria: Tests of some existing models and new calibrations: American Mineralogist, v. 90 , no. 2-3, p. 336-346.

Ragland, P.C., 1989, Basic Analytical Petrology: New York, Oxford University Press, p. 122-123.

Ramos, F.C., Wolff, J.A., Tollstrup, D.L., 2005, Sr isotope disequilibrium in Columbia River flood basalts: Evidence for rapid shallow-level open-systems processes: Geology, v. 33, no.6, p. 457-460.

Rampino, M., and Self, S., 2000, Volcanism and biotic extinctions, in Sigurdsson, H., et al., eds., The encyclopedia of volcanology: San Diego, Academic Press, p. 10831091.

Reichow, M.K., Al'Mukhamedov A.I., Medvedev, A.I., Kirda N.P., Saunders A.D., White, R.V., Pringle M.S., $2002,{ }^{40} \mathrm{Ar} /{ }^{39} \mathrm{Ar}$ dates from the West Siberian Basin: Siberian flood basalt province doubled: Science, v. 296 , no. 5574, p. 1846-1849. 
Reidel, S. P., 1978, The Stratigraphy and Petrogenesis of the Grande Ronde Basalt in the Lower Salmon and Adjacent Snake River Canyons: Ph.D Dissertation, Washington State University.

Reidel, S. P., 1983, Stratigraphy and Petrogenesis of the Grande Ronde Basalt from the Deep Canyon Country of Washington, Oregon, and Idaho: Geological Society of America Bulletin, v. 44, p. 519-542.

Reidel, S.P., Dick, B., Scott, G.R., Bazard, D.R., Cross, R.W., 1984, Post-12 million year clockwise rotation in the central Columbia Plateau, Washington: Tectonics, v. 3, no.2, p. 251-273.

Reidel, S.P., Tolan, T.L., Hooper, P.R., Beeson, M.H., Fecht, K.R., Bentley, R.D., and Anderson, J.L., 1989, The Grande Ronde Basalt, Columbia River Basalt Group: Stratigraphic descriptions and correlations in Washington, Oregon, and Idaho, in Reidel, S.P., and Hooper, P.R., eds., Volcanism and tectonism in the Columbia River flood-basalt province: Geological Society of America Special Paper 239, p. 21-53.

Reidel, S.P., and Tolan, T.L., 1992, Eruption and emplacement of flood basalt: An example from the large-volume Teepee Butte Member, Columbia River Basalt Group: Geological Society of America Bulletin, v. 104, p. 1650-1671.

Reidel, S.P., 1998, Emplacement of Columbia River flood basalt: Journal of Geophysical Research, v. 103, p. 27393-27410.

Reidel, S. P., 2005, A lava Flow without a Source: The Cohassett Flow and Its Compositional Components, Sentinel Bluffs Member, Columbia River Basalt Group: Journal of Geology, v. 113, p. 1-21.

Renne, P.R., 2002, Geology: Flood Basalts- Bigger and badder: Science, v. 296, no. 5574, p. 1812-1813.

Richards, M.A., Duncan, R.A., Courtillot, V., 1989, Flood basalts and hot spot tracks: plume heads and tails: Science, v. 246, p. 103-107.

Russell, J.K., Nicholls, J., 1990, Magma mixing processes: insights and constraints from Thermodynamic calculations: in Modern methods of igneous petrology, understanding magmatic processes, Reviews in Mineralogy, v. 24, p. 153-190.

Sack, R.O. ; Ghiorso, M.S., 1994, Thermodynamics of multicomponent pyroxenes: I. Formulation of a general model: Contributions to Mineralogy and Petrology, v. 116 , no.3, p. 277-286. 
Saltus, R.W., 1993, Upper-crustal structure beneath the Columbia River Basalt Group, Washington: gravity interpretation controlled by borehole and seismic studies: Geological Society of America Bulletin, v. 105, no.9, p. 1247-1259.

Schiffman, P., Lofgren, G.E., 1982, Dynamic Crystallization Studies On the Grande Ronde Pillow Basalts, Central Washington: Journal of Geology, v. 90, p. 49-78.

Self, S., Thordarson, T., and Keszthelyi, L., 1997, Emplacement of continental flood basalt lava flows, in Mahoney, J., and Coffin, M.F., eds., Large igneous provinces: Continental, oceanic, and planetary flood volcanism: American Geophysical Union Geophysical Monograph 100, p. 381-410.

Sen, G., 1983, Deccan Trap intrusion: Magma mixing in the Chalka-Delakhari sill, Chindwara district, Madhya Pradesh: Geological Society of India Journal, v. 24, no. 8, p. 381-393.

Sen, G., 2001, Earth's materials: Minerals and rocks: New Jersey, Prentice-Hall, 542 p.

Shaw, H. R.; Swanson, D. A., 1969, Eruption and flow rates of flood basalts: in 2nd Columbia River basalt symposium; proceedings, eds. Gilmour, Ernest H; Stradling, Dale, 2nd Columbia River basalt symposium, Cheney, WA, United States, Eastern Washington State College Press, Cheney, WA, United States (USA).

Shaw, H.R., Swanson, D.A, 1970, Eruption and flow rates of flood basalts: 2nd Columbia River basalt symposium; proceedings, Eastern Washington State College Press, Cheney, WA.

Sisson, T.W., and Grove, T.L., 1993, Experimental investigations of the role of $\mathrm{H}_{2} \mathrm{O}$ in calc-alkaline differentiation and subduction zone magmatism, Contributions to Mineralogy and Petrology, v. 113, p. 143-166.

Smith, A.D., 1992, Back-arc convection model for Columbia River basalt genesis: Tectonophysics, v. 207, p. 269-285.

Sugawara T., 2001, Ferric iron partitioning between plagioclase and silicate liquid: Thermodynamics and petrological applications: Contributions to Mineralogy and Petrology, v. 141, no.6, p. 659-686.

Swanson, D. A.,1972, Magma Supply Rate at Kilauea Volcano, 1952-1971: Science, v.175, no.4018, p.169-170.

Swanson, D.A., Wright, T.L., Helz, R.T., 1975, Linear Vent Systems and Estimated Rates of Magma Production and Eruption for Yakima Basalt on Columbia Plateau: American Journal of Science, v. 275, p. 877-905. 
Swanson, D.A., Wright, T.L., Hooper, P.R., and Bentley, R.D., 1979, Revisions in stratigraphic nomenclature of the Columbia River Basalt Group: U.S. Geological Survey Bulletin 1457G, p. 1-59.

Swanson, D.A., Cameron, Evarts, Pringle, and Vance, 1989, IGC Field Trip T106: Cenozoic Volcanism in the Cascade Range and Columbia Plateau, Southern Washington and Northernmost Oregon: American Geophysical Union Field Trip Guidebook T106, p.21-24.

Takahashi, E., Nakajima, K., and Wright, T.L., 1998, Origin of the Columbia River basalts: Melting model of a heterogeneous plume head: Earth and Planetary Science Letters, v. 162, p. 63-80.

Thordarson, T., Self, S., 1996, Sulfur, chlorine and fluorine degassing and atmospheric loading by the Roza eruption, Columbia River Basalt Group, Washington, USA: Journal of Volcanology and Geothermal Research, v. 74, p. 49-73.

Thy, P., Lesher, E.E., and Mayfield, J.D., 1999, Low-pressure melting studies of basalt and basaltic andesite from the South-East Greenland continental margin and the origin of dacites at Site 917, in Larsen, H.C., Duncan, R.A., et al., Proceedings of the Ocean Drilling Program: Scientific results, Volume 163: College Station, Texas, Ocean Drilling Program, p. 95-112.

Tolan, T.L., Reidel, S.P., Beeson, M.H., Anderson, J.L., Fecht, K.R., and Swanson, D.A., 1989, Revisions to the estimates of the areal extent and volume of the Columbia River Basalt Group, in Reidel, S.P., and Hooper, P.R., eds., Volcanism and tectonism in the Columbia River flood-basalt province: Geological Society of America Special Paper 239, p. 1-20.

Tormey, D.R., Grove, T.L., Bryan, W.B., 1987, Experimental petrology of normal MORB near the Kane Fracture Zone: $22^{\circ}-25^{\circ} \mathrm{N}$, mid-Atlantic ridge near: Contribution to Mineralogy and Petrology, v. 96, p. 121-139.

Walker, D., Shibata, T., and DeLong, S.E., 1979, Abyssal tholeiites from the Oceanographer Fracture Zone: II. Phase equilibria and mixing: Contributions to Mineralogy and Petrology, v. 70, p. 111-125.

Waters, A.C., 1961, Stratigraphy and lithologic variations in the Columbia River basalt: American Journal of Science, v. 259, p. 583-611.

Watkins A.C., Baksi A.K., 1974, Magnetostratigraphy and oroclinal folding of the Columbia River, Steens, and Owyhee basalts in Oregon, Washington, and Idaho: American Journal of Science, v. 274, p. 148-189. 
White, R., Mckenzie, D., 1989, Magmatism at Rift Zones- The Generation of Volcanic Continental Margins and Flood Basalts: Journal of Geophysical Research- Solid Earth and Planets, v. 94, p. 7685-7729.

Yang, H., Kinzler, R.J., Grove, T.L., 1996, Experiments and models of anhydrous, basaltic olivine-plagioclase-augite saturated melts from 0.001 to $10 \mathrm{kbar}$ : Contributions to Mineralogy and Petrology, v.124, p. 1-18.

Yaxley G.M.,2000, Experimental study of the phase and melting relations of homogeneous basalt + peridotite mixtures and implications for the petrogenesis of flood basalts: Contributions to Mineralogy and Petrology, v. 139, no.3, p. 326338. 


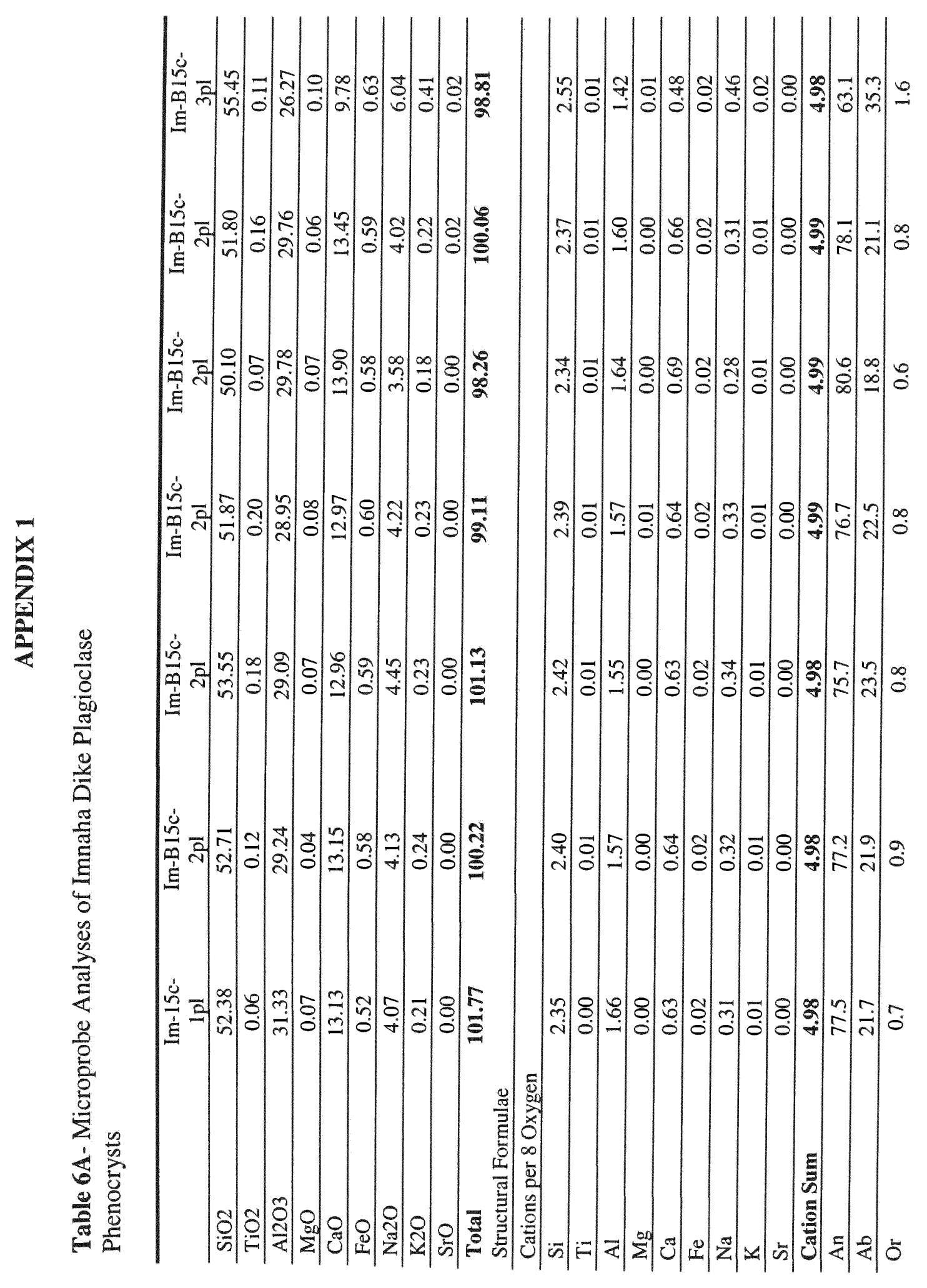

亏 


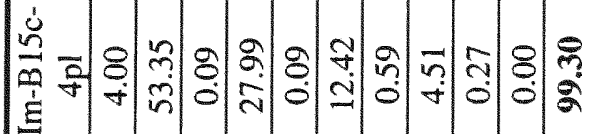

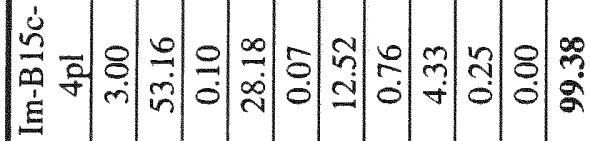

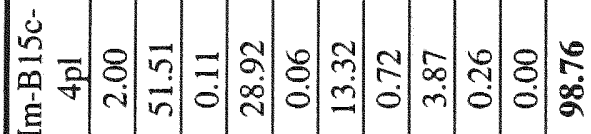

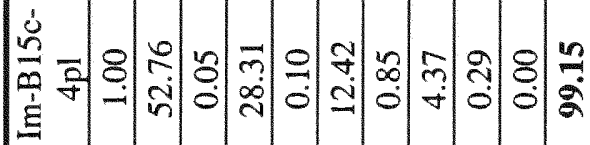
ह

离

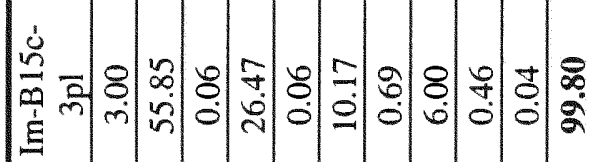

|
辛

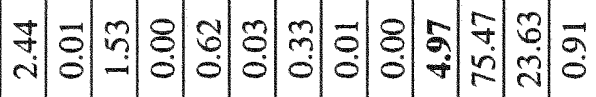

حે

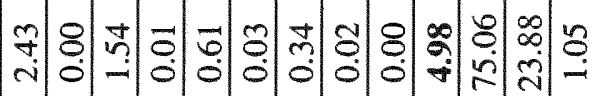

$\overbrace{\text { ก }}^{\infty}$

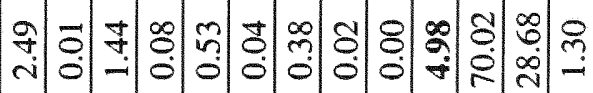

ñ

ñ

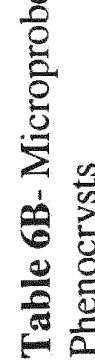




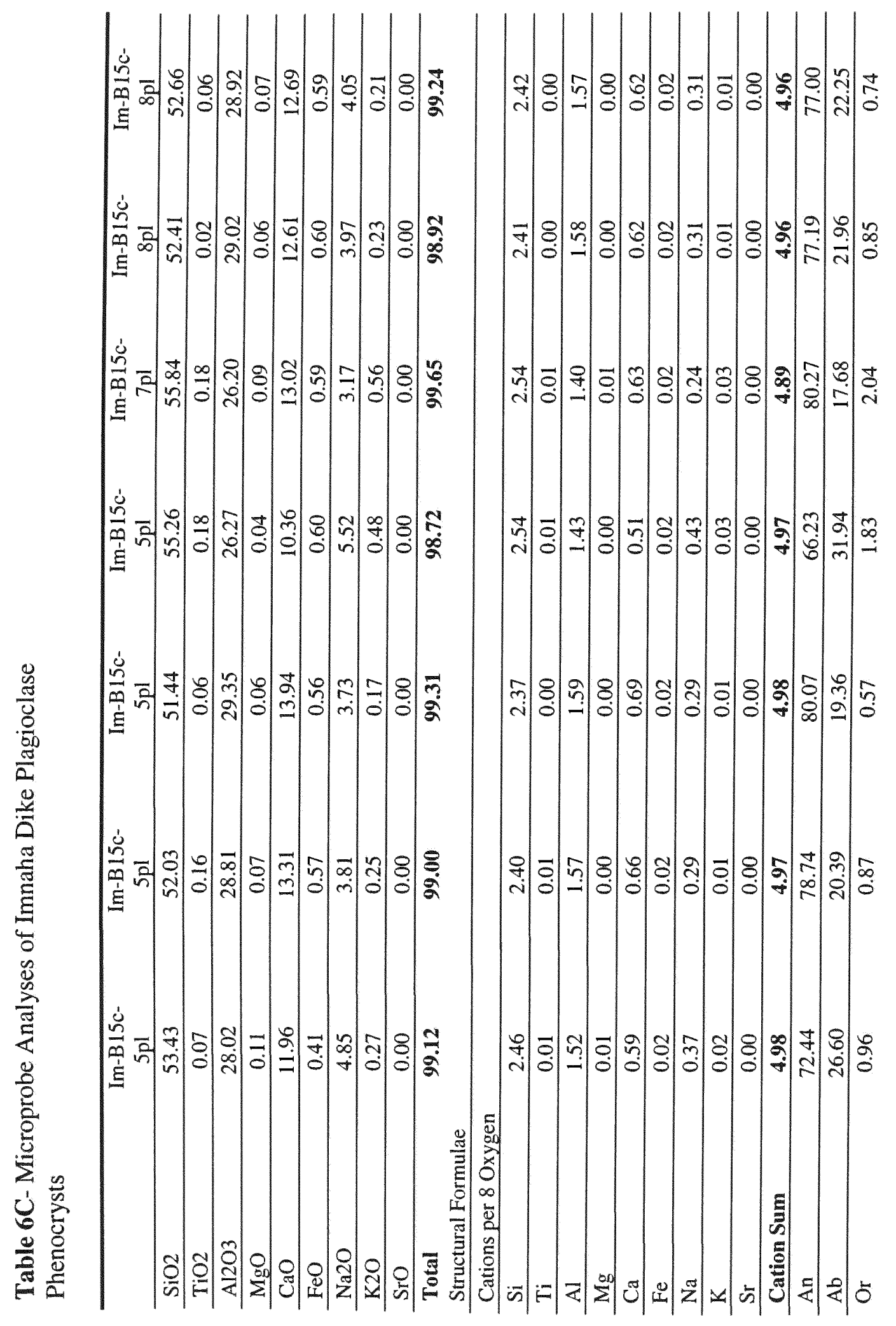




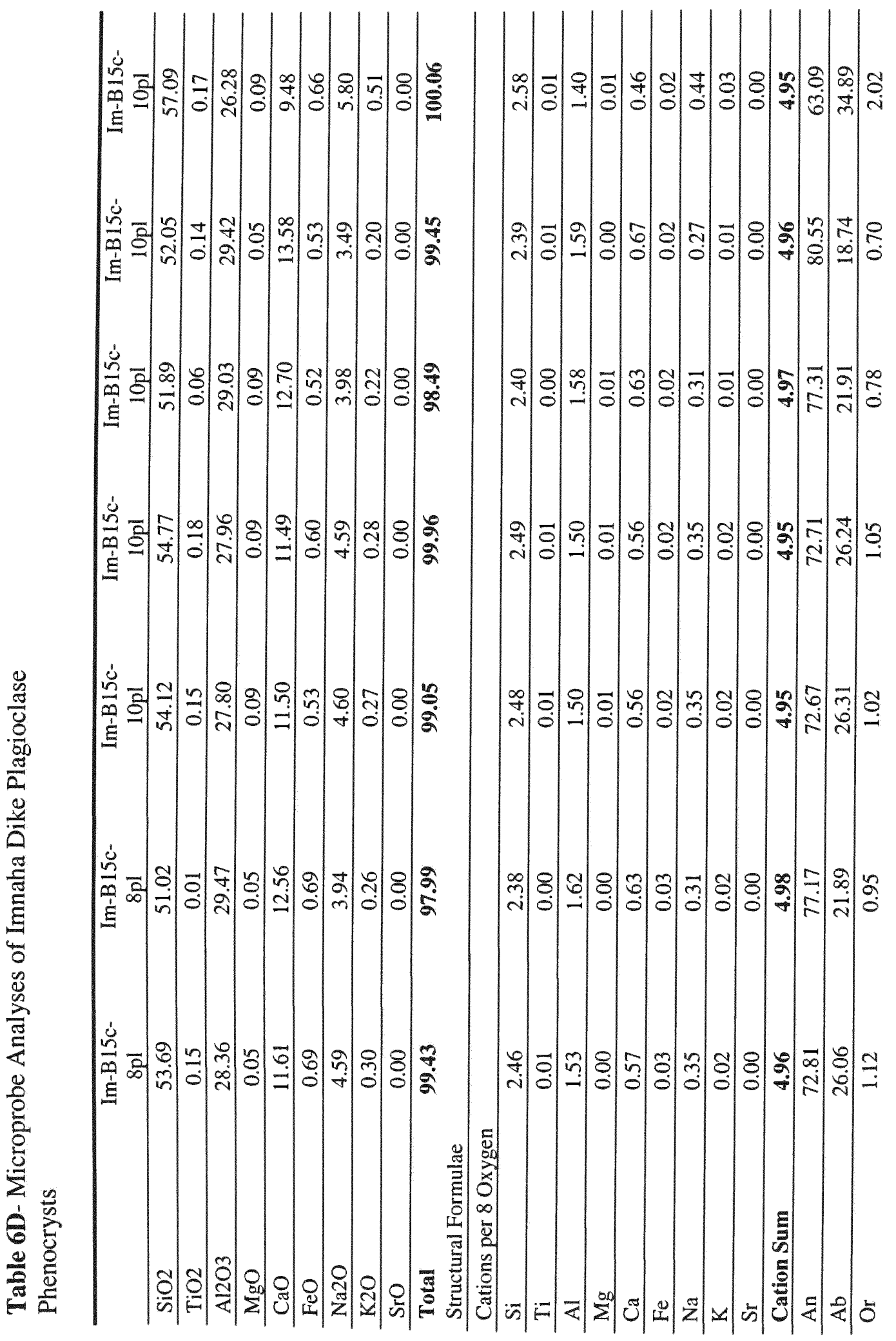

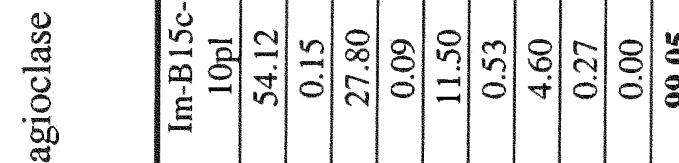

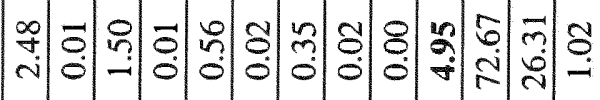

ब

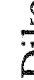

롤

อ

군

8

产 


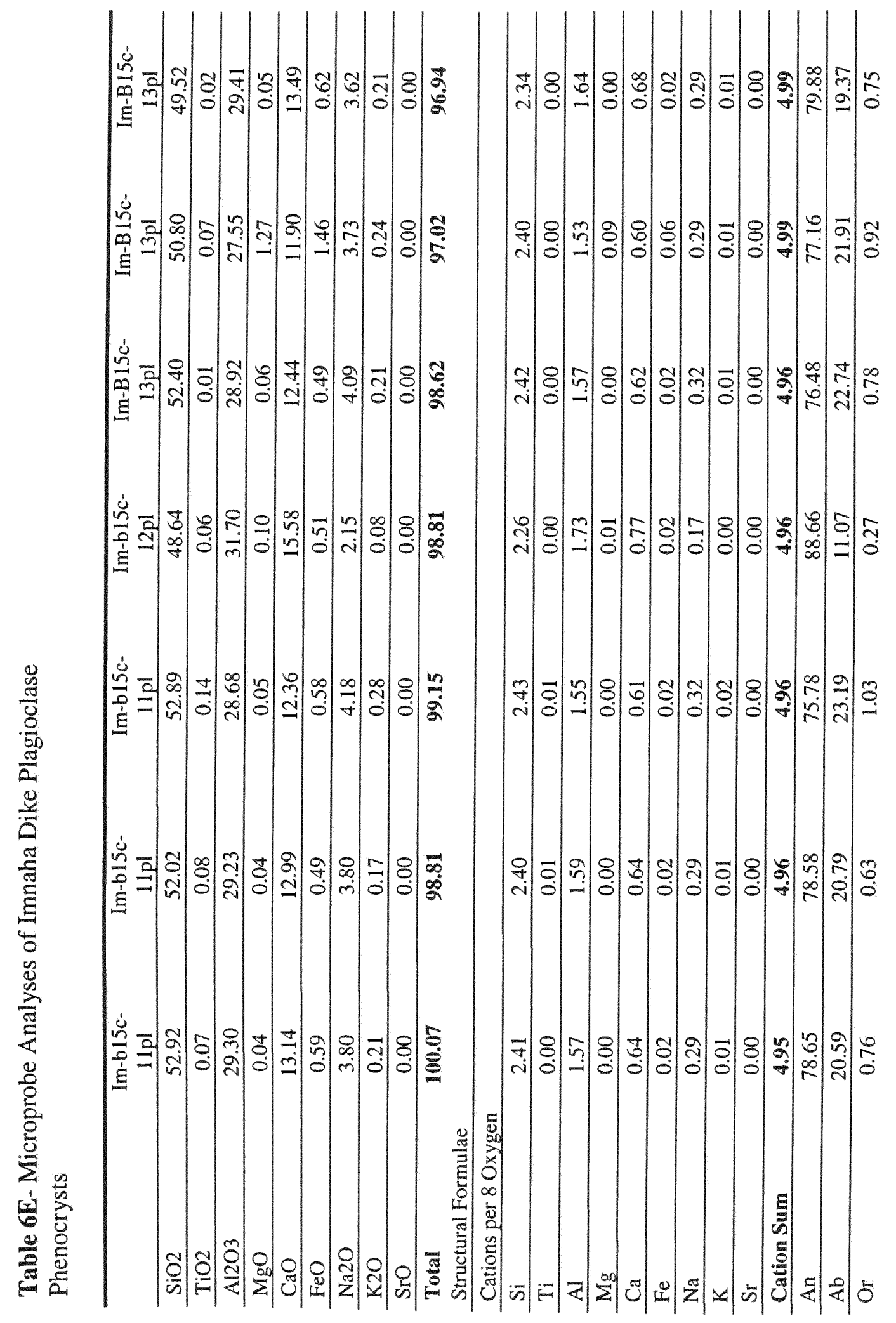




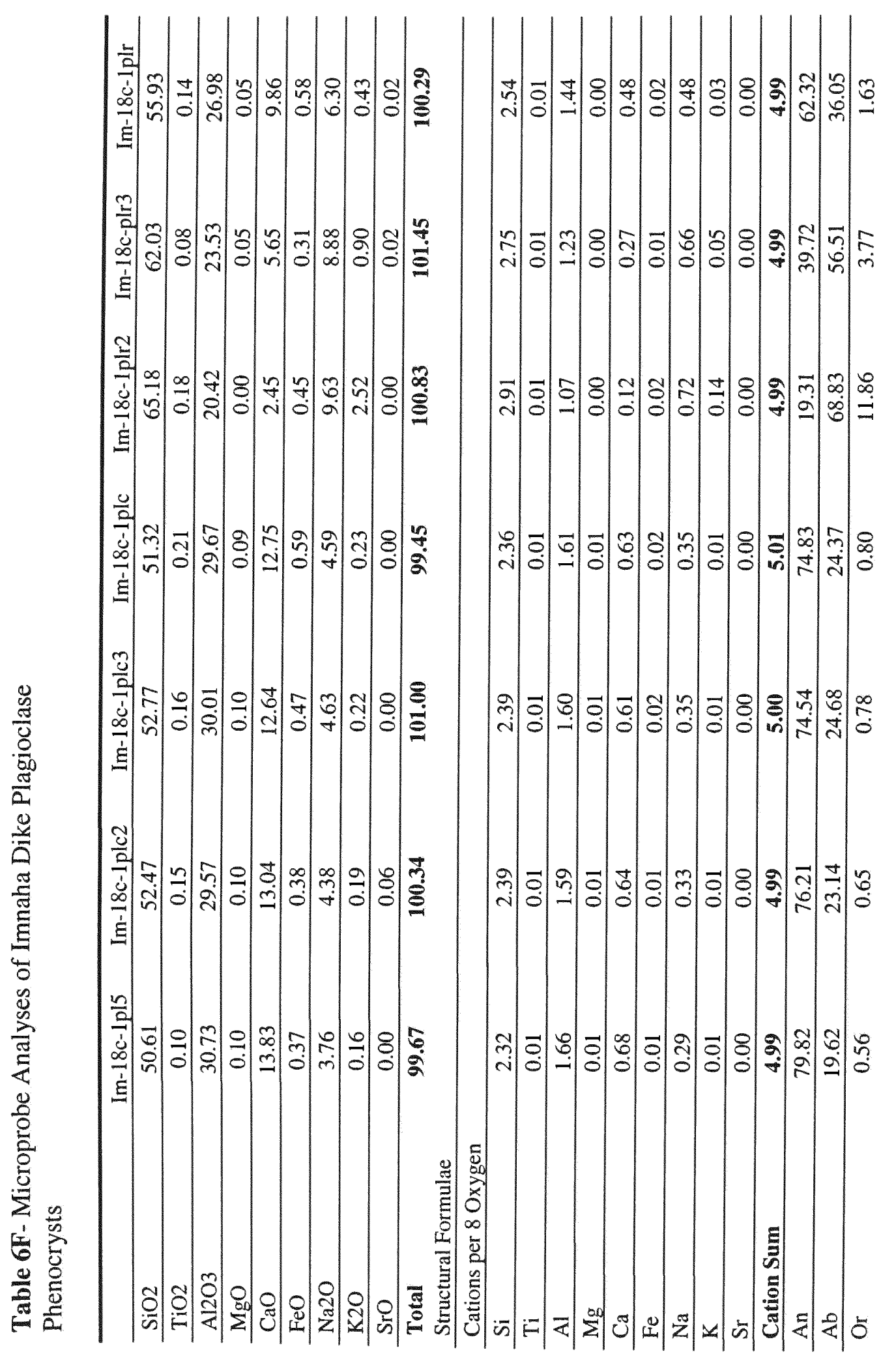




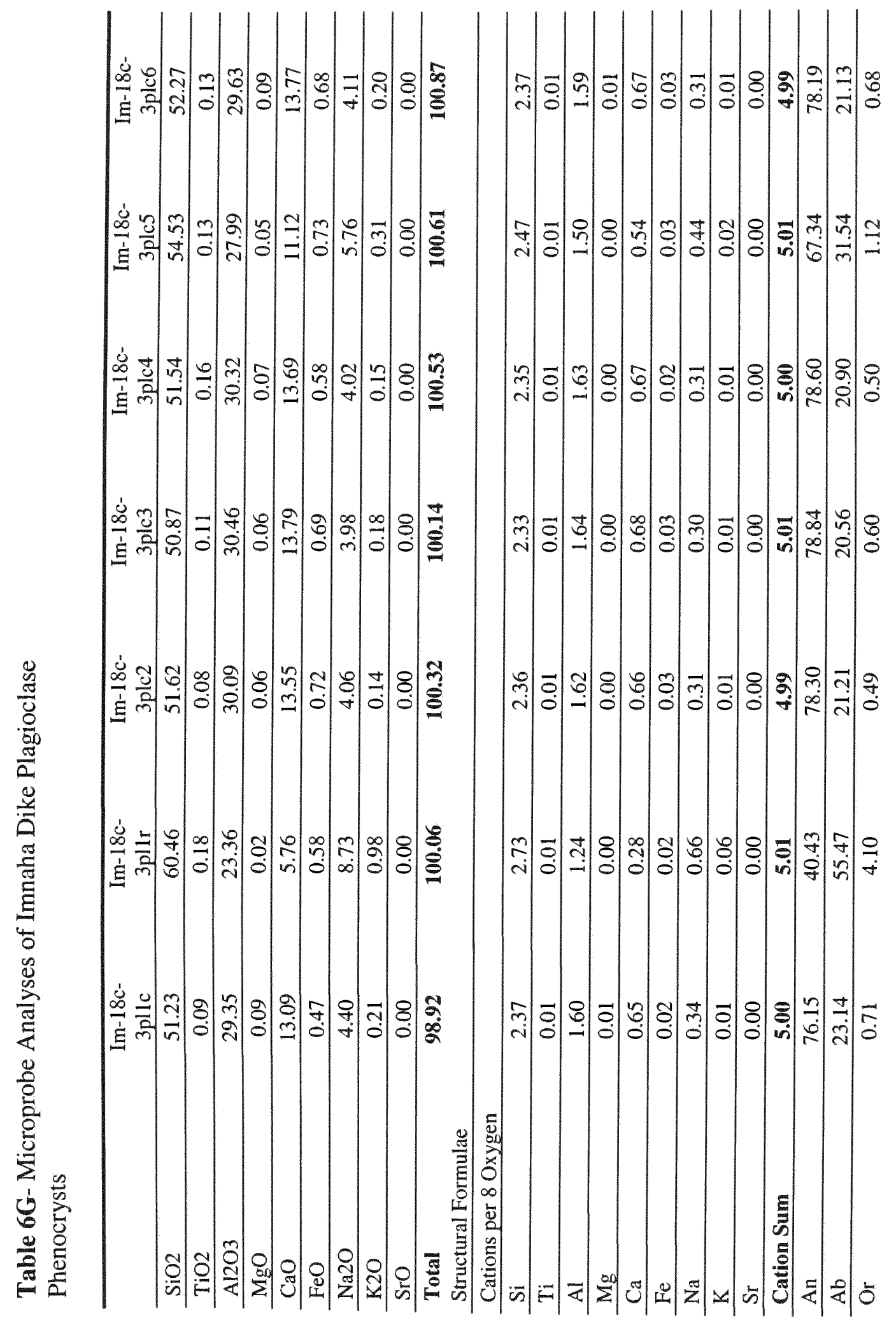

$\stackrel{m}{\pi}$ 


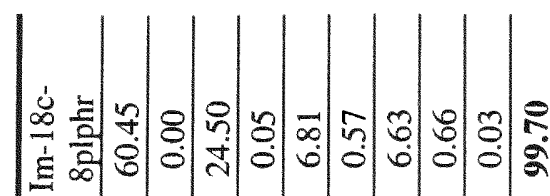

产

定

竞

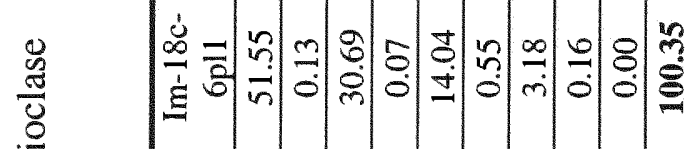

政

竞

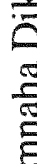

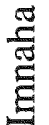

पे

s

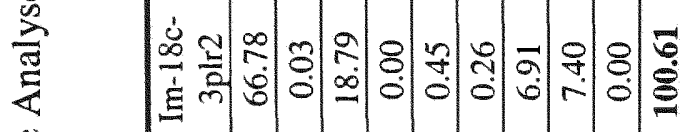

:

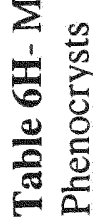

तิ

芒管

خ

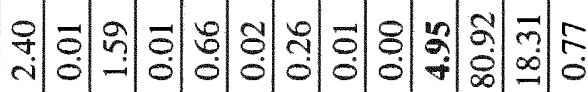

วิن

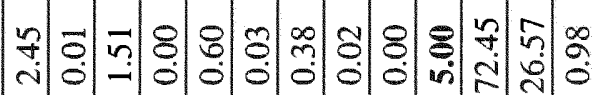

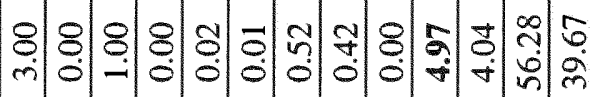

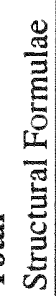




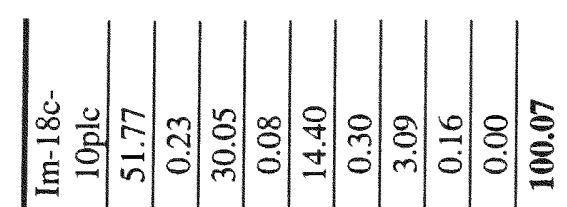

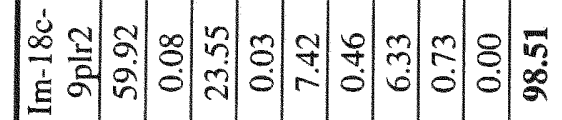

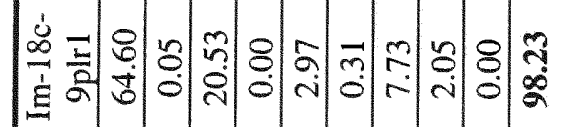

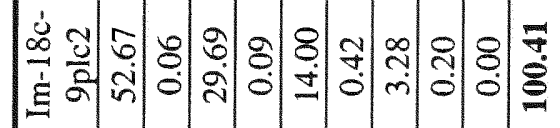

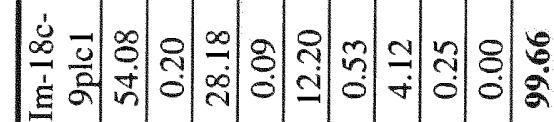

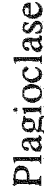

产

ํํำ

岩

竞

ํ․․

.

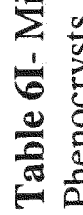

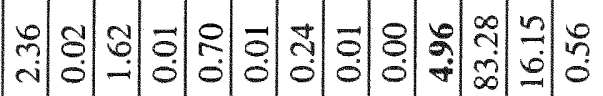

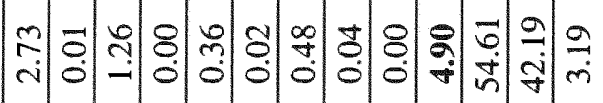

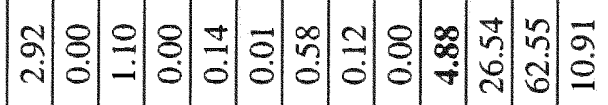

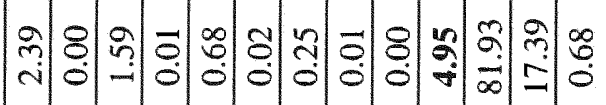

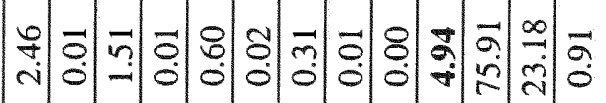

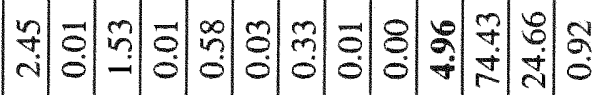

웟형 


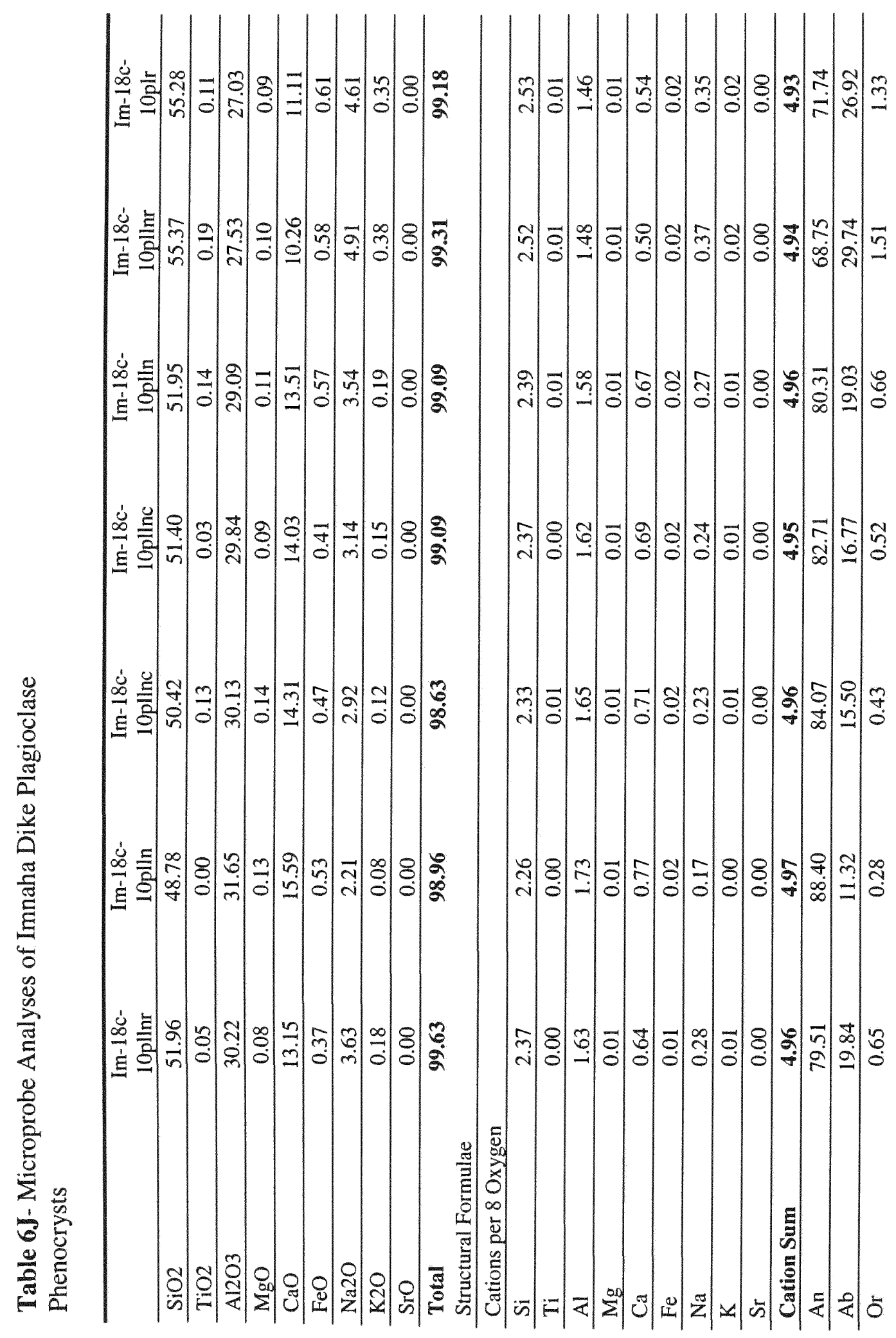




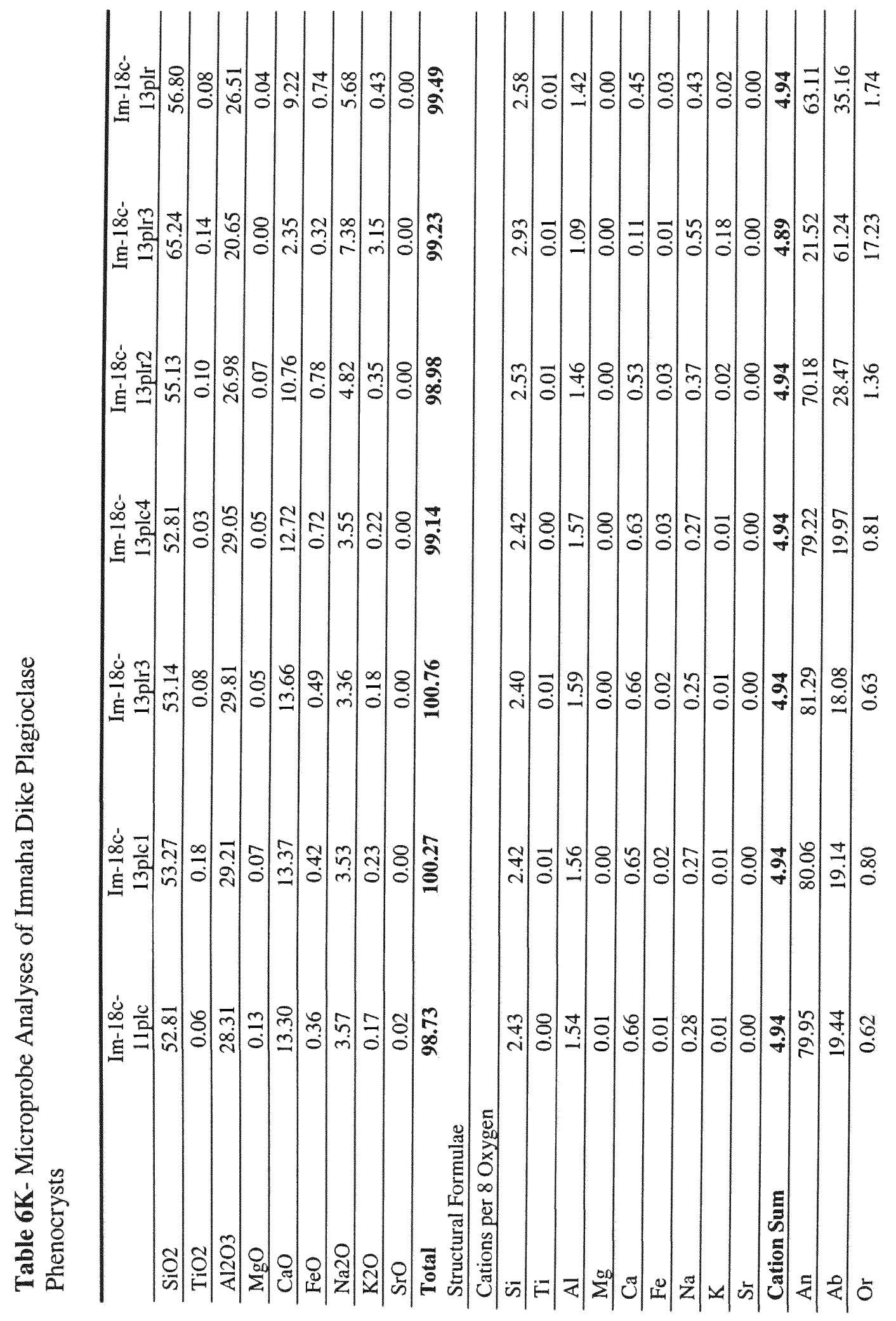




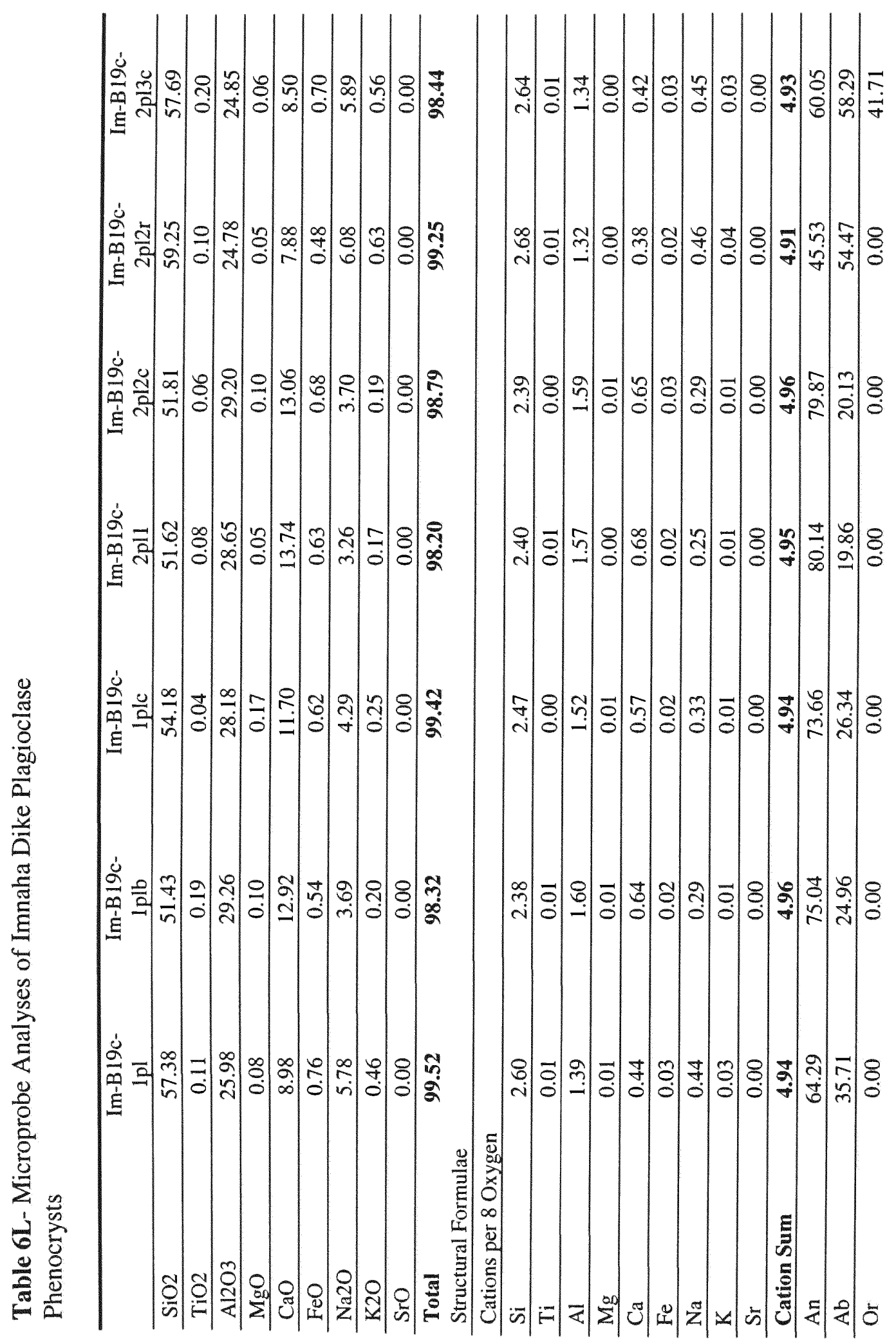




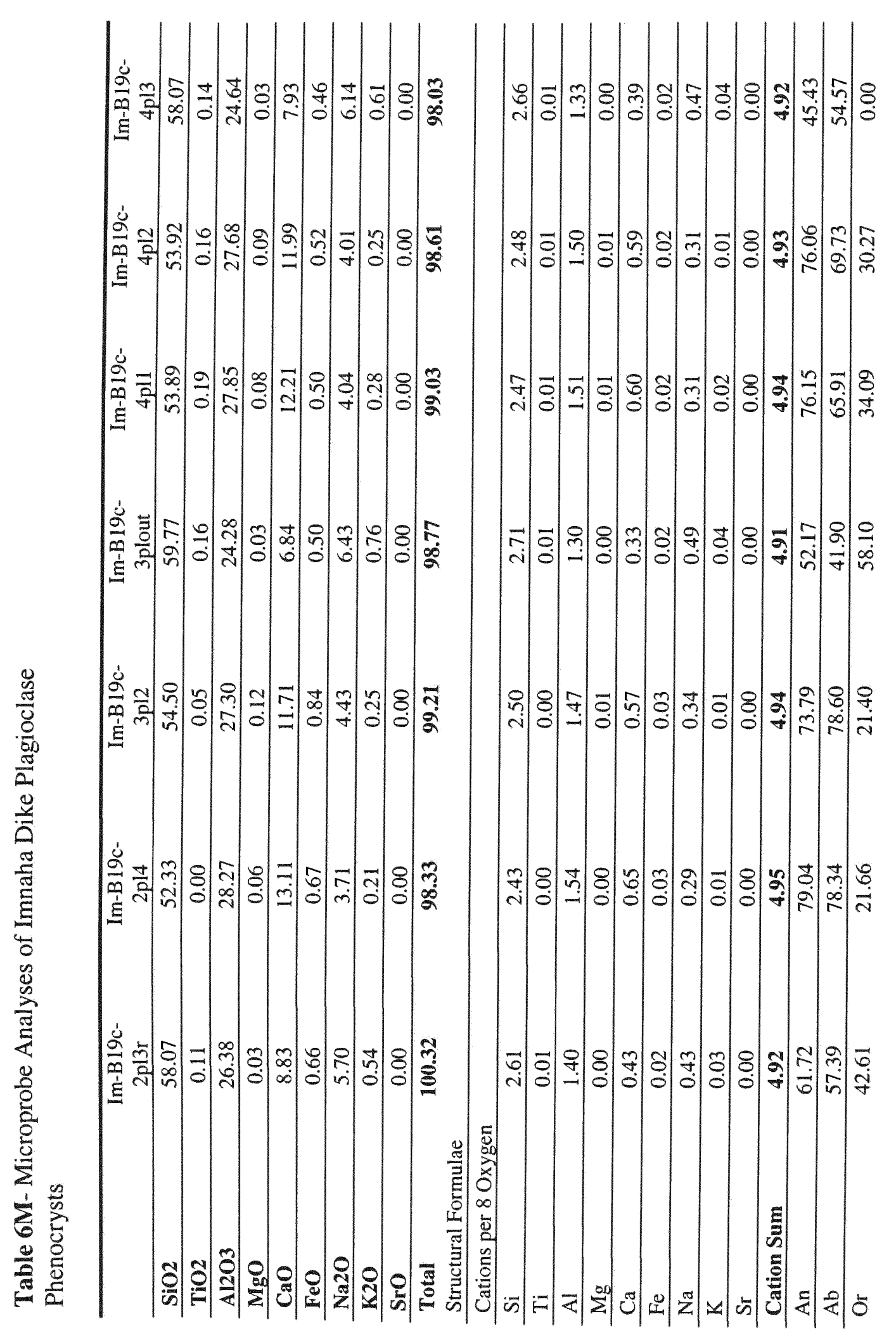




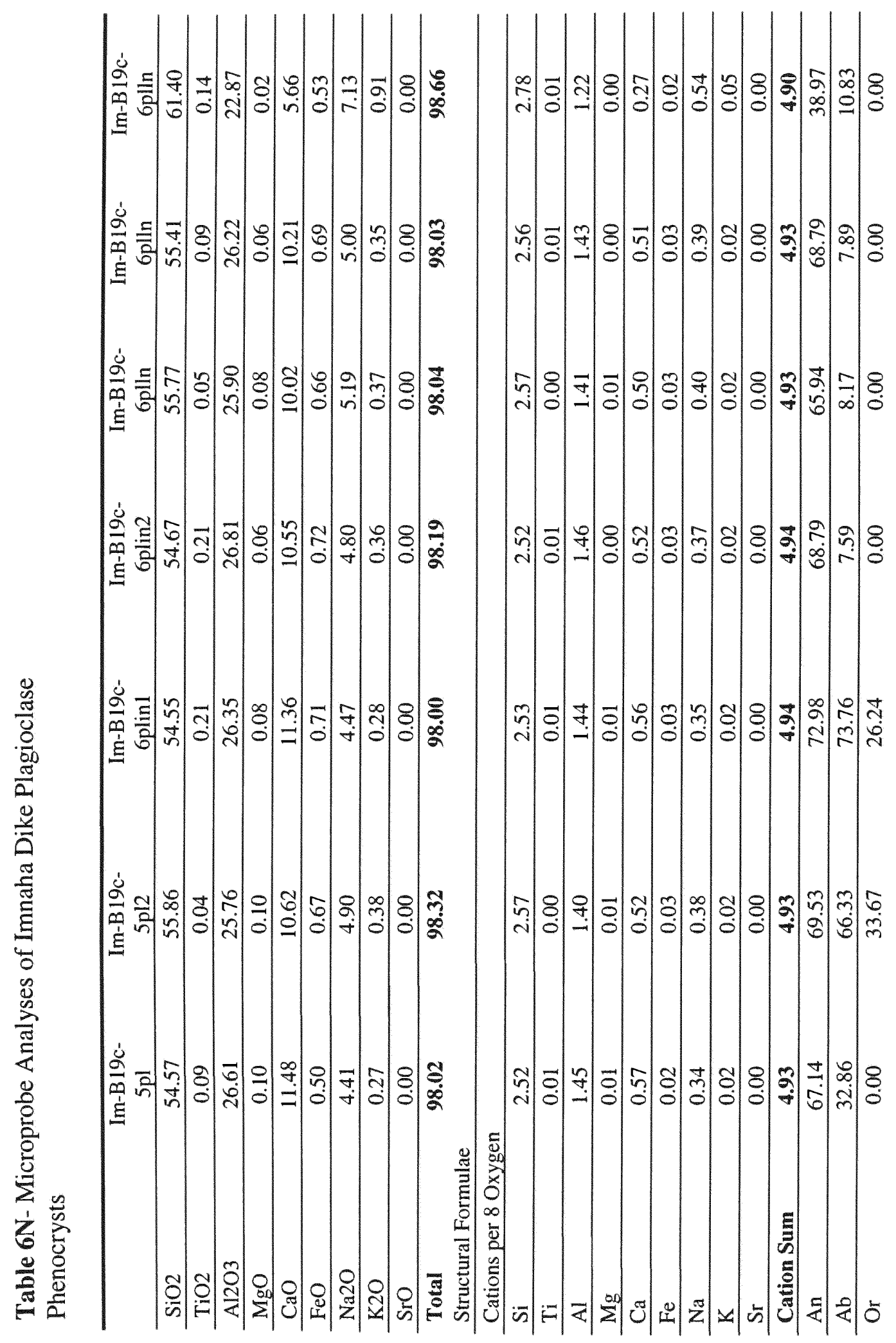




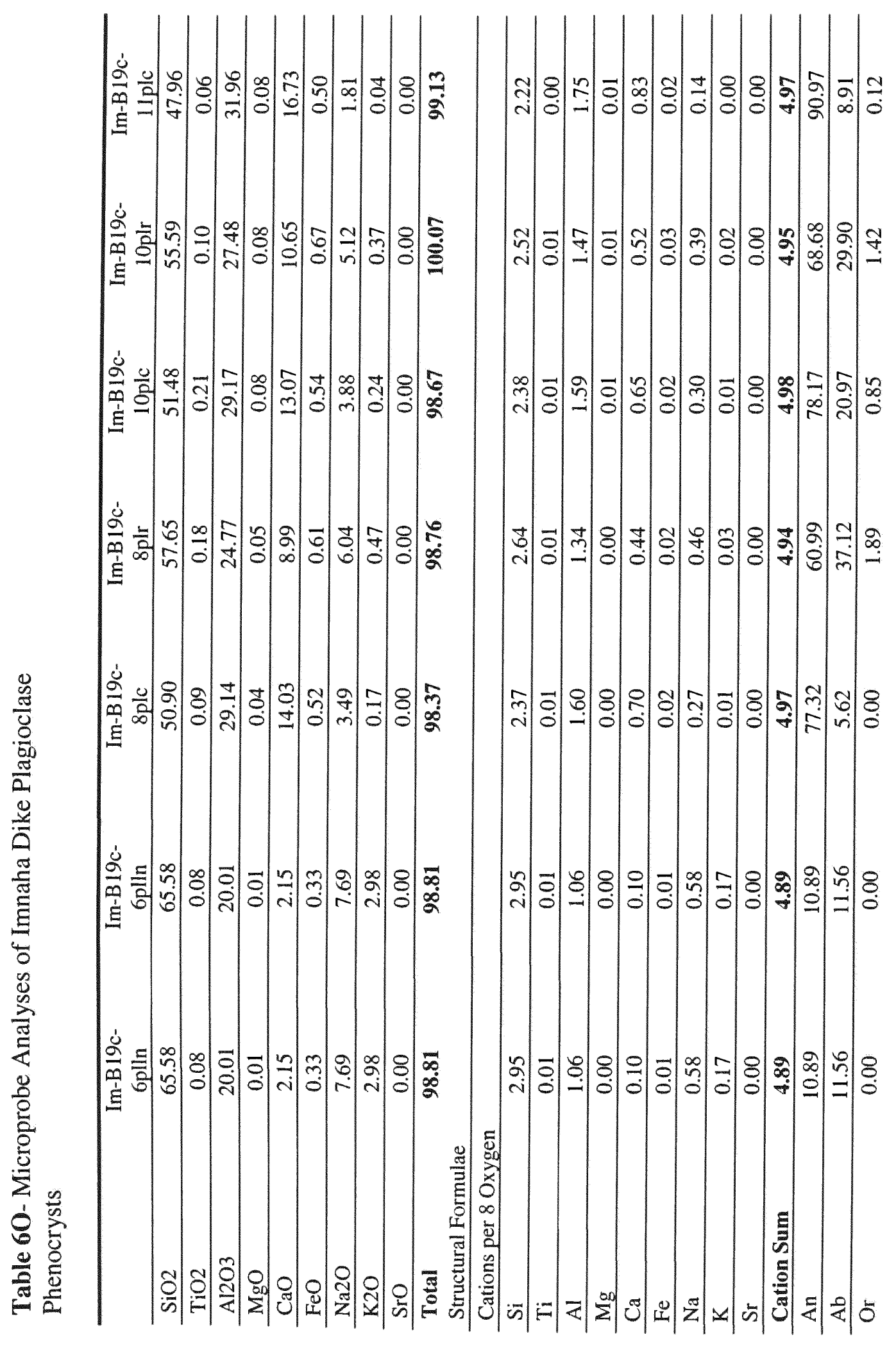




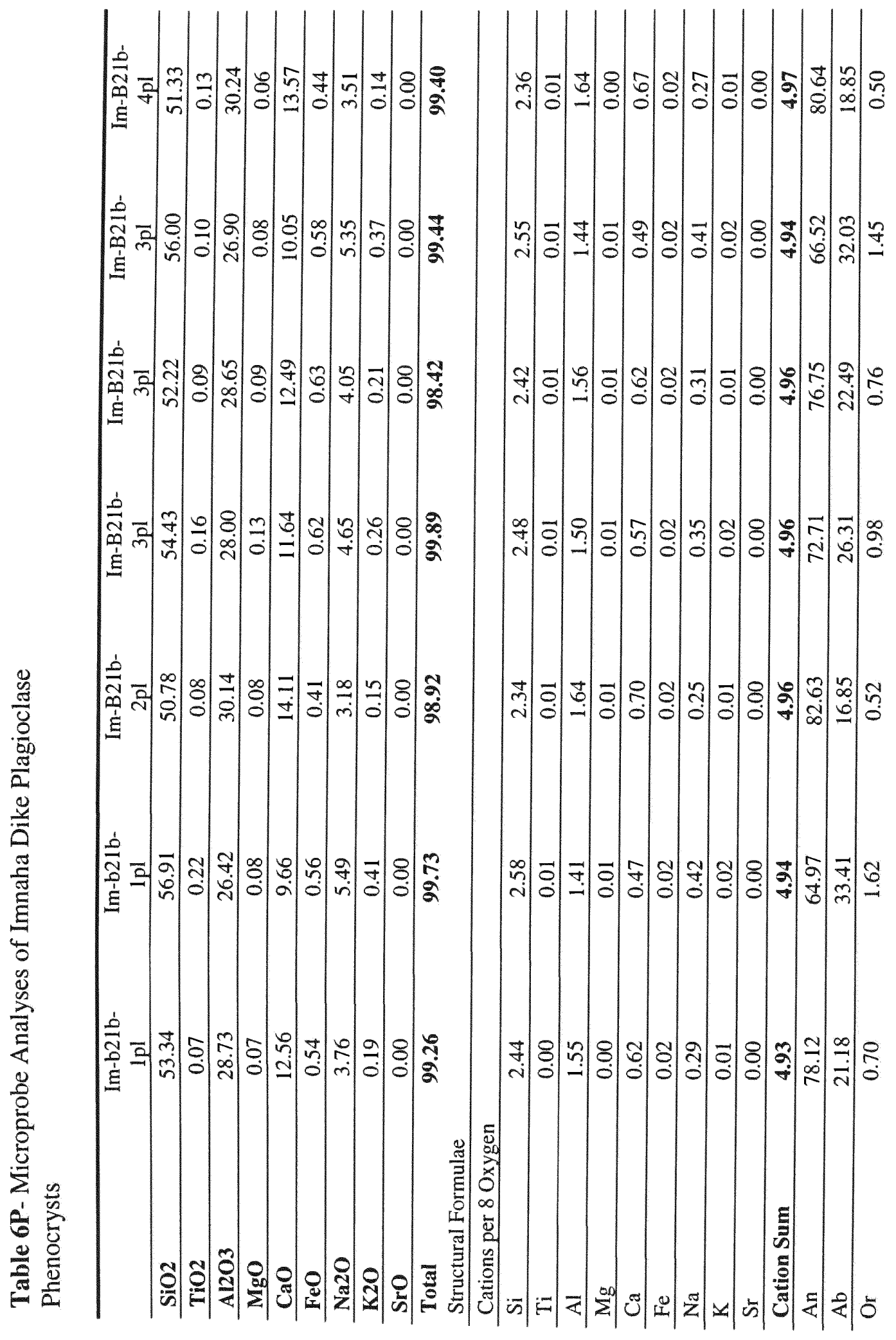




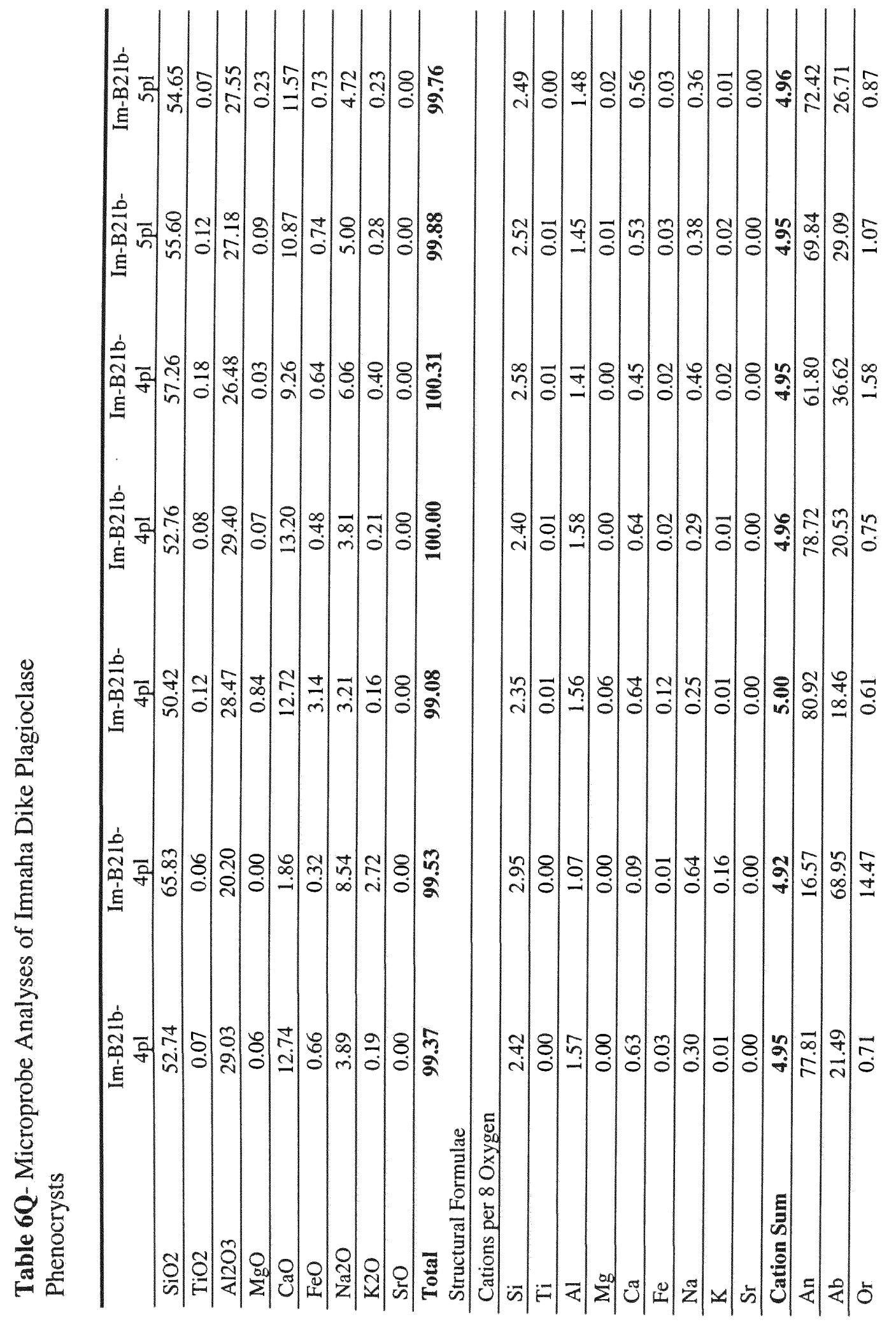




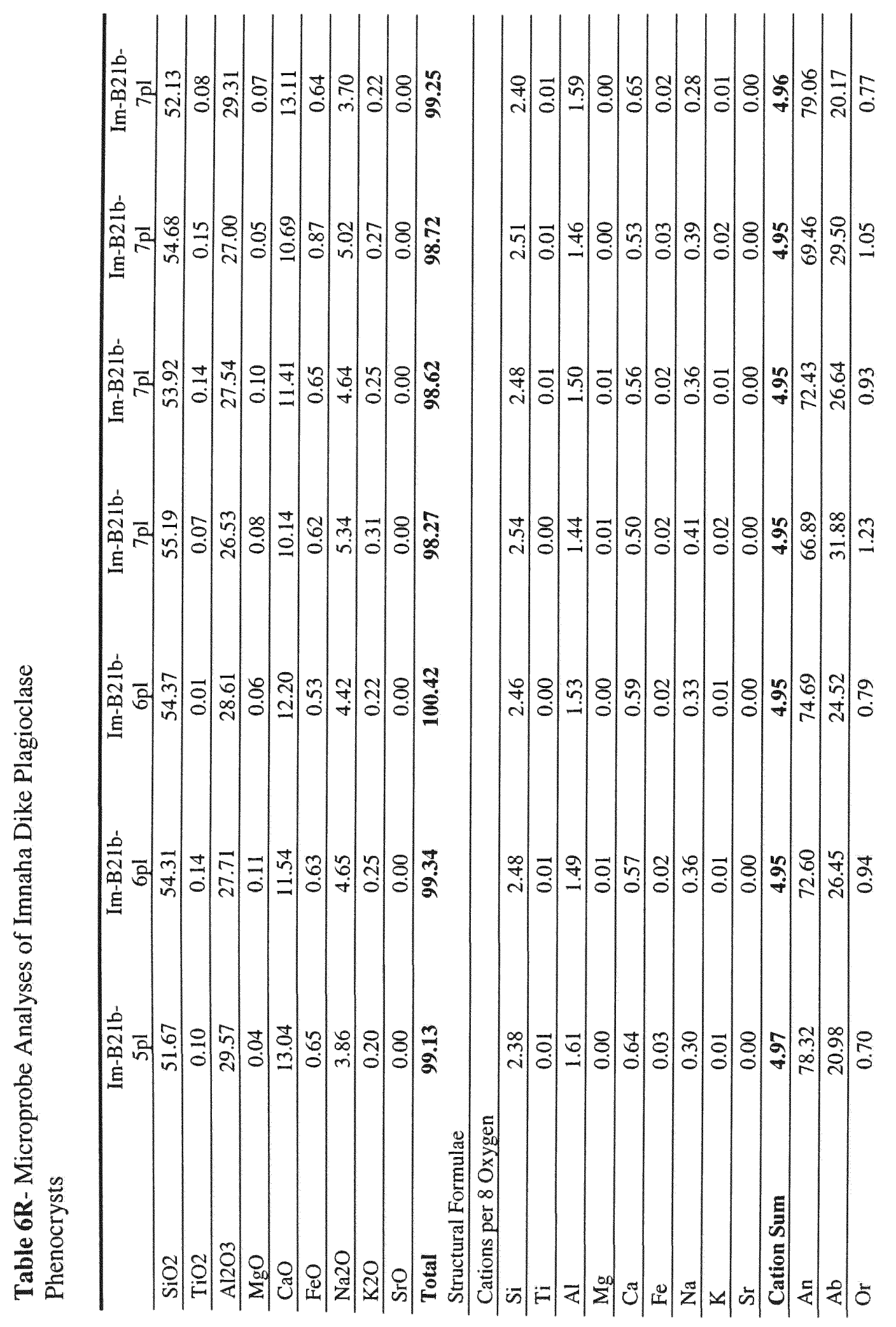




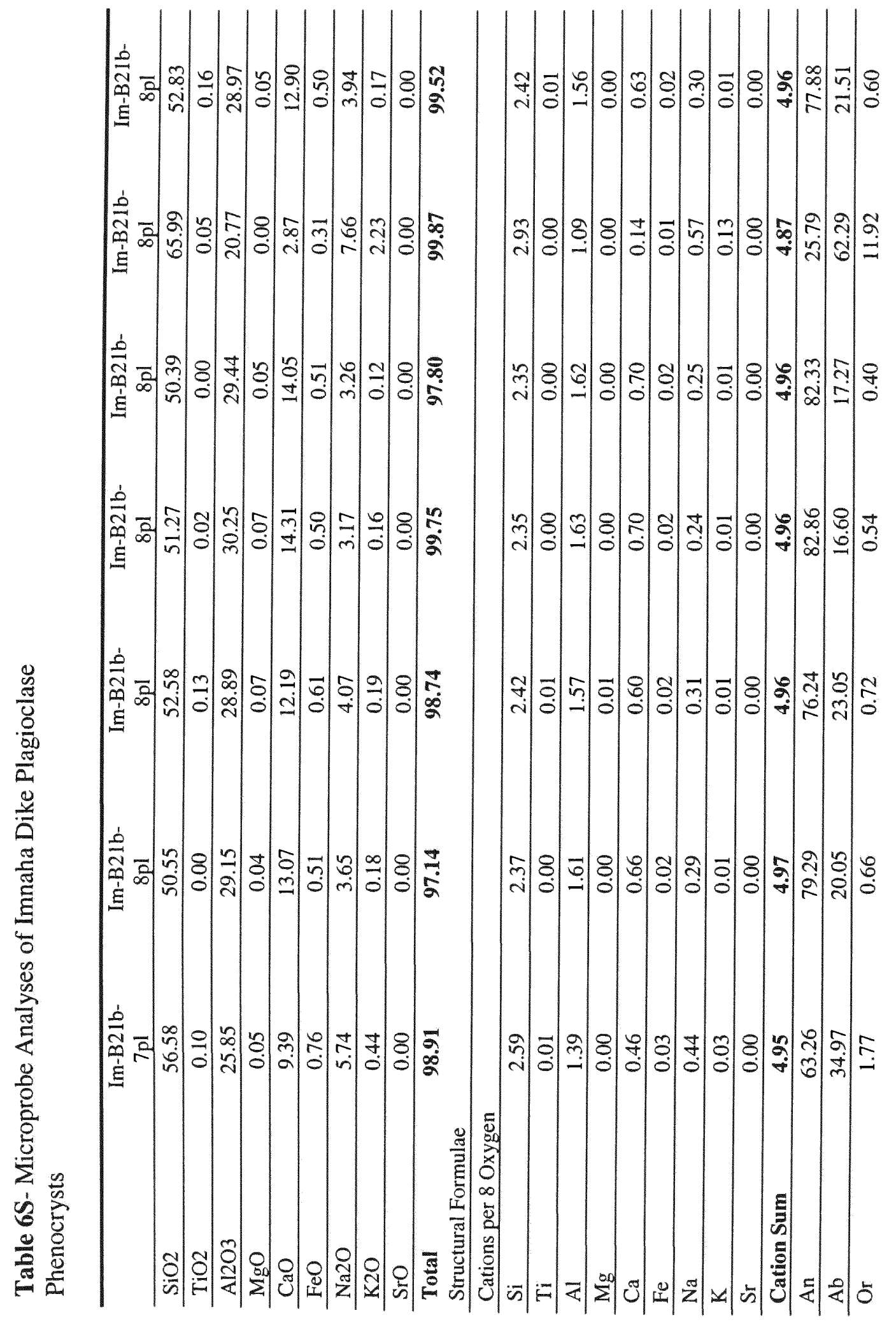




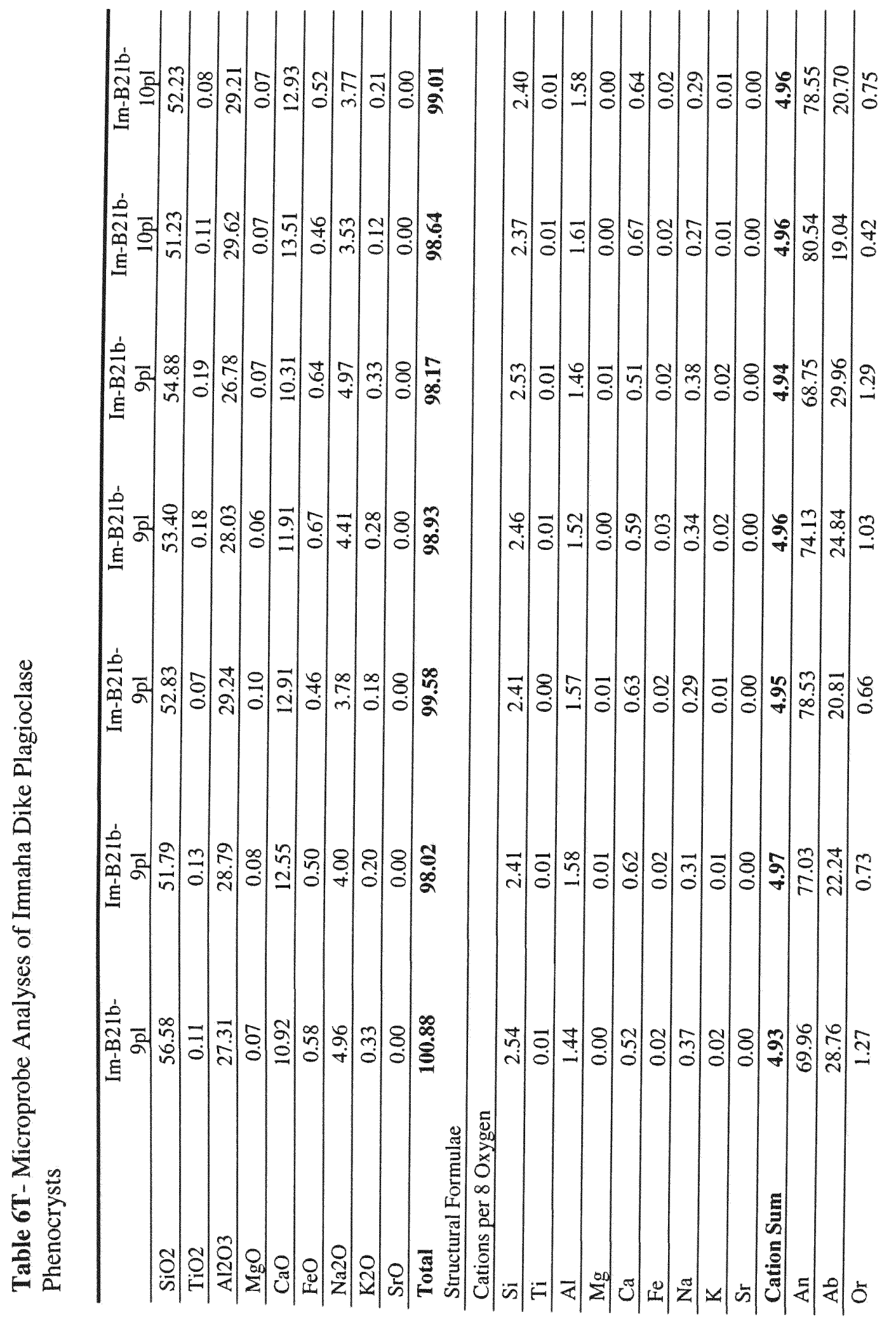

‡్đ 


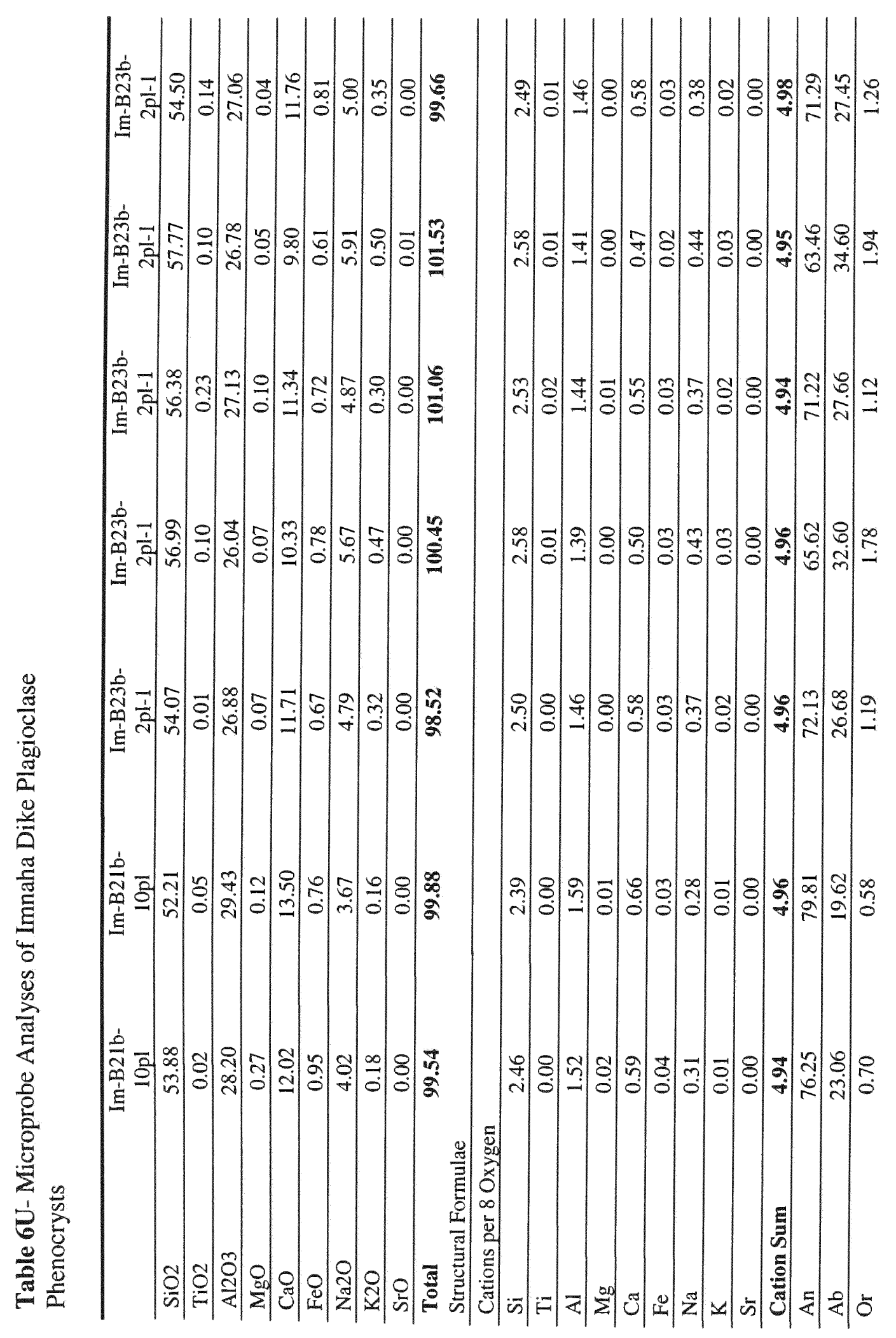

สี 


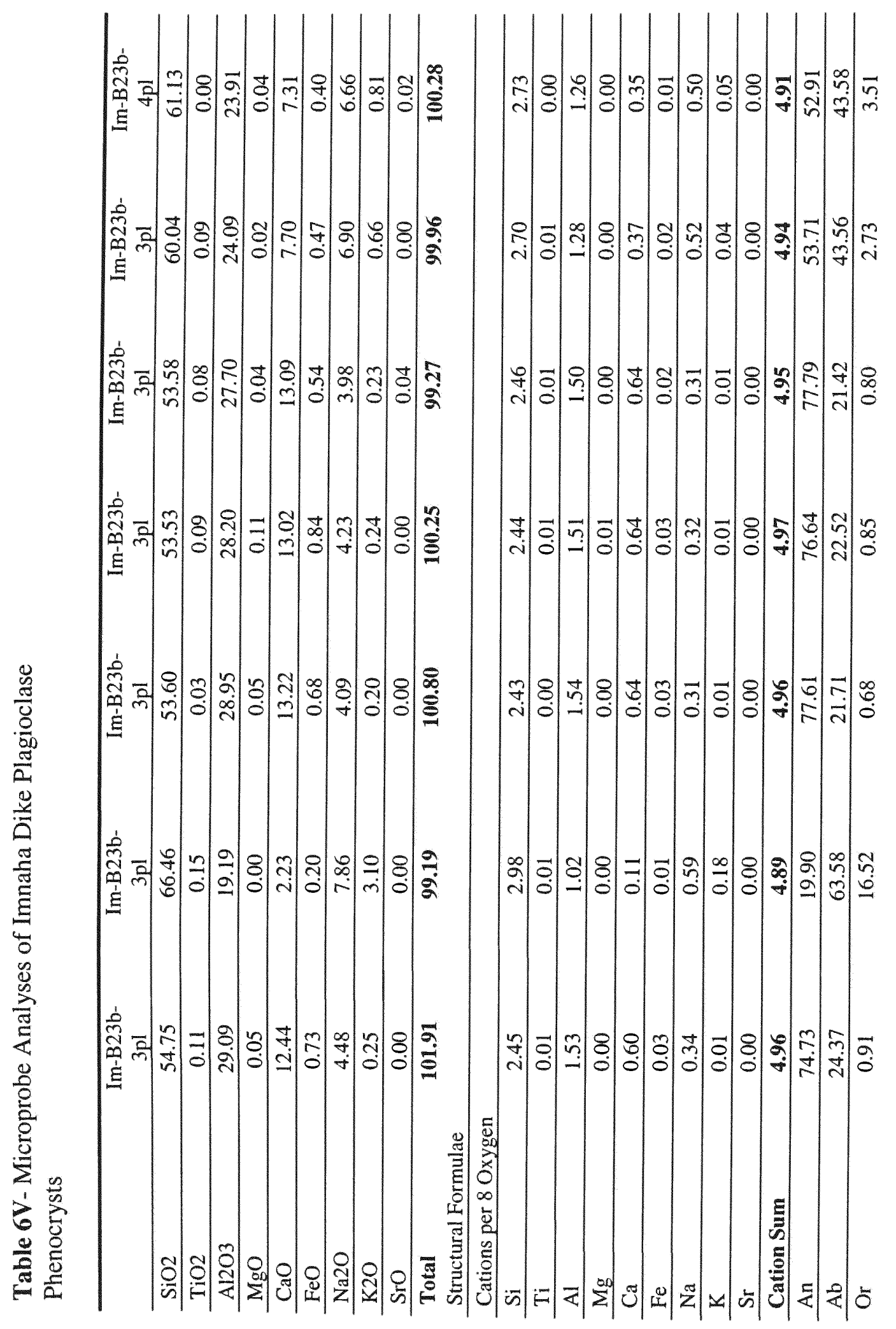




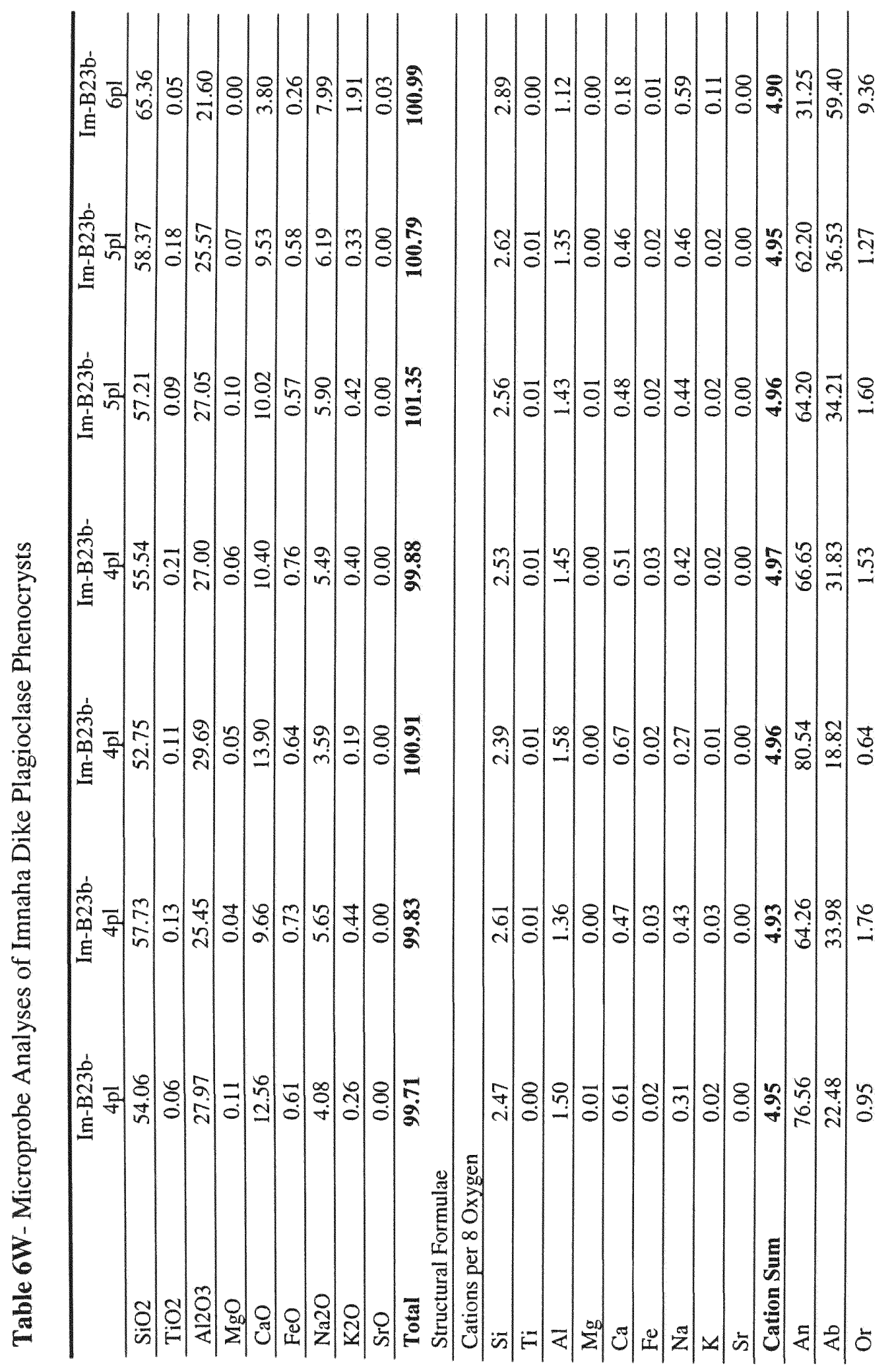




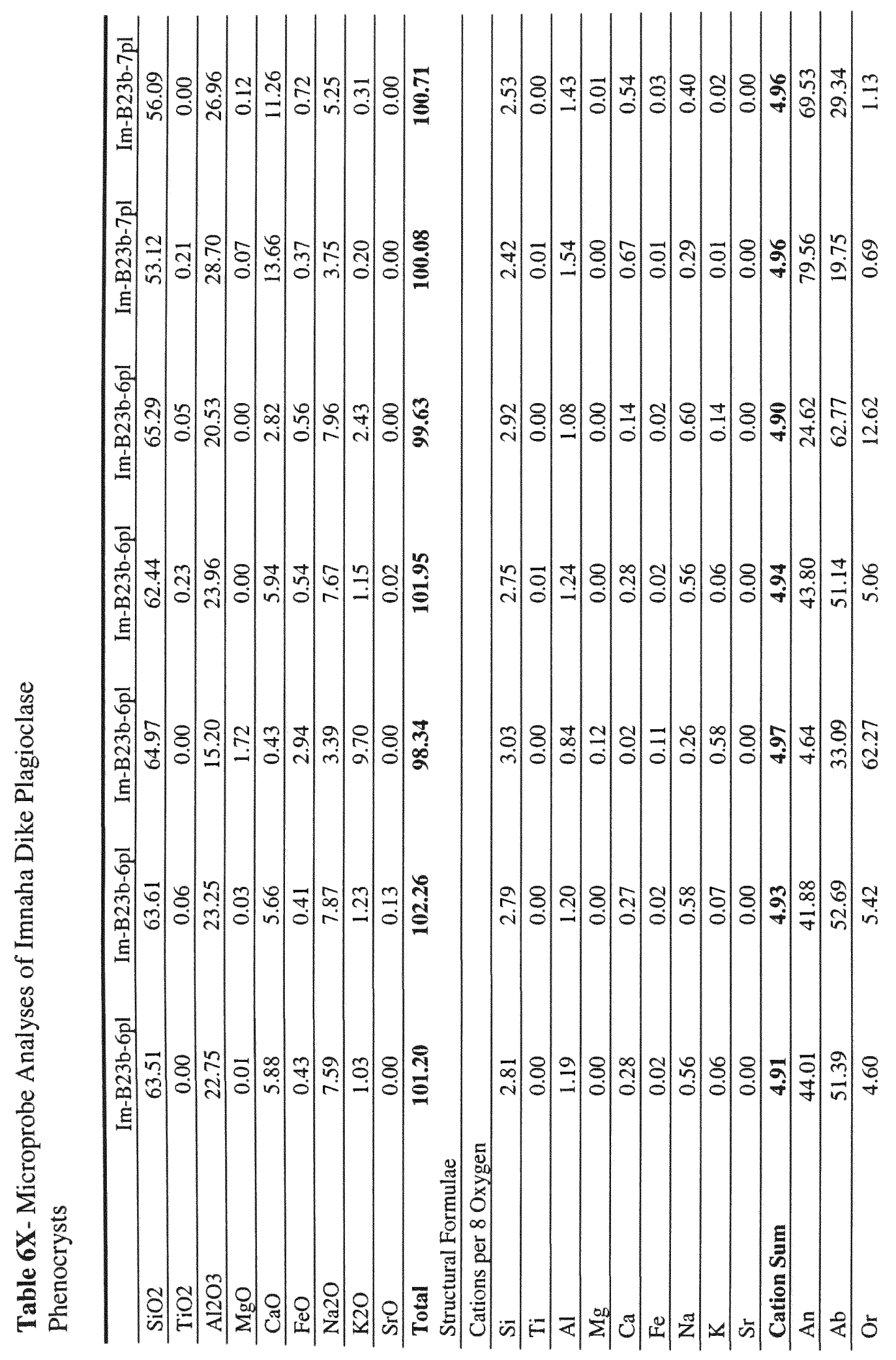




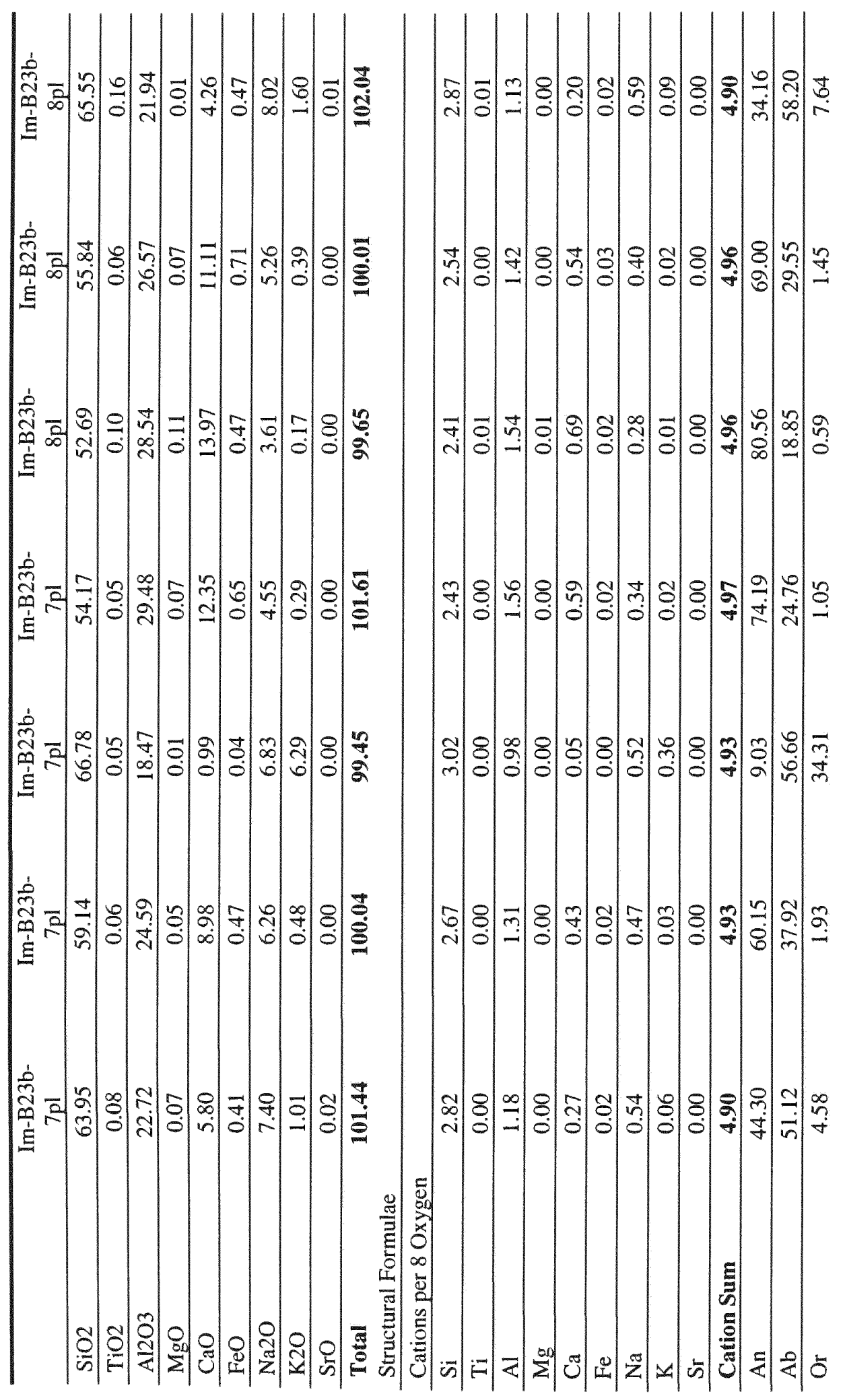




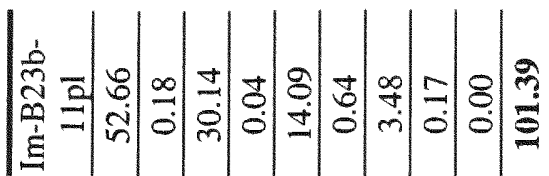

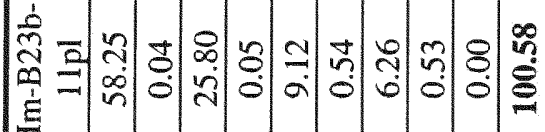

焉

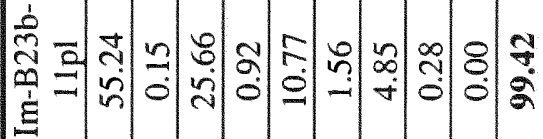

章

을

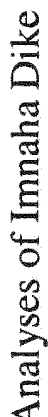

尊

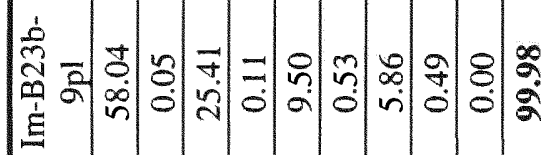

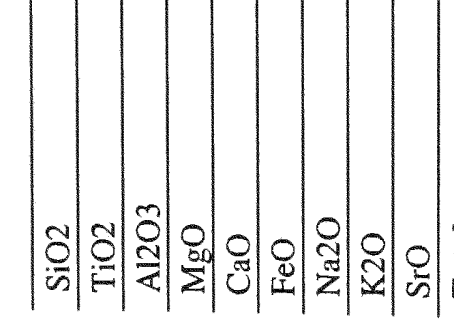

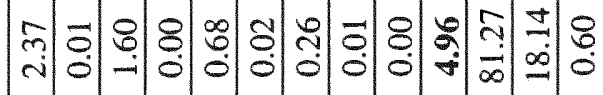

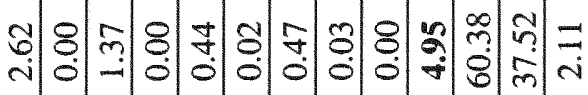

ㄱำ

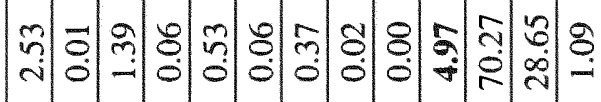

我

స్

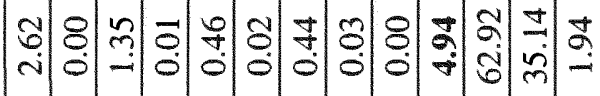

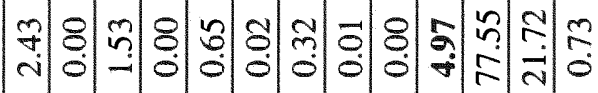

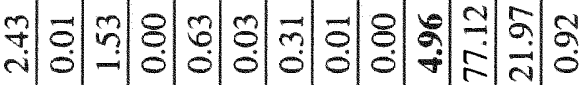




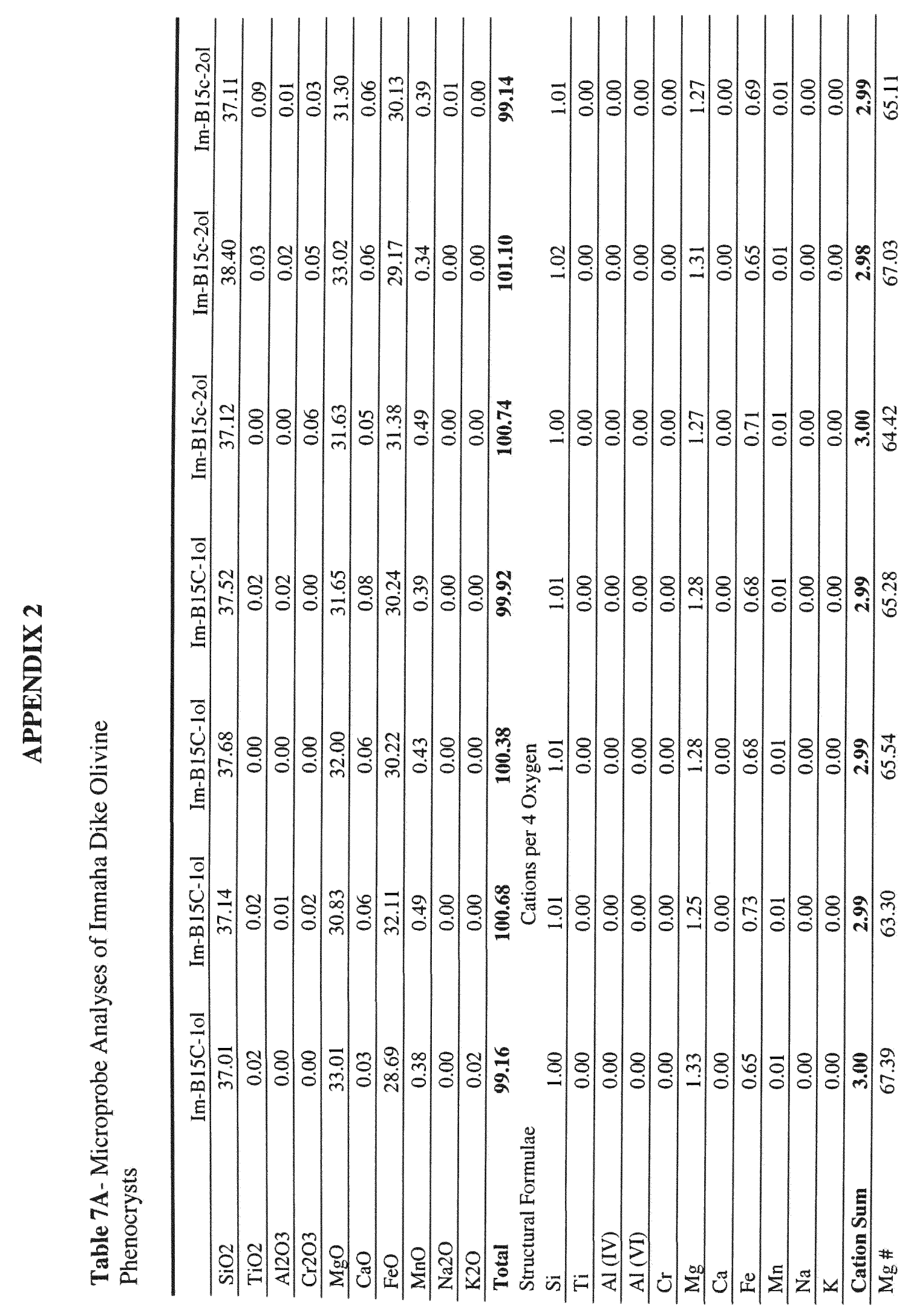




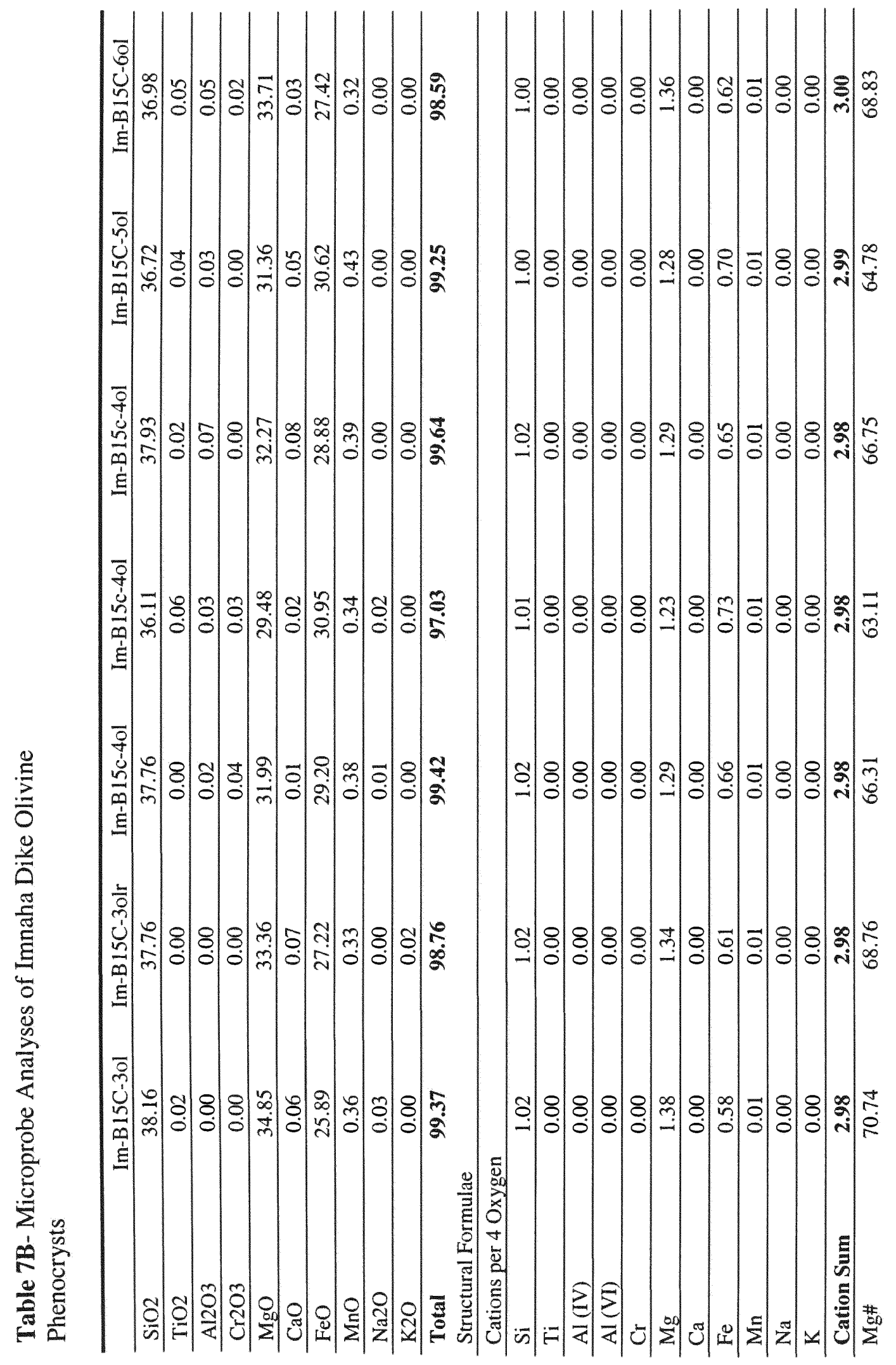




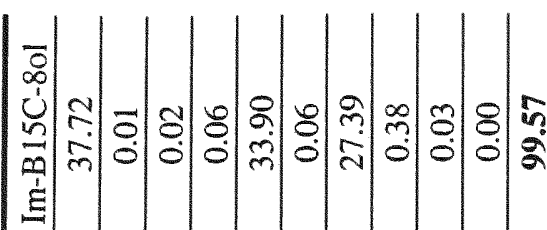

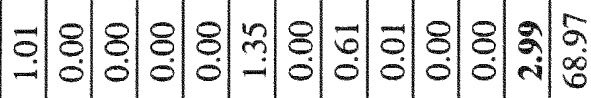

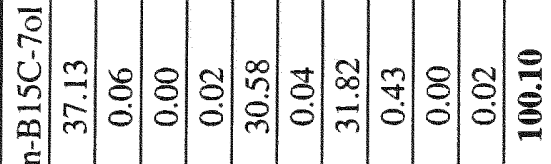

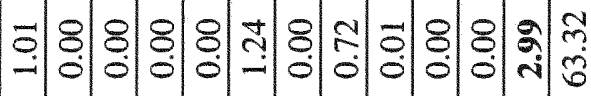

토

웅

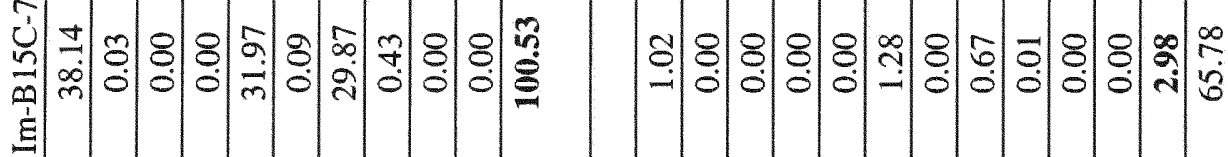

홍

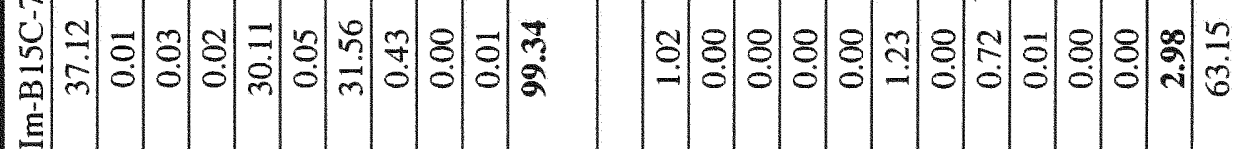

点

竞

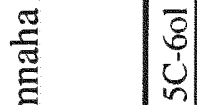

若

过

产

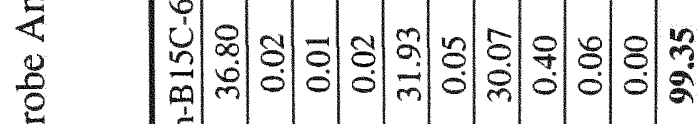

웅융 웅 웅 웅 영

:

웡 $8: 08$ 


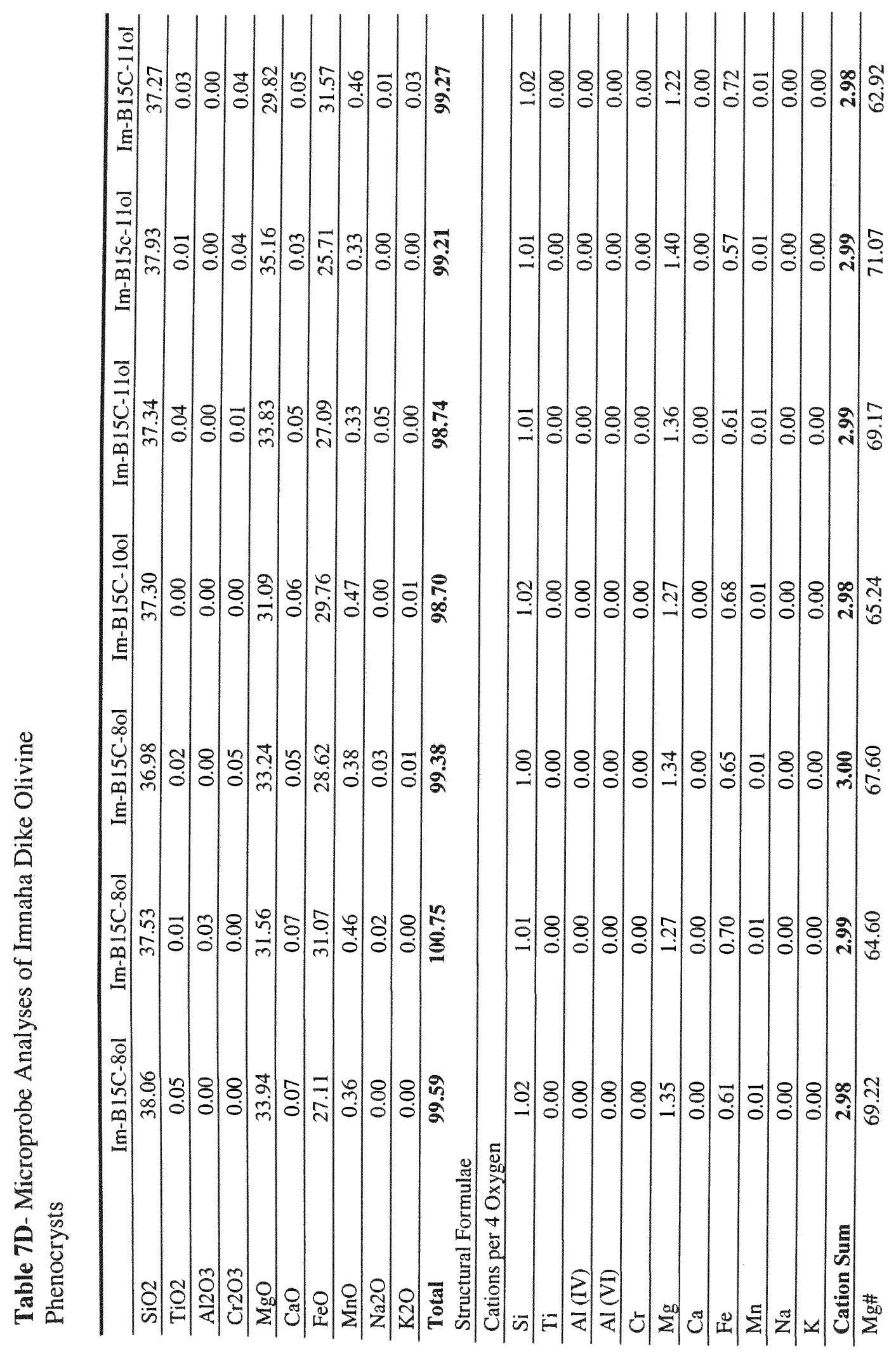




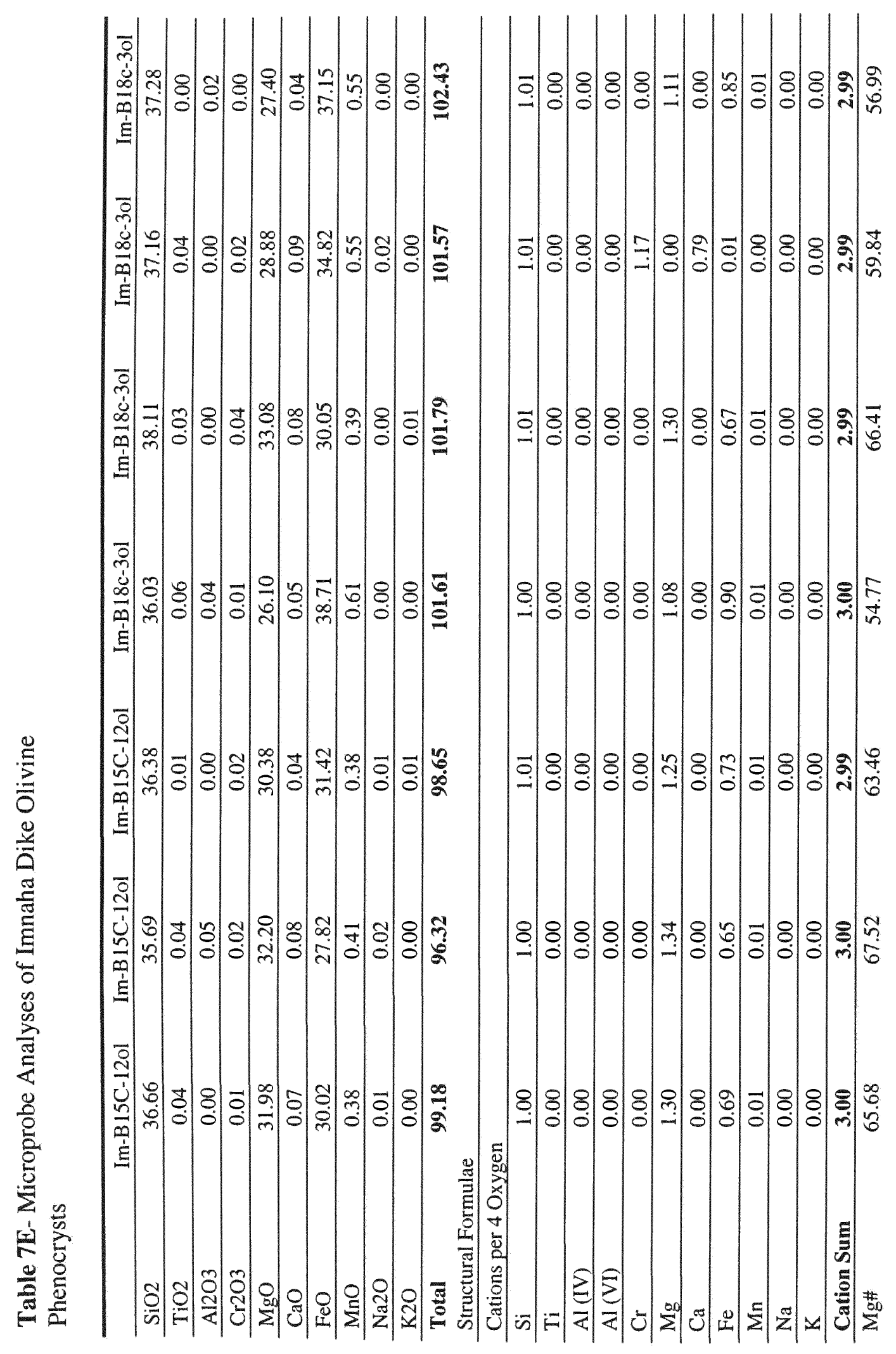




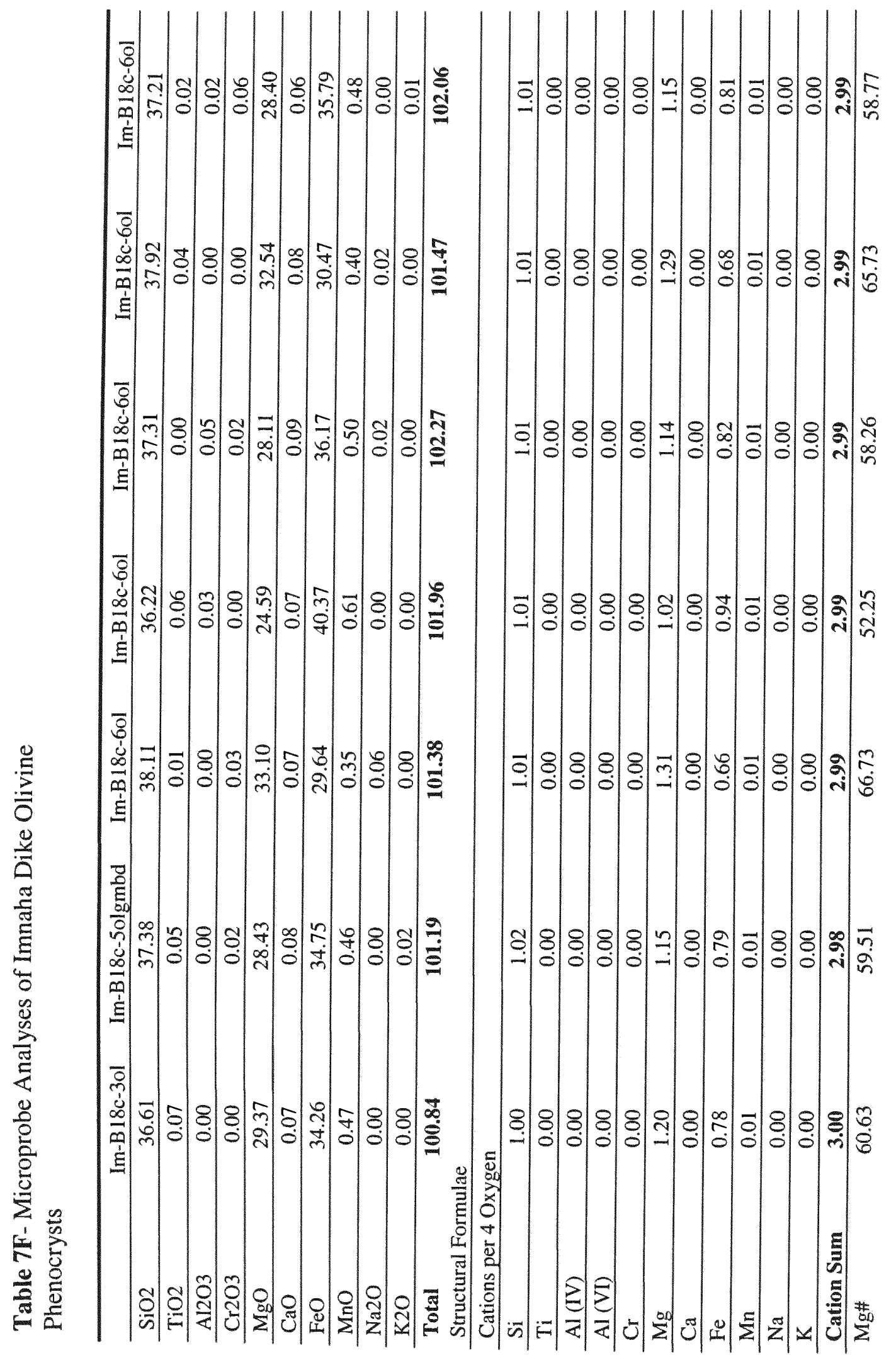




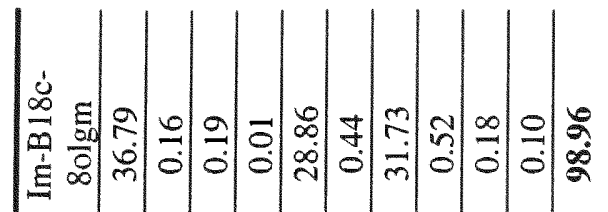

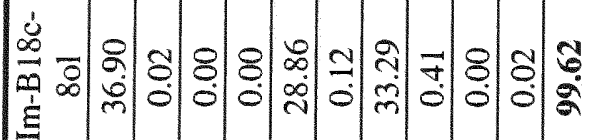

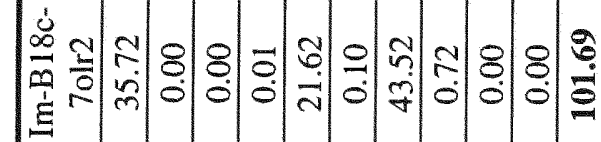

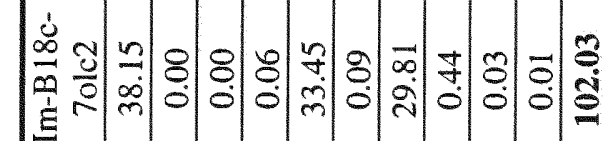

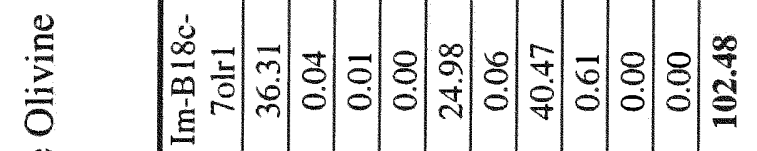

高

章

政

势

竞

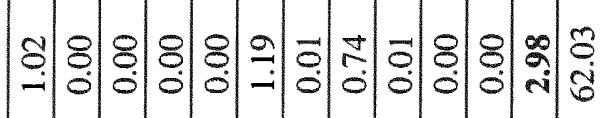

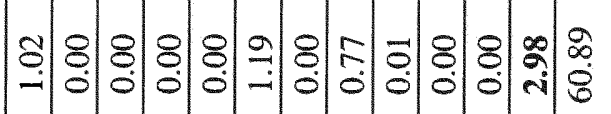

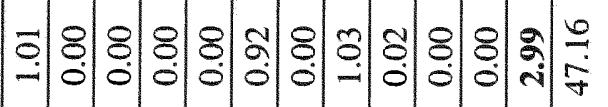

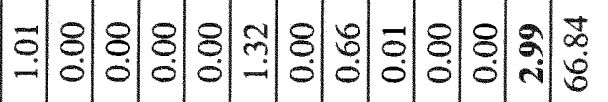

के

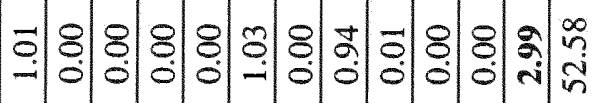

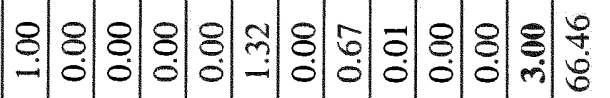

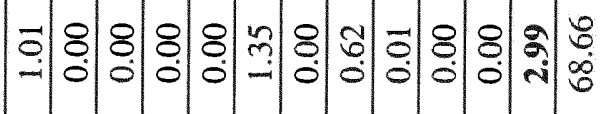
동

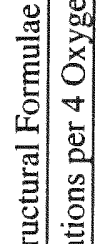

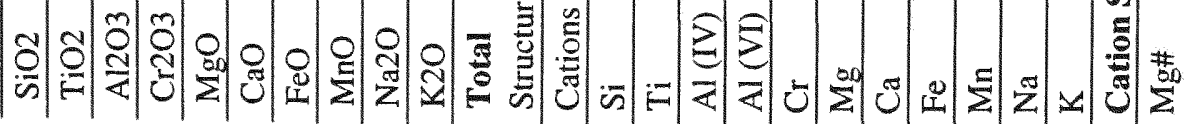




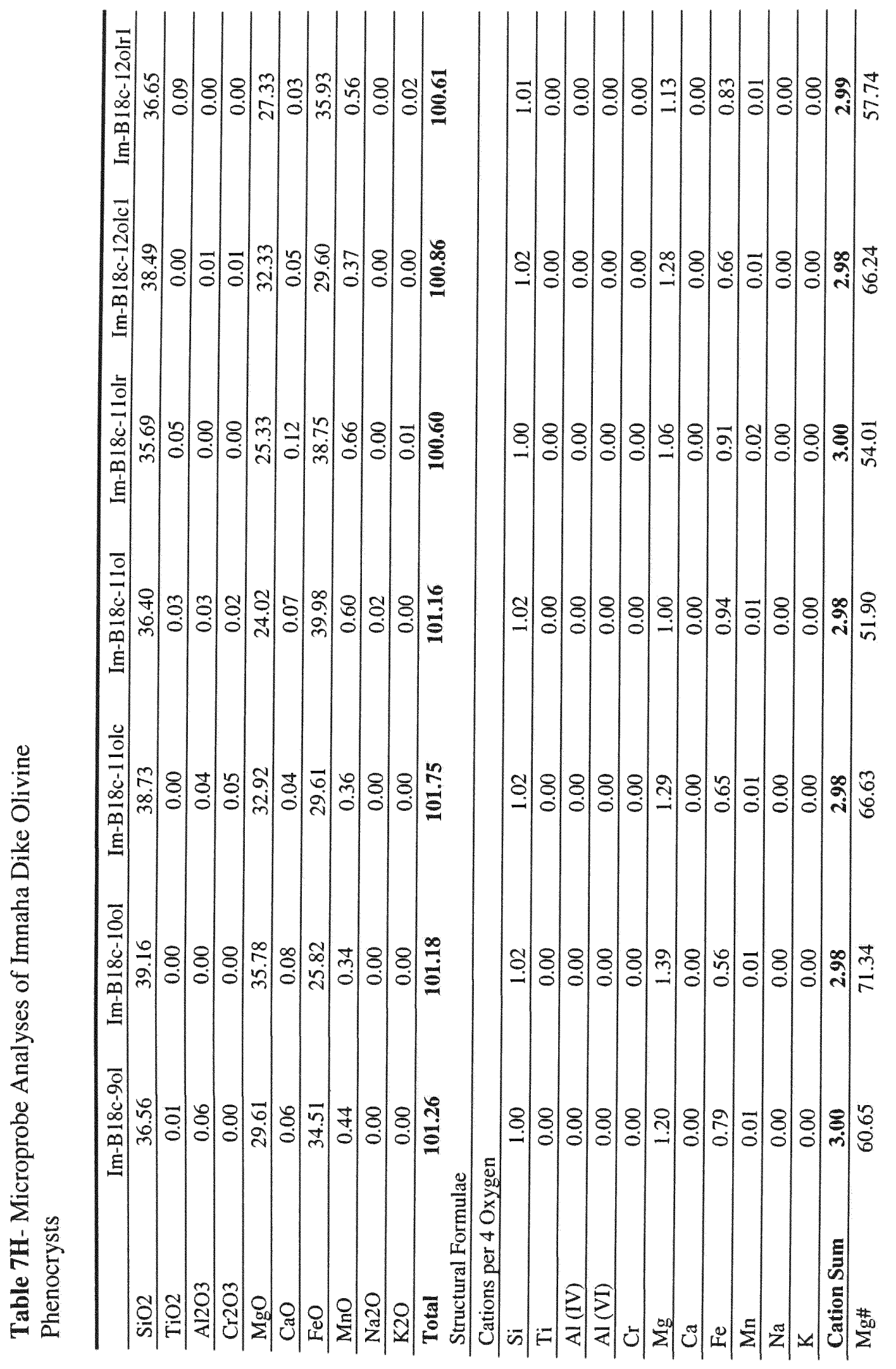




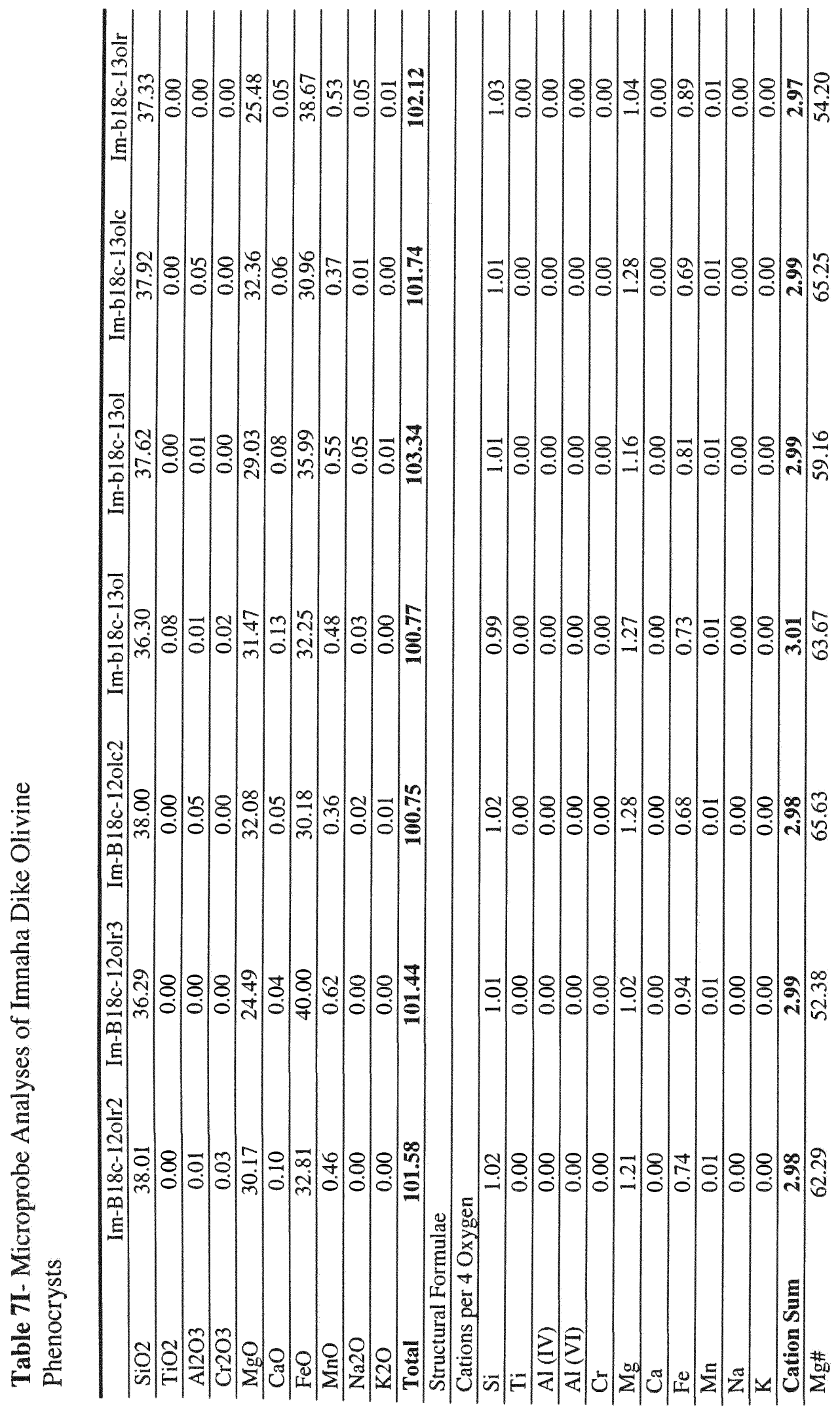




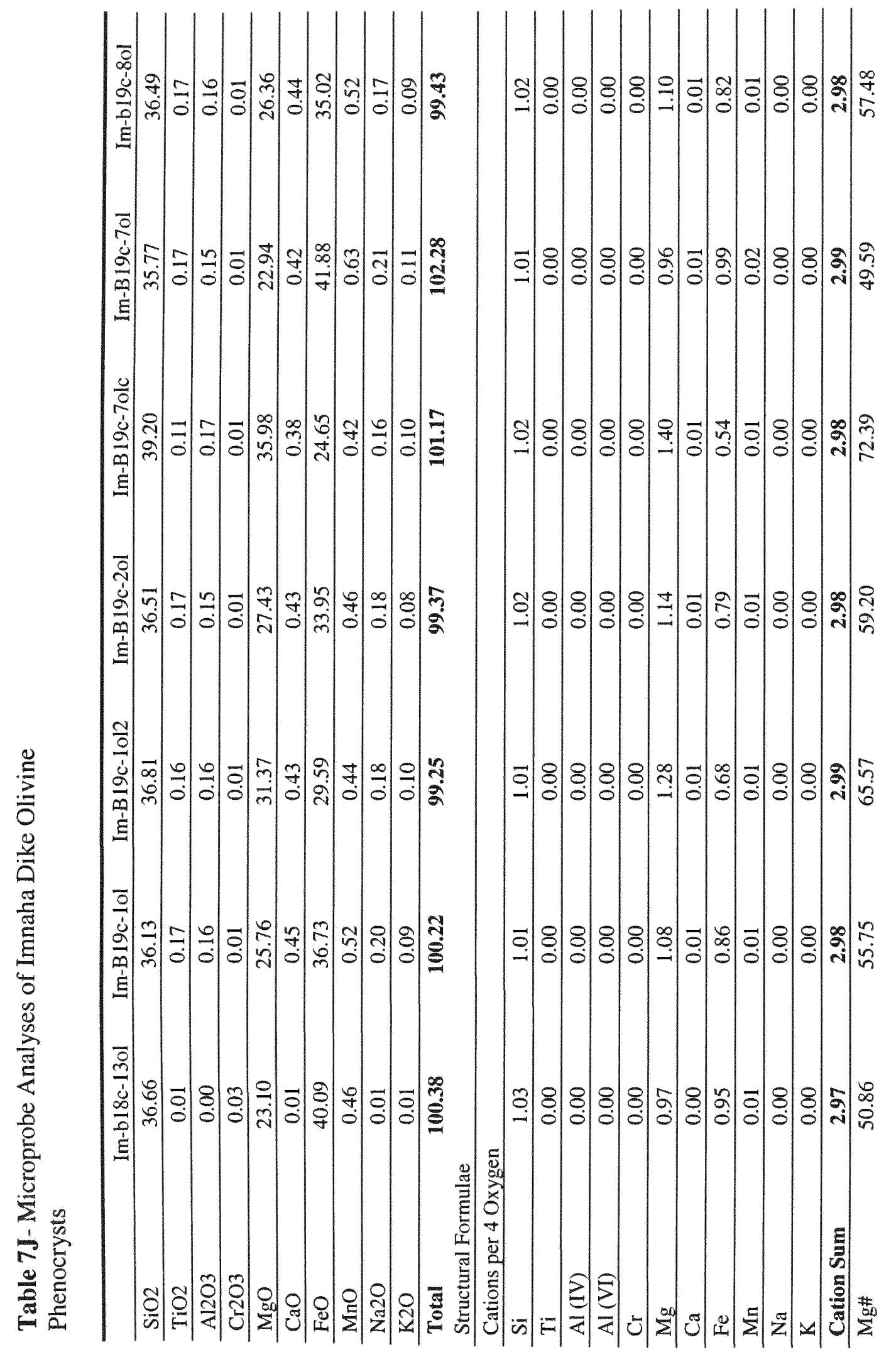




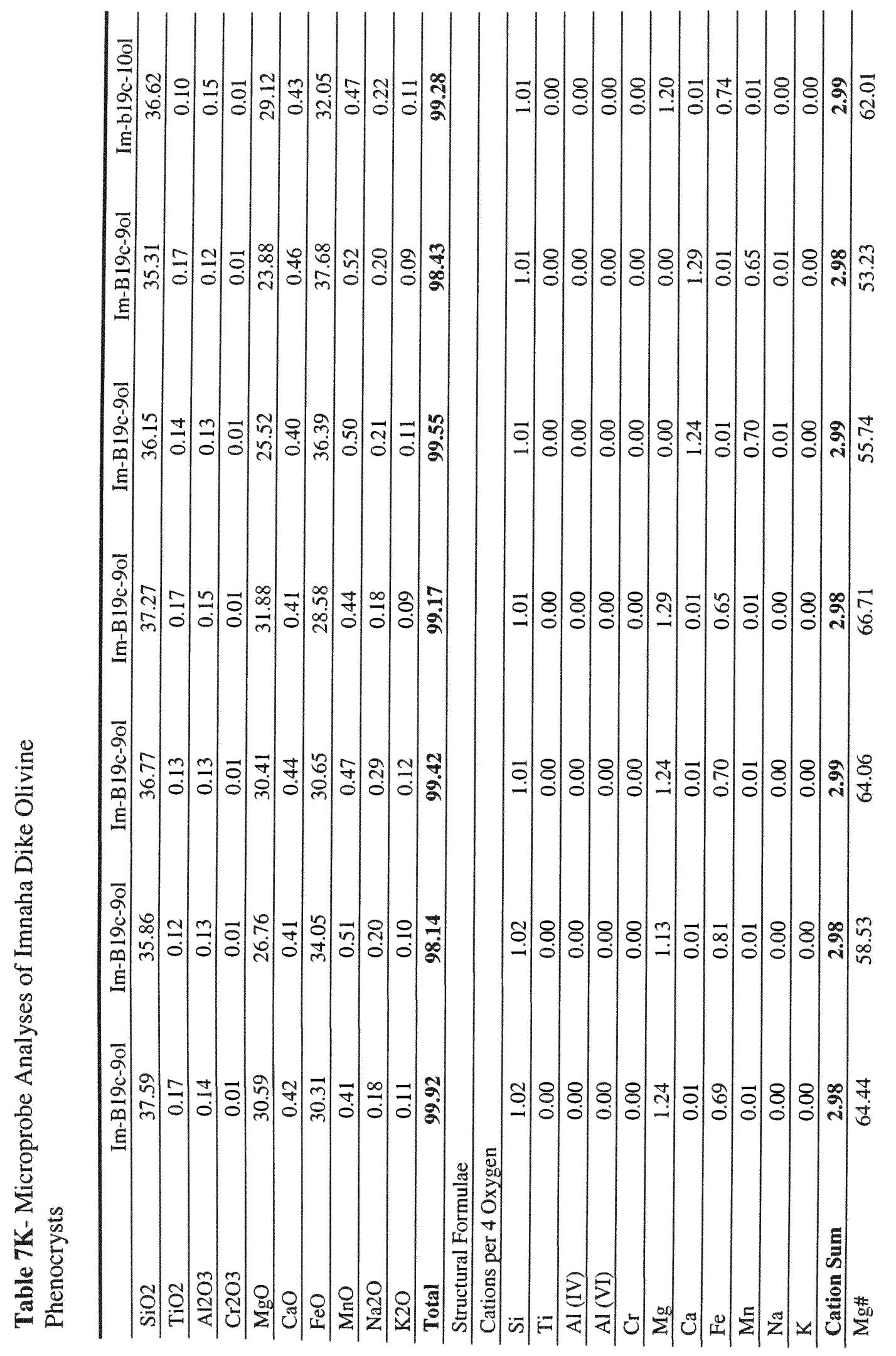




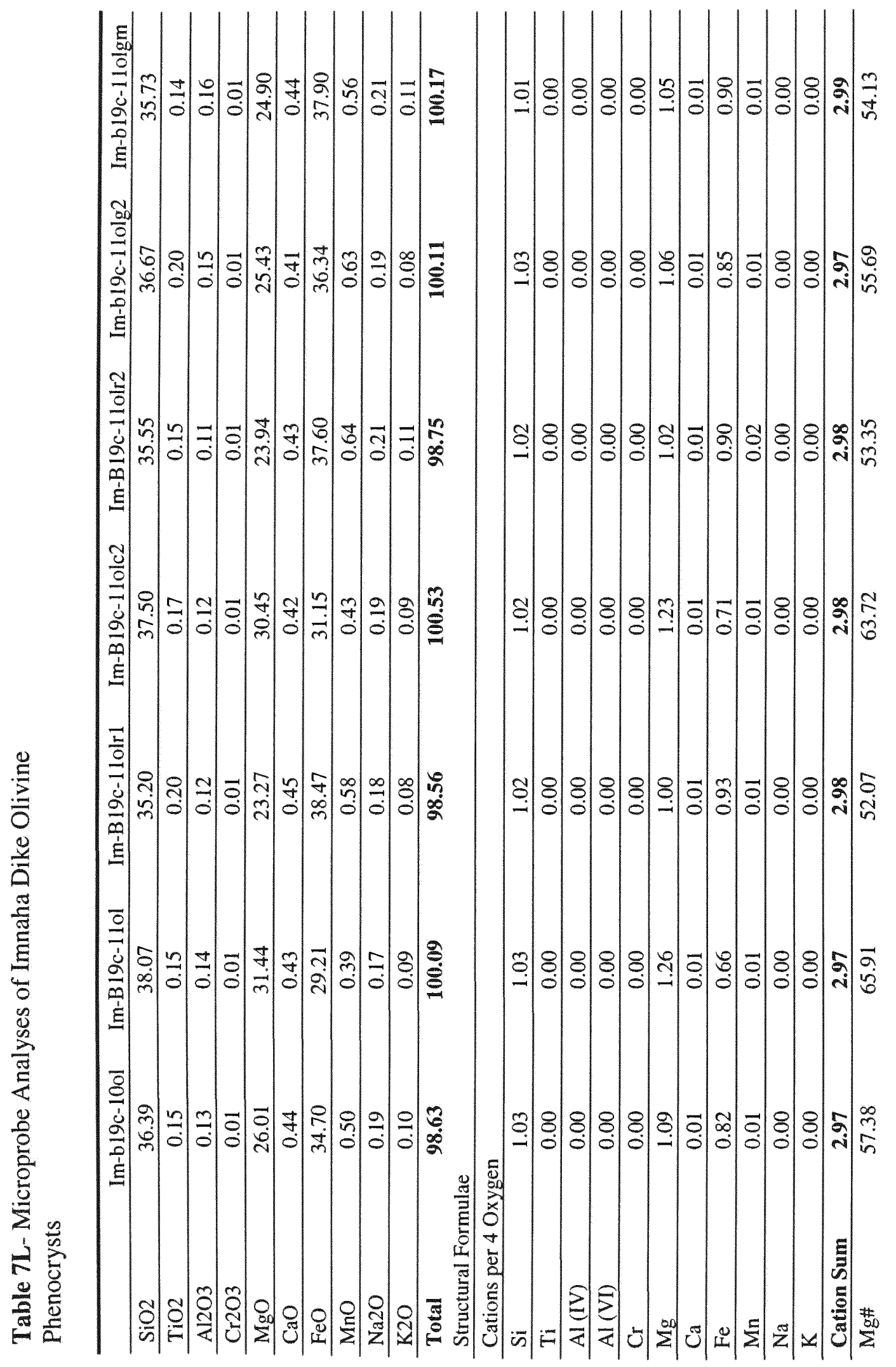




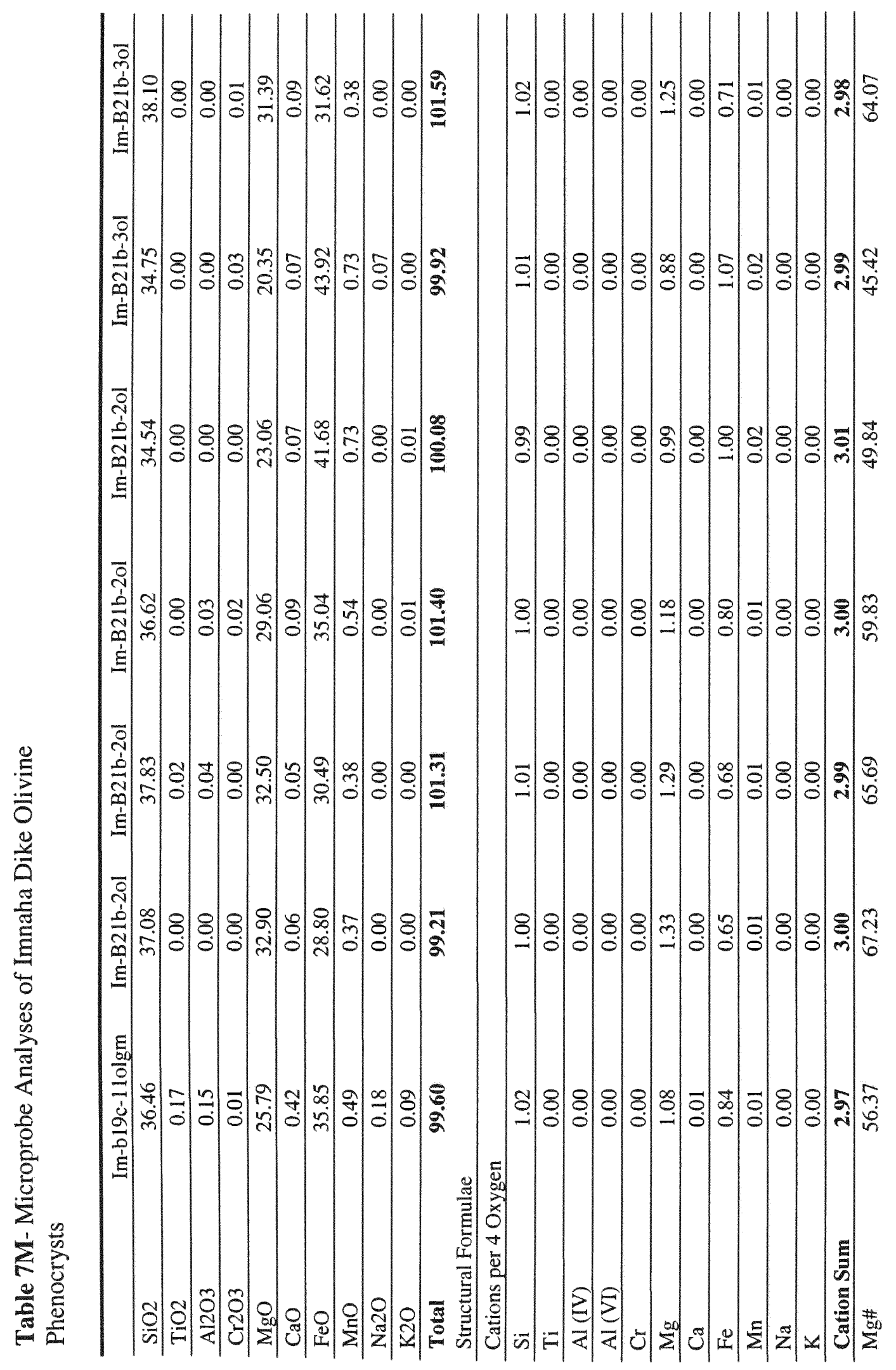




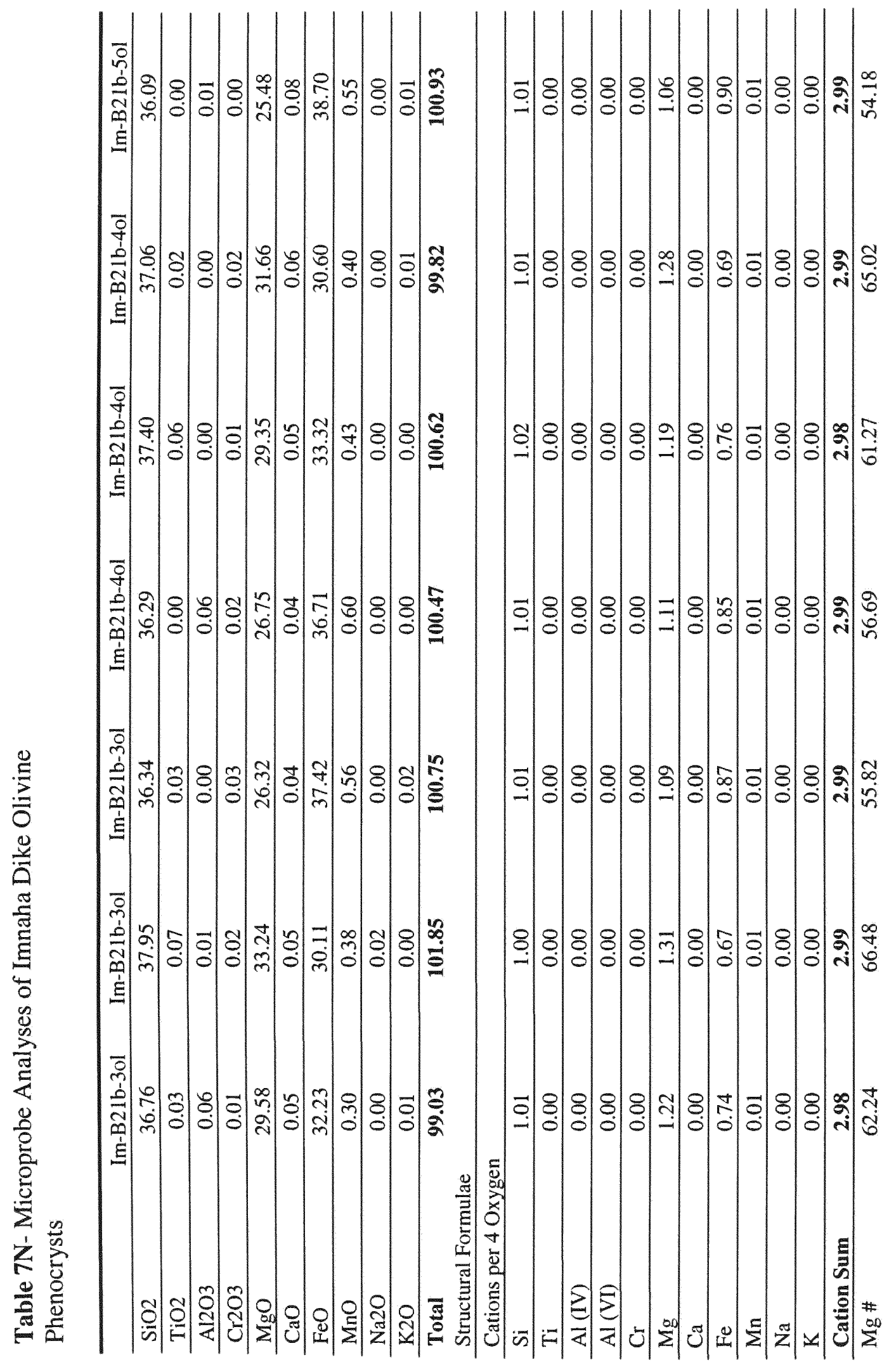




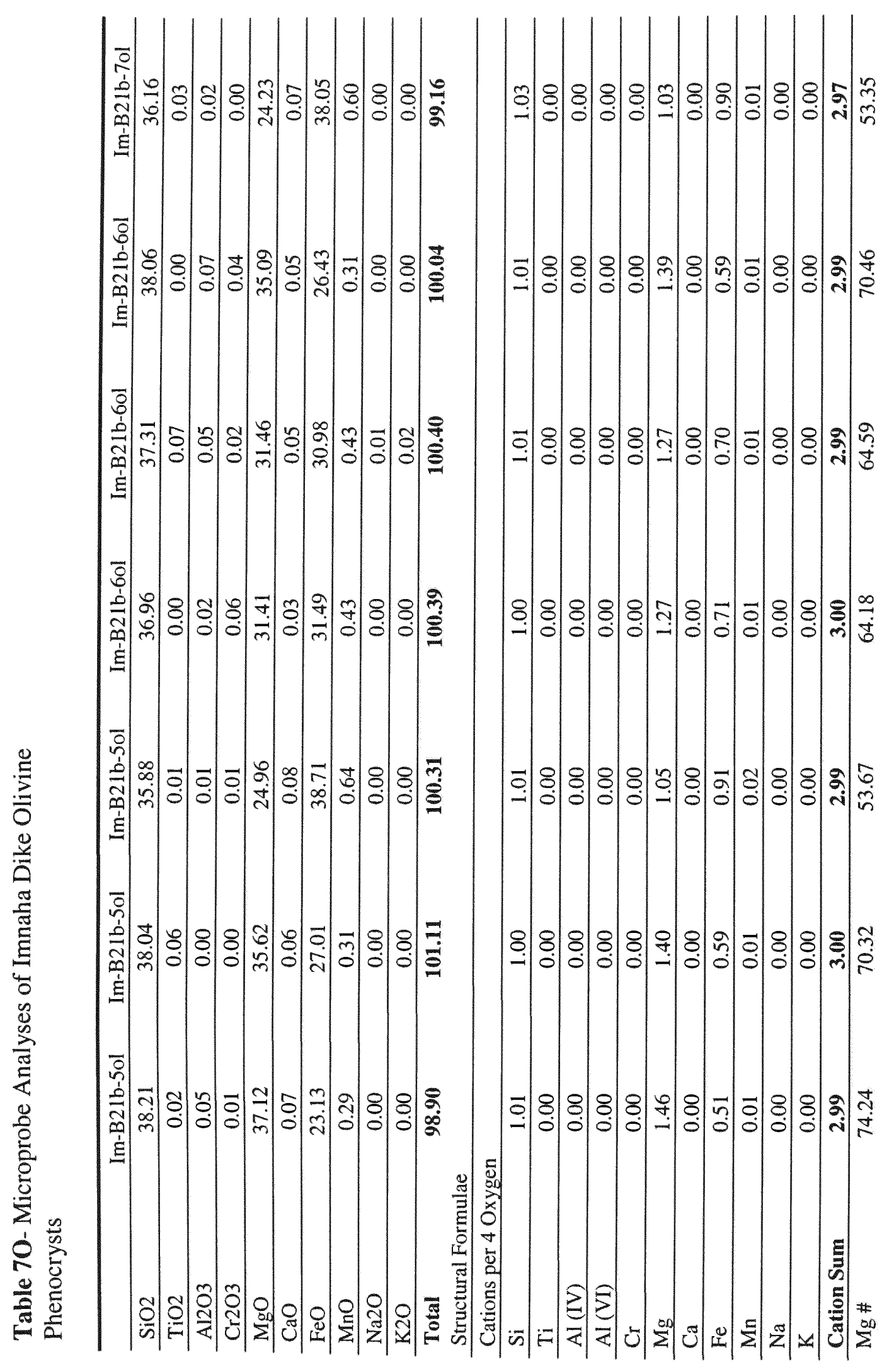




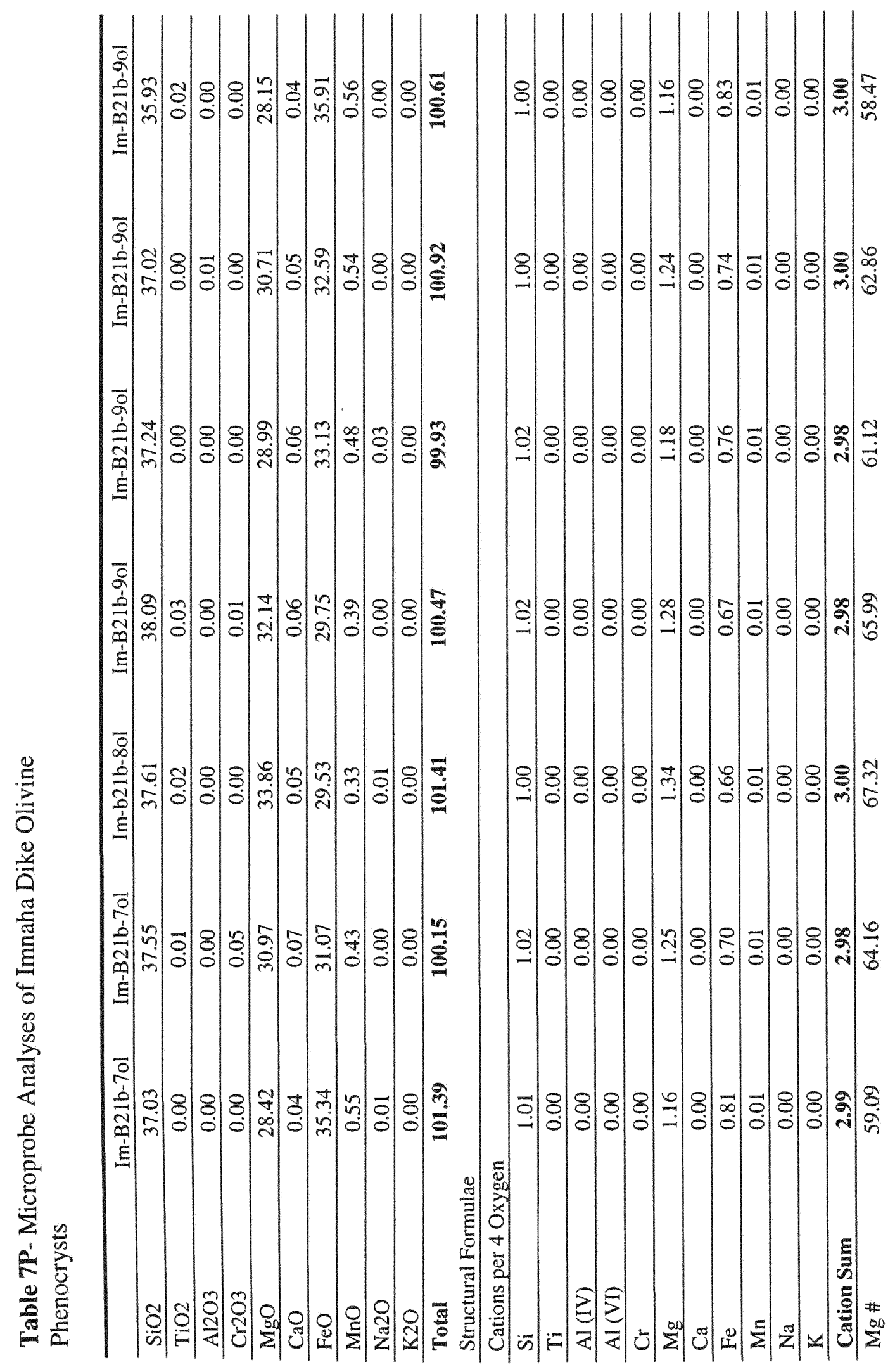




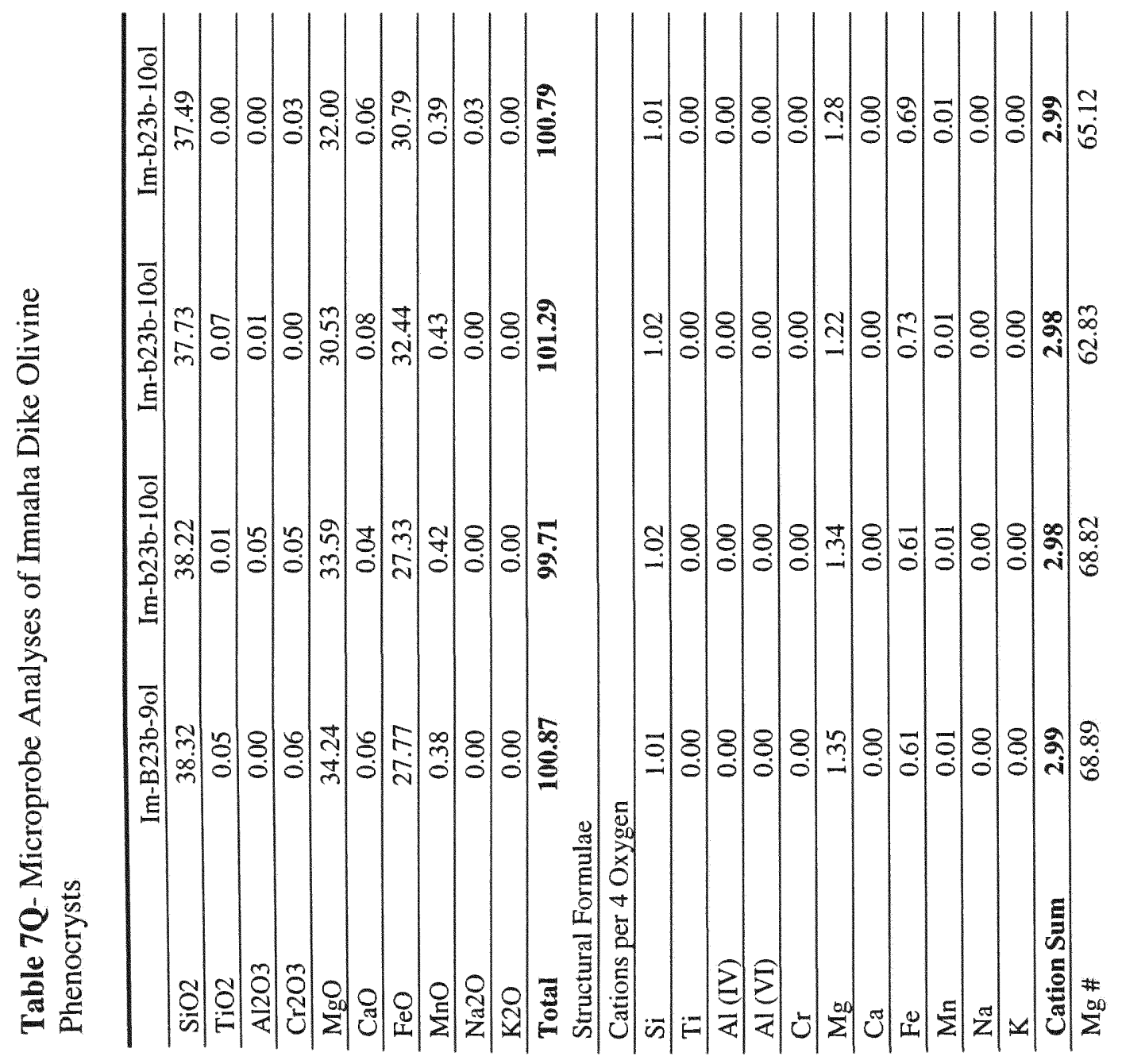




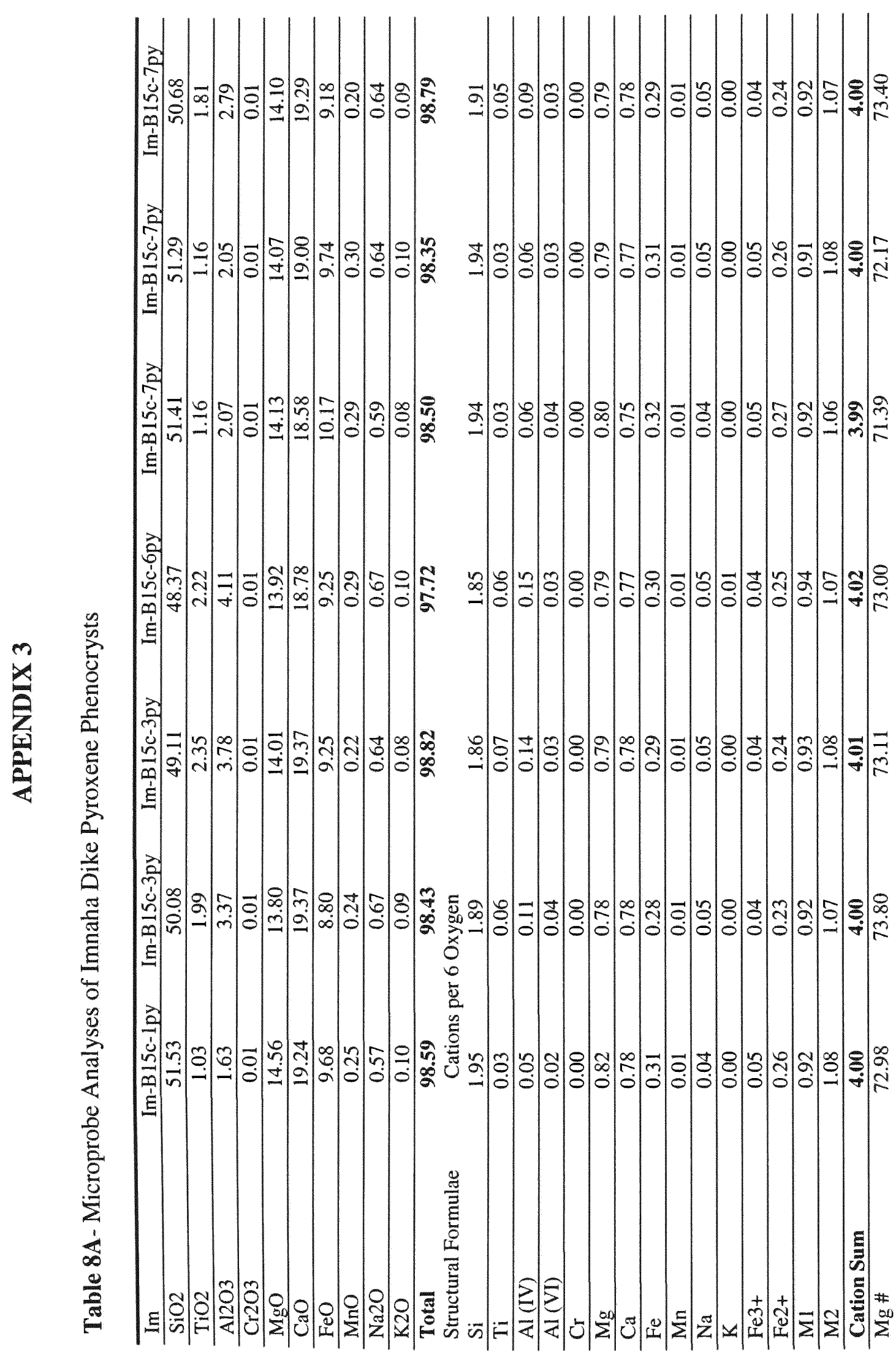




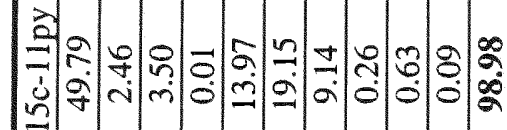
音

글

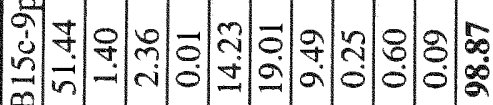

है

高者

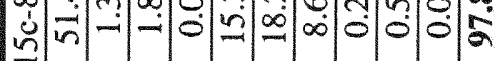

-

实

항

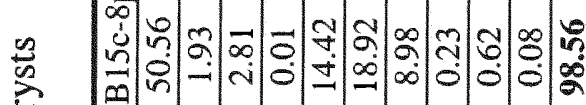

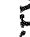

ह

$\stackrel{5}{\frac{1}{4}}$

(.)

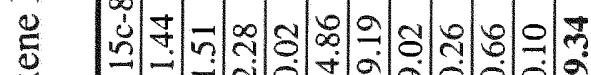

$\stackrel{x}{\circ}$

5

产

苋

臮

4

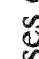

需

$\div$

8

อั

is

竎

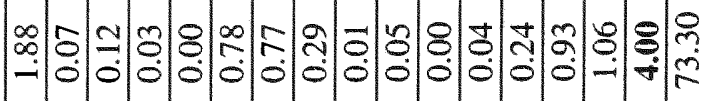

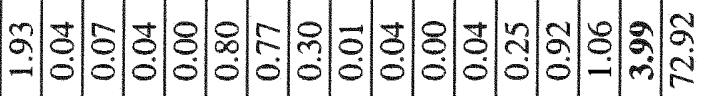

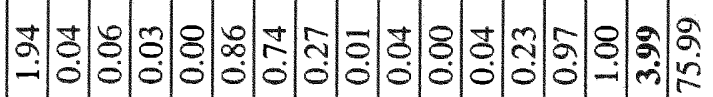

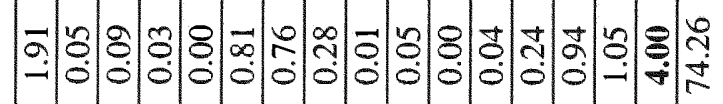

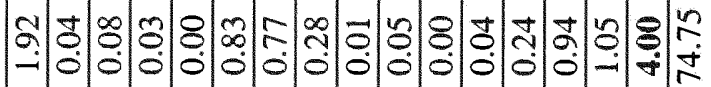

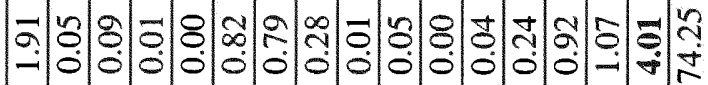

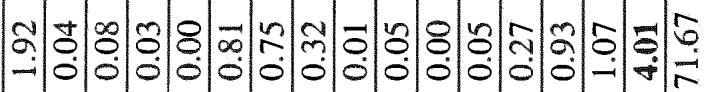

5

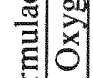

이는

(1)

늘

: 


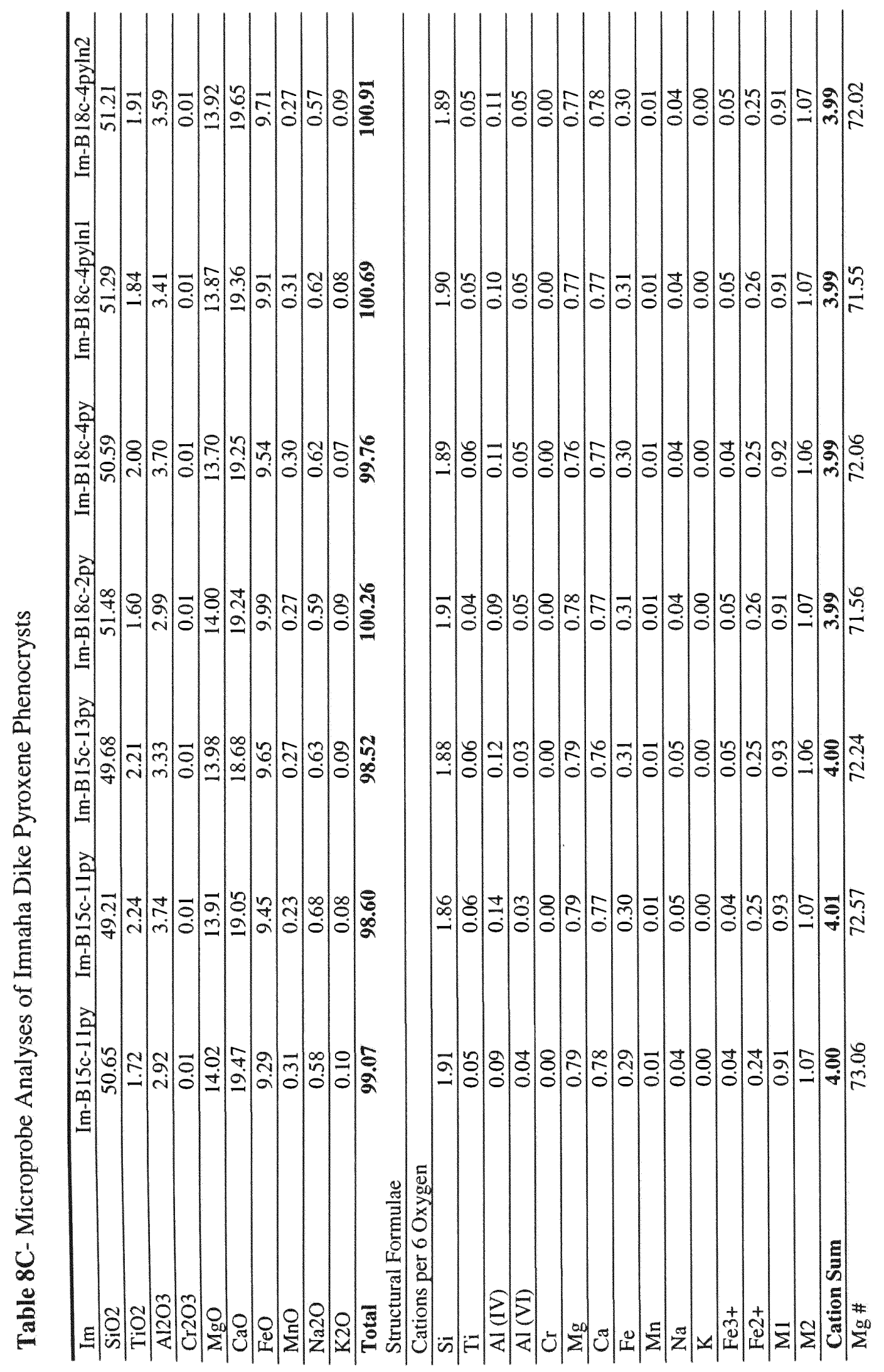




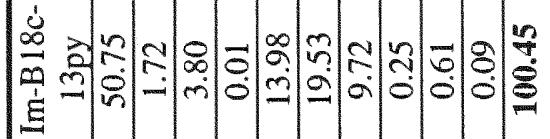

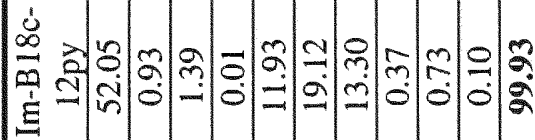

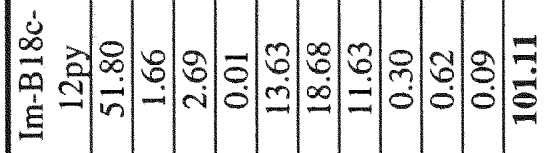

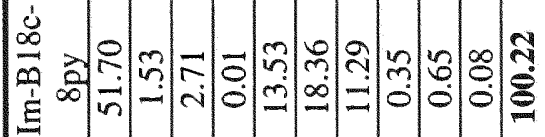

$\frac{\infty}{4}$

过

竞

要

范

政

西

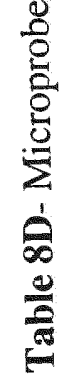

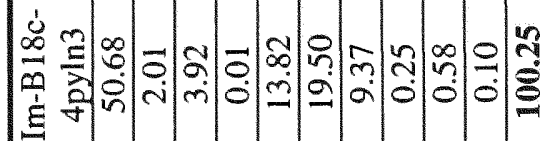

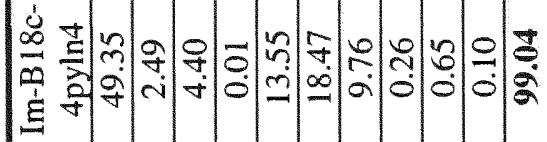

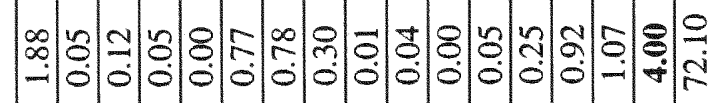

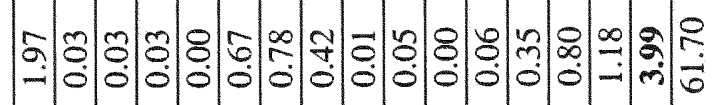

舟:

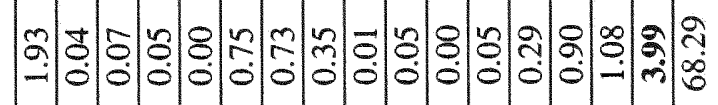

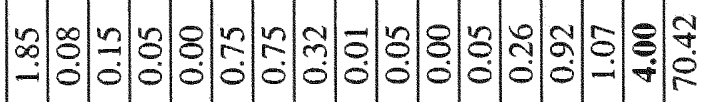

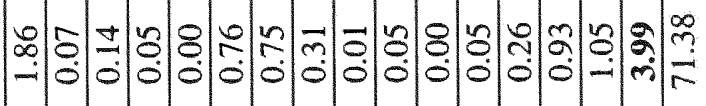

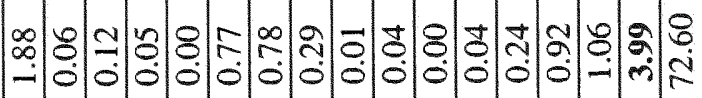

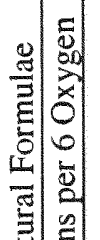

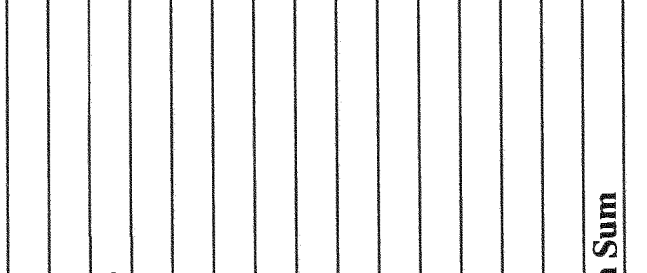

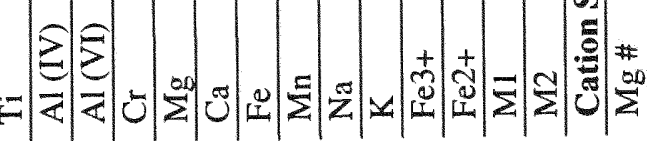




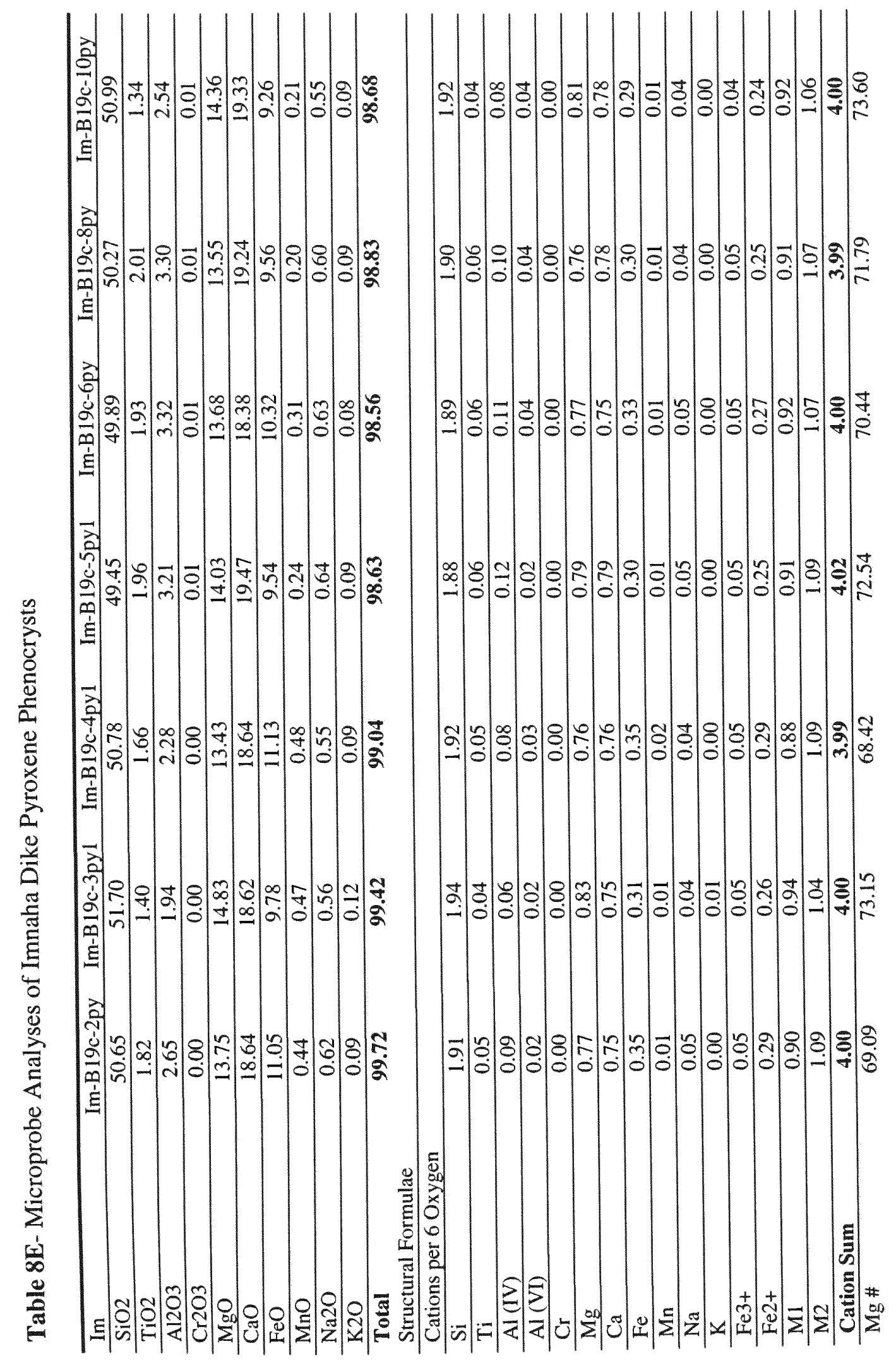


|

a)

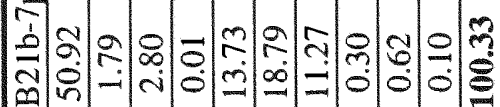

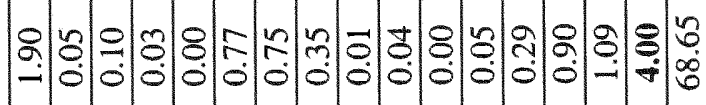

恶

0 f

है

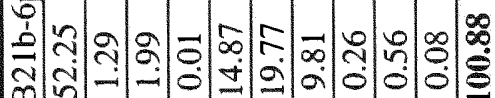

会

워

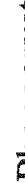

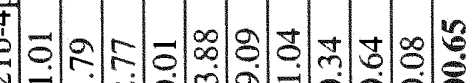

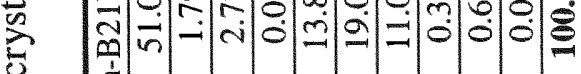

일

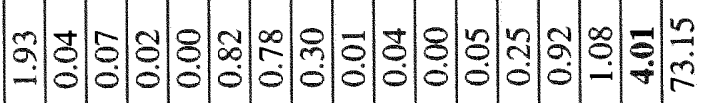

E

की

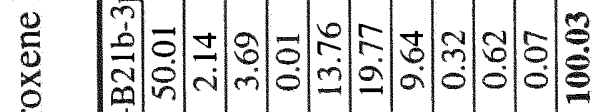

ฉิ

$\frac{0}{3}$ 명

疍

छ

o

.

离

강

려

붕으

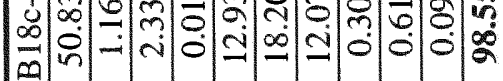

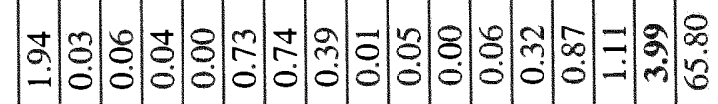

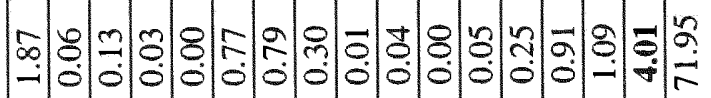

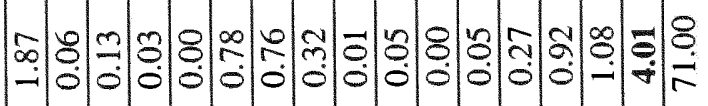
E

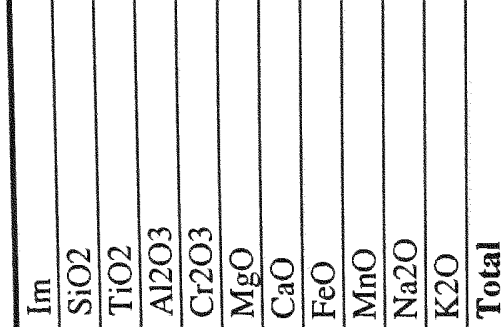

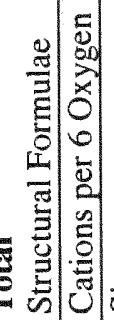




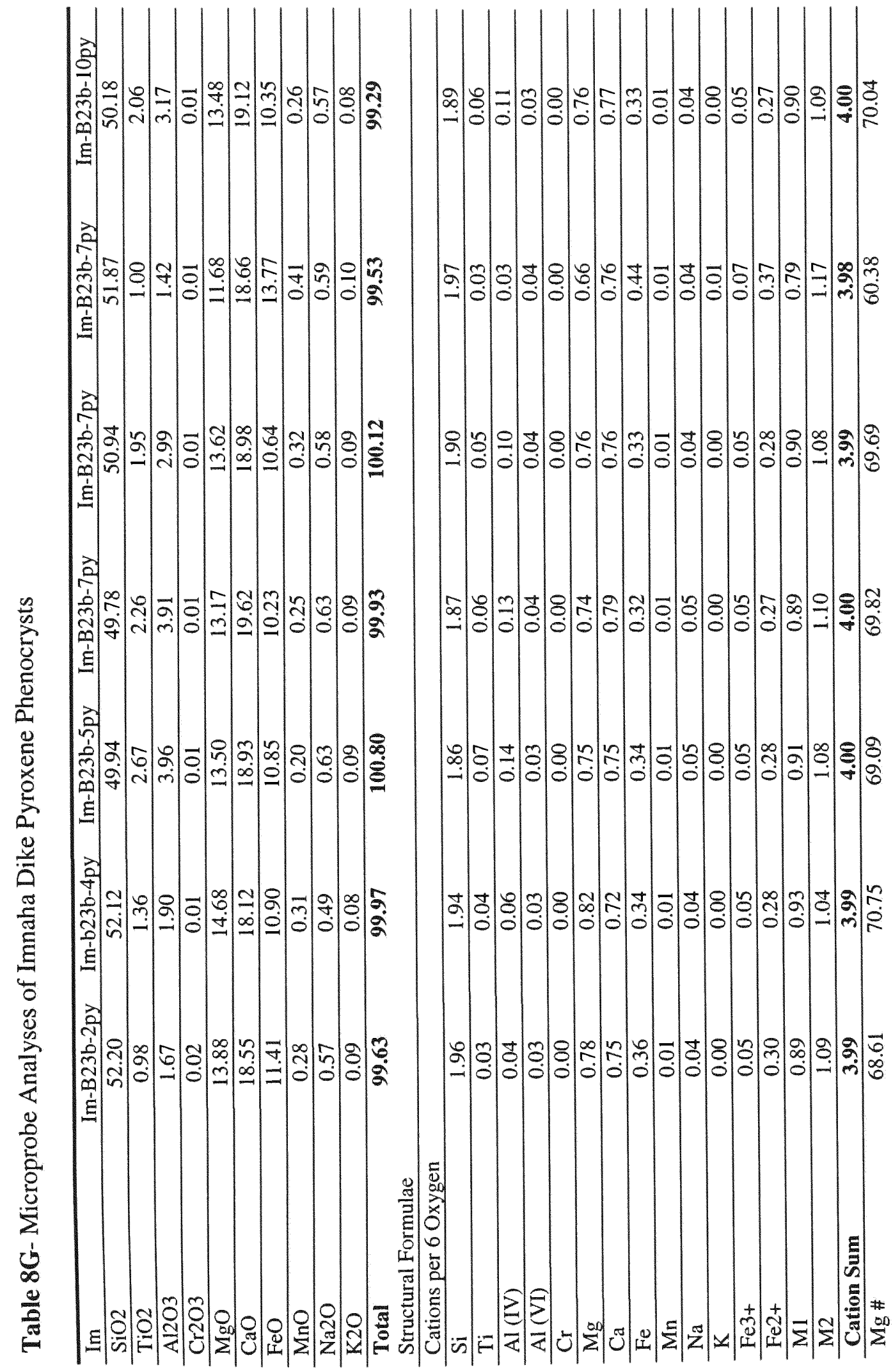




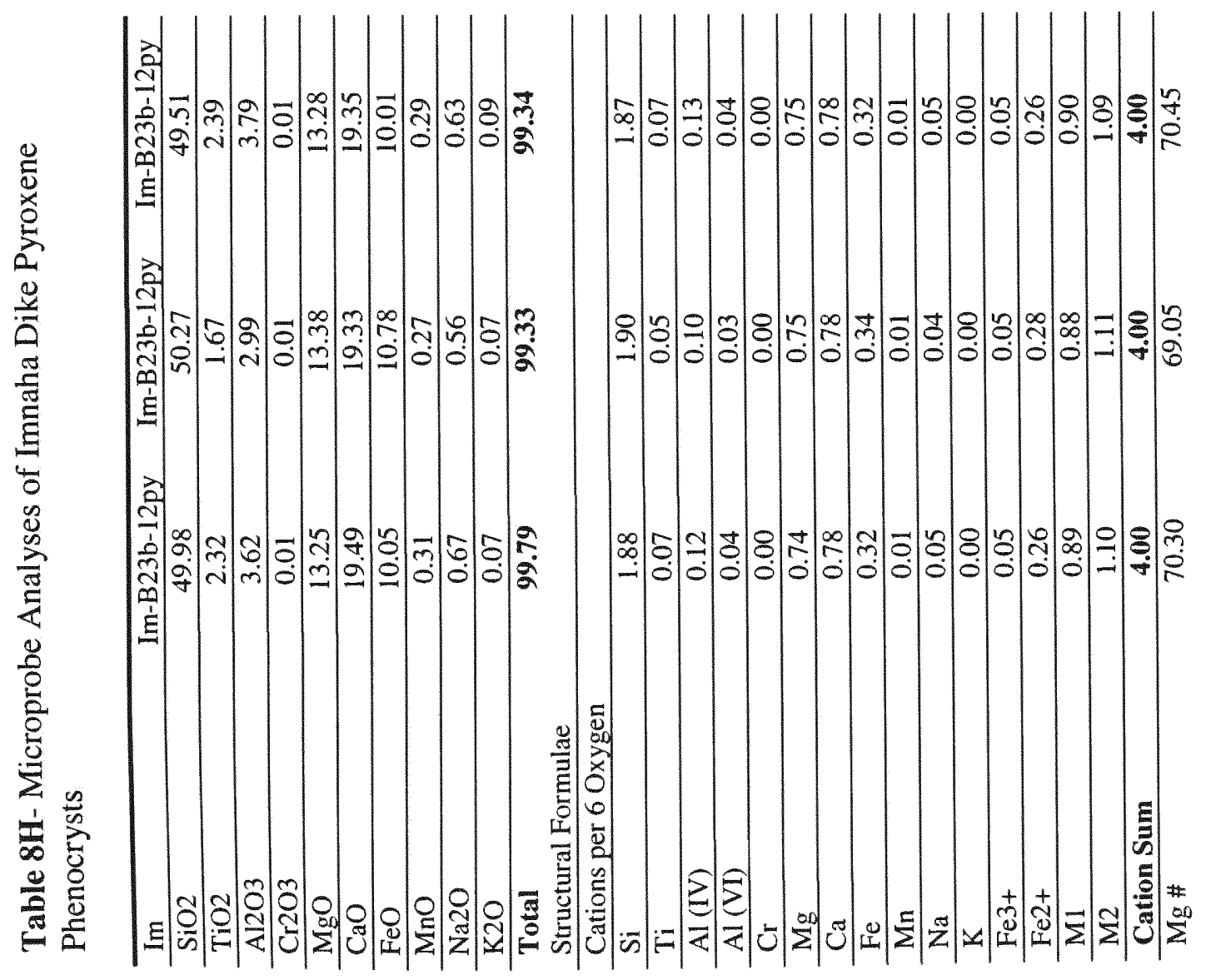

5 


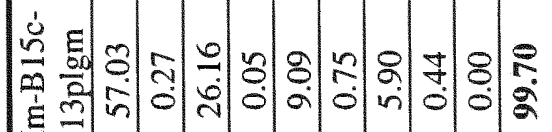

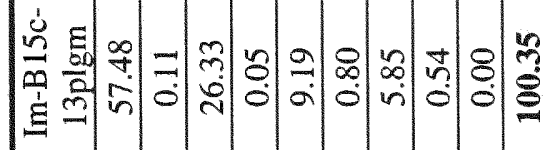

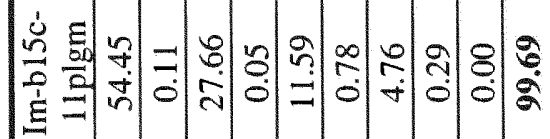

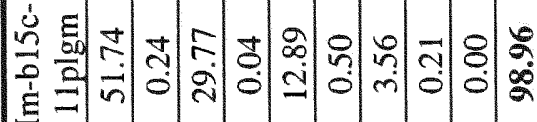

畜

그

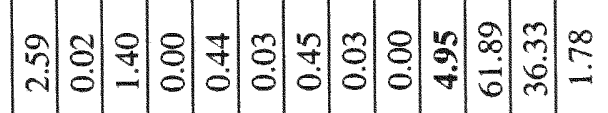

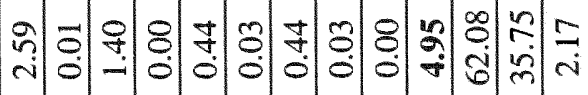

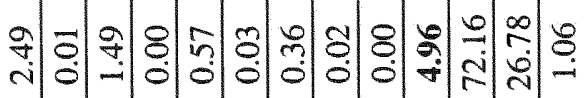

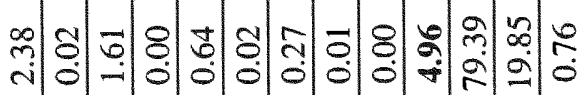

$\stackrel{\infty}{\infty}$

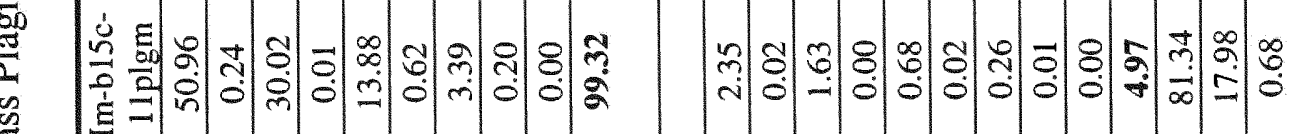

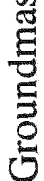

总

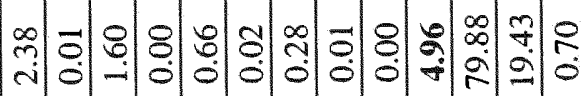

㿣

\%

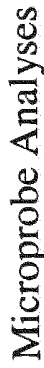

突

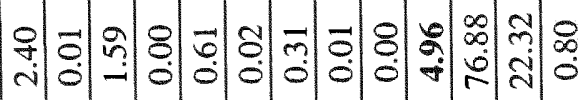

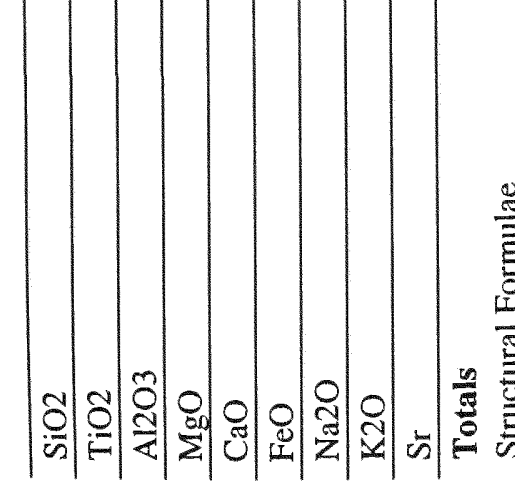

풍

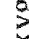

है

E 


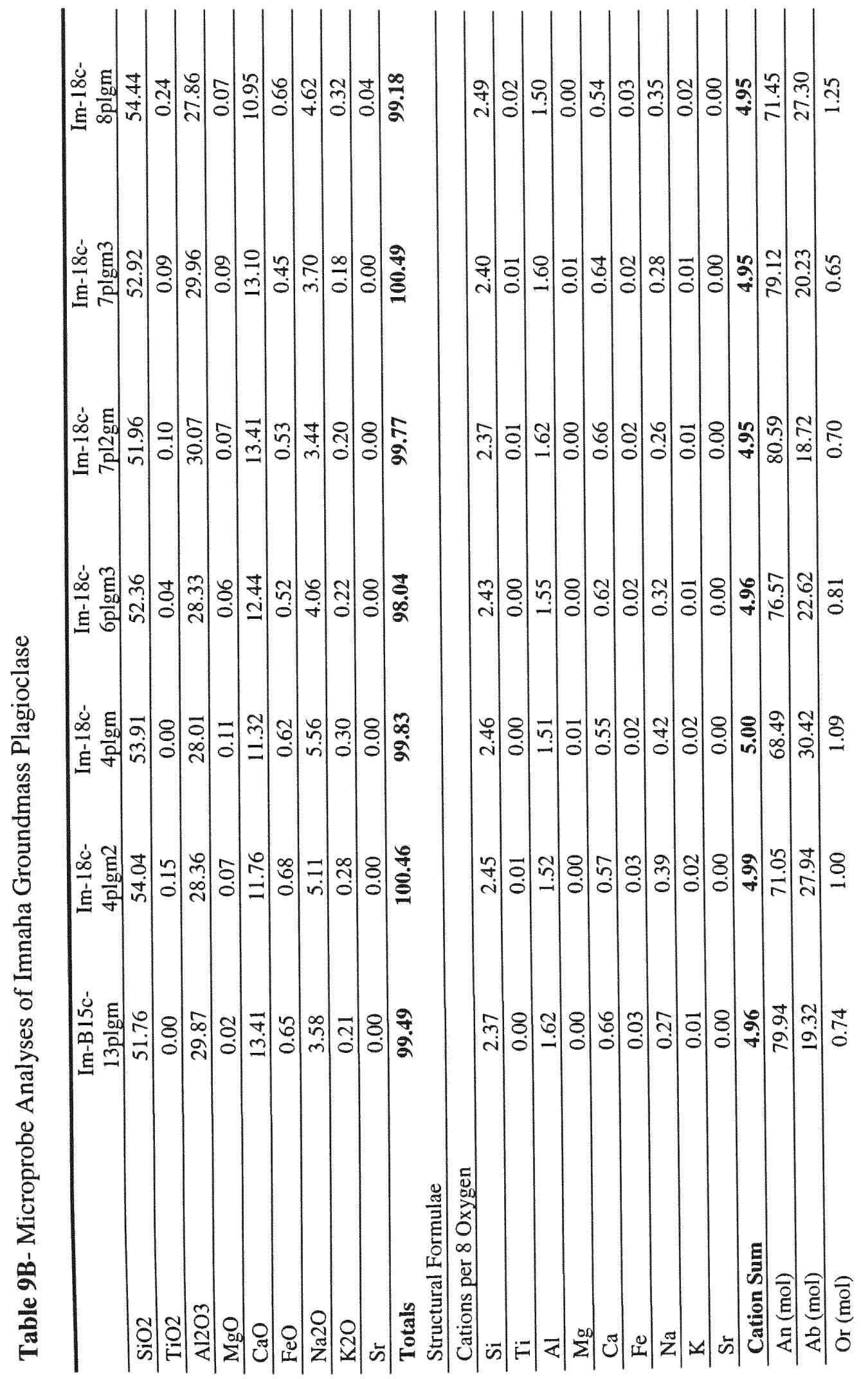




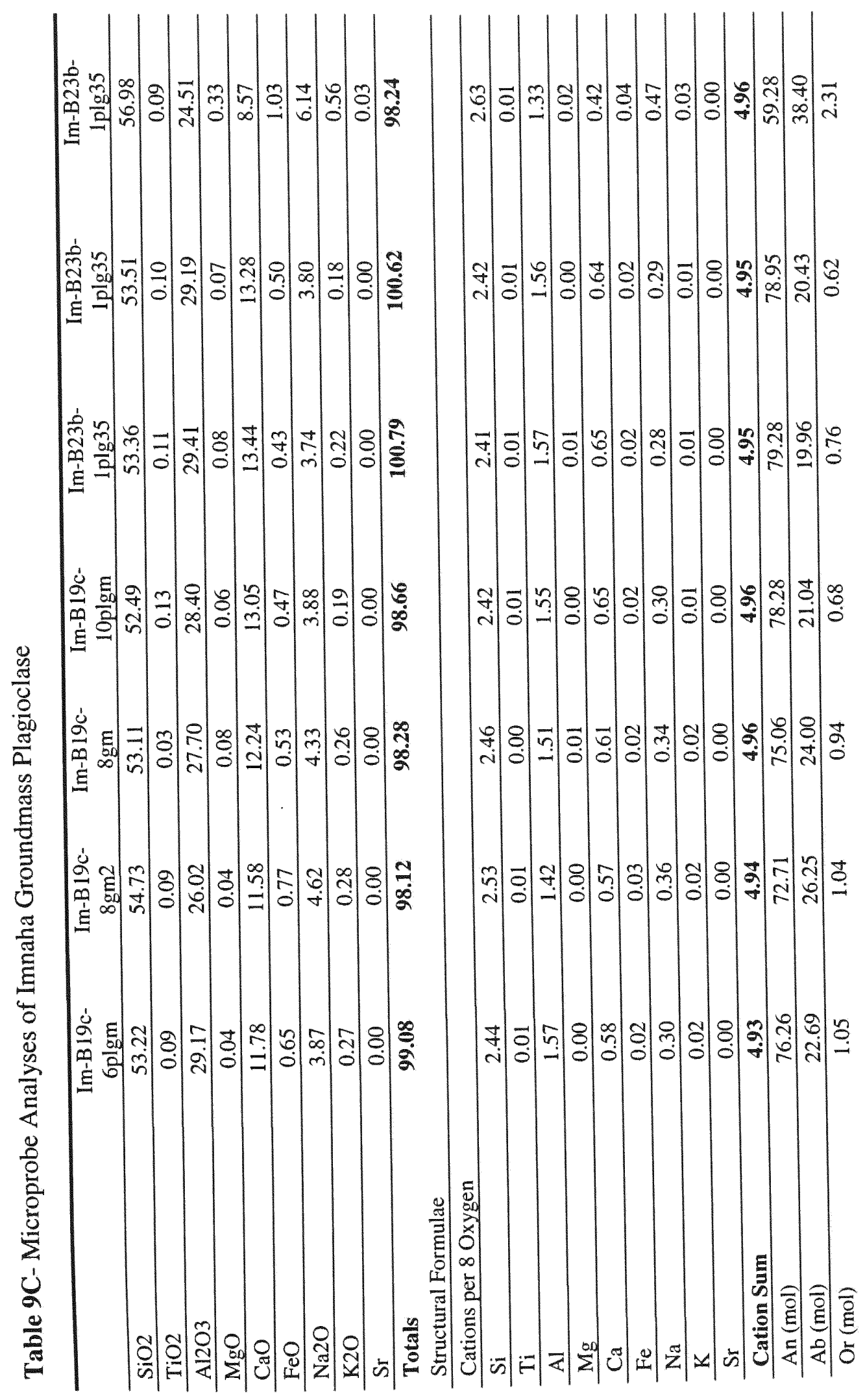




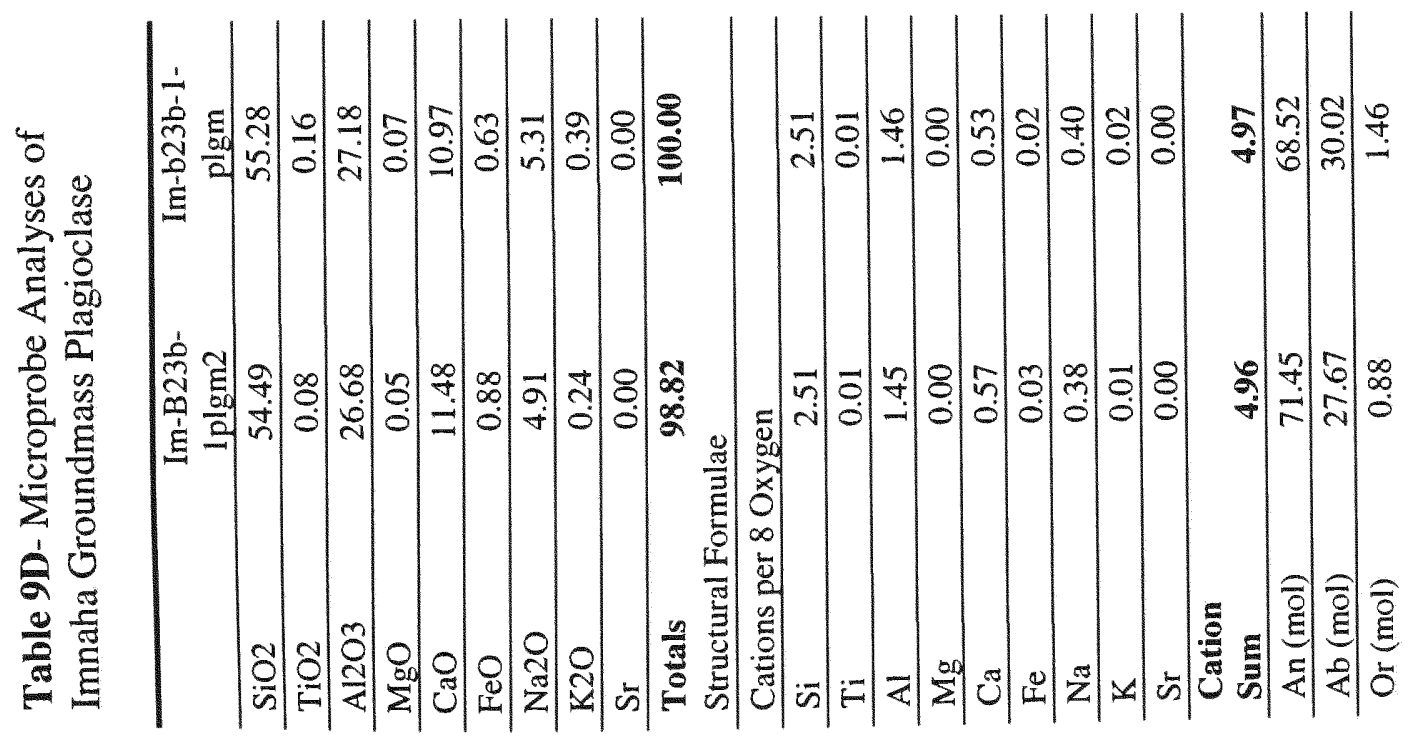




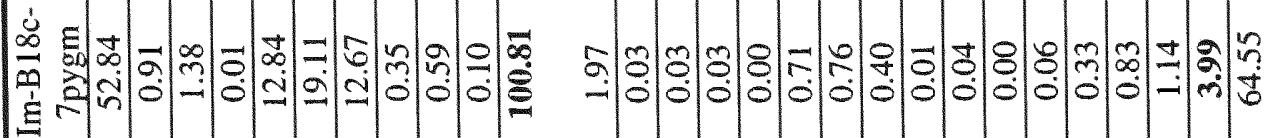

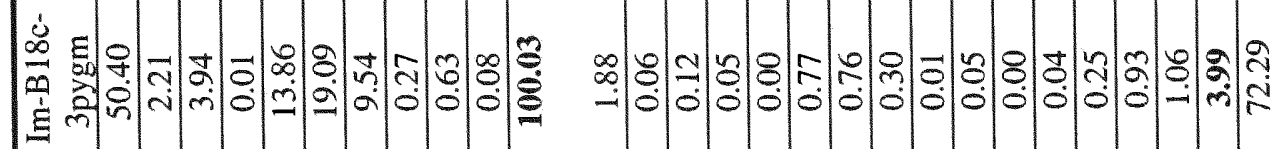

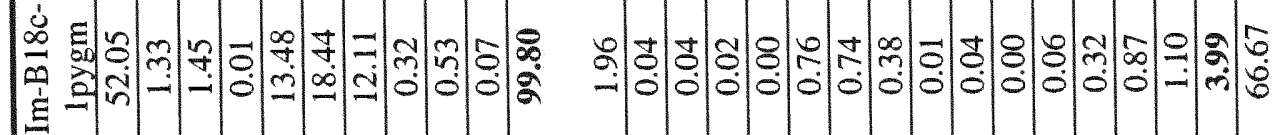

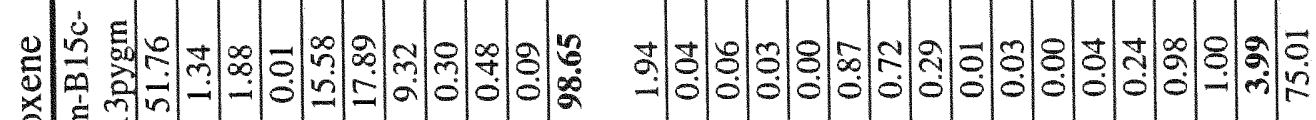

$\frac{\cos }{2}$

:

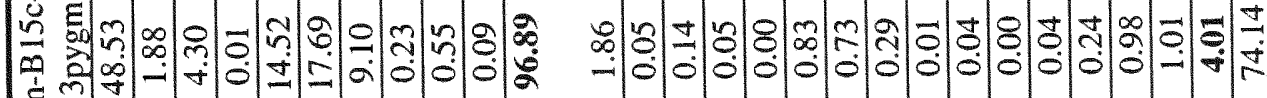
) 它

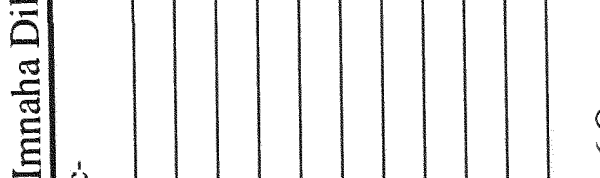

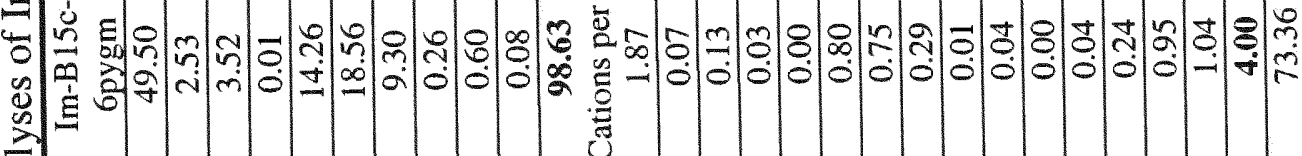

完

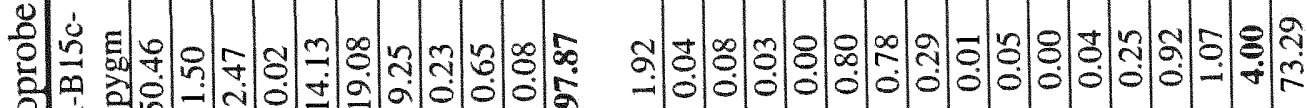

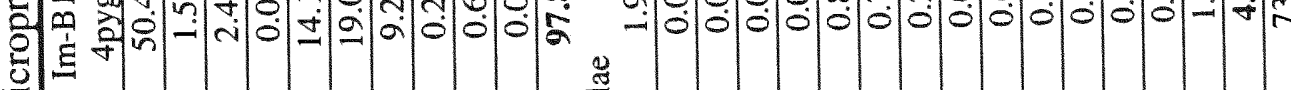

竞

5
0
0
0
0
0
0
0
0
0
0
0
0
0

ช్

章 


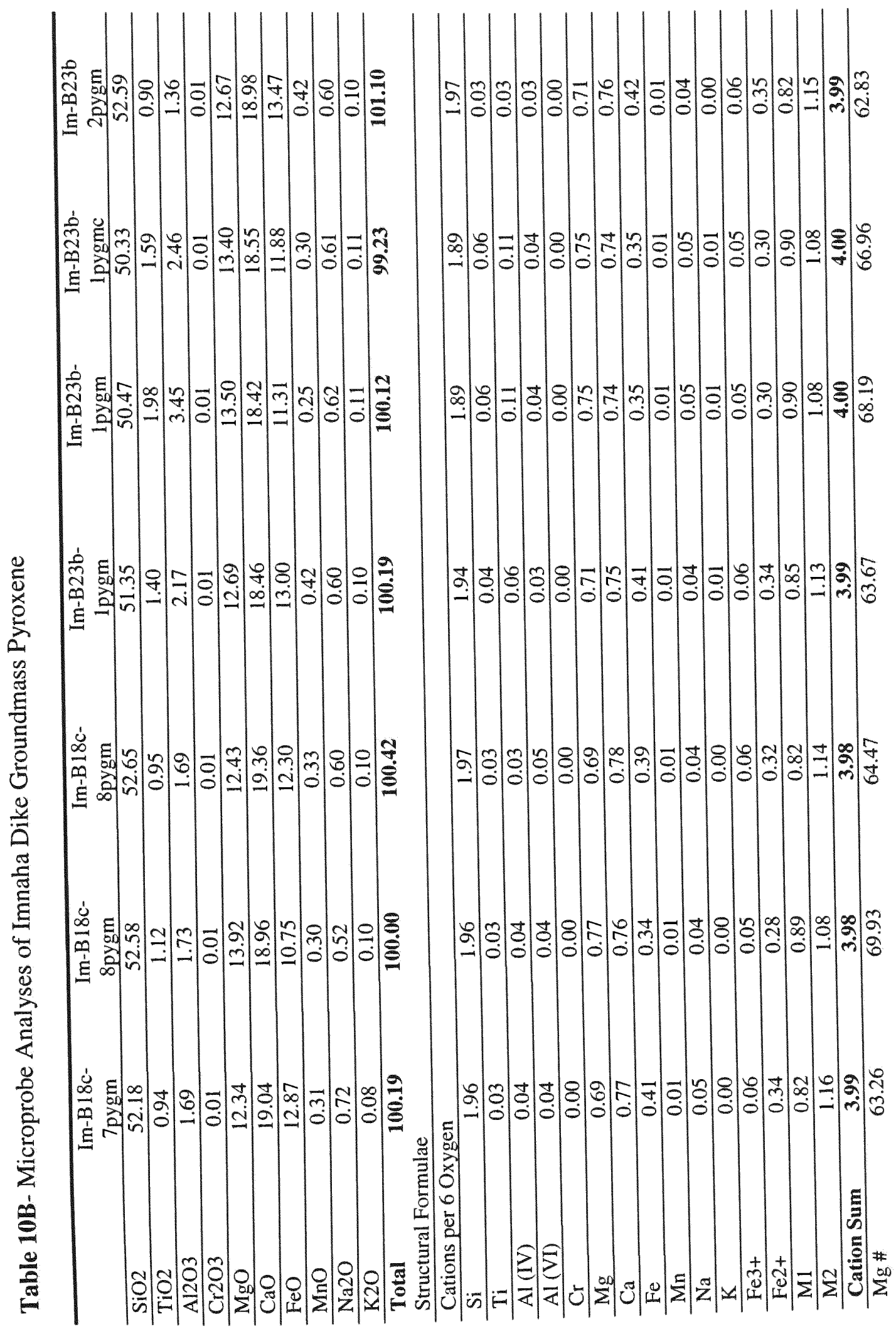




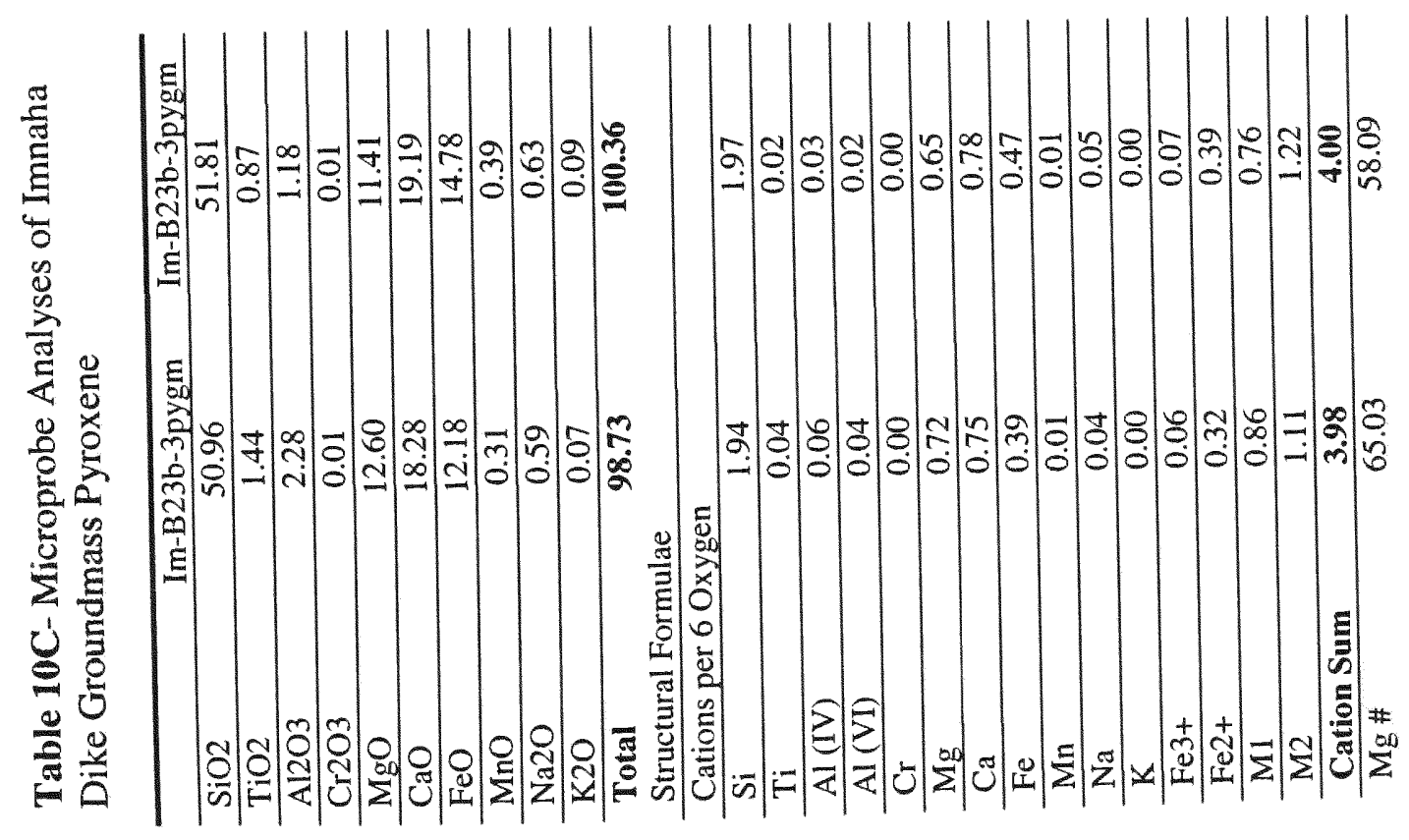




\section{VITA}

\section{SEDELIA RODRIGUEZ DURAND}

EDUCATION Florida International University, Miami FL

Ph.D. Candidate in Geology

Expected Graduation Date: May 2006

Title of Dissertation: Investigation into the Petrogenesis of the Columbia

River Basalt Group of the Pacific Northwest, USA

California State University, Los Angeles

Bachelor in Geological Sciences - 1997

EXPERIENCE

Shipboard Scientist-Igneous Petrologist

IODP Expedition 309 Superfast Spreading 2, Guatemala Basin

R/V JOIDES Resolution, July-Aug 2005

Co-chief scientists: Dr. D. A. H. Teagle (Univ. of Southampton)

Dr. S. Umino (Univ. of Shizuoka)

Laboratory Instructor- Florida International University

2000-2004

Duties included: teaching, preparing lecture and laboratory materials and grading and creating exams and lab exercises. In addition, preparing a curriculum, implementing new topics into the existing exercises using a variety of sources such as internet and outdoor activities.

Geologist- ATLAS Environmental Engineering $1998-2000$

Conducted soil and groundwater sampling, site assessment, remediation and groundwater monitoring. Interfaced with local and state agencies, responsible for writing quarterly groundwater monitoring reports as well as site investigation, underground storage tank (UST) and corrective action reports.

Leg 206, Expedition 309 and 312 Scientific Party (Durand, S.R.), 2006, Drilling to Gabbro in intact ocean crust at the East Pacific Rise; Science, accepted.

Durand, S.R., Sen, G., Reidel, S.P., 2005, Origin of the Grande Ronde Basalts, Columbia River Basalt Group: Eos Tran. AGU, 86(44), Fall Meeting Supplement, Abstract V41C-1454. 
Teagle, D.A.H., Expedition 309 Scientific Party (Durand, S.R.), 2005, The Hard Yards: Deep basement drilling of an in situ section of oceanic crust formed at a superfast spreading rate. Recent results from IODP Expedition 309 to Hole 1256D, Eastern Equatorial Pacific.

Durand, S.R., Sen, G., 2004, Preeruption history of the Grande Ronde Formation lavas, Columbia River Basalt Group, American Northwest: Evidence from phenocrysts: Geology, v. 32 no. 4, p. 293-296.

Durand, S.R., Sen, G., 2003, Invited presenter at the Geological Society of America's 2003 national meeting in Seattle Washington, Evidence for Shallow Differentiation and Magma Mixing of the Grande Ronde Formation, Columbia River Basalt Group: Abstracts with Programs- Geological Society of America Annual Meeting and Exposition, Seattle, WA.

Durand, S.R., Sen, G., 2003, Floods of Fire: The Columbia River Flood Basalt Lava Flows: SACNAS National Meeting, Albuquerque, New Mexico. Received award for Best Oral Presentation.

\section{HONORS AND ACTIVITIES}

- Lamont-Doherty Postdoctoral Research Fellowship-2006-2008

- Joint Oceanographic Institute Research Grant-2006

- Dissertation Year Fellowship 2004-2005, Florida International University

- Research Grant Recipient 2003, Geological Society of America

- Teaching Award 2002 (first place), Florida International University

- Conference Travel Grants, Graduate Student Association-Florida International University, 2002, 2003, 2005.

- Field Trip Leader: GSA 2003 Annual Meeting field trip, The Columbia Flood Basalts and the Yakima fold belt. 